\begin{abstract}
Universidad Nacional de La Plata
Facultad de Ciencias Sociales y Jurídicas

Programa de Posgrado de la Facultad de Ciencias Sociales y Jurídicas
\end{abstract}

María de las Mercedes Rodríguez Fontán Luchino

\title{
HACIA LA CONSTRUCCIÓN DE UN RÉGIMEN JURÍDICO INTERNACIONAL DE LOS DESPLAZADOS AMBIENTALES FORZADOS O REFUGIADOS AMBIENTALES
}

Tesis de Doctorado

Director: Prof. Doctor Eduardo Tinant

Co-Director: Prof. Doctor Wagner Costa Ribeiro 
Universidad Nacional de La Plata

Facultad de Ciencias Sociales y Jurídicas

Programa de Posgrado de la Facultad de Ciencias Sociales y Jurídicas

\title{
HACIA LA CONSTRUCCIÓN DE UN RÉGIMEN JURÍDICO INTERNACIONAL DE LOS DESPLAZADOS AMBIENTALES FORZADOS O REFUGIADOS AMBIENTALES
}

\author{
María de las Mercedes Rodríguez Fontán Luchino
}

Tesis presentada a la Facultad de Ciencias Sociales y Jurídicas de la Universidad Nacional de La Plata, para la obtención del título de Doctor en Derecho

Director: Prof. Doctor Eduardo Tinant Co-Director: Prof. Doctor Wagner Costa Ribeiro 


\section{Dedicatoria}

A mi esposo,

A mi hermana

$\mathrm{y}$

A mis sobrinas, Martina y Cecilia, por ser los soles que iluminan mi vida. 


\section{Agradecimientos}

A Dios por guiarme por este camino, A mi marido, por ser todo para mi. A mi hermana y a mis sobrinas, Martina y Cecilia. A mi Profesor Eduardo Tinant por su constante apoyo, por sus sugestiones y por estar siempre presente a lo largo de todo este trabajo. A mi Profesor Wagner Costa Ribeiro por su valioso aporte, y por enseñarme el camino de la investigación científica. A mi suegra, por tanto apoyo. A mis amigas por la compreensión y el cariño, Cecilia, Benedita, Berenice, Maria Angela, Simone, María Helena, Izabel, Susana, Marcela y Adriana. A mis primos, Mariló y German, por su amistad. A mi grupo de oración, por tanta paciencia y apoyo conmigo. 


\section{RESUMEN}

Existe una laguna en el Derecho Internacional en relación a la protección de los Refugiados Ambientales o Desplazados Ambientales Forzados transfronterizos, pues se verifica la ausencia de un Régimen Específico Internacional, así como la falta un organismo internacional que se encargue de protegerlos.

En esta tesis se sostiene la necesidad de un concepto amplio de Refugiados Ambientales o Desplazados Ambientales Forzados que incluya a todas aquellas personas que tienen que dejar sus hogares por causa de los Desastres o la Degradación ambiental, con independencia de si se han desplazado dentro del país o si son transfronterizos, porque todos sufren la violación de sus Derechos Humanos, lo que los convierte en forzados.

La violación de los Derechos Humanos de estas personas ha sido reconocida tanto por la doctrina que trata del asunto como por diversos organismos internacionales, tales como el Alto Comisionado de Naciones Unidas de Derechos Humanos, el Consejo de Derechos Humanos, el Comité Permanente Inter-agencias de Naciones Unidas (IASC), la Corte Europea de Derechos Humanos, la Comisión Interamericana de Derechos Humanos y la Corte Interamericana de Derechos Humanos.

En este trabajo fueron analizados: los Pequeños Estados Insulares en Desarrollo que sufren los procesos lentos de degradación, así como los desastres repentinos y aquellos países que sufren los desastres repentinos. Los Pequeños Paises insulares en Desarrollo tienen economías de subsistencia, y dependientes del exterior, lo que hace que no tengan relevancia en el orden económico internacional. En segundo lugar, el análisis de los países que sufren los desastres meteorológicos repentinos durante los años 2010 a 2012 demostró que estos países tienen grandes poblaciones de pobres.

Alto Comisionado de Naciones Unidas para los Refugiados (ACNUR) es el organismo que debería hacerse cargo de la protección de estos Desplazados Ambientales Forzados o Refugiados Ambientales porque tiene la experiencia en la protección de los refugiados desde 1950. También, desde 1993 asumió la responsabilidad hecho cargo de la protección de los Desplazados Internos (incluidos los de los desastres), siendo que estas dos figuras son muy semejantes con los Desplazados Ambientales Forzados. Además, este organismo ha asumido el liderazgo para enfrentar algunos Desastres de forma ad hoc.

Esta ampliación de las competencias de ACNUR, así como el regimen jurídico internacional deberia ser otorgada por una Resolución de la Asamblea de General de Naciones Unidas. 


\begin{abstract}
There is a gap in international law regarding the protection of Environmental Refugees or Forced Displaced Environmental that cross the borders of their countries. In that sense, there is the absence of a specific International Regime, as well as a lack of an international body responsible to protect them.

This thesis holds the need for a broad concept of Environmental Refugees or Forced Displaced Environmental, that include all those who have to leave their homes because of disasters or environmental degradation, regardless of whether they have been displaced within the country or are transboundary, because all suffer the violation of their human rights, which makes them forced.

The violation of human rights of these people has been recognized both by the doctrine that treats the matter as by various United Nations agencies such as the United Nations Human Rights High Commissioner, the Human Rights Council, the Inter-Agency Standing Committee (IASC), the European Court of Human Rights, the Inter-American Commission on Human Rights and the Inter-American Court of Human Rights.

In this thesis two situations were analyzed: the Small Island Developing States suffering the slow degradation processes, as well as sudden disasters and those countries experiencing sudden disasters. The Small Island Developing States have subsistence economies, and dependent on foreign States, which makes them not relevant in the international economic order. Second, the study of countries experiencing sudden weather disasters during the years 2010 to 2012 showed that these countries have large poor populations.

UN High Commissioner for Refugees (UNHCR) is the agency that should take care of the protection of these Forced Displaced Environmental or Environmental Refugees because it has experience in protecting refugees since 1950. Also, since 1993 assumed responsibility for taking charge of the protection of Internally Displaced Persons (including disasters), being that these two figures are very similar to the Environmental Forced Displacement. In addition, the agency has taken the leadership to address some Disaster on ad hoc basis. This powers extension of UNHCR and the international legal regime, should be granted by a resolution of the General Assembly of the United Nations.
\end{abstract}




\section{ÍNDICE}

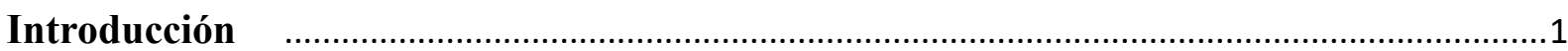

\section{Capítulo I}

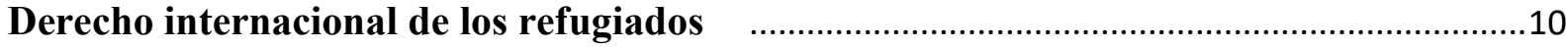

I.1. Introducción

I.2. La creación del ACNUR

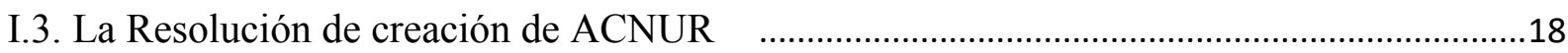

I.4. La Convención de Ginebra sobre el Estatuto del Refugiado de $1951 \quad$................................22

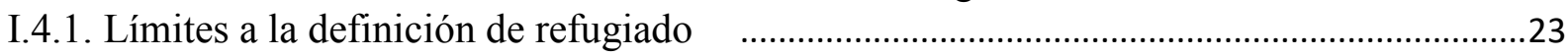

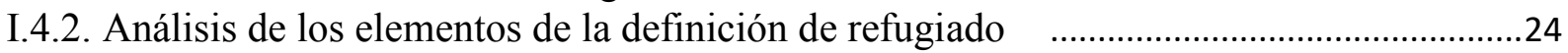

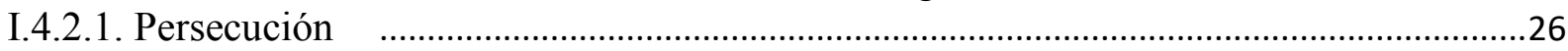

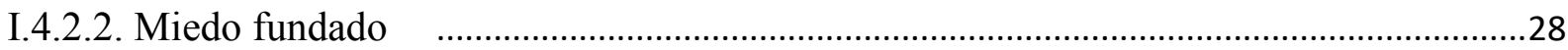

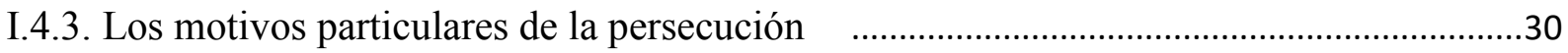

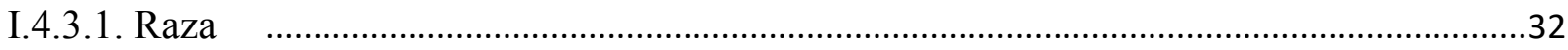

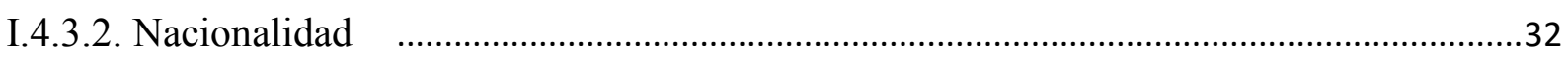

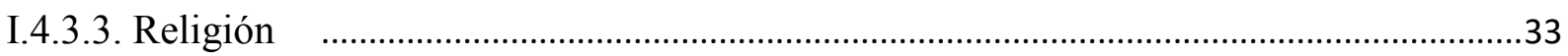

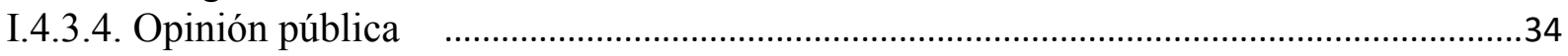

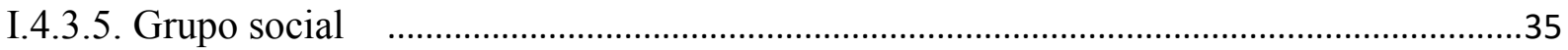

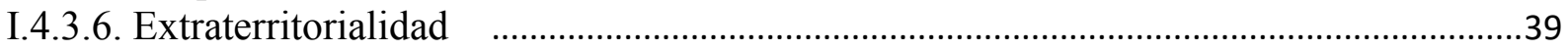

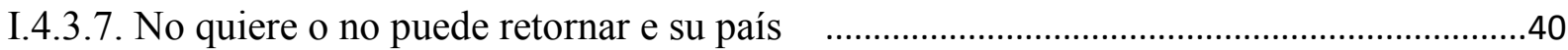

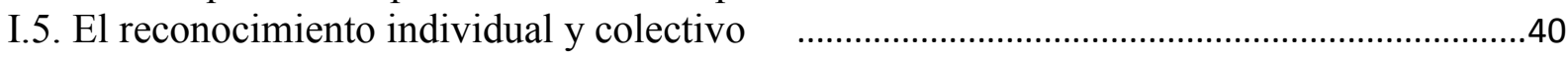

I.6. Determinación de la Condición de Refugiado .................................................................

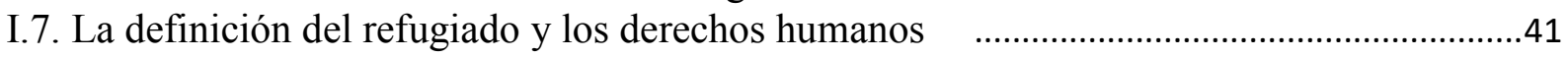

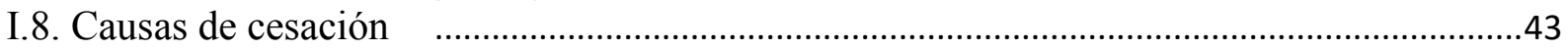

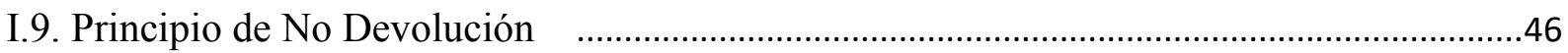

I.10. Aspectos relevantes de ACNUR. De la naturaleza consultiva a la operativa: Buenos

Oficios y Resoluciones de la Asamblea General de Naciones Unidas ....................................49

I.11. ¿Reasentamiento o repatriación? ………......................................................................55

I.12. Derechos de los refugiados reconocidos en la Convención de $1951 \quad$...............................55

I.13. Protocolo relativo al Estatuto de los Refugiados de $1967 \quad$................................................56

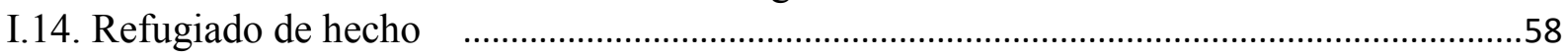

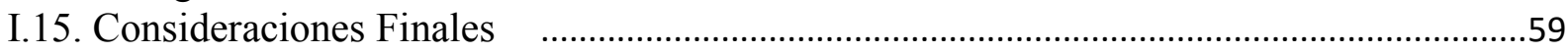

\section{Capítulo II}

Los refugiados ambientales o desplazados ambientales forzados $\quad$..................................64

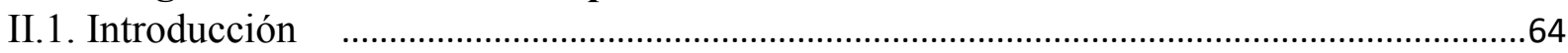

II.2. Refugiados ambientales o desplazados forzados ambientales $\quad$.........................................65

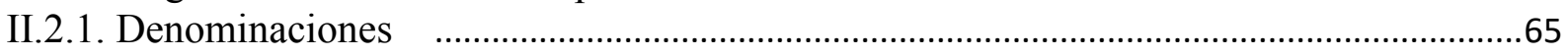

II.3. La evidencia de la existencia del desplazado ambiental forzado $\quad$....................................70

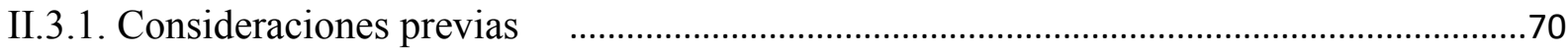

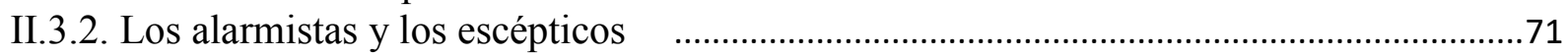

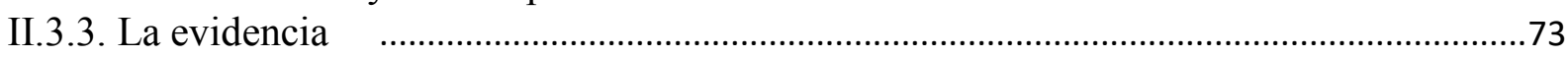

II.4. Las definiciones sobre los desplazados ambientales forzados o refugiados ambientales

II.5. Nuestra propuesta de definición de desplazado ambiental forzado o refugiado ambiental 
II.5.1. Análisis de cada uno de los aspectos constitutivos de nuestra definición de los desplazados ambientales forzados

II.6. Las causas o los escenarios del desplazamiento ambiental forzado ................................92

II.6.1. Los escenarios de los desplazados ambientales forzados $\quad$............................................95

II.7. Los refugiados ambientales o desplazados ambientales forzados y la violación de los

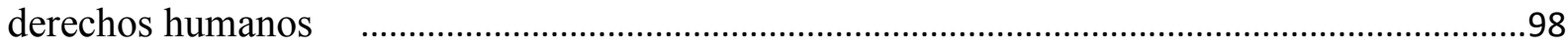

II.8. Refugiados ambientales o desplazados ambientales forzados como individuos o

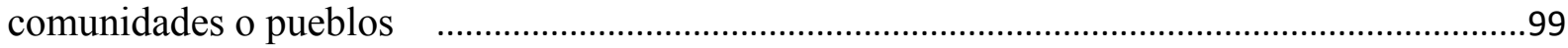

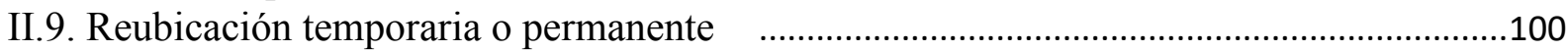

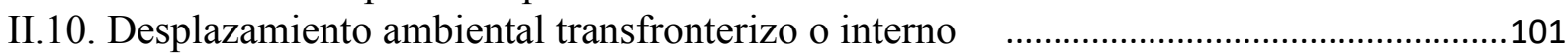

II.11. Los refugiados ambientales como desplazados forzados .............................................103

II.11.1. Los aspectos esenciales de los desplazados ambientales como forzados ...............104

II.11.2. Análisis del desplazamiento forzado en los escenarios de desastre y degradación

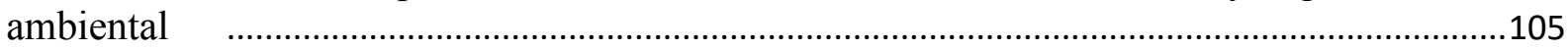

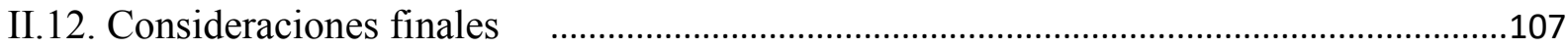

\section{Capítulo III}

Desplazados ambientales forzados y derechos humanos .............................................109

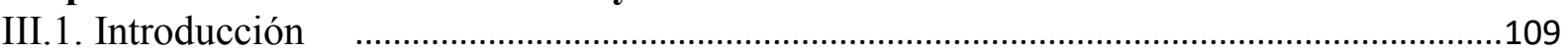

III.2. Breves consideraciones sobre los derechos humanos $\quad$.................................................112

III.2.1. Derechos humanos. Origen. Declaraciones y pactos internacionales de derechos

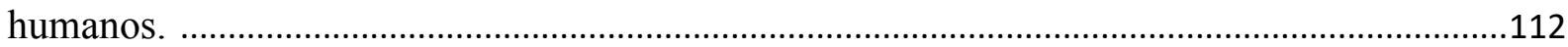

III.2.2. Derechos humanos. Concepto. Características. Generaciones de derechos humanos

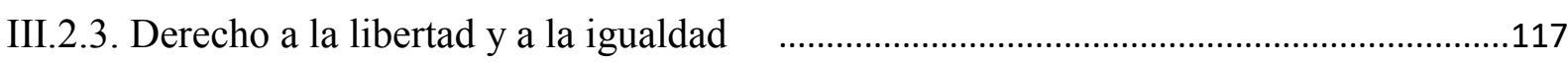

III.2.4. Derechos humanos, dignidad humana y desplazados ambientales forzados. Mínimo

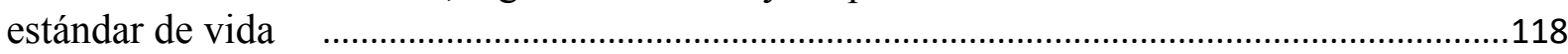

III.3. Los desplazados ambientales forzados, sus derechos humanos y el ámbito del derecho

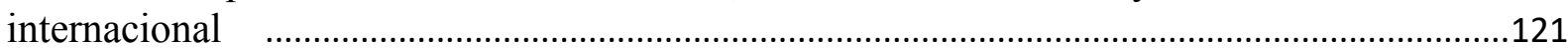

III.4. Naciones Unidas y la violación de los derechos humanos de los desplazados ambientales

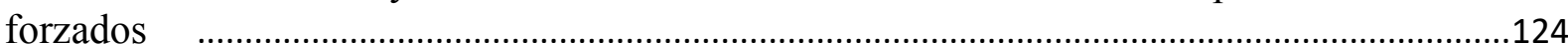

III.5. Cambios climáticos, desastre o degradación ambiental y los derechos humanos $\quad$.......130

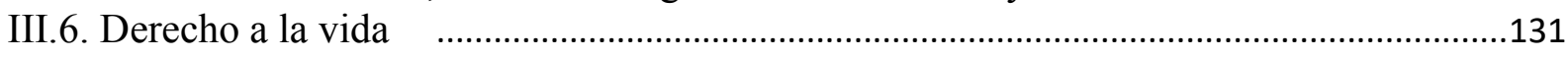

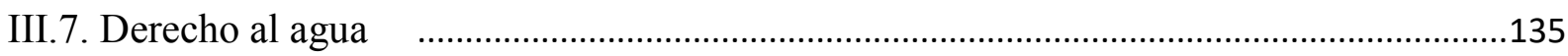

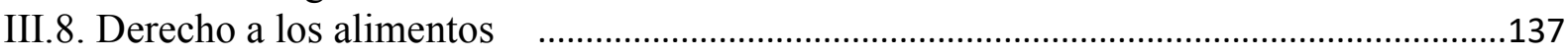

III.9. El derecho a la salud de los desplazados ambientales forzados $\quad$....................................140

III.10. Derecho a la vivienda digna de los desplazados ambientales forzados $\quad$.....................143

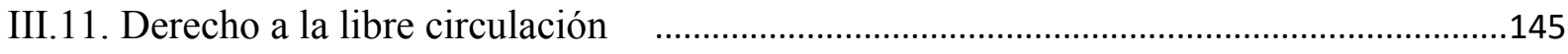

III.12. Derecho de libremente escoger el lugar para residir $\quad$..................................................147

III.13. Derecho a la libertad de expresión y a la opinión $\quad$.........................................................149

III.14. Derecho a la vida privada, a su correspondencia, a su honra, de domicilio de los

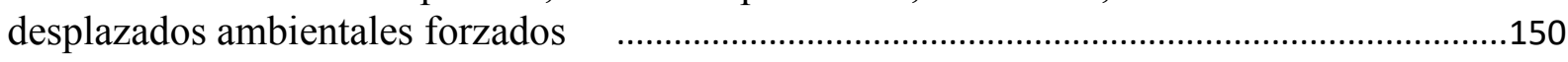

III.15. Derecho a la libertad de religión de los desplazados ambientales forzados $\quad$..............151

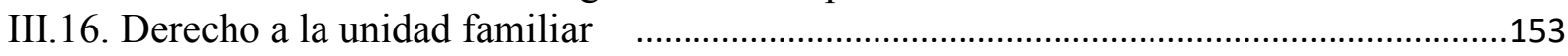

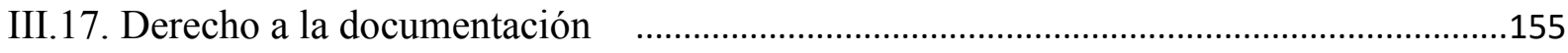

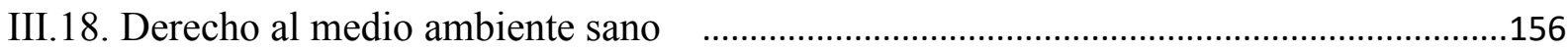

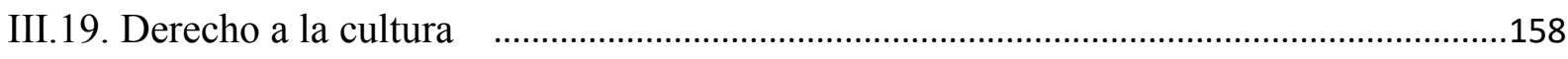

III.20. Los Derechos de Pueblos Indigenas y Tribales . .....................................................158 
III.20.1. La cosmovisión de la Sociedad de Occidente y la de estos pueblos $\quad$...................... 159

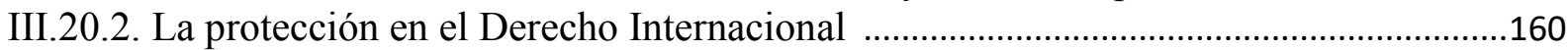

III.20.3. La Declaración de Naciones Unidas sobre los Derechos de los Pueblos Indígenas

\section{Capítulo IV}

Desplazados ambientales forzados y los países en desarrollo, 2010-2012 ………….....170

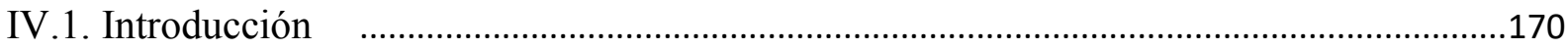

IV.2. La Justicia Ambiental y el Ecologismo de los Pobres o Ecologismo Popular ............172

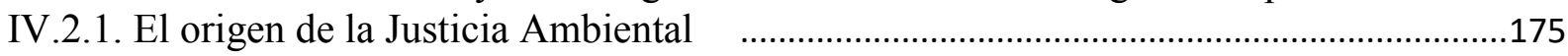

IV .2.2. La Justicia Ambiental: observaciones conceptuales .................................................177

IV.3. Los desplazados ambientales forzados y la Justicia Ambiental ..................................181

IV.4. El problema de los desplazados ambientales ...........................................................182

IV.5. Desplazados ambentales forzados de desastres ambientales de procesos de larga

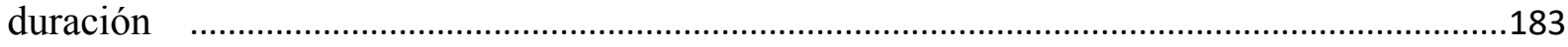

IV.5.1. Pequeños Estados Insulares y regiones costeras bajas .............................................185

IV.5.2. La situación económica de Kiribati, Tuvalu, Maldivas e Islas Marshall …..............195

IV.5.3. Consideraciones previas sobre el análisis de la pobreza en las poblaciones de estos

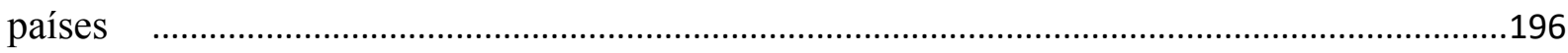

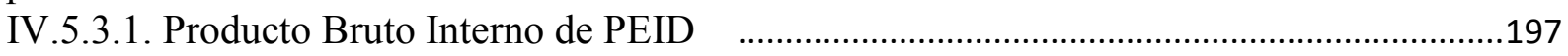

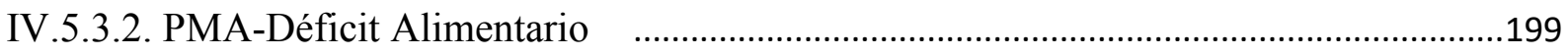

IV.5.3.3. PEID y la Oficina de Naciones Unidas del Alto Representante para los Países Menos Desarrollados, los Países en Desarrollo sin litoral y los Pequeños Estados Insulares en

Desarrollo/ United Nations Office of the High Representative for the Least Developed

Countries, Landlocked Developing Countries and Small Island Developing States (UN-

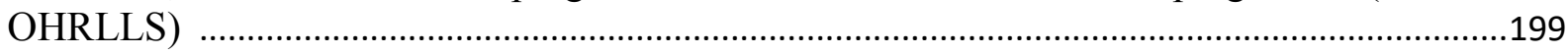

IV.5.3.4. Los PEID: Países En Desarrollo-Países Menos Adelantados . ................................204

IV.5.4. Conclusiones del análisis de los Indicadores sobre PEID $\quad$.........................................213

IV.6. Los desplazados ambientales forzados de los desastres ..............................................215

IV.6.1. Los desplazados ambientales forzados de los desastres en el período 2010-2012 ..215

IV.6.2. Desplazamientos ambientales forzados, vulnerabilidad y pobreza $\quad$............................225

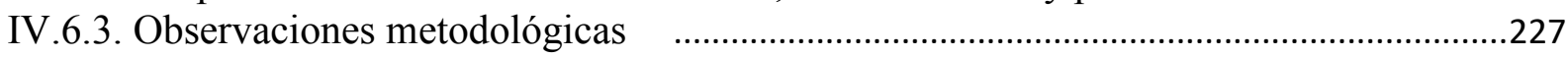

IV.6.3.1. Los mayores desplazamientos ambientales forzados en $2012 \quad$................................227

IV.6.3.2. Los mayores desplazamientos ambientales forzados en $2011 \quad$..............................230

IV.6.3.3. Los mayores desplazamientos ambientales en $2010 \quad$.............................................233

IV.7. Análisis de la situación de pobreza en los países donde ocurrieron los desplazamientos

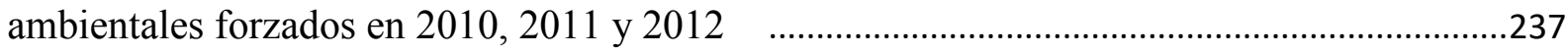

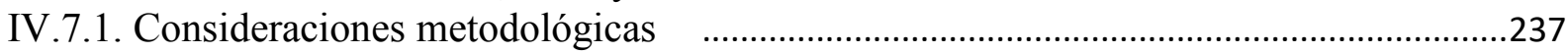

IV 7.2. La pobreza en los países donde ocurrieron los desplazamientos ambientales forzados

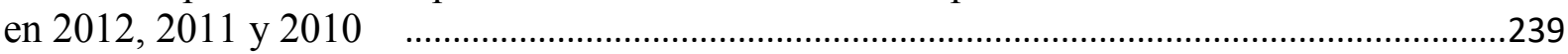

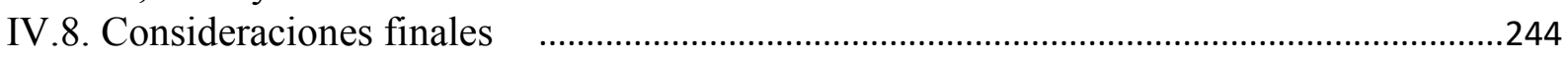

Capítulo V

Propuestas de instrumentos internacionales para la protección de los desplazados

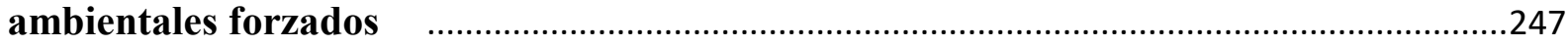

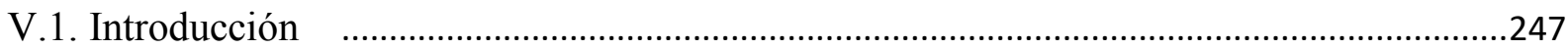

V.2. Creación del Protocolo en el marco de la Convención de Naciones Unidas sobre el

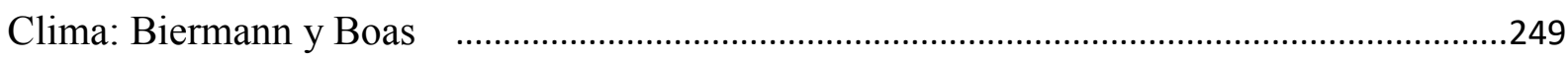


V.3. Convención independiente sobre los desplazados ambientales: propuesta de Docherty y

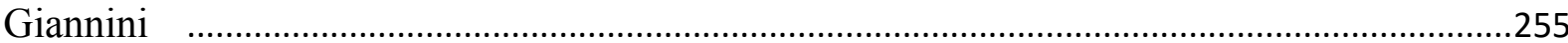

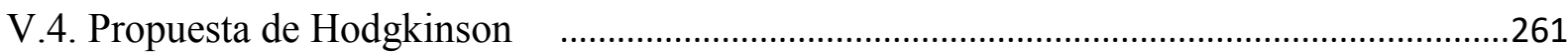

V.5. Propuesta de Mayer sobre la creación de una Resolución de la Asamblea General de Naciones Unidas

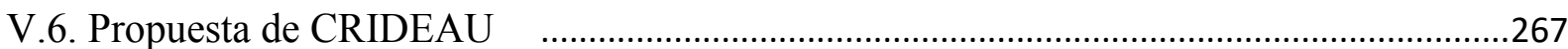

V.7. La reforma de la Convención sobre el Estatuto de los Refugiados: propuesta del gobierno

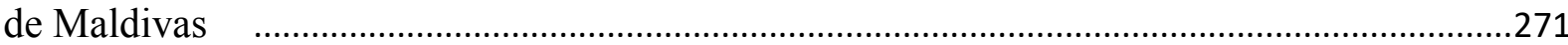

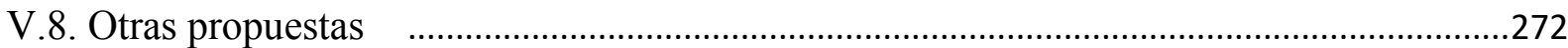

V.9. Consideraciones finales

\section{Capítulo VI}

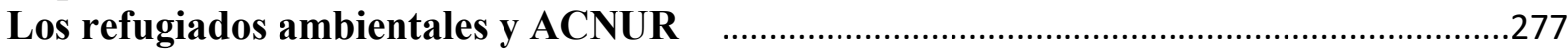

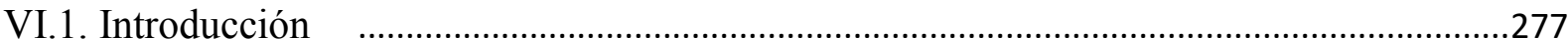

VI.2. Estructura de Naciones Unidas ante desastres ambientales: ERC, IASC y OCHA $\quad . .279$

VI.2.1. Emergencias y desastres ambientales en la órbita de Naciones Unidas …................279

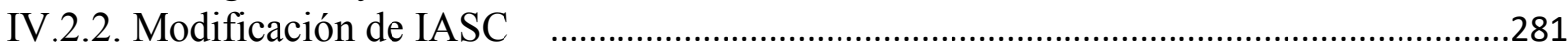

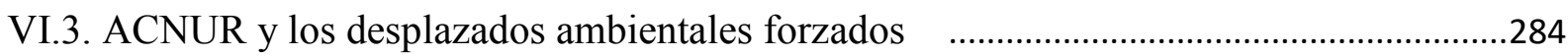

VI.4. ACNUR y los desplazamientos ambientales forzados desde 2007 a $2010 \quad$..................284

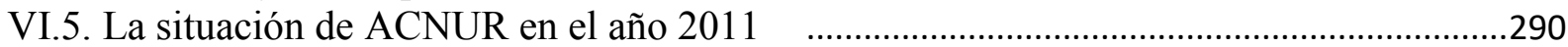

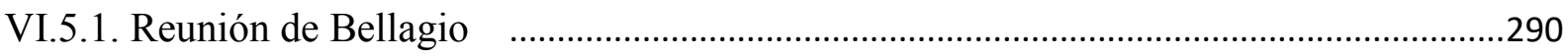

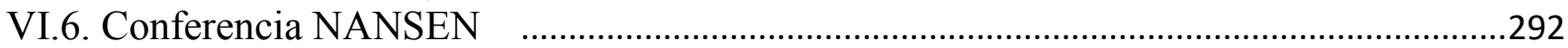

VI.7. El plan piloto de IASC para que ACNUR fuese el líder en la protección de los

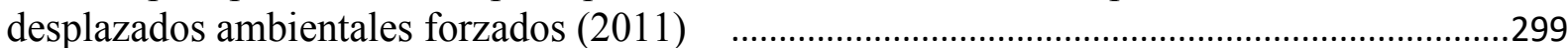

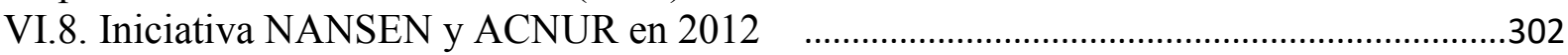

VI.9. Observaciones sobre ACNUR y los desplazados ambientales forzados, 2013-2015 $\quad$ 304

VI.10. Análisis del derecho de las organizaciones internacionales derivado: la Asamblea

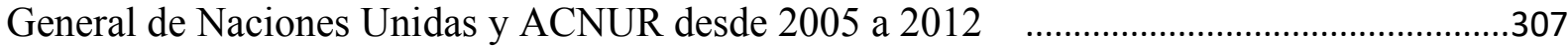

VI.10.1. Las Resoluciones de la Asamblea General Sobre ACNUR de 2005 a $2012 \quad$..........307 VI.10.2. Análisis de los informes de las Reuniones Anuales del Comité Ejecutivo de ACNUR

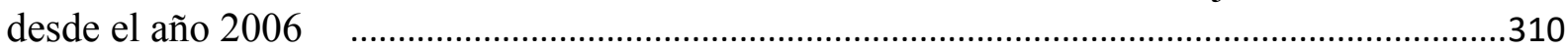

VI.11. Las competencias de ACNUR y los desplazados ambientales forzados ....................313

VI.11.1. ACNUR y su actuación con los desplazados internos $\quad$...............................................314

VI.11.2. ¿Las competencias de ACNUR permiten que se haga cargo de los desplazados

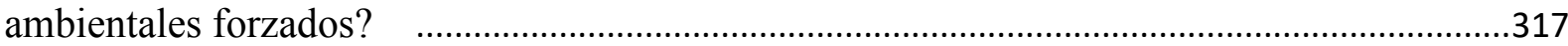

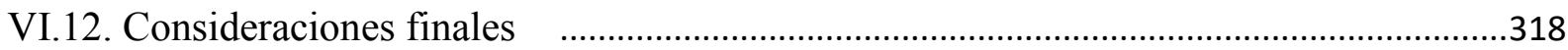

\section{Capítulo VII}

La propuesta de un régimen para los desplazados ambientales forzados ……..............321

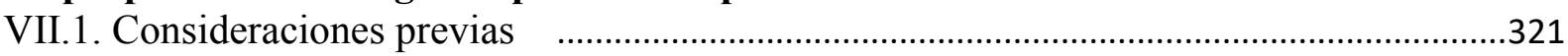

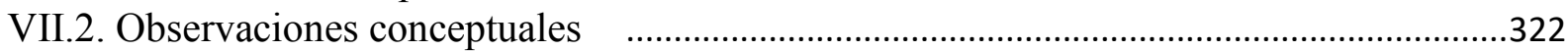

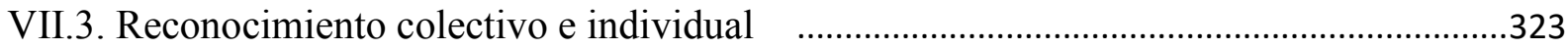

VII.4. Derechos de los desplazados ambientales forzados en cada etapa del desplazamiento

VII.5. Los derechos de los desplazados ambientales según la protección a la vida o

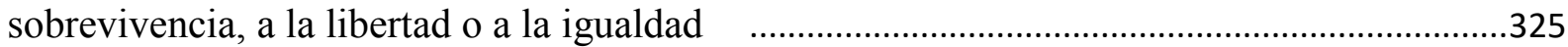

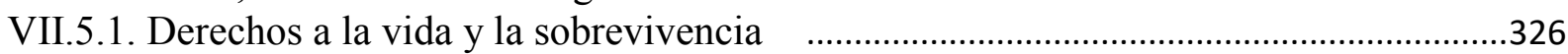

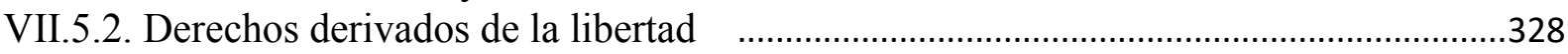

VII.5.3. Derechos derivados de la igualdad: derechos sociales, económicos y culturales $\quad .329$ 
VII.6. Principios. Consideraciones previas

VII.6.1. El Principio de No Discriminación

VII.6.2. El Principio de No Devolución

VII.6.3. El Principio de la Efectividad de los Derechos Humanos ..........................................333

VII.6.4. El Principio de la Activa Participación de la Ciencia $\quad$...................................................334

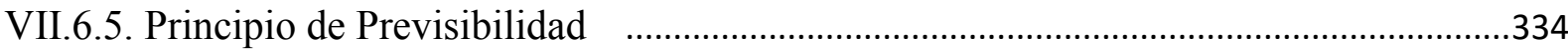

VII.6.6. El Principio de Planificación

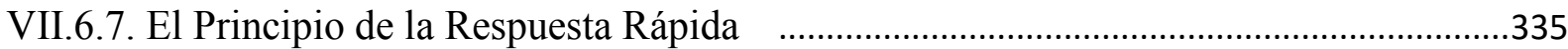

VII.6.8. El Principio de Participacion de las comunidades afectadas $\quad$.....................................335

VII.6.9. El Principio de las Cargas Compartidas ................................................................336

VII.7. El caso de los desplazamientos ambientales forzados: Comunidades/ pueblos o partes

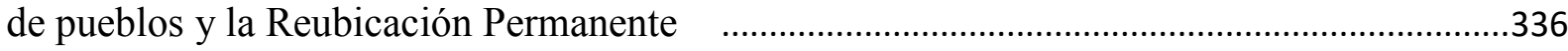

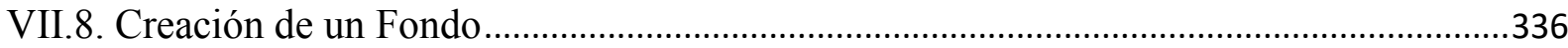

VII.8. ACNUR debe ser el organismo encargado por la protección de los desplazados ambientales forzados

VII.9. Mecanismo para la introducción del régimen especial para los desplazados ambientales forzados y responsabilidad de ACNUR, creado a través de la Resolución de Naciones Unidas 


\section{Lista de abreviaturas}

ACNUR Alto Comisionado de Naciones Unidas para los Refugiados

AOSIS Alliance of Small Island States / Alianza de Pequeños Estados Insulares

BIA Junta de Apelaciones de Inmigración de Estados Unidos

CERF Fondo de Respuesta a Emergencias

CIME Comité Internacional para las Migraciones Europeas

CMNUCC Conferencia de las Naciones Unidas de la Convención Marco sobre el Cambio Climático

CNUMAD Conferencia de las Naciones Unidas sobre el Medio Ambiente y el Desarrollo

COPs / Conferencia de los Estados Partes de UNFCCC

CRC Convención sobre los Derechos del Niño

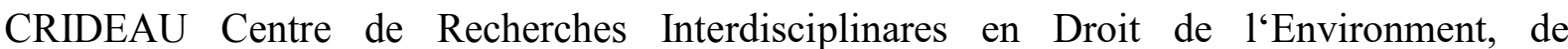
1‘Aménagement et de 1'Urbanisme / Centro de Investigación Interdisciplinaria en Derecho del Medio Ambiente, del Desarrollo y Urbanístico

DHA Departamento de Asuntos Humanitarios

ECOSOC United Nations Economic and Social Council / Consejo Económico y Social de las Naciones Unidas

EPA Enviromental Protection Agency of US / Agencia para la Protección Ambiental de Estados Unidos

ERC Coordinador del Socorro de Emergencias

FONUR Fondo de Naciones Unidas para los Refugiados

GEF Global Environment Facility / Fondo Mundial para el Medio Ambiente

IASC Inter-Agencias de Naciones Unidas, Comité Permanente entre Organismos de Naciones Unidas 
IDMC Internal Disceplacemente Monitoring Center / Centro para el Monitoreo de los Desplazados Internos

IDPs Personas Desplazadas Internas

IFRC International Federation of Red Cros / Federación Internacional de la Cruz Roja

IPCC Grupo Intergubernamental de Expertos sobre Cambio Climático

ISDR International Strategy for Disaster Reduction

ISIM Georgetown University's Institute for the Study of International Migration / Universidad de Georgetown para el Estudio de la Migración Internacional

LES Luisiana Energy Services

NRC Consulado Noruego para Refugiados

OCHA Oficina de Naciones Unidas para la Asistencia Humanitaria

OEA Organización de Estados Americanos

OHCHR Office of the United Nations High Commissioner for Human Rights / Oficina del Alto Comisionado de las Naciones Unidas para los Derechos Humanos

OIM International Organization for Migration / Organización Internacional para los Migrantes ONG Organización No Gubernamental

ONU Organización de las Naciones Unidas

OUA Organización de la Unión Africana

PBI Producto Bruto Interno

PEID Pequeños Estados Insultares en Desarrollo

PID Personas internamente desplazadas

PNUD Programa de las Naciones Unidas para el Desarrollo

PNUMA Programa de las Naciones Unidas para el Medio Ambiente

SIDS Small Island Developing States / PEID Pequeños Estados Insulares en Desarrollo

TPSA Temporary Protection or Stay Arrangement / Directrices sobre las Medidas de Protección Temporal 
UNDP United Nations Development Programme / PNUD

UNDRC United Nations Disaster Relief Coordinador / Coordinador de las Naciones Unidas para los Desastres

UNEP United Nations Environment Programme / Programa del Medio Ambiente de las Naciones Unidas

UNFCCC United Nations Framework Convention on Climate Change / Convención Marco de Naciones Unidas sobre el Cambio Climático

UNHCR United Nations High Commissioner for Refugees / ACNUR

UNHRC United Nations Human Rights Council / Consejo de Derechos Humanos de las Naciones Unidas

UNICEF United Nations Children's Fund / Fondo de las Naciones Unidas para la Infancia

UNOHRLLS United Nations Office of the High Representative for the Least Developed Countries, Landlocked Developing Countries and Small Island Developing States / Oficina del Alto Representante para los Países Menos Desarrollados, Países en Desarrollo sin litoral y Pequeños Estados Insulares en Desarrollo

WAEP World Agency for Environmentally Displaced Persons / Agencia Mundial para Personas Desplazadas Ambientales

WAEP World Agency for Environmentally-Displaced Persons / Agencia Mundial para Personas Desplazadas Ambientales

WFED World Fund for the Environmentally-Displaced / Fondo Mundial para los Desplazados Ambientales

WFED World Fund for the Environmentally-Displaced / Fondo Mundial para los Desplazados Ambientales

WFP World Food Programme / Programa Mundial de Alimentos

WHO World Health Organization/ OMS Organización Mundial de la Salud 


\section{Introducción}

Según los estudios del IDMC ${ }^{1 y 2}$, en el año 2010, hubo 43 millones de personas que fueron obligados a dejar sus hogares por causa de los desastres y degradación ambiental ${ }^{3}$. La cantidad de estos desplazados ambientales forzados en el año 2011 fue de 16,5 millones de personas. Mientras que durante el año 2012, el número de las personas que fueron obligadas a desplazarse fue de 32,4 millones $^{4}$.

Todos estos números solamente corresponden a los desplazamientos ambientales producidos por los desastres o degradación repentina y rápida, tales como tsunamis, tifones, terremotos, huracanes, inundaciones.

Entre los años 2008 y 2012, el total de personas desplazadas por los desastres repentinos fueron de 142 millones $^{5}$, lo que equivale a 3,2 veces la población total de Argentina y 68,3\% de la población de Brasil.

A todo esto, sería necesario agregar aquellas personas que son obligadas a abandonar sus hogares por desastres de lenta duración, como el aumento del nivel del mar, el aumento de la temperatura, la desertificación y la erosión de los suelos.

Además, es relevante observar un caso particular que es el de los Pequeños Estados Insulares en Desarrollo y el de países con regiones costeras bajas. Estos países están en una situación muy grave, ya que son afectados tanto por los desastres repentinos y rápidos (tsunamis, inundaciones devastadoras, tifones y huracanes, entre otros), como por los procesos de lenta degradación, tales como el aumento del nivel del mar. Los países que están en peor situación son los que sufren la amenaza de la sumersión total o parcial de las islas. Estos últimos son Maldivas, Tuvalu, Kiribati e Islas Marshall.

\footnotetext{
${ }^{1}$ El Internal Displacement Monitoring Center (IDMC) es el Centro de Estudios sobre los Desplazamientos Ambientales creado por el Consulado Noruego para Refugiados (NRC).

${ }^{2}$ Estas estimaciones no diferencian si se trató de desplazados ambientales dentro de los países o si fueron transfronterizos, aunque observa que en gran parte permanecieron dentro del país. Además, se consideran únicamente los desplazamientos ambientales forzados causados por desastres repentinos.

${ }^{3}$ IDMC-NRC. Disceplacement due to natural hazard- induced disasters. Global estimates for 2009 and 2010, junio, 2011b, p. 11. Disponible en: <http://www.internal-displacement.org/assets/publications/2011/2011-globalestimates-2009-2010-global-en.pdf $>$ acceso 8 de diciembre de 2015.

${ }^{4}$ IDMC-NRC. Global estimates 2012. People displaced by disasters, mayo, 2013. p. 11. Disponible en: $<$ http://www.internal-displacement.org/assets/publications/2013/2012-global-estimates-corporate-en.pdf $>$ acceso 8 de diciembre de 2015.

${ }^{5}$ IDMC-NRC. Global estimates 2012. People displaced by disasters. Op.Cit., p. 11.
} 
En octubre de 2015, ACNUR declaró que hay 59,5 millones de personas que viven en las regiones más vulnerables a los desastres ${ }^{6}$.

Todos esos números relacionados revelan la magnitud de la situación vivida por los refugiados ambientales o desplazados ambientales forzados, los cuales sufren la violencia del desastre o degradación ambiental que arrastra con todo lo que aparece en su camino: vidas, viviendas, pertenencias personales, medios de vida, dejándoles desprovistos de cualquier mínimo de dignidad humana, sus derechos humanos pisoteados.

A pesar de toda esta situación infrahumana en la que viven los refugiados ambientales o desplazados ambientales forzados transfronterizos o externos, paradójicamente estas personas no tienen ninguna protección jurídica a nivel internacional. Estas personas son obligadas a abandonar sus hogares, debido a que son afectadas por una catástrofe ambiental, teniendo que desplazarse para otros lugares dentro o fuera del país. La catástrofe ambiental puede consistir en un desastre o degradación ambiental repentina o de un proceso gradual de degradación.

El problema que será analizado en esta tesis es la laguna normativa que existe en el derecho internacional en relación con los refugiados ambientales o desplazados ambientales forzados transfronterizos o externos hasta 2012.

Se ha establecido un recorte metodológico en relación con el examen de este objeto de estudio, el cual es espacial, porque solamente se considera la escala internacional, es decir el derecho internacional. Se analizan los desplazamientos ambientales forzados de los Pequeños Países Insulares en Desarrollo, los cuales sufren los procesos lentos de degradación y los desastres repentinos, y la situación de otros paises que sufren solamente los desastres repentinos. En relación con estos últimos países se ha establecido un recorte temporal que se refiere al período de tiempo que es analizado, el cual corresponde a los años 2010, 2011 y 2012.

Solamente, se considera el ámbito del derecho internacional, dejando de considerar otros ámbitos. La causa de este abordaje elegido reside en que los refugiados ambientales o desplazados ambientales forzados constituyen un problema de naturaleza internacional: porque estas personas están desprotegidas tanto por sus países de origen, así como por los países a los que arriban, constituyendo esto una de las justificaciones de la necesidad de que sean protegidos por el derecho internacional.

\footnotetext{
${ }^{6}$ UNITED NATIONS. HIGH COMMISSIONER FOR REFUGEES (UNHCR). The Environment \& Climate Change, octubre, 2015, p. 9. Disponible en: $<\mathrm{http} / / /$ www.unhcr.org/540854f49.pdf $>$ acceso 15 de diciembre de 2015 .
} 
Se podrá observarse posteriormente, los desastres o la degradación ambiental no respetan fronteras, sino que en la mayoría de los casos irrumpen en los escenarios atravesando varios países.

Essam EL-HINNAWI define los refugiados ambientales como "las personas que son forzadas a dejar su hábitat tradicional, temporariamente o permanentemente, debido a disturbios ambiental (natural o provocado por personas) que colocó en riesgo su existencia y/o afectó seriamente su cualidad de vida"7

Existen grandes similitudes entre esta figura y la de los refugiados, de los desplazados internos y los apátridas. Aunque estos tres últimos tienen protección en el derecho internacional. El concepto de desplazados internos incluye aquellos que se trasladan por causa de un desastre natural, aunque solamente se considera a los que se movilizan dentro del país. De modo que los desplazados ambientales forzados externos o los refugiados ambientales, es decir, los que escapan atravesando las fronteras, no tienen ninguna protección internacional.

Así queda configurada la ausencia de protección internacional de los refugiados ambientales o desplazados ambientales transfronterizos.

El camino que va del planteamiento de este problema a las soluciones propuestas en esta tesis gira sobre ejes temáticos, lógicamente concatenados e interrelacionados. Además, cada uno de estos núcleos de análisis responde a los cuestionamientos presentados y corresponde a las hipótesis planteadas en esta tesis.

El primer eje se refiere a la tentativa de establecer un concepto único de los refugiados ambientales o desplazados ambientales forzados, abarcando tanto los internos como los externos o transfronterizos. El segundo considera las violaciones a los derechos humanos sufridas por estas personas. El tercer eje reside en el examen de las causas por las que existe la laguna normativa de los desplazados ambientales transfronterizos o externos. El cuarto se refiere a la necesidad de establecer el organismo internacional que proteja a estos afectados y a la forma más viable para introducir esta protección en el derecho internacional. Por último, son considerados los derechos específicos de los refugiados ambientales o desplazados ambientales forzados que precisan ser considerados. De tal forma, cada uno de estos ejes temáticos gira sobre diversos cuestionamientos relacionados con la laguna normativa existente en el derecho internacional sobre los refugiados ambientales o desplazados ambientales forzados.

\footnotetext{
${ }^{7}$ RAIOL, Ivanilson Paulo Corrêa. Ultrapassando Fronteiras: a proteção jurídica dos refugiados ambientais. Porto Alegre: Nuria Fabris, 2010, p. 159.
} 
Ante esta nueva realidad que se presenta de forma evidente, concreta y extremadamente dramática, emergen principalmente los siguientes cuestionamientos:

1. ¿Existe la posibilidad de establecer un concepto único y que abarque a todas estas personas afectadas por el desastre? ¿Cuál sería la denominación más adecuada para designarlos?

2. ¿Estas personas sufren la violación de sus derechos? ¿Cuáles son los derechos violados de estas personas? ¿Esto justifica una protección internacional para los refugiados ambientales o desplazados ambientales forzados?

3. ¿Cuál es la causa de la falta de un régimen de estos refugiados ambientales o desplazados ambientales forzados transfronterizos o externos?

4. ¿Qué organismo del derecho internacional debería asumir la protección de estas personas?

5. ¿Cuál sería la forma más viable de introducir ese régimen de protección de los refugiados ambientales?

6. ¿Existen derechos específicos violados de los refugiados ambientales o desplazados ambientales forzados o tales derechos son los mismos de las figuras afines como desplazados internos, refugiados, apátridas? ¿Cuáles son los derechos específicos que deberían ser protegidos? ¿Cuáles los principios que necesitarían ser considerados en este régimen?

A cada una de estas líneas de cuestionamiento les corresponden las hipótesis que han sido analizadas en esta tesis, y que serán consideradas a continuación.

La primera hipótesis sostenida en esta tesis es si sería posible conceptualizar la figura de los refugiados ambientales o desplazados ambientales forzados constituyendo una única figura, más allá de si fueron desplazamientos internos o externos, de si el desastre obedeció a las causas de los cambios climáticos u otros cambios en el medio ambiente, de si el desastre fue producido por la actuación del hombre, de la naturaleza o de ambos.

Existen diversas dificultades que se presentan sobre la problemática de los refugiados ambientales o desplazados ambientales forzados. Una de ellas refiere a la falta de acuerdo sobre la denominación, otra a la falta de consenso sobre la conceptualización de estas personas. Ambas cuestiones están interrelacionadas, siendo que la primera es dependiente de la segunda. Porque aquellos que los denominan de refugiados climáticos, están refiriéndose únicamente a 
los que sufren los desastres producidos por los cambios climáticos, otros que los llaman migrantes pueden inducir a confundirlos con los inmigrantes, siendo que se trata de dos figuras diferentes, y así sucesivamente en relación con la multiplicidad de denominaciones. Tanto la denominación como el concepto adoptado derivan en una tercera cuestión que es la propuesta de solución al problema, esta última hará referencia a la limitación contenida en el concepto. De tal modo que, por ejemplo, un concepto que únicamente contemple los refugiados climáticos, solamente considerará una solución a los que fueron causados por los cambios climáticos.

Es necesario avanzar en estas cuestiones para poder consensuar un sistema de protección internacional para todas estas personas afectadas.

La segunda hipótesis es que los desplazados ambientales forzados sufren la violación de sus derechos humanos, lo cual eleva la cuestión a la instancia internacional, demostrando la necesidad de que sea establecido un régimen de protección específico en el derecho internacional.

La violencia del desastre o de la degradación ambiental arrastra con todo lo que encuentra a su paso: vidas, viviendas, pertenencias, alimentos, agua potable, salud, documentos, medios de sobrevivencia, infraestructura, servicios sanitarios, dejando a los sobrevivientes deambulando sobre los destrozos, sin saber para dónde ir, solo movidos por el impulso de sobrevivir escapando. Así, estas personas sufren la falta de alimentos, agua potable, viviendas, pérdidas de seres queridos, separación de las familias, falta de servicios médicos y de saneamiento. En lugar de la libertad de elegir donde vivir sobreviene la obligatoriedad de huir hacia otros lugares forzadamente.

Por otro lado, es preciso observar que del análisis de la figura de los desplazados ambientales forzados transfronterizos surgen algunas similitudes entre estos y el concepto de los refugiados, tales como:

- estas personas tienen que huir de estos países;

- obligatoriamente para salvar sus vidas;

- careciendo de protección en sus países de origen.

A pesar de estas semejanzas, se verifica que los refugiados están protegidos por la Convención sobre el Estatuto de los Refugiados de 1951 y su Protocolo Adicional de 1967, en tanto que los Refugiados Ambientales o Desplazados Ambientales Forzados Transfronterizos carecen de ese tipo de protección y de un organismo internacional que se haga cargo de estas 
personas. También hay similitudes con la figura de los apátridas, siendo que también estos tienen una protección internacional.

Otra contradicción que surge del análisis del derecho internacional vigente en la materia es que la definición de los desplazados internos incluye a los afectados por los desastres naturales, siendo que todos ellos están protegidos por el régimen internacional de los Principios Rectores de los Desplazados Internos.

Existe un denominador común entre los refugiados, los apátridas y los desplazados internos que es la violación de los derechos humanos, lo cual se desprende del análisis de los regímenes internacionales respectivos.

La tercera hipótesis sostiene que la causa de la falta de interés de la comunidad internacional para crear un régimen jurídico de protección específico para los derechos de los desplazados ambientales forzados transfronterizos o externos reside en que los que más precisan de esta protección son aquellos que viven en los países menos adelantados o en desarrollo o con problemas de fragilidad en su nivel de gobernabilidad o en los países con mayores poblaciones más pobres, que precisan de la asistencia internacional.

La definición de los desplazados internos incluye a los desplazados internos de los desastres naturales, siendo que todos ellos están protegidos por los Principios Rectores de los Desplazados Internos, creados por una resolución de la Asamblea General de Naciones Unidas $\mathrm{y}$, además, existe un organismo que cuida de los desplazados internos que es ACNUR, competencia designada a este organismo internacional a través de otra Resolución de la Asamblea General de Naciones Unidas.

Aquí emerge el otro cuestionamiento sobre las causas de que los desplazados internos de los desastres naturales estén protegidos, mientras que los externos no lo están, siendo que la única diferencia entre estas dos figuras es que unos atraviesan las fronteras internacionales y los otros se desplazan dentro del país. Esta diferencia en la trayectoria de la huida mayor o menor obedece en la mayoría de los casos a los recursos financieros que estas personas tienen, y no por causa de la voluntad de estos. Además, cabe reflexionar que en relación con los desplazados internos rige un principio de que el responsable primordial de estos es el Estado Nacional, lo cual lleva a profundizar este cuestionamiento, dada la naturaleza internacional de los Desplazados Ambientales Forzados Transfronterizos, anteriormente ya justificada.

Delante de estas figuras similares como los refugiados, los apátridas y los desplazados internos de los desastres, todas protegidas por el derecho internacional, surge el 
cuestionamiento sobre las causas por las que no son protegidos los desplazados ambientales forzados transfronterizos.

La cuarta hipótesis planteada en esta tesis es que ACNUR es el organismo más apto para asumir la protección de los desplazados ambientales forzados.

La quinta hipótesis sostenida en esta tesis que consiste en que la forma más adecuada a la realidad internacional es que la institucionalización tanto del régimen de protección específico a nivel internacional, así como la designación de ACNUR como organismo responsable por estos afectados es a través del mecanismo de una resolución de la Asamblea General de Naciones Unidas.

En la doctrina y en algunos organismos internacionales se pueden observar diversas propuestas sobre la introducción de un régimen específico de protección internacional a estas personas, sea a través de la creación de un Tratado Independiente, de un Protocolo Adicional o de la modificación de la Convención sobre el Estatuto de los Refugiados, entre otras.

Estas iniciativas contribuyen al debate sobre lo que debe ser protegido, quién debe ser protegido y cómo debe ser el tipo de protección.

Aunque el problema sobre el tipo de solución ${ }^{8}$ presentada para la cuestión por la doctrina consiste en que es necesario llevar en consideración la voluntad de los organismos internacionales y de los Estados, es decir que es necesario incorporar en el análisis la viabilidad de la propuesta a la luz de la realidad internacional ${ }^{9}$.

De ello surgen los cuestionamientos sobre qué derechos deben ser protegidos, cuál es el organismo más apto para hacerse cargo de estos desplazados y cuál es la forma jurídica más factible para aplicarse a esta situación. Estos dos cuestionamientos corresponden a la cuarta hipótesis señalada arriba.

Finalmente, las respuestas a la pregunta sobre cuáles serían los derechos específicos de los refugiados ambientales o desplazados ambientales forzados que precisan ser protegidos derivan del examen de los abordajes de la doctrina y de los organismos internacionales analizados en esta tesis.

Sobre los procedimientos metodológicos utilizados en este estudio, puede decirse que, en rasgos generales, han sido utilizados como fuentes los documentos de los principales organismos que están relacionados con la problemática, entre otros, los de ACNUR, IASC, Alto

\footnotetext{
${ }^{8}$ Ya sea a través de un Tratado Internacional, de un Protocolo Adicional, o por la modificación de la Convención sobre el Estatuto de los Refugiados, y así sucesivamente.

${ }^{9}$ Existe resistencia de los Estados a la creación de una Convención Internacional que regule la situación de los refugiados ambientales, como será observado a lo largo de esta tesis.
} 
Comisionado de Naciones Unidas para los Derechos Humanos, Consejo de Derechos Humanos de Naciones Unidas, Internal Disceplacemente Monitoring Center (IDMC) ${ }^{10}$ del Consejo Noruego de Refugiados, las Resoluciones de Naciones Unidas, incluyendo las de la Asamblea General y de ECOSOC (Consejo Económico y Social de Naciones Unidas), Declaraciones y otros Instrumentos Internacionales de los Derechos Humanos, así como los de los Comités Específicos de ECOSOC para los derechos humanos y la información brindada por el Banco Mundial, Iniciativa NANSEN. El aporte de la doctrina internacional que trata sobre la problemática, en su gran mayoría extranjera, la más actualizada y reciente.

En el primer capítulo serán analizados la génesis, la creación y el Estatuto de ACNUR, así como el proceso evolutivo desarrollado en el seno de este organismo para hacer frente a los desafíos presentados en el período que va desde su creación hasta el año 1960.

En el segundo capítulo serán abordados las denominaciones y los conceptos de esta figura presentados por la doctrina y por algunos organismos internacionales. Además, se introducen los aspectos constitutivos para la construcción de una figura única de los desplazados ambientales forzados o refugiados ambientales.

En el tercer capítulo, se analizará la relación entre los desplazados ambientales forzados o refugiados ambientales y sus derechos humanos.

En el capítulo cuarto, será presentada la relación entre la pobreza y los países que sufren los desplazamientos ambientales forzados en los años 2010, 2011 y 2012, a la luz de la teoría del Ecologismo de los Pobres.

En el capítulo quinto, serán exhibidas las diferentes propuestas presentadas por la doctrina para hacer frente a la falta de regulación internacional de los desplazados ambientales forzados.

En el capítulo sexto, será analizada la capacidad potencial de ACNUR para asumir la responsabilidad por los desplazados ambientales forzados. En segundo lugar, serán consideradas observaciones sobre el tipo de vía utilizada para que fuese viabilizado un régimen internacional de protección para estas personas, así como para la designación del organismo específico.

En el capítulo séptimo, serán presentadas algunas consideraciones específicas que deben ser observadas en el régimen de regulación internacional de los desplazados ambientales forzados.

\footnotetext{
${ }^{10}$ IDMC es el Centro de Información sobre los Desplazamientos Internos del Consejo Noruego de Refugiados.
} 
En último término, en las Consideraciones Finales se establecerá un conjunto de respuestas desarrolladas en relación con las conjeturas propuestas en la Introducción y a lo largo de la tesis sobre el tratamiento de la problemática sostenida. Además, surgen una serie de sugestiones relacionadas con la temática en el ámbito del derecho internacional. 


\section{CAPITULO I}

\section{DERECHO INTERNACIONAL DE LOS REFUGIADOS}

\section{I.1. Introducción}

Después de la Segunda Guerra Mundial, se inició un período en el que surgía la necesidad internacional de atender a los grandes grupos de personas que habían tenido que escapar de sus hogares y países por la persecución realizada por los Estados. Estos seres fueron desplazándose de un lugar a otro, sin destino, con sus derechos humanos violados y sin la protección de un Estado Nacional que les asegurase los mínimos derechos. Estas personas eran los refugiados de la posguerra. Ese problema ya había acontecido anteriormente.

Después de lo ocurrido en el holocausto nazi de judíos y de otros grupos perseguidos, los países depositaron sus ojos en la importancia de proteger la dignidad del hombre, creándose la Declaración Universal de los Derechos Humanos, donde fueron institucionalizados todos los derechos fundamentales para la vida digna del ser humano.

Es necesario observar que, en el período de la Segunda Guerra, así como en los años que la antecedieron, la humanidad vivió los peores horrores contra el ser humano, uno de estos fue el holocausto, el cual significó la muerte de seis millones de judíos.

Esto demostró la terrible capacidad del hombre de usar el poder para eliminar a otros hombres de las peores maneras. Esto tenía por detrás una política de eliminación, de tortura hacia los que eran diferentes, y permite entrever un paradigma de cosificación del hombre. En este último sentido, no se considera al ser humano como tal sino como un objeto que sirve para ser usado como una cosa y, luego, descartado.

El profesor Eduardo TINANT observa que ese período histórico fue regido por el principio de "el fin justifica los medios", donde el hombre es considerado como medio. Además, esa etapa de la historia estuvo marcada por un "darwinismo social", donde observar:

Fueron principios fundamentales del darwinismo social:

- Una moral relativa;

- los seres humanos no tienen un estatuto singular;

- la dignidad humana es relativa;

- algunas vidas no valen la pena ser vividas (Lebensunwertes lebens: vidas indignas de vivirse, propio del programa de eutanasia masiva nazi); 
- la supervivencia de los más aptos ${ }^{11}$.

Todos estos principios implican una concepción relativista de la ética, donde en lugar de que esta sea guiada por la búsqueda del bien común del grupo social, el valor que impera es la cosificación del otro, la superioridad de algunos sobre los otros, la negación de la dignidad humana como valor supremo y universal.

Este período oscuro y sombrío de la historia se opone diametralmente al surgimiento de un tiempo nuevo en la posguerra, caracterizado por el reconocimiento de nuevos paradigmas, donde se considera al hombre como señor de su vida, donde deja de vérselo como una "cosa" y se consagran a nivel universal los derechos mínimos del hombre, derechos necesarios para la realización de la dignidad.

Kant señala que lo que no tiene precio es digno, de forma que la dignidad es lo humano, e implica una barrera para la concepción de la cosificación de la persona.

De este modo, la sociedad internacional llegó al consenso de la necesidad de reconocer un conjunto de reglas mínimas que constituyen mecanismos internacionales que permitan la universalización de la dignidad humana a través de la realización de los derechos humanos.

En tal sentido, el profesor Eduardo TINANT considera:

Los horrores experimentados y la búsqueda y análisis de las causas que los propiciaron y consiguiente toma de conciencia, llevaron a partir de la segunda mitad de la década de 1940, entre otros cambios, a una marcada renovación del pensamiento jusfilosófico, a saber: (a) el resurgimiento del derecho natural, [...] (b) la consagración de la teoría de los derechos humanos (derechos fundamentales), con la Declaración Universal de los Derechos Humanos (ONU, Nueva York, 1948) (14); [... $]^{12}$.

Es así como emergen los Derechos Humanos consagrados universalmente.

La Declaración Universal de los Derechos Humanos de 1948 estableció el derecho a brindar asilo a estas personas. Aunque con este instrumento internacional no alcanzaba para solucionar la gravedad de la situación vivida por estos refugiados.

De tal modo, en diciembre de 1950 fue instituido el Alto Comisionado de Naciones Unidas para los Refugiados (ACNUR), que comenzó a funcionar el 1 de enero de 1951, cuyo objetivo era la protección de estas personas. Además, en 1951 fue creada la Convención sobre el Estatuto de los Refugiados.

El derecho de los refugiados surgió luego de un tenso proceso de negociaciones entre los Estados en medio del contexto de la Guerra Fría, donde cada Estado tenía sus intereses

\footnotetext{
${ }^{11}$ TINANT, Eduardo. El Holocausto y su influencia en el nacimiento de la Bioética. Del Código de Núremberg a la Declaración de Helsinki. En Revista de Derecho de Familia y de las Personas, La Ley, 2013, p. 3.

12 TINANT, 2013. Op.cit., p. 3-4.
} 
propios en relación con la definición del refugiado y la creación de este organismo. La Unión Soviética era contraria, los Estados Unidos pretendían un organismo dependiente y transitorio, y los países europeos querían un órgano autónomo y permanente.

Puede observarse que toda esta situación hizo que cada artículo de esa Convención fuese arduamente discutido, llegando a una definición de refugiado muy restricta y a un ACNUR con competencias consultivas.

Estados Unidos querían que ACNUR solamente realizase los trámites legales en los países receptores, es decir, "actividades consultivas y de coordinación o llamadas de "protección"” y que no se ocupase de la "asistencia material" de estos refugiados. Además, no querían brindar fondos económicos ${ }^{13}$.

En este contexto surgió ACNUR, con todas esas limitaciones. Aunque a pesar de todo ello, ACNUR fue adecuándose a los nuevos desafíos de la realidad social e internacional que tuvo que enfrentar.

El análisis del período 1951-1960, que será realizado en este capítulo, permite considerar que este organismo tiene una gran flexibilidad y un carácter humanitario muy importante por lo que demuestran que ACNUR tiene una gran capacidad de adaptación a las necesidades de la realidad social e internacional.

Esto último lleva a reflexionar sobre la posibilidad sostenida en una de las hipótesis de esta tesis que señala que ACNUR sería el organismo con mayor competencia para tratar la cuestión de los refugiados ambientales o desplazados forzados ambientales.

Este capítulo gira en torno de dos ejes: el primero es el estudio de las situaciones que originaron la creación del Alto Comisionado de Naciones Unidas para los Refugiados (ACNUR), el cual se cristalizó en una estructura normativa con diversas limitaciones. Aunque un análisis de los acontecimientos ocurridos entre 1951 y 1962, permite verificar el proceso de adaptación de esta estructura jurídica restricta a las nuevas exigencias.

El segundo eje es el examen de la Convención sobre los Refugiados de 1951, donde es definida la figura del refugiado. También, este instrumento internacional estuvo lleno de limitaciones. La relevancia de este último análisis reside en las grandes similitudes entre el refugiado y los desplazados ambientales forzados.

\footnotetext{
13 ACNUR. La situación de los refugiados en el mundo: Cincuenta años de acción humanitaria. Barcelona: ICARIA Editorial, 2000, p. 23.

Disponible en: <http://www.acnur.org/t3/fileadmin/scripts/doc.php?file=biblioteca/pdf/2004> acceso

3 de setiembre de 2012.
} 
Por lo tanto, el objetivo de este capítulo es analizar la génesis del proceso que dio origen al ACNUR y la Resolución que lo instituyó, así como considerar la relación entre la creación de ACNUR, su estatuto, la Convención sobre el Estatuto de Refugiados de Ginebra con los acontecimientos históricos ocurridos en ese momento. Tal correlación entre ambos aspectos corresponde a la relación entre la realidad sociopolítica y el derecho.

Otro objetivo de este capítulo busca demostrar la unidad entre la figura del refugiado y la violación de sus derechos humanos, la cual a pesar del transcurso de la historia persiste en el tiempo.

El derecho de los refugiados está íntimamente relacionado con los derechos humanos, pues los refugiados son personas que tienen sus derechos humanos violados y que no tienen la protección de ningún país.

La definición de refugiado de la Convención de Ginebra de 1951 observó específicamente la situación particular de la posguerra de los refugiados, por lo tanto, no consideró los conceptos generales de la figura tales como la violación a los derechos humanos vivida por esas personas. Aunque el análisis de estos supuestos considerados en tal instrumento internacional lleva a comprender la unidad entre la figura del refugiado y sus derechos humanos.

ACNUR ha sido un organismo internacional que, a pesar de las diversas restricciones establecidas en su ordenamiento jurídico, consiguió hacer frente a realidades que estaban fuera de su mandato. Con la finalidad de alcanzar este objetivo, se analizará el proceso de evolución que se produjo en el derecho originario ${ }^{14}$ de este organismo (la evolución de esa normativa jurídica internacional).

Este es el objetivo más importante de este capítulo, pues tiene que ver con la última hipótesis de esta tesis, como ya fue observado anteriormente.

En primer lugar, será analizado el contexto en el que se crea ACNUR y el proceso de resoluciones que surgieron de la Asamblea General de Naciones Unidas que dieron origen al ACNUR, siendo abordados los aspectos de su Estatuto, donde son contenidos los trazos jurídicos de tal organismo como competencias y funciones, financiamiento, duración, relación con ECOSOC y con la Asamblea General de Naciones Unidas.

\footnotetext{
${ }^{14}$ El derecho originario de una organización internacional es el conjunto de normas jurídicas establecidas para su creación, entre las que se encuentran: la finalidad, las competencias y los objetivos del organismo que será creado. Y está formado por la Convención Constitutiva, y por el Protocolo Adicional a la Convención. ACNUR es un organismo de Naciones Unidas, por lo tanto, ha sido creado por las Resoluciones de la Asamblea General de Naciones Unidas.
} 
En segundo lugar, será examinada la Convención de Ginebra de 1951 sobre el Estatuto de los Refugiados, en la cual se establece la definición, sus límites, las causas de cesación y el principio de no devolución.

En tercer lugar, será analizada la serie de acontecimientos que ocurrieron en el período 1951-1960, cuando ACNUR tuvo que hacer frente a grandes desafíos en materia de refugiados que escapaban de su mandato.

En cuarto lugar, serán analizados los aspectos más relevantes del Protocolo Adicional de la Convención de Refugiados de 1967.

En quinto lugar, serán presentadas algunas consideraciones finales.

\section{I.2. La creación del ACNUR}

A finales de la década de 1940, se agudizó la Guerra Fría entre los dos bloques, el de Estados Unidos junto con sus países aliados y el de la Unión Soviética acompañada por los otros países comunistas. Hubo una serie de acontecimientos que recrudecieron la Guerra Fría:

El bloqueo de Berlín de 1948-1949 fue seguido, en rápida sucesión, de la explosión de la primera bomba atómica soviética, la formación de dos Estados alemanes, la creación de la Organización del Tratado del Atlántico Norte, la victoria de Mao Zedong en China y el inicio de la guerra de Corea en 1950.

Una de las consecuencias de tal situación fue el aluvión masivo de nuevos refugiados que escapaban del comunismo de los países que hacían parte de la Unión Soviética ${ }^{15}$.

SARAIVA designa a la etapa entre 1947 y 1955 como "relación caliente" entre los polos de poder, dados los continuos conflictos y crisis ${ }^{16}$.

La Guerra Fría era el nuevo paradigma que reinaría en el orden internacional, el cual puede ser muy bien entendido a través de la teoría de las relaciones internacionales del realismo político.

Se trató de un equilibrio en el orden internacional que se producía a través de la división del poder internacional entre los dos países más poderosos: Estados Unidos y la Unión Soviética. Las organizaciones internacionales no eran más que centros de concentración de poder de los Estados, no teniendo ningún tipo de voluntad diferente a la de sus miembros. La

\footnotetext{
${ }^{15}$ ACNUR. La situación de los refugiados en el mundo: Cincuenta años de acción humanitaria. Barcelona: ICARIA Editorial, 2000, p. 20.

Disponible en: <http://www.acnur.org/t3/fileadmin/scripts/doc.php?file=biblioteca/pdf/2004> acceso

3 de setiembre de 2012.

${ }^{16}$ Saraiva apud en MOREIRA, Julia Bertino. A questão dos refugiados no contexto internacional (de 1943 aos dias atuais). Disertación de Maestría. Universidade Estadual de Campinas. Instituto de Filosofia y Ciencias Humanas, 2006, p. 55. Disponible en: <http://pt.scribd.com/doc/6735041/Refugiados $>$ acceso 7 de septiembre de 2012 .
} 
voluntad de las organizaciones internacionales era idéntica a la suma, o mejor dicho, al resultado de la suma de las voluntades de los Estados miembros (según la New Real Politik). Porque los países que hacían parte de esas organizaciones internacionales no habían concedido competencias supranacionales ${ }^{17}$, sino que los Estados miembros habían recortado los poderes otorgados y existía una dependencia de la voluntad de los Estados partes.

Después de la Segunda Guerra Mundial, hubo grandes poblaciones deambulando por el viejo continente, otras escapaban del bloque comunista, los cuales eran los refugiados. También, surgieron los refugiados como resultado de la división de la India, en Paquistán e India. Además, estaban los refugiados palestinos. La situación de los refugiados precisaba ser solucionada a nivel internacional.

Por un lado, aparece este problema de los refugiados, que cada vez iba aumentando, dejando los límites de Europa y llegando a los más lejanos lugares.

Por otro lado, este escenario demuestra las dificultades que serían enfrentadas para la creación de ACNUR, dadas las circunstancias de la Guerra Fría, que se reflejaba por la divergencia absoluta entre las concepciones de uno y otro bloque. Esta situación afectaba directamente a la formación de consenso en las relaciones internacionales.

La creación del ACNUR fue precedida por ese período de negociaciones tensas propias de la Guerra Fría, presiones entre los dos bloques. Las posiciones enfrentadas eran muy claras: de un lado, la Unión Soviética y su bloque de países que eran contrarios a la creación de este organismo, porque consideraban que serviría para ayudar a los que querían escapar del comunismo. Por otra parte, el resto de los otros países eran favorables a la institucionalización de un organismo que solucionase el problema de los refugiados.

Además, en esta última posición existían diferentes concepciones de cómo debería ser este organismo. Estados Unidos buscaba la creación de un órgano que diese solución al problema, el cual debía ser transitorio, que no necesitase de muchos recursos económicos y con un ámbito de competencias totalmente limitado. En este último sentido, ese organismo solamente debería ocuparse de la protección y no de la asistencia material, pues este último tipo de actividades requerirían muchos recursos económicos. Las actividades de protección solamente se limitaban a brindar los documentos y solicitar la admisión por parte de los Estados receptores. Además, Estados Unidos no quería que ACNUR pudiese buscar fondos económicos voluntarios. Otra posición era la de los países de Europa occidental, Paquistán e India, quienes

\footnotetext{
${ }^{17}$ Las organizaciones supranacionales son aquellas en las que los Estados miembros ceden poderes o competencias propias de los Estados, por los cuales la organización tiene una voluntad propia, que puede llegar a ser diferente a la de los Estados miembros.
} 
pretendían un organismo autónomo, con poder propio, no transitorio, y que pudiese buscar recursos económicos. La posición de estos países refleja los intereses concretos que tenían en la cuestión, pues en Europa Occidental continuaban deambulando los refugiados ${ }^{18}$.

ANDRADE observó que Naciones Unidas presentó tres posibilidades:

1. Un organismo especializado, fuerte y autónomo;

2. que Naciones Unidas asumiese ese compromiso para sí misma;

3. un organismo dependiente de Naciones Unidas ${ }^{19}$.

En realidad, la tercera opción fue la posición adoptada.

ANDRADE consideró que otro de los problemas que se plantearía era el relacionado con el financiamiento de este organismo. Esta cuestión estaba referida a las actividades que se esperaba que el nuevo órgano desarrollase. Los países europeos eran favorables a que ACNUR brindase protección y asistencia material a los refugiados. Consecuentemente, precisaría fuentes de financiamiento. Estados Unidos era de la idea de que ACNUR debería solamente ocuparse de la protección, y no de la asistencia. De este modo, no necesitaría grandes recursos económicos.

Finalmente, lo convenido fue que ACNUR tuviese un escaso financiamiento (el presupuesto era de 300.000 dólares y 88 funcionarios). Con esto, ACNUR podía solamente hacer trámites legales y pedir la aceptación de los refugiados por parte de los Estados. Aunque en el año 1951, la Fundación Ford hizo un aporte voluntario de 3,1 millones de dólares para ACNUR. En 1954, fue creado un Fondo para Refugiados de Alemania, Austria, Grecia e Italia $^{20}$

De tal modo, después de grandes discusiones y negociaciones entre esos sujetos internacionales, los países reunidos en la Asamblea de Naciones Unidas decidieron crear un organismo dependiente de la Asamblea General de Naciones Unidas y de ECOSOC ${ }^{21}$, para que solucionase el problema de los refugiados. La Asamblea General de Naciones Unidas dictó la Resolución 319 (IV), del 3 de diciembre de 1950, a través de la cual se creaba el Alto Comisionario para los Refugiados. La XI Resolución 428 de la Asamblea General de Naciones

\footnotetext{
${ }^{18}$ ACNUR, 2000. La situación de los refugiados en el mundo. Op. cit., p. 23.

${ }^{19}$ ANDRADE, José Enrique Fischel. A Política de Proteção dos Refugiados da Organização de Nações Unidas. Sua Gênese no Período Pós-Guerra (1946-1952). Tesis de Doctorado, Universidade de Brasília. Instituto de Relações Internacionais, Brasília, 2006, p. 264.

${ }^{20}$ ACNUR, 2000. La situación de los refugiados en el mundo. Op. cit., p. 26.

${ }^{21}$ ECOSOC es el Consejo Económico y Social de Naciones Unidas.
} 
Unidas, del 14 de diciembre de 1950, creó el Estatuto del Alto Comisionado de Naciones Unidas, donde fueron establecidas las competencias, la elección y duración en el cargo, el financiamiento y la organización del ACNUR.

El 10 de setiembre de 1951, ECOSOC dictó la Resolución 393 (XIII) B que creó un Comité Consultivo para los Refugiados. El 31 de marzo de 1955, el Consejo Económico y Social transformó ese Comité Consultivo en Comité Ejecutivo del Fondo de las Naciones Unidas para los Refugiados (FNUR), a través de la Resolución 565 (XIX) y en concordancia con la anterior Resolución 832 (IX), de la Asamblea General de Naciones Unidas del 21 de octubre de 1954. El 26 de noviembre de 1957, la Asamblea General de Naciones Unidas elaboró la Resolución 1166 (XII) a través de la cual se transformó ese último órgano en el Comité Ejecutivo del Programa del ACNUR, integrado por 24 países. El 30 de abril de 1958, ECOSOC dictó la Resolución 672 (XXV) en concordancia con esa última resolución, dando cumplimiento a tal transformación. El 12 de diciembre de 1963, la Resolución 1958 (XVIII) de la Asamblea General de Naciones Unidas incrementó los miembros integrantes de tal Comité en 30. El 11 de diciembre de 1967, la Asamblea General de Naciones Unidas dictó la Resolución 2294 (XXII) que aumento ese número en 31 miembros $^{22}$. En síntesis, el Comité Consultivo pasó por diversas transformaciones hasta convertirse en el Comité Ejecutivo del Programa del ACNUR. También, la formación de este Comité fue gradual, ya que comenzó con 24 miembros llegando a tener 31, de modo de tener mayor representatividad de los Estados y, con esto, mayor apoyo.

Como fue observado, el proceso de las negociaciones entre los Estados para la creación de la ACNUR constituyó un juego donde cada país tenía una posición diferente en relación con la situación de los refugiados, la cual dependía del nivel en que se veían afectados sus intereses particulares. Un fiel reflejo de esto fue la posición de los países europeos, de India y de Paquistán.

Otros países pretendían solucionar el problema, aunque sin que fueran establecidos grandes compromisos internacionales para estos países, como era el caso de Estados Unidos.

Por otro lado, había países que si bien buscaban soluciones al problema no querían crear nuevos núcleos de poder, que hicieran más complicada la situación de la política internacional, porque si los Estados aumentaban el poder de una organización, estarían creando un nuevo actor internacional para las negociaciones.

${ }^{22}$ NÚCLEO DE ESTUDOS DE POLÍTICAS PÚBLICAS EM DIREITOS HUMANOS (Universidade Federal de Rio de Janeiro- UFRJ). Introdução, Estatuto do alto comissariado das Nações Unidas para os refugiados, 1949. Disponible en: <http://www.nepp-dh.ufrj.br/onu15-9.html> acceso 5 de agosto de 2012. 
Las propuestas de brindar autonomía a este nuevo organismo, que eran las defendidas por los países afectados fueron totalmente impugnadas, sin que existiese una posibilidad de negociación. Esta situación se verá claramente verificada cuando sean analizadas las Resoluciones que dieron origen al ACNUR, pues en ellas se verifica la dependencia del ACNUR a ECOSOC y a la Asamblea General de Naciones Unidas.

En síntesis, los problemas en relación con la creación del ACNUR fueron la cuestión de la negación de la autonomía, el recorte de sus competencias, así como la transitoriedad y el financiamiento. De tal modo, como se observa, tanto la creación del ACNUR, como la formación de su estructura orgánica, obedeció a un proceso evolutivo de resoluciones de la Asamblea General de Naciones Unidas y de ECOSOC (se trataba de derecho de las organizaciones internacionales derivado). De esa forma, todo lo que se decidía o se realizaba en ACNUR debía ser aprobado por ECOSOC y, finalmente, eran presentados los informes a la Asamblea General.

Además, el proceso de la política internacional en relación con el ACNUR se fue modificando con la entrada de nuevos países a la Asamblea y con esto fue aumentando la voluntad de democratización y representatividad en el organismo, a través de la participación en el Comité Ejecutivo del Programa del Alto Comisionado.

Asimismo, en 1949, fue constituido el Organismo de las Naciones Unidas de las Obras Públicas y Socorro a los Refugiados de Palestina en el Próximo Oriente ${ }^{23}$.

\section{I.3. La Resolución de creación de ACNUR}

La Asamblea General de Naciones Unidas creó el Alto Comisionado de Naciones Unidas para los Refugiados (ACNUR) a través de Resolución 319 (IV), del 3 de diciembre de 1950. La Resolución 428 (V) de la Asamblea General de Naciones Unidas del 14 de diciembre de 1950 instituye y aprueba el Estatuto del Alto Comisionado de Naciones Unidas para los Refugiados, que posteriormente será analizado.

En el primer capítulo del Estatuto del Alto Comisionado de las Naciones Unidas para los Refugiados se establece que el Comisionado se ocupará de la admisión de los refugiados y que la principal función del Comisionado consiste en dar ayuda a los refugiados internacionales, tratando de facilitar la repatriación o la asimilación a la comunidad local.

${ }^{23}$ MOREIRA. Op.cit., p. 55. 
Además, se dispone las relaciones de este órgano con la Asamblea General de Naciones Unidas, sustentando que depende de la autoridad de esta última. También, se instaura las relaciones del Alto Comisionado de Naciones Unidas con el Consejo Económico y Social. Por lo tanto, el Alto Comisionado de los Refugiados recibiría la dirección de esos dos órganos de Naciones Unidas.

El Alto Comisionado de Refugiados tendrá la competencia de dar la protección a los refugiados, comprendiendo la repatriación voluntaria o la reintegración a la nueva sociedad. (apartado 1). En el apartado 2 de la Resolución 428 (V) del 14 de diciembre de 1950 se establece que ACNUR será apolítico ${ }^{24}$.

El Estatuto de la ACNUR considera que la labor de este organismo será apolítica, humanitaria y social. Mas esa primera característica suscitó una serie de dudas sobre si sería posible que un organismo internacional realizase un trabajo apolítico. En el orden internacional, ¿existen actos que pudieran ser considerados como apolíticos?

MOREIRA cita las diferentes posiciones de varios autores. La autora observa que, para LOESCHER, la acción de la ACNUR no era apolítica porque expresaba la voluntad de actores más poderosos del orden internacional. En ese mismo sentido, se manifiestan HATHAWAY, BOOKSTEIN Y KHAN. Según HYNDMAN:

\footnotetext{
No hay soluciones humanitarias apolíticas capaces de resolver o al menos tratar los desplazamientos humanos, teniendo en vista que estos son eventos políticos. En razón de esto, para la autora, el humanitarismo es un proceso politizado que balanza las necesidades de los refugiados y de las otras personas desplazadas con los intereses de los Estados.
}

Algunos autores de la doctrina sostienen que esa característica de "apolítica" era para justificar la actuación del ACNUR en un período de grandes tensiones entre los bloques de la Guerra Fría ${ }^{25}$.

La duración del Alto Comisionado en sus funciones es de 3 años.

Además, sobre la duración del organismo, se establecía en el parágrafo 5 de la Resolución 428 de la Asamblea General de Naciones Unidas: "La Asamblea General reexaminará, más tardar en la octava sesión ordinaria, las disposiciones relativas al Alto

\footnotetext{
24 NACIONES UNIDAS. ASAMBLEA GENERAL. XI Resolución 428 (V), 14 de diciembre de 1950. Establecimiento de la Oficina del Alto Comisionado de las Naciones Unidas para los Refugiados. Disponible en:

$<$ http://www.acnur.org/t3/recursos/bdl/bdl/\%3FeID\%3Ddam_frontend_push\%26docID\%3D5615> acceso 5 de agosto de 2012.

${ }^{25}$ MOREIRA. Op. cit., p. 56.
} 
Comisionado, a fin de decidir si el mismo debe continuar las funciones después del día 31 de diciembre de 1953."

En el apartado 3, establece que adoptará las decisiones de la Asamblea General y de ECOSOC. Además, en el apartado 9 de la misma Resolución, establece: "El Alto Comisionado emprenderá cualquier otra actividad adicional que pueda prescribir la Asamblea General, en particular la de repatriación y reasentamiento de refugiados, dentro de los límites de los recursos puestos a su disposición."

El parágrafo 4 de la Resolución 428 de la Asamblea General de Naciones Unidas establece que es competencia de ECOSOC la de crear un órgano consultivo.

El capítulo segundo establece las funciones y competencias que le caben al Alto Comisionado.

Los apartados 6 y 7 establecen que el Alto Comisionado tendrá competencia sobre los refugiados, entendidos según la definición del Estatuto de los Refugiados.

El aparatado 8 establece la protección de los refugiados. En tal sentido, se observa:

Las principales funciones del ACNUR quedaron establecidas en dos aspectos: en primer lugar, proporcionar protección internacional a los refugiados; $\mathrm{y}$, en segundo lugar, buscar soluciones permanentes al problema de los refugiados ayudando a los gobiernos a facilitar su repatriación voluntaria o su asimilación dentro de unas nuevas comunidades nacionales ${ }^{26}$.

El Alto Comisionado tiene la facultad de crear representaciones en países, previa consulta a los gobiernos de los países de los refugiados (Apartado 16).

ACNUR no tiene la competencia de requerir recursos económicos sin autorización de la Asamblea General de Naciones Unidas (Apartado 10).

Según el apartado 11, todos los años, ACNUR deberá exhibir un informe a la Asamblea General por medio del ECOSOC. Además, el ACNUR podrá manifestar sus pareceres ante el ECOSOC y la Asamblea.

En el capítulo tercero establece las reglas sobre el funcionamiento y la organización de ACNUR.

El Secretario General de Naciones Unidas presenta una lista de posibles candidatos a la Asamblea General y este organismo escoge uno de esa lista. La duración del Alto Comisionado es de 3 años (Apartado 13). El Alto Comisionado designará un adjunto. La duración en las funciones del Alto Comisionado será de 3 años (Apartados 13 y 14).

${ }^{26}$ ACNUR, 2000. La situación de los refugiados en el mundo. Op. cit., p. 26. 
Las actividades desarrolladas para cumplir con la misión de ACNUR están bajo la autoridad del Alto Comisionado y del Secretario General (Apartado 17).

La Sede del ACNUR estará en Ginebra (Apartado 19).

Naciones Unidas enviará los recursos económicos necesarios para el funcionamiento de $\mathrm{ACNUR}^{27}$.

Un problema muy difícil de superar fue la falta de fondos financieros, pues Estados Unidos se negaba a entregárselos. Entonces, la estrategia fue recurrir a particulares que financiaran las actividades de ACNUR. De tal modo se recurrió a la Fundación Ford, la que contribuyó con 3,1 millones de dólares ${ }^{28}$.

Es necesario observar en relación con el dinero aportado por la Fundación Ford: "Esta cantidad se empleó para un proyecto piloto, que por primera vez hizo hincapié en la integración local en países europeos como solución a los problemas de los refugiados". Por otro lado, cabe considerar que se instituyó el Fondo de Naciones Unidas para los Refugiados (FNUR), en 1954. Este Fondo ayudaría a los proyectos de Austria, República Federal de Alemania, Grecia e Italia. Se considera:

Los Estados Unidos no contribuyeron a este fondo tras haberse negado a financiar al ACNUR debido a la decisión adoptada por el Congreso estadounidense en 1950 de vetar el uso de dinero estadounidense para cualquier organización internacional que trabajase en países situados al otro lado del Telón de Acero ${ }^{29}$.

Por otro lado, la Unión Soviética, que era inicialmente opositora de tal organismo, flexibilizó su posición. Este país verificó la entrada de países en desarrollo en las Naciones Unidas y, a su vez, estos veían la importancia de la acción de la ACNUR, y de tal forma le brindaban el apoyo.

En realidad, podría decirse que ACNUR surgió a pesar de las resistencias políticas de la Unión Soviética y de las restricciones impuestas por los Estados Unidos. Posteriormente, este organismo fue abriéndose camino y ganando su campo de actuación enfrentando adversas situaciones.

La Unión Soviética y sus aliados, los países del Este Europeo, sustentaban que detrás de la Convención sobre el Estatuto de los Refugiados estaba la intención de los países

\footnotetext{
${ }^{27}$ NACIONES UNIDAS. ASAMBLEA GENERAL. XI Resolución 428 (V), 14 de diciembre de 1950, Op.Cit.

${ }^{28}$ MOREIRA. Op. cit., p. 58.

${ }^{29}$ ACNUR, 2000. La situación de los refugiados en el mundo. Op. cit., p. 26 y 28.
} 
capitalistas de sacar a las personas que vivían en los países socialistas y comunistas, para debilitar ese bloque, utilizando ese instrumento como forma de promover la salida ${ }^{30}$.

\section{I.4. La Convención de Ginebra sobre el Estatuto del Refugiado de 1951}

En el mes de julio de 1951, se realizó una Conferencia Internacional con la finalidad de crear la Convención sobre el Estatuto de los Refugiados. La vigencia de este instrumento internacional se produjo en 1954.

Este instrumento de protección a los refugiados fue el primero a tener un sentido individualista en vez de ser colectivo como el que tenían los documentos internacionales anteriores.

El primer problema que surgió fue en relación con el concepto de refugiado, si este sería universalista o si se trataría solamente de los refugiados de origen europeo. De tal modo, surgieron dos posiciones entre los países: aquellos que consideraban que debería tratarse solamente a los refugiados de origen europeo y los países que consideraban que la definición debería ser independiente del lugar de donde proviniera el refugiado. Los primeros países fueron llamados europeizantes y los segundos, universalistas.

Estados Unidos era uno de los países que pretendía una definición restringida, porque su preocupación era auxiliar a los que escapaban del comunismo. Así, aquellas personas que escapasen de los países del este europeo quedaban incluidas.

Además, otro de los argumentos en favor de esta posición fue que los países ya habían recibido grandes grupos de refugiados, y un concepto universalista podría significar grandes cargas económicas que no podrían enfrentar.

Esta Convención establecía las obligaciones de los Estados en relación con los refugiados, lo cual precisaría ser incorporado al derecho interno de cada país. Asimismo, instituía los derechos de los refugiados, tales como: "los documentos de viaje, educación, acceso a la justicia, hasta mismo de ser propietarios de inmuebles"31.

El análisis de este proceso de negociación en el derecho internacional permite visualizar el juego entre los intereses y necesidades de los países que estaban por detrás de las posiciones de los sujetos internacionales. Esto es determinante para la posición adoptada en el proceso de

\footnotetext{
${ }^{30}$ FRANCO, Leonardo; NORIEGA, Jorge Santistevan de. La contribución del Proceso de Cartagena al desarrollo del Derecho Internacional de Refugiados en América Latina. IN ACNUR. La Protección de los refugiados en América. Quito: Mantis Comunicación, diciembre, 2011, p. 141. Disponible en: $<$ http://www.acnur.es/PDF/8340_20120402180124.pdf $>$ acceso 12 de agosto de 2012.
}

${ }^{31}$ ANDRADE. Op.cit., p. 268. 
formación del derecho internacional, de lo cual surgió dialécticamente la solución jurídica que permitió contentar a las diferentes partes-Estados que participaron.

El resultado de estos procesos de negociación es la creación del derecho internacional. En este caso, los sujetos de derecho internacional, los Estados, estaban muy interesados en que se limitasen los compromisos que fuesen asumidos. De tal modo, fueron establecidas dos restricciones a la definición: una temporal y otra geográfica, que seguidamente serán analizadas.

Ahora es posible hacer un análisis retrospectivo, y a través de este, se puede concluir que tales temores de los Estados eran infundados, dado que, como se verá a posteriori, las soluciones de la Convención y de la actuación de la ACNUR trajeron satisfacciones a las necesidades de los problemas de los refugiados internacionales, prevaleciendo estas sobre los intereses particulares de los Estados. Entonces, se puede afirmar que el interés colectivo de la comunidad internacional prevaleció sobre los intereses particulares de cada Estado.

\section{I.4.1. Límites a la definición de refugiado}

Como ya fue adelantado, existía esa divergencia en relación con el origen de los refugiados que serían protegidos.

En el parágrafo B del artículo 1 se establecía esa restricción en cuanto al alcance espacial del origen de los refugiados, ya que introdujo dos hipótesis posibles de adhesión por parte de los países contratantes o partes:

1. Podrían considerarse los acontecimientos ocurridos "en Europa" o

2. los hechos ocurridos "en Europa o fuera de esta".

Era muy difícil alcanzar un entendimiento común en este punto de la restricción geográfica. El Vaticano introdujo la posibilidad de que cada país podría optar por la alternativa restricta o amplia en el momento de firmar la Convención, quedando superado el enfrentamiento ${ }^{32}$.

Así quedó la posibilidad de que el Estado contratante eligiese una u otra hipótesis en el momento de la firma, ratificación o adhesión, y aquellos países que hubieran optado por la primera hipótesis podrían ampliarla a la segunda, siendo necesario apenas una comunicación a la Secretaria General de Naciones Unidas.

${ }^{32}$ MOREIRA. Op. cit., p. 62. 
El artículo 1 (apartado 2) limita el ámbito temporal de aplicación de la Convención, pues establecía que los refugiados serían aquellos que sufrieron los acontecimientos ocurridos en el período de tempo que va hasta el día 1 de enero de 1951.

Ese dispositivo legal del artículo 1 (apartado 2) limitaba el ámbito de aplicación de esta Convención, estableciendo una restricción temporal obligatoria y no facultativa. Posteriormente, esta limitación temporal obligatoria fue modificada por el Protocolo de 1967, siendo que uno de los objetivos de este último instrumento internacional fue hacer desaparecer la restricción temporal.

En verdad, ese concepto consagrado en la Convención fue el único aceptado por todos y fue el único camino encontrado para que los países dieran su consenso para participar en esa reunión donde se elaboró la Convención de Ginebra.

Además, en esa definición de refugiado contenida en la Convención también eran incluidos aquellos que fueron beneficiados por los Acuerdos Anteriores: "los Acuerdos del 12 de mayo de 1926 y del 10 de junio de 1928, las Convenciones del 28 de octubre de 1933 y del 10 de febrero de 1938, el Protocolo del 14 de septiembre de 1939 y la Constitución de la Organización Internacional dos Refugiados"33.

La Convención establece el reconocimiento de aquellas personas que fueron admitidas como refugiados por los Acuerdos Anteriores, pues precisa establecer una relación de reconocimiento con el pasado. De tal modo, la concesión del pasaporte NANSEN tendría efectos para la Convención, así como el "Certificado de Elegibilidad"34.

La firma de la Convención de Ginebra significaba para los Estados partes asumir un compromiso, una obligación internacional, y esto generaba mucho temor en los Estados, pues podría derivar en grandes cargas tanto por el hecho de tener que asumir grupos de refugiados como por los gastos económicos que derivarían de la actuación del organismo. Esta fue la causa del establecimiento de tantas limitaciones en lo temporal como en lo geográfico, restricciones que se diluyeron con el correr del tiempo, pues tanto por las necesidades y urgencias que emergieron a nivel internacional, como por la verificación de que las cargas eran menores a los beneficios derivados de la creación de esta Convención.

\footnotetext{
${ }^{33}$ MOREIRA. Op. cit., p. 63.

34 ACNUR. CENTRO DE PROTEÇÃO INTERNACIONAL DE DIREITOS HUMANOS; INSTITUTO MIGRAÇÕES E DIREITOS HUMANOS. Manual de Procedimentos e Critérios para Determinar a Condição de Refugiado: de acordo com a Convenção de 1951 e o Protocolo de 1967 relativos ao Estatuto dos Refugiados. [S.1.] ACNUR Brasil, 2004, p. 28. Disponible en:

$<$ http://www.asylumlawdatabase.eu/sites/asylumlawdatabase.eu/files/aldfiles/UNHCR\%20Handbook\%20ES.pdf $>$ acceso 11 de agosto de 2012.
} 


\title{
I.4.2. Análisis de los elementos de la definición de refugiado
}

Ese mismo artículo de la Convención continúa con la definición del refugiado como aquel que tiene:

\begin{abstract}
miedo en razón de ser perseguido en virtud de su raza, religión, nacionalidad, afiliación a un cierto grupo social o de sus opiniones políticas, se encuentre fuera del país de su nacionalidad y no pueda o, virtud de recelo, no quiera pedir protección de aquel país; o que, si no tuviera nacionalidad y estuviera fuera del país en el cual tenía su residencia habitual después de aquellos acontecimientos, no pueda o, en virtud de tal recelo, a ese país no quiera volver".
\end{abstract}

En relación con la palabra "acontecimientos", se refiere a "acontecimientos de mayor importancia envolviendo modificaciones territoriales o profundas alteraciones políticas bien como persecuciones sistemáticas resultantes de cambios anteriores" de tal modo definido en el Documento ONU E/1618 35 .

La autora PEREIRA, en esa definición de refugiado, identifica los siguientes elementos: persecución, fundado temor y extraterritorialidad. Después, ella considera las causas de la persecución y la voluntad de que no quiera o no pueda pedir la protección de su propio Estado ${ }^{36}$.

MOREIRA analiza el concepto de refugiado considerando las cláusulas de inclusión y las cláusulas de cesación, las primeras serían aquellos elementos que hacen parte del concepto de Refugiado, siendo que las segundas son las que se refieren al final de la condición de refugiado, dado que este no precisa más de esta protección ${ }^{37}$.

En este trabajo serán considerados todos los elementos constitutivos de la definición legal del refugiado, según lo establecido en la Convención:

1. Persecución;

2. fundado temor de persecución;

3. los motivos de la persecución (raza, nacionalidad, religión, afiliación a cierto grupo social y opiniones políticas);

4. la extraterritorialidad; $y$

5. el deseo de no querer ser protegido por el país de origen.

35 ACNUR; CENTRO DE PROTEÇÃO INTERNACIONAL DE DIREITOS HUMANOS; INSTITUTO MIGRAÇÕES E DIREITOS HUMANOS. Op.cit., p. 8.

${ }^{36}$ PEREIRA, Luciana Diniz Durães. O direito internacional dos refugiados: análise crítica do conceito de “refugiado ambiental”, Belo Horizonte: Editorial Del Rey, 2009, p. 72.

${ }^{37}$ MOREIRA. Op. cit., p. 67. 
Tanto la persecución, el temor a esta, como los motivos de la persecución enunciados podrían haber sido considerados en una simple frase: "violación a los derechos humanos".

Los motivos de raza, grupo étnico, nacionalidad, religión, opiniones políticas, todos hacen referencia a la situación de personas que tienen características comunes propias de un grupo minoritario, o que son individuos que tiene alguna diferenciación en relación con el grupo dominante o con el que está en el poder imperante.

La persecución por esos motivos tiene que ver tanto con la falta absoluta de tolerancia, como con la violencia contra los individuos o los grupos sociales.

\title{
I.4.2.1. Persecución
}

El concepto de persecución ha sido un aspecto esencial en la definición de los refugiados, porque lo que en realidad se buscaba con la introducción de ese concepto era incluir entre los refugiados a aquellos que escapaban de la Unión Soviética (del comunismo) ${ }^{38}$.

PEREIRA observa que existen dos concepciones de la persecución: la restricta, que la considera como el ataque efectivo o posible contra el derecho a la vida y a la libertad. La concepción amplia es la que considera el ataque contra los derechos humanos.

Esa autora considera las definiciones de varios autores, observando:

\begin{abstract}
Para Goodwin- Gill y McAdam, por ejemplo, persecución significa, además de una amenaza o eventual amenaza de violación a la libertad y a la vida de los individuos dentro de un Estado o región, también los casos de tortura y de tratamiento o punición cruel o degradante a seres humanos, o sea, en una perspectiva generalista, puede ser entendida como toda y cualquier severa violación de los derechos humanos considerados inderogables por la sociedad internacional, tales como el derecho a la libertad de creencia, a la integridad física y psíquica y a la salud, por ejemplo, o sea, aquellos derechos protegidos por la DUDH de 1948 y por los Pactos Internacionales de Derechos Humanos de 1966, estará presente la persecución ${ }^{39}$.
\end{abstract}

Esta definición de la persecución abarca el ataque a la libertad y a la vida de la víctima, así como actos de tortura y punición cruel contra la persona perseguida.

MOREIRA define la persecución como "acto de impedir la realización de los derechos del individuo, que se caracteriza en una amenaza a su vida o libertad (por motivos de raza, religión, nacionalidad, filiación a grupo social u opinión pública) o bien como en otras violaciones a sus derechos humanos" ${ }^{\prime 4}$.

\footnotetext{
${ }^{38}$ ANDRADE. Op.cit., p. 314.

${ }^{39}$ PEREIRA. Op.cit., p. 71-72.

${ }^{40}$ MOREIRA. Op. cit., p. 68.
} 
Por otro lado, el Manual de Procedimientos y Criterios a Aplicar para Determinar la Condición de Refugiado considera:

\begin{abstract}
Del artículo 33 de la Convención de 1951 puede deducirse que toda amenaza contra la vida o la libertad de una persona por motivos de raza, religión, nacionalidad, pertenencia a determinado grupo social u opiniones políticas es siempre persecución. También constituirían persecución otras violaciones graves de los derechos humanos por las mismas razones ${ }^{41}$.
\end{abstract}

La persecución implica un acontecimiento que consiste en un hostigamiento o un acosamiento motivado en alguna cuestión o motivo injusto enunciado, el cual tiene tal magnitud que obliga a la víctima a escapar para salvar su vida.

La persecución u hostigamiento se traduce en actos exteriores o en la posibilidad de la realización de estos, implicando violencia física o psíquica sobre alguna persona. Los actos de violencia física son aquellos que atacan la integridad de la persona, atentando contra los derechos humanos de la persona y sus pilares fundamentales que son el derecho a la libertad y a la igualdad.

La violencia física contra la persona incluye también un aspecto psíquico, pues indefectiblemente producirá impactos en la psiquis de la persona humana.

Además, esos actos de hostigamiento pueden consistir en actos de violencia psíquica, como las amenazas a determinadas personas. La integridad de la persona incluye un aspecto físico y otro psíquico. Este último puede ser minado por actos que no signifiquen violencia física, aunque creen inseguridad y temor en la persona. De este modo, queda afectada la integridad del hombre, la cual es uno de los fundamentos de los derechos humanos.

La persecución es realizada por el agente perseguidor que cuenta con medios suficientes para realizar el hostigamiento que ataca a los derechos fundamentales de la persona.

Existen tres concepciones sobre el tipo de agente persecutor:

- Un agente estatal;

- un grupo paraestatal;

- ambos.

Austria y Suiza consideran que el agente persecutor es únicamente el Estado. Otros países, como Brasil, consideran ambos actores de la persecución, siendo que en el segundo caso, el Estado precisa mostrarse omiso ante los actos de los grupos no estatales. Un ejemplo de este último tipo de persecución es el caso de Colombia ${ }^{42}$.

\footnotetext{
${ }^{41}$ ACNUR; CENTRO DE PROTEÇÃO INTERNACIONAL DE DIREITOS HUMANOS; INSTITUTO MIGRAÇÕES E DIREITOS HUMANOS. Op.cit., parágrafo 51.

${ }^{42}$ PEREIRA. Op.cit., p. 73.
} 
Aunque en relación con esto fue establecida una interpretación única en el Manual de Procedimientos:

65. La persecución suele ser resultado de la actuación de las autoridades de un país. Puede también emanar de sectores de la población que no respetan las normas establecidas por las leyes de su país. [...] El comportamiento vejatorio o gravemente discriminatorio observado por ciertos sectores de la población local puede equipararse a la persecución si es deliberadamente tolerado por las autoridades o si estas se niegan a proporcionar una protección eficaz o son incapaces de hacerlo ${ }^{43}$.

En ese escenario, de un lado, existe un grupo de poder que es el perseguidor y, del otro, la víctima, que se encuentra en una posición de inferioridad en cuanto a los medios defensivos ante la violencia que le pueda afectar.

Una de las consecuencias que genera la persecución es que la víctima tiene que escapar del lugar que es habitual; otro efecto es que la persona tiene que dejar atrás todo lo que hace a su vida por causa de que está en juego el bien jurídico de la vida, la libertad y la integridad de la persona humana.

Además, es necesario considerar la relación entre persecución y discriminación. Algunos tipos de actos discriminatorios pueden ser considerados como persecución, como cuando se impide que un grupo social desarrolle su trabajo, o sus medios de vida, o practique su religión ${ }^{44}$. De ese modo, se puede observar que la ejecución o posible realización de actos discriminatorios graves que impliquen un atentado contra la vida, la libertad y los derechos humanos pueden ser equivalentes a los actos de persecución.

MOREIRA considera que cuando los actos discriminatorios producen daños a los derechos de la persona o llevan a la persona a sentir miedo de que esto ocurra en sus vidas, estos pueden ser considerados como actos de persecución ${ }^{45}$.

La discriminación contra las personas significa la segregación de alguien del resto de la sociedad motivada en alguna característica del individuo, que sirve al agente persecutor para justificar sus actos, aunque de todos modos estos son ilegítimos, dado que viola el derecho de igualdad de las personas.

\footnotetext{
${ }^{43}$ ACNUR. Manual de procedimientos y criterios para determinar la condición de refugiado en virtud de la Convención de 1951 y el Protocolo de 1967 sobre el Estatuto de los Refugiados. HCR/IP/4/Rev.1, 1979. Primera publicación en español en 1988, enero, 1992, parágrafo 65, p. 13. Disponible en: $<$ http://www.refworld.org/docid/4f5897892.html> acceso 18 de mayo de 2016.

${ }^{44}$ ACNUR, 1988. Manual de procedimientos, Op.cit., p.11.

${ }^{45}$ MOREIRA. Op. cit., p. 69.
} 


\section{I.4.2.2. Miedo fundado}

El miedo puede referirse a un acto real o posible, porque en el último caso puede relacionarse a un peligro o a un riesgo que atenta contra la vida y la libertad (incluyendo todo el conjunto de derechos humanos) de la persona y/o de la familia.

ACNUR observa que la definición de refugiado establece como uno de los aspectos fundamentales "los fundados temores de ser perseguido".

Esta es una novedad introducida por el Estatuto del Refugiado, ya que los instrumentos internacionales anteriores sobre refugiados solamente consideraban los grupos de personas afectadas, de forma colectiva. Es decir, sin considerar las características generales del concepto.

La expresión "fundado temor" hace referencia a un aspecto subjetivo de la persona afectada. El miedo tiene que ser fundado, por lo tanto, precisa basarse en hechos, los cuales hacen referencia a un aspecto objetivo. Aunque puede ocurrir que las acciones aún no se hayan realizado. Este es el caso del riesgo de estas.

Es necesario constatar el elemento objetivo que produce el miedo, para lo cual es preciso que sean apreciadas las situaciones argumentadas por el solicitante, tanto las circunstancias vividas en el país de origen, como las situaciones específicas sufridas por esta persona, por su grupo familiar, amigos y allegados ${ }^{46}$.

PEREIRA dice que la verificación y la prueba de miedo justificado es responsabilidad de quien solicita el estatus de refugiado y del agente examinador que va a analizar la situación de la víctima ${ }^{47}$.

Además, ACNUR observa que el aspecto subjetivo precisa ser constatado a través del análisis de la personalidad del solicitante.

El miedo es un estado psicológico de la persona que teme por la pérdida de la vida, la cual es el bien jurídico supremo de los seres humanos. Además, no puede tratarse de cualquier tipo de temor, sino que tiene que tener una fundamentación fáctica. El miedo puede referirse a la pérdida tanto de la vida, como de una vida íntegra, la cual abarca el derecho a la vida, a la libertad y a la integridad de la persona. Esta última puede ser física o psicológica, siendo que ambas hacen parte del concepto de la dignidad humana y del bien común anhelado por los Estados democráticos, siendo que el bien común no es más que el desarrollo integral de la persona humana, y cuando se dice íntegra se refiere a la plena realización de la persona humana.

\footnotetext{
${ }^{46}$ ACNUR, 1998. Manual de procedimientos, Op.cit., p. 10, parágrafo 42-43.

${ }^{47}$ PEREIRA. Op.cit., p. 76.
} 
De tal modo, queda claro que esa potencial pérdida debe ser de un bien jurídico que justifique la envergadura de la acción de escapar, el cual puede ser la vida, la libertad o la integridad física, es decir, la pérdida o el ataque a los derechos humanos de la persona.

\section{I.4.3. Los motivos particulares de la persecución}

El elenco de motivos enunciados en el artículo demuestra la relación de la Convención con los acontecimientos que afectaban ese momento y le extrae universalidad a ese instrumento, porque son consideradas circunstancias bien específicas. Esta descripción particular de las situaciones fue subsanada posteriormente en las Convenciones Regionales sobre los Refugiados, ya que estas incluyen los conceptos más amplios de refugiado enunciados en la Convención de la OUA ${ }^{48}$ relativa a los derechos de los refugiados africanos y en la Declaración de Cartagena ${ }^{49}$ de 1984.

Según la definición de refugiado de tal Convención, los motivos de la persecución son: raza, nacionalidad, religión, afiliación a cierto grupo social y opiniones políticas.

Estas persecuciones están relacionadas con los actos contra la persona humana realizados por el Estado de origen o por la inactividad del Estado frente a la actuación de los grupos que atacan a la persona.

Francisco GALINDO VÉLEZ, al hacer referencia a las persecuciones según raza, nacionalidad, religión, opinión pública y grupo social, utiliza los conceptos brindados por el Derecho Internacional de los Derechos Humanos. El autor recurre a lo establecido en la Declaración Universal de los Derechos Humanos (artículos 1 y 2), al Pacto Internacional de los Derechos Civiles y Políticos (artículo 2, parágrafo 1) y a la definición de discriminación establecida en la Convención Internacional sobre la Eliminación de todas las Formas de Discriminación Racial (artículo 1, párrafo 1). Cuando considera la persecución por causa de la religión, el autor se refiere al artículo 1 de la Declaración sobre la Eliminación de Todas las Formas de Intolerancia y Discriminación Fundadas en la Religión o las Convicciones. Sobre la persecución contra las mujeres se refiere al artículo 1 de la Convención sobre Todas las Formas de Discriminación contra la Mujer ${ }^{50}$. En tal sentido, se seguirá esa orientación a los fines de

\footnotetext{
48 OUA es la Organización de la Unión Africana.

${ }^{49}$ La Declaración de Cartagena es la que trata los derechos de los Refugiados de la OEA (Organización de Estados Americanos).

${ }^{50}$ GALINDO VÉLEZ, Francisco. Consideraciones sobre la determinación de la condición de refugiado. In NAMIHAS, Sandra. (Coord.). Derecho Internacional de los Refugiados. Pontificia Universidad Católica del Perú. Instituto de Estudios Internacionales. Perú: Fondo Editorial, 2001, p. 51- 52.
} 
buscar los fundamentos al Derecho Internacional de los Refugiados en los conceptos del Derecho Internacional de los Derechos Humanos, dejando constancia de que el primero hace parte del segundo.

Como regla general, se prohíbe la discriminación de la persona en razón de cualquier motivo.

La Declaración Universal de los Derechos Humanos establece en los dos primeros artículos la prohibición a la discriminación.

El artículo 1 proclama: "Todos los seres humanos nacen libres e iguales en dignidad y derechos y, dotados como están de razón y conciencia, deben comportarse fraternalmente los unos con los otros.” Además, afirma en el artículo 2:

- Toda persona tiene todos los derechos y libertades proclamados en esta Declaración, sin distinción alguna de raza, color, sexo, idioma, religión, opinión política o de cualquier otra índole, origen nacional o social, posición económica, nacimiento o cualquier otra condición.

- $\quad$ Además, no se hará distinción alguna fundada en la condición política, jurídica o internacional del país o territorio de cuya jurisdicción dependa una persona, tanto si se trata de un país independiente, como de un territorio bajo administración fiduciaria, no autónomo o sometido a cualquier otra limitación de soberanía ${ }^{51}$.

El Pacto Internacional de los Derechos Civiles y Políticos establece en igual sentido en el artículo 2:

1. Cada uno de los Estados Partes en el presente Pacto se compromete a respetar y a garantizar a todos los individuos que se encuentren en su territorio y estén sujetos a su jurisdicción los derechos reconocidos en el presente Pacto, sin distinción alguna de raza, color, sexo, idioma, religión, opinión política o de otra índole, origen nacional o social, posición económica, nacimiento o cualquier otra condición social ${ }^{52}$.

La Convención Internacional sobre la Eliminación de todas las Formas de

Discriminación Racial (su artículo 1, párrafo 1) define la discriminación racial como:

Toda distinción, exclusión, restricción o preferencia basada en motivos de raza, color, linaje $\mathrm{u}$ origen nacional o étnico que tenga por objeto o por resultado anular o menoscabar el reconocimiento, goce o ejercicio, en condiciones de igualdad, de los derechos humanos y libertades fundamentales en las esferas política, económica, social, cultural o en cualquier otra esfera de la vida pública ${ }^{53}$.

51 NACIONES UNIDAS. Declaración Universal de los Derechos del Hombre. Disponible en: $<$ http://www.un.org/es/documents/udhr/index_print.shtml > acceso 24 de agosto de 2012 .

52 NACIONES UNIDAS. Pacto Internacional de los Derechos Civiles y Políticos. Disponible en: $<$ http://www.ohchr.org/SP/ProfessionalInterest/Pages/CCPR.aspx > acceso 24 de agosto de 2012.

53 NACIONES UNIDAS. Convención Internacional sobre la Eliminación de todas las Formas de Discriminación Racial. Adoptada y abierta a la firma y ratificación por la Asamblea General en su resolución 2106 A (XX), 21 de diciembre de 1965. Entrada en vigor 4 de enero de 1969. Disponible en: $<$ http://www.ohchr.org/SP/ProfessionalInterest/Pages/CERD.aspx> acceso 24 de agosto de 2012. 
Esos ataques de persecución pueden constituir actos de discriminación.

Discriminar significa segregar al otro en virtud de una determinada cualidad de la otra persona, sea en este caso raza, nacionalidad, religión, afiliación a cierto grupo social y opiniones políticas. La discriminación implica la posición de superioridad de un grupo (que es el que está en el poder) en relación con otro, el uso de la fuerza para negar los derechos de aquellos que son segregados. Lo que está por detrás de la discriminación es la negación del derecho de igualdad, establecido en la Declaración Universal de los Derechos Humanos de 1946. Porque el derecho de igualdad coloca a todas las personas en un mismo plano más allá de sus diferencias.

\section{I.4.3.1. Raza}

ACNUR considera el concepto amplio de raza, es decir, incluye los grupos étnicos y lingüísticos.

Según AGUIAR, “existen tres grupos étnicos caucasoide, mongoloide y el negroide”. Ese autor considera que el concepto de raza incluye a las personas que son semejantes en el aspecto exterior y tienen una raíz cultural igual ${ }^{54}$.

Un ejemplo de persecución por la raza fue el caso de los judíos en el régimen nazi.

La idea de raza trae consecuencias muy negativas porque puede llevar al concepto de racismo y a la creencia de que unos son mejores que los otros ${ }^{55}$.

La discriminación racial viola el derecho de igualdad.

En realidad, el concepto de raza ya es algo conceptualmente superado, pues todas las personas vienen de un mismo origen, que es algún lugar de África, luego según los factores climáticos a los que fueron sometidos han ido desarrollando diferentes aspectos en el color de piel.

\section{I.4.3.2. Nacionalidad}

La persecución en virtud de una nacionalidad es una de las hipótesis consideradas en el artículo que define el concepto de refugiado.

ACNUR observa que el concepto de nacionalidad incluye el de ciudadanía y el de los grupos étnicos.

\footnotetext{
${ }^{54}$ MOREIRA. Op. cit., p. 70.

${ }^{55}$ PEREIRA. Op.cit., p. 78.
} 
En igual sentido, MOREIRA señala que el concepto de nacionalidad abarca tanto el vínculo del individuo con un Estado, así como aquel vínculo entre los integrantes de un pueblo (en el sentido de grupo con lazos entre sus miembros, tales como idioma, religión, tradiciones construidas en el tiempo), siendo que en este último caso queda relacionado con las persecuciones a los grupos étnicos ${ }^{56}$.

En primer lugar, PEREIRA se refiere a los tipos de nacionalidad, sea ius soldi: derecho del suelo, sea ius sanguini: derecho de sangre, o la originaria y la adquirida. En segundo lugar, la autora considera que el concepto de nacionalidad tratado en la Convención es el amplio, siendo que incluye los grupos étnicos, así como aquel en el que se establece una relación entre el país y la persona que adquirió la nacionalidad derivada u originaria, de lo cual resulta el estatus de ciudadano. Además, se puede observar la relación intrínseca que existe entre la nacionalidad, los grupos étnicos y la religión. Por otro lado, la autora cita el caso específico de lo ocurrido en Kenia (2007), donde existían 10 grupos étnicos y hubo persecuciones contra ellos ${ }^{57}$.

La nacionalidad por ius soldi es aquella que refiere a que la persona nació en el territorio del país; la que es por ius sanguini es la que es independiente de donde la persona nació, sino que considera la nacionalidad de los padres que es transmitida a través de la sangre; la nacionalidad originaria es aquella que es adquirida porque la persona nació en ese país; la nacionalidad derivada es la adquirida por los actos de naturalización.

En sentido estricto, la nacionalidad es el vínculo de una persona con el Estado como única organización soberana. A partir de tal vínculo, surge el concepto del ciudadano, que es aquella persona que tiene derechos políticos de sufragio, de participar del gobierno de su país, de participar de un partido político. La persecución en razón de la nacionalidad es una violación a los Derechos Humanos. En la Declaración de los Derechos Humanos está contenido el derecho a la nacionalidad.

\section{I.4.3.3. Religión}

La persecución por la religión es otra de las causas por las que puede ser amparado el refugiado. La Declaración Universal de los Derechos del Hombre, en su artículo 18, establece:

\footnotetext{
${ }^{56}$ MOREIRA. Op. cit., p. 71.

${ }^{57}$ PEREIRA. Op.cit., p. 80-81.
} 
libertad de manifestar su religión o su creencia, individual y colectivamente, tanto en público como en privado, por la enseñanza, la práctica, el culto y la observancia.

Sobre la discriminación en relación con la religión, el artículo 1 de La Declaración sobre la Eliminación de Todas las Formas de Intolerancia y Discriminación Fundadas en la Religión o las Convicciones establece:

1. Toda persona tiene derecho a la libertad de pensamiento, de conciencia y de religión. Este derecho incluye la libertad de tener una religión [...], así como la libertad de manifestar su religión o sus convicciones individual o colectivamente, tanto en público como en privado, mediante el culto, la observancia, la práctica y la enseñanza ${ }^{58}$.

Esto es en el mismo sentido a lo proclamado por el Pacto de los Derechos Civiles y Políticos.

Históricamente, las religiones han sido uno de los motivos más comunes de persecución, y tales constituyen una de las barreras más grandes creadas entre personas intolerantes.

ACNUR observa que la persecución por la religión puede consistir en la prohibición de las actividades propias de la práctica de la religión.

PEREIRA observa que la persecución religiosa se caracteriza por tratarse de casos en los que los practicantes tienen una religión contraria a la del Estado o constituyen grupos religiosos minoritarios dentro del Estado.

La autora observa el caso del holocausto judío, otro caso es el de los 3,8 millones de refugiados palestinos (musulmanes), quienes escaparon de sus hogares en 1948 y en 1967. En 2008, Egipto recibió a un grupo de refugiados que eran cristianos eritreos, pero los deportó, violando el principio de No Devolución instituido en la Convención sobre el Estatuto del Refugiado $^{59}$.

\section{I.4.3.4. Opinión pública}

ACNUR observa que, en la mayoría de los casos de persecución por opinión pública, esta se refiere a la política. Además, señala que no es preciso que el gobierno conozca la opinión de la persona ${ }^{60}$.

\footnotetext{
58 NACIONES UNIDAS. Declaración sobre la eliminación de todas las formas de intolerancia y discriminación fundadas en la religión o las convicciones, Proclamada por la Asamblea General de las Naciones Unidas, 25 de noviembre de 1981 [resolución 36/55]. Disponible en: $<$ http://www.ohchr.org/SP/ProfessionalInterest/Pages/ReligionOrBelief.aspx> acceso 24 de agosto de 2012.

${ }^{59}$ PEREIRA. Op.cit., p. 82-83.

60 ACNUR; CENTRO DE PROTEÇÃO INTERNACIONAL DE DIREITOS HUMANOS; INSTITUTO MIGRAÇÕES E DIREITOS HUMANOS. Op.cit., parágrafo 80.
} 
La Declaración Universal de los Derechos del Hombre establece que todas las personas tienen derecho a la libertad de pensamiento y de expresión, siendo estos derechos fundamentales del hombre. El artículo 19 establece:

\begin{abstract}
Todo individuo tiene derecho a la libertad de opinión y de expresión; este derecho incluye el de no ser molestado a causa de sus opiniones, el de investigar y recibir informaciones y opiniones, y el de difundirlas, sin limitación de fronteras, por cualquier medio de expresión.
\end{abstract}

Tanto el derecho a tener una opinión como el derecho a tener una religión y a expresarla y ejercerla hacen parte de uno de los pilares de los derechos humanos que es la libertad, que es el ámbito donde el ser humano puede actuar sin ser limitado por el Estado.

Además, están relacionados con el derecho del ser cultural de la persona, e implica uno de los derechos humanos, los cuales se vinculan con la dignidad humana y con el derecho a tener una identidad.

MOREIRA sustenta que el refugiado tiene que demostrar que la persecución es motivada en sus opiniones políticas ${ }^{61}$.

De modo que, cabe concluir que las persecuciones en virtud de raza, nacionalidad, religión, afiliación a cierto grupo social y opiniones políticas tienen un fundamento en la intolerancia de grupos extremistas que creen en verdades absolutas y que pretenden callar a los disidentes o negar la existencia de otras ideas o modelos de vida. La intolerancia es un retroceso en la vida de la humanidad, siendo que la única forma de avanzar hacia la democracia como mejor forma de gobierno es la afirmación de la pluralidad, la tolerancia y el reconocimiento de las diferencias entre los seres humanos.

\title{
I.4.3.5. Grupo social
}

La causa de persecución por "pertenencia a grupo social" no se encuentra en la definición de refugiado del Estatuto de ACNUR, donde solamente están las otras causas de persecución: nacionalidad, raza, religión y opinión pública. La quinta causa fue incluida a pedido de la Delegación de Suecia durante la realización de los trabajos preparatorios para la elaboración de la Convención del Estatuto de los Refugiados de $1951^{62}$.

\footnotetext{
${ }^{61}$ MOREIRA. Op. cit., p. 70.
}

${ }^{62}$ ATKINSON, Ian. Assumption of Risk inUnited States Refugee Law. The Virginia Journal of International Law Association, Vol. 49, $\mathrm{N}^{\circ}$ 1, 2008, p. 273 y 277.

Disponible en: <http://www.vjil.org/assets/pdfs/vol49/issue1/49_273-306.pdf $>$ acceso 15 de mayo de 2016. 
Aparentemente, parecería una clausula abierta que permitiría la introducción de diversos tipos de refugiados, aunque esta no fue la interpretación de los países.

De tal modo, surgieron diversos pedidos de solicitud de refugiados en los países en virtud de esta cláusula.

En realidad, nacionalidad, grupos étnicos y/o grupos sociales son cuestiones que están muy interrelacionadas, pues la nacionalidad puede incluir una o varias etnias, y a su vez pueden formar grupos sociales. La religión tiene que ver con el concepto de pueblo y ser cultural. La pertenencia al grupo social es un concepto transversal de todos estos conceptos anteriormente considerados (nacionalidad, religión, raza).

Es necesario observar que la Declaración Universal de los Derechos Humanos completa estos derechos fundamentales del hombre diciendo en su artículo 20: "1. Toda persona tiene derecho a la libertad de reunión y de asociación pacíficas. 2. Nadie podrá ser obligado a pertenecer a una asociación" 63 .

Para unos, es necesario que la pertenencia a un grupo social sea inmutable, es decir que la persona no pueda dejar de serlo o que dejar de pertenecer al grupo signifique la violación de la integridad de la persona ${ }^{64}$.

Ian ATKINSON observa las dificultades que surgieron para establecer las características esenciales sobre el concepto de grupo social en los tribunales de Estados Unidos, principalmente. Este autor expone dos concepciones en relación con la pertenencia al grupo social. La primera es la teoría de la percepción social sobre el grupo social y la segunda es la teoría de la asunción de riesgos. En relación con la primera, elaborada por Goodwin- Gill, existen tres aspectos esenciales: la inmutabilidad, "los valores compartidos, perspectivas y aspiraciones" y la percepción externa de la sociedad en relación con el grupo social ${ }^{65}$.

MOREIRA observa que el concepto de grupo social es "un conjunto marcado por relaciones específicas entre los individuos, en que cada uno tiene conciencia del propio grupo y de sus símbolos". La autora menciona la opinión citada por Aguiar, quien observa que "en esa medida, el grupo debe tener una estructura y organización, que se traduce en reglas y rituales, y una base psicológica que opera en la conciencia de sus miembros"66.

Todo esto es en relación con la pertenencia voluntaria al grupo. El grupo social es un conjunto de personas unidas por uno o varios intereses en común, que pueden ser de diferente

\footnotetext{
${ }^{63}$ NACIONES UNIDAS. Declaración Universal de los Derechos Humanos. Op.cit.

${ }^{64}$ ATKINSON. Op.cit., p. 280.

${ }^{65}$ ATKINSON. Op.cit., p. 290.

${ }^{66}$ MOREIRA. Op. cit., p. 71.
} 
naturaleza. Las personas integrantes del grupo sienten una identidad con ese interés colectivo del grupo. Se produce un criterio de pertenencia al grupo social, que implica que los miembros se identifiquen con el grupo y que hace que la sociedad consiga diferenciar los miembros del grupo. Es decir, hay una relación entre el grupo y los integrantes, una relación del grupo con la sociedad y una relación de los miembros del grupo con la sociedad.

Es posible diferenciar distintos tipos de grupos sociales. Por un lado, algunos pueden tener altos niveles de organización, aunque también hay grupos de personas que se aglutinan espontáneamente. En este último caso, la evolución organizativa del grupo no avanza y queda en un estado primario.

De tal modo que el grupo social se forma cuando surge un interés individual en las personas que es idéntico al de las otras personas y que se transforma en interés colectivo con la formación del grupo social. A partir de esa constitución del grupo social, surgen relaciones entre los miembros que marcan la dinámica interna del grupo. La estructura interna del grupo depende del grado de desarrollo de cada caso. Existe una función relevante del grupo social que es el líder, esa función puede ser ejercida por una o varias personas y se establecen reglas de comportamiento y relacionamiento dentro del grupo, las cuales también dependen del nivel de desarrollo del grupo.

Es importante resaltar la diferenciación del grupo social del resto de la sociedad. La sociedad identifica la existencia del grupo por las características comunes de sus miembros, por su actuación, o por los comportamientos diferenciados de los miembros del grupo. Es allí que el Estado identifica el grupo social y en este caso es cuando el Estado puede realizar actos de persecución contra sus miembros.

Las teorías sobre la "pertenencia al grupo social" coinciden en que es necesario que la pertenencia al grupo sea inmutable, de modo que la renuncia signifique la negación de la integridad del hombre. Por otro lado, la teoría de la asunción de riesgos consiste en que si en el momento en que la persona decide pertenecer a un grupo social a sabiendas de los riesgos que esto implicaría, no sería aplicable la concesión de la condición de refugiado. Esta concepción fue adoptada en el juzgamiento de un caso por la Junta de Apelaciones de Inmigración (BIA) de Estados Unidos, en tal sentido ATKINSON observa: "El BIA interpretó la norma mucho más ampliamente, concluyendo que las personas perseguidas que, a sabiendas del riesgo no pueden reclamar protección basada en la pertenencia a un determinado grupo social debe materializarse ese riesgo" ${ }^{\prime \prime}$.

${ }^{67}$ ATKINSON. Op.cit., p. 284. 
Aunque esta concepción solamente fue utilizada en un caso juzgado. El autor concluye que esta teoría no podría ser aplicada. La utilización de esta teoría de la asunción de los riegos es peligrosa, pues implica un gran recorte en relación con el concepto de refugiados.

El grupo social se define como "la característica compartida podría ser innata como por ejemplo el sexo, el color o los lazos de parentesco, o en algunas circunstancias puede ser que sea una experiencia pasada compartida como un ex militar $[\ldots]$ ". Este concepto de grupo social incorpora experiencias pasadas, pues estas no pueden ser borradas, aunque esto sería de poca aplicabilidad. Además, agrega que es necesario el análisis de "caso a caso"68.

Por otro lado, se observó que sería necesario considerar que la pertenencia a un grupo social debería ser inmutable, innata, al igual que lo son las causas anteriores en virtud de la aplicación del principio de ejusdem generis, el cual sostiene que la característica de la cláusula final debe interpretarse en consideración de las cualidades de las anteriores ${ }^{69}$.

Otra posición sostiene que el grupo social: "exige características comunes, que puede ser por adhesión voluntaria, siendo percibido como grupo distinto por parte del resto de la sociedad. La característica de inmutabilidad es dejada de lado"70.

Se ha admitido la inclusión de la discriminación en virtud de género y de orientación sexual, pues estas son dos características innatas e inmutables.

La inclusión de la violencia en razón de género y de orientación sexual fue reconocida por las conclusiones N 73 (XLIV) Protección de los Refugiados y Violencia Sexual del Comité Ejecutivo, donde sostiene:

d) Apoya el reconocimiento como refugiados de personas cuya solicitud para obtener la condición de refugiado se basa en un temor fundado de persecución, mediante la violencia sexual y por razones de raza, religión, nacionalidad, pertenencia a un determinado grupo social u opinión política ${ }^{71}$.

El artículo 1 de la Convención sobre Todas las Formas de Discriminación contra la Mujer establece:

A los efectos de la presente Convención, la expresión "discriminación contra la mujer" denotará toda distinción, exclusión o restricción basada en el sexo que tenga

\footnotetext{
${ }^{68}$ ATKINSON. Op.cit., p. 281.

${ }^{69}$ ALEINIKOFF, Alexander. Protected characteristics and social perceptions: an analysis of the meaning of "membership of a particular social group". Cambridge: Cambridge University Press, junio, 2003. Disponible en: <http://www.refworld.org/docid/470a33b30.html> acceso 15 de mayo de 2016.

${ }^{70}$ RAMOS, André de Carvalho. Teoria Geral dos Direitos Humanos. São Paulo: Saraiva, 2015, p. 93.

${ }^{71}$ ACNUR, COMITÉ EJECUTIVO. Conclusiones del Comité Ejecutivo del Programa del ACNUR, 19752000. Conclusión No 73 (XLIV) Protección de los Refugiados y Violencia Sexual, de 1981. En Colección de Instrumentos Jurídicos Internacionales Relativos a Refugiados, Derechos Humanos y Temas Conexos. Tomo IV., p. 106. México DF, 2002. Disponible en: <http://www.acnur.es/PDF/3065_20120402174630.pdf $>$ acceso 14 de mayo 2016.
} 
por objeto o por resultado menoscabar o anular el reconocimiento, goce o ejercicio por la mujer, independientemente de su estado civil, sobre la base de la igualdad del hombre y la mujer, de los derechos humanos y las libertades fundamentales en las esferas política, económica, social, cultural y civil o en cualquier otra esfera ${ }^{72}$.

Francisco GALINDO VÉLEZ afirma que la inclusión de las mujeres como grupo social deriva de la Conclusión $\mathrm{N}^{\mathrm{o}} 39$ presentada por el Comité Ejecutivo ${ }^{73}$.

La Conclusión No 39 es sobre las Mujeres Refugiadas y la Protección Internacional, de 1985, donde establece:

k) Reconoció que los Estados, en el ejercicio de su soberanía, eran libres de adoptar la interpretación de que las mujeres en busca de asilo que se enfrentaban a tratos crueles o inhumanos debido a haber transgredido las costumbres sociales de la sociedad en que vivían, podían ser consideradas como un determinado grupo social, según lo dispuesto en el párrafo 2 de la sección A del artículo 1 de la Convención de las Naciones Unidas de 1951 sobre el Estatuto de los Refugiados ${ }^{74}$.

De este modo, queda establecida la facultad de los Estados Partes de decidir sobre la configuración de los grupos sociales, incluyendo la mujer.

\section{I.4.3.6. Extraterritorialidad}

Otro aspecto de la definición legal de la Convención de Ginebra es que la persona se encuentre fuera del país de nacionalidad o de residencia; lo cual hace referencia a la extraterritorialidad.

La persona precisa estar fuera de su país, porque el instituto del refugio protege a aquellos que están desamparados por el derecho interno de sus países y no tienen la protección de ningún país. En ese momento surge la necesidad de que el derecho internacional brinde protección a aquellos que están desprotegidos por todos los derechos internos. En este caso, la función del derecho internacional es la de brindar protección (agilizando los trámites para la admisión de estas personas en otros países y consiguiendo las documentaciones necesarias para el viaje) y, además, ACNUR debe darles la asistencia material porque en estos casos las

\footnotetext{
${ }^{72}$ NACIONES UNIDAS. Convención sobre Todas las Formas de Discriminación contra la Mujer, 1979. Disponible en:

$<$ http://www.msssi.gob.es/ssi/igualdadOportunidades/internacional/onu/Documentos/conv_elim_todas_formas_ discrim_c_mujer.pdf $>$ acceso 20 de mayo de 2016 .

${ }^{73}$ GALINDO VÉLEZ. Op.cit., p. 53.

${ }^{74}$ ACNUR, COMITE EJECUTIVO. Conclusiones del Comité Ejecutivo del Programa del ACNUR, 1975-2000, Conclusión $N^{\circ} 39$ (ILIX) de 1981, Las Mujeres Refugiadas y la Protección Internacional. En Colección de Instrumentos Jurídicos Internacionales Relativos a Refugiados, Derechos Humanos y Temas Conexos. Tomo IV, p. 106. México DF, 2002. Disponible en: <http://www.acnur.es/PDF/3065_20120402174630.pdf > acceso 14 de mayo 2016.
} 
personas están totalmente vulnerables y es preciso que sean asegurados sus derechos humanos fundamentales como vivienda, ropas, alimentos, agua y salud.

Es el hecho de que la persona esté "fuera de su país" que acciona la protección del derecho internacional para el refugiado, pues si se encontrara dentro del país (desplazados internos) la responsabilidad es del Estado de origen.

\section{I.4.3.7. No quiere o no puede retornar e su país}

Otro requisito establecido en la Convención es que la persona que no pueda o no quiera retornar a su país. Se refiere a que la persona no tiene voluntad de volver a su país, obviamente en virtud de la acción de persecución que motivó su salida.

\section{I.5. EI reconocimiento individual y colectivo}

Una innovación que fue traída por la Convención fue una diferencia sustancial con los acuerdos anteriores a 1951 que regían la materia de los refugiados, pues todos estos hacían referencia a la protección de grupos determinados, ya sean los referentes a los rusos, a los alemanes y así sucesivamente. La novedad de la Convención fue que dispuso los requisitos generales para la formación de la figura de los refugiados, de modo que ya no se hacía referencia a grupos particulares.

La Convención del Estatuto de los Refugiados establece el reconocimiento individual de la condición de refugiado.

Aunque, posteriormente, en la realidad internacional surgió el problema de los refugiados en gran escala. En 1981, fueron instituidas las Conclusiones del Comité Ejecutivo de ACNUR. Una de ellas (Conclusión $\mathrm{N}^{\mathrm{o}} 22$ ) declaró la posibilidad de que fuese realizado el reconocimiento colectivo de refugiados, pues hace referencia a la "afluencia en gran escala". La contracara de esta decisión es el aumento de las obligaciones de los Estados. Aunque fue establecido que tales serían pasajeras y que ACNUR dividiría las obligaciones de los Estados en virtud del principio de cargas compartidas entre los países y según el principio de la solidaridad. Estas personas deben ser admitidas en el país receptor y no pueden ser enviadas de regreso al país de origen, en aplicación del Principio de No Devolución. Estas personas que ingresan en gran escala permanecerán en el país receptor de forma provisoria, hasta que sea encontrada una solución según el Principio de Cooperación entre los Estados. No se les aplica 
el artículo 31 de la Convención. Los refugiados en gran escala gozarán de la protección de todos los derechos humanos establecidos en el Derecho Internacional de los Derechos Humanos ${ }^{75}$.

\title{
I.6. Determinación de la Condición de Refugiado
}

En relación con el tiempo que es necesario considerar entre la ocurrencia de los hechos y la presentación de la solicitud, Francisco GALINDO VÉLEZ observa que no es necesario que la presentación de la solitud sea inmediatamente sucesiva a la producción de los hechos que motivan el temor de la persecución, según consta en las Conclusiones del Comité Ejecutivo del ACNUR, Conclusión No 15 (XXX) de $1979^{76}$.

En ese sentido, las Conclusiones observan:

\begin{abstract}
i) Si bien puede establecerse que quienes busquen asilo estén obligados a presentar su solicitud dentro de un cierto plazo, el hecho de no hacerlo, o de no cumplir con otros requisitos formales, no debería excluir la consideración de una petición de asilo ${ }^{77}$.
\end{abstract}

\section{I.7. La definición del refugiado y los derechos humanos}

Cada una de las particularidades del concepto de refugiados enunciado en la Convención: "temor fundado en la persecución”, así como los motivos de la persecución (nacionalidad, religión, raza, grupo social, etnia, opiniones políticas) constituyen derechos humanos. La persecución ataca el derecho a la vida, a la libertad y a la igualdad, abarcando de este modo todos los derechos humanos. Además, cada uno de los motivos de la persecución enunciados son derechos humanos de la persona.

Por lo tanto, la figura del refugiado es la de alguien que tiene sus derechos humanos violados.

Los derechos humanos son aquel conjunto de derechos que son imprescindibles a la vida humana. Tales están protegidos por la mayoría de los ordenamientos jurídicos de los países,

\footnotetext{
75 ACNUR, COMITÉ EJECUTIVO. Conclusiones del Comité Ejecutivo del Programa del ACNUR, 19752000. Conclusión $\mathbf{N}^{\circ} 22$ (XXXII) de 1981, Protección de las personas que buscan asilo en situaciones de afluencia en gran escala. In Colección de Instrumentos Jurídicos Internacionales Relativos a Refugiados, Derechos Humanos y Temas Conexos. Tomo IV, p. 78-81. México DF, 2002. Disponible en: $<$ http://www.acnur.es/PDF/3065 20120402174630.pdf $>$ acceso 16 de mayo de 2016.

${ }^{76}$ GALINDO VÉLEZ. Op.cit.

77 ACNUR, COMITÉ EJECUTIVO. Conclusiones del Comité Ejecutivo del Programa del ACNUR, 19752000. Conclusión $\mathbf{N}^{\circ} 15$ (XXX) de 1981, Refugiados sin País de Asilo (30º período de sesiones del Comité Ejecutivo), 1979. In Colección de Instrumentos Jurídicos Internacionales Relativos a Refugiados, Derechos Humanos y Temas Conexos. Tomo IV, p. 64. México DF, 2002. Disponible en: $<$ http://www.acnur.es/PDF/3065_20120402174630.pdf $>$ acceso 16 de mayo de 2016.
} 
pues han sido incorporados con el nombre de derechos fundamentales. Están consagrados en el Derecho Internacional en la Declaración Universal de los Derechos Humanos, en el Pacto Internacional de Derechos Civiles y Políticos y en el Pacto de Derechos Económicos, Culturales y Sociales.

La pérdida de uno de los derechos humanos afecta a todos, pues tales son indivisibles, y porque significan la realización de la integridad física y psíquica, lo cual constituye una unidad. Porque si los actos atacan a la integridad psíquica, la persona se desmorona, aunque tenga su integridad física intacta.

De tal modo, este artículo que define al refugiado está caracterizándolo como una persona que pierde sus derechos humanos porque dice que es aquel que sufre la violación de su derecho a la libertad o a la vida, por motivos religiosos, de raza, de nacionalidad, opinión pública, grupo social. Todas estas situaciones caracterizadas por el artículo hacen referencia a una situación vivida por las personas en el momento de la creación del Estatuto. Aunque no hacen más que referirse parcialmente a la pérdida de los derechos humanos de la persona. La indivisibilidad de los derechos humanos quiere decir que si es afectado uno de tales derechos, significará la perdida de la dignidad humana, la cual es el fundamento de tales derechos.

La definición del refugiado establece los motivos específicos, aunque en lugar de hacer la enunciación de cada uno de esos motivos, se podría haber colocado violación de los derechos humanos. Las causas por las que no se expresó de esta forma pueden haber sido muchas. Los Estados no querían asumir grandes compromisos, ni en relación con que se hicieran grandes aportes económicos. Por otro lado, se sostenía la idea de que la cuestión de los refugiados era un problema pasajero. Esa convención fue el resultado de un momento histórico.

Es indiscutible que las posiciones de las potencias (los países) de ese momento negociaron cada palabra, por lo tanto, hubiera sido imposible un marco legal más general.

De todos modos, la actuación que desarrolló la ACNUR desde su creación demuestra que fueron buscándose caminos alternativos para auxiliar a quienes se encontraban en esa situación a pesar de no poder ser encuadrados dentro de tal definición, como fue el caso de los refugiados húngaros, los refugiados rusos, los refugiados de América del Sur y Central, así como tantos otros. 


\section{I.8. Causas de cesación}

Las causas de cesación de la condición de refugiado están enunciadas en el artículo 1, sección C de la Convención del Estatuto del Refugiado de 1951. Estas podrán ser interpretadas restrictivamente.

En ese sentido, el artículo 1, sección C establece:

C. En los casos que se enumeran a continuación, esta Convención cesará de ser aplicable a toda persona comprendida en las disposiciones de la sección A precedente:

1) Si se ha acogido de nuevo, voluntariamente, a la protección del país de su nacionalidad;

2) si, habiendo perdido su nacionalidad, la ha recobrado voluntariamente; o

3) si ha adquirido una nueva nacionalidad y disfruta de la protección del país de su nueva nacionalidad; o

4) si voluntariamente se ha establecido de nuevo en el país que había abandonado o fuera del cual había permanecido por temor de ser perseguida; o

5) si, por haber desaparecido las circunstancias en virtud de las cuales fue reconocida como refugiada, no puede continuar negándose a acogerse a la protección del país de su nacionalidad.

Queda entendido, sin embargo, que las disposiciones del presente párrafo no se aplicarán a los refugiados comprendidos en el párrafo 1 de la sección A del presente artículo que puedan invocar, para negarse a acogerse a la protección del país de su nacionalidad, razones imperiosas derivadas de persecuciones anteriores.

6) Si se trata de una persona que no tiene nacionalidad y, por haber desaparecido las circunstancias en virtud de las cuales fue reconocida como refugiada, está en condiciones de regresar al país donde antes tenía su residencia habitual.

De tal modo, la Convención de Ginebra sobre el Estatuto del Refugiado observa que no será aplicable:

1. a la persona que vuelva a pedir la protección de su país de origen;

2. a aquella que recuperó su nacionalidad;

3. a la que adquirió otra nacionalidad y este país le da la protección;

4. si volvió para residir en el país donde era perseguida;

5. si desaparecieron las situaciones que la hacían sentir con miedo de la persecución;

6. en el caso del apátrida, desaparecen las situaciones que le hacían sentir miedo de la persecución.

En estas situaciones enunciadas se deja de aplicar la Convención porque demuestran, de una u otra forma, la desaparición de alguno de los elementos del concepto de refugiado, enunciado en el artículo 1. En todas las hipótesis el refugiado deja de ser una persona desprotegida por el derecho, deja de ser vulnerable. 
Las cláusulas de cesación constituyen los casos en los que el refugiado pierde este estatus porque él ya no tiene la necesidad de tal protección. Este elenco restricto de las situaciones en las que cesa la calidad de refugiado tiene por objetivo brindar a estas víctimas la tranquilidad de la estabilidad de su condición ya que los supuestos están reconocidos en la ley. En las cuatro primeras hipótesis enunciadas, las circunstancias vividas por el refugiado han cambiado. En las dos últimas, ha desaparecido la situación de peligro vivida por el refugiado en el país, porque ha mejorado el ambiente ${ }^{78}$.

Seguidamente, se analizan cada una de las hipótesis consideradas en la ley:

1. "Si se ha acogido de nuevo, voluntariamente, a la protección del país de su nacionalidad;"

Esta hipótesis no significa que el refugiado haya vuelto a su país de nacionalidad, sino que él ha pedido la protección de su país. Aunque el hecho de haber solicitado la protección no significa la pérdida de la condición, porque es necesario que sea aceptada por el país de origen. En este caso, el refugiado precisa expresar su voluntad, pues si no hay intención, no se produce la cesación de la condición de refugiado. En el caso de que la persona solicite el pasaporte de su país de origen y se le concede, se considerará como que implícitamente ha perdido la condición de refugiado. Si la persona solicita otros tipos de documentos (por ejemplo, partida de nacimiento) al país de origen, no significará la pérdida de la condición de refugiado. Otro caso en el que no habría pérdida de la condición de refugiado es cuando el refugiado es obligado a ir a su país de origen para pedir su divorcio en el país de origen. Si el refugiado realiza viajes frecuentes a su país, él será encuadrado dentro de esa hipótesis de cesación ${ }^{79}$.

2. "Si habiendo perdido su nacionalidad, la ha recobrado voluntariamente;"

Esta cláusula hace alusión a la situación en la que la persona solicita la nacionalidad de su país de origen, y esta le es concedida. Estas circunstancias no son equivalentes a cuando el país la otorga de oficio. El pedido de la nacionalidad debe ser voluntario ${ }^{80}$.

3. "Si adquirió otra nacionalidad y este país le da la protección";

\footnotetext{
${ }^{78}$ ACNUR. Manual de procedimientos, Op.cit., p. 20.

${ }^{79}$ ACNUR. Manual de procedimientos, Op.cit., p. 19-24, parágrafos 118-123.

${ }^{80}$ ACNUR. Manual de procedimientos, Op.cit., p. 22, parágrafo 126-128.
} 
En esta situación la persona ya no está más desamparada, porque ha sido integrada a otro país que le brindará la protección y asistencia.

El hecho de adquirir otra nacionalidad significa que la persona tiene los derechos de ciudadanía, y deja de estar desprotegida internacionalmente.

4. "Si voluntariamente se ha establecido de nuevo en el país que había abandonado o fuera del cual había permanecido por temor de ser perseguida."

Esta situación significa que la persona ha vuelto a establecer su residencia en el país donde era perseguida. La hipótesis no comprende los casos en los que la persona realiza una simple visita ${ }^{81}$.

5. "Si por haber desaparecido las circunstancias en virtud de las cuales fue reconocida como refugiado, no puede continuar negándose a acogerse a la protección del país de su nacionalidad".

6. "Si se trata de una persona que no tiene nacionalidad y, por haber desaparecido las circunstancias en virtud de las cuales fue reconocida como refugiada, está en condiciones de regresar al país donde antes tenía su residencia habitual”.

En estas dos últimas clausulas, las circunstancias políticas en el país de origen o de residencia han mejorado al punto que no existe más el miedo de la persecución que fundamentaba la condición de refugiado ${ }^{82}$.

La sexta hipótesis se puede referir al caso del apátrida. Esta es la única diferencia con la situación enunciada antes.

La Convención establece lo que ocurre en el caso de una persona con nacionalidad múltiple. En tal caso, puede ocurrir que una persona tenga más de una nacionalidad, y que sea perseguida por uno de los países de su nacionalidad, teniendo la posibilidad de recurrir al otro del que también es nacional, en esta hipótesis no será tratado como un refugiado.

La Convención dice "que no pueda o en virtud de temores, no quiera pedir la protección de aquel país", es decir que hay dos hipótesis: que no puede o que no quiere. En relación con la primera, no existe posibilidad de solicitar la protección, ya en la segunda, la persona no tiene voluntad porque tiene miedo de que pueda ocurrirle algo peor.

\footnotetext{
${ }^{81}$ ACNUR. Manual de procedimientos, Op.cit., parágrafo 133-134.

${ }^{82}$ ACNUR. Manual de procedimientos, Op.cit., parágrafo 115.
} 
La Convención hace referencia a aquellos casos en los que la persona "no tiene nacionalidad y se encuentra fuera del país en el que tiene su residencia habitual y después de esos acontecimientos, no quiera o, en virtud de tal recelo, no quiera volver a ese país".

En esta hipótesis la Convención se refiere al caso del apátrida, es la misma idea anteriormente citada, sólo que cambia el país de su nacionalidad por el país de residencia habitual.

\section{I.9. Principio de No Devolución}

El artículo 33 de la Convención sobre el Estatuto de los Refugiados establece el “Principio de No Devolución”. Este principio tiene gran relevancia en el derecho internacional de los refugiados, pues asegura al refugiado que el país que lo reciba no lo va a deportar al país donde sufrió la persecución. Así, se puede observar que está relacionado de forma directa con el concepto de refugiado, constituyendo un pilar fundamental para asegurar su protección jurídica.

Este principio está enunciado en el artículo 33 de la Convención, así como en la Declaración de Naciones Unidas sobre el Asilo Territorial de 1967 (artículo 3) y en la Convención contra la tortura y otros tratamientos o penas crueles, deshumanos o degradantes de 1984 (artículo 3).

El artículo 33 del Estatuto es el que consagra el Principio de No Devolución, estableciendo:

Artículo 33. -- Prohibición de expulsión y de devolución (refoulement)

1. Ningún Estado Contratante podrá, por expulsión o devolución, poner en modo alguno a un refugiado en las fronteras de los territorios donde su vida o su libertad peligre por causa de su raza, religión, nacionalidad, pertenencia a determinado grupo social, o de sus opiniones políticas.

La regla sostenida en este artículo es muy clara, pues enuncia la obligación de los Estados contratantes de respetar, reconocer y hacer efectivo el principio de "No Devolución". De tal forma, esta regla afirma que los países contratantes no podrán expulsar al refugiado hacia el país donde fue víctima de las persecuciones y donde su vida, su libertad y su integridad estén en riesgo. 
El Principio de No Devolución fue instituido con anterioridad en la Convención Internacional del Refugiado de 1933, aunque este instrumento nunca entró en vigencia por falta de ratificaciones ${ }^{83}$.

Por otro lado, el artículo 33, apartado 2, establece que no serán acogidos por este principio aquellas personas que constituyan un peligro para el orden público del país de acogida.

En tal sentido, afirma:

2. Sin embargo, no podrá invocar los beneficios de la presente disposición el refugiado que sea considerado, por razones fundadas, como un peligro para la seguridad del país donde se encuentra, o que, habiendo sido objeto de una condena definitiva por un delito particularmente grave, constituya una amenaza para la comunidad de tal país.

Además, ese principio fue reconocido por el artículo 2 de la Convención Relativa a los aspectos específicos de los Refugiados Africanos de la OUA del año 1962, el cual establece "la obligación del Estado de no devolver" al refugiado al lugar donde corre riesgo de persecución. Una diferencia entre este artículo 2 y el 33 del Estatuto es que este último se refiere a que el riesgo sea de vida o de la libertad, mientras que el artículo 2 de la citada Convención de la OUA agrega integridad física.

Héctor CUADRA observa que esta regla de la no devolución aparentemente estaría en contradicción con el principio del derecho internacional, que establece "el derecho ilimitado de los Estados de regular la admisión de extranjeros". Aunque el autor sostiene que la obligación de no devolver al refugiado no implica que el Estado no pueda enviarlo a otro país, donde el refugiado pueda vivir en paz $^{84}$.

CUADRA expone la contraposición entre el Principio de No Devolución y la potestad ilimitada de los Estados de decidir sobre la admisión de los extranjeros. Aunque en el caso de los refugiados es distinto, ya que el refugiado es diferente del extranjero: el refugiado no tiene otras posibilidades, pues se trata de elegir entre la admisión o su vida, por lo tanto, entraría en juego uno de los Derechos Humanos que es el derecho a la vida. La voluntad de entrada a un país de un extranjero es una opción, en tanto que en el caso del refugiado no hay opción, no hay otras posibilidades, o trata de entrar o se muere. Por esto, rige la obligación de No Devolución de los refugiados de los Estados.

Esa posibilidad está contemplada expresamente en la segunda parte del artículo 2 de la Convención relativa a los aspectos específicos de los Refugiados Africanos de la OUA, de 1969,

\footnotetext{
${ }^{83}$ ACNUR. La situación de los refugiados en el mundo. Op. cit., p. 30.

${ }^{84}$ CUADRA, Héctor. Protección Internacional de los Derechos Humanos. Instituto de Investigaciones Jurídicas de la UNAM, México DF, 1970, p. 173.
} 
donde se establece que si el Estado receptor no puede dar asilo al refugiado lo comunicará a los otros Estados miembros de la OUA para verificar cuál podrá darle el refugio, aplicándose el principio de la solidaridad internacional.

La posibilidad de la expulsión del refugiado está contenida en la segunda parte del artículo 32 del Estatuto. Este dispositivo legal del Estatuto del Refugiado trata de una excepción a la regla de la No Devolución, que sería la hipótesis de los casos en que se autoriza la expulsión del refugiado del país receptor. Ese artículo observa que la expulsión del refugiado sólo podrá ser en caso de que él constituya un obstáculo a la seguridad nacional y al orden social. Esa persona constituye una amenaza a la sociedad. Tal decisión debe emanar de un proceso realizado ante las autoridades competentes. En tal proceso será verificada la gravedad de la situación, donde el refugiado tendrá derecho a defenderse y oponer pruebas a su favor.

En la tercera parte del artículo 32 se establece que será otorgado un plazo para que este refugiado pueda encontrar otro país de recepción, de modo que se aplica el principio de la No Devolución ${ }^{85}$.

Por ende, es posible señalar que ni siquiera en el caso excepcional de un refugiado que constituya obstáculo al orden público y a la seguridad nacional, se aplicará la devolución, mucho menos en la hipótesis de un refugiado común.

Además, el Estado contratante tiene el derecho de salir de la Convención, o de realizar reservas al instrumento legal. Por tanto, la soberanía del Estado no estaría en juego, en relación con el Principio de No Devolución. La potestad ilimitada de los Estados Contratantes de decidir sobre la admisión de extranjeros es una manifestación de la soberanía de los Estados, aunque del mismo modo la decisión de firmar, ratificar o adherir, o de denunciar a un Tratado Internacional también es una manifestación de la soberanía de los Estados.

Finalmente, se llega a la conclusión de que el Principio de No Devolución contenido en el Estatuto no afecta a la soberanía de los Estados contratantes y está fundado en los principios de los Derechos Humanos de la protección de la vida, la libertad y la dignidad de la persona humana expresados en la Declaración Universal de los Derechos Humanos. Esos constituyen principios basilares del Derecho Internacional y de los Derechos Constitucionales de los países.

El Principio de No Devolución será aplicable tanto al refugiado que se encuentre en condiciones de regularidad como a aquel que esté irregularmente ${ }^{86}$.

\footnotetext{
${ }^{85}$ CUADRA. Op.cit., p. 171.

${ }^{86}$ CUADRA. Op.cit., p. 173.
} 
En tal sentido, el artículo 31 observa en relación con el refugiado irregular:

1. Los Estados Contratantes no aplicarán sanciones penales, debido a la entrada o estadía irregulares, de los refugiados que, llegando directamente del territorio donde su vida o libertad estaban amenazadas en el sentido previsto por el artículo 1, entren o se encuentren en sus territorios sin autorización [...]

Aunque impone la obligación del refugiado en situación irregular de presentarse a la brevedad ante las autoridades competentes para explicar las causas de su situación.

Ese artículo 31 regula la situación los refugiados irregulares, considerando que no se les aplicarán restricciones a no ser aquellas que sean necesarias mientras que este espera la regularización en ese país o en otro que le dé refugio, siendo que para esto se les brindará un plazo considerable y se le darán todas las facilidades que precise.

\section{I.10. Aspectos relevantes de ACNUR. De la naturaleza consultiva a la operativa: Buenos Oficios y Resoluciones de la Asamblea General de Naciones Unidas}

Es importante resaltar que ACNUR comenzó teniendo solamente funciones consultivas, pero este organismo internacional no quedó paralizado en el tiempo, sino que fue ampliando sus funciones con el transcurso de los acontecimientos posteriores. Estados Unidos no quería que ACNUR tuviese competencias de asistencia, pretendía que solamente pudiese brindar protección, la cual consistía simplemente en hacer los trámites legales para que estas personas afectadas fuesen recibidas en otros países.

Jérôme B. ELIE observa que muchos autores consideraron que ACNUR fue un títere del Occidente en el medio de la Guerra Fría, pero es necesario observar:

\footnotetext{
[...] El ACNUR nació con poca autonomía, como un organismo diseñado para hacer lo que los Estados miembros decían que hiciera. Sin embargo, bajo el impulso de los sucesivos Altos Comisionados, se las arregló para superar las limitaciones originales y actuar con un alto grado de autonomía. Esta observación es importante porque parece contradecir las opiniones según las cuales el ACNUR actuó como una herramienta de propaganda para el Occidente, o al menos porque sugiere que dicho análisis debe ser refinado.
}

Los norteamericanos dudaban de ACNUR, pues en esta organización participaban muchos otros países y Estados Unidos no tenía el dominio absoluto del organismo: este organismo estaba bajo la autoridad de la Asamblea General de Naciones Unidas. Por ello, ese 
país creó el Comité Internacional para las Migraciones Europeas (CIME) y el "Escapee Program" de Estados Unidos ${ }^{87}$.

Las limitaciones a la actividad de ACNUR hacían que solamente pudiese actuar como organismo coordinador y consultivo, de modo que no podía realizar actividades de asistencia material en el campo donde estaban los refugiados. Estos límites a la actividad del organismo fueron impuestos por la Resolución que la instituyó, y por la Convención sobre el Estatuto de los Refugiados (1951), cuya definición de refugiado contenía dos restricciones: que fuesen refugiados que resultaban de eventos anteriores a enero de 1951 y que estuviesen en Europa.

Aunque los apartados 3 y 9 de la Resolución que instituyó ACNUR permitía que fuesen ampliadas sus competencias por decisión de la Asamblea General de Naciones Unidas.

Y así ocurrió, porque el aumento de las funciones de ACNUR se produjo a través de las Resoluciones de la Asamblea General de Naciones Unidas.

De tal modo, posteriormente, la Asamblea General de Naciones Unidas fue ampliando las competencias de ACNUR hasta convertirlo en un organismo "operativo". Esta transformación de ACNUR se produjo porque la Asamblea General de Naciones Unidas introdujo los "Buenos Oficios", lo cual consistía en un mecanismo a través del cual ACNUR podía brindar asistencia material a los refugiados que estuviesen fuera de su mandato.

Esto demuestra una flexibilidad en este organismo que opera bajo las directivas de la Asamblea General de Naciones Unidas.

Porque las normativas jurídicas deben acompañar a la realidad social, sino esas estructuras jurídicas quedan obsoletas y sin ninguna utilidad para el momento social contemporáneo.

En un primer lugar, la naturaleza de ACNUR era consultiva, pues era de "protección”, y no de asistencia material. Esta función de protección implicaba solamente la realización de los trámites de admisión en los países. Aunque hubo algunos acontecimientos que exigieron que ACNUR se adaptase a las necesidades que se presentaban. En segundo lugar, aparecieron nuevas situaciones: los refugiados que escapaban de Alemania Oriental (1953), los refugiados húngaros (1956) y los refugiados argelinos (1960). Todos estos refugiados estaban fuera del concepto definido en la Convención sobre el Estatuto de los Refugiados y además exigían que ACNUR no sólo realizase las funciones de protección sino también de asistencia material. En

\footnotetext{
${ }^{87}$ ELIE, Jérôme B. (Coord.). The UNHCR and the Cold War: A Documented Reflection on the UN Refugee Agency's Activities in the Bipolar Context. A working-paper of "The UNHCR and the Global Cold War, 1971-1984". A joint UNHCR/GIIS/GCSP project with funding from the GIAN. Junio, 2007, p. 4-7. Disponible en: $<$ http://hei.unige.ch/sections/hp/UNHCRProject.htm> acceso 5 de agosto de 2015.
} 
tercer lugar, CUADRA enuncia todas las resoluciones de la Asamblea de Naciones Unidas, que fueron ampliando las funciones de ACNUR. De tal modo, ACNUR adquirió la función de asistencia material a través de esas resoluciones de la Asamblea General. Además, Cuadra demuestra cómo, por medio de esas resoluciones, ACNUR consiguió atender a los refugiados que estaban fuera de la definición. Porque estas resoluciones introdujeron el mecanismo de los Buenos Oficios ${ }^{88}$.

CUADRA destaca que la Resolución 1388 de la Asamblea de Naciones Unidas del 20 de septiembre de 1959 introdujo la noción de Buenos Oficios que permitiría que ACNUR pudiese cuidar de los refugiados que no estaban dentro de su mandato. A través de este principio, ACNUR pudo ocuparse de todos los refugiados de diferentes partes del mundo ${ }^{89}$.

El éxodo húngaro se produjo en 1955 y 1956, en el cual miles de húngaros escapaban hacia Austria o Yugoslavia, pues este último país había roto relaciones con el régimen de la Unión Soviética. Aunque estos países receptores comenzaron a ver cómo se agotaban los medios para recibir a estos refugiados. Austria hacía pocos meses que había recobrado su soberanía. Ambos países pidieron la ayuda de ACNUR, aunque existía un inconveniente, pues en la definición de ACNUR se señalaba que solamente se ocuparía de las personas que habían sufrido los acontecimientos de antes de enero de 1951, por lo tanto, no era aplicable el Convenio a esta situación ${ }^{90}$.

Estados Unidos era contrario a que ACNUR ayudase a los refugiados de Hungría. A pesar de esto, la actuación de ACNUR fue relevante, pues realizó los trámites con los países para reasentar grandes cantidades de refugiados ${ }^{91}$.

Es necesario destacar el papel del reasentamiento en otros países, y la cuestión del financiamiento, en tal sentido se puede decir:

El Alto Comisionado también pidió contribuciones especiales y la respuesta fue generosa. En noviembre de 1956, se creó un comité conjunto integrado por el ACNUR, el Comité Intergubernamental para las Migraciones Europeas, el gobierno austríaco, el Escapee Program de los Estados Unidos y organizaciones de voluntarios. En el invierno de 1956 y a lo largo de 1957, las organizaciones de voluntarios desempeñaron un papel clave en la asistencia de ayuda de emergencia y al reasentamiento de los refugiados húngaros ${ }^{92}$.

\footnotetext{
${ }^{88}$ CUADRA. Op.cit., p. 155.

${ }^{89}$ CUADRA. Op.cit., p. 162.

${ }^{90}$ ACNUR. La situación de los refugiados en el mundo. 2000. Op. cit., p. 34.

${ }^{91}$ ELIE. Op.cit., p .7.

${ }^{92}$ ACNUR. La situación de los refugiados en el mundo. Op.cit., p. 39.
} 
Además, la Resolución 1006 fue la llave que permitió que ACNUR pudiera hacerse cargo de estos refugiados húngaros, pues establecía:

La Asamblea General [...]

Considerando que, como consecuencia de la acción rigurosa y represiva de las fuerzas armadas soviéticas, un número cada vez mayor de refugiados se ven obligados a salir de Hungría y a buscar asilo en países vecinos,

1 Pide al Secretario General que encargue al Alto Comisionado de las Naciones Unidas para los Refugiados que celebre consultas con otros organismos internacionales apropiados y con los Gobiernos interesados a fin de adoptar disposiciones rápidas y eficaces para prestar asistencia urgente a los refugiados procedentes de Hungría ${ }^{93}$;

En 1941, Hong Kong tenía una población de 650.000 habitantes, aunque entre 1953 y 1954 aumentó a 2.000.250 habitantes. Dicho incremento se debió a la llegada de los refugiados chinos que escapaban del régimen comunista. Estas personas podían huir hacia Taiwán, pero no querían hacerlo pues temían que el régimen comunista llegase a ese país también. Se pidió que ACNUR actuase bajo los principios de los Buenos Oficios ${ }^{94}$.

La situación de los refugiados de Hong Kong y la actuación de ACNUR fue muy complicada. En primer lugar, los refugiados chinos escapaban de un país que no era reconocido por Naciones Unidas. En segundo lugar, estos refugiados tenían la posibilidad de irse a Taiwán, que podía ser considerada como otra China, aunque no tenía ese régimen. En tercer lugar, según la definición del refugiado de la Convención, no correspondería la actuación de ACNUR en este caso (porque estaban fuera de Europa y los acontecimientos eran posteriores a la fecha límite establecida en el Estatuto de los Refugiados, que era el 1 de enero de 1951).

En todo esto reside la importancia de la Resolución 1167 del 26 de noviembre de 1957, que amplía el campo para ayudar a refugiados chinos de Hong Kong, aunque lo más importante de esta Resolución es que se autoriza la actuación de ACNUR en la asistencia de los refugiados introduciendo el concepto de los Buenos Oficios.

La Resolución 1167 permitió que ACNUR pudiese actuar en este caso.

En tal sentido, la Resolución 1167 considera:

La Asamblea General [...]

Habiendo considerado el problema de los refugiados chinos en Hong Kong, de acuerdo con la resolución adoptada por el Comité Ejecutivo del Fondo de Refugiados de Naciones Unidas en su cuarta sesión,

Reconoce la carga pesada sobre el gobierno de Hong Kong debido a este problema y los esfuerzos hechos para aliviarlo,

${ }^{93}$ NACIONES UNIDAS. ASAMBLEA GENERAL. Resolución 1006, 9 de noviembre de 1956, 571º Sesión Plenaria.

${ }^{94}$ ACNUR. La situación de los refugiados en el mundo. 2000. Op.cit., p. 39. 
Reconoce de cualquier manera que el problema concierne a la comunidad internacional,

Tomando en cuenta que la necesidad para la emergencia y la asistencia de largo plazo,

$[\ldots]$

2. Autoriza al Alto Comisionado para los Refugiados de Naciones Unidas para hacer uso de sus "Buenos Oficios" para fomentar los arreglos para contribuir".

En 1954 se produjo la lucha por la independencia de Argelia de Francia. Esto llevó a que doscientos mil refugiados argelinos escaparan de sus hogares para protegerse de los conflictos armados, y fueron hacia Túnez y Marruecos. El gobierno de Túnez solicitó la ayuda de ACNUR, la cual se hizo presente en el lugar ${ }^{96}$.

Existía el problema de que Francia había sido uno de los países que más apoyaban a ACNUR y, por esto, este organismo tuvo que realizar arduas negociaciones para que Francia aceptase la intervención de ACNUR para proteger a los refugiados argelinos ${ }^{97}$.

La Resolución 1500 de la Asamblea de Naciones Unidas apoya la actuación de ACNUR en el caso de los refugiados argelinos, observando:

La Asamblea General [...]

Reconociendo la acción tomada por el Alto Comisionado y encorajando los resultados alcanzados durante el Año Mundial de los Refugiados,

Apreciando los progresos hechos con los refugiados argelinos en Marrocos y Tunísia, $[\ldots]$

Recomienda que el Alto Comisionado de los Refugiados debe:

A) Continuar sus presentes acciones ${ }^{98}$.

Esta Resolución también es muy importante dado que se verifica que se amplían las funciones de ACNUR, tanto en relación con el espacio como con sus actividades, pues dejan de ser de consultoría y coordinación para brindar asistencia a los refugiados.

El nuevo Comisionado universalizó el mandato a través de la Resolución 1285.

En relación con ello, esta resolución establece:

La Asamblea General [...]

Habiendo considerado la propuesta de Año Mundial de los Refugiados que comienza en junio de 1959,

Tomando nota de que esta propuesta tiene dos objetivos, a saber: a. centrar los intereses sobre el problema de los refugiados y alentar contribuciones adicionales financieras de los gobiernos, agencias de voluntarios y el público en general para su solución,

b. fomentar las oportunidades adicionales para soluciones permanentes respecto de los refugiados, a través de la repatriación voluntaria, el reasentamiento o

\footnotetext{
95 NACIONES UNIDAS. ASAMBLEA GENERAL. Resolución 1167 (XII) Chinese refugees in Hong Kong, 26 de noviembre de $1957,723^{\circ}$ Sesión Plenaria.

${ }^{96}$ ACNUR. La situación de los refugiados en el mundo. Op.cit., p. 45.

${ }^{97}$ ELIE. Op.cit., p. 7.

${ }^{98}$ NACIONES UNIDAS. ASAMBLEA GENERAL. Resolución 1500 (XV) Refugees form Argelia in Morocco and Tunisia, 5 de diciembre de 1960, 935 Sesión Plenaria.
} 
la integración, sobre una base puramente humanitaria y de acuerdo con los deseos libremente expresados de los propios refugiados,

[...] Insta a los Estados Miembros de las Naciones Unidas y miembros de los organismos especializados a cooperar [...] en la promoción del Año Mundial de los Refugiados como un medio práctico para asegurar el aumento de Asistencia para los refugiados en todo el mundo, $[\ldots]^{99}$.

Esta resolución establece que deberían ser dados fondos financieros para que ACNUR pueda alcanzar las soluciones necesarias a los problemas de los refugiados. Por otro lado, considera que ACNUR debe realizar repatriación voluntaria, reasentamiento e integración de los refugiados. Además, autoriza a ACNUR a realizar actividades de asistencia, dejando de ser un organismo meramente consultivo.

La Resolución 1388 del 20 de noviembre de 1959 vuelve a referirse a la actuación de ACNUR, utilizando el mecanismo de los Buenos Oficios:

\section{La Asamblea General [...]}

2. Autoriza al Alto Comisionado, al respecto de los refugiados que no están incluidos dentro de su competencia por Naciones Unidas, para usar los buenos oficios en proveer asistencia, a través de las contribuciones hechas para proveer asistencia a los refugiados ${ }^{100}$.

De esta forma, en noviembre de 1959 se repite la autorización para actuar a través del mecanismo de los Buenos Oficios, ampliando el campo de actuación de ACNUR.

Por otro lado, la Resolución 1388 del 20 de noviembre de 1959 observa que es necesario que los Estados miembros de Naciones Unidas contribuyan con ACNUR para que consiga realizar sus funciones. Especialmente, tal Resolución expresa que los países miembros deben mejorar la situación en la que viven los refugiados, ayudando al restablecimiento, la integración y la asimilación de los refugiados enviados, y que ACNUR profundice sus esfuerzos en tal sentido. Además, observa la importancia de que sea realizada la repatriación voluntaria.

La Resolución 1673 (XVI) otorga al Alto Comisionado de los Refugiados la competencia discrecional de decidir el momento y lugar para la utilización del mecanismo de Buenos Oficios. Esto es de gran relevancia pues implica el aumento de las competencias del Alto Comisionado de Refugiados ya no refiriéndose a casos específicos de grupos de refugiados.

\footnotetext{
${ }^{99}$ NACIONES UNIDAS. ASAMBLEA GENERAL. Resolución 1285 (XIII) World Refugees Year, 5 de diciembre de $1958,782^{\circ}$ Sesión Plenaria.

${ }^{100}$ NACIONES UNIDAS. ASAMBLEA GENERAL. Resolución 1388 (XIV) Report of United Nations High Comissioner for Refugees, 20 de noviembre de 1959, $841^{\circ}$ Sesión Plenaria.
} 
En tal sentido observa:

La Asamblea General,

$[\ldots]$

Tomando nota con satisfacción de la asistencia que ACNUR puede dar a los refugiados en el manejo de la contribución designada para brindar su asistencia y en la utilización del fondo de emergencia establecido por la Resolución 1166 de la Asamblea General del 26 de noviembre 1957. [...]

1. Solicita que el Alto Comisionado para los Refugiados de las Naciones Unidas ejerza sus actividades en favor de los refugiados que están dentro de su mandato o de aquellos que pueden ser incluidos en los Buenos Oficios, y que continúe informando al Comité Ejecutivo del Programa del Alto Comisionado y acatar las instrucciones que dicho comité podría darle en lo que se refiere a las situaciones en materia de refugiados ${ }^{101}$.

Así quedó expresamente ampliada la competencia del Alto Comisionado. Además, según el primer parágrafo citado quedó establecido que ACNUR podría utilizar los fondos de emergencias de las contribuciones, pues no bastaba ampliar las competencias sin darle el financiamiento.

\section{I.11. ¿Reasentamiento o repatriación?}

Algunos países eran favorables al reasentamiento porque buscaban mano de obra, pues después de la guerra habían quedado sin suficientes personas para realizar los trabajos ${ }^{102}$. Otros países eran contrarios al reasentamiento y favorables a la repatriación porque de ese modo tendrían sus habitantes reintegrados nuevamente, este era el caso de la Unión Soviética y de otros países de Europa Oriental, que hacían parte del bloque comunista. Ambos mecanismos fueron utilizados, aunque la repatriación solamente podría ser voluntaria.

\section{I.12. Derechos de los refugiados reconocidos en la Convención de 1951}

Los refugiados tendrán garantizados los derechos a la compra de un inmueble, así como de bienes muebles, a los derechos de propiedad intelectual e industrial.

Por otro lado, serán asegurados los derechos a participar de asociaciones y el acceso a la justicia.

\footnotetext{
${ }^{101}$ NACIONES UNIDAS. ASAMBLEA GENERAL. Resolución 1673 (XVI) Report of United Nations High Comissioner for Refugees, 18 de diciembre de 1961, $1081^{\circ}$ Sesión Plenaria.

102 ANDRADE. Op.cit., p. 299.
} 
Los refugiados tendrán derecho al empleo remunerado, al ejercicio de la profesión autónoma y al ejercicio de su profesión liberal cuando sus títulos hayan sido reconocidos por los países.

Estos afectados tendrán derecho a la vivienda, a la educación pública, así como al reconocimiento de los títulos educacionales extranjeros.

Se asegura el derecho al trabajo y a todos los beneficios establecidos por las leyes laborales y seguros sociales.

También, les son garantizados el derecho a la libertad de circulación y a elegir libremente el lugar de su residencia.

Por otro lado, les son asegurados el derecho a los documentos de identidad y de viaje.

\section{I.13. Protocolo relativo al Estatuto de los Refugiados de 1967}

El Protocolo de 1967 hizo desaparecer la limitación temporal referente a que los refugiados fuesen originarios de Europa, así como las limitaciones temporales que hacían referencia a los acontecimientos anteriores al 1 de enero de 1951.

En primer lugar, la Convención relativa al Estatuto de los Refugiados de 1951 establecía un límite temporal, siendo aplicado solamente a aquellas personas que fueran víctimas hasta el día 1 de enero de 1951.

En 1967 fue creado el Protocolo Adicional de la Convención sobre el Estatuto del Refugiado.

El nuevo Protocolo "representaba la base jurídica, así como el símbolo de la agencia de la universalización, la emancipación y la capacidad de actuar de forma autónoma"103.

Este Protocolo establecía:

Artículo I. Disposiciones generales

1. Los Estados Partes en el presente Protocolo se obligan a aplicar los artículos 2 a 34 inclusive de la Convención a los refugiados que por el presente se definen.

2. A los efectos del presente Protocolo y salvo en lo que respecta a la aplicación del párrafo 3 de este artículo, el término "refugiado" denotará toda persona comprendida en la definición del artículo 1 de la Convención, en la que se darán por omitidas las palabras "como resultado de acontecimientos ocurridos antes del 1 de enero de 1951" y las palabras "a consecuencia de tales acontecimientos", que figuran en el párrafo 2 de la sección A del artículo 1.

De tal modo, el parágrafo 2 del artículo 1 del Protocolo deja sin vigor la limitación temporal.

${ }^{103}$ ELIE. Op.cit., p. 12. 
En tal sentido:

Además, al adherir al Protocolo, los Estados que aún no habían firmado o ratificado
la Convención asumían las disposiciones de los artículos 2 a 34 de esta y no tenían la
posibilidad de adoptar la reserva geográfica. Era una forma de subsanar esa limitación,
haciendo con que los Estados que pasasen a comprometerse con la cuestión de los
refugiados pudiesen recibir personas oriundas de cualquier parte del mundo. Con eso,
el Protocolo agrandaba las obligaciones de los Estados-partes estipuladas por la
Convención ${ }^{104}$.

De tal forma, los Estados que adherían al Protocolo, sin haber adherido anteriormente a la Convención, no podían hacer la reserva geográfica. Esta solamente se mantenía para los que la hubieran hecho en el momento de la adhesión a la Convención.

El parágrafo 3 del artículo 1 del Protocolo, establece:

3. El presente Protocolo será aplicado por los Estados Partes en el mismo sin ninguna limitación geográfica; no obstante, serán aplicables también en virtud del presente Protocolo las declaraciones vigentes hechas por Estados que ya sean Partes en la Convención de conformidad con el inciso a) del párrafo 1 de la sección $\mathrm{B}$ del artículo 1 de la Convención, salvo que se hayan ampliado conforme al párrafo 2 de la sección B del artículo 1.

El inciso a) del párrafo 1 de la sección $\mathrm{B}$ del artículo 1 de la Convención establece: "B. 1) A los fines de la presente Convención, las palabras “acontecimientos ocurridos", que figuran el artículo 1 de la sección A, podrán entenderse como: a) 'Acontecimientos ocurridos en Europa"”.

Por lo tanto, significa que se respetará el derecho de aquellos Es tados que hicieron la reserva geográfica (admitiendo solamente refugiados de Europa).

El artículo 1, 3 del Protocolo continúa diciendo: "Salvo que se hayan ampliado conforme al párrafo 2 de la sección B del artículo 1". Esta última parte hace referencia al siguiente parágrafo de la Convención: “2) Todo Estado Contratante que haya adoptado la fórmula podrá en cualquier momento extender sus obligaciones, mediante la adopción de la fórmula b por notificación dirigida al Secretario General de las Naciones Unidas”.

El artículo 2 establece las obligaciones de los Estados contratantes en relación al ACNUR, las cuales no habían sido establecidas en el Estatuto. Estas obligaciones comprenden la presentación de informes relacionados con la situación de los refugiados, en relación con la aplicación del Estatuto y las leyes que reglamenten la situación del refugiado. Esas 
comunicaciones serán enviadas a la Secretaria de Naciones Unidas. Estas mismas obligaciones son establecidas en la Convención de OUA.

El artículo 4 establece que las controversias que surjan entre las partes (sean en cuanto a la interpretación, así como a la aplicación de este Protocolo) serán solucionadas a través de la Corte Internacional de Justicia.

Según el artículo 5, todos los Estados pueden adherir a este Protocolo.

El artículo 6 trata de la hipótesis de un Estado Federal, estableciendo que cuando la legislación necesaria para la aplicación de este Protocolo dependa de un Poder Legislativo Federal, esta obligación será la misma que la de los Poderes Legislativos de los Estados que no constituyen federación.

En el caso de aquellos Estados Federados que tienen dentro de su competencia la posibilidad de decidir su propia legislación, el Estado Federal comunicará a las autoridades competentes locales lo establecido en el Protocolo.

El artículo 7 considera las reservas que pueden ser hechas por los Estados cuando va a efectuar su adhesión, sosteniendo que los Estados podrán hacer reservas en cuanto al sistema de controversias en relación con la interpretación del Protocolo (artículo 4 del Protocolo) y de su aplicación por el artículo 1 del Protocolo, de todas las disposiciones de la Convención, con excepción de los artículo 1 que trata de la definición del refugiado; del artículo 3, que se refiere a la prohibición de discriminación en razón de raza, religión o país de origen; del artículo 4, el cual reconoce la libertad de practicar la religión y la libertad de educar en la religión a sus hijos; del artículo 16 (I) que trata del acceso a los Tribunales; y del 33, que en su primera parte se refiere a la regla que rige el Principio de No Devolución y en su segunda parte, a las excepciones a tal Principio que son las que se refieren a los casos en los se afecte la seguridad del país o que cuando se tenga por objeto una condenación definitiva puedan constituir una amenaza grave a la sociedad del país.

Por lo tanto, los Estados podrán hacer reservas en relación con la resolución de controversias y de todas las disposiciones de la Convención con excepción de las reglas específicas referidas anteriormente, pues estas constituyen el núcleo de la razón de ser de la Convención.

Sobre su entrada en vigor, se estableció que se produciría con el depósito del sexto documento de adhesión al mismo instrumento. 


\title{
I.14. Refugiado de hecho
}

Existen casos que no se encuadran en las hipótesis del refugiado de la Convención del Estatuto del Refugiado de 1951. En tales casos se puede decir:

\begin{abstract}
Se trata de una zona gris de refugiados que huyen de guerras, de situaciones de extrema violencia o de la vulneración de los más elementales derechos humanos, pero que no pueden probar persecución o tener fundados temores a la misma, por motivos de raza, religión, nacionalidad, pertenencia a un grupo social determinado o por sus opiniones políticas, tal y como establece la Convención de Ginebra.
\end{abstract}

Algunos de los autores han considerado la necesidad de modificación de la definición, aunque esto es improbable porque sería muy difícil la realización de otra Conferencia de Derecho Internacional $^{105}$.

La figura del refugiado de hecho exige que sean consideradas situaciones que están fuera de las hipótesis contenidas en la definición del tratado. Aunque esencialmente se trata de la misma figura.

En algunos de estos casos, el Estado se obliga a aceptarlos en el cumplimiento de una razón humanitaria, como fue el caso de la entrada de los refugiados de Haití en Brasil en los últimos años.

En esta situación, Brasil concedió a estas personas el visto humanitario. Esta fue la salida encontrada por el gobierno brasilero, porque no podía encuadrarlos en la Convención de los Refugiados, ni considerarlos según las leyes de los inmigrantes. Este "Visto Humanitario" otorgado a los haitianos ya fue utilizado por Venezuela y México. De tal modo, gracias a esta innovación jurídica, estas personas pueden tener las documentaciones necesarias para trabajar y vivir legalmente en el país ${ }^{106}$.

\section{I.15. Consideraciones Finales}

En primer lugar, es posible realizar algunas observaciones sobre las tensiones que se generaron con la creación de ACNUR y el Estatuto de los Refugiados.

Tanto la creación de ACNUR como la formulación de la Convención sobre el Estatuto de Refugiados fueron el resultado de un proceso de intensas negociaciones, donde cada artículo fue producto de una contienda entre los sujetos de Derecho Internacional. Esto debido a que

\footnotetext{
105 PÉREZ BARAHONA, Sergio. El Estatuto de "Refugiado" en la Convención de Ginebra de 1951. In REDUR, $\mathrm{N}^{\mathrm{o}} 1,2003$, p. 248.

${ }^{106}$ RAMOS, André de Carvalho; RODRIGUES, Gilberto; ALMEIDA, Guilherme de Assis. (Orgs.). 60 anos de ACNUR: perspectivas de futuro. São Paulo: Editora CL-A Cultural, 2011, p. 63.
} 
cada uno de los países tenía sus propios intereses en relación con la cuestión de los refugiados. Había Estados para los que solucionar la cuestión de los refugiados era esencial, y otros para los que era un tema secundario. Según esto, cada uno adoptó una posición en defensa de sus intereses. Por lo tanto, en primer lugar, el estudio de estos instrumentos internacionales requiere del análisis del contexto socio-político en el cual se produjo la creación de ACNUR y la Convención sobre el Estatuto de los Refugiados.

ACNUR fue creada en la época de la Guerra Fría, constituyendo una respuesta a un problema concreto que aquejaba a países de Europa después de la guerra.

Había países que pretendían la creación de un organismo fuerte y autónomo, otros eran favorables a un órgano transitorio, dependiente de Naciones Unidas y con un financiamiento muy reducido. Después del proceso de negociaciones, el Estatuto de ACNUR estableció que dependería de la Asamblea de Naciones Unidas y de ECOSOC. Su duración era limitada a 3 años, prorrogables por decisión de la Asamblea General. Su financiamiento era muy reducido. A pesar de estas restricciones iniciales, la situación de ACNUR fue fortaleciéndose con el transcurso de los años.

En segundo lugar, la complejidad del proceso de creación de la Convención sobre el Estatuto de los Refugiados se debió a que de ella derivarían las obligaciones internacionales de los Estados-partes.

Esta Convención adoptó una visión individualista de la figura del refugiado, lo cual fue innovador ya que hasta la fecha las definiciones establecidas por los instrumentos internacionales anteriores hacían referencia a conceptos colectivos de grupos de determinados refugiados.

En tercer lugar, es necesario observar que la figura del refugiado tiene una relación directa con la violación de los derechos humanos. Se optó por una definición de refugiado que lo caracteriza como aquel que tenía miedo fundado a ser perseguido por el Estado u otros grupos. La interpretación dada por ACNUR considera que ese miedo se basa en que fuesen violados los derechos a la vida y a la libertad. La persecución debe ser provocada por los motivos estrictamente considerados en el artículo del Estatuto: por raza, nacionalidad, religión, pertenecer a un grupo social u opinión pública. La persecución por todos estos motivos caracteriza la violación de los derechos humanos.

Es necesario observar que, si se analiza de forma general el concepto de refugiado, la Convención buscó proteger en un sentido amplio los derechos humanos que habían sido violados. Porque la Convención estableció que el grupo que sería protegido es el de los que 
sufren la violación o que existe la posibilidad de violación de sus derechos a la vida, la libertad, la no discriminación por la raza o por la nacionalidad, la libertad de religión, de opinión pública, de pertenecer a un grupo social.

Por lo tanto, la definición de refugiado adoptada restringió la figura, porque esa consideración específica de estos motivos caracterizó un momento histórico. Aunque posteriormente, otros instrumentos internacionales, como la Declaración de Cartagena de 1986, vendría a caracterizar al refugiado como aquel que sufre cuando la "violación o amenaza de violación de los derechos humanos".

En cuarto lugar, se puede verificar que el proceso de negociación de la Convención sobre el Estatuto del Refugiado fue muy tenso, y de esto derivaron los límites: temporal y geográfico de la definición del refugiado de tal instrumento. El límite geográfico refería a que los acontecimientos hubiesen ocurrido en Europa (aunque existía la posibilidad de que los países eligieran una formula universalista). El límite temporal consistía en que se referiría a "los refugiados hasta la fecha del 1 de enero de 1951". Sin la consideración de estos dos límites, muchos de los países no hubieran aceptado firmar la Convención porque reflejaban la voluntad de los Estados en limitar sus responsabilidades.

En quinto lugar, es relevante señalar que en esta Convención de 1951 se introduce por segunda vez el Principio de No Devolución, el cual ya había sido considerado por primera vez en la Convención de 1933, aunque este último instrumento nunca entró en vigor, quedando como letra muerta. Por esto, sería la primera vez que aparece el Principio de No Devolución en una Convención que entró en vigor. Este principio constituye un pilar del derecho de los refugiados, porque impide la deportación de estas personas. Este principio es de fundamental importancia para la protección de los derechos humanos de la persona y constituye una obligación de los Estados que firmaron la Convención. Lo contrario significaría colocar a la persona en aquella situación de violación a los derechos humanos que estaba viviendo, sin la protección de su país. El reconocimiento de este principio significa que la comunidad internacional y los países le brinden la posibilidad de encontrar un lugar donde pueda desarrollar su vida con dignidad.

La Convención sobre el Estatuto del Refugiado considera todos los derechos fundamentales de la persona para que pueda tener una vida digna.

Este instrumento internacional es una obra jurídica caracterizada por reconocer cada una de las situaciones por las que atravesaría el refugiado, consagrando de forma simple las soluciones a cada una de las necesidades de estas personas. 
En sexto lugar, el análisis de los acontecimientos ocurridos de 1951 a 1961, así como la flexibilidad dada a ACNUR a través de los apartados 3 y 9 de la Resolución de su creación es muy relevante, porque permite verificar cómo la normativa jurídica acompaña a los hechos sociales y a las necesidades que van surgiendo en el orden internacional. La gravedad de los eventos ocurridos en ese período obligó a que la ACNUR actuase, a pesar de que todos esos acontecimientos estaban fuera de su mandato.

Por otro lado, esa flexibilidad ante los eventos trágicos demostrada por ACNUR es permitida por los apartados 3 y 9 de la Resolución de su creación, los cuales establecen que ACNUR podrá realizar todos los actos adicionales que la Asamblea General de Naciones Unidas le autorice.

En tal sentido, cabe observar que la definición de Refugiado de la Convención de Ginebra de 1951 establecía limites tales como que solamente serían objeto de protección los refugiados que correspondían a los hechos ocurridos hasta el 1 de enero de 1951, y la segunda restricción correspondía a que los acontecimientos deberían haber ocurrido en Europa.

Además, la naturaleza de las actividades de ACNUR era únicamente consultiva y de coordinación, consistiendo en trámites legales para la aceptación de los refugiados en los países receptores.

A pesar de todas estas limitaciones legales, ACNUR consiguió responder a las demandas surgidas en la realidad social de ese período. Porque se produjo una transformación de las actividades de ACNUR, las cuales dejaron de ser consultivas para ser operativas.

La Asamblea General de Naciones Unidas pudo ampliar las competencias y además convertirlas en operativas, a través de sus Resoluciones. Esto nos lleva a reflexionar que ACNUR podría hacerse cargo de los Refugiados Ambientales o Desplazados Forzados Ambientales. Esto último será considerado en el Capítulo VI.

Es necesario recordar que la tercera hipótesis sostenida en esta tesis es que ACNUR es el organismo que debe hacerse cargo de la protección y asistencia de los Refugiados Ambientales o Desplazados Forzados Ambientales. Porque como lo demuestra el análisis desarrollado en este capítulo, ACNUR es el organismo internacional cuyo mandato se refiere específicamente a la protección y asistencia de las personas que escapan de sus hogares por la violación a sus derechos humanos. Aunque no solamente deben ser consideradas la particularidad y especificidad de sus funciones, sino que ACNUR es un organismo internacional que trae una experiencia en esta área que viene desde 1951. Este último aspecto ha sido comprobado en el análisis de los acontecimientos ocurridos en el período 1951-1960, 
aunque el período posterior también demuestra la capacidad de ACNUR de adaptarse a la realidad social e internacional, y su flexibilidad.

Finalmente, es importante observar cómo ACNUR y las resoluciones de la Asamblea General de Naciones Unidas fueron acompañando los nuevos desafíos que se fueron presentando en la realidad social internacional. A pesar de las restricciones establecidas en la Convención de 1951, ACNUR no quedó sin dar respuesta a los acontecimientos ocurridos en el período 1951-1960 analizado.

En 1967 fue creado el Protocolo Adicional de la Convención de 1951, donde fueron retiradas las restricciones temporales y geográficas. De tal modo, esto lleva a concluir que ACNUR ha sido un organismo que siempre ha acompañado los acontecimientos presentados en la realidad social. De este modo, todo este análisis revela que el derecho y las problemáticas sociales siempre precisan estar acompañadas, pues si el derecho se separa de la realidad social, se convierte en una estructura abstracta y básica.

De modo que el Derecho Internacional tuvo que proveer soluciones y estas vinieron a través de la creación del Protocolo Adicional de 1967 sobre el Estatuto de Refugiados a la Convención de Ginebra. Porque el Derecho tiene que acompañar a la realidad social, y no puede quedar como una estructura pétrea.

La restricción temporal fue derogada por el Protocolo de la Convención de 1967. Estas dos restricciones reflejaron la voluntad de los países en limitar sus responsabilidades.

Así queda demostrado uno de los objetivos considerado en la Introducción, que es la inseparabilidad de la realidad sociopolítica y el derecho, así como la necesidad de adaptación del derecho a las nuevas problemáticas. 


\section{CAPITULO II}

\section{LOS REFUGIADOS AMBIENTALES O DESPLAZADOS AMBIENTALES FORZADOS}

\section{II.1. Introducción}

Las víctimas fatales de las catástrofes ambientales ya no pueden hablar, sus seres queridos quedaron como testimonios de la terrible tragedia, ellos ya nunca volverán a ser los mismos, pues se ha producido un cisma en el interior de esas personas que les ha marcado la vida para siempre, su futuro, su porvenir. Esto se refleja en la expresión de las caras de los sobrevivientes de los desastres o de la degradación ambiental.

Ellos son los que, además de la pérdida de sus seres queridos, tendrán que enfrentar la nueva realidad que es el día después del desastre o degradación ambiental. Esto significa la continuación de la tragedia del desastre ambiental, que es el día en que estas personas se hacen conscientes de la pérdida de su familia, de su historia, de su lugar, de su hogar. Tal vez ellos sean los muertos vivos, que deambulan entre lo que ha quedado de la construcción de la central hidroeléctrica o de la ruta, de las inundaciones, del ciclón, del terremoto, de la avalancha. Ellos son los desplazados ambientales forzados.

Esta es una de las peores consecuencias de la degradación ambiental y de los desastres ambientales, el surgimiento de estos desplazados. Ellos son obligados a escapar de sus hogares y lugares de origen para salvar sus vidas, debido a la catástrofe.

Ellos pueden llegar a atravesar las fronteras de sus países o movilizarse dentro del país. Los primeros son los que cuentan con más recursos económicos. Los segundos hacen parte del grupo de los desplazados internos.

DOCHERTY y GIANNINI observan que "la comunidad internacional se enfrenta ahora con la aparición de la migración inducida por el cambio climático que probablemente conducirá a millones de refugiados a cruzar las fronteras estatales durante el próximo siglo"107.

${ }^{107}$ DOCHERTY, Bonnie; GIANNINI, Tyler. Confronting a Rising Tide: A Proposal for a Convention on Climate Change Refugees. In Harvard Environmental Law Review. Harvard School, julio, 2009, p. 361. Disponible en: $<$ http://www.law.harvard.edu/students/orgs/elr/vol33_2/Docherty\%20Giannini.pdf $>$ acceso 15 de marzo de 2014. 
Los desplazados ambientales forzados o refugiados ambientales que atraviesan las fronteras no cuentan con una protección jurídica en el derecho internacional, constituyendo esto una laguna jurídica.

Ni siquiera existe consenso sobre su denominación ni en la doctrina, ni en el derecho internacional.

Además, tanto en la doctrina como en los organismos internacionales existen diferentes posiciones en relación con este problema. Algunos autores niegan la existencia de los desplazados ambientales forzados o refugiados ambientales, justificándose en la multicausalidad que lleva a los desplazamientos ambientales. Por otro lado, existe una parte de la doctrina que los reconoce y trata de analizar la situación y presentar soluciones.

Uno de los problemas relacionados es establecer la línea que permite separar a los desplazados ambientales forzados de los voluntarios. La importancia de afirmar que estos son forzados reside en la justificación de la necesidad de protección internacional, pues los voluntarios podrían ser tratados como inmigrantes.

En este capítulo se trata de construir un concepto de refugiados ambientales, indagando las características comunes de estos grupos, buscando los fundamentos para afirmar que se trata de desplazados forzados.

Los objetivos de este Capítulo son: construir un concepto que abarque a todos los refugiados ambientales y establecer las justificaciones para afirmar que los refugiados ambientales son forzados.

En primer lugar, serán realizadas algunas observaciones sobre las diferentes denominaciones utilizadas en la doctrina y en los organismos internacionales.

Segundo, serán analizadas las diferentes definiciones presentadas en la doctrina.

En tercer lugar, serán establecidas las características más importantes que hacen que estos grupos de refugiados ambientales sean considerados como forzados.

Finalmente, serán realizadas algunas observaciones finales.

\section{II.2. Refugiados ambientales o desplazados forzados ambientales}

\section{II.2.1. Denominaciones}

Uno de los problemas sobre los que aún no existe consenso ni en la doctrina, ni en los organismos internacionales es la denominación de estos grupos de personas desplazadas por la catástrofe ambiental. 
La importancia de la determinación de la denominación apropiada reside en que cada expresión tiene una connotación diferente que incide en la demarcación del grupo a ser considerado. Eso se debe a que, si a este grupo se los denomina de refugiados, podría significar una asimilación con los refugiados estatutarios de la Convención sobre el Estatuto de los Refugiados, siendo que en el artículo 1 de ese instrumento internacional existen las condiciones específicas para la caracterización de los refugiados estatutarios, y no está contenido el concepto del grupo de personas estudiado en este trabajo. En segundo lugar, si se opta por calificarlos de refugiados climáticos o de los cambios climáticos, estos quedarán restringidos a los que sufren los impactos de los cambios climáticos. En tercer lugar, si se les califica como ambientales, permitirá abarcar a todos aquellos que sufren los impactos producidos por los cambios climáticos, por la intervención del hombre (accidentes industriales biológicos, químicos, nucleares como los de Bhopal, Chernóbil), por aquellos hechos relacionados con cambios de la naturaleza, por ejemplo, terremotos, desertificación, y por acontecimientos naturales, o causados tanto por la naturaleza y por el hombre.

DUM y GEMENNE observan que las expresiones utilizadas tanto en la doctrina como entre los organismos internacionales son: "migración ambiental, migración inducida por los cambios climáticos, refugiados ecológicos, refugiados ambientales, migrantes de los cambios climáticos y migrantes forzados inducidos por el medio ambiente"108.

La primera denominación que surgió para designarlos fue "refugiados ambientales", utilizada por Lester BROWN en la década del setenta.

Posteriormente, en 1985, la publicación de EL HINNAWE en UNEP (United Nations Environment Program) popularizó la expresión: refugiados ambientales. Otro que utilizó la misma denominación fue Jodi JACOBSON y también lo hizo MYERS.

El PNUMA los llama refugiados medioambientales, observando que estos surgen del deterioro ambiental, siendo que considera que "el deterioro del entorno implica cualquier cambio físico, químico y/o biológico del ecosistema, que lo hace temporal o permanentemente inadecuado para ser habitado"109.

${ }^{108}$ DUM, Olivia; GEMENME, François. Defining Environmental Migration. In Forced Migration Revieu, $\mathrm{N}^{\circ}$ 31, 2008, p. 10-11.

${ }^{109}$ Disponible en: $<\mathrm{http}: / /$ www.liser.eu/> acceso 5 de marzo de 2014. 
Maria STAVROPOULOU observa que, si bien ACNUR no aprueba el uso de la expresión refugiados ambientales, esta es aconsejable pues enfatiza la responsabilidad de los Estados ante los desastres ambientales ${ }^{110}$.

ACNUR $^{111}$ no considera apropiado el uso de la denominación de refugiados ambientales o climáticos, debido a que sostiene que la palabra refugiado ya tiene un contenido legal en el derecho internacional, el cual está definido en la Convención de Ginebra de 1951 y en su Protocolo Anexo, siendo que el artículo 1 del Protocolo los define de la siguiente manera:

\begin{abstract}
Una persona que, debido a un miedo fundado de ser perseguido por razones de raza, religión, nacionalidad, pertenencia a un grupo social o de opinión política en particular, se encuentra fuera de su país de nacimiento y es incapaz, o, debido a tal miedo, no está dispuesto a servirse de la protección de aquel país; o de quien, por no tener nacionalidad y estar fuera del país de su antigua residencia habitual como resultado de tales eventos, es incapaz, debido a tal miedo, de estar dispuesto a volver a este ${ }^{112}$.
\end{abstract}

Por lo tanto, la palabra refugiado hace referencia solamente a este grupo de personas que han tenido que escapar de su país por persecuciones fundadas únicamente en las causas enunciadas en la definición. La gran preocupación de ACNUR en relación con la extensión de esta denominación es que pueda buscarse la modificación de la Convención sobre el Estatuto de los Refugiados de 1951, lo cual podría aparejar un recorte en los derechos de los refugiados estatutarios.

Otro problema que surge es si se trata de desplazados ambientales o climáticos.

El uso de la denominación refugiados climáticos implica un gran recorte en el ámbito de la denotación de los grupos afectados, porque, en este caso, el desplazamiento estaría relacionado únicamente con los impactos de los cambios climáticos. De tal modo, el uso de esa denominación llevaría a excluir a aquellos que huyen por otro tipo de causas como:

- degradación ambiental que no ha resultado de los cambios climáticos;

- de los accidentes químicos, nucleares, biológicos, industriales;

- de proyectos de desarrollo (como construcción de carreteras, hidroeléctricas), de adaptación (cuando el país declara una región inhabitable por causa del riesgo para

\footnotetext{
110 STAVROPOUlOU, Maria. Drowned in definitions? In Forced Migration Review, $\mathrm{N}^{\mathrm{o}}$ 31, Climate Change and Displacement, octubre, 2008, p. 11-12. Disponible en: <http://reliefweb.int/report/world/forced-migrationreview-no-31-climate-change-and-displacement $>$ acceso 8 de marzo de 2014.

111 ACNUR es el organismo de Naciones Unidas que protege los refugiados.

112 UNITED NATIONS. HIGH COMMISSIONER FOR REFUGEES (UNHCR). La Convención del Estatuto de los Refugiados, 1951; Protocolo Anexo, 1961, art. 1.
} 
la vida) o de mitigación (por ejemplo, cuando el Estado pretende desarrollar áreas de forestación para mitigar los impactos ambientales), entre otros escenarios.

BIERMANN y BOAS utilizan la expresión refugiados climáticos. Existen dos justificativas para que estos autores hayan elegido esta denominación: la primera es que el concepto de refugiados defendido por estos autores únicamente considera como tales a aquellos que se han desplazado por una causa directamente relacionada con los cambios climáticos; la segunda fundamentación es que estos autores proponen la creación de un Protocolo que sea inserido en el UNFCCC (United Nations Framework Convention on Climate Change) ${ }^{113}$.

La expresión refugiados climáticos tiene una connotación especial porque resalta la responsabilidad de los Estados industrializados por el calentamiento del clima frente a los deslazamientos humanos de los desastres y degradaciones ambientales relacionados directamente y únicamente con los cambios climáticos ${ }^{114}$.

Por otro lado, es necesario observar que la denominación refugiados climáticos ha sido y es utilizada por IASC ${ }^{115}$ (Sistema de Asistencia Humanitaria a la Emergencia de los desastres naturales instituido por Naciones Unidas) ${ }^{116}$.

DOCHERTY y GIANNINI los denominan de refugiados de los cambios climáticos, que hace clara referencia a la restricción del concepto de estos autores, quienes también se refieren únicamente a los desplazados de los cambios climáticos ${ }^{117}$.

WOOD los denomina ecomigrantes, pues así quedan incluidos tanto los migrantes ecológicos como los económicos, siendo que para este autor ambos aspectos están íntimamente relacionados ${ }^{118}$.

\footnotetext{
${ }^{113}$ BIERMANN Frank; BOAS, Ingrid. Preparing for a Warmer World: Towards a Global Governance System to Protect Climate Refugees. En Global Environmental Politics, No 10, Amnsterdam, 2007, p. 66-67. Disponible en: $\quad<$ http://www.environmentalmigration.iom.int/preparing-warmer-world-towards-global-governance-systemprotect-climate-refugees> acceso 15 de febrero de 2014.

${ }^{114}$ Posteriormente, será analizado más detalladamente el tema de la responsabilidad.

${ }^{115}$ IASC es el Comité Permanente Inter-agencias de Naciones Unidas, cuyo objetivo es hacerle frente a las Emergencias Complejas y a los desastres naturales. En el Capítulo VI será estudiado de forma más específica. 116 INTER-AGENCY STANDING COMMITTEE (IASC). Climate Change, Migration and Displacement: Who Will be Affected? 31 de octubre de 2008. Disponible en:

$<$ http://unfccc.int/resource/docs/2008/smsn/igo/022.pdf $>$ acceso 4 de marzo de 2014.

117 DOCHERTY; GIANNINI. Op.cit.

${ }^{118}$ CASTLES, Stephen. Environmental change and forced migration: making sense of the debate. New issues in refugee research. Working Paper $\mathrm{N}^{\circ} 70$. Refugees Studies Centre. Oxford: University of Oxford, 2002. Disponible en: <www.unhcr.ch> acceso 14 de marzo de 2014.
} 
Es necesario destacar que la utilización de esa denominación no es acertada porque existen grandes diferencias entre ambas figuras ${ }^{119}$, siendo demasiado amplia y, por lo tanto, puede llevar a aumentar la confusión en relación con este tema.

Mostafa Mahmud NASER prefiere usar la expresión desplazados de los cambios climáticos debido a las orientaciones de ACNUR, y también, por la multiplicidad de causas que pueden originarlos ${ }^{120}$.

La primera referencia a este grupo de personas afectadas en un Acuerdo de Derecho Internacional ocurrió en el Cancún Agreement de 2010, parágrafo 14, apartado f, donde se los denominó desplazados inducidos por los cambios climáticos ${ }^{121}$.

En tal sentido, Carolina de Abreu Batista CLARO observa:

\begin{abstract}
De hecho, mucha crítica se hace a la expresión aquí utilizada, siendo preferida, por ACNUR "migrantes ambientalmente motivados" o "desplazados ambientales", ninguna de las cuales expresa la real condición de esos migrantes que son refugiados, sí, pero no en el sentido jurídico del término y sí en los aspectos sociológico y etimológico de la palabra según el cual es refugiado todo aquel que busca abrigo o protección fuera de su hábitat de origen ${ }^{122}$.
\end{abstract}

Es evidente que la expresión refugiados ambientales tiene un impacto mayor en el discurso, pues llama más la atención sobre el problema ante los organismos internacionales, la comunidad académica, los gobiernos, las Organizaciones No Gubernamentales (Ongs), lo cual es importante para que sea creado un consenso sobre la necesidad de una protección internacional a este grupo de personas.

En este trabajo, la expresión que se sostiene como correcta es la de desplazados ambientales forzados, siendo que en el transcurso de este capítulo serán consideradas las causas por las que se fundamenta la cuestión de que son forzados.

Esta expresión está relacionada con la definición utilizada en este trabajo, la cual considera el grupo afectado por el desastre o la degradación ambiental, dejando de lado las causas ( si son cambios climáticos, si se trata de proyectos de desarrollo como la construcción

\footnotetext{
${ }^{119}$ Las diferencias entre los migrantes económicos y los desplazados ambientales serán consideradas en el Capítulo $\mathrm{V}$ al analizar la posición de Alexander Betts.

120 NASER, Mostafa Mahmud. Climate Change- Induced Displacement: definitional issues and concerns, 2011-2012, p. 32. Disponible en: <http://studentorgs.kentlaw.iit.edu/ckjeel/?attachment_id=24> acceso 10 de marzo de 2014.

${ }^{121}$ COP (CANCUN). The Cancun Agreements: Outcome of the work of the Ad Hoc Working Group on Long-Term Cooperative Action under the Convention, Decision 1/CP.16. Report of the Conference of the Parties on its sixteenth session, Addendum, Part Two: Action taken by the Conference of the Parties, FCCC/CP/2010/7/Add.1, 15 de marzo de 2011, parágrafo 14 (f). Disponible en: $<$ http://unfccc.int/resource/docs/2010/cop16/eng/07a01.pdf $>$ acceso 7 de febrero de 2014 .

122 CLARO, Carolina de Abreu Batista. Refugiados Ambientais: mudanças climáticas, migrações internacionais e governança global. Tesis de Maestría, Centro de Desenvolvimento Sustentável, Universidade de Brasília, Brasília, 2012, p. 58.
} 
de una ruta, si fue un terremoto, y así sucesivamente) que originaron estas catástrofes ambientales. El problema de los desplazados ambientales forzados es de naturaleza humanitaria, donde existen denominadores comunes que son muy fuertes, tales como la violación de sus derechos humanos, el sufrimiento de la catástrofe ambiental, la huida forzada, la recolocación en otro lugar. Ante estas situaciones comunes, no sirve de nada diferenciar si se trata de personas que han escapado de sus países (transfronterizos), o si han escapado de sus lugares de origen hacia otros lugares dentro del país. Generalmente, los que consiguen escapar hacia otros países son los que tienen más recursos económicos, los cuales son los menos. El problema de los que quedan dentro del país es muy grave porque una de las características de los desastres meteorológicos extremos es la repetición durante el mismo año, en los años subsiguientes en las mismas épocas y lugares ${ }^{123}$. A esto, se suma la falta de soluciones de los países, condenando a estas personas a vivir en un estado de continuo desplazamiento ambiental forzado. Porque la mayoría de los países afectados no tienen recursos económicos suficientes para brindarles la protección, lo cual será analizado en el Capítulo IV.

Aunque en este de trabajo también se utilizará la expresión refugiados ambientales, debido a que esta denominación provoca mayor impacto en la comunidad internacional, en la doctrina y en los organismos internacionales.

\section{II.3. La evidencia de la existencia del desplazado ambiental forzado}

\section{II.3.1. Consideraciones previas}

Tanto en la doctrina como en los organismos internacionales no existe un consenso sobre la definición de los desplazados ambientales forzados o refugiado ambiental, lo que torna muy difícil la tarea de conceptualizarlos.

Además, hay algunos autores en la doctrina que sustentan que no existe la figura del refugiado ambiental, argumentando que existe una multiplicidad de causas que los originan. Por otro lado, hay otros autores que consideran que estos pueden hacer parte de la figura protegida por la Convención de 1951 y su Protocolo Anexo. También, hay algunos autores que tienden a crear innumerables clasificaciones que no permiten avanzar en la cuestión central de la definición y terminan aumentando la confusión. Otros autores y organismos internacionales, como es el caso de ACNUR, los reconocen y tratan de construir las definiciones y establecer soluciones al problema.

\footnotetext{
${ }^{123}$ Esta característica de los desastres repentinos será analizada en el Capítulo VI.
} 


\section{II.3.2. Los alarmistas y los escépticos}

En relación con el tema de la existencia de los refugiados ambientales surgen dos corrientes: los alarmistas y los escépticos. Aunque es necesario resaltar que este debate fue desarrollado desde mediados de los años noventa hasta 2007, y fue ultrapasado por la evidencia de la existencia de estas personas presentada a partir del último año señalado.

MYERS es uno de los autores que es considerado como alarmista, quien considera que a consecuencia de los problemas ambientales van a surgir masas de millones de refugiados ambientales desplazándose sobre los países desarrollados.

BLACK dirige su crítica contra la posición de MYERS, y sostiene que no existen los refugiados ambientales, pues no es posible establecer un vínculo entre estos desplazamientos y la degradación o el desastre ambiental. Este autor defiende la idea de que el discurso sobre la existencia de grandes masas de refugiados ambientales avanzando sobre los países desarrollados tiene por detrás la intención de llamar la atención para la inseguridad que surgiría en los países desarrollados con la entrada de grandes masas de estos refugiados ambientales. Por otro lado, BLACK observa que ese discurso sirve de justificación para que los países del Norte instituyan restricciones en las políticas de asilo. Además, el autor observa que de esa forma se trata de despolitizar la problemática de los refugiados ambientales, descuidando el desarrollo de políticas para los afectados. Por otro lado, BLACK señala que la obligación de brindar asistencia y ayuda ante la producción de un desastre o degradación ambiental es del Estado Nacional.

BLACK considera que, en relación con el aumento del nivel del mar, las poblaciones se desplazan de los ambientes rurales a las ciudades. Además, analiza 11 casos de conflictos producidos en la década del noventa, considerando que en ninguno de ellos se puede decir que exista una relación causal entre el conflicto ambiental que surge de la degradación o del desastre ambiental y los refugiados ambientales. El autor observa que en el caso de la Guerra del Golfo y de Sudan, los conflictos fueron por el control del petróleo y "de los recursos". Por otro lado, en los casos de Azerbaiyán y Kazakstán, Yugoslavia y Greats Lakes, la causa de los conflictos fue un problema étnico ${ }^{124}$.

${ }^{124}$ BLACK, Richard. Environmental Refugees: Myth or Reality? New Issues in Refugee Research Working Paper 34. Ginebra: United Nations High Commissioner for Refugees, 2001, p. 8-10. Disponible en: $<$ http://www.unhcr.org/3ae6a0d00.pdf $>$ acceso 20 de febrero de 2014. 
Por su parte, CASTLES afirma:

\begin{abstract}
No parece ser un caso convincente de que los factores ambientales causen grandes conflictos violentos, los cuales, a su vez, puedan liderar flujos masivos de migrantes forzados. Otros factores, como las divisiones políticas, rivalidades étnicas e intereses económicos parecen ser mucho más importantes en las causas de la violencia y de la guerra. Una vez más, no debemos descuidar las cuestiones ambientales, pero las entendemos como parte de los procesos más amplios del cambio social ${ }^{125}$.
\end{abstract}

De tal modo, CASTLES se posiciona del mismo lado de BLACK, sugiriendo la imposibilidad de establecer el vínculo entre refugiados ambientales o desplazados ambientales forzados y problemas ambientales, considerando la multicausalidad.

Hugo GRAEME observa que la más grande parte de los afectados ambientales por los cambios climáticos se queda en el lugar de origen. Además, considera que los más pobres no se desplazan, sino que permanecen en el lugar. El autor reflexiona sobre la importancia de las redes sociales en la migración, tales como amigos y familiares, quienes brindan el apoyo local

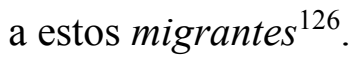

GRAEME parece querer asimilar el problema de los refugiados ambientales a la migración, sosteniendo que esta siempre existió en la historia de la humanidad. Aunque como se sabe existen diferencias fundamentales entre migración y desplazamientos forzados.

La posición alarmista de MYERS en relación con los desplazados ambientales forzados o refugiados ambientales se justifica por la cuestión de la seguridad de los países del Norte, los cuales pueden ver como una amenaza el flujo masivo de estas personas queriendo entrar en esos países. Esto no ha ocurrido, pues los desplazados ambientales forzados en general no tienen recursos económicos para realizar grandes viajes, siendo que los que más consiguen escapar sólo lo hacen hacia países limítrofes.

La posición escéptica de BLACK choca con la realidad actual de los estudios realizados por organismos internacionales en relación con la innegable existencia de desplazados forzados ambientales, como será demostrado en el Capítulo IV.

\footnotetext{
${ }^{125}$ CASTLES. Op.cit., p. 7.

126 HUGO, Graeme. Climate Change and migration some lessons from existing knowledge of migration in southeast Asia. Cap. 4. En LORRAINE, Elliott. Climate Change, Migration and Human Security in Southeast Asia. S. Rajaratnam School of International Studies. Booksmith: Singapur, 2012, p. 45-48. Disponible en: $<$ http://reliefweb.int/sites/reliefweb.int/files/resources/Monograph24.pdf > acceso 15 de febrero de 2014.
} 


\title{
II.3.3. La evidencia
}

Desde 2007, existe un cambio en relación con la consideración de los desplazados forzados ambientales porque en ese año los organismos internacionales comenzaron a realizar estudios sobre estos, los cuales permitieron descubrir la verdadera situación de emergencia, así como la gravedad de la cuestión. ACNUR comenzó a observar la gravedad de la situación desde 2007, lo cual podrá ser observado en el análisis de la posición adoptada por este organismo, así como de sus Resoluciones Anuales emitidas desde ese año, lo cual será abordado en el Capítulo VI. En 2005, $\operatorname{IASC}^{127}$ realizó una reforma institucional para atender a la situación de emergencia de los desplazamientos de los desastres naturales, la cual tuvo que ser profundizada, posteriormente. Esto también será profundizado en el capítulo mencionado.

En 2009, OCHA ${ }^{128}$ observa:

\begin{abstract}
Los desastres naturales son una de las principales causas del desplazamiento forzado. El cambio climático ya está aumentando la frecuencia y la intensidad de los peligros, y el número de desastres naturales reportados y de los afectados está aumentando. La falta de estimativas seguras sobre los desplazamientos forzados de los desastres es una dificultad para que los responsables políticos tomen en cuenta en el contexto de la adaptación al cambio climático.
\end{abstract}

Por ello, OCHA realizó un estudio sobre los desplazados forzados de los desastres naturales, considerando:

En 2008, aproximadamente 36 millones de personas fueron desplazadas como resultado de los desastres naturales repentinos. [...] Los desastres, por lo tanto, pueden ser considerados como un conductor extremadamente importante del desplazamiento forzado en todo el mundo ${ }^{129}$.

En el mismo sentido, en 2011, ACNUR consideró:

En septiembre de 2009, el Secretario General de las Naciones Unidas emitió un informe a pedido de los Estados Miembros de conformidad con la Resolución 63/281 de la Asamblea General sobre las posibles implicaciones de seguridad del cambio climático. El informe señaló que el cambio climático fue el que más ha operado como un multiplicador de amenazas, exacerbando las amenazas existentes resultantes, por ejemplo, de la pobreza o de la mala gobernanza. Más significativamente, es puesta en relieve la migración y la situación del apátrida como siendo los caminos en los que los cambios climáticos podrían afectar la seguridad internacional ${ }^{130}$.

\footnotetext{
${ }^{127}$ IASC es el Comité Permanente Inter- Agencias de Naciones Unidas, creado para hacer frente a la Emergencia Humanitaria.

${ }^{128}$ OCHA, la Oficina de Naciones Unidas para la Asistencia Humanitaria, es la encargada de dirigir el IASC.

129 OFFICE FOR THE COORDINATION OF HUMANITARIAN AFFAIRS (OCHA)-IDMC. Monitoring disaster displacement in the context of climate change. Findings of a study by the United Nations Office for the Coordination of Humanitarian Affairs and the Internal Displacement Monitoring Centre, septiembre, 2009 , p. 15. Disponible en: <http://www.internal-displacement.org/assets/publications/2009/200909-monitoring-disasterdisplacement-thematic-en.pdf $>$ acceso 15 de marzo de 2014.

130 UNITED NATIONS. HIGH COMMISSIONER FOR REFUGEES (UNHCR). Climate Change And Displacement: Identifying Gaps And Responses. Expert Roundtable. Concept Note. Bellagio Conference
} 
En junio de 2011 fue realizada la Conferencia NANSEN ${ }^{131}$ para tratar de los cambios climáticos y los desplazamientos. Posteriormente, fue creada la Iniciativa NANSEN:

\begin{abstract}
El objetivo general de la Iniciativa NANSEN es construir consenso sobre los principios y elementos claves en consideración para la protección de los desplazados que atraviesan las fronteras en el contexto de los desastres naturales y del cambio climático que establecerá la agenda para la futura acción en los niveles: nacional, regional e internacional. El resultado esperado es una agenda internacional para la protección de las personas desplazadas por las fronteras en el contexto de los desastres naturales ${ }^{132}$.
\end{abstract}

Tanto la Conferencia NANSEN como la Iniciativa NANSEN ${ }^{133}$ reconocen el problema de los desplazados ambientales forzados. La primera tuvo como resultado la creación de diez principios para guiar las actuaciones de los organismos internacionales y de los Estados en relación con estos tipos de desplazamientos. La Iniciativa NANSEN solamente se ocupa de la situación de los desplazados forzados ambientales transfronterizos ${ }^{134}$.

Actualmente, existe evidencia empírica sobre la existencia de los desplazados forzados ambientales a través de diversos estudios realizados por los organismos internacionales, los cuales irán siendo desvendados a lo largo de esta tesis ${ }^{135}$.

\title{
II.4. Las definiciones sobre los desplazados ambientales forzados o refugiados ambientales
}

Hay tres definiciones que precisan ser consideras obligatoriamente dado que fueron las primeras relacionadas con la problemática de los refugiados ambientales, como ellos los denominan. Estas son la de EL HINNAWi, de JACOBSON y la de MYER. La contribución de tales autores consiste en que han abierto el debate sobre esta problemática y han sido los primeros en asumir el desafío de la construcción de los conceptos ante esta situación. El principal aporte de EL HINNAWI es que fue uno de los primeros en realizar ese esfuerzo teórico en el año 1985, considerando los diversos aspectos que caracterizan a los refugiados

Centre with the support of the Rockefeller Foundation, Bellagio, 22-26 de febrero de 2011, p. 1. Disponible en: $<$ http://www.unhcr.org/4d1c92bb9.html> acceso 15 de febrero de 2014.

${ }^{131}$ Conferencia Nansen fue una reunión que se realizó en el año 2011, con la finalidad de tratar la relación entre los cambios climáticos y los desplazamientos. Fue auspiciada por los gobiernos de Suiza y Noruega.

132 NANSEN INITIATIVE. Towards a Protection Agenda for Disaster-Induced Cross-Border Displacement. Information Note. Ginebra, 20 de octubre de 2013, p. 5. Disponible en $<$ https://www.nanseninitiative.org $>$ acceso 20 de febrero de 2014.

133 INICIATIVA NANSEN es un fórum internacional, creado en 2012, encargado de analizar y presentar soluciones a los problemas de los desplazados ambientales forzados "trans fronterizos".

${ }^{134}$ La Conferencia NANSEN y la Iniciativa NANSEN serán consideradas de forma más específica en el Capítulo VI.

${ }^{135}$ En el Capítulo IV serán analizados los estudios que tratan sobre los datos de los desplazamientos forzados. 
ambientales. Además, este autor popularizó la expresión refugiados ambientales, que hasta ese momento era tímidamente considerada. A pesar de las críticas de la doctrina a esta definición, es relevante observar la actualidad que tiene ese concepto, pues abarca todas las situaciones que pueden motivar el surgimiento de esta figura, como será analizado posteriormente. El segundo a contribuir en la elaboración del concepto fue JACOBSON, quien estableció tres tipos de refugiados ambientales. Si bien pueden ser hechas varias críticas sobre el criterio utilizado para establecerlas, puede decirse que los acontecimientos de desastre y degradación están todos comprendidos en ese concepto. Por otro lado, MYER trae una definición que puede ser objeto de diversas críticas tanto en relación con el concepto como con las motivaciones que lo impulsaron. Este autor fue quien les dio mayor repercusión a los refugiados ambientales en los años noventa, cuando pocos se referían a esta cuestión, y hasta muchos negaban la existencia de la figura, como fue el caso de BLACK y CASTLE, entre otros, como ya fue observado anteriormente. Sobre este último aspecto, es necesario observar que la negación de esta categoría de los refugiados ambientales ya ha sido superada, especialmente desde el año 2007. Porque a partir de ese momento, los organismos internacionales y la doctrina comenzaron a resaltar las evidencias sobre la existencia de esta figura, a través de los estudios que aportaron datos concretos sobre la cuestión.

EL HINNAWI considera a los refugiados ambientales de la siguiente manera:

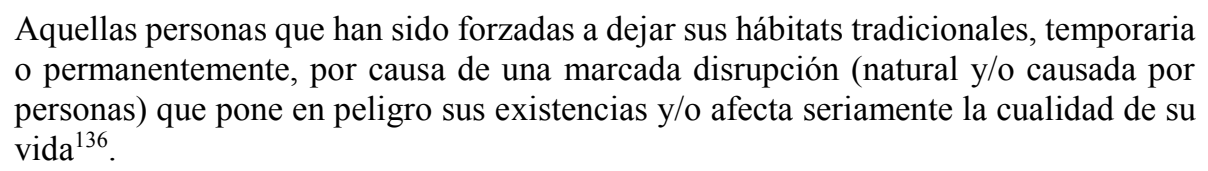

Este autor define la disrupción ambiental como "cualquier cambio físico, químico o biológico en el ecosistema que torne insoportable, temporaria o permanentemente, la sobrevivencia humana"137.

Este concepto de refugiados ambientales se refiere a los desplazamientos forzados: cuando no existe la opción de elegir entre quedarse o irse, surge la obligación de irse para sobrevivir. En tal sentido, el concepto de los refugiados ambientales sostiene que son "aquellas personas que han sido forzadas a dejar sus hábitats". Por otro lado, el concepto de disrupción ambiental dice que el cambio en el ecosistema "torne insoportable [...] la sobrevivencia".

${ }^{136}$ EL-HINNAWI, Essam. Environmental Refugees. Nairobi: United Nations Environment Programme, 1985, p. 4.

${ }^{137}$ EL-HINNAWI. Op.cit., p. 4. 
El análisis de la definición parece apuntar más al concepto de desplazamiento forzado, porque dice: "pone en peligro sus existencias".

Además, el concepto de EL HINNAWI apunta a la identidad entre refugiados ambientales y los desplazamientos forzados, cuando tal definición agrega: "y/o afecta seriamente la calidad de su vida”. Estas serían las dos situaciones en las que la fuga es reconocida como única salida, haciendo que la persona no tenga otra posibilidad sino escapar.

Esta definición incluye a todos los afectados por el desastre y la degradación ambiental, sin diferenciar si estos fueron causados por los cambios climáticos.

Las críticas a la definición de EL HINNAWI se basan en que se trata de una definición muy genérica, que no establece categorías de refugiados ambientales. Todas estas observaciones son insustentables, porque este autor observa que una característica del refugiado ambiental es que son forzados a abandonar sus tierras, mientras que los inmigrantes tienen la posibilidad de elegir entre quedarse e irse, hasta en los casos de los inmigrantes económicos. Además, el autor señala otra diferencia con los inmigrantes que es la causa que genera el desplazamiento del refugiado ambiental, siendo que esta es la "disrupción ambiental", la cual es la catástrofe ambiental que es específicamente sufrida por los desplazados ambientales forzados.

En 1988, JACOBSON califica a los refugiados ambientales:

\footnotetext{
Las personas desplazadas temporalmente debido a una alteración local, como un alud o un terremoto; los que emigran porque la degradación ambiental ha minado su sustento o presenta riesgos inaceptables para la salud; y los que se restablecen por causa de la degradación de la tierra que ha resultado en la desertificación o debido a otros cambios permanentes e insostenibles en su hábitat ${ }^{138}$.
}

El concepto de este autor considera dos cuestiones: de un lado, la temporalidad o la permanencia del desplazamiento; y por otro, el tipo de acontecimiento ambiental que lo desencadena, siendo que cuando lo caracteriza, termina diciendo: "otros cambios [...] en su hábitat", con lo cual acaba dando una amplitud muy grande al concepto.

Esta definición, en primer lugar, observa dos casos de refugiados ambientales, aunque concluye refiriéndose a todos los refugiados ambientales dado que primero observa los provenientes de "una alteración local” y de la "degradación de la tierra como desertificación",

\footnotetext{
${ }^{138}$ RENAUD, Fabrice; BOGARDI, Janos J.; DUN, Olivia; WARNER, Koko. Environmental Degradation and Migration, 2008, p. 2. Disponible en: $<$ http://www.berlin-institut.org/en/online-handbookdemography/environment/environmental-migration.html > acceso 8 de febrero de 2014 .
} 
pero en el final de la definición señala: "o debido a otros cambios permanentes e insostenibles en su hábitat". La última parte de la definición abarca a todos los refugiados ambientales.

MYERS, por su parte, define a los refugiados ambientales:

\begin{abstract}
Quien ya no puede ganar un sustento seguro en sus hábitats tradicionales debido a los factores ambientales de alcance inusual, especialmente la sequía, la desertificación, la deforestación, la erosión del suelo, la escasez de agua y el cambio climático, también los desastres naturales como ciclones, tormentas e inundaciones. Frente a estas amenazas ambientales, las personas sienten que no tienen otra alternativa más que buscar sustento en otros lugares, ya sea dentro de sus propios países o más allá, y ya sea de forma semipermanente o permanente ${ }^{139}$.
\end{abstract}

Este autor enumera las causas ambientales que generan el desplazamiento de los refugiados ambientales, aunque no considera ni los proyectos de desarrollo, tales como la construcción de un dique o una ruta, ni las medidas de mitigación, ni los accidentes industriales o militares, sean químicos, biológicos o nucleares.

La principal crítica a la concepción de los refugiados ambientales de MYERS es que este establece un vínculo directo entre el desplazamiento y la causa climática o ambiental, sin considerar la posibilidad de que surjan otras cuestiones que aceleren el proceso. Además, como fue señalado anteriormente, es bastante alarmista, buscando generar miedo en los países desarrollados sobre grandes olas de refugiados ambientales que irían a invadir esos países, lo cual provocaría una gran inseguridad, desencadenándose conflictos étnicos y luchas por los recursos escasos ${ }^{140}$.

Los últimos años trajeron más claridad tanto en relación con la fundamentación de la existencia de estos refugiados ambientales o desplazados ambientales forzados debido a la mayor cantidad de estudios sobre la temática, demostrando su existencia, así como sobre el aumento de los desastres, haciendo dejar de lado todas aquellas dudas o negaciones en cuanto a la existencia de estas personas desplazadas ambientales forzadas, desarrolladas en la década del noventa ${ }^{141}$.

La definición de refugiados ambientales, refugiados climáticos o desplazados ambientales forzados debe abarcar todas las características esenciales de estas personas o

\footnotetext{
${ }^{139}$ RENAUD, Fabrice; BOGARDI, Janos J.; DUN, Olivia; WARNER, Koko. Control, Adapt or Flee, How to Face Environmental Migration? UNU Institute for Environment and Human Security (UNU-EHS). Bonn: Paffenholz: Bornheim, 2007, p. 13. Disponible en $<$ http://collections.unu.edu/eserv/UNU:1859/pdf3973.pdf $>$ acceso 20 de marzo de 2014.

${ }^{140}$ CASTLES. Op.cit., p. 2.

${ }^{141}$ MAYER, Benoit. The International Legal Challenges of Climate-Induced Migration: Proposal for an International Legal Framework, 22 COLO. J. INT'L ENVTL. L. \& POL'Y 357, 366, 2011, p. 367. Disponible en: $<$ http://www.colorado.edu/law/sites/default/files/Mayer\%20\%28Corrected\%29-S.pdf $>$ acceso 15 de marzo de 2014.
} 
grupos de personas y, además, precisa tener coherencia con las construcciones teóricas esbozadas por cada uno de los autores para dar solución al problema. En tal sentido, las definiciones de la doctrina tienen la finalidad de buscar construcciones coherentes con esas propuestas esbozadas. Este es el caso de los conceptos presentados por BIERMANN y BOAS, DOCHERTY y GIANNINI, HODKINGSON et al., MAYER, y el gobierno de Maldivas. Las primeras se refieren solamente a los refugiados de los cambios climáticos, siendo que las últimas abarcan a todos los desplazados ambientales forzados.

La relación de coherencia entre tales definiciones y las propuestas de solución a esta problemática de estos autores será analizada en el Capítulo V, aunque ya pueden ser abordados algunos aspectos generales en ese sentido. Se puede observar la relación entre estos conceptos y los tipos de acontecimientos ambientales catastróficos considerados por cada autor, ya sea un desastre o degradación ambiental producido por los cambios climáticos, o bien otros tipos de desastres o degradaciones independientes de los cambios climáticos.

BIERMANN y BOAS observan la necesidad de que el concepto de este grupo de personas afectadas sea más específico, porque así será más viable la creación de un cuadro institucional de protección efectiva. Por ello, estos autores construyen su definición estableciendo una serie de recortes.

En primer lugar, observan que los refugiados climáticos son una subclase de desplazados ambientales.

En segundo lugar, no diferencian entre refugiados climáticos internos y transfronterizos, pues consideran que la solución de esta problemática reside en la gobernanza internacional, la cual es global.

En tercer lugar, consideran que los cambios climáticos producen diferentes tipos de impactos, siendo que la relación de causalidad puede ser establecida solamente en relación con algunos de esos. Por otro lado, observan que los impactos de los cambios climáticos generan interrelaciones, desencadenando una multicausalidad. En tal sentido, la definición de esos autores va a considerar únicamente tres tipos de causas de los desplazamientos ambientales: aumento del nivel del mar, eventos climáticos extremos y desertificación y escasez de agua.

Por consiguiente, no consideran como posibles causas "las enfermedades tropicales, las medidas de mitigación y adaptación, los accidentes industriales y los conflictos por escasez de recursos $" 142$.

${ }^{142}$ BIERMANN; BOAS. Op.cit., p. 4. 
BIERMANN y BOAS definen a los refugiados climáticos:

Las personas que tienen o tendrán que dejar sus hábitats, inmediatamente o en un futuro cercano, debido a alteraciones graduales o repentinas del medio ambiente relativas a tres impactos del cambio climático: aumento del nivel del mar, eventos extremos del clima y sequías y escasez del agua ${ }^{143}$.

En síntesis, estos autores centran su estudio en los desplazamientos derivados de esas tres causas de migración desencadenadas por los cambios climáticos, y proponen la creación de un Protocolo en el ámbito de United Nations Framework Climate Change. De tal modo, el problema y la solución presentadas acaban teniendo congruencia, aunque subsiste la desprotección a todos aquellos que son desplazados ambientales forzados, aunque no están encuadrados en esas tres hipótesis.

Estos autores hacen un recorte muy grande en cuanto a las problemáticas que afectan a los desplazados ambientales forzados, dejando de lado a una serie de personas que también son afectadas por los desastres ambientales y por la degradación ambiental.

Así, esa definición no soluciona la cuestión, porque queda excluido un conjunto de personas que también son afectadas.

DOCHERTY y GIANNINI definen al refugiado de los cambios climáticos:

El individuo que es forzado a escapar de su hogar y a restablecerse temporaria o permanentemente a través de las fronteras nacionales como resultado de una repentina o gradual disrupción ambiental que es consistente con el cambio climático y a lo que probablemente han contribuido las personas ${ }^{144}$.

Esta definición excluye los desplazados ambientales forzados que deben moverse dentro del país, enfatizando solamente la cuestión de aquellos que ultrapasan las fronteras.

DOCHERTY y GIANNINI consideran:

La nueva definición de refugiado de los cambios climáticos propuesta requiere de seis elementos que deben cumplirse para que un refugiado pueda ser considerado como una víctima:

1. La migración forzada;

2. la reubicación temporal o permanente;

3. el movimiento a través de las fronteras nacionales;

4. la disrupción en consonancia con el cambio climático;

5. disrupción del medio ambiente repentina o gradual; $y$

6. una alta probabilidad de contribución humana a la disrupción ${ }^{145}$.

${ }^{143}$ BIERMANN; BOAS. Op.cit., p. 8.

${ }^{144}$ DOCHERTY; GIANNINI. Op.cit., p. 361.

${ }^{145}$ DOCHERTY; GIANNINI. Op.cit., p. 372. 
La crítica a estos autores es en igual sentido que la hecha a BIERMANN y BOAS, ya que ellos restringen el concepto a aquellos que han sufrido los impactos de los cambios climáticos, dejando de lado una serie de situaciones que provocan los desplazamientos ambientales forzados, tales como los proyectos de desarrollo, los accidentes industriales de naturaleza química, nuclear, biológica.

Es necesario considerar que lo ambiental no solamente es la causa sino la consecuencia. HODKIGNSON et al., los denominan "personas desplazadas de los cambios climáticos".

Según su conceptualización, se trata de "grupos de personas cuyos hogares habituales se han convertido o se convertirán, temporal o permanentemente, en inhabitables como consecuencia de un evento de los cambios climáticos". Por otro lado, estos autores definen el acontecimiento que hará que esos hábitats sean inhabitables, considerando que "un evento de los cambios climáticos se define como una perturbación del medio ambiente repentina o gradual que es consistente con el cambio climático y al que las personas muy probablemente contribuyeron" $" 146$.

Lo primero a decir sobre ese concepto de "personas desplazadas de los cambios climáticos" es que estos autores hacen un recorte considerando como causa únicamente a las catástrofes producidas por los cambios climáticos. En segundo lugar, es necesario señalar que este concepto incluye "los desplazamientos climáticos preventivos", pues dice "o se convertirán [...] en inhabitables". Por lo tanto, ellos están considerándolos dos tipos de desplazamientos, forzados y voluntarios, pues en este último caso la persona no es obligada a irse por algo que ocurre en el presente, sino por un acontecimiento futuro.

El problema de incluir a los voluntarios es que estos tienen la libertad de elegir, lo cual puede llevar a confundir la figura de los desplazados ambientales con los inmigrantes, que es muy perjudicial porque son figuras conceptualmente muy distantes.

MAYER los denomina "migrante climático". Inicialmente, este autor considera las definiciones de la OIM y de RENAUD, las que serán analizadas posteriormente.

MAYER considera que "los migrantes climáticos son los que sólo se mueven a causa del cambio climático global en oposición a cualquier 'cambio en el medio ambiente"”. Además, considera dentro de esta figura a desplazados climáticos permanentes y transnacionales ${ }^{147}$.

${ }^{146}$ HODGKINSON, David; YOUNG, Lucy. "In the face of looming catastrophe": a Convention for Climate Change Displaced Persons, 2009, p. 7. Disponible en:

$<$ http://www.ccdpconvention.com/documents/A\%20Convention\%20for\%20Climate\%20Change\%20Displaced\% 20Persons\%20\%28January\%202012\%29.pdf> acceso 20 de febrero de 2014 .

${ }^{147}$ MAYER, 2011. Op.cit., p. 368. 
Por lo tanto, el análisis de esta definición permite verificar tres recortes: el primero, se refiere a que la causa del desastre o degradación ambiental es únicamente los cambios climáticos, mientras que el segundo límite del concepto consiste en que exclusivamente aprecia a los “permanente". En tercer lugar, la otra restricción es que examina a los que atraviesan las fronteras, solamente.

NASER se preocupa solamente con los desplazados de los Cambios Climáticos, dejando de lado el resto de desplazados de otros tipos de desastres o degradación. Por esto, en primer lugar, considera las definiciones amplias de los refugiados ambientales. En segundo lugar, observa las que se refieren a los desplazados de los Cambios Climáticos. Este autor define a estos últimos como:

\begin{abstract}
las personas o grupos de personas que se ven obligados a abandonar sus hogares, principalmente por razones de cambios repentinos o graduales en el medio ambiente como consecuencia del cambio climático (a lo que las personas probablemente han contribuido) que afecta negativamente a la vida o las condiciones de vida y que se mueven, ya sea dentro de su país o en el extranjero. ${ }^{148}$
\end{abstract}

De tal modo, este concepto restringe los desastres a los que fueron causados por los cambios climáticos, sin interesar si fueron causados por desastres repentinos o graduales, ni si se trata de desplazamientos permanentes o temporarios, ni si atraviesan las fronteras o permanecen en dentro del país de origen. Ese autor sostiene que lo que importa es que en todas esas situaciones es necesaria la asistencia internacional. ${ }^{149}$

Hasta aquí es necesario observar que las definiciones de BIERMANN y BOAS, de DOCHERTI y GIANNINI, de HODKINGSON et al., de MAYER y de NASER tienen un eje en común: relacionan la figura únicamente con los acontecimientos catastróficos derivados de los cambios climáticos. Una similitud entre el concepto de DOCHERTI y GIANNINI y el de MAYER es que solamente tienen en cuenta a los "que atraviesan las fronteras".

Los desplazados de los cambios climáticos constituyen una sub-categoría de desplazados ambientales forzados, pero no pueden ser considerados como los únicos.

Los gobiernos de Maldivas y de otros Pequeños Estados Insulares en Desarrollo sustentan que debería ser modificada la definición de la Convención del Estatuto de los Refugiados, incluyéndose: "Miedo de poner en peligro la vida, daño o pérdida de la vida debido

\footnotetext{
148 NASER, Op. Cit.p. 23.

${ }^{149}$ NASER, Op. Cit. p. 33 a 48.
} 
a un impacto ambiental severo o debido a los materiales dejados, existentes o a ser liberados en el lugar del desplazamiento por el Estado, o por las entidades comerciales, o ambos"150.

La definición de refugiado de la Convención establece que el miedo a persecución está asociado a criterios restrictos en razón de: nacionalidad, raza, religión, pertenencia a grupo social u opinión pública. Si fuese incluido ese parágrafo, ese concepto ganaría un significado más amplio agregando "peligro a la vida, daño o pérdida de la vida" asociados a desastre o degradación ambiental.

Este concepto observa que las personas se desplazan por "un impacto ambiental muy severo", de tal forma que puede incluir a todos los que escapan tanto del desastre como de la degradación. Aunque, en realidad, la verdadera preocupación del gobierno de Maldivas son los impactos de los cambios climáticos. Porque uno de estos, el aumento del nivel del mar, es el que más incide sobre la sumersión de las tierras de estos Estados Insulares.

Tal definición no es aceptada por ACNUR porque considera que cualquier tentativa de alteración de la Convención sobre el Estatuto de los Refugiados podría traer recorte a los refugiados estatutarios. Además, existe la dificultad o casi la imposibilidad de que se realice una Conferencia internacional para la creación de otro Protocolo Internacional que modifique la Convención sobre el Estatuto de los Refugiados.

El gobierno de Maldivas y los Pequeños Estados Insulares en Desarrollo son los que tienen un interés más urgente, debido a que esas islas, Maldivas, Tuvalu, Islas Marshall y Kiribati, están a punto de quedar sumergidas y volverse inhabitables. Por lo tanto, a mayores intereses concretos corresponden mayores acciones.

RENUAD et al. afirman que es necesario que sea creado el consenso sobre una definición de los refugiados ambientales para que puedan ser instituidas las políticas y las instituciones que se ocupen de este problema. La definición de Renaud et al. considera la intensidad del desplazamiento, así como la de un tipo de degradación gradual o progresiva, pues lo primero depende de lo segundo. Los desastres o degradaciones graduales permiten que haya personas que decidan irse porque visualizan que en un futuro cercano tales impactos producirán la falta de medios para la sobrevivencia o sus vidas correrán peligro. Este es el caso de las personas que viven en los Pequeños Estados Insulares en Desarrollo, donde el aumento del nivel del mar es gradual. Cuando se trata de un desastre repentino, la intensidad de este

\footnotetext{
${ }^{150}$ BOANO, Camillo; ZETTER, Roger; MORRIS, Tim. Environmentally displaced people. Understanding the linkages between environmental change, livelihoods and forced migration. Forced Migration Policy Briefing 1, Refugee Studies Centre, Oxford: University of Oxford, noviembre, 2008, p. 25. Disponible en:

$<$ http://www.unicef.org/socialpolicy/files/Environmentally_displaces_people.pdf > acceso 10 de abril de 2014.
} 
acontecimiento arrasa con todo lo que encuentra y las personas se ven obligadas a escapar para salvar sus vidas. En este caso, la naturaleza de la catástrofe es tan intensa que provoca el desplazamiento rápido, para salvar sus vidas ${ }^{151}$.

Por lo tanto, estos autores consideran la intensidad del desastre o degradación ambiental y su relación con el grado de desplazamiento ambiental, así como la asistencia humanitaria.

De este análisis se desprenden las categorías establecidas por RENAUD et al.:

\begin{abstract}
Migrantes ambientales motivados, migrantes ambientales forzados y refugiados ambientales. El migrante ambiental motivado puede dejar un constante deterioro del medio ambiente con el fin de adelantarse a lo peor. [...] Por otro lado, el migrante forzado ambiental tiene que dejar con el fin de evitar lo peor, frecuentemente de forma permanente [...] refugiados ambientales (incluyendo refugiados de desastres) huyen de lo peor y los desplazamientos pueden ser temporarios o permanentes y pueden ser ilustrados por los desplazamientos debidos a inundaciones, sequías intensas y éxodos como el huracán Katrina ${ }^{152}$.
\end{abstract}

Aquí se observa la construcción teórica de estos autores, donde se establecen las tres categorías: migrante ambiental motivado, migrante forzado ambiental y refugiado ambiental. De tal forma, el primero no sería forzado sino voluntario, es decir, no es obligado a abandonar su hábitat, mientras que los últimos son forzados.

GORDICK observa que ACNUR los define de la siguiente manera:

\footnotetext{
Las personas que se desplazan o que se sienten obligados a abandonar su lugar de residencia habitual, porque sus vidas, sus medios de vida y el bienestar se han colocado en grave riesgo como consecuencia de los eventos y procesos adversos medioambientales, ecológicos o climáticos ${ }^{153}$.
}

En este sentido, ACNUR no considera a los desplazados ambientales voluntarios, sino a los forzados, porque establece dos aspectos principales: el primero observa que se desplazan de sus hogares obligados; y el segundo se refiere a que lo que motiva su acción es el peligro a la vida y a la sobrevivencia de la persona. Estos dos elementos son los que impiden el libre ejercicio de la libertad de elegir dónde vivir. Por otro lado, observa que la causa de este desplazamiento forzado es una catástrofe ambiental, sin hacer diferenciaciones sobre las causas que le dieron origen a la catástrofe. En tal sentido establece "grave riesgo como resultado de eventos y procesos adversos medioambientales, ecológicos o climáticos”. Además, no diferencia entre si se trata de desplazamientos ambientales forzados dentro o fuera del país de origen.

\footnotetext{
${ }^{151}$ RENAUD et al., 2007. Op.cit., p. 31.

152 RENAUD et al., 2007. Op.cit., p. 29-30.

${ }^{153}$ Apud BOANO et al. Op.cit., p. 8.
} 
OIM los define:

\begin{abstract}
Migrantes por motivos medioambientales son personas o grupos de personas que, por motivo de cambios ambientales repentinos o progresivos que afectan negativamente a su vida o las condiciones de vida, están obligados a abandonar sus hogares habituales, o elijen hacerlo, ya sea temporal o permanentemente, y que se mueven dentro de sus propios países o en el extranjero ${ }^{154}$.
\end{abstract}

En primer lugar, es necesario observar que los desplazados ambientales forzados o refugiados ambientales no pueden ser llamados migrantes, porque justamente lo que caracteriza a un migrante es la capacidad de elegir irse, aunque esta autonomía sea mínima. Es justamente sobre este último aspecto que se trata de construir nuestra propuesta de definición, es decir, sobre la tentativa de identificar a los desplazados ambientales como forzados, porque esto será lo que articulará y justificará la necesidad de que estos afectados sean protegidos por el Derecho Internacional.

En este sentido, en la primera parte del concepto hace referencia a los que son forzados, mientras que en la segunda parte introduce a los voluntarios, pues dice "o eligen hacerlo". Esta consideración a los voluntarios no es muy feliz, porque estos últimos pueden ser clasificados como inmigrantes, como fue analizado anteriormente.

En segundo lugar, cabe señalar que este concepto no hace referencia a la causa que motivó el desastre o degradación ambiental. Tal definición reconoce que las causas del desplazamiento son "cambios en el medio ambiente", lo cual es muy saludable, pues abarca tanto a aquellos que derivan de los cambios climáticos, de la degradación ambiental, los ocasionados por la naturaleza, como a los derivados de los hechos del hombre o de ambos. En tercer lugar, incluye el cambio en el medio ambiente de larga duración, así como aquel repentino. En cuarto lugar, considera el desplazamiento tanto temporal como permanente. También, este concepto incluye tanto aquellas personas que se desplazan dentro del país como las que se ven obligadas a salir de sus países.

WARNER considera la existencia de los problemas que obstaculizan la unificación de una terminología y de un concepto que abarque a los afectados. Además, observa la cuestión temporal entre la asistencia humanitaria y la catástrofe ambiental ${ }^{155}$.

\footnotetext{
${ }^{154}$ OIM. International Migration Law $\mathbf{N}^{\circ} \mathbf{2 5}$ - Glossary on Migration. Richard Perruchoud and Jillyanne Redpath-Cross, eds. Volume: 25, ISSN: 1813-227825, Ginebra: 2011, p. 32. Disponible en: $<$ http://www.epim.info/wp-content/uploads/2011/01/iom.pdf> acceso: 17 de octubre de 2016

155 WARNER, Koko. Environmental Change and Migration: Issues for European governance and migration management. In Network Migration in Europe, p.2. Disponible en: <www.migrationeducation.org> acceso 20 de marzo de 2014.
} 


\section{II.5. Nuestra propuesta de definición de desplazado ambiental forzado o refugiado ambiental}

El objetivo de este trabajo es tratar de construir una definición de los desplazados ambientales forzados que unifique los diferentes tipos, con independencia de las causas que los originaron, el desastre o la degradación. Además, se busca no diferenciar entre los desplazados ambientales forzados internos, que son los que se desplazan dentro del país, y los externos, que son los que escapan a través de las fronteras. Este último aspecto se justifica en que la trayectoria del viaje de los desplazados ambientales forzados no obedece a sus voluntades sino a los recursos económicos con los que cuentan, dado que aquellos más pobres tiene que quedarse en las cercanías del desastre o degradación ambiental debido a que no tienen recursos financieros.

Tampoco interesa si la recolocación es temporaria o permanente.

En este estudio, el concepto de refugiado ambiental o desplazados ambientales forzados incluirá a todos aquellos que sean víctimas de un desastre o de la degradación ambiental, sin diferenciar si tales hechos fueron producidos únicamente por la naturaleza, por la acción de hombre, por ambos o por los cambios climáticos.

La decisión de considerar un concepto amplio de los desplazados ambientales forzados que sea inclusivo y no excluyente implica que puedan ser observadas las peculiaridades de los desplazamientos de los cambios climáticos, tales como el problema de la responsabilidad compartida y diferenciada, pues estos entran dentro de la categoría de los desplazamientos ambientales forzados.

Además, uno de los objetivos de la elaboración de esta definición es determinar la línea que permita considerar a los desplazamientos ambientales que son forzados, dejando de lado a los voluntarios. Es decir, que el concepto abarque a todas aquellas personas que son obligadas a dejar sus hogares por un desastre o por la degradación ambiental, que andan deambulando de un lugar a otro, sin destino cierto.

Nuestra propuesta de definición para los desplazados ambientales forzados es la siguiente:

El desplazado forzado ambiental es toda persona, pueblo o parte de un pueblo que es obligado a dejar su hábitat, debido a un desastre ambiental o degradación ambiental, porque estos colocan su vida en peligro, o porque no permiten asegurar su sobrevivencia, que sufre la violación de los derechos humanos y que por esa situación es obligado a trasladarse a otro lugar 
dentro o fuera de su país, y que no puede ser obligado a retornar a sus hábitats mientras dure esa situación de inseguridad para su vida y sus derechos, a quien necesariamente se le debe aplicar el Principio de Asistencia a la Víctima.

Por lo tanto, es necesario analizar cada uno de estos aspectos que componen la definición:

1. Estas personas no tienen la opción de elegir entre quedarse o irse, siendo esto una violación al derecho de libertad de elegir donde residir.

2. Los desplazados ambientales forzados sufren la violación tanto de sus derechos humanos como de su dignidad humana violados.

3. El desplazado ambiental es un desplazado forzado.

4. Los diferentes escenarios de desastre o degradación ambiental que producen el desplazamiento forzado ambiental.

5. Se trasladan a otro lugar dentro o fuera de su país.

6. Existe la necesidad de aplicar el Principio de Asistencia a la Víctima.

7. La necesidad de aplicar el Principio de No Devolución de los desplazados ambientales forzados mientras dure la situación de riesgo.

8. Los desplazados ambientales forzados pueden constituir pueblos o partes de pueblos, porque el desastre o degradación ambiental se produce en un lugar determinado, afectando a toda una comunidad o parte de esta de forma homogénea.

\section{II.5.1. Análisis de cada uno de los aspectos constitutivos de nuestra definición de los desplazados ambientales forzados}

A. El desplazado ambiental forzado es obligado a dejar su hogar, sin la voluntad de hacerlo o mismo contra su voluntad.

La negación del derecho de la libertad de elegir donde residir está representada por la figura del desplazado forzado ambiental.

El ejercicio de la voluntad constituye un aspecto fundamental de la dignidad humana, surgiendo a partir de esto la integridad del hombre que es la piedra fundamental de la protección de los derechos humanos.

La autonomía de la voluntad humana significa que el hombre es señor de su destino, lo cual hace parte del derecho humano a la libertad. 
Sobre la autonomía de la voluntad se pueden verificar dos aspectos: la acción real libre y la intención. La acción libre es la manifestación exterior de la voluntad de la persona. Mientras que la voluntad o intención es el elemento subjetivo o interno de la acción libre. La voluntad consiste en el deseo del ser humano. La acción libre es la exteriorización del proceso psicológico del hombre (intención) en que es necesario que exista la libertad psicológica de elección. ${ }^{156}$

La autonomía de la voluntad humana significa que es la persona que decide la acción que desea realizar, según su intención.

Eduardo BITTAR observa que lo contrario a la conducta libre y autónoma es "el agente manipulado para actuar inconscientemente, por fuerza de un poder arbitrario o de una imposición coercitiva, que no puede ser considerado autónomo en sus deliberaciones, y, por lo tanto, esa acción no puede ser considerada de su libre autoría". El autor considera que "la conducta dirigida por la convicción personal" implica "el auto- convencimiento", el cual es "el ejercicio que transforma ideas, ideologías, raciocinios y pensamientos en principios de acción, sobre la única y exclusiva propulsión de los intereses del individuo"157.

Esto significa que la acción del hombre como señor de su destino no puede estar bajo coacción ni física, ni psíquica, pues estas constituyen la negación del derecho de libertad, específicamente de la libertad de elegir el lugar para residir. La coacción puede ser una fuerza física ejercida sobre la persona o una amenaza de ejercer un acto físico que impida la libertad del ejercicio de la voluntad.

Una característica fundamental del desplazado forzado es la negación de ejercicio del derecho a la libertad de elegir, es decir, la falta de autonomía de voluntad, siendo que el lugar de esa voluntad libre (que resultaría en una acción libre) es ocupado por una fuerza que obliga a dejar el sitio donde la persona tiene su hogar.

La violación al derecho a la libertad de elegir dónde residir del desplazado forzado será tratada de modo más particular en el capítulo siguiente.

Específicamente, en el caso de los desplazados forzados ambientales, la negación de la libertad de elegir entre quedarse o irse está representada por la violencia contra la vida o la sobrevivencia ejercida por el desastre o la degradación ambiental que le obliga a huir, sin existir otra opción.

\footnotetext{
${ }^{156}$ BITTAR, Eduardo. Curso de ética jurídica: ética geral e profissional. São Paulo: Saraiva, 2010.

${ }^{157}$ BITTAR, Eduardo. Op. Cit, p. 27.
} 
B. El desplazado ambiental forzado tiene sus derechos humanos violados.

Los derechos humanos son el conjunto de derechos mínimos del hombre que aseguran la dignidad de la persona humana.

Los derechos humanos son conquistas alcanzadas por la humanidad a través de lucha, a lo largo de la historia ${ }^{158}$. Estos derechos humanos son indivisibles, lo que significa que la violación de uno, afecta al conjunto porque están interrelacionados, teniendo como piedra fundamental la dignidad humana.

Es justamente esa violación a los derechos humanos de la persona humana que hace que él tenga que desplazarse forzadamente.

La figura del desplazado forzado ambiental representa la cara del ser que es privado de sus derechos humanos, pues no tiene derecho a permanecer en su hogar, porque el desastre o degradación ambiental tienen una magnitud tal que pone en peligro su vida y/o su sobrevivencia.

Así, la violencia contra la vida y/o la sobrevivencia significan una situación de desprotección de los derechos básicos como la vida, agua, alimento, abrigo, asistencia médica, documentación; muchas veces pierde su familia, es obligado a dejar su historia, su pueblo, su ser cultural, sus propiedades; en síntesis: su vida queda arrasada. Esto será tratado de forma más específica en el capítulo siguiente. Todo esto causado por el desastre o la degradación ambiental.

C. Esas personas sufren la violencia en sus vidas del desastre o la degradación ambiental que arrasa con todo, dejándolas desprovistas hasta de la propia dignidad, teniendo sólo una salida: escapar.

No se trata de cualquier tipo de desastre o degradación ambiental, sino que es necesario que estos hechos tengan la suficiente magnitud para poner en peligro la vida o/y la sobrevivencia de la persona.

De tal forma que esos derechos humanos sean violados, transformándose en seres que deambulan de un lugar para otro, desprotegidos jurídicamente y desprovistos de las condiciones mínimas de vida que hacen a la dignidad humana y a la integridad de la persona humana.

La magnitud del desastre o de la degradación ambiental implica la negación de los derechos de la persona para asegurar su sobrevivencia, verificándose que los afectados están en una situación forzada, donde la autonomía de la voluntad no existe, quedando solamente el

${ }^{158}$ BOBBIO, Norberto. A era dos direitos. Rio de Janeiro: Editora Campus, 2004. 
deseo de sobrevivir. Por lo tanto, aquellos casos en los que se produce una degradación o desastre ambiental leve, donde la persona deja su hogar de forma preventiva o por su libre voluntad no llevan a la configuración de la figura del desplazado forzado ambiental. Estos serían especialmente aquellos casos de degradación ambiental o desastre ambiental de proceso lento o de repercusión leve.

D. Los desplazados ambientales son forzados.

Los refugiados ambientales constituyen una subclase de los desplazados forzados porque esos son expulsados de su hábitat por un desastre o degradación ambiental que coloca en peligro su vida y/o su sobrevivencia, sin poder ejercer el derecho a la libertad de elegir el lugar para residir y sufriendo la violación de sus derechos humanos. Este aspecto será analizado más detenidamente seguidamente.

E. Existe la necesidad de aplicar el Principio de Asistencia a la Víctima.

El Principio de Asistencia a la Víctima fue reconocido internacionalmente por la Convención de Munición en Ramos (Cluster Munition). Este instrumento internacional de 2008 protege a las víctimas de las minas en ramo, por lo tanto, este Principio observa que es necesario que sea brindada asistencia médica y psicológica, que sean incluidas social y económicamente. DOCHERTY y GIANNINI observan que este Principio debe aplicado a los desplazados ambientales forzados, adaptándose su contenido para estos casos. ${ }^{159}$

Esto implica que el contenido de este Principio debe incluir: brindarles alimentos, refugio, agua potable, asistencia médica (incluyendo la psicológica), medicamentos, vestimentas y servicios sanitarios.

Cuando se produce el desastre o la degradación, la violencia de estos arrasa con todo lo que encuentra en su camino, incluyendo en primer lugar las vidas. Los que consiguen sobrevivir quedan en una situación infrahumana, pues la catástrofe ambiental se llevó todo, es decir, sus casas, sus pertenencias personales, sus medios de sobrevivencia. Estas personas quedan desoladas, deambulando sin destino, sin alimentos, agua, refugio, ropas. Toda esta situación propia de la catástrofe justifica la aplicación de este Principio.

${ }^{159}$ DOCHERTY; GIANNINI. Op.cit., p. 378. 
F. Por otro lado, existe otro criterio que sirve para identificar un desplazado ambiental forzado que es la necesidad imperiosa de aplicar el Principio de No Devolución.

Este Principio implica que las personas afectadas no pueden ser regresadas a aquellos lugares donde han sido violadas su integridad, su dignidad y/o donde corre riesgo su vida y/o su sobrevivencia.

Por lo tanto, en la medida que el Principio de No Devolución precisa ser aplicado a las personas desplazadas ambientales, estas podrán ser consideradas como desplazados forzados.

El Principio de No Devolución se encuentra consagrado en la Convención sobre el Estatuto de los Refugiados de 1951. Tal Principio constituye una obligación del Estado receptor y una garantía de protección de la vida y de la sobrevivencia del refugiado.

Sobre el Principio de No Devolución, DOCHERTY y GIANNINI sostienen:

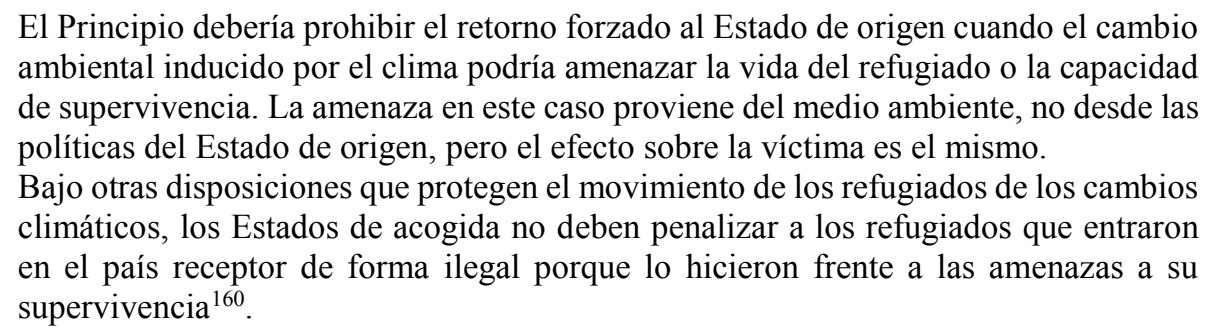

Estos autores sólo consideran la aplicación del Principio de No Devolución en relación con los desplazados de los cambios climáticos, por esto observan que el Estado de origen no tuvo responsabilidad en el desplazamiento.

Además, señalan que no puede aplicarse la devolución al Estado de origen, mismo si la persona ha entrado ilegalmente en el país receptor, porque estas no actúan libremente sino forzadamente con la única intención de proteger sus vidas o /y sobrevivencia.

Por otro lado, el Principio de No Devolución ingresó en el ámbito de los derechos humanos al ser incorporado a la Convención contra la Tortura y Otros Tratos o Penas Crueles, Inhumanas o Degradantes, en su artículo 3.

El artículo 3 establece:

1. Ningún Estado Parte procederá a la expulsión, devolución o extradición de una persona a otro Estado cuando haya razones fundadas para creer que estaría en peligro de ser sometida a tortura.

$[\ldots]$

3. A los efectos de determinar si existen esas razones, las autoridades competentes tendrán en cuenta todas las consideraciones pertinentes, inclusive, cuando proceda, la

${ }^{160}$ DOCHERTY; GIANNINI. Op.cit., p. 377. 
existencia en el Estado de que se trate de un cuadro persistente de violaciones manifiestas, patentes o masivas de los derechos humanos ${ }^{161}$.

De tal modo, el Principio de No Devolución ultrapasó el derecho de los refugiados e ingresó como pilar de la protección de los derechos humanos. Igualmente, podría ser considerada su aplicación al caso de los desplazados forzados ambientales, en el sentido de que estos no sean obligados a regresar mientras sus vidas estén en peligro o no existan posibilidades de sobrevivencia, siendo estos dos últimos aspectos esenciales en la garantía de los derechos humanos a la vida.

La obligación de no devolución, en la dimensión de los derechos humanos significa:

La prohibición de retorno al riesgo real de la privación arbitraria de la vida, ni a tratos inhumanos o degradantes. Queda por verse si los impactos del cambio climático podrían alcanzar el umbral establecido en la jurisprudencia de derechos humanos existente $^{162}$.

Los derechos humanos reconocen un conjunto de protecciones que aseguran la integridad de la persona humana y la vida:

\begin{abstract}
El Principio de No Devolución por lo tanto proporciona una protección esencial para el individuo de que no regrese a la persecución en el sentido de la Convención de 1951 o al tratamiento considerado abominable, y además protegido en virtud del derecho internacional de los derechos humanos (por ejemplo, una amenaza para la vida o la amenaza de tortura, tratos inhumanos o degradantes o pena de muerte).

Podría garantizar implícitamente la protección adicional a las personas desplazadas por las consecuencias del cambio climático. Podría decirse que, el retorno es imposible o no puede razonablemente exigirse al individuo, también existe una obligación del Estado extranjero a por lo menos temporalmente admitir para que permanezca esa persona ${ }^{163}$.
\end{abstract}

\footnotetext{
${ }^{161}$ UNITED NATIONS. HIGH COMMISSIONER FOR REFUGEES (UNHCR). Convención contra la Tortura y Otros Tratos o Penas Crueles, Inhumanos o Degradantes. Adoptada y abierta a la firma, ratificación y adhesión por la Asamblea General en su resolución 39/46, 10 de diciembre de 1984. Entrada en vigor: 26 de junio de 1987, de conformidad con el artículo 27 (1). Disponible en: $<$ http://www2.ohchr.org/spanish/law/cat.htm> acceso 28 de marzo de 2014.

${ }^{162}$ UNITED NATIONS. HIGH COMMISSIONER FOR REFUGEES (UNHCR). Summary of Deliberations on Climate Change and Displacement, $22-25$ de febrero de 2011, p. 4. Disponible en: $<$ http://www.unhcr.org/4da2b5e19.pdf> acceso 15 de marzo de 2014.

163 OFFICE OF THE UNITED NATIONS HIGH COMMISSIONER FOR REFUGEES (in cooperation with the Norwegian Refugee Council, The Representative of The Secretary-General On The Human Rights Of Internally Displaced Persons And The United Nations University). Forced Displacement in the context of climate change: Challenges for States under international law. 6th session of the Ad Hoc Working Group on Long Term Cooperative Action under the Convention (AWG-LCA 6), Bonn, 19 de mayo de 2009, p. 11. Disponible en: $<$ http://unfccc.int/resource/docs/2009/smsn/igo/049.pdf > acceso 10 de febrero de 2014 .
} 
ACNUR observa que la posibilidad implícita de la aplicación del Principio de No Devolución a los desplazados ambientales forzados deriva de la observancia de los derechos humanos basados en la dignidad.

De tal modo, la utilización de este principio podría extenderse a todos los desplazados ambientales forzados, independiente de las causas que originaron el desplazamiento pues todos ellos no podrían retornar a sus lugares de origen porque esto implicaría un peligro para sus vidas y sobrevivencia. Este principio es aplicado a nivel internacional, aunque también podría ser aplicado a los desplazados ambientales forzados internos, mientras dure la situación de la emergencia humanitaria, ocasionada por el desastre o por la degradación ambiental.

G. Se trasladan a otro lugar dentro o fuera de su país.

No es considerada la diferencia entre los desplazados ambientales forzados internos (que se trasladan dentro del país) y los externos (que atraviesan las fronteras) porque en la mayoría de los casos los que se quedan dentro del país son los más pobres. Dado que la trayectoria del viaje depende de los recursos económicos que estos tengan.

Por otro lado, las características enunciadas anteriormente constituyen el denominador común de estas personas, sin importar la trayectoria del desplazamiento.

\section{II.6. Las causas o los escenarios del desplazamiento ambiental forzado}

En primer lugar, es necesario decir que los desplazamientos forzados ambientales son producidos por un desastre o degradación ambiental.

En segundo lugar, se observa que parte de la doctrina relaciona el tipo de causa que originó el desastre o la degradación ambiental, considerando si fueron causados por los cambios climáticos o por la acción del hombre, de la naturaleza o de ambos.

En tercer lugar, cabe destacar que el enfoque de esta tesis no considera si el desastre o la degradación ambiental fueron producidos por los cambios climáticos o por esas otras causales.

Esta posición adoptada se justifica en que si solamente son considerados los desastres o degradación ambiental producidos por los cambios climáticos se realiza un recorte muy grande dejando de lado otras situaciones de desplazados ambientales forzados que sufren las mismas violaciones de derechos humanos. 
En vez de detenerse en esta diferenciación, serán considerados los escenarios en los que se producen los desplazamientos forzados ambientales, los cuales serán abordados en el ítem siguiente.

En nuestra definición de los desplazados forzados ambientales ya se observó que nuestro foco es en relación con lo que motiva el surgimiento de estos desamparados, que es el desastre ambiental o la degradación ambiental, porque lo que importa es la situación de aquellos desamparados que surgen de estos escenarios, que tiene sus derechos humanos violados.

El análisis de las causas que originan los desastres o la degradación ambiental requiere una visión evolutiva del proceso, mientras que el examen del escenario donde surge la figura del desplazamiento ambiental forzado exige considerar el momento determinado en el que se produce el desastre o la degradación ambiental, esto es el escenario del desplazado forzado ambiental. Esta visión es la más factible para fijar la relación de causalidad, dados los límites de la ciencia.

En la definición de Essam EL-HINNAWI se observa que las causas que producen los desplazamientos de los refugiados ambientales son los disturbios ambientales producidos tanto por la naturaleza, como por el hombre o por ambos. De tal modo, quedarían comprendidos dentro del segundo grupo los derivados de la acción del hombre como el desastre provocado por la Unión Carbide en Bhopal, India, el 3 de diciembre de 1984 o el ocurrido en Chernóbil el 26 de abril de 1986, en Ucrania. Así como todos aquellos hechos producidos por la acción del hombre, como la construcción de diques, que hacen imposible la vida de las personas que viven en el lugar, obligándolas a abandonar sus hogares ${ }^{164}$.

El PNUMA observa que los refugiados medioambientales surgen del "deterioro ambiental", siendo que en tal sentido considera que "el deterioro del entorno implica cualquier cambio físico, químico y/o biológico del ecosistema, que lo hace temporal o permanentemente inadecuado para ser habitado" 165 .

La Iniciativa NANSEN utiliza la definición de desastre presentada por la International Strategy for Disaster Reduction (ISDR): “una perturbación grave del funcionamiento de una comunidad o de una sociedad que causa pérdidas humanas, materiales, económicas o ambientales, las cuales exceden la capacidad de la comunidad o sociedad afectada para hacer

\footnotetext{
${ }^{164}$ RAIOL. Op.cit., p. 169-170.

${ }^{165}$ Disponible en $<$ http://www.liser.eu/>.
} 
frente utilizando sus propios recursos", donde también incluye los factores humanos que aumentan la repercusión del desastre ${ }^{166}$.

Los autores consideran dos definiciones de desastres naturales: la de IASC y la de la International Federation of Red Cross y Red Crescent Societies. IASC define al desastre natural como "las consecuencias de los acontecimientos provocados por los peligros o riesgos naturales que superan la capacidad de respuesta local y afectan gravemente el desarrollo social y económico de una región"167.

Se puede observar que tal definición del desastre no es tan precisa en relación con la gravedad del impacto del desastre porque establece: "superan la capacidad de respuesta local y afectan gravemente el desarrollo social y económico de una región”. En este sentido, se refiere a que tales hechos obstaculizan el desarrollo social y económico, no dando idea de la magnitud del daño a los derechos humanos de las personas que se ven obligados a escapar del desastre.

Por otro lado, la International Federation of Red Cross and Red Crescent Societies (IFRC), define desastre natural de la siguiente manera:

\begin{abstract}
Una perturbación grave en el funcionamiento de la sociedad, lo que supone una significativa amenaza generalizada para la vida humana, la salud, la propiedad o el medio ambiente, ya sea ocasionado por un accidente, la naturaleza o la actividad humana, de que sobrevenga súbitamente o como resultado de procesos a largo plazo, pero con exclusión de los conflictos armados ${ }^{168}$.
\end{abstract}

Esta última definición es más apropiada porque establece la dimensión de los derechos afectados: "vida humana, salud, bienes o medio ambiente".

Los desastres pueden producirse de forma repentina o a través de un proceso gradual.

Como puede observarse, no se consideran las causas que producen el desplazamiento ambiental forzado, solamente son observadas dos situaciones: el desastre y la degradación ambiental, independientemente de si fueron producidos por los impactos de los cambios climáticos. Esto se debe a que la situación sufrida por los desplazados ambientales forzados es la misma.

\footnotetext{
${ }^{166}$ NANSEN INITIATIVE. Towards a Protection Agenda for Disaster-Induced Cross-Border Displacement. Op.cit., p. 3.

${ }^{167}$ FERRIS, Elizabeth; PAUL, Diane. Protection in Natural disasters. Paper submitted to Protecting people in conflict and crisis: Responding to the challenges of a changing world, The Refugee Studies Centre at the University of Oxford (RSC), en colaboración con Humanitarian Policy Group at the Overseas Development Institute (HPG), Harris Manchester College \& Queen Elizabeth House, University of Oxford, septiembre de 2009, p. 4. Disponible en: <http://www.brookings.edu/research/papers/2009/09/22-natural-disasters-ferris > acceso 10 de marzo de 2014. ${ }^{168}$ FERRIS; PAUL. Op.cit., p. 4.
} 


\section{II.6.1. Los escenarios de los desplazados ambientales forzados}

KALIN observa que "el cambio climático en sí no provoca la circulación de personas, pero algunos de sus efectos, como los desastres naturales, la degradación del medio ambiente, la elevación del nivel del mar o conflictos por los recursos tienen el potencial para hacerlo"169.

La Iniciativa NANSEN considera los desastres repentinos y los de procesos de larga duración, incluyendo expresamente entre los primeros: "peligros geofísicos como terremotos, tsunamis o erupciones volcánicas, así como los riesgos climáticos y atmosféricos como inundaciones, tornados, ciclones y la sequía" ${ }^{\prime 70}$.

IASC (considerando las observaciones de KÄLIN) señaló cuatro escenarios de este tipo de desplazamiento ambiental:

- Eventos Extremamente Riesgosos Hidro-Meteorológicos;

- Degradación Ambiental y/o eventos extremamente riesgosos de lenta duración;

- Pérdida significativa permanente del territorio del Estado como resultado del aumento del nivel del mar, etc.;

- Conflictos por disminución de los escases de recursos ${ }^{171}$.

Por otro lado, Vikram Odedra KOLMANNSKOG señala los siguientes escenarios:

1. Desastres naturales / desastres repentinos;

2. degradación del medio ambiente / desastres de evolución lenta, gradual;

3. conflictos ambientales;

4. destrucción del medio ambiente como consecuencia de los conflictos armados;

5. conservación del medio ambiente;

6. proyectos de desarrollo (como la construcción de presas);

7. accidentes de trabajo (como el de Bhopal y Chernóbil) ${ }^{172}$.

La desaparición de una isla o región costera baja por el aumento del nivel del mar está contenida en la segunda categoría de este autor.

La tercera categoría de estos escenarios incluye la lucha por escasez de recursos.

La conservación del medio ambiente puede incluir las medidas de mitigación establecidas por los gobiernos, tales como la creación de áreas de reforestación como forma de contrarrestar los impactos ambientales negativos.

\footnotetext{
${ }^{169}$ KÄLIN, Walter; KÄLIN, Schrepfer. Protecting People Crossing Borders in the Context of Climate Change Normative Gaps and Possible Approaches. University of Bern, UNHCR, 2012. Disponible en: $<$ http://www.unhcr.org/4f33f1729.pdf> acceso 17 de febrero de 2014.

${ }^{170}$ NANSEN INITIATIVE. Towards a Protection Agenda for Disaster-Induced Cross-Border Displacement. Op.cit., p. 3.

171 INTER-AGENCY STANDING COMMITTEE (IASC). Climate Change, Migration and Displacement: Who Will Be Affected? Op.cit., p. 2.

${ }^{172}$ KOLMANNSKOG, Vikram Odedra. Future floods of refugees: a comment on climate change, conflict and forced migration. Oslo: Norwegian Refugee Council, 2008, p. 8. Disponible en: $<$ http://www.nrc.no/arch/_img/9268480.pdf> acceso 16 de febrero de 2014.
} 
Los proyectos de desarrollo son aquellos desenvueltos por el Estado como formas de mejorar la infraestructura del país.

En lugar de decir "accidentes de trabajo" sería más apropiado hablar de accidentes industriales, militares o de otra especie de naturaleza química, biológica o nuclear.

En esta clasificación es interesante observar los dos últimos escenarios, porque tanto los proyectos de desarrollo como los accidentes ambientales producen la degradación ambiental, afectando los recursos usados para la sobrevivencia de las personas. En algunos casos, se crean situaciones de peligro para la vida o para la salud, y queda afectada la integridad humana de quienes viven en estos lugares, que se encuentran obligados a abandonar sus hogares.

Otra clasificación de los escenarios es la de Robert Stojanov, quien considera:

1. Los desastres naturales (inundaciones, terremotos, erupciones de volcanes, deslizamientos de tierras y severas tormentas en las regiones costeras (incluyendo ciclones tropicales). $[\ldots]$

2. Cambios acumulados (desertificación, degradación del suelo y erosión, sequía y deficiencia en la seguridad del agua, cambios climáticos, aumento del nivel del mar, hambrunas). [...]

3. Accidentes causados involuntariamente y accidentes industriales (accidentes nucleares, desastres industriales (fábricas químicas), polución ambiental. [...]

4. Proyectos de desarrollo (construcción de diques en ríos, canales de irrigación, extracción de recursos de minas). [...]

5. Conflictos y guerra biológica $[\ldots]$

Este autor observa que en la primera categoría lo que más incide es la vulnerabilidad de las personas afectadas. En relación con la segunda categoría, el autor la identifica con los procesos de lenta duración, subrayando que las causas de estos están en la estrecha relación que se produce entre las acciones de la naturaleza y del hombre. Sobre el tercer escenario, se advierte que, en el término de seis años, se produjeron 75 grandes accidentes químicos que resultaron en 2 millones de desplazados. El autor considera en relación con el quinto escenario que el conflicto opera como causa y consecuencia, pues los conflictos se pueden iniciar por la lucha de recursos naturales y a su vez, esa lucha empeora la situación del medio ambiente ${ }^{173}$.

El aumento del nivel del mar es la causa de la pérdida de regiones costeras bajas y de islas bajas.

\section{Según Vikram Odedra KOLMANNSKOG:}

Se espera el aumento del nivel del mar debido a la expansión del agua (por el aumento de las temperaturas) y el derretimiento del hielo. De acuerdo con una estimación del IPCC sobre las emisiones (escenario A1B), el nivel del mar podría aumentar en casi

173 STOJANOV, R. Environmental Refugees. Introduction. En Acta Universitatis Palackianae Olomucensis, Geographica, Vol. 38, No 1, 2004, p. 78. Disponible en: <http://www.stojanov.org/cs/publikace.html> acceso 10 de marzo de 2014. 
medio metro hasta el 2100. Más de 600 millones de personas viven en zonas costeras bajas $^{174}$.

Las consecuencias de este escenario son tanto la desaparición de algunos Estados Isleños como el desplazamiento de las poblaciones que viven en tales regiones costeras bajas.

Por otro lado, KÄLIN diferencia los 5 escenarios:

1. Desastres repentinos;

2. desastres o Degradación ambiental derivados de procesos lentos;

3. islas y regiones costeras sumergidas por el aumento del mar;

4. áreas prohibidas de ser habitadas por riesgo para la vida de las personas o porque se han instituido medidas de mitigación;

5. conflictos emergentes de la lucha por la disminución de los recursos debido a los cambios climáticos.

Juan Pablo TERMINIELLO considera acertadamente:

A los escenarios descritos por Walter KÄLIN deberíamos agregar las situaciones de desastres naturales asociados a fenómenos geológicos como los terremotos, tsunamis y erupciones u otras manifestaciones volcánicas que también han demostrado su impacto en el desplazamiento forzado de personas $^{175}$.

Este autor agrega en relación con estos últimos escenarios:

De acuerdo con el informe del IDMC, se estima que 4 millones de personas fueron desplazadas en 2010 como consecuencia de terremotos y fenómenos geológicos. Los terremotos fueron una causa importante de desplazamiento por desastres naturales en América como consecuencia, principalmente, de lo sucedido en Haití y Chile ${ }^{176}$.

Finalmente, sería relevante agregar a esos escenarios de los accidentes ambientales, sean industriales, militares o de otros tipos, de naturaleza nuclear, química, biológica, así como los proyectos de desarrollo como la construcción de un dique o de una ruta o autopista.

Hannah ENTWISLE establece las diferencias entre los impactos de las inundaciones, tifones, ciclones, terremotos y tsunamis, proyectos de desarrollo, catástrofes ambientales y sumersión de islas o regiones costeras.

En primer lugar, las inundaciones pueden producirse en un corto período de tiempo, provocando la pérdida de las pertenencias personales, de vidas, de viviendas. Aunque también pueden producirse en un período prolongado de tiempo. En este último caso, puede ser mejor la respuesta para proteger las personas. Las personas tratan de protegerse, yendo para los lugares

${ }^{174}$ KOLMANNSKOG. Op.cit., p. 16.

175 TERMINIELLO, Juan Pablo. Los desastres naturales, el cambio climático y la protección de los derechos humanos. Realidades y desafíos frente al desplazamiento forzado. En ABRAMOVICH, Víctor et al. Protección internacional de refugiados en el sur de Sudamérica. Remedios de Escalada: UNLa-Universidad Nacional de Lanús, 2012, p. 151. Disponible en:

$<$ http://www.unla.edu.ar/documentos/centros/derechos_humanos/Proteccion\%20Internacional\%20de\%20refugia dos\%20en\%20el\%20sur\%20de\%20sudamerica.pdf> acceso 14 de febrero de 2014 .

176 TERMINIELLO. Op.cit., p. 151. 
más altos, como los techos de las viviendas a la espera de ayuda. Las precipitaciones de lluvias rápidas que provocan las inundaciones son muy características en lugares tropicales. Esta situación es peor en las regiones urbanas y más pobres, porque las personas con menores recursos establecen sus viviendas en lugares bajos, cerca de arroyos o ríos.

En segundo lugar, los impactos de los tifones, ciclones, terremotos y tsunamis son más rápidos que los producidos por las inundaciones. La previsibilidad es menor en los terremotos y tsunamis. El número de afectados es mayor cuando el desastre se produce en una región urbana.

En tercer lugar, los proyectos de desarrollo, así como las áreas prohibidas de ser habitadas por las personas son situaciones previsibles, por lo tanto, es posible que el Estado nacional pueda implementar las medidas necesarias para evitar los impactos de la degradación y los desastres. Las catástrofes ambientales de naturaleza industrial o militar, química, biológica o nuclear son imprevisibles. Aunque el Estado podría implementar las mayores medidas de seguridad para evitarlas.

En cuarto lugar, la sumersión de islas o regiones costeras son situaciones que se caracterizan por prolongarse en el tiempo, lo cual permitiría una acción previsible para evitar las pérdidas ${ }^{177}$.

\section{II.7. Los refugiados ambientales o desplazados ambientales forzados y la violación de los derechos humanos}

ACNUR considera:

[...]Algunos de estos movimientos podrían ser considerados voluntarios, por ejemplo, al ser motivados por el deseo de las personas de buscar mejores condiciones de vida en zonas que no estén afectadas por dicho fenómeno y que, por lo tanto, pueden ser parte de las estrategias de adaptación.

En otros casos, sin embargo, existe un elemento de coerción, incluyendo las amenazas a la vida o a la salud, la propiedad y los medios de vida. Los movimientos que se encuentran dentro de esta última categoría son más fácilmente clasificados como movimientos forzados $[\ldots]^{178}$.

De tal modo, ACNUR establece la primera cuestión que permite diferenciar los voluntarios de los forzados, la cual consiste en verificar si la persona desplazada tiene asegurados el conjunto mínimo de derechos necesarios para sobrevivir con dignidad.

\footnotetext{
${ }^{177}$ ENTWISLE, Hannah. The world turned upside down. A review of protection risks and UNHCR's role in natural disasters. United Nations High Commissioner For Refugees. Policy Development And Evaluation Service (PDES) y Division Of International Protection (DIP), marzo, 2013.

178 OFFICE OF THE UNITED NATIONS HIGH COMMISSIONER FOR REFUGEES. Forced Displacement in the context of climate change. Op.cit., p. 3.
} 
DOCHERTY Y GIANNINI hacen referencia a lo que James HATHAWAY denomina “tratamiento general estándar", el cual consiste en asegurar un conjunto mínimo de derechos humanos a los refugiados. DOCHERTY y GIANNINI consideran que ese tratamiento estándar mínimo debería ser asegurado a los desplazados de los cambios climáticos ${ }^{179}$.

Este tema será analizado en el capítulo siguiente.

\section{II.8. Refugiados ambientales o desplazados ambientales forzados como individuos o comunidades o pueblos}

Los desplazados ambientales forzados pueden ser personas individuales, pueblos enteros o parte de estos.

En el primer caso, quedaría incluido el caso de degradación ambiental en Estambul que produjo la muerte y problemas en la salud de las personas. Este fue el caso de Oneryildiz versus Turquía, donde fue reconocida la responsabilidad de Turquía por la Corte Europea de Derechos Humanos. Este caso de jurisprudencia será analizado en detalle en el capítulo siguiente.

La segunda situación, es decir, la de comunidades o poblaciones enteras o parte de estas, es una característica específica de los desplazamientos ambientales forzados. Esto deriva de la naturaleza y de la magnitud de la causa motivadora del desplazamiento, que es el desastre ambiental o la degradación ambiental que afecta un lugar de manera uniforme.

La característica de que se trate de comunidades o poblaciones enteras lleva a tener que relacionar una serie de derechos, tales como el derecho al ser cultural, el derecho a la lengua, al idioma, a la conservación de la historia.

Además del hecho de constituir pueblos enteros o partes de estos, deriva otra necesidad que es que el lugar del restablecimiento precisa tener las mayores similitudes con el lugar de origen. De este modo, ellos puedan mantener los medios de vida tradicionales de estas comunidades, así como también constituye una forma de evitar que se produzca la desestructuración del pueblo.

En el caso de la inmersión de una isla o de regiones costeras, no cabe duda que serán comunidades o poblaciones enteras que tendrán que ser evacuadas. Los casos que pueden ser citados como ejemplo son Tuvalu (la pérdida de una de sus islas en 1997), Inuits, así como regiones costeras de Bangladesh.

${ }^{179}$ DOCHERTY; GIANNINI. Op.cit., p. 376. 
Los escenarios de una catástrofe industrial o un proyecto de desarrollo como de la construcción de un dique o de una ruta son también otras situaciones en las que el movimiento de los desplazados ambientales forzados es colectivo.

Un desastre repentino, como un tsunami o un terremoto o una inundación, son situaciones en las que se configura la emergencia humanitaria y en la que, en muchos casos, la población precisa ser desplazada de forma urgente, siendo que la evacuación será masiva y no de forma individual. Por esto, es preciso que sean reconocidos los derechos colectivos del pueblo que tiene que abandonar sus casas y sus raíces.

Un desastre o degradación gradual, como el proceso de desertificación, donde la población ya no puede permanecer, también demuestra la característica de desplazamiento colectivo. En estos casos existe la ventaja de la posibilidad de planificación del futuro restablecimiento, lo cual es muy importante porque permite una acción organizada, donde los derechos de las poblaciones pueden ser mejor protegidos. Esta ventaja no se puede observar en los casos de desastre repentino.

La lucha por la escasez de recursos, como sería la situación de la falta de agua, es una condicionante que va a afectar a un pueblo entero y no a algunos.

La situación en la que el Estado prohíba habitar una región por causa de peligro a la vida o por la instauración de medidas de mitigación son escenarios en los que los afectados constituyen un ser colectivo, esto es un pueblo o parte de esos pueblos.

\section{II.9. Reubicación temporaria o permanente}

El desplazado ambiental forzado puede ser restablecido en otro lugar, de forma permanente o temporaria, dependiendo esto de la posibilidad de recuperación de las condiciones de su hábitat originario.

Aunque estas dos cuestiones no inciden sobre la construcción del concepto del desplazado ambiental forzado. Estas situaciones tienen relación con la última etapa por la que atraviesan esas personas, que es la posibilidad de ejercer el derecho al retorno o a reintegrarse a la nueva sociedad en la que ellas viven, o elegir otra sociedad para vivir.

La condición de reubicación permanente o temporaria depende de la naturaleza del desastre o degradación ambiental que ocurrió; pues, por ejemplo, en el caso de las islas sumergidas no habrá opción de regreso. 
DOCHERTY y GIANNINI observan que el restablecimiento temporario depende del grado de deterioro natural producido ${ }^{180}$.

Otro punto que puede ser cuestionado es el plazo de tiempo en el que transcurren los movimientos de los desplazados ambientales forzados. Es decir, si estos deben ser inmediatos a la degradación o si se pueden prolongar en un lapso de tiempo largo subsecuente al desastre o a la degradación ambiental. El desastre repentino va a provocar un desplazamiento súbito de personas que será subsecuente a la producción del acontecimiento. Aunque es necesario observar que los desplazamientos forzados ambientales pueden continuar ocurriendo a lo largo de un tiempo, constituyendo un proceso de movimiento de población como en el caso de Haití. Sin embargo, es preciso que exista una continuidad en ese movimiento, y que se trate de contingentes de personas que pertenecen al pueblo afectado. Porque puede ocurrir que muchos se queden en el lugar sin recursos para poder iniciar el viaje, pues justamente los más pobres son aquellos que sin la ayuda internacional no podrán moverse y tendrán que convivir en el medio del desastre.

Además, el tipo de desastre gradual o repentino va a definir el flujo de los desplazados ambientales forzados, pues un desastre repentino seguramente será seguido de los desplazamientos masivos, aunque de todos modos estos pueden llevar años realizándose, porque los desastres repentinos tienen la particularidad de ser repetitivos.

En el caso del desastre o degradación gradual, el proceso de desplazamiento es lento y abarcará seguramente un lapso mayor de tiempo.

Por otro lado, la trayectoria del viaje también va a derivar de la disponibilidad de los recursos económicos que tenga el individuo. Por ello, muchas veces los desplazamientos forzados ambientales son internos, es decir, dentro de las fronteras del país. El hecho de que un desplazamiento sea interno no significa que la persona no quiera irse a otro país, donde pueda recuperar su dignidad humana. En realidad, muchas veces estas personas son forzadas a quedarse por la falta de recursos para trasladarse, lo cual no significa que ellas quieran quedarse en su país, donde no existen recursos de infraestructura o de asistencia.

\section{II.10. Desplazamiento ambiental transfronterizo o interno}

Los desplazados de desastres ambientales internos están protegidos por la Guía de Principios de los Desplazados Internos. Algunos aspectos de esa guía podrían utilizarse para

${ }^{180}$ DOCHERTY; GIANNINI. Op.cit. 
proteger a aquellos que salen del país (externos o transfronterizos), aunque existe otros que no están considerados ${ }^{181}$.

La Iniciativa NANSEN solamente se preocupa por los desplazados forzados ambientales que atraviesan las fronteras. En el mismo sentido, Noruega y Suiza afirman:

\begin{abstract}
Un enfoque a nivel internacional más coherente y consistente es necesario para satisfacer las necesidades de protección de las personas desplazadas "externas" a causa de los desastres repentinos, incluyendo aquellos donde el cambio climático juega un papel.

Por lo tanto, nos comprometemos a cooperar con los Estados interesados, el ACNUR y otros actores relevantes con el objetivo de obtener una mejor comprensión de tales movimientos transfronterizos a nivel regional y subregionales, identificando las mejores prácticas y desarrollando un consenso sobre la mejor manera de ayudar y proteger a las personas afectadas ${ }^{182}$.
\end{abstract}

En realidad, independientemente de si el desplazamiento forzado ambiental es interno o trasfronterizo, se trata de un problema de naturaleza internacional porque son violados los derechos humanos de estas personas (lo cual será observado en el capítulo siguiente), porque el medio ambiente es responsabilidad común de todos, por el principio de la cooperación y de la solidaridad, siendo que todos los países tienen la obligación de brindar asistencia. Sin hablar de la responsabilidad de los países desarrollados por el empeoramiento de la crisis ambiental.

Consecuentemente, el problema ambiental tiene una naturaleza internacional y precisa de una acción internacional.

Los desastres ambientales y los procesos de degradación ambiental no miran las fronteras, por lo tanto, la protección precisa ser brindada a todos, sin interesar si son desplazados dentro del mismo país o si atraviesan las fronteras.

BECK afirma que los riesgos globales avanzan sobre las fronteras ${ }^{183}$, y esto es lo que ocurre con los desastres y la degradación ambiental. La incoherencia es que los desplazados ambientales internos están protegidos en el Derecho Internacional por los Principios Rectores de los Desplazados Internos, siendo que la responsabilidad primordial es del Estado de origen; mientras que aquellos que tienen verdadera naturaleza internacional, no están protegidos por ningún Estado y los que atraviesan las fronteras son los que quedan a merced de su suerte.

\footnotetext{
${ }^{181}$ UNHCR. Summary of Deliberations on Climate Change and Displacement. Op.cit., p 2.

182 NANSEN INITIATIVE. Towards a Protection Agenda for Disaster-Induced Cross-Border Displacement. Op.cit.

${ }^{183}$ BECK, Ulrich. La sociedad del riesgo: hacia una nueva modernidad. Barcelona: Litografia Roses S/A, 2006.
} 


\section{II.11. Los refugiados ambientales como desplazados forzados}

Nuestra definición de desplazados ambientales o refugiados ambientales observa que estos constituyen una subcategoría de los desplazados forzados. Y es este tipo de refugiados ambientales o desplazados ambientales que interesa a los fines de este trabajo porque son aquellos que no han tenido la libertad de elegir si quieren quedarse en sus hábitats o si quieren irse, pues esta coerción es la negación de los derechos humanos y una violación a la dignidad de la persona, lo que los convierte en víctimas que escapan para salvar sus vidas, o para sobrevivir. Estas personas son obligadas a deambular por lugares desconocidos, muchas veces separados de sus familias, lo que nos trae a la memoria la fragilidad humana sufrida por aquellas víctimas que tenían que escapar para salvar sus vidas en el período de la Segunda Guerra Mundial.

Cuando se considera la relación entre los desplazados forzosos y los refugiados ambientales, existe un discurso reiterado en parte de la doctrina y en los organismos internacionales sobre la dificultad de que pueda definirse la línea divisoria entre desplazados forzados y voluntarios.

Una cuestión muy importante es establecer las condiciones en las que se puede considerar como desplazado forzado a aquellas personas que escapan del desastre o de la degradación ambiental.

En primer lugar, la referencia a los desplazados forzados surge en diversos textos de los organismos internacionales, así como en algunos de la doctrina que a continuación serán considerados.

ACNUR utiliza la expresión desplazados forzados, cuando observa: "ACNUR es la agencia líder de las Naciones Unidas responsable por los refugiados, desplazados forzosos y que tiene la experiencia en el área del desplazamiento forzoso ${ }^{184}$.

También IASC hace uso de la expresión desplazados forzados, cuando analiza la situación de la emergencia en cada uno de los escenarios de los desplazamientos ambientales y diferencia ambos tipos: voluntarios y forzados ${ }^{185}$.

El principal problema de la diferencia entre los desplazados forzados y los voluntarios es con los desplazados ambientales de procesos de lenta duración, porque cuando la

\footnotetext{
${ }^{184}$ UNITED NATIONS. HIGH COMMISSIONER FOR REFUGEES (UNHCR). Climate Change, Natural Disasters and Human Displacement: A UNHCR Perspective, 23 de octubre de 2008, p. 2. Disponible en: <http://www.refworld.org/docid/492bb6b92.html> acceso 10 de marzo de 2014.

${ }^{185}$ INTER-AGENCY STANDING COMMITTEE (IASC). Climate Change, Migration and Displacement: Who Will Be Affected? Op.cit., p. 2.
} 
degradación ambiental se inicia, puede ocurrir que los primeros desplazados ambientales sean voluntarios, como sucede cuando una isla comienza a sufrir los impactos negativos de la degradación ambiental, los primeros en irse serán voluntarios. Aunque a medida que avanza ese lento proceso de degradación o desastre ambiental, tales personas van convirtiéndose en desplazados forzados. De tal modo, cuando las condiciones de sobrevivencia de la persona desaparecen o su vida está en peligro y tal comienza a sufrir las adversidades de la degradación o del desastre ambiental, surge el desplazado forzado.

El interés de la Iniciativa NANSEN es solamente en relación con los desplazados ambientales que son forzados, a diferencia de los voluntarios ${ }^{186}$.

OIM define a los desplazados forzados como:

\begin{abstract}
Un movimiento migratorio en el que existe un elemento de coerción, incluyendo amenazas a la vida y el sustento, ya sea ocasionado por causas naturales o hechos del hombre (por ejemplo, los movimientos de refugiados y desplazados internos, desplazados por desastres naturales o ambientales, desastres químicos o nucleares, el hambre o proyectos de desarrollo ${ }^{187}$.
\end{abstract}

\title{
II.11.1. Los aspectos esenciales de los desplazados ambientales como forzados
}

La importancia de la asimilación del concepto de los desplazados ambientales a los forzados reside en que esto obliga a los organismos internacionales a crear un régimen jurídico específico para protegerlos.

Según la International Asociation for the Study of Forced Migration:

La migración forzada es una expresión general que se refiere a los movimientos de refugiados y desplazados internos (aquellos desplazados por conflictos) tanto como a las personas desplazadas por desastres naturales o ambientales, desastres químicos o nucleares, hambrunas o proyectos de desarrollo ${ }^{188}$.

En tal afirmación quedan incluidos algunos de los acontecimientos que pueden llevar a la configuración de la migración forzada.

La construcción del concepto del desplazado forzado exige que sea considerado tanto el derecho internacional de los refugiados como los derechos humanos.

\footnotetext{
${ }^{186}$ NANSEN INITIATIVE. Towards a Protection Agenda for Disaster-Induced Cross-Border Displacement. Op.cit.

187 OIM. Glossary on Inmigration. Genova: Editado por International Organization for Migration, ISSN 18132278, 2004, p. 87. Disponible en: <http://www.iomvienna.at/sites/default/files/IML_1_EN.pdf>, acceso: 17 de octubre de 2016.

188 "A general term that refers to the movements of refugees and internally displaced people (those displaced by conflicts) as well as people displaced by natural or environmental disasters, chemical or nuclear disasters, famine, or development projects". Disponible en:

$<$ http://www.forcedmigration.org/about/whatisfm> acceso el 14 marzo de 2014.
} 
En primer lugar, es necesario considerar la gravedad del hecho (en este caso, es el desastre o la degradación ambiental) que provoca el desplazamiento.

En segundo lugar, es imprescindible verificar si el desplazado tiene o no la voluntad de irse o quedarse.

En tercer lugar, es necesario observar que el desplazado forzado tiene sus derechos humanos violados.

En cuarto lugar, un parámetro que permite verificar que se está en presencia de un desplazado forzado es la obligatoriedad de la aplicación del Principio de la No Devolución.

En quinto lugar, otro criterio para examinar si se trata de un desplazado forzado es la necesidad imperiosa de aplicar el Principio de Asistencia a la Víctima.

Estos cinco aspectos están íntimamente relacionados entre sí, porque uno conduce necesariamente al otro, y todos están fundados en la negación de la dignidad humana.

En relación con lo que impulsa al desplazado forzado a irse de su hogar, cabe señalar que lo que origina el desplazamiento es un hecho de violencia contra la vida o la sobrevivencia del ser humano, el cual puede ser ocasionado por de la naturaleza, o por el hombre o por ambos.

\section{II.11.2. Análisis del desplazamiento forzado en los escenarios de desastre y degradación ambiental}

Por lo tanto, cabe combinar los criterios definidores de los desplazados forzados (la magnitud y la violencia del hecho generador del desplazamiento, la imposibilidad de sobrevivir, la ausencia de la voluntad de irse, la violación a los derechos humanos, la obligatoriedad de la aplicación del Principio de la No Devolución y el Principio de Asistencia a la Víctima) a los escenarios del desastre y de la degradación ambiental.

Una cuestión que es importante para diferenciar el desplazado forzado del voluntario es la magnitud del desastre o de la degradación ambiental porque de esta deriva la coerción sobre la voluntad de la persona. En la medida que esta aumenta, disminuye el ejercicio de la voluntad del desplazado hasta llegar a desaparecer, transformándose en la necesidad obligatoria de escapar, es allí cuando se está ante la presencia del desplazado ambiental forzado. Además, el aumento de la violencia de tales hechos implica una mayor gravedad en la violación de los derechos humanos y la necesidad de aplicar el Principio de Asistencia a la Víctima.

En el caso de un desastre o degradación ambiental producida por un lento proceso, en un primer momento, puede haber desplazados que ante el inicio de tales procesos eligen irse a otros lugares, por lo tanto, estos son voluntarios. Cuando se consolida el escenario del desastre 
o la degradación ambiental, y la vida de los habitantes del lugar comienza a estar en peligro o se produce la violación de los derechos humanos de la persona, estos son desplazados forzados ambientales.

El desplazado forzado de un desastre repentino de gran magnitud es aquel que tiene obligatoriamente que escapar porque su vida está en peligro o porque no existen condiciones de sobrevivencia, no habiendo lugar para que la persona ejerza su voluntad de elegir si se queda o se va.

Cuando el nivel del mar comienza a subir en las islas bajas o las regiones costeras bajas surgen dos situaciones: la primera es la de los que se van preventivamente cuando la situación aún permite vivir en la isla o región costera. Estas personas son desplazadas voluntarias, por lo cual no hacen parte del concepto que interesa a los fines de esta tesis. Los segundos son los que escapan porque existe un peligro real a sus vidas o/y a sus sobrevivencias. Cuando la isla va quedando sumergida bajo el océano, las personas que habitan esos lugares no tienen la posibilidad de escoger si continúan viviendo en sus hogares, pues ese lugar va a desaparecer, por tanto, estas personas pueden ser consideradas como desplazados forzados ambientales.

En 1997, una isla del Estado Insular de Tuvalu ya despareció, esta es la isla de Tepuka Savilivili ${ }^{189}$

Si un Estado nacional decide declarar la prohibición de vivir en un lugar porque ha determinado que esa área es inhabitable, pues en esa región existe riesgo para la vida. Las personas que tienen su hogar allí son obligadas a abandonar el lugar hasta en contra de su voluntad, es otro caso en que no hay duda de que estos serán considerados como desplazados forzados ambientales.

Otra situación de desplazados forzados ambientales es la que surge del conflicto por la lucha de los recursos naturales escasos, dado que esas personas tienen que escapar para sobrevivir sea para buscar lugares donde puedan encontrar alimentos o porque su vida está en riesgo por la lucha armada generada por los recursos escasos.

En estos cinco escenarios de desplazamientos ambientales es constante la presencia del desplazado forzado sin lugar a dudas, pues son todas situaciones en las que existe una fuerza de coerción sobre el desplazado ambiental que lo deja sin su autonomía de voluntad y desprovisto de sus derechos humanos. Por lo tanto, surge la configuración del desplazado ambiental forzado.

\footnotetext{
189 MASON, Moya K. Tuvalu: Flooding, Global Warming, and Media Coverage, s/f, p. 4. Disponible en:
} $<$ http://www.moyak.com/papers/tuvalu-climate-change.html > acceso 4 de abril de 2015. 
En sexto lugar, cuando ocurre un accidente ambiental, industrial, militar, nuclear, químico o biológico, trae consecuencias terribles para las personas que son obligadas a abandonar sus hogares, como ha ocurrido en Chernóbil.

En séptimo lugar, cuando el Estado autoriza la realización de un proyecto de desarrollo, como la construcción de rutas, diques, esto puede provocar los desplazamientos ambientales forzados. Un caso muy representativo de esto fue el pueblo Yanomami, que sufrió muertes y violaciones de derechos humanos.

\section{II.12. Consideraciones finales}

En primer lugar, es necesario observar que la denominación más apropiada para designar a estos grupos de afectados es la de desplazados ambientales forzados.

La expresión refugiados ambientales provoca mayor impacto, aunque su uso no es recomendado por ACNUR, pues podría implicar el recorte de las garantías de los refugiados de la Convención sobre el Estatuto de los Refugiados, y podría llevar a confundirlos con los estatutarios.

Los desplazados ambientales considerados en este trabajo son los forzados, es decir, aquellos que están obligados a escapar de sus hogares por riesgo de pérdida de la vida o por la imposibilidad de sobrevivencia en el lugar de origen. De tal modo, quedan excluidos los desplazados ambientales voluntarios. La línea que diferencia a los desplazados voluntarios de los forzados fue demostrada a lo largo de este capítulo.

Esa situación forzada de escapar del lugar de origen es causada por un desastre o degradación ambiental.

Nuestra propuesta de definición para los desplazados ambientales forzados es la siguiente.

El desplazado ambiental forzado es toda persona, pueblo o parte de un pueblo que es obligado a dejar su hábitat, debido a un desastre ambiental o degradación ambiental, porque estos colocan su vida en peligro, o porque no permiten asegurar su sobrevivencia, que sufre la violación de los derechos humanos y que por esa situación es obligado a trasladarse a otro lugar dentro o fuera de su país, y que no puede ser obligado a retornar a sus hábitats mientras dure esa situación de inseguridad para su vida y sus derechos humanos, a quien necesariamente se le debe aplicar el Principio de Asistencia a la Víctima.

Este concepto de los desplazados ambientales forzados abarca tanto a aquellos que han sufrido el desastre o la degradación causada por los cambios climáticos, o por la naturaleza, o 
por el hombre o por ambos. Porque lo que interesa es focalizar en la situación infrahumana que viven los desplazados ambientales forzados.

Otra de las características es que estos desplazados ambientales forzados padecen la violación de sus derechos humanos, tema que será tratado en el capítulo siguiente.

Estas personas que sufren el desastre o la degradación ambiental pueden ser calificadas como forzadas:

- Sufren el desastre o la degradación ambiental que irrumpe en sus vidas.

- Tienen que escapar para sobrevivir, por lo tanto, no es una decisión libre sino obligada.

- Tienen sus derechos humanos violados por la violencia del desastre o de la degradación ambiental, que arrasa con todo, desde sus viviendas, sufren la falta de alimentos, agua potable, ropas, salud y hasta en muchos casos sufren la muerte de sus seres queridos.

- La necesidad de la aplicación del Principio de No Devolución, pues el Estado tiene la obligación de no retornarlos al lugar de origen mientras exista el riesgo a la vida o a la sobrevivencia.

- Es preciso la aplicación del Principio de Asistencia a la Víctima.

El concepto de desplazados ambientales forzados no diferencia si estos atraviesan las fronteras de los países o si escapan dentro del país. Hay muchos casos de comunidades tradicionales o indígenas que han establecido una relación ancestral con sus tierras de la que deriva su ser colectivo y su identidad colectiva, para los cuales el traslado hasta dentro del país puede significar la desintegración de ese pueblo, como ocurrió con el pueblo indígena Yanomami que será analizado en el capítulo siguiente.

La naturaleza del problema de los desplazados ambientales es internacional y precisa de una solución internacional, como ha sido reconocido por el Consejo de Derechos Humanos y por el Alto Comisionado de los Refugiados de Naciones Unidas. Estas últimas afirmaciones se constatarán a lo largo de este trabajo. La naturaleza internacional del problema deriva de la violación a los derechos humanos sufrida por los desplazados ambientales forzados, de la naturaleza del desastre o degradación que muchas veces abarcan varios países. Un caso que deja en evidencia la naturaleza internacional del problema es la situación de los Pequeños Estados Insulares que se están sumergiendo por el aumento del nivel del mar, lo cual será analizado en el Capítulo IV. 


\title{
CAPÍTULO III
}

\section{DESPLAZADOS AMBIENTALES FORZADOS Y DERECHOS HUMANOS}

\section{III.1. Introducción}

Los desplazados ambientales forzados son personas que han tenido que enfrentar el desastre o la degradación ambiental. Estos acontecimientos han puesto en peligro sus vidas, no dejándoles otra opción que escapar. Ellos han perdido sus viviendas y todas sus pertenencias, sus ropas, sus medios de sustentación, no tienen servicios médicos, no tienen ni alimentos, ni agua potable, se encuentran sin sus documentos personales, en muchos casos separados de sus familias, algunos de sus seres queridos han muerto en el desastre, y lo único que les queda es escapar para salvar sus vidas. Se encuentran en una situación subhumana, pues ni la dignidad de la persona humana les es respetada.

En este último sentido, el profesor TINANT considera:

\begin{abstract}
Como ha señalado con toda propiedad Roberto Adorno, "ser persona" equivale a "ser digno": dignidad ontológica -cualidad inseparablemente unida al ser mismo del hombre- y dignidad ética -la que hace referencia a su obrar-. Noción que recoge la amplitud teórico-práctica que tenía en la etapa griega constitucional el término ajxivon, en latín dignitas, tal como lo emplease Cicerón. Los axiómata o dignitates son, en este sentido, tanto las verdades por sí evidentes, aquellas que no precisan justificación desde otras (por ejemplo, los axiomas euclidianos), como la consideración o dignidad -ética- a que es acreedor el hombre en razón de su naturaleza específica, en palabras de Urbano Ferrer Santos ${ }^{190}$.
\end{abstract}

Estas personas que sufren el desastre o la degradación ambiental no tienen otra opción que huir de sus hogares. Pero esta partida forzada es desorganizada en la mayoría de los casos, muchos escapan para lugares adyacentes, los que cuentan con mayores recursos escapan para otros países.

Los desplazados ambientales forzados transfronterizos no cuentan con una respuesta organizada en el derecho internacional, ni a través de un conjunto de normas jurídicas que los proteja, ni a través de un organismo internacional que se haga cargo de ellos.

Los desastres y la degradación ambiental que provocan los desplazamientos forzados pueden ocurrir tanto en países desarrollados como en los que están en vías de desarrollo. La

190 TINANT, Eduardo. El principio de dignidad humana. En Revista del Consejo Académico de Ética en Medicina, N$^{\circ}$ 931. Buenos Aires: Academia Nacional de Medicina, 2012. 
diferencia reside en que, en el primer caso, los Estados conseguirán brindarles la asistencia humanitaria, la protección, así como los medios para que sus habitantes vuelvan a la situación de normalidad, como fue el caso del terremoto y el tsunami en Japón, o el Sandy en los Estados Unidos. En el segundo caso de los países en vías de desarrollo es necesaria la ayuda humanitaria internacional para hacer frente a la catástrofe.

La hipótesis sostenida en esta tesis consiste en la afirmación de que los desplazados ambientales forzados sufren la violación de sus derechos humanos, siendo esta la fundamentación para justificar la necesidad de la creación de un régimen jurídico internacional que les brinde protección, y la designación de un organismo específico que cuide del problema.

Por lo tanto, el objetivo de este capítulo es demostrar que existe la violación a los derechos humanos de los desplazados ambientales forzados transfronterizos, lo cual los convierte en forzados, a través del análisis de los discursos de los diferentes organismos internacionales relacionados con la cuestión.

Según IDMC: "En 2012, una estimado de 32,4 millones de personas fueron nuevamente desplazadas por desastres en 82 países [...]. En 5 años, desde 2008 a 2012, cerca de 143,9 millones de personas fueron desplazadas [...]”. En 2012, los continentes más afectados en términos numéricos fueron: Asia con 22,2 millones de personas y África con 8,2 millones de víctimas. “Algunos de los Pequeños Países Insulares (SIDS) -incluyendo Samoa, Cuba, Fiji, los Comoros y Papua Nueva Guinea- tuvieron los más altos niveles per cápita de desplazamientos por desastres en 2012”. Haití fue el más afectado considerando el período 2008-2012 ${ }^{191}$.

En 2012, India tuvo 9,1 millones de desplazados ambientales forzados, que fueron obligadas a dejar sus pueblos, aldeas y ciudades. Los lugares más afectados fueron los estados de Assam, de Arunachal y Pradesh ${ }^{192}$. Muchas de estas personas sufrieron más de un desplazamiento durante ese año. Una de las víctimas de Arunachal, alojada en una carpa en un lugar alto al que consiguió huir junto con su familia, testimonió que ese era su tercer desplazamiento en ese año y que hubiera preferido morir a tener que ver a su familia morir de hambre, allí. En Assam, el agua cubrió 2.600 aldeas, 400.000 hectáreas de áreas de cultivos. Estos desplazamientos ambientales forzados en los países en vías de desarrollo se caracterizan porque, usualmente, cada uno se escapa como puede ${ }^{193}$.

\footnotetext{
${ }^{191}$ IDMC-NRC. Global estimates 2012. People displaced by disasters, Op.cit., (mayo) 2013, p. 27-34.

192 IDMC-NRC. Global estimates 2012. People displaced by disasters, Op.cit., p. 15.

${ }^{193}$ IASC, Humanitaria Early Warning Service. Disponible en:

$<$ http://www.hewsweb.org/floods/flood.asp?FID=198379> acceso 10 de junio de 2014.
} 
En ese mismo año, Filipinas fue otro de los países que sufrió uno de los mayores desplazamientos con 3,9 millones de personas ${ }^{194}$. Uno de los desastres ocurridos en Filipinas fue el de la tormenta tropical de Washi/Sendong (diciembre de 2011), donde las personas tenían que escapar espontáneamente y se establecían en lugares tan carentes que hasta era necesario pagar por el agua, los alojamientos eran improvisados por los propios desplazados ${ }^{195}$.

El estudio de los diferentes casos de desplazamientos ambientales forzados permite verificar la constante violación a los derechos humanos que sufren estas personas. Lo llamativo es la escasez de referencias a esta situación en la doctrina y en los discursos de los organismos de Naciones Unidas.

Los derechos humanos constituyen aquellas condiciones mínimas necesarias para que la persona pueda tener una vida digna, es decir, que pueda ser considerada como titular de la ciudadanía efectiva. De tal modo, la vigencia de los derechos humanos asegura: el derecho a la vida, a la vivienda, a los alimentos, al agua, a la salud, a la identidad de la persona, a tener una familia, a la libertad y a la igualdad.

La humanidad ha luchado a lo largo de la historia por alcanzar el reconocimiento de los derechos humanos. Finalmente, esto fue logrado en el orden internacional a través de la creación de las Declaraciones de los Derechos Humanos, que fueron el resultado del consenso existente entre los países en relación con su reconocimiento. Este acuerdo se refleja al verificar la incorporación de los derechos humanos en las Constituciones de los países, con el nombre de derechos fundamentales del hombre.

Los derechos humanos están basados en el equilibrio entre el principio de la igualdad y el de la libertad, significando la realización de la dignidad de la persona. La efectividad de los derechos humanos se concretiza en la realización de la ciudadanía.

El reconocimiento de la gravedad de la situación subhumana constituida por la violación de los derechos humanos de los desplazados ambientales forzados permite verificar la relevancia de la necesidad de la protección internacional.

En primer lugar, serán realizadas algunas observaciones generales acerca de derechos humanos en general.

\footnotetext{
${ }^{194}$ IDMC/NRC. Global estimates 2012. People displaced by disasters, Op.cit., p. 22.

195 INTERNAL DISPLACEMENT MONITORING CENTER. NORWEGIAN REFUGEE COUNCIL (IDMCNRC). Disaster-induce internacional displacement in Philippines. The case of Tropical Storm Washi/Sendong, 2013, p. 9. Disponible en:

$<$ http://www.internal-displacement.org/assets/publications/2013/2013-ap-philippines-DRR-country-en.pdf> acceso 14 de julio de 2014.
} 
En segundo lugar, será considerado el estado del debate y las resoluciones del Consejo de Derechos Humanos de Naciones Unidas, del Alto Comisionado de Derechos Humanos (desde 2008), así como de otras instancias internacionales referentes a los derechos humanos de los desplazados ambientales forzados.

En tercer lugar, serán analizados los derechos humanos de los desplazados ambientales forzados.

En cuarto lugar, serán considerados cada uno de los derechos humanos de los desplazados ambientales forzados afectados.

Finalmente, serán realizadas algunas observaciones finales.

\section{III.2. Breves consideraciones sobre los derechos humanos}

\section{III.2.1. Derechos humanos. Origen. Declaraciones y pactos internacionales de derechos humanos.}

El desastre y la degradación ambiental irrumpen en la vida de los desplazados ambientales forzados llevándolos a pasar por situaciones de sufrimiento por las pérdidas de sus hogares, de las condiciones mínimas de vida (vivienda, alimentos, salud, agua), la muerte de seres queridos, la separación de las familias (en muchos casos), la pérdida de sus pueblos, de su identidad individual y colectiva. Todo esto implica la violación a sus derechos humanos causada por el desastre o por la degradación ambiental.

Uno de los peores aspectos de estas violaciones es la violación de la dignidad humana.

Hablar de los derechos humanos lleva a pensar en la historia de la humanidad, y a reflexionar sobre la naturaleza del hombre, la cual se ha debatido entre la dominación o la lucha contra esa sumisión que provoca la cosificación del ser humano. Muchas contiendas, mucha sangre derramada contra ese poder que se imponía sobre las personas llevó a que surgiera como síntesis de ese dualismo de dominadores y dominados: el estado de derecho, la democracia y el reconocimiento de los derechos humanos.

La Revolución Francesa constituyó un momento de ruptura con el sistema del absolutismo monárquico, tal fue la consecuencia histórica de una situación de insuperable crisis económica y política.

Las tres revoluciones inglesa, americana y francesa constituyeron el soporte fáctico de la Declaración Universal de los Derechos del Ciudadano de 1789, la cual vino a reconocer los derechos políticos y civiles de las personas. En este primer momento, se pusieron límites a la actuación del Estado en relación con las personas, estableciendo un modelo de Estado 
abstencionista. Esa Declaración afirmó la primacía de la libertad y la igualdad como principios fundamentales para las personas. Aunque con el transcurso del tiempo, se observó que las desigualdades no habían desaparecido, porque la igualdad sustentada en la Declaración era formal ${ }^{196}$.

En el "antiguo orden europeo" existían tres sistemas jurídicos que correspondían a tres sectores en los que se dividía la sociedad: el clero, la aristocracia y el pueblo. En la cúpula de la estructura social estaba el clero, lo seguía la aristocracia y en la base estaba el pueblo. Para cada uno de estos sectores sociales correspondían un ordenamiento jurídico diferente, siendo que a los primeros y a los segundos les correspondían más derechos, y así respectivamente. El reconocimiento de los derechos iba gradualmente en disminución hasta llegar al último escalón de la sociedad que era el que tenía menos derechos. Este escenario derivaba en una situación de privilegios que pertenecían a las primeras clases sociales. Así surge la necesidad de que se estableciera la igualdad de derecho, la cual significaba que todos serían titulares y regulados por los mismos derechos. La igualdad de derecho significaba que "la ley debe ser la misma para todos" 197

La Declaración Universal de los Derechos del Ciudadano se inspiró en las construcciones teóricas del contractualismo y del individualismo. Entre los primeros, se puede mencionar a Rousseau.

La efectividad de los derechos humanos depende de la eficacia de los dos principios: de libertad y de igualdad.

A mediados del siglo XIX, surgieron los movimientos socialistas que buscaban la incorporación de los derechos sociales (estos derivan del principio de igualdad), es decir que fuesen mejoradas las condiciones de vida para todas las personas, sin que estos derechos fueran restringidos a grupos de elite. Pero esto ocurrió solamente a inicios del siglo XX, cuando la Constitución de Weimar vino a reconocer los derechos sociales. En otras palabras, ya no bastaba la igualdad formal establecida en la Declaración Universal de los Derechos del Ciudadano de 1789 , sino que se quería el reconocimiento de una igualdad real ${ }^{198}$.

Se puede observar que el proceso de reconocimiento de los derechos humanos se produjo de forma lenta. En primer lugar, vinieron las construcciones teóricas que fundamentaron el surgimiento de los derechos humanos que aparecieron como luces en medio

\footnotetext{
196 SAGÜÉS, Néstor P. Elementos de Derecho Constitucional, Tomo I. Buenos Aires: Astrea, 1997, p. 4-5.

${ }^{197}$ FERREIRA FILHO, Manoel Gonçalves. Princípios do direito constitucional: o estado da questão no início do século XXI, em face do direito comparado e, particularmente, do direito brasileiro. São Paulo: Saravia, 2015, p. 216

198 SAGÜÉS. Op.cit., p. 6.
} 
de la oscuridad (etapa teórica). En un segundo momento, después de grandes luchas de los dominados, surgió la incorporación de los derechos humanos a las constituciones de los países (etapa concreta). En un tercer momento, vino el reconocimiento de los derechos humanos en el derecho internacional (universalización) ${ }^{199}$.

El momento de la teorización de los derechos humanos puede ser considerado como la construcción racional que queda en un plano de las ideas, que puede ser aplicada a cualquier lugar y tiempo.

El segundo momento de la incorporación de esos derechos a las constituciones de los países constituye la etapa de recepción por parte de los Estados, en el tiempo y en el espacio. En esta segunda etapa, se verifican dos momentos: el primero, que correspondía a la concepción del constitucionalismo racionalista, el cual establecía solamente principios y reglas generales que pudiesen ser aplicados en cualquier tiempo y lugar. El segundo, correspondía al constitucionalismo programático, con dispositivos más descriptivos y detallados.

La tercera etapa es cuando se produce el reconocimiento internacional de los derechos humanos, que significa que rigen en todo momento y en todo lugar, es decir, en el orden internacional. Este último momento emerge como síntesis de los dos anteriores (el primero: sin tiempo, sin espacio; el segundo: tiempo y espacio determinado; y el tercero: en todo tiempo y en todo lugar). Finalmente, se llega a la universalización de los derechos humanos.

En el orden internacional, los derechos humanos fueron reconocidos por la Declaración Universal de los Derechos Humanos de 1948. Posteriormente, fueron reconocidos dos Pactos Internacionales de los Derechos Humanos: el Pacto Internacional de los Derechos Civiles y Políticos y el Pacto Internacional de los Derechos Económicos, Sociales y Culturales.

El análisis del proceso de formación del Derecho Internacional de los Derechos Humanos permite observar que hay una primera etapa, donde la preocupación es con el reconocimiento de los derechos humanos de forma general y que abarca a todos (la Declaración Universal de los Derechos Humanos y los Pactos Internacionales). Una segunda etapa, en la que son reconocidos los derechos humanos correspondientes a grupos particulares (Convención de los Derechos de los Niños, etc.). En un momento posterior, se verifica el reconocimiento de los derechos que corresponden a toda la humanidad, como el derecho al desarrollo, el derecho al medio ambiente sano.

${ }^{199}$ BOBBIO, Norberto. A era dos direitos. Rio de Janeiro: Editora Campus, 2004, p. 30. 


\title{
III.2.2. Derechos humanos. Concepto. Características. Generaciones de derechos humanos
}

\author{
Thomas POGGE afirma:
}

\begin{abstract}
Nos enfrentamos, entonces, a dos preguntas: ¿qué son los derechos humanos?, y ¿qué derechos humanos existen? Creo que estas dos preguntas están asimétricamente relacionadas en este sentido: no podemos justificar convincentemente una lista particular de derechos humanos sin antes obtener un significado claro de qué son los derechos humanos ${ }^{200}$.
\end{abstract}

Ese autor relaciona la conceptualización de los derechos humanos con su contenido, de modo que sustenta la individualización de los derechos humanos. Esto hace necesario establecer primeramente una definición con las características de los derechos humanos.

Perez LUÑO define los Derechos Humanos de la siguiente manera:

\begin{abstract}
Un conjunto de facultades e instituciones que, en cada momento histórico, concretizan las exigencias de la dignidad, de la libertad y de la igualdad humanas, las cuales deben ser reconocidas positivamente por los ordenamientos jurídicos en nivel nacional e internacional $^{201}$.
\end{abstract}

Esta definición hace referencia a la realización de los principios ya considerados y al reconocimiento necesario del ordenamiento jurídico nacional, sin el cual tales derechos quedarán en un plano filosófico, y la aceptación por parte del derecho internacional.

Por otro lado, José CASTAN TOBEÑAS:

\begin{abstract}
Define los derechos humanos como aquellos derechos fundamentales de la persona humana considerada tanto en su aspecto individual como comunitario que corresponden a esta en razón de su propia naturaleza (de esencia al mismo tiempo corpórea, espiritual y social) y que deben ser reconocidos y respetados por todo poder $\mathrm{y}$ autoridad, inclusive las normas jurídicas positivas, cediendo no obstante, en su ejercicio, ante las exigencias del bien común ${ }^{202}$.
\end{abstract}

Este concepto establece la dimensión individual y social que se relaciona con el ejercicio de tales derechos. También relaciona los derechos humanos con la idea de bien común.

La universalidad de los derechos humanos consiste "en la atribución de estos derechos a todos los seres humanos, no importando ninguna otra cualidad adicional, como nacionalidad,

\footnotetext{
${ }^{200}$ POGGE, Thomas. La importancia internacional de los Derechos humanos. In Revista Argentina de Teoría Jurídica, Vol. 2, No 1, noviembre de 2000. Disponible en: <https://es.scribd.com/document/239006007/ThomasPogge-La-Importancia-Internacional-de-Los-Derechos-Humanos $>$ acceso: 5 de julio de 2014.

${ }^{201}$ MORAES, Alexandre de. Direitos humanos fundamentais: teoria geral, comentários aos artigos 1 ao 5 da Constituição da República Federativa de Brasil, doutrina e jurisprudência. São Paulo: Atlas, 2005, p. 22. 202 MORAES. Op.cit., p. 22.
} 
opción política, orientación sexual, religión, entre otras". La universalidad vino a tener vigencia con la internacionalización de los derechos humanos ${ }^{203}$.

La característica de universalidad de los derechos humanos fue la respuesta a una fase nefasta que correspondió al nazismo, donde el derecho positivo era el que regía la vida de las personas, y que permitió la realización de crímenes lesa humanidad. La creación del Sistema Internacional de los Derechos Humanos significó la internacionalización de los derechos humanos, lo cual se traduce en la universalidad.

La Declaración Universal de Derechos Humanos, así como las dos Cumbres Mundiales de los Derechos Humanos, la de Terán de 1968 y la de Viena de 1993, han reafirmado la universalidad de los derechos humanos en el sentido del alcance internacional, independientemente de los derechos positivos ${ }^{204}$.

Según André de Carvalho RAMOS, la inherencia de los derechos humanos "consiste en la cualidad de pertenencia de esos derechos a todos los miembros de la especie humana, sin cualquier distinción".

La interdependencia de los derechos humanos:

\begin{abstract}
Consiste en el reconocimiento de que todos los derechos humanos contribuyen para la realización de la dignidad humana, interactuando para la satisfacción de las necesidades esenciales del individuo, lo que exige, nuevamente, la atención integral a todos los derechos humanos, sin exclusión. El contenido de un derecho puede vincularse al contenido de otro, demostrando la interacción y la complementariedad entre ellos, bien como que ciertos derechos son desdoblamientos de otros ${ }^{205}$.
\end{abstract}

LAFER observa que existe "una complementariedad entre los derechos de la primera y la segunda generación", pues los segundos garantizan la realización de los primeros, transformando "en reales los derechos formales"206.

Existe una clasificación de los derechos humanos que los divide en generaciones: la primera corresponde a los derechos civiles y políticos, la segunda generación concierne a los derechos económicos sociales y culturales, y así sucesivamente con las generaciones de tercera y cuarta. Aparentemente, esto podría interpretarse como niveles de importancia, aunque no es así porque esa clasificación simplemente obedece al momento en que los derechos humanos

\footnotetext{
${ }^{203}$ RAMOS, André de Carvalho. Curso de Direitos Humanos. São Paulo: Saraiva, 2016, p. 92-95.

204 TRINDADE, António Augusto Cançado. O Legado da Declaração Universal e o Futuro da proteção internacional dos Direitos Humanos. En AMARAL JUNIOR, Alberto; PERRONE-MOISÉS, Cláudia. (Org.). O cinquentenário da Declaração Universal dos Direitos do Homem. São Paulo: Editora da Universidade de São Paulo, 1999, p. 19.

${ }^{205}$ RAMOS. Curso de Direitos Humanos. Op.cit., p. 92-95.

${ }^{206}$ LAFER, Celso. A reconstrução dos Direitos Humanos. Um diálogo com o pensamento de Hannah Arendt. São Paulo: Companhia das Letras, 1988, p. 127.
} 
fueron reconocidos a nivel internacional, recordando las características de indivisibilidad e interdependencia de los derechos humanos.

Los derechos de tercera y cuarta generación "tienen como titular no el individuo en su singularidad, pero sí grupos humanos como la familia, el pueblo, la nación, colectividades regionales o étnicas y la propia humanidad". Se puede observar que algunos de estos derechos son el derecho a la autodeterminación, el derecho al desarrollo, el derecho al medio ambiente, entre otros ${ }^{207}$.

\section{III.2.3. Derecho a la libertad y a la igualdad}

Existen dos pilares de los derechos humanos: la libertad y la igualdad, del equilibrio de estos surge la ciudadanía efectiva. La dignidad es el fundamento o la finalidad de los derechos humanos/fundamentales.

El derecho a la libertad es aquel que permite ejercer los derechos civiles y políticos, y hace que el ser humano pueda sentirse señor de sus decisiones, ejercer su voluntad, en otras palabras, es como el aire necesario para la vida de los seres vivos, pues la libertad es lo que hace sentir al hombre vivo y sujeto activo realizador de su destino, y no esclavo de un señor.

Aunque tan importante como el derecho a la libertad es el de la igualdad, pues sin esta no es posible la plena realización de la libertad, pues el hombre vive en una sociedad y por lo tanto él está en relación con otros. La afirmación de la igualdad permite que él tenga las mismas posibilidades de los otros para acceder a su realización como sujeto de la ciudadanía efectiva, permitiendo que él pueda gozar de la dignidad humana. El principio de la igualdad tiene que ver con la realización de todos aquellos derechos sociales, económicos y culturales que permiten la realización de la dignidad y que tienen que ver con la integridad humana.

La realización del principio de la igualdad significa la vigencia efectiva de la integridad humana, pues permite al hombre el acceso al estándar mínimo de vida, es decir, alimento, educación, vivienda digna, ropa, salud, seguridad, justicia, derecho a la familia, derecho al ser cultural, a su documentación. Los seis primeros aspectos tienen que ver con la sobrevivencia, es decir con la efectividad del derecho a la vida. Todos tienen que ver con la integridad, mientras que los tres últimos están más relacionados con la integridad psíquica.

El hombre es una unidad biológica y psíquica, tiene la libre voluntad y la razón, lo cual lo hace ser diferente del resto de los animales. En la psiquis están sus emociones, su

${ }^{207}$ LAFER, 1988. Op.cit., p. 131. 
intelectualidad o raciocinio, sus deseos y voluntades, y resulta de allí sus acciones. La preservación de la psiquis es fundamental para la existencia del ciudadano, pues permite que él pueda sentirse señor de sí mismo. Esa integridad psíquica tiene que ver con la identidad del ser humano; la desestructuración de tal identidad persona y social constituye una de las principales aberraciones por las que pasan los desplazados forzosos.

\section{III.2.4. Derechos humanos, dignidad humana y desplazados ambientales forzados. Mínimo estándar de vida}

El reconocimiento de los derechos humanos en el derecho internacional significa la afirmación universal de que el hombre es el titular de la ciudadanía efectiva, la cual debe ser respetada por toda la sociedad internacional.

De tal modo surgen diversos cuestionamientos, uno de ellos: ¿Cuáles son sus fundamentos?

Preliminarmente, es necesario indagar sobre el origen de la necesidad de buscar los fundamentos. Esta necesidad surge cuando se elabora una teoría jurídica, porque ellos sirven para justificar su reconocimiento por parte de los ordenamientos jurídicos. Otro momento, cuando se procura la justificación de los derechos, es cuando estos son negados por los sistemas jurídicos.

En este último sentido, RAMOS observa que los fundamentos sirven cuando los derechos humanos son negados o contestados, como sería el caso de los regímenes totalitarios o absolutistas ${ }^{208}$.

A lo largo de la historia, muchos autores trataron de buscar los fundamentos de los derechos humanos.

La posición iusnaturalista sostiene que los derechos humanos son anteriores al ordenamiento jurídico. Por ello, el Derecho solamente los reconoce:

\footnotetext{
El Estado reconoce formalmente lo que ya existe como exigencias básicas derivadas de la condición humana [...]. La aceptación de los derechos fundamentales es fruto de la concientización de la dignidad humana y sus exigencias históricas [...]. Los derechos naturales integran la estructura de la persona humana, siendo antecedentes lógicos de la positivización ${ }^{209}$.
}

\footnotetext{
${ }^{208}$ RAMOS. Curso de Direitos Humanos. Op.cit., p. 50.

${ }^{209}$ PEDROSO, Antonio Carlos. A dimensão antropológica dos Direitos Humanos. En CUNHA FERRAZ, Anna; BITTAR, Eduardo C.B. (orgs.). Direitos Humanos Fundamentais, Positivação e Concretização. Osasco: Edifieo, 2006, p. 10.
} 
RAMOS observa que el iusnaturalismo racionalista sostiene que "la razón humana es la fuente de los derechos inherentes al ser humano, afirma, entonces la supremacía del hombre frente al Estado, que es fundado en la realización de los derechos naturales del hombre" ${ }^{210}$.

Por otro lado, el positivismo no se preocupa con la fundamentación de los derechos humanos, reconoce que tales derechos son "históricos" y lo que realmente importa es que sean reconocidos por los ordenamientos jurídicos. Según esta posición, el derecho los crea ${ }^{211}$.

BOBBIO concluye que no es tan importante buscar sus fundamentos, sino reconocer el consenso alcanzado a través de las Declaraciones Internacionales y de los derechos internos de los países en relación con los derechos humanos. Este consenso es el resultado de la historia, reconociendo al hombre como titular de la ciudadanía efectiva, la cual no es más que la realización de la dignidad humana.

Cabe preguntarnos: ¿Qué es la dignidad humana? ¿Cuál es su relación con los derechos humanos?

KANT sostiene que todo aquello que no tiene precio es digno, permitiendo así reconocer la diferencia entre la cosificación del hombre y el reconocimiento de la naturaleza humana como persona, como señor universal de la naturaleza.

Flavia PIOVESAN observa:

\begin{abstract}
Para los universalistas, los derechos humanos derivan de la dignidad humana, en cuanto valor intrínseco a la condición humana. Se defiende, en esta perspectiva, el mínimo ético irreductible -a pesar de que pueda discutirse el alcance de este "mínimo ético" 212
\end{abstract}

La autora identifica la dignidad humana como "valor intrínseco de la persona" y con ese "mínimo ético irreductible".

La teoría del mínimo ético fue esbozada por Jeremías BENTHAM y luego por George JELLINEK, quien consideró que "el Derecho representa el mínimo moral necesario para que la sociedad pueda sobrevivir",213.

Ese mínimo necesario para que la civilización sobreviva es justamente el conjunto de derechos fundamentales que hacen parte del núcleo fuerte de los derechos humanos, cuya

\footnotetext{
${ }^{210}$ RAMOS. Curso de Direitos Humanos. Op.cit., p. 52.

${ }^{211}$ PEDROSO, 2006, Op.cit., p. 10.

212 PIOVESAN, Flávia. Direitos Humanos: desafios da ordem internacional contemporânea. En PIOVESAN, Flavia (org.). Direitos Humanos, V. I. Curitiba: Jurúa, 2007 (2006), p. 22.

${ }^{213}$ REALE, Miguel. Introducción al Derecho. Madrid: Ediciones Pirámide, 1988, p. 51.
} 
efectividad lleva a la realización de la dignidad humana. La dignidad humana se concretiza en la medida de la eficacia de los derechos humanos.

La teoría del mínimo ético establece que existe un núcleo mínimo de derechos fundamentales o mínimos que precisan ser reconocidos por los sistemas jurídicos de los países y por el derecho internacional. De tal núcleo derivan aquellos derechos necesarios a la sobrevivencia de las personas.

Dignidad humana y derechos humanos constituyen un núcleo inseparable. Es necesario observar que la realización de dignidad humana significa el respeto a la integridad física y psíquica de la persona. El ser humano es una unidad física y psíquica, siendo ambas igualmente importantes.

De la efectividad de la integridad física derivan los derechos humanos a los alimentos, al agua, a la salud, a la vivienda, a la vestimenta, a la seguridad. Es decir, las condiciones mínimas necesarias para que la persona tenga una vida digna, con salud y bienestar como reza el artículo 11 del Pacto Internacional de los Derechos Económicos, Sociales y Culturales. Estos constituyen el contenido del Principio de Asistencia a la Víctima establecidos en la Convención de "Cluster Munition". La vigencia de estos derechos es fundamental en la vida del desplazado ambiental forzado, pues el desastre y la degradación ambiental arrastran con vidas, viviendas, medios de sustentación, dejándolos desprovistos de alimentos, agua, ropas. Esa integridad física violada afecta de forma directa la integridad psíquica de la persona, porque la somete a una condición subhumana.

Además del restablecimiento de los derechos humanos anteriormente enunciados, la integridad psíquica efectiva requiere la efectividad de los derechos humanos a la unidad familiar, a la documentación, a sus tradiciones culturales, al ejercicio de su religión, al derecho a la identidad cultural del pueblo y el derecho a la libertad.

Los desplazados ambientales forzados sufren la pérdida de estos derechos, lo cual produce un terrible daño psíquico en la persona, pues es violada su integridad psíquica. Porque la situación del desastre o degradación ambiental lleva a que estas personas tengan que escapar dejando atrás hasta sus documentos.

La pérdida de la documentación de la persona es mucho más que la pérdida de un registro o cédula dada por el Estado para identificarse. Esta tiene que ver con la identidad de la persona dentro de una sociedad, que ante el desastre es afectada.

El derecho a la unidad familiar es fundamental para el ser humano, pues es el ámbito nuclear inicial donde la persona desarrolla sus vínculos afectivos y su personalidad. El desastre 
puede provocar la muerte de miembros de la familia, de hijos, maridos, madres, abuelos, y ¿será que puede haber algo más doloroso que la desintegración de la familia para el ser humano?

La pérdida de los derechos al ejercicio de su religión, de sus tradiciones culturales, de sus derechos a la identidad cultural de su pueblo provocados por la situación vivida por los desplazados ambientales llevan a la perdida de la identidad de la persona, y qué más doloroso que sentirse un paria caminando sin rumbos.

\section{III.3. Los desplazados ambientales forzados, sus derechos humanos y el ámbito del derecho internacional}

La violencia de la catástrofe ambiental arrasa con los derechos humanos de los desplazados ambientales forzados.

Mas cabría indagar sobre ¿cuáles son los derechos fundamentales que aseguran la dignidad de los desplazados ambientales forzados?

DOCHERTY y GIANNINI introducen el "Principio de la Asistencia a la Víctima" en el tratamiento de los desplazados ambientales forzados.

El Principio de Asistencia a la Víctima fue inicialmente reconocido en la Convención de Cluster Munition o de Minas en Racimo de 2008. Este principio asegura a las víctimas protegidas por esa Convención: un tratamiento psicológico, médico e "inclusión social y económica".

Estos autores consideran que este principio debe ser adaptado para la situación de los desplazados ambientales forzados. En tal sentido, se traduciría en asegurarles los derechos mínimos para sobrevivir, los cuales serían el derecho al agua, a la alimentación, al abrigo y a la salud $^{214}$.

Resulta evidente que estos derechos constituyen el mínimo necesario para poder sobrevivir ante el desastre. Es necesario que estos derechos sean asegurados a los afectados desde el momento en el que se produce la emergencia.

Es preciso observar que la vida del desplazado ambiental forzado va pasando por etapas:

- El momento en el que se produce el desastre o la degradación;

- el viaje para refugiarse;

- cuando son ubicados en el lugar del refugio;

${ }^{214}$ DOCHERTY; GIANNINI. Op.cit., p. 378. 
- el restablecimiento cuando ya ha pasado el peligro del desastre o de la degradación ambiental, el cual puede consistir en el retorno a su lugar de origen, en la integración a la sociedad donde viven o en otro lugar elegido.

De tal forma, en cada uno de estos momentos es necesario que sea asegurada la serie de derechos humanos que permitan que el desplazado ambiental forzado tenga una vida digna.

Las Directrices de IASC dividen los derechos de estas personas en:

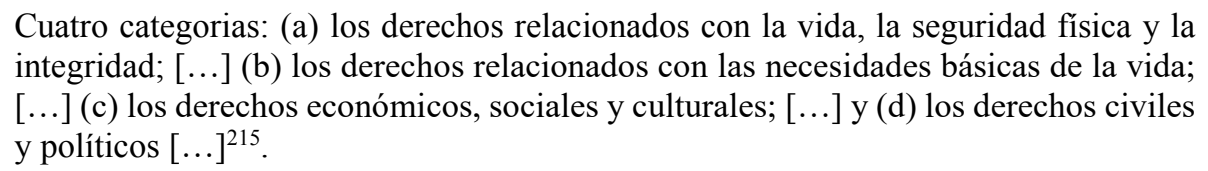

La primera categoría de derechos enunciada por IASC apunta al primer momento del desastre ambiental, es decir cuando se está frente a la situación de calamidad y se inicia la evacuación organizada o por cuenta propia (como es en la mayoría de los casos como será considerado en el capítulo siguiente), donde está en juego la vida de las personas y la integridad física. El segundo grupo de derechos establecidos por IASC hace referencia al bien jurídico protegido que es la sobrevivencia de las personas. Este segundo grupo de derechos, así como los primeros deben ser asegurados a los desplazados ambientales forzados tanto en el momento de la calamidad, en la etapa de la evacuación o traslado, así como cuando estas personas están viviendo en los campos de refugiados.

Todo este conjunto de derechos puede ser entendido a través del Principio de la Asistencia a la Víctima, considerado anteriormente.

En el primer grupo de derechos se establece la protección a la vida, la unidad familiar, la protección contra la violencia física y la seguridad. El segundo grupo reconocidos por IASC son: el derecho al agua potable, al saneamiento, al alojamiento, a la vestimenta adecuada, a los servicios básicos de salud y a la educación. La tercera categoría abarca: los derechos a la vivienda, a la tierra, a la propiedad, a los medios de subsistencia y a la educación.

Se puede observar que con la vigencia de estas tres primeras categorías de derechos enunciadas por IASC se busca asegurar la igualdad efectiva.

El último grupo de derechos apunta al restablecimiento de los derechos derivados del principio de la libertad. Estos son: los derechos a la libertad de circulación, al restablecimiento de los lazos familiares, la libertad de expresión, opinión y elecciones.

215 INTER-AGENCY STANDING COMMITTEE (IASC). Directrices operacionales del IASC sobre la protección de las personas en situaciones de desastres naturales. Proyecto de Brookings-Bern sobre Desplazamiento Interno, mayo de 2011a, p. 10. Disponible en:

$<$ http://www.hewsweb.org/floods/flood.asp?FID=198379> acceso 20 de julio de 2014. 
Los derechos humanos son indivisibles, por lo tanto, la violación de uno repercute sobre los otros, debido a que su fundamento es la dignidad humana, la cual no puede ser dividida: la dignidad humana existe o no. Por ello no se pueden establecer categorías relacionadas con la importancia de unos sobre los otros. Las categorías o géneros de derechos humanos corresponden al momento en que surgieron, nada más.

Los Principios Rectores de los Desplazados Internos protegen los derechos de aquellos desplazados internos de los desastres naturales, dejando de lado a los que atraviesan las fronteras de los países, siendo que la única diferencia entre los primeros y los transfronterizos (que están desprotegidos por el derecho internacional) es que los últimos atraviesan los límites políticos, las fronteras que separan a los países.

Los derechos humanos reconocidos por los Principios Rectores de los Desplazados Internos consideran las siguientes etapas: durante el desplazamiento y el regreso, el reasentamiento y la reintegración ${ }^{216}$.

En primer lugar, es necesario concluir que, en el ámbito del derecho internacional, no existe una regulación específica que proteja los derechos humanos de los desplazados ambientales forzados transfronterizos.

En segundo lugar, existen las Directrices de IASC creadas en 2006, y mejoradas en 2011, las cuales constituyen un conjunto de recomendaciones de IASC, aunque no tienen ningún tipo de naturaleza jurídica en el derecho internacional, siendo que solamente sirven como guías. Este conjunto de directrices únicamente considera los desplazados "internos" de los desastres naturales, dejando de lado los transfronterizos, así como aquellos que sufren otros tipos de catástrofes ambientales, como la degradación, los accidentes industriales y los proyectos de desarrollo.

En tercer lugar, también se presentan los Principios Rectores de los Desplazados Internos que únicamente consideran a aquellos que han sufrido el desastre pero que no han salido de las fronteras de sus países. La naturaleza jurídica de estos principios es una Resolución de la Asamblea General de Naciones Unidas no vinculante, es decir, no es obligatoria.

En cuarto lugar, existen las Resoluciones del Consejo de Derechos Humanos y del Alto Comisionado de Derechos Humanos de Naciones Unidas, las cuales solamente se preocupan con los desplazamientos producidos por los cambios ambientales (las que serán analizadas en la sección siguiente). De modo que recortan la temática, dejando de lado todos los otros

${ }^{216}$ NACIONES UNIDAS. Principios Rectores de los Desplazados Internos, Oficina de Coordinación de Asuntos Humanitarios, 1998. Disponible en: <http://www.law.georgetown.edu/idp/spanish/GPSpanish.pdf> acceso diciembre de 2014. 
escenarios de los desplazados ambientales forzados que fueron enunciados en el capítulo anterior. Además, estas resoluciones tienen un alcance muy limitado en el derecho internacional.

\section{III.4. Naciones Unidas y la violación de los derechos humanos de los desplazados ambientales forzados}

El reconocimiento de estas violaciones a los derechos humanos por parte de las organizaciones internacionales y de los países es muy importante para que surja el consenso en la comunidad internacional y se abran los caminos para la creación de la estructura normativa internacional para proteger a estas personas.

Debido a ello, en esta sección se analiza el discurso existente en el seno de Naciones Unidas sobre la violación de los derechos humanos de los desplazados ambientales forzados.

Preliminarmente, debe admitirse que hay muchas resistencias a la cuestión, como ya fue visto en el transcurso del Capítulos II, especialmente por parte de la doctrina como en los países desarrollados. La razón de esa oposición al reconocimiento de tales violaciones es que justificaría la protección internacional de estas personas. Esto implicaría un aumento en las cargas sobre los países industrializados en relación con la responsabilidad común y diferenciada por el medio ambiente, especialmente porque surgiría la obligación de tales países de hacer contribuciones financieras para ayudar a estas personas. Además, los países podrían ser obligados a recibir a estas personas.

En 2006, en Naciones Unidas, IASC elaboró las Directrices Operacionales sobre la Protección de las Personas en situaciones de Desastres Naturales, la cual fue direccionada a proteger los derechos humanos de estas poblaciones. Es preciso observar que IASC restringió la protección a los desplazados internos de los desastres, dejando de lado a todos los que atravesaban las fronteras. Esta limitación es injustificada porque, como fue afirmado en el Capítulo II, los desastres y la degradación ambiental no reconocen las fronteras políticas de los países. Otro límite es que solamente reconocen a los desplazados internos de los desastres naturales, dejando de lado los resultantes de la degradación ambiental, lo cual también es injustificado.

Margaretha WEWERINKE enuncia las resoluciones que fueron creadas por el Consejo de Derechos Humanos y por el Alto Comisionario de los Derechos Humanos de Naciones Unidas. En tal sentido, la autora observa: la Resolución 7/23 del Consejo de Derechos Humanos, la Resolución 10/61, la Resolución 10/4 de marzo 2009, la Reunión de junio de 2009, 
realizada por el Consejo de Derechos Humanos, la Reunión realizada en febrero de 2012, la UN Doc. A/HRC/20/7 (10 de abril de 2012), la Resolución de 18/22 de setiembre de 2012, febrero de 2012, la adopción de un Experto independiente, John Knox. Además, también se refiere a la reunión realizada por los Pequeños Estados Insulares ${ }^{217}$.

En los días 13 y 14 de noviembre de 2007, en la ciudad de Malé (Maldivas), los Pequeños Estados Insulares en Desarrollo realizaron una Conferencia, cuyo tema fue los impactos de los cambios climáticos sobre los derechos humanos. El resultado de esta Conferencia fue una Declaración.

En esta Declaración fueron realizados dos pedidos, en el primero se requería que este problema hiciera parte de la agenda de la reunión de Bali del UNFCCC. En segundo lugar, se solicitaba que el Alto Comisionado de Naciones Unidas sobre Derechos Humanos y el Consejo de Derechos Humanos realizaran un estudio detallado sobre los cambios climáticos y los derechos humanos ${ }^{218}$.

La inclusión del tema de los derechos humanos de los desplazados en la Conferencia Marco de Cambios Climáticos de Naciones Unidas podría constituir un error, porque ese Marco no trata ni de los desplazamientos, ni de los derechos humanos, ni establece obligaciones de los Estados con las personas. El UNFCCC crea obligaciones para los Estados, únicamente. Además, su objetivo es negociar las reducciones de emisión de los gases de efecto invernadero, el cual ya demuestra grandes dificultades para avanzar en tal sentido. Consecuentemente, sería muy difícil que esta tentativa tuviese éxito. Esta temática será analizada con más detalle en el Capítulo V.

Por otro lado, desde 2007, ACNUR asumió un discurso criticando la actuación de Naciones Unidas en relación con los desplazados ambientales forzados (la evolución del discurso de ACNUR será tratada en el Capítulo VI). Posteriormente, ACNUR propuso asumir esta problemática, y esto generó grandes tensiones en el seno de Naciones Unidas sobre quién tendría la responsabilidad por los desplazados ambientales forzados.

Seguidamente, el Secretario General de Naciones Unidas decidió conceder el tratamiento de esta temática al Alto Comisionado de Derechos Humanos de Naciones Unidas, y también pasó esa competencia al Consejo de Derechos Humanos. Aunque como ya fue

${ }^{217}$ WEWERINKE, Margaretha. Climate Change, Human Rights and the International Legal Or der: The Role of the UN Human Rights Council. 4CMR Working Paper Series. Cambridge Centre for Climate Change Mitigation Research (4 CMR). Disponible en: <http://be.4cmr.group.cam.ac.uk/workingpapers/pdf/4CMR_WP_04.pdf $>$ acceso 5 de junio de 2014

${ }^{218}$ CONFERENCIA DE PEQUEÑOS ESTADOS INSULARES EN DESARRROLLO. Male' Declaration on the Human Dimension of Global Climate Change. Male', Maldivas, 14 de noviembre de 2007. Disponible en: $<$ http://www.ciel.org/Publications/Male_Declaration_Nov07.pdf $>$ acceso 7 de julio de 2014. 
observado, este Consejo solamente considera la violación a los derechos humanos de los desplazados ambientales de los cambios climáticos, dejando de lado aquellos que escapan de la degradación. Esta diferencia es injusta porque, como ya ha sido considerado, la figura de los desplazados ambientales forzados es única.

El 28 de marzo de 2008, el Consejo de Derechos Humanos emitió la Resolución 7/23: "derechos humanos y cambios climáticos", donde se solicitó al Alto Comisionado de Derechos Humanos de Naciones Unidas que realizase un estudio detallado de los impactos de los cambios climáticos sobre los derechos humanos. Esta resolución constituye el primer reconocimiento de este órgano de Naciones Unidas de la incidencia negativa del cambio climático sobre los mencionados derechos. Así, este instrumento observa:

\begin{abstract}
El Consejo de Derechos Humanos, Preocupado porque el cambio climático crea una amenaza inmediata y de gran alcance para la población y las comunidades de todo el mundo y tiene repercusiones sobre el pleno disfrute de los derechos humanos [...].

Tomando nota de las conclusiones del Cuarto Informe de Evaluación del Grupo Intergubernamental de Expertos sobre Cambios Climáticos, en particular el hecho de que el calentamiento del sistema climático es inequívoco y de que la mayor parte del aumento observado en las temperaturas medias mundiales desde mediados del siglo XX ha sido muy probablemente causada por el hombre ${ }^{219}$.
\end{abstract}

Es importante destacar que la mencionada resolución se apoya en las conclusiones del panel intergubernamental de científicos, otorgándole un peso mayor a sus afirmaciones.

En esta resolución se reconoce "el derecho al desarrollo" como uno de los derechos humanos. Además, observa que los países más afectados son los que están en vías de desarrollo. En tal sentido señala:

\begin{abstract}
El Consejo de Derechos Humanos, [...]
Considerando también que los pobres del mundo, en particular los que están concentrados en zonas de alto riesgo, son especialmente vulnerables a los efectos del cambio climático y además tienden a tener capacidades de adaptación más limitadas, Considerando además que los países de baja altitud y otros países insulares pequeños, los países con zonas costeras bajas, zonas áridas y semiáridas o zonas expuestas a inundaciones, sequía y desertificación, y los países en desarrollo con ecosistemas montañosos frágiles son particularmente vulnerables a los efectos adversos del cambio climático $[\ldots]^{220}$.
\end{abstract}

El 22 de octubre de 2008, la Oficina del Alto Comisionado para los Derechos Humanos (ACNUDH) realizó una Reunión en Ginebra sobre "los derechos humanos y los cambios

\footnotetext{
${ }^{219}$ HUMAN RIGHTS COUNCIL. Resolution 7/23 on Human Rights and Climate Change, Res. 7/23, UN Doc. A/HRC/7/78, 28 de marzo de 2008, parágrafos 1 y 4 .

${ }^{220}$ HUMAN RIGHTS COUNCIL. Resolution 7/23..., Op.cit., parágrafos 8-9.
} 
climáticos", donde fueron discutidos y reconocidos los impactos negativos sobre los derechos humanos de los desplazados ambientales forzados.

El 15 de enero de 2009, el Alto Comisionado de Derechos Humanos presentó el estudio detallado a través de Doc. A/HRC/10/61 (2009), respondiendo a los diversos pedidos anteriormente mencionados ${ }^{221}$.

En primer lugar, esa resolución restringe su alcance a tratar los impactos negativos de los cambios climáticos y los derechos humanos de los afectados. En vez de esto, se podría haber considerado la situación de los desplazados ambientales forzados independientemente de las causas que originaron los desplazamientos. De tal modo, observa que el ámbito adecuado para tratar estas cuestiones es el UNFCCC. Esta es la misma idea sostenida por la Declaración de los Pequeños Estados Insulares de 2007.

Esta Resolución se divide en dos partes: la primera trata los cambios climáticos y sus impactos negativos sobre los derechos humanos de los desplazados de los cambios climáticos; la segunda analiza las obligaciones que derivan de esa situación.

Es relevante destacar que en esta Resolución se analizaron cada uno de los derechos humanos afectados por el cambio climático, considerando el derecho a la vida, a los alimentos, al agua, a la salud, a la vivienda, a la autodeterminación de los pueblos. Además, es considerado el problema de los grupos vulnerables.

El 12 de mayo de 2009, el Consejo de los Derechos Humanos emitió la Resolución 10/4, donde se observa que "los derechos humanos son universales, indivisibles e interdependientes $[\ldots] "$

Esta Resolución introduce una referencia específica a los derechos humanos afectados por los cambios climáticos que aseguran las condiciones mínimas de dignidad de la persona:

\footnotetext{
Parágrafo 7: Tomando nota de que los impactos relacionados con el cambio climático tienen una serie de implicaciones, tanto directa como indirecta, para el goce efectivo de los derechos humanos, incluidos, entre otros, el derecho a la vida, la derecho a la alimentación adecuada, el derecho al goce del grado máximo de salud, el derecho a una vivienda adecuada, el derecho a la autodeterminación y a los derechos humanos relacionadas con el acceso al agua potable y saneamiento, y recordando que en ningún caso podrá privarse a un pueblo de sus propios medios de subsistencia, $[\ldots]$.
}

${ }^{221}$ OHCHR. Report of the Office of the United Nations High Commissioner for Human Rights on the Relationship between Climate Change and Human Rights, UN Doc. A/HRC/10/61, 15 de enero de 2009a, parágrafos 25-41. Disponible en: <http://www.ohchr.org/Documents/Press/AnalyticalStudy.pdf> acceso 12 de julio 2014. 
Además, en esta Resolución se pide la realización de un encuentro para debatir esta problemática $^{222}$.

Todas estas Resoluciones anteriormente citadas tienen un aspecto muy importante que es la construcción efectiva de un consenso internacional sobre las violaciones a los derechos humanos de los desplazados forzados ambientales (aunque en estos casos solamente se refieren a los producidos por los cambios climáticos).

En junio de 2009 se realizó un encuentro en Ginebra, organizado por el Alto Comisionado de Naciones Unidas de Derechos Humanos, donde se debatió sobre el tema de los derechos humanos y los impactos de los cambios ambientales. Además, se hizo el pedido de que fuese instituido un Relator Especial para cuidar de los derechos humanos y los cambios climáticos $^{223}$.

La Resolución de la Asamblea General de Naciones Unidas A/64/255 del 6 de agosto de 2009 , establece ${ }^{224}$ que la magnitud global del problema de los derechos humanos y los cambios climáticos exige una solución global ${ }^{225}$.

El 6 de octubre de 2010 se realizó el Foro Social, cuyo tema fue: "los cambios climáticos y los derechos humanos", donde fue reiterado el pedido de la creación de un Relator Especial ${ }^{226}$.

El 30 de setiembre de 2011, el Consejo de Derechos Humanos dicta la Resolución 18/22, también considerada como A/HRC/18/L.26/Rev. sobre "Derechos Humanos y Cambio Climático. Esta Resolución establece:

\footnotetext{
Afirmando que las obligaciones, las normas y los principios en materia de derechos humanos pueden guiar y reforzar la formulación de políticas internacionales y nacionales en la esfera del cambio climático y fomentar su coherencia política, legitimidad y durabilidad de sus resultados,
}

\footnotetext{
${ }^{222}$ HUMAN RIGHTS COUNCIL. Resolution 10/4 on Human Rights and Climate Change, Res. 10/4, UN Doc. A/HRC/10/L.11; A/HRC/7/11, 31 de marzo de 2009, p. 19, parágrafo 7.

${ }^{223}$ OHCHR. Summary of Discussion of Human Rights Council Panel Discussion on the Relationship between Climate Change and Human Rights, 15 de junio de 2009b, parágrafo 104, Palais des Nations, Ginebra. Disponible en:

$<$ http://www.ohchr.org/EN/Issues/HRAndClimateChange/Pages/HRClimateChangeIndex.aspx $>$ acceso 30 de julio de 2014.

224 "Los Estados tienen obligaciones claramente definidas en virtud de las normas internacionales de derechos humanos de respetar, proteger y hacer efectivo el derecho a una vivienda adecuada y de buscar, por medio de la cooperación internacional, soluciones mundiales al problema mundial del cambio climático y sus efectos en la vivienda. Por tanto, es necesario que se tomen en cuenta las normas internacionales de derechos humanos para responder a los desafíos que plantea el cambio climático [...]".

${ }^{225}$ NACIONES UNIDAS. ASAMBLEA GENERAL. A/64/255. Sexagésimo cuarto período de sesiones. Tema 71 b) del programa provisional. Promoción y protección de los derechos humanos: cuestiones de derechos humanos, incluidos otros medios de mejorar el goce efectivo de los derechos humanos y las libertades fundamentales, 6 de agosto de 2009.

${ }^{226}$ NACIONES UNIDAS. Report of the 2010 Social Forum, UN Doc. A/HRC/16/62 at paras. 12, 43 and $60 a$, Ginebra, 4-6 de octubre de 2010.
} 
1. Reitera su preocupación de que el cambio climático plantea una amenaza inmediata y de gran alcance para la población y las comunidades de todo el mundo y tiene consecuencias adversas en el pleno disfrute de los derechos humanos $[\ldots]^{227}$.

En mayo de 2012 se dictó la resolución A/HRC/19/10, en la cual fue instituido el mandato del Relator Independiente para el medio ambiente y derechos humanos ${ }^{228}$.

El análisis de todas estas resoluciones permite verificar que el reconocimiento de la violación de los derechos humanos de los desplazados ambientales forzados ha sido realizado principalmente por el Consejo de los Derechos Humanos y por el Alto Comisionado de Naciones Unidas.

Se trata de un proceso de reconocimiento que se inició en 2008 y llega hasta nuestros días, durante el cual se fueron presentando las resoluciones en tal sentido, realizando encuentros para discutir las cuestiones y estudio para avanzar en la problemática.

El inicio de esta discusión se produjo por la presión de ACNUR y por la Declaración de la Organización de Pequeños Estados Insulares en Desarrollo. Estos últimos tenían intereses propios en el problema porque sufren la elevación del nivel de mar y de la sumersión de las regiones costeras.

Estas Resoluciones permiten verificar que las violaciones a los derechos humanos de los desplazados ambientales forzados son reconocidas por el Consejo de Derechos Humanos de Naciones Unidas, lo cual ya constituye un apoyo en favor de la cuestión.

Ello es un precedente en la construcción del consenso internacional sobre la violación de los derechos humanos de este grupo de personas que están desprotegidas.

Por otro lado, es necesario observar que estas Resoluciones del Consejo de Derechos Humanos se refieren solamente a la relación entre los impactos negativos de los cambios climáticos sobre los derechos humanos, de lo cual se desprende el siguiente cuestionamiento: ¿no sería mejor referirse a los desplazados ambientales forzados de los impactos de los desastres y de la degradación ambientales de forma amplia?

Porque este recorte hace que sean dejados de lado aquellos afectados por los desastres y degradación ambiental originados en causas diferentes a los cambios climáticos, y lleva solamente a reconocer las violaciones a los derechos humanos de las personas afectadas por aquellas catástrofes desencadenadas por los cambios climáticos (islas y regiones costeras

\footnotetext{
${ }^{227}$ NACIONES UNIDAS. ASAMBLEA GENERAL. A/HRC/18/L.26/Rev.1 Consejo de Derechos Humanos. $18^{\circ}$ período de sesiones. Tema 3 de la agenda. Promoción y protección de todos los derechos humanos, civiles, políticos, económicos, sociales y culturales, incluido el derecho al desarrollo, 28 de septiembre de 2011, p. 3, parágrafo 16.

228 HUMAN RIGHTS COUNCIL. Resolution 19/10, Human Rights and the Environment, UN Doc. A/HRC/19/10, 22 de marzo de 2012, punto 2, p. 2.
} 
sumergidas por el aumento del nivel del mar, aumento de la desertificación, tsunamis, entre otras situaciones), siendo que deja de lado otros escenarios de catástrofe de desastre ambiental y degradación ambiental que tienen origen en otras causas, como los accidentes industriales (como el de Bhopal, en la India) los proyectos de desarrollo (como la construcción de una ruta, o la creación de un dique), los procesos de degradación ambiental causados por el hombre o por la naturaleza, o por ambos, como la deforestación, acumulación de basura en lugares que obligan a la población a irse, entre otros.

La figura de los desplazados ambientales forzados es la misma sin importar la causa que provoque el desastre o la degradación ambiental. El sufrimiento de estas personas por la pérdida de sus derechos humanos es el mismo.

\section{III.5. Cambios climáticos, desastre o degradación ambiental y los derechos humanos}

Es necesario reconocer que la violación de los derechos humanos de los desplazados ambientales forzados no se produce solamente por los impactos negativos de los cambios climáticos, sino que también es causada en forma general por los desastres o degradación ambiental producidos por otras causas.

Esas Resoluciones enunciadas anteriormente únicamente se refieren a la relación entre los impactos negativos de los cambios climáticos y los derechos humanos, constituyendo un recorte arbitrario. Porque la violación de los derechos humanos de las personas que sufren un desastre ambiental provocado por un accidente industrial, sea químico, biológico, o de otra naturaleza, es la misma que si el desastre fuera provocado por los cambios climáticos. Lo mismo ocurre con aquellos que han sido obligados a escapar de sus hogares por causa de la degradación ambiental, provocada por la acción de la naturaleza o del hombre o por ambos.

No se debe perder de vista lo que caracteriza a los desplazados ambientales forzados: sufrir el desastre o la degradación ambiental, tener que escapar dejando sus hogares y la violación a los derechos humanos. Estas tres características constituyen la figura del desplazado ambiental forzado. Por lo tanto, reconocer solamente la violación a los derechos humanos de aquellos desplazados de los cambios climáticos es injustificado.

Yuvraj D. PATIL observa que la violación de los derechos humanos de los desplazamientos humanos no es únicamente el resultado de los impactos de los cambios climáticos, sino que es necesario considerar que el hecho generador de esta violación es más amplio, incluyendo los desastres y degradación ambiental. 
En este sentido, este autor observa:

[...] Pueden deberse a causas naturales, negligencia o accidente. Terremotos, volcanes, inundaciones, tsunamis, ciclones, tornados, etc., son muestras de desastres naturales, mientras que los que ocurrieron en Chernóbil (Rusia) y recientemente en Japón son la muestra de accidentes. La fuga de gas de Bhopal es una instancia de desastre debida a presunta negligencia criminal. Independientemente de la causa, las consecuencias de un desastre son muy graves ya que conllevan la pérdida sustancial de la vida y el sufrimiento humano por causa de los daños y la destrucción de la propiedad o desplazamiento o la degradación del medio ambiente ${ }^{229}$.

La situación de desastre o de degradación ambiental por la que atraviesan los desplazados ambientales forzados afecta la normalidad de la vida de estas personas, constituyendo una ruptura en el ejercicio regular de los derechos humanos.

El análisis de la relación entre los derechos humanos y los cambios climáticos implica un recorte que no favorece el estudio completo de la situación de los desplazados ambientales.

Por esto, en esta tesis se considera la figura de los desplazados ambientales forzados, independientemente de las causas que les dieron origen.

\title{
III.6. Derecho a la vida
}

La Resolución 10/61 de 2009 reconoce que los impactos negativos de los cambios climáticos atentan contra el derecho a la vida. En tal sentido, observa:

\begin{abstract}
Varios efectos observados y previstos del cambio climático plantearán amenazas directas e indirectas a la vida humana. En el Informe de Evaluación $\mathrm{N}^{0} 4$ del IPCC se prevé con un alto grado de certeza un aumento en el número de personas que morirán o sufrirán enfermedades y lesiones como consecuencia de olas de calor, inundaciones, tormentas, incendios y sequías.
\end{abstract}

En el período 2000-2004, hubo 262 millones de personas perjudicadas por los desastres. "Se calcula que los ciclones tropicales, que afectaron a aproximadamente 120 millones de personas cada año, mataron a 250.000 personas entre 1980 y 2000 "230.

La gravedad del desastre o de la degradación que ataca el derecho a la vida $y$, consecuentemente, lleva a estas poblaciones a escapar sin rumbo, justifica que sean llamados desplazados forzados, como ya fue analizado en el Capítulo II.

${ }^{229}$ PATIL, Yuvraj D. Disaster affected Environmental Refugees \& Human Rights, 2012, p. 2. Disponible en: $<$ http://ssrn.com/abstract=2002497> acceso 20 de junio de 2014.

${ }^{230} \mathrm{OHCHR}$, Report of the Office of the United Nations..., Op.cit., paragrafos 22-23. 


\title{
Hannah ENTWISLE observa:
}

Dentro de los 60 segundos, el terremoto en Haití mató a más de 230.000 personas y dejó heridas a otras 300.000. El terremoto de 2005 en Paquistán mató a 73.000 personas, mientras que en el Océano Índico el terremoto-tsunami mató a más de 300.000 personas en nueve países ${ }^{231}$.

Sobre la importancia del derecho a la vida, Tiffany DOUNG observa:

\begin{abstract}
El derecho a la vida es el derecho humano más importante: "sin él, ningún otro derecho tendría sentido", y se considera una norma imperativa de derecho internacional. Por lo tanto, ninguna derogación es permitida, incluso en momentos de emergencia, y sólo puede ser modificada por una norma posterior de carácter general de derecho internacional general que tenga la misma categoría. El derecho a la vida es universal y obligatorio, consagrado explícita o implícitamente en todos los instrumentos internacionales de derechos humanos ${ }^{232}$.
\end{abstract}

El derecho a la vida está garantizado en el derecho internacional en el artículo 3 de la Declaración de Derechos Humanos, en el artículo 6 del Pacto Internacional de Derechos Civiles y Políticos, en el artículo 4 de la Convención Americana de Derechos Humanos, en el artículo 3 de la Convención Europea para la protección de los derechos humanos y en el artículo 4 de la Carta Africana de Derechos Humanos.

El artículo 3 de la Declaración Universal de los Derechos Humanos establece que "todo individuo tiene derecho a la vida, a la libertad y a la seguridad de su persona".

El artículo 6 del Pacto Internacional de Derechos Civiles y Políticos afirma que "el derecho a la vida es inherente a la persona humana. Este derecho deberá ser protegido por la ley. Nadie podrá ser arbitrariamente privado de su vida”.

La Convención Americana de Derechos Humanos de San José de Costa Rica de 1969 establece en su artículo 4 que "toda persona tiene derecho a que se respete su vida. Este derecho estará protegido por la ley y, en general, a partir del momento de la concepción. Nadie puede ser privado de la vida arbitrariamente".

El Comité de Derechos Humanos en el Comentario General del artículo 6 (derecho a la vida) observa:

1. El derecho a la vida, enunciado en el artículo 6 del Pacto ha sido tratado en todos los informes de los Estados. Es el derecho supremo respecto del cual no se autoriza derogación incluso ni en situaciones excepcionales que pongan en peligro la vida de

\footnotetext{
${ }^{231}$ ENTWISLE. Op.cit., p. 12.

${ }^{232}$ DUONG, Tiffany T.V. When Islands Drown: The Plight of "Climate Change Refugees" and Recourse to International Human Rights Law. In University of Pennsylvania Journal of International Law, Vol. 31, $\mathrm{N}^{\circ} 4$, Summer, 2010, p. 1256-1257 (2014). Disponible en:

$<$ https://www.law.upenn.edu/journals/jil/articles/volume31/issue4/Duong31U.Pa.J.Int\%271L.1239\%282010\%29. pdf $>$ acceso 20 de marzo de 2015.
} 
la nación (Art. 4). Sin embargo, el Comité ha observado que con frecuencia la información aportada en relación con el artículo 6 se limita sólo a uno u otro aspecto de ese derecho. Es un derecho que no debe interpretarse de forma restrictiva ${ }^{233}$.

En relación con que tanto el Estado como los particulares deben abstenerse de realizar actos contra la vida, Sheila WATT-CLOUTIER observa:

\begin{abstract}
La Decimocuarta Enmienda de la Constitución de los EE.UU. protege la vida de los ciudadanos porque prohíbe a los Estados privar a cualquier persona de la vida sin el debido proceso de ley. La Quinta Enmienda impone limitaciones similares en el gobierno federal [...]. La Corte Suprema de los Estados Unidos interpreta las cláusulas del debido proceso de la Enmienda Decimocuarta y Quinta como limitaciones al poder gubernamental para actuar $[\ldots]^{234}$.
\end{abstract}

De este modo, en la Constitución de Estados Unidos queda consagrada la protección del derecho a la vida como una prohibición de los actos arbitrarios de los Estados contra la existencia de las personas.

El reconocimiento de la protección a la vida tiene dos sentidos: por un lado, es necesario que tanto el Estado como los particulares no realicen actos contra la vida de las personas, lo cual implica la abstención de la realización de actos por parte del Estado. Por otro lado, la afirmación del derecho a la vida significa que sean aseguradas las condiciones mínimas para una vida digna, siendo que en los casos en los que no existen tales condiciones, es necesaria la actuación del Estado.

El artículo 11 del Pacto Internacional de los Derechos Económicos, Sociales y Culturales observa:

Los Estados-partes en el presente Pacto reconocen el derecho de toda persona a un nivel de vida adecuado para sí mismo y para su familia, inclusive la alimentación, la vestimenta y la vivienda adecuada, así como una mejoría continua de sus condiciones de vida.

La protección de estos derechos mínimos para asegurar un nivel de vida adecuado deriva del derecho a la igualdad efectiva, la cual se traduce en la igualdad real de oportunidades de los ciudadanos y no en una simple igualdad formal. El derecho a la igualdad es uno de los pilares de los derechos humanos.

\footnotetext{
${ }^{233}$ HUMAN RIGHTS COMMITTEE. General Comment 6, Article 6 (Sixteenth session, 1982). Compilation of General Comments and General Recommendations Adopted by Human Rights Treaty Bodies, U.N. Doc. HRI/GEN/1/Rev.1 at 6 (1994), in UN Doc./A/37/40, 30 de abril de 1982, punto 1. Disponible en: $<$ www.unhchr.ch/tbs/doc.nsf/(Symbol)/84ab9690ccd81fc7c12563ed0046fae3?Opendocument $>$ acceso 10 de julio de 2014.

${ }^{234}$ WATT-CLOUTIER, Sheila. Petition to the Inter-American Commission on Human Rights Seeking Relief from Violations Resulting from Global Warming Caused by Acts and Omissions of the United States, $7 \mathrm{de}$ diciembre de 2005, p. 112. Disponible en:

$<$ http://www.ciel.org/Publications/ICC_Petition_7Dec05.pdf $>$ acceso 18 de julio de 2014.
} 
La violación del derecho a la vida de los desplazados ambientales puede ser considerada en un sentido estricto como un ataque a la vida humana que resulta en la muerte de personas como consecuencia del desastre o de la degradación ambiental, como ya ha ocurrido en diversas oportunidades. Aunque también, por otro lado, ese derecho a la vida puede ser interpretado en un sentido más amplio, como el goce pleno de una vida digna, lo cual significaría la vigencia de un conjunto de derechos que satisfagan las necesidades mínimas de la persona. En ambas situaciones, este derecho es violado por los desastres o la degradación ambiental.

El derecho a la vida de los desplazados ambientales forzados exige la realización de actos por parte de los Estados, tanto en el sentido de la seguridad, como al respecto de asegurar una vida digna. En este último sentido, el Estado precisa asegurar ese conjunto mínimo de derechos que satisfagan un nivel adecuado de vida.

De tal modo, el derecho a la vida supone la necesidad de protección de una serie de derechos fundamentales, como el derecho a los alimentos, al agua, a la salud física y psíquica, a la vivienda, a la salud, a la libertad y a la igualdad, a la identidad individual y colectiva de las personas. Porque la protección del derecho a la vida implica la realización de la dignidad humana.

Así queda establecida la relación necesaria entre el derecho a la vida, el derecho a la igualdad efectiva y a los derechos a la alimentación, al agua, a la vivienda, a la salud, a la vestimenta, a la identidad individual y colectiva, a la libertad.

Esto permite observar que el derecho a la vida es un derecho supremo, porque es un presupuesto de todos los otros derechos humanos.

La Comisión Interamericana de Derechos Humanos admitió que la degradación ambiental provocada por la construcción de la ruta transamazónica llevó a la violación del derecho a la vida del pueblo Yanomami por parte del gobierno de Brasil. Además, estos hechos causaron la violación de otros derechos humanos de este pueblo ${ }^{235}$.

El Caso 7615 Yanomami, de 1985 señala:

Las violaciones reportadas tienen su origen [...] en la autorización para explotar los recursos del subsuelo de los territorios indígenas; al permitir la penetración masiva en el territorio de los indios, de personas extrañas transmisoras de enfermedades contagiosas diversas que han causado numerosas víctimas entre la comunidad indígena y al no proporcionar la atención médica esencial a las personas afectadas; y

\footnotetext{
${ }^{235}$ KOIVUROVA, Timo; DUYCK, Sébastien; HEINÄMÄKI, Leena. Climate Change and Human Rights. En HOLLO, Erkki J.; KULOVESI, Kati; MEHLING, Michael. (eds.). Climate Change and the Law. Ius Gentium: Comparative Perspectives on Law and Justice, Vol. 21, 7 de octubre de 2013, Dordrecht: Springer, p. 293. Disponible en: <http://ssrn.com/abstract=2336876> acceso 15 de julio de 2014.
} 
finalmente, por proceder al desplazamiento de los indios de sus tierras ancestrales, con todas las consecuencias negativas para su cultura, tradiciones y trajes ${ }^{236}$.

Todos estos actos violatorios de los derechos humanos llevaron a considerables números de muertes (violando el derecho a la vida), así como a la desintegración de la comunidad indígena Yanomami.

Así se puede observar cómo la degradación ambiental producida por un proyecto de desarrollo, como fue la construcción de la ruta BR-210 transamazónica, tuvo una incidencia directa en la violación del derecho a la vida.

KOIVUROVA, DUYCK y HEINÄMÄKI observan que “otro cuerpo legal de derechos humanos ${ }^{237}$ ha encontrado una conexión directa entre el derecho a la vida y la interferencia ambiental". Este fue el caso de Öneryildiz versus Turkey, que fue juzgado por la Corte Europea de Derechos Humanos, "fundamentándose en el artículo 2 (el derecho a la vida) y en el artículo 1 del Protocolo (que protege el derecho de propiedad) de la Convención Europea de Derechos Humanos". La explosión de gas metano producida por la acumulación de residuos provocó un deslizamiento de tierras que terminó destruyendo las casas y matando a 39 personas en la ciudad de Estambul en 1993. La Corte Europea de Derechos Humanos reconoció la violación al derecho a la vida y a la propiedad, causada por la degradación ambiental ${ }^{238}$.

Esta decisión reconoció la responsabilidad del Estado por no haber actuado, y estableció la indemnización correspondiente.

Los dos casos citados permiten ilustrar el reconocimiento al derecho a la vida y su violación a través de la degradación del medio ambiente, producida con la intervención de la acción del hombre.

De tal forma, se puede concluir que el derecho a la vida puede ser violado tanto por actos de degradación ambiental como por desastres ambientales, ya sean realizados por el hombre, por la naturaleza o por ambos.

\section{III.7. Derecho al agua}

El derecho al agua no ha sido mencionado expresamente ni en la Declaración Universal de Derechos Humanos, ni en el Pacto Internacional de los Derechos Económicos, Sociales y

\footnotetext{
${ }^{236}$ INTER-AMERICAN COMMISSION ON HUMAN RIGHTS. Case of Yanomami Indians, Judgement, 1985, Case 7615 (Brazil), Inter-Am. C.H.R., OEA/Ser.L/V/II.66 doc. 10 rev. 1985, p. 5. Disponible en: $<$ www.cidh.org/annualrep/84.85eng/Brazil7615.htm> acceso 15 de julio de 2014.

${ }^{237}$ Se refiere a la Convención Europea de Derechos Humanos y su Protocolo.

${ }^{238}$ KOIVUROVA et al., Op.cit., p. 293-294.
} 
Culturales. Aunque este derecho es considerado por tales instrumentos de forma implícita, pues estos reconocen el derecho a la vida y a la salud, siendo que la persona no puede vivir, ni tener salud, sin el agua. El agua es un elemento indispensable para la vida de las personas.

Sobre el reconocimiento internacional del derecho al agua, Meghan CLARKE observa que "el derecho al agua se articula expresamente en la Convención sobre los Derechos del Niño (CRC) y la Convención sobre la Eliminación de todas las Formas de Discriminación contra la mujer"239.

En el año 2002, el Comité de Derechos Económicos, Sociales y Culturales de ECOSOC lo reconoció expresamente a través de la Observación $\mathrm{N}^{\mathrm{o}} 15$, el derecho al agua.

La Observación $\mathrm{N}^{\mathrm{o}} 15$ define el derecho al agua como "el derecho de todos a disponer de agua suficiente, salubre, aceptable, accesible y asequible para el uso personal y doméstico" $" 240$.

Àlex PEÑALVER CABRÉ observa que el derecho al agua tiene tres características principales: se trata de un derecho individual, una obligación de prestación del Estado, y un "requisito básico para la vida y la salud de las personas". En relación con lo primero, se trata de un derecho individual del que es titular cada persona, siendo así caracterizado por "el Informe del Relator Especial sobre el derecho al agua (2005) que lo califica como 'el derecho individual al agua y al saneamiento"”. La segunda característica enunciada por el autor es que el derecho al agua se traduce en una obligación de hacer/prestación que es parte del conjunto de funciones que el Estado debe realizar para que sea alcanzado el bien común y el bienestar de su población. La obligación de hacer consiste en "una prestación de los poderes públicos de suministrar agua potable y de sanear las aguas residuales". Esta función de los poderes públicos puede ser realizada de forma directa por el Estado o por terceros, que serían los concesionarios. La última de las características del derecho al agua es que se trata de "un requisito básico para la vida y la salud de las personas". El derecho al agua no ha sido reconocido expresamente hasta la Observación N 15 del año 2002, realizada por el Comité de Derechos Económicos, Sociales y Culturales del ECOSOC. Aunque hay otros derechos que dependen de la realización de aquel,

\footnotetext{
${ }^{239}$ CLARKE, Meghan Elisabeth. Climate Change and Human Rights: A Case Study of the Canadian Inuit and Global Warming in the Canadian Arctic. Tesis de Doctorado, Universidad de Toronto, Toronto, 2010, p. 62. Disponible en:

$<$ https://tspace.library.utoronto.ca/bitstream/1807/25457/1/Clarke_Meghan_E_201011_LLM_thesis.pdf $>$ acceso 10 de julio de 2014.

${ }^{240}$ NACIONES UNIDAS. Committee on Economic, Social, and Cultural Rights, General Comment $\mathbf{N}^{\mathbf{0}}$ 15, The Right to Water, U.N. Doc. E/C.12/2002/11, 26 de noviembre de 2002. Reprinted in Compilation of General Comments and General Recommendations Adopted by Human Rights Treaty Bodies, U.N. Doc. HRI/GEN/1/Rev.6 at 105, 2003, p. 2.
} 
tales como el derecho a los alimentos, al nivel de vida adecuado y el derecho a la salud. Estos últimos fueron reconocidos por la Declaración Universal de Derechos Humanos, por el Pacto Internacional de Derechos Civiles y Políticos y por el Pacto Internacional de los Derechos Económicos, Sociales y Culturales. Ninguno de esos derechos podría realizarse si no hubiese el goce del derecho al agua. La falta de agua puede provocar la muerte por deshidratación de la persona o traer enfermedades ${ }^{241}$.

La Observación $\mathrm{N}^{0} 15$ establece la relación entre el derecho al agua y los refugiados, desplazados internos y otras figuras afines, considerando que la necesidad de que este derecho sea accesible a todos, especialmente a tales grupos. En tal sentido, la Observación establece:

En particular, los Estados Partes deben adoptar medidas para velar para que [...] f) Los refugiados, los solicitantes de asilo, los desplazados internos y los repatriados tengan acceso al agua potable tanto si permanecen en campamentos o en las zonas urbanas y rurales. Es preciso otorgar a los refugiados y a los solicitantes de asilo el derecho al agua en las mismas condiciones que a los nacionales ${ }^{242}$.

Esto puede ser aplicado por analogía a los desplazados ambientales forzados.

La Observación $\mathrm{N}^{\mathrm{o}} 15$ considera la necesidad de efectividad del derecho al agua en las situaciones de emergencia y de desastres, afirmando:

22. El Comité observa que, durante los conflictos armados, las situaciones de emergencia y los desastres naturales, el derecho al agua abarca las obligaciones que impone a los Estados Partes el derecho internacional humanitario. Ello incluye la protección de objetos indispensables para la supervivencia de la población civil, incluidas las instalaciones y reservas de agua potable y las obras de regadío, así como la protección del medio natural contra daños generalizados, graves y a largo plazo y la garantía de que los civiles, los reclusos y los presos tengan acceso al agua potable ${ }^{243}$.

Así queda contemplado el derecho al agua de los desplazados ambientales forzados.

\section{III.8. Derecho a los alimentos}

Se puede verificar que el desastre arrasa con todo lo que encuentra en su camino, viviendas, infraestructura, medios de sobrevivencia. En Haití, las personas sufrieron la pérdida de los medios de vida y consecuentemente, el derecho a los alimentos. Esto se debió a la

\footnotetext{
${ }^{241}$ CABRÉ, Àlex Peñalver. Aproximación al marco jurídico del derecho humano al agua: una perspectiva desde el derecho interno, p. 89. Disponible en:

$<$ http://eva.universidad.edu.uy/pluginfile.php/212347/mod_resource/content/0/Unidad_3/Paginas_de_AguaPotab leySaneamiento.pdf $>$ acceso 20 de julio de 2014.

${ }^{242}$ NACIONES UNIDAS. Committee on Economic, Social, and Cultural Rights, General Comment $\mathbf{N}^{\mathbf{0}} \mathbf{1 5}$, Op.cit., parágrafo 16 .

${ }^{243}$ NACIONES UNIDAS. Committee on Economic, Social, and Cultural Rights. General Comment $\mathbf{N}^{\mathbf{0}} \mathbf{1 5}$, Op.cit., parágrafo 22 .
} 
repetición de los desastres. En Filipinas, las inundaciones de 2009 produjeron la pérdida de campos para la agricultura, dejando 500.000 trabajadores sin sus medios de vida ${ }^{244}$.

El derecho a los alimentos está reconocido en el derecho internacional, tanto en la Declaración Universal de Derechos Humanos como en el Pacto Internacional de los Derechos Económicos, Sociales y Culturales.

El artículo 25 de la Declaración Universal de los Derechos Humanos observa que "toda persona tiene derecho a un nivel de vida adecuado que le asegure, así como a su familia, la salud y el bienestar, y en especial la alimentación [...]".

El artículo 11 del Pacto Internacional de los Derechos Económicos, Sociales y Culturales establece: "Los Estados Partes en el presente Pacto reconocen el derecho de toda persona a un nivel de vida adecuado para sí y su familia, incluso la alimentación [...]”. Además, observa que los Estados- partes del Pacto deben instituir políticas y leyes que hagan posible la concretización de este derecho.

Oliver de SHUTER observa que los países tienen la obligación de establecer los mecanismos necesarios para que este derecho sea efectivo en su territorio. Este proceso de incorporación al derecho interno de los países deberá respetar los principios de los derechos humanos. El derecho a los alimentos ha sido reconocido por los Estados e incorporado en 24 Constituciones, de las cuales 15 son de los países de América Latina y el Caribe ${ }^{245}$.

El derecho a los alimentos de los desplazados ambientales forzados es afectado. Es muy común que en estas situaciones no haya ni siquiera disponibilidad de alimentos, consecuentemente las autoridades nacionales e internacionales precisan asegurar este derecho.

La Observación $\mathrm{N}^{\mathrm{o}} 12$ sobre el derecho a una alimentación adecuada establece:

Incluso en lugares donde el Estado enfrenta [...] condiciones climáticas u otros
factores, deben aplicarse medidas para garantizar que se cumpla el derecho a una
alimentación adecuada especialmente para grupos de población e individuos
vulnerables. $[\ldots]$
Millones de personas sufren hambrunas causadas por los desastres naturales.
[...] Será necesario prestar especial atención a la accesibilidad de los alimentos a las
personas que viven en zonas propensas a los desastres $[\ldots]$.

Es necesario observar que "el derecho a la alimentación adecuada se ejerce cuando todo hombre, mujer o niño, ya sea solo o en común con otros, tiene acceso físico y económico en

\footnotetext{
${ }^{244}$ ENTWISLE. Op.cit., p. 16, parágrafos 50-52.

${ }^{245}$ SCHUTER, Olivier de. Relator Especial sobre el Derecho a la Alimentación, por el Consejo de Derechos Humanos de Naciones Unidas. Nota Explicativa 6, del Relator Especial sobre el Derecho a la Alimentación: "Una revolución de derechos: La aplicación del Derecho a la Alimentación a nivel nacional en América Latina y el Caribe", 27 de setiembre de 2011, p. 3. Disponible en: $<$ http://www.srfood.org/es/notas-explicativas $>$ acceso 18 de julio de 2014.
} 
todo momento, a la alimentación adecuada o a los medios para obtenerla". De tal concepto pueden extraerse los siguientes aspectos: disponibilidad, adecuación y accesibilidad. La adecuación significa que los alimentos deben ser suficientes para satisfacer las necesidades especiales de cada persona, según su edad, su trabajo, su salud. Por otro lado, la adecuación implica considerar las condiciones particulares de los grupos sociales. Por ejemplo, la adecuación de los alimentos según los aspectos culturales implica considerar que hay grupos que por su religión no pueden consumir algunos alimentos. La disponibilidad de este derecho significa que no hay desabastecimiento de alimentos. La accesibilidad a los alimentos consiste en la posibilidad de poder adquirirlos o alcanzarlos a través de los medios necesarios. La accesibilidad puede ser económica y física, la primera implica que las personas tendrán los recursos financieros para adquirirlos o los medios para obtenerlos de la naturaleza. La accesibilidad física significa que las personas tengan los medios necesarios para alcanzar los alimentos, como por ejemplo, el acceso físico a los alimentos que están en la naturaleza significa que existen los instrumentos para extraerlos. La accesibilidad física debe ser asegurada especialmente en relación a los grupos más vulnerables como los ancianos, los niños, los enfermos y los discapacitados ${ }^{246}$.

Tiffany T.V. DUONG observa que "también existe un entrelazado de los derechos a la vida y la salud con el derecho a los alimentos y al agua" ${ }^{247}$.

En la isla de Tuvalu ya han surgido grandes dificultades causadas por los cambios climáticos, en relación con el cultivo de pulaka. Este alimento hace parte de la dieta tradicional de las personas que habitan la isla, y dadas las condiciones actuales deberá ser substituida por otro alimento ${ }^{248}$.

La Resolución 10/61 del Consejo de Derechos Humanos observa:

\begin{abstract}
Según una estimación, 600 millones de personas sufrirán malnutrición a causa del cambio climático, con un efecto especialmente negativo en el África subsahariana. Las personas pobres que viven en los países en desarrollo son particularmente vulnerables debido a su desproporcionada dependencia de los recursos sensibles al clima como medio de alimento y de subsistencia ${ }^{249}$.
\end{abstract}

\footnotetext{
${ }^{246}$ NACIONES UNIDAS. CONSEJO ECONÓMICO Y SOCIAL, COMITÉ DE DERECHOS ECONÓMICOS, SOCIALES Y CULTURALES. Observación $\mathbf{N}^{\circ}$ 12: El derecho a una alimentación adecuada (art. 11), 1999. ${ }^{247}$ DUONG, 2010, Op.cit., p. 1257 (2014).

${ }^{248}$ DUONG, 2010, Op.cit., p. 1258 (2014).

${ }^{249}$ NACIONES UNIDAS. A/HRC/10/61, parágrafo 26.
} 
El derecho a los alimentos de las comunidades tradicionales será especialmente afectado por los desastres y la degradación ambiental. Históricamente, estos grupos han sobrevivido buscando sus alimentos en la naturaleza, a través de la pesca, la caza o los cultivos.

Andrea CARMEN, Directora Ejecutiva del Consejo Internacional de Tratados Indios señala:

\begin{abstract}
El derecho a la alimentación es un ejemplo de un derecho humano que actualmente es amenazado por el cambio climático, es una amenaza crítica y creciente de los derechos humanos de todos los pueblos. [...] El derecho a la alimentación es un derecho colectivo y transversal para los pueblos indígenas, y abarca los derechos a tierras y territorios, la salud, la subsistencia, el desarrollo económico y los derechos culturales, entre otros". Hizo hincapié en que muchos de los derechos humanos relacionadas con el disfrute del derecho a la alimentación se afirman en la Declaración de la ONU sobre los Derechos de los Pueblos Indígenas $[\ldots]^{250}$.
\end{abstract}

La afirmación de que para los pueblos indígenas el derecho a los alimentos abarca el derecho a las tierras, la salud, la subsistencia y los derechos culturales, se debe a que la cosmovisión de estos pueblos es colectiva y no individualista.

Un ejemplo de la transversalidad e invisibilidad de los derechos humanos es el caso de la demanda de la Comunidad Maya del Distrito de Toledo contra el Estado de Belice presentado ante la Comisión Interamericana de Derechos Humanos. La Comunidad Maya reclamó la violación de sus derechos de propiedad sobre sus tierras. El gobierno de Belice dio concesiones para la explotación del petróleo en ese mismo territorio a favor de dos empresas. La realización de las actividades de explotación de petróleo en la región produjo la quiebra del equilibrio ecológico de esta región, llevándola a la degradación ambiental. La violación del derecho de propiedad derivó en las violaciones de otros derechos, como el derecho a obtener su sustento, el derecho a los alimentos, el derecho a la integridad cultural. Las conclusiones de la Comisión reconocieron la violación al derecho de propiedad de estas tierras ${ }^{251}$.

\title{
III.9. EI derecho a la salud de los desplazados ambientales forzados
}

La salud de los desplazados ambientales forzados puede ser muy afectada porque ellos viven en situaciones muy precarias, las cuales son propicias para el surgimiento y la transmisión

\footnotetext{
${ }^{250} \mathrm{OHCHR}$. Study on the relationship between climate change and human rights: Open-ended consultation meeting, Summary of Discussions, Palais des Nations, Ginebra, Room XII, 22 de octubre de 2008, parágrafo 18. Disponible en:

<http://www.ohchr.org/EN/Issues/HRAndClimateChange/Pages/Consultation.aspx> acceso 12 de julio 2014. 251 OEA. COMISIÓN INTERAMERICANA DE DERECHOS Humanos. Maya indigenous community of the Toledo District v. Belize, Case 12.053, Report No 40/04, Inter-Am. C.H.R., OEA/Ser.L/V/II.122 Doc. 5 rev. 1 at 727, 2004a.
} 
de enfermedades contagiosas. La falta de atención médica y de sanidad en general en tales lugares constituye otras de las variables que influyen en el surgimiento de estas enfermedades.

\title{
Hannah ENTWISLE observa:
}

\begin{abstract}
En las zonas inundadas en las Filipinas, Myanmar y Paquistán ${ }^{252}$, surgieron preocupaciones específicas acerca de los riesgos para la salud derivados de las aguas estancadas, el hacinamiento y la falta de instalaciones de saneamiento en las comunidades afectadas, algunas de los cuales permanecieron inundadas durante más de cinco meses. En casi todos los desastres, la asistencia humanitaria evitó una segunda oleada de muertes o enfermedades. Por desgracia, en Haití ${ }^{253}$, las instalaciones de agua y saneamiento inadecuados contribuyeron a un brote de cólera que comenzó en octubre de 2010 y mató a más de 5.000 haitianos ${ }^{254}$.
\end{abstract}

El derecho a la salud es un derecho humano reconocido por el derecho internacional.

El artículo 25 de la Declaración Universal de Derechos Humanos establece que "toda persona tiene derecho a un nivel de vida adecuado que le asegure, así como a su familia, la salud y el bienestar, y en especial la alimentación, el vestido, la vivienda, la asistencia médica y los servicios sociales necesarios".

Así, queda reconocido que el derecho a la salud es un derecho humano que hace parte de las condiciones mínimas de vida digna y deriva del derecho a la igualdad efectiva.

El artículo 12 del Pacto Internacional de los Derechos Económicos, Sociales y Culturales establece: "Los Estados Partes en el presente Pacto reconocen el derecho de toda persona al disfrute del más alto nivel posible de salud física y mental".

Es importante resaltar que la persona constituye una unidad física y psíquica, y que la protección del derecho a la salud comprende ambos aspectos de la persona.

El desastre afecta la salud mental de los damnificados produciendo traumas psicológicos, porque estos pierden todo, sus vidas, familias, viviendas, medios de sobrevivencia, documentos, alimentos, sus pueblos. Este trauma afecta la integridad psicológica de la persona. Por esto es necesario que en la recuperación sea dada asistencia psicológica a los desplazados. Esto se verificó en Pakistan, Myanmar y Filipinas ${ }^{255 y 256}$.

\footnotetext{
252 Ciclón Nargis en Myanmar (2008), inundaciones de Filipinas (2009), terremoto en Pakistan (2005) e inundaciones (2010) y terremoto en Haití (2010).

${ }^{253}$ Terremoto de Haití de 2010.

${ }^{254}$ ENTWISLE. Op.cit., p. 12.

255 Ciclón Nargis en Myanmar (2008), inundaciones de Filipinas (2009), terremoto de Pakistan (2005) e inundaciones (2010).

${ }^{256}$ ENTWISLE. Op.cit., p. 14, parágrafos 43-44.
} 
Tiffany DUONG observa que "el cambio climático también plantea serias consecuencias para la salud, 'tales como muerte prematura, enfermedad grave y la propagación de la enfermedad" ${ }^{\prime 257}$.

Este autor agrega en el caso del impacto sobre las islas:

Este derecho podría ser fundamental para el argumento de Tuvalu de que, incluso el cambio climático [...] destruirá todas las posibilidades de vida saludable que permanecerían: las islas serían inhabitables debido a la invasión de agua salada, el envenenamiento de los cultivos, inundaciones, tormentas y enfermedades ${ }^{258}$.

\title{
Meghan CLARKE considera:
}

\begin{abstract}
El Comité de Derechos Económicos, Sociales y Culturales establece que este derecho es indispensable para el disfrute de los otros derechos humanos.

Según la interpretación del Comité de $\operatorname{DESC}^{259}$ y otros organismos competentes o judiciales, el contenido esencial de este derecho incluye la atención de salud oportuna y apropiada, el acceso al agua limpia potable, saneamiento adecuado, un suministro adecuado de alimentos sanos, nutrición y vivienda, condiciones laborales y ambientales sanas, y acceso a la información y educación sobre la salud, educación e información. Además, el Comité continúa afirmando que las víctimas de violaciones del derecho a la salud deben tener acceso a los remedios, tanto a nivel nacional e internacional y debería tener derecho a reparación adecuada ${ }^{260}$.
\end{abstract}

La protección del derecho a la salud incluye que sean aseguradas las condiciones mínimas de vida digna, como el acceso a los alimentos, al agua potable y el saneamiento, porque estas aseguran el goce del derecho a la salud.

La Resolución 7/11 del Consejo de Derechos Humanos observa: “36. El derecho internacional de los derechos humanos señala el contenido y los contornos del derecho al más alto nivel posible de salud"261.

La Resolución 10/61 del Consejo de Derechos Humanos considera:

[...] 31. El derecho al disfrute del más alto nivel posible de salud física y mental (el derecho a la salud) está exhaustivamente consagrado en el artículo 12 del Pacto Internacional de Derechos Económicos, Sociales y Culturales y aparece mencionado en otros cinco tratados internacionales principales de derechos humanos. Ese derecho entraña el disfrute y el acceso en condiciones de igualdad a una atención médica adecuada y, más en general, a bienes, servicios y condiciones que permitan a la persona vivir una vida sana. Los factores determinantes básicos de la salud incluyen una alimentación y una nutrición adecuada, una vivienda apropiada, agua potable salubre y un saneamiento adecuado, y un medio ambiente sano.

32. Se prevé que el cambio climático afectará al estado de salud de millones de personas, en particular mediante un aumento de la malnutrición, las enfermedades y lesiones debidas a fenómenos meteorológicos extremos, y la carga de las

${ }^{257}$ DUONG, 2010. Op.cit., p. 1257 (2014).

${ }^{258}$ DUONG, 2010. Op.cit., p. 1239, 1247 (2014).

${ }^{259}$ Derechos Económicos, Sociales y Culturales.

${ }^{260}$ KOIVUROVA et al., Op.cit., p. 296.

${ }^{261} \mathrm{~A} / \mathrm{HRC} / 7 / 11$, parágrafo 36. 
enfermedades diarreicas, cardiorrespiratorias e infecciosas. El calentamiento del planeta podría afectar también a la propagación del paludismo y otras enfermedades transmitidas por vectores en algunas partes del mundo. En general, los efectos negativos para la salud se dejarán sentir desproporcionadamente en el África subsahariana, el Asia meridional y el Oriente Medio. La mala salud y la malnutrición aumentan la vulnerabilidad y reducen la capacidad de las personas y grupos para adaptarse al cambio climático ${ }^{262}$.

De tal modo, la protección de la salud no significa solamente brindar la atención médica, sino que requiere de la vigencia de los otros derechos mínimos que son los que aseguran una vida saludable.

La Corte Europea de Derechos Humanos, así como la Comisión Interamericana de Derechos Humanos y la Corte Interamericana de Derechos Humanos han venido reconociendo la violación de los derechos humanos por la degradación ambiental. Esto constituye un gran adelanto en la cuestión y una innovación tanto en la jurisprudencia como en el derecho, porque queda establecido el vínculo entre la violación de los derechos humanos por la degradación ambiental.

\section{III.10. Derecho a la vivienda digna de los desplazados ambientales forzados}

Una de primeras consecuencias del desastre o de degradación ambiental es la pérdida o destrucción de sus viviendas.

Tanto en el momento posterior a la evacuación como después del desastre, el Estado o la asistencia humanitaria precisa brindarles una vivienda digna, adecuada a las necesidades de la familia. Este último constituye un verdadero problema porque las personas han perdido sus tierras y sus hogares. Esto se repitió en Sri Lanka, Haití y Paquistán ${ }^{263}$. Específicamente, el gobierno paquistaní no conseguía encontrar solución porque se enfrentaban a los intereses de los terratenientes que no querían ceder sus tierras ${ }^{264}$.

La vivienda no significa solamente un lugar de albergue, sino que es el ámbito donde la persona puede desarrollar su intimidad, sus relaciones familiares y personales.

El derecho a la vivienda es un derecho humano reconocido por el artículo 25 de la Declaración Universal de los Derechos Humanos y por el artículo 11 del Pacto Internacional de los Derechos Económicos, Sociales y Culturales.

\footnotetext{
${ }^{262}$ NACIONES UNIDAS. A/HRC/10/61, parágrafos 31-32.

${ }^{263}$ Terremoto en Pakistan (2005) e inundaciones (2010) y terremoto de Haití (2010).

${ }^{264}$ ENTWISLE. Op.cit., parágrafos 43-44.
} 
En tal sentido, la Declaración Universal de los Derechos Humanos establece en su artículo 25 que "toda persona tiene derecho a un nivel de vida adecuado que le asegure, así como a su familia, la salud y el bienestar, y en especial la alimentación, el vestido, la vivienda, la asistencia médica y los servicios sociales necesarios".

El Pacto Internacional de los Derechos Económicos, Sociales y Culturales establece en su artículo 11 que "los Estados Partes en el presente Pacto reconocen el derecho de toda persona a un nivel de vida adecuado para sí y su familia, incluso alimentación, vestido y vivienda adecuados, y a una mejora continua de las condiciones de existencia".

En relación con el derecho a una vivienda, se observa:

\begin{abstract}
El acceso a una vivienda adecuada puede ser la condición previa para el disfrute de varios derechos humanos, en particular en la esfera del trabajo, la salud, la seguridad social, el voto, la privacidad y la educación. La posibilidad de ganarse el sustento puede verse gravemente menoscabada cuando, como consecuencia de un desalojo forzoso, una persona es reasentada en un lugar alejado de las oportunidades de empleo. Sin prueba de su residencia, las personas sin hogar no pueden ejercer su derecho al voto, disfrutar de los servicios sociales ni recibir atención sanitaria. Las escuelas pueden negarse a matricular a los niños de los tugurios porque sus asentamientos no tienen condición oficial. Una vivienda inadecuada puede tener repercusiones en el derecho a la salud; por ejemplo, si las viviendas o los asentamientos no cuentan con suficiente agua potable y saneamiento, sus residentes pueden enfermarse de gravedad ${ }^{265}$.
\end{abstract}

El Estado tiene una obligación en relación con la violación del derecho a la vivienda.

En los casos de procesos lentos de degradación existiría la posibilidad de un desplazamiento planificado, siendo probable la creación de viviendas en regiones fuera de los riesgos ambientales ${ }^{266}$.

Cuando interviene IASC, los desplazados ambientales forzados pueden ser llevados hacia lugares similares a los campos de refugiados. En otras situaciones, estas personas escapan hacia cualquier lugar. En ambas situaciones, han perdido su derecho a la vivienda digna.

La Oficina del Alto Comisionado para los Derechos Humanos observa:

Las personas itinerantes, ya sean refugiados, solicitantes de asilo, personas
internamente desplazadas (PID) o migrantes, son particularmente vulnerables a una
gama de violaciones de los derechos humanos, incluido el derecho a una vivienda
adecuada. Las personas desplazadas también son particularmente vulnerables a la
discriminación, el racismo y la xenofobia, lo cual puede aumentar sus dificultades
para lograr condiciones de vida adecuada y sostenible. Las personas que son objeto
de desplazamientos forzosos a menudo sufren trauma durante su huida y pierden las
estrategias de adaptación al entorno y los mecanismos de apoyo conocidos. Los
campamentos de refugiados y de PID en todo el mundo frecuentemente se encuentran

265 NACIONES UNDAS, COMITÉ DE DERECHOS ECONÓMICOS, SOCIALES Y CULTURALES. Observación General $\mathrm{N}^{\circ}$ 4, El derecho a una vivienda adecuada (párrafo 1 del artículo 11 del Pacto) E/1992/23, 13 de diciembre de 1991, № 21/Rev.1 p. 10.

${ }^{266} \mathrm{~A} / \mathrm{HRC} / 10 / 61$, parágrafos 37-38. 
en estado ruinoso y de hacinamiento y proporcionan vivienda y servicios inadecuados, particularmente cuando el desplazamiento es prolongado. A veces sus habitantes no disfrutan de ningún servicio básico ${ }^{267}$.

Los desplazados ambientales forzados pueden desarrollar sus vidas en los campos de refugiados, siendo que estos se caracterizan por la precariedad.

\section{III.11. Derecho a la libre circulación}

El artículo 12 del Pacto Internacional de los Derechos Civiles y Políticos considera:

1. Toda persona que se halle legalmente en el territorio de un Estado tendrá derecho a
circular libremente por él y a escoger libremente en él su residencia.
2. Toda persona tendrá derecho a salir libremente de cualquier país, incluso del propio.
3. Los derechos antes mencionados no podrán ser objeto de restricciones salvo cuando
estas se hallen previstas en la ley, sean necesarias para proteger la seguridad nacional,
el orden público, la salud o la moral públicas o los derechos y libertades de terceros,
y sean compatibles con los demás derechos reconocidos en el presente Pacto.
4. Nadie podrá ser arbitrariamente privado del derecho a entrar en su propio país.

Las restricciones a esta libertad son aquellas que están fundadas en la seguridad nacional, el orden público, la salud o moral pública y los derechos de terceros. Porque lo que se coloca en la balanza es el derecho a la libertad de las personas y el derecho colectivo de la seguridad nacional y del orden público de la sociedad, prevaleciendo este último.

Estos instrumentos internacionales de derechos humanos reconocen cuatro derechos a la libertad: la libertad de circular, la de elegir donde vivir, la libertad de salir de cualquier país y la libertad de salir de su propio país. Todos estos derechos corresponden a las personas que ingresaron regularmente al país.

El artículo 13 del Pacto de los Derechos Civiles y Políticos establece la situación específica del extranjero que ha ingresado legalmente al país, el cual "sólo podrá ser expulsado de él en cumplimiento de una decisión adoptada conforme a la ley" fundadas en la seguridad nacional.

Esas libertades solamente se extienden a aquellos que "han entrado al país de acuerdo con las leyes", siendo excluidos los trabajadores ilegales. La Convención Internacional sobre la Protección de los Derechos de los Trabajadores Inmigrantes de 1990, establecida por la Asamblea General de Naciones Unidas, en su artículo 39 considera lo mismo ${ }^{268}$.

\footnotetext{
${ }^{267}$ NACIONES UNDAS. Observación General No 4, El derecho a una vivienda adecuada. Op.cit, № 21/Rev.1, p. 27.

268 COMPARATO, Fabio Konder. Afirmação histórica dos Direitos Humanos. Sétima Edição. São Paulo: Editora Saraiva, 2011, p. 319.
} 
Esto es una restricción que alcanza a grandes grupos de personas que, encontrándose sin recursos y hasta en la miseria, son obligadas a salir de sus países en busca de una esperanza de trabajo y de mejorar sus vidas.

En el caso de las personas desplazadas por un desastre o una degradación que son obligadas a escapar para salvar sus vidas, así como en la situación de los refugiados, no podrían considerarse las restricciones del ingreso regular al país. Porque la situación de estas personas afectadas constituye una excepción a la normalidad, pues ellas escapan para sobrevivir. Entonces, es necesario colocar en la balanza: de un lado, el derecho a la vida de los desplazados ambientales forzados y, por el otro, el derecho del Estado al control del ingreso en su territorio, quedando evidente la prevalencia del derecho a la vida, que es el derecho supremo de los derechos humanos.

En ese sentido, el Estatuto de los Refugiados no sólo reconoce el derecho a la libertad de circulación por el país y el derecho a elegir el lugar de su residencia en el artículo 26, sino que además agrega que el Estado receptor deberá otorgar los documentos necesarios para transitar por el país (artículo 27 y 28).

En tal sentido, el artículo 26 del Estatuto observa:

\footnotetext{
Libertad de movimiento. Cada Estado Contratante dará a los refugiados que se encuentren en su territorio el derecho de en él elegir el lugar de su residencia y de circular, libremente, con las reservas instituidas por la reglamentación aplicable a los extranjeros en general en las mismas circunstancias.
}

Cuando el Estatuto de los refugiados establece la obligación del Estado receptor de brindar la documentación necesaria, está reconociendo la posibilidad de que el refugiado no haya ingresado legalmente al país. Las figuras del refugiado y de los desplazados ambientales forzados son muy similares (como ya fue establecido) debido a que ambos escapan para salvar sus vidas, y tienen sus derechos humanos violados. Por lo tanto, analógicamente, esa restricción de los países referente al ingreso a su país no podría aplicarse a los desplazados ambientales forzados, así como no es aplicada a los refugiados. Aunque en el caso de los desplazados ambientales forzados esto no está previsto en la ley.

La Guía de Directrices de IASC de 2011 establece el derecho a la libertad de circulación de las personas afectadas, y las restricciones que son enunciadas específicamente. El derecho a la libertad de circular está relacionado con el derecho a proteger sus vidas ante el desastre o degradación ambiental. En tal sentido, observa: 
decidir libremente si uno quiere quedarse o abandonar una zona en peligro. No estará sujeto a restricciones, salvo aquellas que: (i) estén estipuladas por ley, (ii) su único propósito es proteger la seguridad de las personas afectadas, y (iii) se utilizan solamente cuando no hay otras medidas menos intrusivas al alcance ${ }^{269}$.

De esta forma, IASC reconoce el derecho a la libre circulación y el derecho a elegir libremente el lugar de la residencia, quedándose en sus hogares o yéndose a otros. El límite a estos derechos es la obligación del Estado de proteger la vida y la seguridad de las personas. El Estado tiene la obligación de proteger la vida de sus habitantes. En el caso de que hubiese una zona de riesgo, la obligación del Estado es impedir que las personas permanezcan allí. La Corte Europea de Derechos Humanos, en el caso Öneryildiz versus Turquía, condenó a este país por las omisiones en relación con impedir la permanencia de las personas en esa zona de riesgo.

\section{III.12. Derecho de libremente escoger el lugar para residir}

Otro derecho derivado de la libertad es el de la libre elección del lugar para establecer su residencia. Esta libertad de la persona exige que el Estado no imponga restricciones a los desplazados ambientales forzados, absteniéndose de realizar actos que constituyan impedimentos al ejercicio de este derecho.

Por otro lado, el Estado receptor tiene que asegurar las condiciones mínimas y necesarias para hacer efectivo el derecho de residir en un lugar seguro y su libre elección.

En el caso de los desplazados ambientales forzados es necesario considerar los diferentes momentos por los que atraviesan: la situación del desastre, la evacuación y cuando ya ha pasado la emergencia. En todas estas etapas, es necesario que sea asegurado el derecho de residir. En el primer caso, es necesario aplicar la asistencia humanitaria, poniendo en primer lugar el derecho a la vida. En tanto que, en el segundo momento, es necesario que se realice el traslado hacia un lugar seguro. Esta ubicación es transitoria. Lo fundamental de este traslado es la preservación de la vida y que sean brindadas las condiciones mínimas de una vida digna. En el momento de la emergencia del desastre, muchas veces las personas son asentadas en lugares que no constituyen el destino final, lo cual trae graves problemas porque la persona acaba viviendo una situación de transitoriedad. Por esto, es necesario que estas situaciones sean evitadas o que tengan una duración breve. Existe el problema derivado de la repetición de los desastres ambientales en los mismos lugares. En estas situaciones, los desplazados ambientales forzados terminan viviendo en un estado provisorio, y de precariedad, agravado por la falta de

${ }^{269}$ IASC. Directrices operacionales del IASC... Op.cit., p. 50. 
asistencia humanitaria, pues en muchos casos tienen que valerse por sí mismos. Esta situación es una realidad que será analizada en el capítulo siguiente.

En relación con ello, la Guía establece:

D.2.2 Después de la fase de emergencia, los “desplazados internos" deberán recibir apoyo para encontrar una solución duradera a su desplazamiento. Se entenderá por solución duradera la integración sostenible de los desplazados internos:

- En el lugar de origen ("retorno");

- en las áreas donde se refugiaron ("integración local"); o

- en otra parte del país ("asentamiento en cualquier otro lugar del país") ${ }^{270}$.

IASC observa que es necesaria "la solución duradera", identificando a esta con la integración de esas personas a su lugar de origen, al lugar donde fueron trasladados o a la nueva sociedad, lo que implica que la persona y su familia puedan ejercer todos sus derechos fundamentales de forma efectiva.

Es muy importante considerar que IASC establece las Directrices Operacionales sobre la Protección de las Personas en situación de desastres naturales, aunque solamente se refiere a los desplazados internos, es decir, aquellos que no salen de su país. La situación vivida ante el desastre obliga a las personas a escapar hacia otros lugares, independientemente de las fronteras de los países. La diferencia de si la persona atraviesa la frontera o no, parece no ser relevante ante el desastre.

El IASC observa la necesidad de que los Estados tomen medidas para que sea alcanzada una vida digna. En tal sentido, observa: "D.2.3 Deberán establecerse medidas, a la mayor brevedad posible, para que los desplazados puedan regresar, integrarse localmente o asentarse en otra parte del país en condiciones sostenibles [...]”.

Además, observa que el Estado debe crear las medidas que hagan posible el ejercicio de esta libertad en condiciones dignas. Sobre estas últimas, la Guía observa:

Las condiciones se considerarán sostenibles cuando los desplazados internos:

(a) se sienten protegidos y seguros, libres de acoso e intimidación, así como de riesgos no mitigados de otros desastres naturales;

(b) han podido acceder a vivienda adecuada, incluyendo, en el caso de retorno, a volver a tomar posesión de sus hogares y estos han sido adecuadamente reconstruidos o rehabilitados; $\mathrm{y}$

(c) pueden retomar sus vidas con la mayor normalidad posible, sin discriminación alguna, con acceso a agua potable, servicios básicos, escuelas, sustentos, empleo, mercados, etcétera ${ }^{271}$.

\footnotetext{
${ }^{270}$ IASC. Directrices operacionales del IASC..., Op.cit., p. 49.

${ }^{271}$ IASC. Directrices operacionales del IASC..., Op.cit., p. 49.
} 
Todas estas medidas son necesarias porque hacen que la persona pueda ejercer el pleno derecho a la libertad ya que ellas no están coaccionadas, y sus decisiones se fundan en la voluntad autónoma de cada uno.

Las condiciones sostenibles enunciadas por IASC apuntan a que los Desplazados consigan retornar a sus vidas con dignidad. En el primer caso, IASC observa "libres de riesgos de otros desastres naturales". En relación con esto es preciso reconocer la relevancia de esta situación, porque si se analizan los desastres ambientales (lo cual será hecho en el próximo capítulo) se puede verificar:

- La repetición de los desastres en los mismos lugares, durante el mismo año.

- La repetición de los desastres en las mismas épocas y lugares.

- La inacción de los gobiernos de los países pobres o en vías de desarrollo, donde ocurren los desastres o la degradación ambiental.

Tanto el regreso a su lugar de origen o al nuevo lugar donde quieren reintegrarse podrá ser prohibido cuando estas situaciones impliquen situaciones de riesgo para sus vidas. Esto deberá constar en la ley y deberá ser informado en ley. En este caso, debe existir la posibilidad de que los desplazados puedan asentarse en otro lugar.

\section{III.13. Derecho a la libertad de expresión y de opinión}

El artículo 19 de la Declaración Universal de los Derechos Humanos establece:

\footnotetext{
Todo individuo tiene derecho a la libertad de opinión y de expresión; este derecho incluye el de no ser molestado a causa de sus opiniones, el de investigar y recibir informaciones y opiniones, y el de difundirlas, sin limitación de fronteras, por cualquier medio de expresión.
}

El derecho a la libertad no significa solamente que la persona esté físicamente libre de obstáculos materiales, sino que implica mucho más. En este sentido, la persona tiene derecho a tener sus propias ideas y a expresarlas, sin que por ello pueda ser afectado o perjudicado. Este derecho se ejerce a través de la exteriorización de las ideas de la persona y significa el reconocimiento a la pluralidad de ideas, que hace parte del fundamento del Estado de derecho y democracia.

El artículo 19 del Pacto Internacional de los Derechos Civiles y Políticos considera: 
informaciones e ideas de toda índole, sin consideración de fronteras, ya sea oralmente, por escrito o en forma impresa o artística o cualquier otro procedimiento de su elección.

El artículo 13 de la Convención Americana de Derechos Humanos de San José de Costa Rica de 1969 se refiere a la libertad de pensamiento y de expresión, prohibiendo los controles de los poderes públicos o privados de tales derechos.

De tal modo, es establecida una restricción al poder del Estado o de grupos particulares, cuando van contra el derecho a la libertad individual de la persona ${ }^{272}$.

El artículo 21 del Pacto Internacional de los Derechos Civiles y Políticos observa que "el derecho de reunión pacífica será reconocido" estando ese derecho sujeto a restricciones previstas en la ley y que sean necesarias en razón de la paz nacional, del orden público y de la seguridad nacional "o para proteger otros derechos y libertades de otras personas".

Ese dispositivo legal se refiere a "restricciones" y no dice "suspensión" de tal derecho, por lo tanto, es muy diferente hablar de limitaciones en vez de considerar cortes abruptos de tal derecho, lo cual sería una suspensión.

IASC considera la importancia de la protección de los derechos a la expresión de opinión, a realizar asambleas y reuniones y la posibilidad de asociarse. En tal sentido, IASC observa:

D.4.1 Las personas y comunidades afectadas podrán expresar su opinión y presentar quejas o reclamos sobre la respuesta de socorro y recuperación en casos de desastre. Deberán estar protegidas frente a reacciones desfavorables a la expresión de sus opiniones. Deberá brindarse a las personas afectadas la oportunidad de llevar a cabo asambleas pacíficas o formar asociaciones con este propósito ${ }^{273}$.

\section{III.14. Derecho a la vida privada, a su correspondencia, a su honra, de domicilio de los desplazados ambientales forzados}

El artículo 12 de la Declaración Universal de Derechos Humanos establece que es necesario que sea respetada la vida privada de la persona, su familia, su domicilio, su correspondencia, y su honra objetiva y subjetiva.

El artículo 17 del Pacto Internacional de los Derechos Civiles y Políticos establece:

1. Nadie será objeto de injerencias arbitrarias o ilegales en su vida privada, su familia, su domicilio o su correspondencia, ni de ataques ilegales a su honra y reputación.

2. Toda persona tiene derecho a la protección de la ley contra esas injerencias o esos ataques.

${ }^{272}$ COMPARATO. Op.cit., p. 329.

${ }^{273}$ IASC. Directrices operacionales del IASC... Op.cit., p. 55. 
Por lo tanto, ese artículo establece un límite a la actuación del Estado y de los particulares en la vida privada de la persona.

La privacidad de la vida de las personas es un derecho que tiene que con el ejercicio de la libertad en su ambiente privado. Esta protección implica una prohibición a la injerencia del Estado en la vida de las personas en una democracia.

Sin embargo, actualmente, ese ámbito de lo privado es más invadido porque las intervenciones pueden traspasar los límites de las fronteras de los países. Las innovaciones tecnológicas pueden ser utilizadas en el sentido de la invasión de la vida privada de las personas. Hoy, el Estado puede tener mayor control de la vida privada de las personas a través de los medios electrónicos, pues en la medida en que la vida actual se desarrolla utilizando innumerables formas en este sentido, sea a través de las compras por tarjetas de crédito, sea por el uso de Internet, sea con las cámaras para seguridad colocadas en las calles.

En la segunda parte de ese artículo protege la honra y la reputación de las personas, siendo que el bien protegido es el derecho personalísimo de la imagen de la persona.

\section{III.15. Derecho a la libertad de religión de los desplazados ambientales forzados}

El derecho a la libertad de religión está reconocido en los instrumentos de derecho internacional.

El artículo 18 del Pacto Internacional de los Derechos Civiles y Políticos observa lo siguiente:

1. Toda persona tiene derecho a la libertad de pensamiento, de conciencia y de religión; este derecho incluye la libertad de tener o de adoptar la religión o las creencias de su elección, así como la libertad de manifestar su religión o sus creencias, individual o colectivamente, tanto en público como en privado, mediante el culto, la celebración de los ritos, las prácticas y la enseñanza.

2. Nadie será objeto de medidas coercitivas que puedan menoscabar su libertad de tener o de adoptar la religión o las creencias de su elección.

3. La libertad de manifestar la propia religión o las propias creencias estará sujeta únicamente a las limitaciones prescritas por la ley que sean necesarias para proteger la seguridad, el orden, la salud o la moral públicos, o los derechos y libertades fundamentales de los demás.

4. Los Estados Partes en el presente Pacto se comprometen a respetar la libertad de los padres y, en su caso, de los tutores legales, para garantizar que los hijos reciban la educación religiosa y moral que esté de acuerdo con sus propias convicciones.

Marconi observa:

La religión es un aspecto universal de la cultura [...]. Todas las poblaciones estudiadas por los antropólogos demuestran poseer un conjunto de creencias en poderes sobrenaturales de alguna especie. Todas las sociedades, frecuentemente, desarrollan 
normas de comportamiento con la finalidad de preservarse contra lo inesperado, lo imprevisible, lo desconocido, y de establecer cierto control sobre las relaciones entre los hombres y el mundo que lo cerca. Las normas religiosas de comportamiento se basan en las incertezas de la vida [...], se tornan más evidentes en los momentos de crisis, o sea, nacimiento, adolescencia, casamiento, enfermedad, hambre, muerte, etcétera $^{274}$.

El derecho a la religión es un derecho fundamental del hombre que hace parte de su identidad cultural, y que no puede ser negado. La historia demuestra como las persecuciones religiosas han llevado a los peores momentos de la humanidad, tales como el holocausto.

Aunque, en la sociedad occidental del paradigma de la modernidad, la ciencia avanzó sobre la naturaleza tratando de dominarla, y tratando de hacer desaparecer las incertezas, los acasos, imprevistos, los riesgos. La racionalidad científica avanzó sobre el imprevisto, estableciendo medios de control sobre la naturaleza y las sociedades. Aunque han quedado demostrados los límites del dominio y de la previsibilidad de la ciencia ante las incertezas, los riesgos. ${ }^{275}$ Un ejemplo de esto son los desastres nucleares como el de Chernóbil y el de Japón en 2011. Actualmente, la crisis ambiental con los cambios climáticos que producen los desastres ambientales, así como sus consecuencias inesperadas demuestra la incerteza de la vida. Ante los imprevistos de la vida, el hombre busca en la Religión un apoyo y una seguridad.

De todos modos, el derecho a la libertad de religión es un derecho humano cuyo ejercicio hace a la realización de la dignidad humana.

El respeto al derecho a la religión de los refugiados también es reconocido en el Estatuto de los Refugiados:

\footnotetext{
Art. $4^{\circ}$ - Religión

Los Estados Contratantes proporcionarán a los refugiados en su territorio un tratamiento al menos tan favorable como el que es proporcionado a los nacionales en lo que concierne a la libertad de practicar su religión y en lo que concierne a la libertad de instrucción religiosa de sus hijos.
}

En relación con la libertad religiosa de los desplazados de los desastres, IASC considera lo siguiente:

D.4.2 Las creencias religiosas y tradiciones culturales deberán ser respetadas, en la mayor medida posible, cuando se planifique y ejecute la asistencia humanitaria, especialmente en el contexto de la despensa de alimentos, servicios de atención de la salud, arreglos de vivienda y saneamiento.

\footnotetext{
${ }^{274}$ MARCONI, Marina de Andrade. Antropologia: uma introdução. São Paulo: Atlas, 2011, p. 151.

${ }^{275}$ LEFF, Enrique. Saber Ambiental: sustentabilidade, racionalidade, complejidade, poder. Petrópolis, RJ: Vozes, 2001, p. 15.
} 
Por otro lado, sostiene que nadie podrá molestar o discriminar a otra persona en razón de su religión. Así observa:

D.4.3 Las personas afectadas tendrán la oportunidad de ejercer la fe religiosa y las tradiciones culturales, de manera que se respeten los derechos y creencias de los demás y no incite a la discriminación, hostilidad o violencia ${ }^{276}$.

El Estatuto de los Refugiados al igual que el artículo 18 del Pacto Internacional de Derechos Civiles y Políticos reconocen esos dos derechos: a la libertad religiosa y a la posibilidad de los padres de brindar una educación religiosa a sus hijos. Esta es una forma de mantener la cultura y las tradiciones familiares vivas.

\section{III.16. Derecho a la unidad familiar}

El derecho a que sea respetada la familia está enunciado en el artículo 12 de la Declaración Universal de Derechos Humanos, el cual establece: "Nadie será objeto de injerencias arbitrarias en su vida privada, su familia, su domicilio o su correspondencia, ni de ataques a su honra o a su reputación. Toda persona tiene derecho a la protección de la ley contra tales injerencias o ataques."

El artículo 17 de Pacto Internacional de los Derechos Civiles y Políticos observa sobre el derecho a la familia:

Artículo 17.

1. Nadie será objeto de injerencias arbitrarias o ilegales en su vida privada, su familia, su domicilio o su correspondencia, ni de ataques ilegales a su honra y reputación.

2. Toda persona tiene derecho a la protección de la ley contra esas injerencias o esos ataques.

El reconocimiento al derecho a la unidad familiar es muy importante, porque es el ámbito nuclear donde se desarrollan los primeros vínculos afectivos, y es donde existe una identidad entre sus miembros, permitiendo el desarrollo de una personalidad sana.

La familia es una institución que puede ser observada en todos los pueblos: "La familia, en general es considerada el fundamento universal de las sociedades pues se encuentra en todos los agrupamientos humanos, variando las estructuras y el funcionamiento"277.

\footnotetext{
${ }^{276}$ IASC. Directrices operacionales del IASC... Op.cit., p. 55.

${ }^{277}$ MARCONI. Op.cit., p. 92.
} 
Las funciones de la familia son la social, de reproducción, económica y educacional. Además, es necesario observar que tiene una función socializadora y social. "La función socializadora: en la medida en que trasmite la herencia cultural y social, durante los primeros años de vida: lenguaje, usos, costumbres, valores, creencias (proceso de endoculturización), preparando al niño para su ingreso en la sociedad"278.

Todas estas llevan a la preservación de la vida de la persona y de la sociedad.

IASC reconoce este derecho:

D.3.1 Las operaciones de socorro se diseñarán de manera que preserven la unidad familiar. Los miembros de las familias desplazadas que deseen permanecer juntos podrán hacerlo y recibir asistencia para ello, durante todas las etapas de la respuesta para casos de desastre, y deberá evitarse su separación.

La preservación de la unidad de la familia durante la vida del desplazado ambiental forzado hace que sea más fácil hacer frente a las dificultades específicas del desastre y la degradación ambiental.

IASC establece que es relevante que sea protegida la unidad de la familia de los desplazados en todos los momentos por los que atraviesa, especialmente en los casos de niños y de ancianos. En los casos de separación de las familias deben tomarse medidas para reunificarlas.

En ese sentido, IASC observa: "D.3.2. [...] Se facilitará la reunificación de las familias, si así estas desearlo, especialmente cuando se trate de niños o personas de la tercera edad".

IASC establece que, en la asistencia de alimentos, de medicamentos y de ropas debe considerar al núcleo familiar y no a los individuos. Porque si se realizasen entregas dispersas que no satisfagan al total de los miembros de la familia, se estaría incentivando la separación de la familia.

IASC observa específicamente:

D.3.2 Las personas afectadas deberán recibir asistencia para averiguar el destino y paradero de los familiares desaparecidos. Los parientes más próximos deberán ser informados sobre el progreso de la investigación y los resultados obtenidos a través del uso de servicios o mecanismos de búsqueda y rastreo ${ }^{279}$.

En medio del desastre ambiental, puede ocurrir que algún miembro de la familia desaparezca, esto causa un profundo dolor en el núcleo familiar. Por esto, IASC reconoce que

${ }^{278}$ MARCONI. Op.cit., p. 95.

${ }^{279}$ IASC. Directrices operacionales del IASC..., Op.Cit., p. 52. 
es necesario que se trate de mantener informada a la familia sobre los integrantes que se encuentren desaparecidos.

\section{III.17. Derecho a la documentación}

El desastre y la degradación ambiental pueden arrasar con todo lo que está en la casa de estas personas, incluso la documentación.

Cuando ocurre el desastre, las personas tratan de escapar para salvar sus vidas, y una de las consecuencias de la catástrofe ambiental es la pérdida de los documentos personales, de certificados de casamientos, de escrituras de propiedades. Además, se produce la destrucción de las instalaciones del gobierno donde se guarda la documentación, en muchos casos. De este modo, las personas quedan indocumentadas. Esto puede dificultar la recepción de ayuda de los gobiernos. Esto último fue lo que ocurrió en Myanmar y Pakistan ${ }^{280}$. En Haití, la situación de indocumentados era masiva ${ }^{281}$.

La pérdida de la documentación no sólo implica la falta de identificación y controles del Estado. La documentación puede ser referente a los aspectos personales, como cédula de identidad, pasaporte, aunque también puede referirse a los bienes de la persona. La documentación personal hace parte de la identidad de la persona. La importancia de estos documentos solamente es entendida cuando estos faltan, como es en el caso de los inmigrantes ilegales que son obligados a pasar por las peores situaciones de violación de los derechos humanos, llegando a ser obligados a trabajar en condiciones infrahumanas, y hasta de esclavitud, como es visto en diversos casos, debido a la falta de documentación.

El artículo 6 de la Declaración Universal de los Derechos Humanos establece: "Todo ser humano tiene derecho, en todas partes, al reconocimiento de su personalidad jurídica”.

El artículo 16 del Pacto Internacional de los Derechos Civiles y Políticos tiene el mismo contenido que el artículo anteriormente citado.

El desastre puede producir el extravío de los documentos de las personas, ya sean partidas de nacimiento, casamiento, defunción, pasaportes, cédulas de identidad, documentos de propiedad y tenencia, así como otros documentos personales. IASC observa que será facilitada la entrega la documentación personal ${ }^{282}$.

\footnotetext{
${ }^{280}$ Ciclón Nargis en Myanmar (2008), terremoto en Pakistan (2005) e inundaciones (2010) y terremoto en Haití (2010).

${ }^{281}$ ENTWISLE. Op.cit., p. 15, paragrafos 46-49.

${ }^{282}$ IASC. Directrices operacionales del IASC..., Op.cit., p. 47.
} 


\section{III.18. Derecho al medio ambiente sano}

Previamente, es necesario observar que ya no se puede considerar la separación dualista entre el medio ambiente y el hombre, sino que el hombre hace parte de ese medio ambiente. Esto se puede entender mejor si se considera la relación de las comunidades tradicionales con el medio ambiente, las cuales no consiguen vivir ni sobrevivir sin ese medio ambiente donde han desarrollado sus vidas, han construido su historia y su cultura. ¿Cómo podría considerarse el derecho a la sobrevivencia, a los alimentos, al agua, a la salud, a la cultura de estos pueblos fuera del medio ambiente?

Esa visión dualista corresponde al paradigma de la sociedad de la modernidad, donde la ciencia buscaba entender las problemáticas de la naturaleza para establecer el control sobre esta. Aunque los nuevos desafíos que actualmente se presentan demuestran los límites de esa ciencia, tales como los acasos, imprevistos, los riesgos. Uno de estos son los cambios climáticos, los cuales surgen produciendo consecuencias temibles para las comunidades afectadas, provocando los desplazamientos ambientales forzados.

Susana BORRAS PENTINAT sostiene que el derecho de las personas al medio ambiente sano ha sido reconocido en el principio I y en parágrafos 1 y 2 del preámbulo de la Declaración de Naciones Unidas sobre el Medio Humano de Estocolmo $1972^{283}$. El principio 1 establece:

\footnotetext{
El hombre tiene derecho fundamental a la libertad, la igualdad y el disfrute de condiciones de vida adecuadas en un medio de calidad tal que le permita llevar una vida digna y gozar de bienestar, y tiene la solemne obligación de proteger y mejorar el medio para las generaciones presentes y futuras.
}

De este modo, queda consagrado que las personas tienen derecho a vivir "en un medio de calidad tal que les permita una vida digna". Por otro lado, establece la obligación de proteger el medio ambiente para las generaciones presentes y futuras.

Además, la Declaración observa que "los dos aspectos del medio ambiente, natural y artificial, son esenciales para el bienestar del hombre y para que él goce de todos los derechos humanos fundamentales, incluso el derecho a la vida misma”.

283 BORRAS PENTINAT, Susana. Refugiados ambientales: el nuevo desafío del derecho internacional del medio ambiente. En Rev. derecho (Valdivia) [online]. 2006, Vol.19, N $\mathrm{N}^{\mathrm{O}}$ 2, p. 85-108. Disponible en: $<$ http://dx.doi.org/10.4067/S0718-09502006000200004> acceso 10 de junio de 2014. 
Gabriela CUADRADO QUESADA observa que "la protección ambiental puede ser considerada una precondición para la satisfacción de otros derechos humanos, como la vida, la salud y las condiciones favorables de trabajo" 284 .

La indivisibilidad de los derechos humanos se verifica del análisis del derecho al medio ambiente sano, pues sin este ninguno de los derechos anteriormente señalados tendría sentido.

Sobre los destinatarios de este derecho, esa autora observa una peculiaridad, la cual es que el titular de este derecho puede ser un grupo o una comunidad.

\begin{abstract}
Un sistema efectivo de protección ambiental puede ayudar a asegurar el bienestar de las futuras generaciones, así como la supervivencia de los grupos indígenas y los grupos de personas económicamente marginados, quienes dependen directamente de los recursos naturales para sobrevivir ${ }^{285}$.
\end{abstract}

Los impactos ambientales negativos son la contracara del derecho a un medio ambiente sano. En tal sentido, se observa:

\begin{abstract}
Estos problemas medioambientales mundiales tan importantes incluyen, por ejemplo, todo tipo de contaminación, el cambio climático, la reducción de la capa de ozono, el uso y administración de los océanos y los recursos de agua dulce, la deforestación excesiva, la desertificación y la degradación de la tierra, los vertidos peligrosos y la disminución de la diversidad biológica. [...]

También se reconoció [...] los problemas medioambientales regionales o locales, como la urbanización extensa, la deforestación, la desertificación, y la escasez general de recursos naturales $[\ldots]^{286}$.
\end{abstract}

Una de las características de los impactos ambientales negativos es la dificultad de establecer el ámbito donde se producen. En este sentido, se observa que tales se expanden, sin límites, y muchas veces no es posible establecer el origen donde se produjeron y resulta difícil determinar quién los produjo. Este último aspecto implica la dificultad de establecer la relación de causalidad y la responsabilidad de quién los produjo. Todo esto configura la problemática de los impactos ambientales.

BECK observa que esas características son las de los riesgos globales. ${ }^{287}$

\footnotetext{
${ }^{284}$ CUADRADO QUESADA, Gabriela. El reconocimiento del derecho a un medio ambiente sano en el derecho internacional y en Costa Rica. In Revista Cejil Debates sobre Derechos Humanos y el Sistema Interamericano, Año IV, No 5, diciembre, 2009, p. 104-113. Disponible en:

$<\mathrm{http}$ ://www.corteidh.or.cr/tablas/r24270.pdf $>$ acceso 6 de abril de 2016.

${ }^{285}$ CUADRADO QUESADA. Op.cit.

${ }^{286}$ CNUMAD, Conferencia de las Naciones Unidas sobre el Medio Ambiente y el Desarrollo. Disponible en: $<$ http://www.un.org/spanish/conferences/wssd/unced.html $>$ acceso 6 de abril de 2016.

${ }^{287}$ BECK, Ulrich. La sociedad del riesgo: hacia una nueva modernidad. Barcelona: Litografia Roses S/A, 2006.
} 
De tal modo, se observa que "la contaminación no reconoce los límites políticos o geográficos y afecta a los países, regiones y pueblos más allá de su punto de origen [...]”288.

\section{III.19. Derecho a la cultura}

Este derecho está reconocido en el Pacto Internacional de los Derechos Económicos, Sociales y Culturales, en el artículo 15, el cual establece: “1. Los Estados Partes en el presente Pacto reconocen el derecho de toda persona a: (a) Participar en la vida cultural [...]”.

Julia SANTILLI observa

No es posible comprender los bienes culturales sin considerar los valores en ellos investidos y lo que representan -su dimensión inmaterial- y, de la misma forma, no se puede entender la dinámica del patrimonio inmaterial sin el conocimiento de la cultura material que le da soporte. [...]

Los bienes inmateriales abarcan las más diferentes formas del saber, hacer y crear, como músicas, cuentos, leyendas, recetas culinarias, técnicas artesanales y de manejo ambiental. Incluyen aun los conocimientos, innovaciones y prácticas culturales de los pueblos indígenas, quilombolas y poblaciones tradicionales que van desde formas y técnicas de manejo recursos naturales, y hasta métodos de caza y pesca y conocimientos sobre sistemas ecológicos y especies con propiedades farmacéuticas, alimenticias y agrícolas, $[\ldots]$ como también sus costumbres, lenguas, creencias y tradiciones ${ }^{289}$.

Este es el sentido de la cultura que es considerado en este trabajo. Un concepto amplio, el cual abarca todo lo que el hombre y su pueblo producen.

\section{III.20. Los Derechos de Pueblos Indigenas y Tribales}

Los pueblos indígenas y tribales son uno de los grupos que más sufren con los desastres y degradación ambiental, pues han sido históricamente vulnerables.

Es necesario considerar esta problemática debido a que en gran parte de los países más propensos a los desastres y procesos de degradación ambiental viven estas comunidades, especialmente en los Pequeños Estados Insulares en Desarrollo.

Estos pueblos han vivido históricamente la violación de sus derechos humanos y hasta mucho de estos han llegado a ser extinguidos.

\footnotetext{
${ }^{288}$ CNUMAD. Op.cit.

${ }^{289}$ SANTILLI, Julia. Os "novos" direitos socioambientais. In FREITAS, Vladimir Passos de. (Coord.). Direito Ambiental em Evolução. Curitiba: Jurúa, 2007, p. 227.
} 
Por todo eso, es necesario que existan los mecanismos de protección a nivel internacional, además de los mecanismos nacionales para crear, implementar, y desarrollar políticas públicas que garanticen sus derechos. Aunque estas protecciones legales sean nacionales o internacionales precisan llevar en consideración la cosmovisión de estos pueblos, porque tales no pueden ser elaboradas desde el punto de vista de nuestra visión de occidente. La cosmovisión de estos pueblos es diametralmente opuesta a la anterior.

\section{III.20.1. La cosmovisión de la Sociedad de Occidente y la de estos pueblos}

Uno de los obstáculos al reconocimiento de esos derechos de estos pueblos, ha sido la falta de entendimiento de la cosmovisión de estos pueblos diferente a la imperante en occidente.

De este modo, LEFF observa que el paradigma de la modernidad de la sociedad occidental ha sido construido en el tiempo y en el espacio de los países desarrollados, sostenido a través de sus instituciones. Esa sociedad industrial fue guiada por la insaciable motivación de incrementar el crecimiento económico de los países desarrollados para aumentar el lucro.

LEFF observa que en ese sentido el aporte de la ciencia ha sido fundamental, pues el conocimiento ha sido movido por la búsqueda del entendimiento de los fenómenos de la naturaleza para poder dominarla, controlarla, evitando los riesgos y los acasos. En este sentido, ese paradigma ha permitido el desarrollo del paradigma de la sociedad occidental. En este escenario surge la crisis ambiental, demostrando los límites de la ciencia de la sociedad de la modernidad, siendo que algunos de estos son los impactos de los cambios climáticos, los desastres y la degradación ambiental. Otros fenómenos que causan conflicto son las luchas por mantener las culturas de los pueblos indígenas y comunidades tradiciones.

El desarrollo de la Sociedad de la Modernización de occidental, por medio del fenómeno de la globalización, trae consigo la homogeneización cultural a través de los medios de comunicación tales como la internet, la televisión, diarios y revistas. ${ }^{290}$

Aunque en este proceso que inicialmente aparentaba ser pacífico, comenzaron a surgir las contradicciones internas de las luchas por la vida y por la subsistencia de los grupos excluidos como los pueblos indígenas o comunidades tradicionales que tratan de mantener sus tradiciones, las cuales hacen al ser cultural de estos pueblos. Sin estas, se provocaría la extinción

\footnotetext{
${ }^{290}$ LEFF, Enrique. Saber Ambiental: sustentabilidade, racionalidade, complejidade, poder. Petrópolis, RJ: Vozes, 2001, p. 15.
} 
del ser colectivo de estos pueblos y, estas perdidas afectarían a la identidad individual y colectiva de las personas que integran estos grupos.

Por lo tanto, de un lado, sobreviene el proceso de homogeneidad cultural de la sociedad de occidente que se impone por el fenómeno de la globalización, propio del paradigma vigente. Por otro lado, surge el repudio a ese proceso de asimilación por parte de los pueblos indígenas y tradicionales. De este modo, como rechazo a ese proceso de homogeneidad cultural surgen los movimientos sociales que reivindican nuevos derechos tales como el derecho a la vida de los pueblos indígenas y tribales, de las comunidades tradicionales. ${ }^{291}$

Estos pueblos tradicionales luchan por el reconocimiento de su derecho a la subsistencia, sus derechos al hábitat, sus derechos a sus territorios, sus derechos a mantener su tipo de educación, sus tradiciones, sus derechos cultuales, idiomas, tradiciones, religión, historia ${ }^{292}$.

Porque estos pueblos parten de la idea de la unidad entre el hombre y el medio ambiente de sus hábitats. Esto se revela en la interrelación entre esos derechos, donde todos dependen del reconocimiento de la protección al medio ambiente. En la cosmovisión de estos pueblos no existe el lucro en la explotación del medio ambiente, sino su derecho a la subsistencia (se trata de economías de subsistencia) y la construcción de sus derechos.

\section{III.20.2. La protección en el Derecho Internacional}

A nivel internacional, la protección de los derechos de los pueblos indígenas fue establecida por la Convención 169 de la OIT, y posteriormente por la Declaración de los Derechos de los Pueblos Indígenas y Tribales de 2007.

El análisis del articulado de la Convención 169 de OIT y de la Declaración de ONU de derechos de los pueblos indígenas de 2007, permiten verificar un avance en el sentido de que, en vez de buscar asimilarles, se trate de reconocer la diversidad de sus culturas y el respeto a la existencia de estos pueblos. Aunque el segundo Instrumento es el que va más en ese sentido.

Todo el cuadro normativo precisa ser construido partiendo de la base de la no asimilación, y gira en torno de los siguientes aspectos:

1. Respeto a la diversidad cultural;

2. Conservación de las culturas;

\footnotetext{
${ }^{291}$ LEFF. Op. Cit., p. 346.

${ }^{292}$ LEFF. Op. Cit., p. 348.
} 


\section{Tierras;}

4. Trabajo;

5. Educación;

6. Autodeterminación;

La no asimilación constituye el eje fundamental de cualquier tratado, Declaración o Legislación que garanta la existencia de estos pueblos. Es preciso reconocer que existen dos fuerzas opuestas escondidas por tras de esta cuestión: la globalización y el reconocimiento y protección cultural de estos pueblos.

La Declaración de ONU de derechos de los pueblos indígenas de 2007 es la que avanza más en todos estos derechos, por esto será analizada a seguir.

\section{III.20.3. La Declaración de Naciones Unidas sobre los Derechos de los Pueblos Indígenas}

El análisis de la Declaración de Naciones Unidas sobre los derechos de los pueblos indígenas permite verificar que la re-afirmación del elenco de los derechos humanos reconocidos por los Instrumentos Internacionales Generales sobre derechos humanos, y además garantiza la protección de las necesidades particulares de estos pueblos, resaltando la protección a los derechos de estas comunidades que han sido violados históricamente, y fundamentalmente garantizando la protección de su diversidad cultural.

Esta Declaración reconoce, de un lado, los derechos humanos universales y, de otro, los derechos humanos específicos que protegen las necesidades particulares esenciales que caracterizan a estos pueblos. Esto implica el diálogo entre la universalidad y los relativismos vividos por cada pueblo, sin que un aspecto se imponga sobre el otro y coexistiendo equilibradamente ambas visiones.

Además, el estudio del articulado de esta Declaración permite verificar de un lado, el reconocimiento de cada uno de estos derechos y de otro, la obligación de los Estados de implementar las medidas para hacerlos efectivos.

La cuestión indígena trae consigo una serie de violaciones históricas sufridas por estos pueblos que han llegado al punto de hasta hacer desaparecer pueblos enteros provocado por los diversos genocidios reconocidos históricamente. 
Uno de los principales problemas ha sido la falta de respeto a los derechos ancestrales sobre sus tierras, recursos y medio ambiente.

Otro ha sido la creencia en la superioridad de la cultura occidental, lo que ha provocado en las peores situaciones la extinción de culturas de estos pueblos.

Esta Declaración apunta a reconocer y garantizar los derechos humanos de estos pueblos, esto significa la protección de su integridad física y psíquica.

Este reconocimiento no tendría ningún sentido si no se tratase de entender la visión colectiva propia de estas comunidades, la cual es diferente de la cosmovisión imperante en el mundo occidental.

Como ya fue observado anteriormente, esa visión de mundo de las comunidades tradicionales y pueblos indígenas nace de la relación entre el hombre y el medio ambiente, constituyendo esta una unidad indivisible.

Estos pueblos han resuelto sus problemas de adaptación al medio ambiente a través de ancestrales mecanismos propios y diferentes de los de la cultura de occidente. De modo que, la sobrevivencia de estos pueblos se ha producido en forma armónica con la naturaleza, entendiendo a esta no como un aspecto externo del hombre sino como parte de él, lo cual significa un equilibrio entre el hombre y el medio ambiente. Sus economías son de sobrevivencia. Este es un aspecto fundamental en el entendimiento de las dinámicas entre la relación del hombre y la naturaleza, pues la sobrevivencia de estos pueblos no implica la destrucción ambiental sino la conservación del medio ambiente.

La Declaración reconoce a estos pueblos todos los derechos humanos y libertades y, por otro lado, reconoce los derechos específicos de estos pueblos. Este último aspecto la Declaración se desarrolla sobre los ejes:

- la libre determinación de los pueblos;

- la prohibición de genocidio y discriminación;

- el derecho a sus tierras;

- el derecho a la protección del patrimonio cultural de estos pueblos. 
En el artículo 3 y 4, la Declaración reconoce el derecho a la libre determinación de los pueblos. En tal sentido, el artículo 3 observa que: "En virtud de ese derecho determinan libremente su condición política y persiguen libremente su desarrollo económico, social y cultural."

Es decir que se reconoce el derecho de los pueblos indígenas a elegir y decidir autónomamente los aspectos sociales, políticos, económicos y culturales de sus sociedades.

El derecho a la libre determinación de los pueblos implica la autonomía y el autogobierno. Es decir que se reconoce el derecho a un ordenamiento normativo propio y a las formas institucionales de ejecución de ese gobierno. La negación de estos aspectos implicaría la negación del ser colectivo de estos pueblos, afectando la integridad de estas personas.

En este sentido la primera parte del artículo 5 es explícito pues establece: "Los pueblos indígenas tienen derecho a conservar y reforzar sus propias instituciones políticas, jurídicas, económicas, sociales y culturales".

En la segunda parte de ese dispositivo reconoce la posibilidad estos pueblos de participar en la vida del Estado. Es decir que primero reconoce el derecho particular a mantener sus mecanismos sociales propios y en segundo lugar, les da la posibilidad participar en el país.

El reconocimiento de la "libre determinación de los pueblos" no es entendido como un derecho contrario a la soberanía del pueblo. Esto se constata a través de lo establecido en el artículo 46 de la Declaración, el cual establece:

\section{Nada de lo contenido en la presente Declaración se interpretará en el sentido de que confiere a un Estado, pueblo, grupo o persona [...] acción alguna encaminada a quebrantar o menoscabar, total o parcialmente, la integridad territorial o la unidad política de Estados soberanos e independientes.}

El artículo 7, en su primera parte reconoce a los pueblos indígenas los derechos humanos reconocidos a todos los seres humanos: "a la vida, la integridad física y mental, la libertad y la seguridad de la persona."

En su segunda parte, se refiere al derecho diferencial propio de estas comunidades, garantizando "el derecho colectivo a vivir en libertad, paz y seguridad como pueblos distintos".

Además, en la última parte del artículo 7 así como en el artículo 8 de la Declaración se protege a estos pueblos de las atrocidades vividas por estos pueblos como genocidio, traslado forzado, asimilación forzada, y destrucción de sus culturas. 
En tal sentido, los pueblos indígenas no podrán ser obligados a la asimilación forzada, ni destrucción de sus culturas (artículo 8).

La educación es el instrumento que sirve para que sea alcanzada la adaptación del individuo al medio, y posibilita la preservación de la identidad cultural de estos pueblos. Es fundamental porque permite la construcción de la identidad cultural de la persona, necesaria para la preservación de la integridad psíquica del individuo. Además, posibilita la garantía de la continuidad del ser cultural diverso de cada pueblo para las generaciones futuras.

En el artículo 14 de la Declaración reconoce el derecho de los pueblos indígenas a decidir los medios más apropiados para que sea impartida la educación preservando el idioma, las creencias, las tradiciones, la religión, y todas las formas culturales propias de estas comunidades. Por otro lado, asegura la posibilidad al acceso a la educación del país. De tal modo, se abre el diálogo entre la preservación a la diversidad cultural propia de estos pueblos y la cultura del país.

El artículo 17 de la Declaración garantiza los derechos laborales para estos pueblos, resaltando la prohibición de la explotación económica y de la discriminación en el trabajo, protegiendo especialmente a los niños.

El artículo 21 establece que los pueblos indígenas tendrán derecho a "la educación, el empleo, la capacitación y el readiestramiento profesionales, la vivienda, el saneamiento, la salud y la seguridad social."

En el artículo 22 se reconoce la especial protección a los grupos vulnerables formados por mujeres, niños y ancianos.

Tienen el derecho a sus formas medicinales para mantener la salud, así como a los servicios médicos del Estado (artículo 24).

Los conocimientos tradicionales de estos pueblos quedan garantizados en el artículo 24.1, pues este se refiere a la protección de plantas medicinales, animales y minerales.

En el artículo 24.2 establece que: "2. Las personas indígenas tienen igual derecho a disfrutar del nivel más alto posible de salud física y mental.”

Se reconoce el derecho de estos pueblos a sus tierras y recursos naturales (artículo 25). 
El artículo 31 se refiere a la preservación del patrimonio cultural de estos pueblos. Ese dispositivo establece:

1. Los pueblos indígenas tienen derecho a mantener, controlar, proteger y desarrollar su patrimonio cultural, sus conocimientos tradicionales, sus expresiones culturales tradicionales y las manifestaciones de sus ciencias, tecnologías y culturas, comprendidos los recursos humanos y genéticos, las semillas, las medicinas, el conocimiento de las propiedades de la fauna y la flora, las tradiciones orales, las literaturas, los diseños, los deportes y juegos tradicionales, y las artes visuales e interpretativas. También tienen derecho a mantener, controlar, proteger y desarrollar su propiedad intelectual de dicho patrimonio cultural, sus conocimientos tradicionales y sus expresiones culturales tradicionales.

2. Conjuntamente con los pueblos indígenas, los Estados adoptarán medidas eficaces para reconocer y proteger el ejercicio de estos derechos.

Muchas veces, las fronteras de los países han sido establecidas sin llevar en cuenta la formación de estos pueblos, por lo tanto, esta Declaración reconoce que estos pueblos puedan mantener relaciones fluidas con los integrantes de la misma comunidad que han quedado separados por las fronteras (artículo 36).

\section{III.21. Consideraciones finales}

La violación a los derechos humanos de los desplazados ambientales forzados ha sido reconocida por varias instancias de organismos internacionales como puede ser verificado a lo largo de este capítulo.

En primer lugar, es necesario observar que los desplazados ambientales forzados pueden haber sido afectados por el desastre ambiental o por la degradación ambiental, en ambos casos se produce la violación de los derechos humanos (la cual es una de las características de estas figuras).

En segundo lugar, es necesario constatar las diferentes instancias internacionales que reconocen estas violaciones.

En este sentido, tanto el Consejo de Derechos Humanos como el Alto Comisionado de Derechos Humanos de Naciones Unidas han reconocido que los impactos de los cambios climáticos sobre las poblaciones de desplazados producen la violación a los derechos humanos. Esta afirmación consta en las resoluciones emanadas de estos órganos de Naciones Unidas desde 2008, analizadas en este capítulo.

Aunque cabe observar que estos organismos solamente se refieren a los afectados de los cambios climáticos, dejando de lado a aquellos que sufren el desastre o la degradación 
ambiental proveniente de otras causas. La situación vivida por ambos grupos no tiene diferencias en cuanto a los sufrimientos que atraviesan, demostrando que las violaciones de los derechos humanos son las mismas.

En este último sentido, los diversos casos de la jurisprudencia internacional citados a lo largo del capítulo reconocen la violación a los derechos humanos de desplazados ambientales forzados de situaciones de degradación ambiental.

La Corte Europea de Derechos Humanos ha reconocido las violaciones a los derechos humanos de las personas que sufren la degradación, siendo que esto los obliga a desplazarse.

La Comisión Interamericana de Derechos Humanos ha reconocido las violaciones a los derechos humanos producidas por la degradación, obligando a las comunidades a desplazarse, como es el caso emblemático del pueblo Yanomami.

La Corte Interamericana de Derechos Humanos también se ha pronunciado en ese sentido, a través de diversas sentencias.

Existen algunas particularidades en las decisiones de estos dos últimos organismos, una es que principalmente reconocen las violaciones de los derechos humanos de las comunidades indígenas. Por otro lado, el análisis de tales manifestaciones permite verificar la indivisibilidad de la violación de un derecho humano, lo cual lleva a la violación de los otros.

Se puede verificar esa indivisibilidad de los derechos humanos, pues cuando un desplazado ambiental forzado sufre la falta de alimentos, esto afecta a su derecho a la salud, así como cuando no tiene derecho a servicios básicos de sanidad o de agua potable, esto afecta el derecho a una vida digna y a la salud. Asimismo, la pérdida de la vivienda por un caso de degradación (como fue considerado anteriormente) produce también la pérdida de todos los derechos a las necesidades básicas, así como de los medios de sustento y de sobrevivencia. Estas personas afectadas tanto por los desastres como por la degradación ambiental son forzadas no solamente porque pierden la libertad de elegir donde vivir, sino porque sufren la violación de sus derechos humanos, siendo obligadas a escapar para salvar sus vidas.

Por otro lado, IASC ha reconocido la violación de los derechos humanos de los desplazados de los desastres, estableciendo las Directrices Operacionales del IASC sobre la protección de las personas en situaciones de "desastres naturales", aunque se refiere solamente a los desplazados internos.

Además, es necesario afirmar que los Principios Rectores de los Desplazados "Internos" reconocen los derechos humanos de estas personas, garantizándolos a lo largo de su texto. Este 
conjunto de principios está dirigidos a los desplazados internos, incluyendo los que sufren los desastres.

En tercer lugar, en relación con el reconocimiento de la violación de los derechos humanos de los desplazados ambientales forzados ha quedado en evidencia (como ya fue observado) un problema, el cual consiste en que los organismos internacionales, si bien reconocen esas violaciones, lo hacen de forma parcial. Porque cada una de esas instancias internacionales considera un tipo de desplazados ambientales forzados. En este sentido, la Comisión de Derechos Humanos de Naciones Unidas y el Alto Comisionado de los Derechos Humanos de Naciones Unidas solamente se refieren a la violación de los derechos humanos de los afectados por los impactos ambientales negativos de los cambios climáticos. IASC únicamente reconoce los casos de los afectados "internos" por los desastres naturales. La Corte Europea de Derechos Humanos reconoce a los que afectados por degradación. La Comisión Interamericana de Derechos Humanos y la Corte Interamericana de Derechos Humanos solamente consideran a las "comunidades indígenas" afectadas.

Todo esto lleva a la división en categorías de una única figura que es la de los desplazados ambientales forzados, cuya unidad conceptual ha sido demostrada en el capítulo anterior.

Tales reconocimientos de las violaciones a los derechos humanos de estas personas afectadas por parte de todas estas instancias son bienvenidos, aunque es preciso que ese reconocimiento se extienda a todos los desplazados ambientales forzados. De esto, emerge la necesidad de una regulación internacional y de un organismo específico que proteja a estas personas.

Esas divisiones reconocidas por los organismos no tienen relación con la única figura de los desplazados ambientales forzados. Porque estos pueden surgir en diferentes escenarios, pero existe una unidad conceptual.

El análisis de las necesidades sufridas y de las violaciones a los derechos humanos de los desplazados de los desastres ambientales, de los desplazados de la degradación ambiental, de los desplazados internos de los desastres naturales, así como de los desplazados ambientales transfronterizos permite verificar que existe una única figura, la cual es la de los desplazados ambientales forzados. Esto debe ser considerado en el momento de la creación de un sistema jurídico internacional de protección, así como en la institución de un organismo internacional especializado. 
En cuarto lugar, la necesidad de una regulación internacional que proteja los derechos humanos de los desplazados ambientales forzados precisa ser específica, dado que estas personas pasan por situaciones especiales que hacen que sea necesario considerar esas particularidades.

Por un lado, es necesario observar que los Principios Rectores de los Desplazados Internos consideran cada uno de los momentos que son vividos en el desplazamiento forzado, pero no especifican los problemas de aquellas personas que son obligadas a atravesar las fronteras de los países.

Todos, desplazados ambientales forzados "internos" y "transfronterizos", los que han sufrido los impactos de los “desastres" y de la "degradación”, los afectados por catástrofes ambientales "repentinas" o resultado de "procesos lentos", así como los que vieron partes de sus islas sumergirse como los que sufren la pérdida total de sus territorios (islas) pasan por la violación de sus derechos humanos.

En el caso de los transfronterizos (incluyendo los que escapan de las islas sumergidas), la situación vivida por estos afectados es la peor a la que puede ser sometida una persona porque no tienen la protección de ningún Estado, quedan abandonados a su propia suerte. Los derechos humanos de estas personas tienen que ver con la necesidad de:

- que exista un Estado receptor;

- que ese Estado aplique el Principio de No Devolución;

- que la persona sea tratada en la misma categoría que los nacionales.

Así, queda en evidencia la necesidad de la existencia de un organismo internacional especializado que se encargue de la asistencia material de estas personas, así como de su protección, incluyendo en esta la tramitación de la recepción ante terceros Estados.

Específicamente, en el caso de los desplazados forzados de los Pequeños Estados Insulares en Desarrollo que están sufriendo los impactos del aumento del nivel del mar, es necesario que sea asegurado a estas personas el derecho a un territorio propio, los derechos a la identidad cultural, al traslado del pueblo entero, las cuestiones derivadas de la soberanía.

De tal modo que, si estas personas pierden el territorio del país, derivan de una serie de cuestiones muy graves que están relacionadas con los derechos humanos, como:

- ¿quién podrá asegurarles un nuevo territorio?;

- ¿cuáles serán las formas de adquirir ese nuevo territorio?; 
- ¿qué ocurrirá con la soberanía de ese Estado?

Por lo tanto, es evidente la necesidad de que exista un organismo internacional que se haga cargo de dar respuesta, protección y asistencia a estos pueblos.

Finalmente, se puede concluir que la hipótesis presentada en la introducción de este capítulo, que sostiene que existe la violación de los derechos humanos de los desplazados ambientales forzados, ha sido verificada y reconocida por los organismos internacionales citados. Consecuentemente, el reconocimiento de las violaciones a los derechos humanos de los desplazados ambientales forzados permite justificar la necesidad de la creación de una regulación internacional específica, así como la constitución de un organismo internacional que se asuma la responsabilidad de hacerse cargo, dadas las particularidades de estos pueblos o personas.

Además, esta regulación específica internacional debe contener todos los derechos humanos considerados en este capítulo. 


\section{CAPÍTULO IV}

\section{DESPLAZADOS AMBIENTALES FORZADOS \\ Y LOS PAÍSES EN DESARROLLO EN EL PERIODO DE 2010 A 2012}

\section{IV.1. Introducción}

Los países del "mundo no desarrollado" 293 sufren más gravemente el problema de los desplazados ambientales forzados, porque estos Estados no tienen ni medios económicos, ni estructuras institucionales fuertes para hacer frente al desastre y a la degradación ambiental. Por ello, precisan de la ayuda internacional para hacerle frente a esta situación. Mientras que los países desarrollados pueden enfrentar la cuestión a través de sus propios medios.

La argumentación dominante entre los organismos internacionales y los países desarrollados demuestra una falta de compromiso con la temática de los desplazados ambientales forzados.

A pesar de que el discurso de ACNUR evidencia interés por abordar la solución a esta problemática, este organismo no ha obtenido una respuesta favorable por parte de Naciones Unidas.

En este trabajo se sostiene que la causa por la que no se les da solución a los desplazados ambientales forzados en el derecho internacional reside en que los países más afectados por este problema son los del "mundo no desarrollado"294, y específicamente con grandes poblaciones sumergidas en la pobreza. La ausencia de respuesta al problema reside en la falta de un marco jurídico internacional que proteja a los desplazados ambientales forzados, quienes viven mayoritariamente en los países con grandes poblaciones pobres.

El objetivo de este capítulo es analizar la relación entre la localización de los desplazados ambientales forzados y los países con grandes poblaciones pobres afectadas por este problema (en el período 2010-2012), a la luz de la construcción teórica de la Justicia Ambiental o del Ecologismo de los Pobres. Esto permitirá concluir que la causa de la falta de

\footnotetext{
${ }^{293}$ Esta expresión es utilizada por Martínez Allier para referirse a los países que no hacen parte del concepto de los "países desarrollados". Este autor también los denomina "países del Tercer Mundo".

${ }^{294}$ Esta expresión de Martínez Allier.
} 
respuesta a este problema es porque los que sufren son los países en desarrollo o los que tienen problemas de alta vulnerabilidad, menos adelantados o con bajo desarrollo y con grandes porciones de sus poblaciones pobres.

Uno de los mayores desafíos de este trabajo ha sido encontrar un criterio que permita calificar a un país con la mayoría de su población pobre.

Por esto, el aporte de la teoría de la Justicia Ambiental o el Ecologismo de los Pobres ha contribuido a esa sustentación. Ya que, en los orígenes de esta teoría, se consiguió establecer la relación directa que existe entre los impactos ambientales negativos y la exclusión racial o la pobreza en los Estados Unidos en el estudio de 1987, denominado Toxic Wastes and Race in the United States ${ }^{295}$. Este estudio ha servido para poder concebir la idea de cómo establecer si un país tiene la mayoría de su población inmersa en la pobreza. Porque por la analogía se consiguió establecer teóricamente un paralelismo con nuestra cuestión de estudio. Además, esta teoría hace un gran aporte conceptual introduciendo conceptos como externalidades de la economía ${ }^{296}$.

En segundo lugar, es preciso observar que en este trabajo son analizados los dos tipos de catástrofes ambientales que producen los desplazamientos forzados ambientales:

- Las que constituyen procesos lentos de degradación ambiental, tales como las derivadas del aumento del nivel del mar, específicamente las que afectan a los Pequeños Estados Insulares en Desarrollo.

- Los desastres ambientales repentinos, como tsunamis, huracanes, tifones, ciclones, terremotos e inundaciones.

En tercer lugar, es necesario verificar el lugar donde se han producido los desastres ambientales o los procesos de degradación entre los años 2010 y 2012. De tal modo, esto llevará a determinar cuáles han sido los países afectados por los desastres ambientales o por los procesos de degradación lentos. A los fines de este análisis, en relación con los desplazamientos forzados ambientales serán utilizados los datos que resultan de los estudios de IDMC.

Finalmente, se desprende la necesidad de analizar si los países afectados tienen gran parte de sus poblaciones en la pobreza. La demostración de este argumento es uno de los grandes desafíos de esta tesis. Esta tarea es muy difícil, porque, por un lado, se puede verificar

\footnotetext{
${ }^{295}$ Ese título en español se traduce como: "Desechos tóxicos y raza en los Estados Unidos".

${ }^{296}$ Estos conceptos serán abordados en el apartado siguiente.
} 
que existen criterios que llevan a considerar países con grandes economías, aunque, por el otro, esos mismos Estados tienen grandísimos contingentes de sus poblaciones sumergidos en la pobreza.

La causa de la necesidad de determinar el nivel de la pobreza de los países afectados se debe a que los desastres ambientales y la degradación ocurren en cualquier país, pero la diferencia está en la respuesta de los gobiernos nacionales, ya que los países ricos consiguen por sí mismos hacer frente a los desastres ambientales, mientras que los otros, países en desarrollo, o menos adelantados o con menor desarrollo y con alto nivel de poblaciones pobres, son incapaces de brindar una protección a las poblaciones afectadas, precisando de la ayuda internacional.

En la primera sección de este capítulo, serán hechas algunas consideraciones sobre la teoría de la Justicia Ambiental o Ecologismo de los Pobres.

En segundo lugar, serán considerados los Pequeños Estados Insulares en Desarrollo que sufren el problema de los desplazados ambientales forzados resultantes de degradación ambiental de procesos de lenta evolución.

En tercer lugar, será abordada la relación de los países que sufren los desastres repentinos, afectados por los desplazados ambientales forzados, considerando el período de tiempo de los años 2010, 2011 y 2012.

En cuarto lugar, se establece la relación entre los países donde se han producidos los desplazamientos ambientales forzados y la pobreza.

Por último, serán plasmadas algunas observaciones finales.

\section{IV.2. La Justicia Ambiental y el Ecologismo de los Pobres o Ecologismo Popular}

Hay una posición ambientalista conocida como Ecologismo de los Pobres o Ecologismo Popular o Justicia Ambiental.

Inicialmente, el Ecologismo de los Pobres y la Justicia Ambiental fueron corrientes que surgieron separadamente, y en diferentes lugares. Ambas se fundieron en una única, pues tienen la misma preocupación y sustentación teórica.

Su principal preocupación es que el crecimiento económico de los países desarrollados produce impactos ambientales negativos, los cuales son sufridos por las comunidades más desfavorecidas, y a nivel global por los países más pobres. Esas poblaciones son aquellas formadas por personas de étnicas minoritarias y/o de bajos ingresos. 
La teoría de la Justicia Ambiental surgió en los Estados Unidos, y emerge como una respuesta al racismo ambiental, pues los depósitos de residuos tóxicos fueron localizados donde vivían las comunidades de minorías étnicas o/y con menores ingresos económicos. Esta situación de injusticia ambiental produjo una reacción social de protesta y rechazo por parte de estos grupos afectados. De modo que, la Justicia Ambiental surgió primero como un movimiento social de rechazo a esta situación de injusticia $\mathrm{y}$, posteriormente, se produjo su desarrollo teórico.

Por otro lado, en "el mundo de los países no desarrollados", surge el Ecologismo de los Pobres, que se preocupa por los impactos ambientales negativos sufridos por los países más pobres, y que son producidos por el capitalismo salvaje en la búsqueda de un aumento incesante y continuo del crecimiento económico de los países desarrollados.

En referencia a ello, MARTÍNEZ ALLIER observa:

La Justicia Ambiental como movimiento organizado permaneció limitado a su país de origen, aunque el Ecologismo Popular o Ecologismo de los Pobres constituyen denominaciones aplicadas a movimientos del Tercer Mundo que luchan contra los impactos ambientales que amenazan a los pobres que constituyen la amplia mayoría de la población en muchos países ${ }^{297}$.

Se puede observar que ambas teorías convergen en la denuncia de la misma situación de injusticia ambiental, donde quienes sufren los perjuicios ambientales son los pobres, demostrando una estrecha relación entre la pobreza y los daños ambientales.

Consecuentemente, es posible señalar que el Ecologismo de los Pobres hace parte de la teoría de la Justicia Ambiental.

Además, el Ecologismo de los Pobres incorpora la dimensión global de los países pobres (del mundo "no desarrollado" o países del Tercer Mundo) que sufren los impactos negativos del medio ambiente producidos por el crecimiento económico de los países desarrollados.

En tal sentido, Anthony Goebel MC DERMOTT observa:

El crecimiento económico crea impactos ambientales no resueltos por las políticas económicas $\mathrm{y} / \mathrm{o}$ los cambios tecnológicos, los cuales al caer de manera desproporcionada sobre algunos grupos sociales generan movimientos de protesta y resistencia $[\ldots]^{298}$.

\footnotetext{
${ }^{297}$ MARTÍNEZ ALLIER, Joan. O Ecologismo dos pobres: conflitos ambientais e linguagens de valoração. São Paulo: Contexto, 2007, p. 35.

298 MC DERMOTT, Anthony Goebel. Ecologismo de los pobres y marginalidad social: vehículos de complementariedad y puentes dialógicos. En Reflexiones, Vol. 89, № 1, 2010, p. 128.
} 
Muchos pensaban que la innovación tecnológica de la mano del crecimiento económico podría traer soluciones que harían desaparecer el problema de los impactos ambientales negativos, aunque esto no ha ocurrido.

En tal sentido, Henri ACSELRAD observa que la modernización ecológica sostiene la posibilidad de que las soluciones a los problemas ambientales puedan venir de la economía de mercado, a través de la innovación tecnológica y de otros mecanismos como la creación de consensos. La modernización ecológica "propone conciliar el crecimiento económico con la resolución de los problemas ambientales"299.

La innovación tecnológica es una condicionante de la economía del mercado, que es aplicada por los países para aumentar el nivel de competitividad internacional. El orden internacional global imperante, que busca el establecimiento de un mercado libre mundial sin barreras arancelarias y no arancelarias entre los países, exige que, si estos pretenden aumentar su crecimiento económico, incorporen la innovación tecnológica para disminuir los costos de las mercaderías y servicios. Aunque la innovación tecnológica exige que los países realicen inversiones financieras, generando la exclusión de los países más pobres. La innovación tecnológica es aplicada por los países desarrollados para generar más lucros, y no ha sido usada de manera sostenible para aliviar los impactos ambientales sufridos por los países más pobres.

Anthony Goebel MC DERMOTT considera:

El Ecologismo de los Pobres, según lo señala Martínez Allier, da cuenta de cómo el
crecimiento económico está acompañado de mayores impactos en el medio ambiente,
llamando la atención sobre el desplazamiento geográfico de fuentes de recursos y
sumideros de residuos; es decir, la expansión de la huella ecológica de los países ricos
a expensas de los ecoespacios de los países pobres. [...]
Así la expropiación del ambiente de los países pobres por parte de los países ricos da
lugar a una deuda ecológica, derivada de la construcción de un intercambio
ecológicamente desigual, creciente en la evolución del capitalismo, e inherente a la
propia dinámica de este. [...]
Por lo tanto, los deudores económicos del sur son los acreedores ecológicos del Norte.
[...]
En suma, el concepto del Ecologismo Popular o Ecologismo de los Pobres nos remite
a los movimientos de protesta y resistencia generados por aquellos grupos
marginalizados, desplazados o excluidos de la distribución de los recursos básicos
para su subsistencia. La acción de ecologismo popular se desarrolla, entonces, en el
marco de lo que se ha dado en llamar conflictos ecológicos distributivos ${ }^{300}$.

El crecimiento económico trae ganancias económicas para los países ricos y produce impactos ambientales negativos para los países pobres, surgiendo una relación de desigualdad

${ }^{299}$ ACSELRAD, Henri. Justiça ambiental e construção social do risco. Trabajo presentado en el XIII Encontro da Associação Brasileira de Estudos Populares, Ouro Preto, noviembre, 2002, p. 1.

${ }^{300}$ MC DERMOTT. Op.cit., p. 129-130. 
ambiental que no es más que la injusticia ambiental. De esta deriva el conflicto socio-ambiental o conflicto ecológico distributivo, y surge de la deuda ecológica.

Anthony Goebel MC DERMOTT señala:

\begin{abstract}
En la misma línea de análisis, José María BORRERO distingue, en el proceso de la generación de la deuda ecológica, actores y agentes dramáticos, donde los primeros son y han sido las islas de privilegio, es decir, aquellos que unilateral y casi exclusivamente, han recibido los mayores beneficios del capital ambiental del planeta (las corporaciones, la banca internacional, los burócratas del Norte y del Sur), mientras los segundos están constituidos por un grupo amplio y sectores sociales entre los que se puede mencionar campesinos sin tierra, pescadores pobres y otros marginados de los beneficios planetarios ${ }^{301}$.
\end{abstract}

Así surgen dos tipos de actores en esta relación de desigualdad ambiental: los beneficiados del crecimiento económico que producen los impactos negativos; y los que sufren los impactos ambientales negativos.

Las poblaciones afectadas de los países pobres resisten a esta situación creada a través de protestas, manifestando su contrariedad por medio de una resistencia organizada.

Ese proceso del crecimiento económico de los países más ricos avanza cada vez más, y demanda más recursos naturales, produciendo más impactos negativos ambientales, como los residuos tóxicos. Entre los impactos ambientales negativos, puede observarse el calentamiento de la atmósfera, cuyas consecuencias son principalmente sufridas por los países más pobres. El crecimiento económico de los países desarrollados resulta en aumento del calentamiento de la atmosfera, por la emisión de gas del efecto invernadero de los países desarrollados a expensas de los países pobres que no han realizado acciones para contribuir al cambio climático, aunque sufren más gravemente los impactos de los cambios climáticos.

Por otro lado, introduce los conceptos de expropiación del eco-espacio de los países pobres, deuda ecológica, conflicto ambiental y Justicia Ambiental como objetivo buscado por esta teoría.

\title{
IV.2.1. El origen de la Justicia Ambiental
}

La Justicia Ambiental constituye un movimiento social de las minorías étnicas, de las clases sociales de menores ingresos y de otros excluidos que luchan por una igualdad ambiental. Este movimiento social surgió en los Estados Unidos como consecuencia de que los impactos ambientales negativos eran sufridos por las comunidades más desfavorecidas de la sociedad,

${ }^{301}$ MC DERMOTT. Op.cit., p. 130. 
generando un movimiento de resistencia frente a la injusticia ambiental que afectaba a los más desprotegidos de la sociedad. Los depósitos de residuos tóxicos, los basurales, la construcción de fábricas con actividades de polución eran establecidos en los barrios donde vivían esas comunidades.

Ese movimiento social de protesta fue llamado Justicia Ambiental. Aunque, por otro lado, la Justicia Ambiental también emerge como una construcción teórica que da soporte intelectual a ese movimiento social que rechaza la situación de desigualdad ambiental.

La Justicia Ambiental se nutrió de otros movimientos sociales de resistencia, como el de los derechos civiles, de los pueblos indígenas, de los campesinos, de los sindicatos y de profesores de las universidades.

Según Alicia ARRIAGA LEGARDA y Mercedes PARDO BUENDÍA, fue Bullard quien sostiene que los primeros vestigios de este movimiento de resistencia a las injusticias ambientales se iniciaron en 1967, cuando una niña de 8 años cayó en un depósito de basura tóxica, causándole la muerte. Fue en ese momento cuando los jóvenes estudiantes se revelaron ante esta situación, generando protestas. En 1978, la EPA ${ }^{302}$ emitió un comunicado sobre el problema que sufrían las comunidades de color con los impactos ambientales negativos (titulado Our Common Concern). En 1979, se realizó la Conferencia donde se reunieron el Sierra Club (con sus preocupaciones ambientales) y la Liga Nacional Urbana (con sus intereses por los derechos civiles).

En 1983, en el condado de Warren, hubo grandes protestas y esto llevó a que la US General Accounting Office tuviese que realizar un estudio considerando la relación entre la localización de los depósitos de residuos tóxicos y las comunidades menos favorecidas de la sociedad. Posteriormente, fue presentado el primer estudio, realizado por la "United Church of Christ Commission for Racial Justice, titulado Toxic Waste and Race in the United States"303.

En 1987, a BULLARD le fue encomendada la realización del tercer estudio sobre la localización de depósitos de basura tóxica en barrios de comunidades de bajos ingresos.

En 1989, la empresa Luisiana Energy Services (LES) obtuvo la autorización para establecer plantas de enriquecimiento de uranio en Claiborne Parish (Luisiana), siendo que esta región era habitada por comunidades de baja renta y de origen afroamericano. Este fue un caso

\footnotetext{
302 Environmental Protection Agency (Agencia de Protección Ambiental de Estados Unidos).

${ }^{303}$ ARRIAGA LEGARDA, Alicia; PARDO BUENDÍA, Mercedes. Justicia Ambiental. El estado de la cuestión.

Revista Internacional de Sociología (RIS), Vol. 69, setiembre-diciembre, 2011, p. 636-637.
} 
que sirvió para que se consolidara más la lucha que el movimiento por la Justicia Ambiental venía desarrollando ${ }^{304}$.

Según observa ACSELRAD, en el año 1990, la EPA se vio tan presionada por estos movimientos sociales que tuvo que crear una Comisión para estudiar la repercusión de los impactos ambientales negativos sobre las poblaciones de baja renta.

En 1991, se celebró la Cúpula Nacional de Liderazgos Ambientales de Pueblos de Color, donde fueron establecidos los 17 principios de la Justicia Ambiental. En 1994, el presidente de Estados Unidos requirió a la EPA que fuese introducida la cuestión de la Justicia Ambiental, para lo cual firmó la "Environmental Justice Executive Order 12898: Federal Actions to Address Environmental Justice in Minority Populations and Low-Income Populations"305.

Posteriormente, se fueron realizando numerosos estudios sobre las problemáticas que abarca la Justicia Ambiental, hasta llegar a formar un marco teórico que apoya a la cuestión.

\section{IV.2.2. La Justicia Ambiental: observaciones conceptuales}

Existe un discurso ambientalista dominante que afirma que todos somos o seremos víctimas de los impactos ambientales negativos de la crisis ambiental de forma igualitaria, independientemente del origen étnico, de los ingresos económicos, del género, de la clase social. Aunque se puede observar que tales impactos recaen más sobre los que tienen menos recursos, ya sean personas pobres o países pobres.

Esta es la visión crítica que impera en la teoría de la Justicia Ambiental o Ecologismo de los Pobres, pues estas construcciones resaltan la relación de desigualdad que subyace en la distribución de los impactos ambientales negativos, así como en el reparto de los beneficios, siendo que los primeros son sufridos por comunidades más desfavorecidas y los segundos se dirigen a las clases más privilegiados dentro de la sociedad.

El 4 de noviembre de 2005, EPA consideró la Justicia Ambiental de la siguiente manera:

El tratamiento imparcial y la implicancia significativa de todas las personas, independientemente de su raza, origen nacional o ingresos económicos con respecto al desarrollo, implementación y aplicación de las leyes medio ambientales, regulaciones y políticas ${ }^{306}$.

\footnotetext{
${ }^{304}$ LÓPEZ, Iván. Justicia Ambiental. Eunomía. Revista en Cultura de la Legalidad, No 6, Universidad Carlos III de Madrid, marzo-agosto, 2014, p. 262.

${ }^{305}$ ARRIAGA LEGARDA; PARDO BUENDÍA. Op.cit., p. 638.

${ }^{306}$ LÓPEZ, 2014. Op.cit., p. 263.
} 
En primer lugar, el concepto afirma que la Justicia Ambiental es "el tratamiento imparcial”, lo cual significa que la repartición de la justicia precisa ser neutral, es decir, no puede realizarse arbitrariamente.

En segundo lugar, se observa que la definición establece que "la Justicia Ambiental abarca a todos", lo que significa que está dirigida de forma igualitaria y democrática, sin diferencias. Por lo tanto, no se puede establecer criterios para privilegiar a grupos con características especiales, otorgándoles beneficios ambientales. Del mismo modo, los impactos ambientales negativos no pueden recaer sobre un grupo predeterminado con características específicas, tales como clase social, ingresos económicos bajos, minoría étnica, raza, ser habitante de un país pobre, porque lo contrario configuraría una injusticia ambiental.

En tercer lugar, establece "con respecto al desarrollo, implementación y aplicación de las leyes medioambientales, regulaciones y políticas", lo cual hace a la institucionalización de los medios que hagan efectivo el goce de un medio ambiente sano y para todos.

Helfand y Peyton definen la Justicia Ambiental:

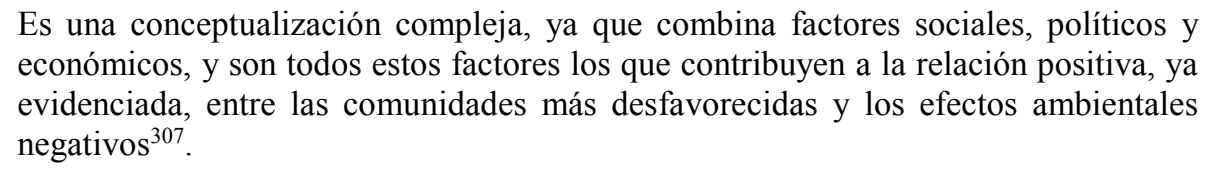

Este concepto apunta a la construcción teórica que se ha desarrollado entorno de que la localización de los impactos ambientales negativos se produce en los lugares donde viven las comunidades más desfavorecidas.

Los impactos ambientales negativos son todos aquellos acontecimientos que producen la contaminación del medio ambiente y la degradación ambiental, afectando la vida del hombre o de las comunidades, impidiéndoles el ejercicio del derecho de vivir en un medio ambiente sano, seguro y confiable. Algunos de estos son: los depósitos de desechos tóxicos, la contaminación del aire, del agua y de las tierras, los depósitos de basura, la deforestación de florestas, la desertificación de tierras, los proyectos de desarrollo, los fenómenos climáticos catastróficos causados por los cambios climáticos, como las inundaciones de áreas, la erosión de regiones costeras, el aumento de tormentas tropicales, tsunamis, ciclones, el aumento del nivel del mar, la desertificación, la escasez de recursos y la sumersión de las islas. Otros como los terremotos, cuando ocurren en países pobres, los gobiernos no consiguen hacerles frente

${ }^{307}$ ARRIAGA LEGARDA; PARDO BUENDÍA. Op.cit., p. 642. 
debido a que no tienen los medios ni económicos ni humanos, y precisan de la ayuda internacional.

El lugar en donde son producidos los impactos ambientales negativos puede ser considerado desde las perspectivas: local, regional, nacional o global. A nivel global, hay países en desarrollado que sufren los impactos ambientales negativos como las consecuencias de los cambios climáticos, provocadas por el calentamiento de la atmósfera, producto de las actividades degradantes, y de la emisión del gas dióxido de carbono de los países desarrollados.

Además, encontramos países titulares de la deuda ecológica. El conflicto ambiental generado por la desigual repartición de los impactos negativos del medio ambiente, puede ser observado en la relación entre los países. Hay países desarrollados que han aumentado su producción y su crecimiento económico gracias a la explotación indiscriminada de los recursos naturales limitados, produciendo degradación en los territorios de los países no desarrollados exportadores de materias primas. De tal modo, el conflicto ambiental adquiere una dimensión internacional.

Muchos países desarrollados han basado sus riquezas en el aumento de la producción desenfrenada de gases de efecto invernadero.

De un lado, surgen los actores que producen los impactos ambientales negativos y, del otro, los que sufren los impactos de la degradación ambiental. En el medio de esta relación debería haber un sujeto regulador que asegurase la equidad de las relaciones entre ambos polos. Si la relación de conflicto ambiental se desarrolla en el ámbito de un país, el actor regulador debe ser el Estado. Si el conflicto ambiental se produce en el orden internacional, el ente regulador de la situación debería ser la sociedad internacional a través del consenso entre los países y, de forma más específica, las Naciones Unidas.

La distribución de los impactos ambientales negativos para las comunidades más excluidas de la sociedad deriva en un ataque al derecho de vivir en un medio ambiente sano y, fundamentalmente, al derecho de tener una vida digna. De ese modo, la injusticia ambiental significa la violación de los derechos humanos indivisibles (entre estos, el derecho a la salud, al alimento sano, al agua potable, a una vivienda digna y a la justicia).

La Justicia Ambiental implica el pleno ejercicio del derecho a un medio ambiente sano, lo cual implica la posibilidad efectiva del derecho a la vida, de sobrevivir y a otros derechos implícitos en tal concepto. 
El concepto de Justicia Ambiental exige una re-conceptualización de la relación del hombre con la naturaleza. ${ }^{308}$ Es preciso que sea dejada de lado la visión que separa a la naturaleza del hombre, considerando a la primera como un objeto o cosa y al hombre como señor o sujeto. Porque el hombre hace parte de esa naturaleza, y si destruye la naturaleza, está atacando a su propia sobrevivencia. El ser humano no tiene cómo vivir fuera de la naturaleza o sin la naturaleza, sino que debe vivir con la naturaleza. Por otro lado, las comunidades más afectadas por la injusticia ambiental son justamente aquellas que están más excluidas en la sociedad, especialmente los casos de comunidades indígenas y comunidades tradicionales cuyas formas de sobrevivencia son de subsistencia de la naturaleza.

Estas comunidades tienen una visión diferente de la del Occidente sobre diversos conceptos, como: la naturaleza, la propiedad, el trabajo, la familia, el ocio. Para ellos, la naturaleza no significa un ámbito externo para la extracción de recursos, sino que existe una unidad inseparable entre el hombre y la naturaleza. En estas comunidades existe un enfoque colectivo, en vez del individualista que rige el paradigma de la sociedad occidental. ${ }^{309}$

MARTINEZ ALLIER observa que "el eje principal de esta tercera corriente (la Justicia Ambiental) no es una reverencia sagrada a la naturaleza, sino un interés material por el medio ambiente como fuente de condición para la subsistencia"310.

La redefinición del medio ambiente lleva a que sean reconsideradas las formas como la ciencia trata el problema, exigiendo una perspectiva interdisciplinar. Los impactos de la crisis ambiental global actual escapan a la previsibilidad de la ciencia.

Todo esto se verifica en la incapacidad de establecer las relaciones de causalidad directa que podían ser establecidas en la sociedad industrial ${ }^{311}$, el efecto boomerang ${ }^{312}$ (sostenido por Beck) que hace que los riesgos se vuelvan contra quien los produjo.

La interdisciplinariedad implica que debe existir un diálogo de saberes, lo cual aumenta las exigencias de quien trata de estudiar el problema, pues precisa considerar otros aspectos que son ajenos a su área de estudio. Por lo tanto, el perfil del estudioso precisa ser el de un especialista en su área, aunque también debe tener una visión generalista, la cual le permita leer y entender conocimientos de otras áreas.

\footnotetext{
${ }^{308}$ LEFF, Enrique. Saber Ambiental: sustentabilidade, racionalidade, complejidade, poder. Petrópolis, RJ: Vozes, 2001.

${ }^{309}$ LEFF, Enrique. Op. Cit.

${ }^{310}$ MARTÍNEZ ALLIER. Op.cit., p. 34.

311 BECK, Ulrich. Liberdade ou capitalismo/Ulrich Beck conversa com Johannes Willms. São Paulo: Editora UNESP, 2003.

312 BECK, Ulrich. La sociedad del riesgo: hacia una nueva modernidad. Barcelona: Litografia Roses S/A, 2006.
} 
La Justicia Ambiental introduce nuevos conceptos como el de la deuda ecológica, el racismo ambiental y la huella ecológica. Además, se refiere a la equidad intergeneracional, intrageneracional y la interespecies.

Las principales críticas están dirigidas a que la Justicia Ambiental es un movimiento antropocéntrico, en contraste con las otras corrientes ecológicas. Aunque esto tiene que ver con la redefinición exigida de la cuestión ambiental para hacer frente a la crisis ambiental, la cual significa que existe una unidad inseparable del hombre y naturaleza.

Otra de las críticas es que la Justicia Ambiental se preocupa por que las consecuencias negativas ambientales no sean distribuidas a las comunidades excluidas, sin que se preocupe por la eliminación de tales impactos ambientales. En realidad, no se trata de que la Justicia Ambiental pierda el objetivo principal que es la no producción de los impactos ambientales negativos para todos, sino que además de esta preocupación, se centre en el problema real que afecta a esos pueblos pobres.

Ivan López observa:

\begin{abstract}
Las definiciones se diferencian, al mismo tiempo que se complementan, según el énfasis que pongan en dimensiones como la clase social o el origen étnico; el ámbito local o global; las causas (carácter proactivo) o las consecuencias (carácter reactivo) del impacto medioambiental, tanto positivas como negativas; en su desarrollo procedimental en el ejercicio democrático de la ciudadanía, o en la justicia distributiva en relación con el desigual reparto de los daños sociales, políticos y económicos sobre los distintos segmentos socioeconómicos de la población ${ }^{313}$.
\end{abstract}

\title{
IV.3. Los desplazados ambientales forzados y la Justicia Ambiental
}

Uno de los aspectos de la definición de la Justicia Ambiental es el referente a los impactos ambientales negativos. En el caso de los desplazados ambientales forzados, estos impactos ambientales negativos están representados por la degradación ambiental y el desastre, los cuales son sufridos principalmente por las poblaciones más pobres de los países en desarrollo, que se ven obligadas a escapar de sus hogares para poder sobrevivir.

El análisis de la definición de la Justicia Ambiental aplicada al problema de los desplazados ambientales forzados permite verificar que estos son las víctimas que viven en los países del mundo "no desarrollado" 314 , donde el país no tiene ningún tipo de recursos económicos, ni institucionales, para brindarles el socorro en la emergencia.

\footnotetext{
${ }^{313}$ LÓPEZ, 2014. Op.cit., p. 263.

${ }^{314}$ Esta expresión es utilizada por Martínez Allier.
} 
Aunque también, los desastres y la degradación ambiental pueden ocurrir en países desarrollados, como fue el caso del Huracán Sandy en Estados Unidos o el posible aumento del nivel del mar en Holanda. La gran diferencia reside en que estos países desarrollados consiguen hacerle frente al desastre y a la degradación ambiental a través de sus instituciones, protegiendo a sus nacionales. Además, los países desarrollados tienen a su favor el desarrollo de la innovación, la cual está siendo focalizada para encontrar nuevas formas de disminuir tales impactos. Este es el caso de Holanda.

Por otro lado, es importante observar que estos países con menores condiciones de desarrollo no han contribuido con sus actividades para el empeoramiento del calentamiento de la atmósfera, produciendo o exacerbando los cambios climáticos y sus impactos ambientales negativos, como el aumento del nivel del mar, invadiendo las regiones costeras y sumergiendo a las islas más bajas, el derretimiento de las capas polares, el aumento de la desertificación, el aumento de tifones, de los ciclones tropicales, los huracanes, las inundaciones, dejando áreas devastadas.

Por el contrario, quienes han sido los que han contribuido a esta crisis ambiental son los Estados industrializados con sus actividades de polución, siguiendo la lógica desenfrenada del capitalismo salvaje.

Todos esos impactos ambientales negativos obligan a las personas a desplazarse hacia otros lugares dentro del mismo país o ultrapasando las fronteras, siendo obligadas a dejar sus hogares para poder sobrevivir, transformándose en desplazados ambientales forzados.

\section{IV.4. El problema de los desplazados ambientales}

Los desplazados ambientales forzados sufren la violación de sus derechos humanos (esto ya fue demostrado en el Capítulo III). Esta situación denuncia la gravedad del problema y la necesidad de que sea incorporado como un tema importante en la agenda internacional de Naciones Unidas.

En este sentido, surge la necesidad de que la comunidad internacional (a través de Naciones Unidas, de otros organismos internacionales y de los países) reconozca la triste realidad de la catástrofe ambiental que afecta a estas personas que se ven obligadas a abandonar sus países, escapando hacia otros países, y les brinde una protección en el derecho internacional tanto a través de la creación de un ordenamiento legal que regule la situación, así como que designe un organismo de Naciones Unidas para que asuma la responsabilidad de cuidar de la situación de los desplazados ambientales forzados. 
Los desplazados ambientales forzados transfronterizos están desprotegidos en el derecho internacional, en tanto que los Principios Orientadores de los Desplazados Internos protegen a aquellos desplazados internos que escapan de los desastres naturales. Como ya ha sido señalado, la postura de esta tesis es que la figura de los desplazados ambientales forzados es única, no existiendo diferencias entre los internos y los trasfronterizos, pues todos se unen en los mismos denominadores comunes, como la violación de los derechos humanos. Todo esto ha sido sostenido a través de los Capítulos II y III. Por lo tanto, no serán hechas diferencias entre los internos y los transfronterizos.

ACNUR es un organismo con gran experiencia que ya ha demostrado su capacidad ante situaciones similares. Por ello, en este trabajo se sostiene que el organismo de Naciones Unidas que debe ser designado para proteger a los desplazados ambientales forzados es ACNUR (como será considerado en el Capítulo VI).

En este estudio se consideran la situación y la localización de los desplazados ambientales forzados de los desastres y la degradación ambiental, lo cual demostrará que los países más afectados tienen grandes contingentes de sus poblaciones sumergidas en la pobreza, siendo esa la causa de la falta de respuesta del derecho internacional.

En primer lugar, será considerada la situación de los desplazados ambientales forzados de los casos de degradación ambiental de procesos lentos, como es la situación de los Pequeños Estados Insulares en Desarrollo, los cuales sufren los desastres meteorológicos extremos y, además, la subida del mar, siendo que algunos ya están padeciendo la pérdida de su territorio. En este último sentido, los países insulares que se encuentran en peor situación son Maldivas, Kiribati, Tuvalu y las Islas Marshall.

En segundo lugar, será analizada la situación de los desplazados ambientales forzados de los desastres ambientales o degradación ambiental de evolución rápida en el período de 2010-2012.

\section{IV.5. Desplazados ambientales forzados de desastres ambientales de procesos de larga duración}

\section{IV.5.1. Pequeños Estados Insulares y regiones costeras bajas}

Los Pequeños Estados Insulares en Desarrollo son aquellos que están sufriendo el aumento del nivel del mar (causado por el incremento de la temperatura que produce el derretimiento de las capas de hielo del Polo Norte), lo que lleva a la pérdida de partes de su 
territorio. Algunos de estos países están en una situación más grave, pues perderán partes o todo su territorio en un futuro muy próximo. Estos son Maldivas, Kiribati, Tuvalu e Islas Marshall.

La Alianza de Pequeños Estados Insulares (Alliance of Small Island States-AOSIS) es una organización internacional creada en 1990. Tiene 44 Estados miembros.

Cabe observar que:

\begin{abstract}
La Alianza de los Pequeños Estados Insulares (AOSIS) es una coalición de Pequeños Estados Insulares y países costeros de baja altitud que comparten retos y preocupaciones sobre el medio ambiente, especialmente su vulnerabilidad a los efectos adversos del cambio climático global. Funciona principalmente como un grupo de presión ad hoc y es la voz de negociación de los Pequeños Estados Insulares en Desarrollo (SIDS) dentro del sistema de las Naciones Unidas ${ }^{315}$.
\end{abstract}

Estos países se unieron para defender sus intereses y hacer frente a la dramática situación sufrida. Los Estados Miembros son: Antigua y Barbuda, Bahamas, Barbados, Belice, Cape Verde, Comoros, Cook Islands, Cuba, Dominica, República Dominicana, Fiji, Federated States of Micronesia, Grenada, Guinea-Bissau, Guyana, Haití, Jamaica, Kiribati, Maldivas, Islas Marshall, Mauritius, Nauru, Niue, Palau, Papua New Guinea, Samoa, Singapur, Seychelles, San Tome and Príncipe, Solomon Islands, St. Kitts and Nevis, St. Lucia, St. Vincent and the Grenadines, Suriname, Timor Oriental, Tonga, Trinidad y Tobago, Tuvalu y Vanuatu. Los Estados observadores son: American Samoa, Antillas Holandesas, Guam, U.S. Virgin Islands y Puerto Rico.

Los Pequeños Estados Insulares tienen características comunes, como pequeño territorio, tierras bajas, localización en regiones predispuestas a los riesgos de los cambios climáticos, en regiones tropicales o altitudes bajas; recursos naturales limitados; escasez de agua dulce; poblaciones localizadas en regiones costeras más bajas; poca infraestructura; sus economías pequeñas.

En tal sentido, el Tercer Informe de Evaluación del IPCC observa:

\footnotetext{
Los Pequeños Estados Insulares comparten muchas similitudes (por ejemplo, tamaño físico, la propensión a los desastres naturales, catástrofes y fenómenos climáticos extremos, la apertura extrema de su economía, la baja capacidad de adaptación) que aumentan su vulnerabilidad y reducen su capacidad de adaptación a la variabilidad y a los cambios climáticos ${ }^{316}$.
}

\footnotetext{
${ }^{315}$ ALLIANCE OF SMALL ISLAND STATES. About AOSIS. Disponible en: <http://aosis.org/about/> acceso 10 de agosto de 2014.

${ }^{316}$ MIMURA, N.; NURSE, L.; MCLEAN, R.F.; Agard, J.; BRIGUGLIO, L.; LEFALE, P.; PAYET, R.; SEM, G. 2007: Small islands. Climate Change 2007: Impacts, Adaptation and Vulnerability. Contribution of Working Group II to the Fourth Assessment Report of the Intergovernmental Panel on Climate Change. M.L. Parry, O.F. Canziani, J.P. Palutikof, P.J. van der Linden y C.E. Hanson (eds.). Cambridge: Cambridge University Press, 2007, p. 690.
} 
Los principales eventos ambientales catastróficos son el aumento del nivel del mar, de la temperatura (los procesos de lenta degradación) y la producción de los desastres meteorológicos extremos (desastres repentinos).

Las principales consecuencias de estos eventos son: pérdida de los medios de sobrevivencia, escasez de agua dulce, escasez de alimentos, salinización de los suelos y aguas subterráneas, enfermedades, pérdidas de viviendas e infraestructura, desplazamientos, erosión de las regiones costeras, inundaciones, deslizamientos de tierras, perdida de tierras usadas para la agricultura, pérdida de hogares, así como la pérdida de las tradiciones culturales y ser cultural de los pueblos y separaciones de familias. Aunque el impacto peor es la pérdida del territorio del país.

La gravedad de la situación varía de un país para otro.

En primer lugar, hay algunos Estados que ya están perdiendo sus territorios como consecuencia del aumento del nivel de mar. Estos países son obligados a trazar las futuras estrategias de desplazamientos en masa.

En segundo lugar, existen otros de estos Estados que sufren desplazamientos temporarios producidos como consecuencia de inundaciones, tsunamis y tifones, obligando a la población a desplazarse provisoriamente.

Cabe señalar que “en 2007, el IPCC ${ }^{317}$ estimó que para 2100, el calentamiento global conducirá a un aumento del nivel del mar entre 180 y $590 \mathrm{~mm}$, mientras que investigaciones más recientes sugieren que estas estimaciones son propensas a llegar al menos al doble". Además, fue observado que "en este escenario, Kiribati, Maldivas, Islas Marshall y Tuvalu se convertirán en inhabitables, mientras que una gran parte de la población de muchos otros PIED $^{318}$ serán desplazadas o afectadas de manera negativa"319.

Por otro lado, el Grupo Intergubernamental de Expertos sobre Cambios Climáticos consideró que si la temperatura aumentase 4 grados, los territorios de "Estados de Kiribati, Maldivas, Islas Marshall y Tuvalu serían inhabitables"320.

Es necesario destacar que estos países han sido los que menos han contribuido con las emisiones de gases de efecto invernadero.

\footnotetext{
317 Grupo Intergubernamental de Expertos sobre Cambio Climático.

318 Pequeños Estados Insultares en Desarrollo.

319 UNITED NATIONS. DEPARTMENT OF ECONOMIC AND SOCIAL AFFAIRS. DIVISION FOR SUSTAINABLE DEVELOPMENT. Trends in sustainable development. Small island developing states (SIDS). Nueva York, 2010, p. 4.

${ }^{320}$ STEINER, Achim. Help small island states win their battle against climate change, s/f. Disponible en: $<$ www.theguardian.com> acceso 29 de agosto 2014 .
} 
Es decir, las peores consecuencias serán sufridas para las poblaciones de estos países insulares, cuyos territorios van a desaparecer. De tal forma, se convertirán en Estados sin territorios, siendo este uno de los elementos fundamentales del concepto de Estado. En efecto, surgirán nuevos desafíos para el derecho internacional, como el problema de la soberanía de estos países, la nacionalidad de sus habitantes que perderán sus Estados, el problema del mar nacional de estos Estados, lo que ocurrirá con la participación en Naciones Unidas, la pérdida de los derechos culturales, la desintegración de los pueblos y de su ser cultural.

Este constituye un gran reto para Naciones Unidas y la comunidad internacional, que deberán asumir y solucionar.

DALLARI observa que "el territorio es un elemento constitutivo del Estado, representado por la porción de superficie sobre la cual este ejerce, habitualmente, su dominación exclusiva, o el conjunto de derechos, inherentes a la soberanía"321.

La población construye el ser cultural del pueblo, su historia, sus formas de sobrevivencia, a partir de la relación con su territorio y su medio ambiente.

La pérdida del territorio para un pueblo significa una violación de los derechos humanos, pues la identidad colectiva y la identidad individual se construyen sobre su ambiente natural. Esta violación abarca los derechos civiles, políticos, sociales y culturales.

Ello obliga a las personas a tener que escaparse de sus países, quedando desprotegidas $\mathrm{y}$ dejando de ser ciudadanos, significando un quiebre interno en las personas. Estas se convierten en desplazados forzados, pues no tienen la libertad de elegir entre quedarse o irse.

La obligatoriedad de irse significa la negación de la autonomía de la voluntad. BITTAR observa que la autonomía de la voluntad es aquella que está libre de coacciones físicas o psicológicas $^{322}$.

\footnotetext{
${ }^{321}$ DALLARI, Dalmo de Abreu. Elementos de teoria geral do Estado. São Paulo: Saraiva, 2003.

${ }^{322}$ BITTAR. Op.cit., p. 27.
} 


\section{Imagen 1 - Referente a algunos de los Pequeños Estados Insulares en Desarrollo más afectados}

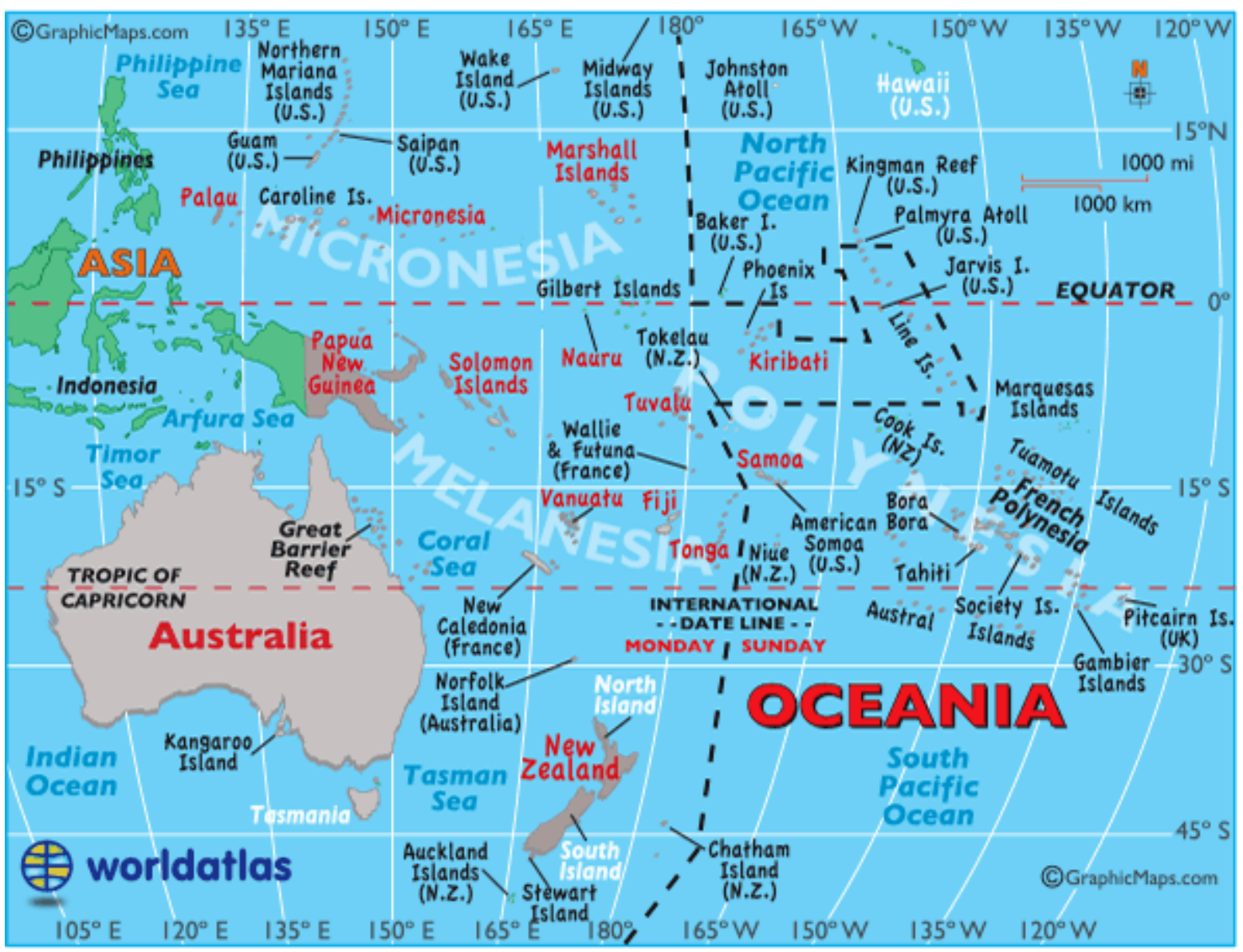

Fuente: $<$ http://www.worldatlas.com/webimage/countrys/au.htm>.

En relación con el problema del agua en Kiribati, cabe señalar:

La urgente necesidad de proteger y gestionar eficazmente las reservas de agua en Buota y Bonriki es reconocida por el Gobierno de Kiribati en el Plan de Implementación Nacional de Recursos Hídricos, el Agua y el Saneamiento Tarawa Hoja de Ruta 2011-2030 y el Plan de Desarrollo de Kiribati 2012-2015. El estado crítico de las reservas de agua es probable que se haga más grave en el futuro como resultado de los impactos del cambio climático en el futuro de los patrones de lluvia/sequía, junto con el crecimiento de la población. Debido a que la preservación de las reservas de agua en zonas periurbanas y Buota Bonriki es fundamental para la salud a largo plazo y el crecimiento económico del sur de Tarawa, el Consejo de Ministros aprobó la creación de un Grupo de Trabajo Interministerial Agua Reservas $^{323}$.

${ }^{323}$ REPUBLICA DE KIRIBATI, OFFICE OF THE PRESIDENT. Governance Roadmap on Water Reserves first workshop, complete, 2014. Disponible en: <http://www.climate.gov.ki/2014/10/31/governance-roadmapon-water-reserves-first-workshop-complete/> acceso 23 de agosto de 2014. 
Sobre la posibilidad de desplazamientos no existen estrategias gubernamentales, sin embargo, se indica:

El Gobierno de Kiribati reconoce que "la reubicación de nuestro pueblo puede ser inevitable", y que "sería irresponsable reconocer esta realidad y no hacer nada para preparar nuestra comunidad para la eventual migración en circunstancias que les permita migrar con dignidad" 324 .

En Kiribati, un tercio de la población reside en Tawara. La vulnerabilidad socioambiental de este país es agravada por los cambios climáticos, que repercuten con tormentas más fuertes y con la erosión del suelo. La problemática social está relacionada con las siguientes cuestiones:

\footnotetext{
- Inaceptables niveles de desigualdad emergentes;

- aumento de la población;

- deterioro de los Estados de las zonas costeras, arrecifes de coral, la pesca, agua dulce subterránea, la salud humana y la biodiversidad;

- servicios urbanos inadecuados, tales como suministro de agua y saneamiento;

- la sobreexplotación de los recursos naturales en Tarawa dificulta la aplicación de estrategias de gestión de uso de la tierra y de controles ${ }^{325}$.
}

${ }^{324}$ INTERNAL DISPLACEMENT MONITORING CENTER. NORWEGIAN REFUGEE COUNCIL (IDMCNRC). Neglected displacement. Human mobility in Pacific disaster risk management and climate change adaptation mechanisms, septiembre, 2014a, p. 12.

${ }^{325}$ INTERNAL DISPLACEMENT MONITORING CENTER. NORWEGIAN RFUGEE COUNCIL. Neglected displacement. Op.cit., p. 11. 


\section{Imagen 2- Kiribati}

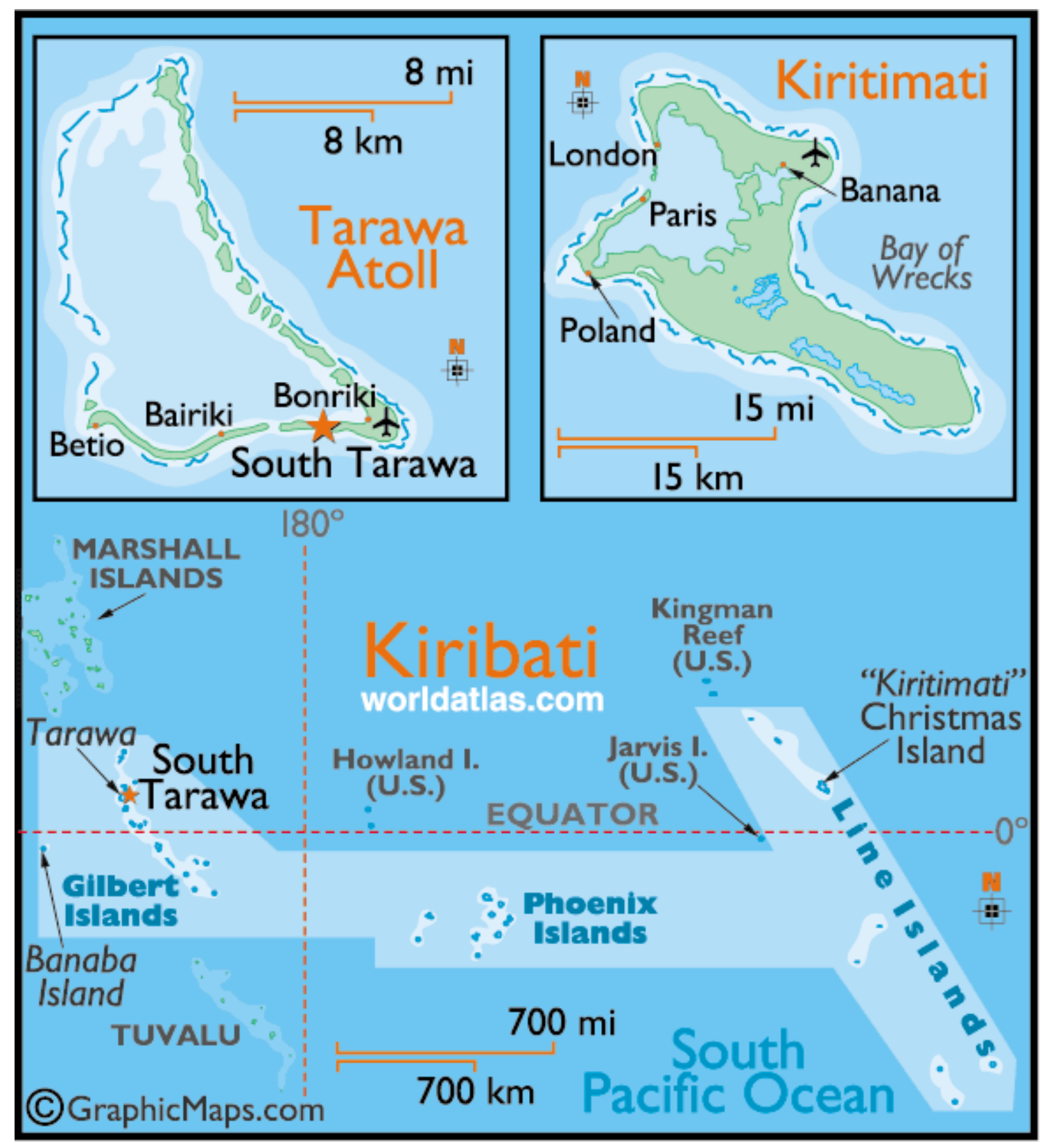

Fuente: $<$ http://www.worldatlas.com/webimage/countrys/oceania/lgcolor/kicolor.htm $>$.

Tuvalu es un pequeño país insular ubicado en el Océano Pacífico, con una población muy reducida (11.206 habitantes, en 2011); el 53\% se localiza en la capital, Funafuti. Sus tierras son todas bajas. 
En este país, existen grandes desafíos para vencer las vulnerabilidades derivadas del cambio climático:

La erosión costera, intrusión de agua salada y el aumento de vectores de las enfermedades transmitidas por el agua debido al aumento del nivel del mar y los desastres naturales. [...] Las principales causas de la erosión son: aumento del nivel del mar, inundaciones, tormentas, ciclones tropicales, huracanes de gran intensidad, remoción de la tierra que se utiliza como agregado para la construcción de los edificios y actividades de desarrollo costero ${ }^{326}$.

En Tuvalu, en 1997, ya desapareció una de sus islas: Tepuka Savilivili y Te Pukasavilivili. Además, en este país hay personas que debieron escapar hacia otro país, debido a inundaciones. Tuvalu ha tratado de realizar negociaciones con Nueva Zelandia ${ }^{327}$. Este último Estado solamente acepta 75 habitantes de Tuvalu por año y estos deben cumplir con las exigencias establecidas por el gobierno de Nueva Zelandia. Todo eso es a través de un sistema llamado Pacific Acess Category ${ }^{328}$.

Existen otros problemas que han surgido, como la salinización de los suelos, impidiendo los cultivos, la pérdida del agua subterránea por "la entrada del agua del mar" que perjudica las actividades de la agricultura de sobrevivencia, el uso personal. Otra de las preocupaciones es las inundaciones de las tierras ${ }^{329}$.

\footnotetext{
${ }^{326}$ INTERNAL DISPLACEMENT MONITORING CENTER. NORWEGIAN RFUGEE COUNCIL. Neglected displacement. Op.cit., p. 15.

327 MASON. Op.cit.

328 NEW ZEALAND'S IMMIGRATION. How do I qualify for residence under the Pacific access category? s/f. Disponible en: <http://www.immigration.govt.nz/migrant/stream/live/pacificaccess/residence/> acceso de abril de 2015.

${ }^{329}$ MASON. Op.cit., p. 3-4.
} 


\section{Imagen 3- Tuvalu}

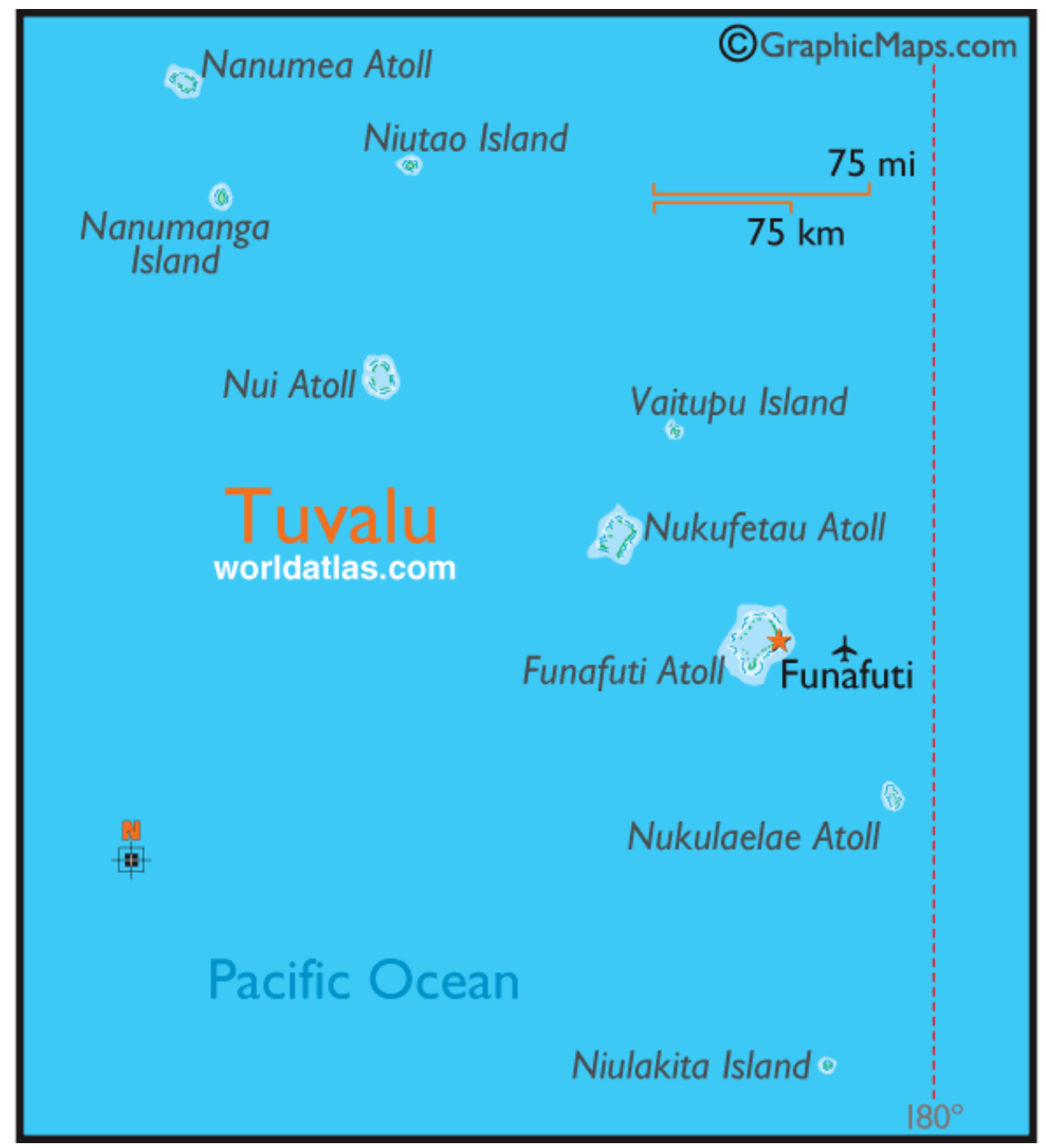

Fuente: $<$ http://www.worldatlas.com/webimage/countrys/oceania/lgcolor/tvcolor.htm>.

Maldivas es otro de los Pequeños Estados Insulares más afectado por el aumento del nivel del mar. 
La población total de Maldivas es de 340.000 habitantes $^{330}$. Maldivas es un Estado que se encuentra en el Océano Índico, a 750 km de India y Sri Lanka. Su capital es Malé, con una población de 104.403 personas $^{331}$. Su extensión territorial es de $235 \mathrm{~km}^{2}$. El país está formado por 1.190 islas. El turismo es una de las principales actividades. Otra de las actividades es la pesca. La agricultura del país incluye el cultivo de "coco, sandía, plátano, pepino, calabaza, papaya, col, taro y berenjena" 332 .

Gran parte del territorio de Maldivas está a $1 \mathrm{~m}$ de altura sobre el nivel del mar, lo que aumenta su vulnerabilidad.

Aunque estos países vienen haciendo declaraciones y denuncias sobre su situación a través de la Alianza de Pequeños Estados Insulares y por medio de sus gobiernos ${ }^{333}$, existe una falta de respuesta internacional para el problema de la pérdida total de sus territorios.

Por otro lado, hay propuestas en la doctrina para establecer soluciones, las cuales serán analizadas en el Capítulo $\mathrm{V}^{334}$.

El gobierno de Maldivas propuso la modificación de la definición de los refugiados establecida en la Convención sobre el Estatuto de los Refugiados de 1951 y su Protocolo ${ }^{335}$, aunque es muy difícil que sea alcanzado el consenso para esta modificación. Además, ACNUR no acepta la propuesta de modificación, pues tal podría implicar el recorte de las garantías actuales de los refugiados políticos.

Todos los problemas de los Pequeños Estados Insulares enunciados anteriormente también son sufridos por Maldivas.

\footnotetext{
330 UNSTATS. Environment Statistics Country Snapshot. Maldivas, s/f. Disponible en: $<$ https://unstats.un.org/unsd/ENVIRONMENT/envpdf/Country_Snapshots_Aug\%202013/Maldives.pdf $>$ acceso 4 de abril de 2015.

${ }^{331}$ REIS DE FREITAS, Luisa. The Maldives Islands' Case: Climate Change and Climate Refugees. ICE Case Studies 283, mayo, 2013, p. 5. Disponible en: <http://www1.american.edu/ted/ICE/maldives.html $>$ acceso 4 de abril de 2015.

332 REPUBLIC OF MALDIVES. National Adaptation Program of Action. Ministry of Environment, Energy and Water, 2006, p. 23-25.

${ }^{333}$ ALLIANCE OF SMALL ISLAND STATES. Leaders Declaration. Op.cit.

${ }^{334}$ DOCHERTY; GIANNINI. Op.cit., p. 375. También BIERMANN; BOAS. Op.cit., p 25.

${ }^{335}$ BOANO et al. Op.cit., p. 25.
} 
Imagen 4- La localización de Maldivas

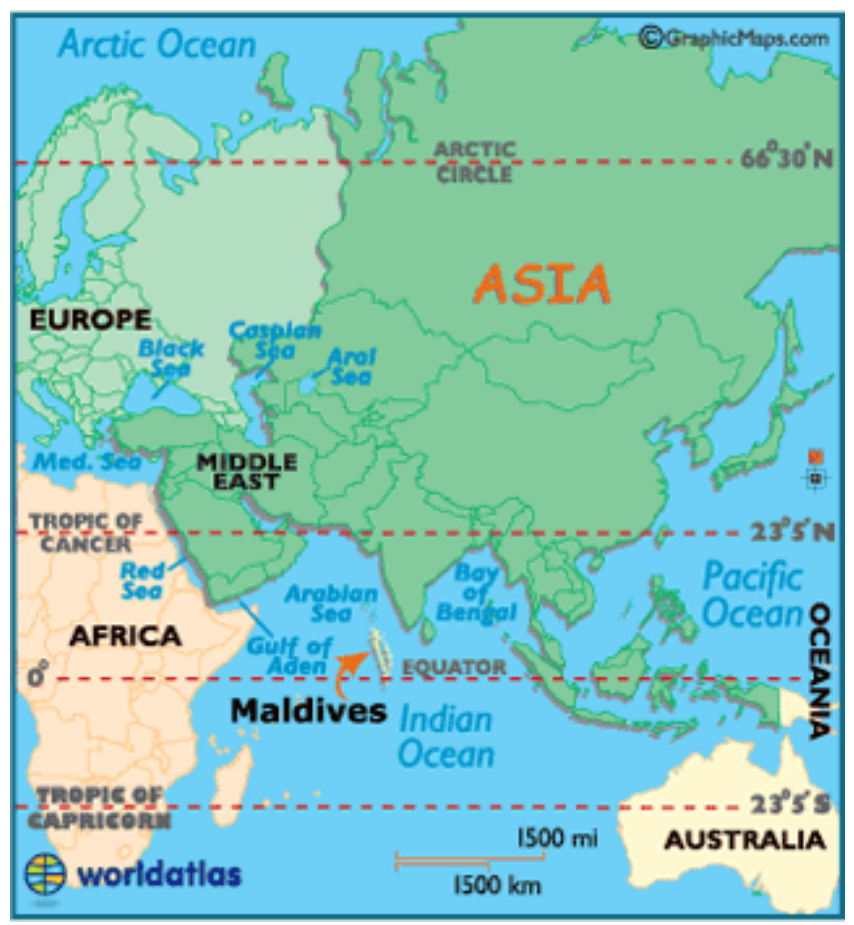

Fuente: $<$ http://www.worldatlas.com/webimage/countrys/asia/mv.htm>. 


\section{Segunda Imagen de Maldivas extraído de:}

$<$ http://www.worldatlas.com/webimage/countrys/asia/mv.htm $>$

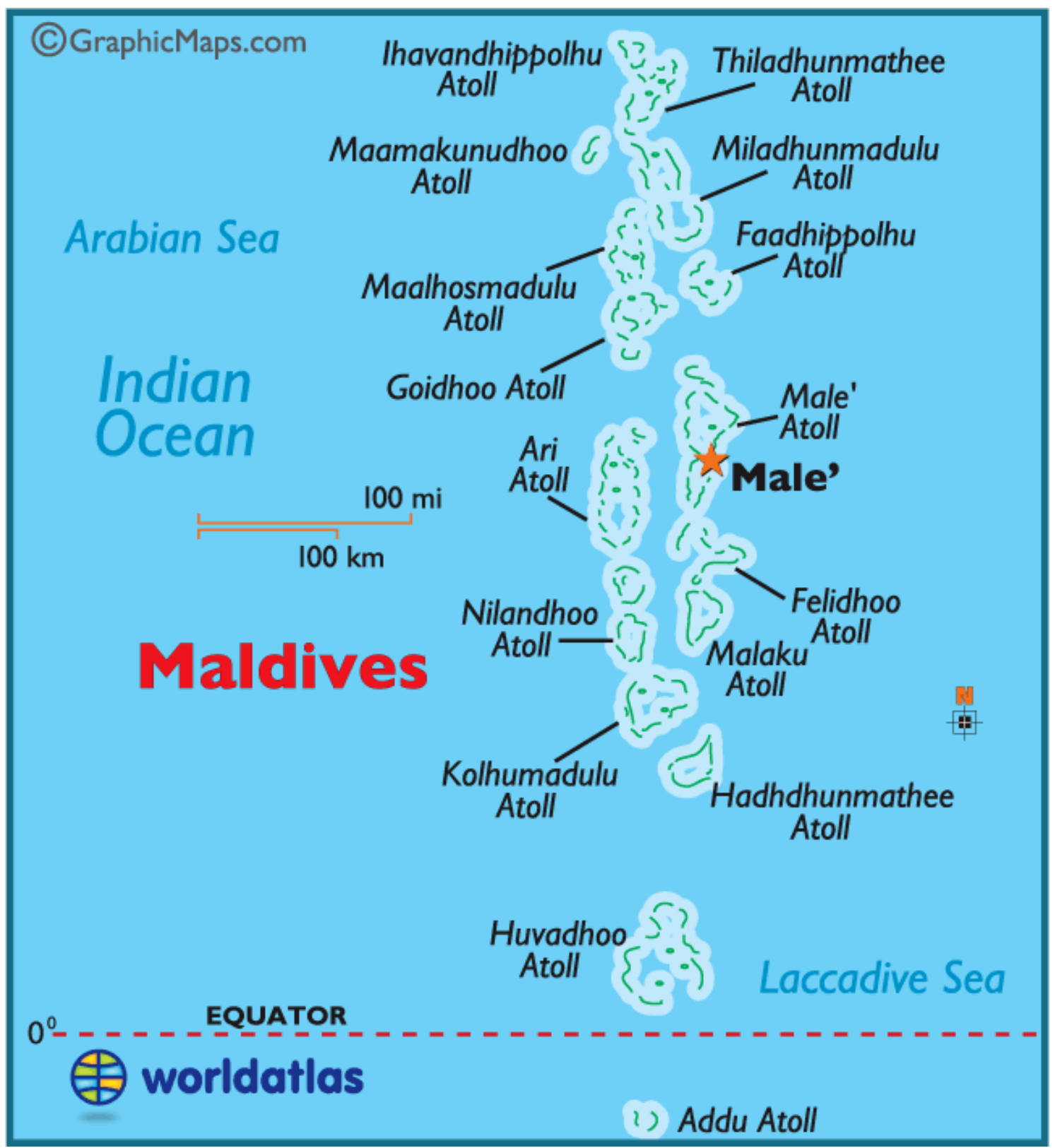

Una de las principales preocupaciones de estos países es la desaparición de su territorio, causado por el aumento del nivel del mar. Esto los obliga a buscar otras soluciones para sus poblaciones, ya sea a través de diferentes propuestas como la compra de un territorio, o iniciar negociaciones para que un Estado les ceda parte de su territorio.

Otro de los problemas que estos países también tienen es sobre la forma de hacer frente a los desastres repentinos (como ciclones, tsunamis, inundaciones, fuertes tormentas) que se 
producen provocando los desplazamientos temporarios de personas, así como las pérdidas materiales de infraestructura.

\section{IV.5.2. La situación económica de Kiribati, Tuvalu, Maldivas e Islas Marshall}

Estos países tienen la característica de que sus economías son muy pequeñas y dependientes del exterior. Sus territorios y poblaciones son también muy pequeñas. Los recursos naturales son limitados. Estos tres factores inciden sobre la economía de estos Estados Insulares.

La superficie territorial de estos países es muy pequeña: Kiribati $\left(717 \mathrm{~km}^{2}\right)$, Maldivas $\left(235 \mathrm{~km}^{2}\right)$, Tuvalu $\left(25,44 \mathrm{~km}^{2}\right)$, Islas Marshall $\left(181,4 \mathrm{~km}^{2}\right)$. Además, sus poblaciones son pequeñas también: Kiribati tiene 100.000 habitantes, Tuvalu, 10.000 habitantes, las Islas Marshall, 56.429 habitantes y Maldivas, 340.000 habitantes $^{336}$.

Maldivas es un Estado que se encuentra en el Océano Índico, a 750 km de India y Sri Lanka. Su capital es Malé con una población de 104.403 personas $^{337}$.

Las principales actividades económicas son la pesca y la agricultura de sobrevivencia. Además, en el caso de Maldivas, el turismo es una de las principales actividades.

Por otro lado, estos países tienen comunidades tradicionales, las cuales tienen economías de sobrevivencia, totalmente relacionada con el medio ambiente.

Según el Banco Mundial, el Producto Bruto Interno (PBI) de estos países es pequeño.

Maldivas tiene 2.300 millones de dólares de PBI, ocupando la posición 165 de la lista elaborada por el Banco Mundial correspondiente al año 2013. Las Islas Marshall tienen un PBI de 191 millones de dólares, ocupando el lugar 190, el PBI de Kiribati es de 169 millones de dólares (posición 191) y el de Tuvalu es de 38 millones de dólares colocándose en la posición $192^{338}$.

Esta lista considera un ranking de 192 países y, como se puede verificar, las últimas posiciones son ocupadas por estos Estados Insulares. Este es un indicativo del volumen de las economías de estos países, verificándose que son las menores.

Kiribati, Maldivas y Tuvalu son considerados en la lista de los países menos adelantados. Esta lista comprende un total de los 50 países en peor situación. Según el Índice de Países de Bajos Ingresos y con déficit de alimentos, también están Kiribati, Maldivas y

\footnotetext{
${ }^{336}$ UNSTATS. Op.cit.

${ }^{337}$ REIS DE FREITAS, 2013. Op.cit.

338 THE WORLD BANK. IBRO-IDA. Poverty \& Equity, s/f. Disponible en:

$<$ http://povertydata.worldbank.org/poverty/country/COL> acceso 4 de abril de 2015.
} 
Tuvalu. Esta lista abarca un total de 75 países $^{339}$. Kiribati y Tuvalu están en la Lista de Países Menos Desarrollados también.

\section{IV.5.3. Consideraciones previas sobre el análisis de la pobreza en las poblaciones de estos países}

La mayoría de estos Estados son países de bajo desarrollo. En gran parte, esto se debe a las características que les son propias, como territorios muy reducidos, economías de subsistencia (pesca y cultivos), economías muy dependientes del exterior y gran parte de sus poblaciones son comunidades tradicionales (estas se caracterizan por no buscar actividades lucrativas, sino que simplemente procuran sobrevivir).

La determinación del nivel de la pobreza de las poblaciones de estos países ha requerido que fuese realizada una investigación exhaustiva de los diferentes índices que podrían dar una noción sobre la cuestión tratada.

Uno de los problemas que se ha presentado es que gran parte de estos países no figuran en el mapa de la pobreza del Banco Mundial, por lo tanto, no ha podido ser utilizado este camino. Probablemente, la ausencia de estos países del mapa de la pobreza se deba a que no tienen representatividad significativa en el orden económico internacional.

Por otro lado, se analiza el PBI de estos países para verificar el nivel de incidencia de ellos en la Economía Mundial. De este modo, se puede verificar el nivel de riqueza de estos países en relación al orden económico internacional y así, la relevancia de estos países en el seno de la sociedad internacional y la repercusión de sus decisiones en relación a los otros países.

Otra dificultad es que muchos de estos constan como en desarrollo, siendo esta una designación demasiada amplia.

La posición de vulnerabilidad de estos Estados llevó a que Naciones Unidas creara la United Nations Office of the High Representative for the Least Developed Countries, Landlocked Developing Countries and Small Island Developing States (UN-OHRLLS), la cual se encarga de brindar soporte para contribuir al desarrollo de todas estas categorías de países que se encuentran en una situación de vulnerabilidad.

Por todo ello, se ha utilizado el Índices de Déficit Alimentario. Así, el análisis sobre la situación de estos países se hace a través de la combinación entre los datos resultantes del

${ }^{339}$ UNSTATS. Op.cit. 
análisis de la situación de estos países, tales como el Producto Bruto Interno, lo cual representa el nivel del crecimiento económico del país, el estudio de los países menos adelantados y el de los países con Déficit Alimentario.

\section{IV.5.3.1. Producto Bruto Interno de PEID}

Los Pequeños Estados Insulares en Desarrollo tienen economías muy limitadas. Esto se puede comprobar del análisis del índice de PBI de tales Estados. El análisis de esta variable permite que sea verificada la poca relevancia de estos países en el concierto del orden internacional. Se puede observar que, del total de las 194 posiciones del PBI de los Estados, la mayor parte de los PEID ocupan las peores situaciones. Esto se verifica porque del total de 194, estos países ocupan la mitad inferior de las posiciones (la posición 97 constituye la mitad inferior de la lista).

Singapur, Cuba y República Dominicana son los únicos países que están ubicados en posiciones que corresponden a la mitad superior de esta lista (arriba de la posición 97). El resto de estos países están en la mitad inferior de este cuadro.

El total de los Pequeños Estados Insulares en Desarrollo es de 36. Además, otra observación que puede establecerse del examen del cuadro sobre el PBI es que a partir de la posición 174, todas las posiciones siguientes son ocupadas por los PEID. Además, pueden ser considerados Belice y Cabo Verde. Esto constituye un total de 22 Estados. Estos países constituyen el 58\% del total de los PEID.

Por otro lado, se puede considerar que de la posición 142 ocupada por Haití a la 171, hay un total de 7 Estados, los que sumados a los anteriores constituyen el 85\% del todos de países considerados.

Este cuadro ha sido elaborado extrayendo los datos de la lista del PBI de los países del Banco Mundial correspondiente al año 2014 (Gross domestic product ${ }^{340}-2014$ elaborado por el Banco Mundial correspondiente al año 2014) $)^{341}$.

\section{Producto Bruto Interno de PEID}

A continuación, el detalle del PBI de los PEID.

\footnotetext{
${ }^{340}$ Es el Producto Bruto Interno de los Estados.

${ }^{341}$ WORLD BANK. Gross domestic product, 2014. Disponible en:

$<$ http://databank.worldbank.org/data/download/GDP.pdf> acceso 8 de abril de 2016.
} 


\section{Cuadro - PBI de los PEID}

\begin{tabular}{|c|c|c|}
\hline Posición & PEID & $\begin{array}{l}\text { PBI (en millones } \\
\text { de dólares) }\end{array}$ \\
\hline 36 & Singapur & 305,675 \\
\hline 67 & Cuba & 77,150 \\
\hline 73 & República Dominicana & 64,138 \\
\hline 102 & Trinidad y Tobago & 28,883 \\
\hline 115 & Papua New Guinea & 16,778 \\
\hline 125 & Jamaica & 13,891 \\
\hline 130 & Mauritius & 12,630 \\
\hline 142 & Haití & 8,713 \\
\hline 143 & Bahamas & 8,511 \\
\hline 153 & Suriname & 5,210 \\
\hline 157 & Fijo & 4,553 \\
\hline 160 & Barbados & 4,355 \\
\hline 163 & Guyana & 3,097 \\
\hline 165 & Maldivas & 3,062 \\
\hline 170 & Cabo Verde & 1,871 \\
\hline 172 & Belice & 1,699 \\
\hline 174 & Seychelles & 1,417 \\
\hline 175 & Timor Oriental & 1,407 \\
\hline 176 & St, Lucia & 1,221 \\
\hline 177 & Antigua y Barbuda & 1,221 \\
\hline 178 & Salomon Islands & 1,156 \\
\hline 179 & Guinea-Bissau & 1,022 \\
\hline 180 & Grenada & 912 \\
\hline 182 & St. Kitts and Nevis & 852 \\
\hline 183 & Vanuatu & 815 \\
\hline 184 & Samoa & 800 \\
\hline 185 & St. Vincent and the Grenadines & 729 \\
\hline 186 & Comoros & 624 \\
\hline 187 & Dominica & 524 \\
\hline 188 & Tonga & 434 \\
\hline 189 & São Tome and Principe & 337 \\
\hline 190 & Federated States of Micronesia & 318 \\
\hline 191 & Palau & 251 \\
\hline 192 & Islas Marshall & 187 \\
\hline 193 & Kiribati & 167 \\
\hline 194 & Tuvalu & 38 \\
\hline
\end{tabular}

Fuente: Elaboración propia con base en Banco Mundial, datos extraídos en octubre de 2014.

Como se puede observar de un total de 194 países los Pequeños Estados Insulares ocupan las peores posiciones en el ranking del Indice del Producto Bruto Interno, pues estos están en debajo de la mitad de esta lista de países. 


\section{IV.5.3.2. PMA-Déficit Alimentario}

Este cuadro considerando el Déficit Alimentario de los Pequeños Estados Insulares en Desarrollo ha sido elaborado con base a la lista total de los países en esas situaciones ${ }^{342}$.

Cuadro - PEID como PMA-Déficit Alimentario

\begin{tabular}{|l|l|}
\hline 19 & Comoros \\
\hline 22 & Cuba \\
\hline 36 & Guinea Bissau \\
\hline 37 & Haití \\
\hline 42 & Kiribati \\
\hline 49 & Maldivas \\
\hline 61 & Papua Nueva Guinea \\
\hline 64 & Samoa \\
\hline 65 & Saint Tome and Principe \\
\hline 68 & Islas Salomon \\
\hline 79 & Tuvalu \\
\hline 81 & Vanualu \\
\hline
\end{tabular}

Fuente: Elaboración propia.

IV.5.3.3. PEID y la Oficina de Naciones Unidas del Alto Representante para los Países Menos Desarrollados, los Países en Desarrollo sin litoral y los Pequeños Estados Insulares en Desarrollo/ United Nations Office of the High Representative for the Least Developed Countries, Landlocked Developing Countries and Small Island Developing States (UN-OHRLLS)

Una de las dificultades encontradas en relación con la imposibilidad de encontrar estos países en el mapa de la pobreza del Banco Mundial consiste en que algunos de estos Estados tienen economías demasiado pequeñas que no son representativas en el orden económico, y además algunos ni son miembros de Naciones Unidas. La UNOHRLLS (Oficina del Alto Representante para los Países Menos Desarrollados, los Países en Desarrollo sin litoral y los Pequeños Estados Insulares en Desarrollo) fue creada para brindar apoyo y contribuir a su desarrollo de los países más pobres, considerando entre estos la categoría de los Pequeños Países Insulares en Desarrollo. Aunque este organismo también se ocupa de los Países Menos Adelantados, y de los Países en Desarrollo Sin Litoral.

\footnotetext{
${ }^{342}$ FAO. Índice de Déficit Alimentar. Disponible en:

<http://www.fao.org/docrep/meeting/008/j2993s/j2993s01.pdf $>$ acceso 8 de abril de 2014.
} 
La Resolución 56/227 de la Asamblea General de Naciones Unidas de 24 de diciembre 2001 instituye la Oficina del Alto Representante para los Países Menos Desarrollados, los Países en desarrollo sin litoral y los Pequeños Estados Insulares en Desarrollo. Esto se fundamenta en la Resolución A/56/645 de la Asamblea General de Naciones Unidas de 28 de febrero de 2002.

La Resolución A/56/645 de la Asamblea General de Naciones Unidas incluye en la misma categoría a los Países Menos Desarrollados, los Países en desarrollo sin litoral y a los Pequeños Estados Insulares en Desarrollo, debido a que estos sufren un alto grado de vulnerabilidad.

En este sentido el parágrafo 2 de esta resolución observa:

2. El desarrollo económico y social de los países menos desarrollados, que representan los más pobres y segmento más débil de la comunidad internacional, continúa siendo un desafio importante para los países, así como por sus asociados para el desarrollo.

Juntos con el litoral países en desarrollo y los Pequeños Estados insulares en desarrollo, que se caracterizan por su exposición a una serie de vulnerabilidades y restricciones.

Esta Resolución recomienda que la Oficina del Coordinador Especial para los países menos desarrollados, países sin litoral e países insulares en desarrollo se convierta en la Oficina del Alto Representante para los Países Menos Desarrollados, los Países en Desarrollo sin litoral y los Pequeños Estados Insulares en Desarrollo. Además, establece que este organismo trabajaría en colaboración con UNCTAD.

Las funciones de ese organismo fueron establecidas en el parágrafo 17 de la Resolución A/56/645 de la Asamblea General de Naciones Unidas, donde se establece que la principal función de este organismo será brindar todo el apoyo para que estos países puedan alcanzar un desarrollo suficiente. Además, establece que trabajará junto con Ecosoc y proporcionará los informes anuales a la Asamblea General de Naciones Unidas.

También, observa en relación a los Pequeños Estados Insulares en Desarrollo que este organismo será responsable por el Programa de Acción para el Sostenible Desarrollo de los Pequeños Estados Insulares en Desarrollo. En este sentido, el parágrafo 17, apartado C señala:

(C) Apoyar, según proceda, el seguimiento coordinado de la aplicación de la Marco global de transporte de tránsito 
La cooperación entre litoral y de tránsito para los países en desarrollo sin litoral y el donante Comunidad

y el Programa de Acción para el Sostenible Desarrollo de los Pequeños Estados Insulares en Desarrollo;

Además, establece que trabajará en conjunto con sectores de la sociedad civil. En este sentido observa:

(D) Para llevar a cabo el trabajo de incidencia apropiado en favor de los países menos desarrollados, países en desarrollo sin litoral y los pequeños Estados insulares Estados en desarrollo en colaboración con las correspondientes partes de las Naciones Unidas, así como con los derechos civiles la sociedad, los medios de comunicación, el mundo académico y las fundaciones; ${ }^{343}$

Por otro lado, es preciso recordar que, en la ciudad de Bridgetown, Barbados, entre los días 25 de Abril y 6 de Mayo de 1994 se realizó la Conferencia Internacional sobre el Desarrollo Sustentable de los Pequeños Países Insulares en Desarrollo, de la cual resultó el Programa de Acción para el Desarrollo Sustentable de los Pequeños Países Insulares en Desarrollo. $^{344}$

La Oficina del Alto Representante para los Países Menos Desarrollados, los Países en Desarrollo sin litoral y los Pequeños Estados Insulares en Desarrollo considera un mayor número de países que la Alianza de Pequeños Países Insulares en Desarrollo.

Este Organismo hace una diferenciación entre países miembros de Naciones Unidas y aquellos que no son miembros.

\footnotetext{
${ }^{343}$ A / 56/645

${ }^{344}$ Programme of Action for the Sustainable Development of Small Island Developing States (Report of the Global Conference on the Sustainable Development of Small Island Developing States, Bridgetown, Barbados, 25 April6 May 1994.
} 
Cuadro - PEID miembros y no miembros de Naciones Unidas, cuadro creado por UNOHRLLS ${ }^{345}$

\section{Miembros de Naciones Unidas (38)}

$1 \quad$ Antigua y Barduba

2 Bahamas

3 Bahrain

4 Barbados

5 Belice

6 Cabo Verde

7 Comoros*

8 Cuba

9 Dominica

10 República Dominicana

11 Fiji

12 Grenada

13 Guinea-Bissau*

14 Guyana

15 Haití*

16 Jamaica

17 Kiribati*

18 Maldivas

19 Islas Marshall

20 Federated States of Micronesia

21 Mauritius

22 Nauru

23 Palau

24 Papua New Guinea

25 Samoa

26 São Tomé and Príncipe*

27 Singapur

28 St. Kitts and Nevis

29 St. Lucia

30 St. Vincent and the Grenadines

31 Seychelles

32 Solomon Islands*

33 Suriname

34 Timor Oriental*

35 Tonga

36 Trinidad y Tobago

37 Tuvalu*

38 Vanuatu*

*Son PMA

345 UNOHRLlS. Peid Miembros y No Miembros de Naciones Unidas, s/f. Disponible en: $<$ http://unohrlls.org/about-sids/country-profiles/>. 
No miembros de Naciones Unidas/ Miembros Asociados de las Comisiones Regionales (Non-UN Members/ Associate Members of the Regional Commissions) (cuadro creado por UNOHRLLS) ${ }^{346}$

1 American Samoa

2 Anguilla

3 Aruba

4 Bermuda

5 British Virgin Islands

6 Islas Caimán

7 Commonwealth of Northern Marianas

$8 \quad$ Islas Cook

9 Curacao

10 Polinesia Francesa

11 Guadalupe

12 Guam

13 Martinica

14 Montserrat

15 New Caledonia

16 Niue

17 Puerto Rico

18 Saint Maarten

19 Turks and Caicos Islands

20 U.S. Virgin Islands

* Solo Países Menos Adelantados

Fuente: UNOHRLLS.

${ }^{346}$ UNOHRLLS. Op.cit. 
No Miembros de la ONU / Miembros Asociados de las Comisiones Regionales (Non-UN Members/ Associate Members of the Regional Commissions) y los Países a los que pertenecen estos territorios. Cuadro elaborado por Oficina del Alto Representante para los Países Menos Desarrollados, los Países en Desarrollo sin litoral y los Pequeños Estados Insulares en Desarrollo

1. Samoa Americana (Estados Unidos)

2. Anguilla (Reino Unido)

3. Aruba (Países Bajos)

4. Bermudas (Reino Unido)

5. Islas Vírgenes Británicas (Reino Unido)

6. Islas Cayman (Reino Unido)

7. Islas Marianas del Norte (Estados Unidos)

8. Islas Cook (Nueva Zelandia)

9. Curacao

10. Polinesia Francesa (Francia)

11. Guadeloupe (Francia)

12. Guam (Estados Unidos)

13. Martinica (Francia)

14. Monserrat (Reino Unido)

15. New Caledonia (Francia)

16. Niue

17. Puerto Rico (Estados Unidos)

18. Saint Martin

19. Islas Turcas y Caicos (Reino Unido)

20. Islas Vírgenes Americanas (Estados Unidos)

\section{IV.5.3.4. Los PEID: Países En Desarrollo-Países Menos Adelantados}

Uno de los Índices que puede ser considerado, es el que califica los países desarrollados, países en desarrollo y países menos adelantados. El problema de este Índice es que son claramente definidos los extremos: países desarrollados y países menos adelantados, mientras que en el rol de los países en desarrollo quedan incluidos una variedad de países muy diversos. 
Cuadro - Los PEID: Países En Desarrollo-Países Menos Adelantados

\begin{tabular}{|l|}
\hline Países en desarrollo \\
\hline Antigua y Barbuda \\
\hline Bahamas \\
\hline Belice \\
\hline Cape Verde \\
\hline Cuba \\
\hline Dominica \\
\hline República Dominicana \\
\hline Fiji \\
\hline Federated States of Micronesia \\
\hline Grenada \\
\hline Guyana \\
\hline Jamaica \\
\hline Maldives \\
\hline Islas Marshall \\
\hline Mauritius \\
\hline Nauru \\
\hline Palau \\
\hline Papua New Guinea \\
\hline Samoa \\
\hline Seychelles \\
\hline St. Lucia \\
\hline St. Vincent y las Grenadines \\
\hline Suriname \\
\hline Tonga \\
\hline Trinidad y Tobago \\
\hline Países menos adelantados \\
\hline Comoros \\
\hline Guinea-Bissau \\
\hline Haití \\
\hline Kiribati \\
\hline São Tome and Principe \\
\hline Solomon Islands \\
\hline Timor Oriental \\
\hline
\end{tabular}

Fuente: Elaboración propia

${ }^{347}$ NACIONES UNIDAS. List of Least Developed Countries, 16 de febrero de 2016. Disponible en: $<$ http://www.un.org/en/development/desa/policy/cdp/ldc/ldc_list.pdf $>$ acceso 8 de abril de 2016. 


\begin{tabular}{|c|c|c|c|c|}
\hline \multirow[b]{2}{*}{ PAIS } & \multicolumn{4}{|c|}{$\begin{array}{c}\text { PRODUCTO } \\
\text { INTERNO BRUTO }\end{array}$} \\
\hline & Posición & $\begin{array}{l}\text { BANCO MUNDIAL } \\
\text { (PIB en U\$D) }\end{array}$ & Posición & $\begin{array}{l}\text { NACIONES UNIDAS } \\
\text { (PIB en U\$D ) }\end{array}$ \\
\hline Antigua y Barbuda & 177 & 1,221 & & \\
\hline Bahamas & 142 & 8,511 & & \\
\hline Barbados & 159 & 4,355 & & \\
\hline Belice & 172 & 1,699 & & \\
\hline Cabo Verde & 170 & 1,871 & & \\
\hline Comoros & 186 & 624 & & \\
\hline Cuba & 67 & 77,15 & & \\
\hline Dominica & 187 & 524 & & \\
\hline Republica Dominicana & 69 & 67,103 & & \\
\hline Estados Federados de Micronesia & 190 & 318 & & \\
\hline Fiji & 156 & 4,532 & & \\
\hline Granada & 181 & 884 & & \\
\hline Guinea Bissau & 179 & 1,209 & & \\
\hline Guyana & 162 & 3,097 & & \\
\hline Haiti & 141 & 8,713 & & \\
\hline Jamaica & 125 & 13,891 & & \\
\hline Kiribati & 193 & 167 & & \\
\hline Maldivas & 164 & 3,062 & & \\
\hline Islas Marshall & 164 & 3,062 & & \\
\hline \multicolumn{5}{|l|}{ Estados Federados de Micronesia } \\
\hline Mauricios & 129 & 12,63 & & \\
\hline Palau & 191 & 251 & & \\
\hline Papua Nueva Guinea & 115 & 16,929 & & \\
\hline \multicolumn{5}{|l|}{ Samoa } \\
\hline Singapur & 38 & 292,739 & & \\
\hline Saint Kitts anda Nevis & 174 & 852 & & \\
\hline Saint Lucia & 176 & 1,404 & & \\
\hline Saint Vicent and The Grenadines & 185 & 729 & & \\
\hline Seychelles & 174 & 1,423 & & \\
\hline Islas Salomon & 178 & 1,158 & & \\
\hline Suriname & 152 & 5,21 & & \\
\hline Timor del Este & 175 & 1,417 & & \\
\hline Tonga & 188 & 434 & & \\
\hline Trinidad and Tobago & 100 & 27,806 & & \\
\hline Tuvalú & 194 & 27,806 & & \\
\hline Vanuatu & 183 & 38 & & \\
\hline Puerto Rico & 59 & 103,135 & & \\
\hline Samoa Americana & & & & \\
\hline
\end{tabular}




\begin{tabular}{|c|c|c|c|c|}
\hline \multirow{2}{*}{ PAIS } & \multicolumn{3}{|c|}{$\begin{array}{c}\text { PRODUCTO } \\
\text { INTERNO BRUTO }\end{array}$} & \multirow[b]{2}{*}{$\begin{array}{l}\text { NACIONES UNIDAS } \\
\text { (PIB en U\$D ) }\end{array}$} \\
\hline & Posición & $\begin{array}{l}\text { BANCO MUNDIAL } \\
\text { (PIB en U\$D) }\end{array}$ & Posición & \\
\hline $\begin{array}{l}\text { Guam } \\
\text { Comoros } \\
\text { Nauru } \\
\text { Anguilla } \\
\text { Aruba } \\
\text { Bermudas } \\
\text { Islas Cayman } \\
\text { Curacao } \\
\text { Monserrat } \\
\text { New Caledonia } \\
\text { Saint Marteen } \\
\text { Turks and Caicos } \\
\text { Commonwealth of the Northen } \\
\text { Marianas } \\
\text { Islas Cook } \\
\text { French Polynesia } \\
\text { Guadeloupe } \\
\text { Martinique } \\
\text { Montserrat } \\
\text { Niue } \\
\text { US Virgin Islands }\end{array}$ & 189 & 624 & $\begin{array}{l}208 \\
205 \\
173 \\
156 \\
167 \\
169 \\
210 \\
141 \\
190 \\
197\end{array}$ & $\begin{array}{c}182 \\
311 \\
2,664 \\
5,601 \\
3,48 \\
3,159 \\
63 \\
10,234 \\
1,059 \\
797 \\
\\
\\
311 \\
5,623 \\
\\
63 \\
\ldots\end{array}$ \\
\hline
\end{tabular}




\begin{tabular}{|c|c|c|}
\hline PAIS & $\begin{array}{c}\text { ASISTENCIA OFICIAL Y } \\
\text { MAYORES SOCIOS PARA EL } \\
\text { DESARROLLO }\end{array}$ & MAYORES SOCIOS PARA EL DESARROLLO \\
\hline Antigua y Barbuda & $\$ 2,350,000$ USD & US \\
\hline Bahamas & no evaluable & \\
\hline Barbados & US $\$ 16,200,000$ (en 2010) & $\begin{array}{l}\text { E.U. Instituciones, } \\
\text { Canada, IDB Sp. } \\
\text { Fund, Japón, GEF }\end{array}$ \\
\hline Belice & US $\$ 25,180,000$ & $\begin{array}{l}\text { E.U, CardBD, Japón } \\
\text { Ofid, Kuwait (OECD } \\
\text { 2010) }\end{array}$ \\
\hline Cabo Verde & $\begin{array}{c}\text { Net ODA } \\
\text { US\$ } 246,140,000 \\
\text { OEDC } 2013\end{array}$ & $\begin{array}{l}\text { Portugal, Estados } \\
\text { Unidos, Unión } \\
\text { Europea, España, } \\
\text { Japón }\end{array}$ \\
\hline Comoros & $\begin{array}{c}\text { Net ODA } \\
\text { US\$ 68,670,000 (OEDC } \\
2014) \\
\end{array}$ & $\begin{array}{c}\text { Francia, IDA y } \\
\text { Comunidad Europea }\end{array}$ \\
\hline Cuba & $\begin{array}{c}\text { Net ODA } \\
\text { US\$ 87,850,000 (OEDC } \\
2012)\end{array}$ & $\begin{array}{c}\text { España, Estados } \\
\text { Unidos, Canada } \\
\text { Global Fund }\end{array}$ \\
\hline Dominica & $\begin{array}{c}\text { Net ODA } \\
\text { US\$ 25,660,000 } \\
\text { OECD } 2012\end{array}$ & $\begin{array}{c}\text { Caribian } \\
\text { Development } \\
\text { Bank, IMF, } \\
\text { Comunidad Europea }\end{array}$ \\
\hline Republica Dominicana & $\begin{array}{c}\text { Net ODA } \\
\text { US\$ 26,130,000 (OEDC } \\
2012)\end{array}$ & $\begin{array}{l}\text { E.U. Instituciones, } \\
\text { Estados Unidos, } \\
\text { España, Global } \\
\text { Fund, Japón }\end{array}$ \\
\hline Estados Federados de Micronesia & $\begin{array}{c}\text { Net ODA } \\
\text { US\$ 60.8 Millones }\end{array}$ & $\begin{array}{l}\text { Estados Unidos, Japón, } \\
\text { Australia, E.U. Institution, } \\
\text { AsDB Fundo Especial } \\
\text { (OEDC 2012) }\end{array}$ \\
\hline Fiji & $\begin{array}{c}\text { Net ODA } \\
\text { US\$ 107,340,000 (OEDC } \\
2012 \\
\end{array}$ & $\begin{array}{c}\text { Australia, Japón, Estados } \\
\text { Unidos, Nueva Zelandia } \\
\text { UNDP }\end{array}$ \\
\hline Granada & $\begin{array}{c}\text { Net ODA } \\
\text { US\$ 7,650,000 }\end{array}$ & $\begin{array}{c}\text { Banco De Desarrollo del } \\
\text { Caribe } \\
\text { Comunidad Europea y Reino } \\
\text { Unido }\end{array}$ \\
\hline
\end{tabular}




\begin{tabular}{|c|c|c|}
\hline PAIS & $\begin{array}{c}\text { ASISTENCIA OFICIAL Y } \\
\text { MAYORES SOCIOS PARA EL } \\
\text { DESARROLLO }\end{array}$ & MAYORES SOCIOS PARA EL DESARROLLO \\
\hline Guinea Bissau & $\begin{array}{c}\text { Net ODA } \\
\text { US\$ 78,870,000 (OEDC } \\
2012)\end{array}$ & $\begin{array}{c}\text { AfDf, E.U. Institutions, } \\
\text { IDA, Portugal, IMF Concesional } \\
\text { Funds }\end{array}$ \\
\hline Guyana & $\begin{array}{c}\text { Net ODA } \\
\text { US\$ } 114,450,000\end{array}$ & $\begin{array}{l}\text { IDB Sp. Funds, E.U. } \\
\text { Institutions } \\
\text { U.S.A., Noruega, } \\
\text { Global Fund }\end{array}$ \\
\hline Haiti & $\begin{array}{l}\text { Net ODA US\$ } \\
1,275,190,000\end{array}$ & $\begin{array}{c}\text { Estados Unidos, IBD Sp. Fund } \\
\text { IDA (OECD, 2012) }\end{array}$ \\
\hline Jamaica & $\begin{array}{c}\text { Net ODA } \\
\text { US\$ 21,050,000 }\end{array}$ & $\begin{array}{c}\text { Estados Unidos, Comunidad } \\
\text { Europea, Reino Unido }\end{array}$ \\
\hline Kiribati & $\begin{array}{c}\text { Net ODA } \\
\text { US\$ 64,660,000 }\end{array}$ & $\begin{array}{c}\text { Australia, Japón, Nueva } \\
\text { Zelandia, GEF, E.U. Instituciones }\end{array}$ \\
\hline Maldivas & $\begin{array}{c}\text { Net ODA } \\
\text { US\$ 58,010,000 }\end{array}$ & $\begin{array}{l}\text { Japón, AsDB Especial Funds, } \\
\text { IDA, Dinamarca, E.U. } \\
\text { Instituciones, Australia } \\
\text { (OEDC 2012) }\end{array}$ \\
\hline Islas Marshall & $\begin{array}{c}\text { Net ODA } \\
\text { US\$ 76,010,000 }\end{array}$ & $\begin{array}{c}\text { Estados Unidos, Japón, } \\
\text { Australia }\end{array}$ \\
\hline Estados Federados de Micronesia & $\begin{array}{c}\text { Net ODA } \\
\text { US\$ } 115,040,000\end{array}$ & $\begin{array}{l}\text { Estados Unidos, Japón, } \\
\text { Australia, E.U. Institution, } \\
\text { AsDB Fundo Especial }\end{array}$ \\
\hline Mauricius & US\$ 28 Millones & $\begin{array}{c}\text { Australia, Japón, Nueva } \\
\text { Zelandia, E.U. Instituciones, Suiza } \\
\text { Suiza }\end{array}$ \\
\hline Palau & $\begin{array}{c}\text { Net ODA } \\
\text { US\$ } 15,000,000\end{array}$ & $\begin{array}{l}\text { Estados Unidos, Japón, } \\
\text { Australia y España }\end{array}$ \\
\hline Papua Nueva Guinea & $\begin{array}{c}\text { Net ODA } \\
\text { US\$ } 664,840,000\end{array}$ & $\begin{array}{c}\text { Australia, E.U. Institution, } \\
\text { Japón, Global Fund, Nueva } \\
\text { Zelandia } \\
\end{array}$ \\
\hline Samoa & $\begin{array}{c}\text { Net ODA } \\
\text { US\$368.3 Millones }\end{array}$ & $\begin{array}{c}\text { Australia, Japón, AsDB } \\
\text { Special Fund, Nueva Zelandia }\end{array}$ \\
\hline
\end{tabular}




\begin{tabular}{|c|c|c|}
\hline PAIS & $\begin{array}{c}\text { ASISTENCIA OFICIAL Y } \\
\text { MAYORES SOCIOS PARA EL } \\
\text { DESARROLLO }\end{array}$ & MAYORES SOCIOS PARA EL DESARROLLO \\
\hline Singapur & $\ldots$ & $\ldots$ \\
\hline Saint Kitts anda Nevis & $\begin{array}{c}\text { Net ODA } \\
\text { US\$21,910,000 }\end{array}$ & $\begin{array}{l}\text { Banco de Desarrollo del } \\
\text { Caribe, y Comunidad Europea }\end{array}$ \\
\hline Saint Lucia & $\begin{array}{c}\text { Net ODA } \\
\text { US\$26,840,000 }\end{array}$ & $\begin{array}{c}\text { E.U. Instituciones, } \\
\text { CarDB, IDB, IMF } \\
\text { (Concessional Trust Fund, Japón } \\
\text { Japón }\end{array}$ \\
\hline Saint Vicent and The Grenadines & $\begin{array}{c}\text { Net ODA } \\
\text { US\$ 8,560,000 }\end{array}$ & $\begin{array}{l}\text { E.U. Instituciones, CarDB, } \\
\text { IMF, Japón, IDA }\end{array}$ \\
\hline Seychelles & $\begin{array}{c}\text { Net ODA } \\
\text { US\$ } 35.330 .000\end{array}$ & $\begin{array}{c}\text { Francia, Japón, Emiratos } \\
\text { Árabes, Unidos, E.U. Instituciones } \\
\text { Instituciones, Italia }\end{array}$ \\
\hline Islas Salomon & $\begin{array}{c}\text { Net ODA } \\
\text { US\$ } 304,980,000\end{array}$ & $\begin{array}{c}\text { Australia, Nueva Zelandia, E.U. } \\
\text { Instituciones, Japón, AsDB } \\
\text { Special Fund }\end{array}$ \\
\hline Suriname & $\begin{array}{c}\text { Net ODA } \\
\text { US\$ } 39,600,000\end{array}$ & $\begin{array}{l}\text { Netherlands, E.U. } \\
\text { Instituciones, Global Fund } \\
\text { Francia, IDB Sp. Fund }\end{array}$ \\
\hline Timor del Este & $\begin{array}{c}\text { Net ODA } \\
\text { US\$283,070,000 }\end{array}$ & $\begin{array}{c}\text { Australia, Portugal, Estados } \\
\text { Unidos, Japón, E.U } \\
\text { Instituciones }\end{array}$ \\
\hline Tonga & $\begin{array}{c}\text { Net ODA } \\
\text { US\$ 78,260,000 }\end{array}$ & $\begin{array}{c}\text { Japón, Australia, Nueva } \\
\text { Zelandia, IDA, AsDB Special } \\
\text { Fund }\end{array}$ \\
\hline Trinidad and Tobago & US\$ 4.330.000 & $\begin{array}{l}\text { E.U. Instituciones, Canadá, } \\
\text { Estados Unidos, Francia, } \\
\text { IDB Sp. Fund }\end{array}$ \\
\hline Tuvalú & $\begin{array}{c}\text { Net ODA } \\
\text { US\$ } 24,490,000\end{array}$ & $\begin{array}{c}\text { Japón, Australia, Nueva } \\
\text { Zelandia, AsDB Special Funds } \\
\text { E.U. Instituciones. }\end{array}$ \\
\hline Vanuatu & $\begin{array}{c}\text { Net ODA } \\
\text { US\$ } 101,420,000\end{array}$ & $\begin{array}{l}\text { Australia, Estados Unidos, } \\
\text { Japón, Nueva Zelandia, } \\
\text { Francia }\end{array}$ \\
\hline \multicolumn{3}{|l|}{ Puerto Rico } \\
\hline Samoa Americana & $\begin{array}{c}\text { más de } 40 \text { millones em } \\
\text { em } 1994\end{array}$ & $\begin{array}{c}\text { soporte financiero de US } \\
\ldots\end{array}$ \\
\hline
\end{tabular}




\begin{tabular}{|c|c|c|}
\hline PAIS & $\begin{array}{c}\text { ASISTENCIA OFICIAL Y } \\
\text { MAYORES SOCIOS PARA EL } \\
\text { DESARROLLO }\end{array}$ & MAYORES SOCIOS PARA EL DESARROLLO \\
\hline \multicolumn{3}{|l|}{ Guam } \\
\hline \multicolumn{3}{|l|}{ Comoros } \\
\hline \multicolumn{3}{|l|}{ Nauru } \\
\hline Anguilla & Net ODA US $\$ 8$ milliones. & $\begin{array}{c}\text { Comunidad Europea, } \\
\text { Reino Unido y Canada (OECD } \\
\text { 2010) }\end{array}$ \\
\hline Aruba & $\begin{array}{l}\text { Net ODA em } 2006 \\
\text { US\$ } 76 \text { Millones }\end{array}$ & $\begin{array}{c}\text { Netherlands, } \\
\text { Banco de Desarrollo del Caribe } \\
\text { y Reino Unido }\end{array}$ \\
\hline Bermudas & & $\ldots$ \\
\hline Islas Cayman & & $\ldots$ \\
\hline Curacao & $\ldots$ & $\ldots$ \\
\hline Monserrat & US \$26 Millones. & $\begin{array}{c}\text { Reino Unido, E.U. } \\
\text { Instituciones, Canadá, } \\
\text { CardDB, UNDP (OECD 2010) }\end{array}$ \\
\hline New Caledonia & $\ldots$ & $\ldots$ \\
\hline \multicolumn{3}{|l|}{ Saint Marteen } \\
\hline Turks and Caicos & $\ldots$ & .. \\
\hline Commonwealth of the Northen & & Receives extensive funding from the US. \\
\hline Marianas & & de Estados Unidos \\
\hline Islas Cook & Net ODA US \$13 Millones. & $\begin{array}{l}\text { Italia, Nueva Zelandia y } \\
\text { Australia (OEDC 2010) }\end{array}$ \\
\hline French Polynesia & $\ldots$ & $\ldots$ \\
\hline Guadeloupe & $\ldots$ & $\ldots$ \\
\hline Martinique & $\ldots$ & $\ldots$ \\
\hline Montserrat & US \$26 Millones & $\begin{array}{l}\text { Reino Unido, } \\
\text { Canada, E.U. Instituciones, } \\
\text { CarDB, UNDP (OECD 2010) }\end{array}$ \\
\hline Niue & Net ODA US \$15 Millones & $\begin{array}{c}\text { Nueva Zelandia, Australia } \\
\text { y Comunidad Europea } \\
\text { (OECD 2010) }\end{array}$ \\
\hline US Virgin Islands & $\ldots$ & $\ldots$ \\
\hline
\end{tabular}




\begin{tabular}{|c|c|c|c|}
\hline \multirow{2}{*}{ PAIS } & \multicolumn{2}{|c|}{ INDICADORES AMBIENTALES } & \multirow{2}{*}{\begin{tabular}{|c} 
DESARROLLO \\
HUMANO \\
(UNDP 2013) \\
\\
Posición
\end{tabular}} \\
\hline & $\begin{array}{c}\text { \% DE ESPECIES EN } \\
\text { PELIGRO DE } \\
\text { EXTINCION }\end{array}$ & $\begin{array}{l}\text { EMISIONES CO2 (TON PER } \\
\text { CAPITA ) UNDP ( } 2013\end{array}$ & \\
\hline Antigua y Barbuda & 0,083 & 5.1 & 67 \\
\hline Bahamas & 0,1 & 6,5 & 49 \\
\hline Barbados & $8.7 \%$ & 5 & 38 \\
\hline Belice & $6,40 \%$ & $1, .3$ & 96 \\
\hline Cabo Verde & 12.5 & 0.6 & 132 \\
\hline Comoros & 11.7 & 0.2 & 169 \\
\hline Cuba & 18.1 & 2.8 & 59 \\
\hline Dominica & 8.6 & 1.9 & 72 \\
\hline Republica Dominicana & 16.1 & 2.2 & 96 \\
\hline Estados Federados de Micronesia & 13.7 & 0.6 & 117 \\
\hline Fiji & 13.1 & 1.5 & 96 \\
\hline Granada & 10.5 & 2.4 & 63 \\
\hline Guinea Bissau & 5.7 & 0.2 & 176 \\
\hline Guyana & 3.8 & 2.0 & 118 \\
\hline Haiti & 19.4 & 0.3 & 161 \\
\hline Jamaica & 15.2 & 4.5 & 85 \\
\hline Kiribati & 12.4 & 0.3 & 121 \\
\hline Maldivas & 9.1 & 3.0 & 104 \\
\hline Islas Marshall & 11 & 1.9 & $\ldots$ \\
\hline Estados Federados de Micronesia & 13.7 & 0.6 & 117 \\
\hline Mauricios & 15,2 & 3,1 & 80 \\
\hline Palau & 12.1 & 3.9 & 52 \\
\hline Papua Nueva Guinea & 11.4 & 0.3 & 156 \\
\hline Samoa & 10.8 & 0.9 & 96 \\
\hline Singapur & 13.7 & 6.7 & 18 \\
\hline Saint Kitts anda Nevis & 8.6 & 4.9 & 72 \\
\hline Saint Lucia & 9.4 & 2.3 & 88 \\
\hline Saint Vicent and The Grenadines & 9 & 1.8 & 83 \\
\hline Seychelles & 16.1 & 7.8 & 46 \\
\hline Islas Salomon & 14.8 & 0.4 & 143 \\
\hline Suriname & 3.5 & 4,7 & 104 \\
\hline Timor del Este & 5.2 & 0.2 & 134 \\
\hline Tonga & 8,5 & 1.7 & 95 \\
\hline Trinidad and Tobago & 6.8 & 37.4 & 67 \\
\hline Tuvalú & 13 & $\ldots$ & $\ldots$ \\
\hline Vanuatu & 12 & 0.4 & 124 \\
\hline Puerto Rico & & & $52(2008)$ \\
\hline Samoa Americana & $\ldots$ & $\ldots$ & $103(2008)$ \\
\hline
\end{tabular}




\begin{tabular}{|c|c|c|c|}
\hline \multirow{2}{*}{ PAIS } & \multicolumn{2}{|c|}{ INDICADORES AMBIENTALES } & \multirow{2}{*}{$\begin{array}{l}\text { DESARROLLO } \\
\text { HUMANO } \\
\text { (UNDP 2013) } \\
\text { Posición }\end{array}$} \\
\hline & $\begin{array}{c}\text { \% DE ESPECIES EN } \\
\text { PELIGRO DE } \\
\text { EXTINCION } \\
\end{array}$ & $\begin{array}{l}\text { EMISIONES CO2 (TON PER } \\
\text { CAPITA ) UNDP ( } 2013\end{array}$ & \\
\hline Guam & $\ldots$ & $\ldots$ & $54(2008)$ \\
\hline Comoros & & & 159 \\
\hline \multicolumn{4}{|l|}{ Nauru } \\
\hline Anguilla & $\ldots$. & $\ldots$ & $79(2009)$ \\
\hline Aruba & $\ldots$ & 22.8 & $49(2008)$ \\
\hline Bermudas & $\ldots$ & $\ldots$ & $7(2008)$ \\
\hline Islas Cayman & $\ldots$ & $\ldots$ & $4(2008)$ \\
\hline Curacao & $\ldots$ & $\ldots$ & $\ldots$ \\
\hline Monserrat & $\ldots$ & $\ldots$ & 106 (2009) \\
\hline New Caledonia & $\ldots$ & $\ldots$ & 77 \\
\hline \multicolumn{4}{|l|}{ Saint Marteen } \\
\hline Turks and Caicos & $\ldots$ & $\ldots$ & 72 \\
\hline Commonwealth of the Northen & & & 71 \\
\hline \multicolumn{4}{|l|}{ Marianas } \\
\hline Islas Cook & $\ldots$ & $\begin{array}{c}12.7 \text { (2009) U.s. Energy } \\
\text { Information } \\
\text { Administration }\end{array}$ & 101 \\
\hline French Polynesia & $\ldots$ & $\ldots$ & 58 \\
\hline Guadeloupe & $\ldots$ & $\ldots$ & 91 (2009) \\
\hline Martinique & $\ldots$ & $\ldots$ & $53(2009)$ \\
\hline Montserrat & $\ldots$ & $\ldots$ & $106(2009)$ \\
\hline Niue & $\ldots$ & $\ldots$ & $129(2009)$ \\
\hline US Virgin Islands & $\ldots$ & $\ldots$ & $59(2009)$ \\
\hline
\end{tabular}

\section{IV.5.4. Conclusiones del análisis de los Indicadores sobre PEID}

La situación de vulnerabilidad de los Pequeños Países Insulares se extiende a diversos aspectos como la poca extensión territorial, la escasez de recursos, economías dependientes del exterior y de subsistencia, problemas ambientales.

Los Pequeños Paises Insulares en Desarrollo no tienen importancia en el concierto de la economía mundial, pues esto queda demostrado a partir del análisis del índice del Producto Bruto Interno tanto el considerado por el Banco Mundial como el de Naciones Unidas, lo cual ha quedado demostrado del análisis del Cuadro sobre PBI. 
Además, la fragilidad de estos países queda demostrada al verificar que todos estos países reciben ayuda económica internacional, porque hacen parte de la lista de países que precisan de soporte económico. Algunos de estos países son Países Menos Adelantados, lo que significa que ocupan las peores posiciones.

Todos estos países tienen economías primarias, pues solamente venden al exterior productos primarios, lo cual demuestra la fragilidad de las economías.

Se trata de economías dependientes del extranjero tanto por la necesidad de ayudas económicas, así como por las deudas externas, así como por los flujos de dinero del exterior que reciben.

El Indice de Desarrollo Humano apuntado en el cuadro demuestra que la mayoría de estos países ocupan las peores posiciones, por lo tanto, sus poblaciones sufren la falta del desarrollo.

El análisis de las variables ambientales demuestra que todos estos países sufren la pérdida de especies.

Por otro lado, queda demostrado que estos países han sido los que menos han contribuido a las emisiones de gases de Dióxido de Carbono, lo que contribuye a la pérdida de la capa de ozono, provocando el efecto invernadero.

Además, la vulnerabilidad de estos países queda demostrada pues ha sido creada la Oficina para fomentar el desarrollo de estos países. 


\section{IV.6. Los desplazados ambientales forzados de los desastres}

\section{IV.6.1. Los desplazados ambientales forzados de los desastres en el período 2010-2012}

En el período de 2008-2012, los países con mayores cantidades de desplazados ambientales forzados fueron:

$\begin{array}{ll}\text { China } & 49.782 .000 \\ \text { India } & 23.775 .000 \\ \text { Paquistán } & 14.991 .000 \\ \text { Filipinas } & 12.343 .000 \\ \text { Nigeria } & 6.818 .000^{348}\end{array}$

Filipinas y Paquistán son dos países que tienen altos desplazamientos ambientales forzados en términos relativos a la población total de esos países.

En el caso de China, es necesario observar que se trata de un país que, en términos absolutos, tiene una altísima cantidad de desplazados ambientales forzados, así como de personas que viven bajo la línea de pobreza (con menos de 3,10 dólares por día): 257,3 millones de pobres $^{349}$.

Hay regiones que son las más afectadas por los desastres ambientales repentinos. En tal sentido, es necesario advertir:

\footnotetext{
La región de Asia-Pacífico está altamente expuesta a los peligros relacionados con el clima. Tiene la mayor densidad de población de cualquier continente, especialmente a lo largo de sus costas, y es el hogar del mayor número de personas que viven en la pobreza. Seis de los diez países más vulnerables al cambio climático en el mundo se encuentran en la región. En consecuencia, el desplazamiento inducido por el clima es un problema importante en algunas partes de la región ${ }^{350}$.
}

El sudeste de Asia atraviesa por las peores situaciones en relación con los desplazamientos ambientales forzados, repitiéndose todos los años las mismas catástrofes ambientales. Esto demuestra la falta de adopción de medidas preventivas y de políticas de asistencia ante la emergencia por parte de los gobiernos, así como por parte de la comunidad internacional, siendo esta cuestión de vital importancia para hacerle frente a la crisis producida por los desastres repentinos.

\footnotetext{
${ }^{348}$ Datos extraídos de la Tabla 5.1 de INTERNAL DISPLACEMENT MONITORING CENTER. NORWEGIAN REFUGEE COUNCIL (IDMC-NRC). Global Estimatives 2012. Peaple displaced by disasters, mayo 2013. Disponible en: $<$ http://www.internal-displacement.org/assets/publications/2013/2012-global-estimates-corporateen.pdf $>$ acceso 10 de octubre de 2014.

${ }^{349}$ THE WORLD BANK. IBRO-IDA. Op.cit.

${ }^{350}$ INTERNAL DISPLACEMENT MONITORING CENTER. NORWEGIAN REFUGEE COUNCIL (IDMCNRC). Quarterly Update, enero-marzo, 2012a, p. 3.
} 
El informe de Internal Displacement Monitoring Center. Norwegian Refugee Council observa:

En 2012, como en el período 2008-2012 en general, los mismos cinco países (China, India, Paquistán, Filipinas y Nigeria) tuvieron el mayor número de personas desplazadas. India tuvo el más nuevo número de personas desplazadas en todo el mundo en 2012 (9,1 millones) y el segundo mayor número de desplazados en el período 2008-2012 (23,8 millones).

Sin embargo, esto era casi la mitad del número en China, donde hubo 49,8 millones de desplazados durante el mismo período de cinco años.

En el período 2008-2012, los niveles de desplazamiento en las Filipinas y Paquistán, los colocan también entre los países con los más altos niveles de desplazamiento en relación con el tamaño de sus poblaciones. En Filipinas, los desplazamientos anuales tuvieron entre 1 y 3,9 millones de personas, mientras que en Paquistán, las estimaciones anuales han variado ampliamente entre los 85.000 en 2009 y 11 millones en $2010^{351}$.

El IDMC ${ }^{352}$ considera que "en 2010, al menos 42,3 millones de personas fueron nuevamente desplazadas por los desastres naturales repentinos”. En ese año, se puede observar que los desplazamientos causados por los desastres ambientales se han localizado principalmente en Asia, correspondiendo a este continente el $77 \%$ del total. El 19\% de los desastres ocurrieron en América y el 4\% del total correspondió a África. Las regiones menos afectadas fueron Europa con 63.000 desplazados y Oceanía con 31.000 personas desplazadas. Además, IDMC observa que los 38,4 millones de desplazados corresponden a 10 países, de los cuales seis son de Asia (China, Paquistán, India, Filipinas, Tailandia y Bangladesh) y cuatro de América (Colombia, Chile, Haití y México). En África, hubo grandes desplazamientos en Nigeria con 560.000 personas $^{353}$.

En 2010, en China, los peores desastres ambientales fueron las inundaciones del 7 de mayo, que provocaron 15,2 millones de desplazados.

En las inundaciones de julio de 2010, Paquistán tuvo 11 millones de desplazados ambientales forzados. Esta situación se produjo por las intensas lluvias de las tormentas monzónicas que han arrasado el noroeste del país siendo las más fuertes de los últimos 80 $\operatorname{años}^{354}$.

\footnotetext{
${ }^{351}$ IDMC-NRC. Global Estimatives 2012. Peaple displaced by disasters. Op.cit., p. 31.

${ }^{352}$ Centro de Monitoreo de Desplazamientos Internos.

${ }^{353}$ IDMC-NRC. Disceplacement due to natural hazard- induced disasters. Global estimates for 2009 and 2010, 2011b. Op.cit., p. 11-13.

${ }^{354}$ NELSON. David. El monzón en Pakistán: "un desastre de primera magnitud". En El País, Madrid, 3 de agosto de 2010. Disponible en:

$<\mathrm{http} / /$ internacional.elpais.com/internacional/2010/08/03/actualidad/1280786401_850215.html $>$ acceso $14 \mathrm{de}$ octubre de 2014.
} 


\section{Imagen 6- Paquistán. Región afectada por la inundación del río Indo}
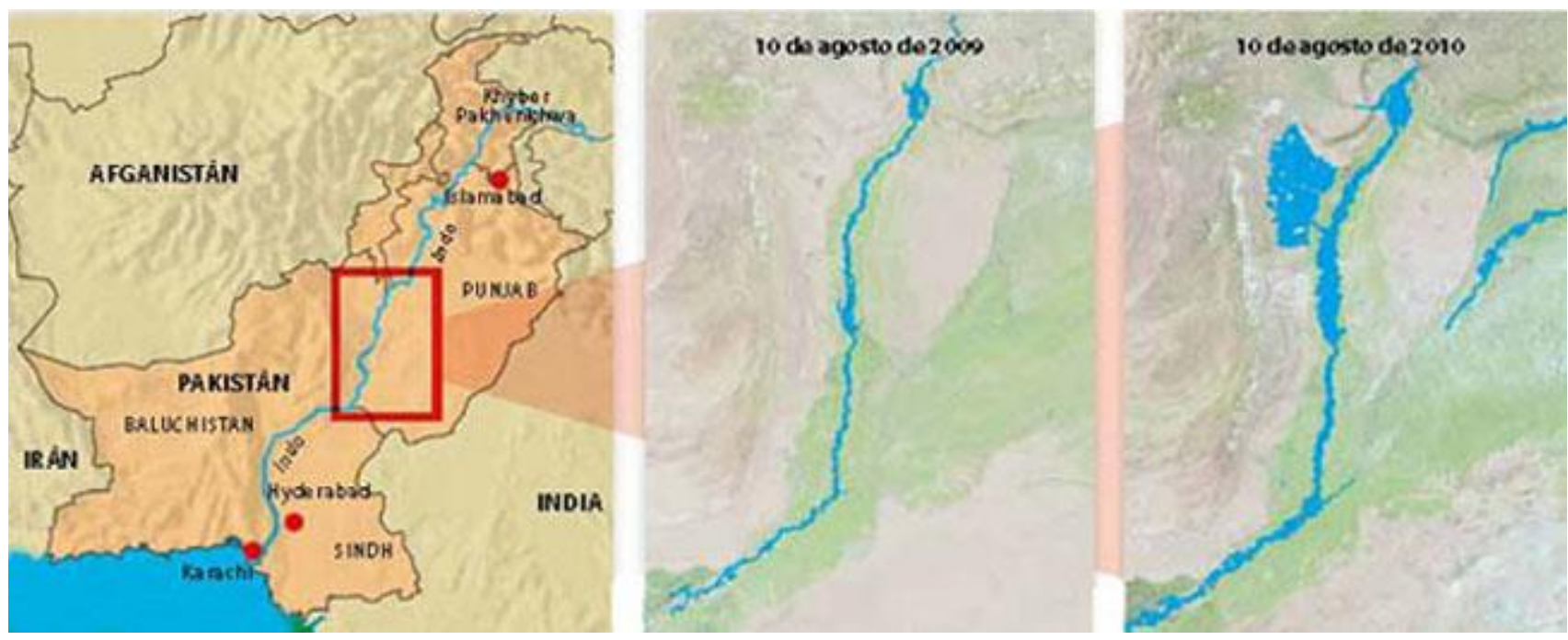

Fuente: Revista del Movimiento Internacional de la Cruz Roja y de la Media Luna Roja. Disponible en $<$ http://www.redcross.int/ES/mag/magazine2010_3/12-15.html >.

Imagen 7- Paquistán. Vista aérea de unas casas anegadas por el agua en Kok Addu, en la provincia de Punjab

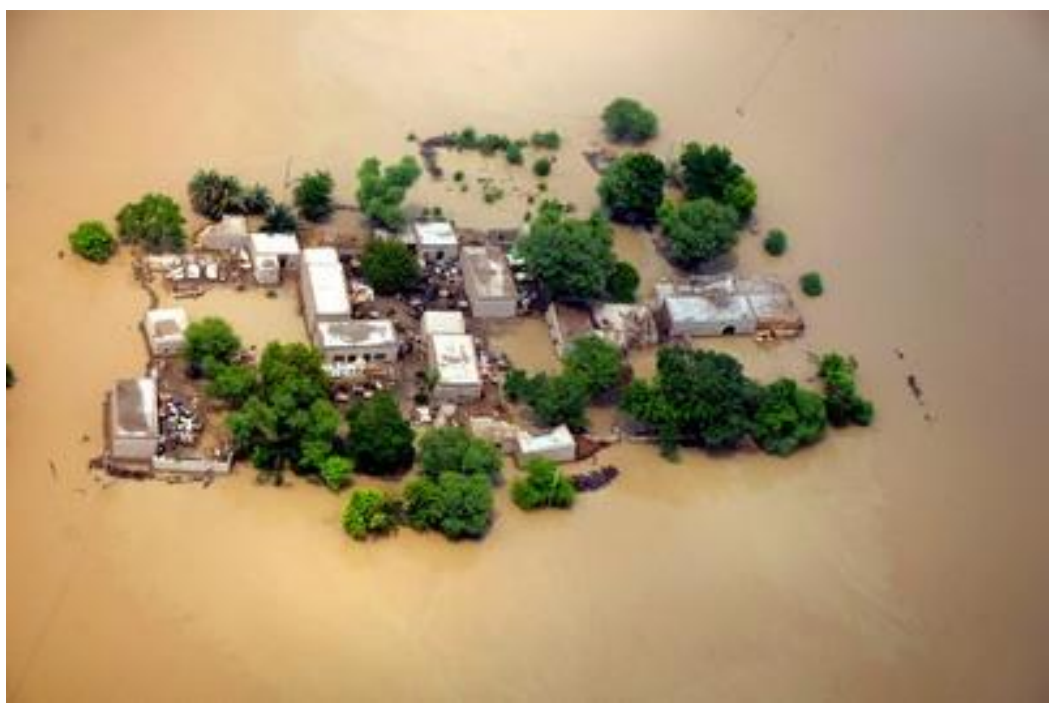

Fuente: El monzón en Paquistán, “un desastre de primera magnitud”. En El País, Madrid, 3 de agosto de 2010. Disponible en:

$<$ http://internacional.elpais.com/internacional/2010/08/03/actualidad/1280786401_850215.ht $\mathrm{ml}>$.

Por otro lado, una particularidad específica de ese año que puede ser apuntada son los desplazados ambientales forzados de los terremotos ocurridos en Chile ( 2 millones de personas) 
y en "Haití con 1.500.000 personas desplazadas"355. Es importante destacar la rápida respuesta del gobierno de Chile a los afectados por esa catástrofe, a diferencia de la ausencia de respuesta del gobierno de Haití.

Es necesario observar la diferencia entre estos dos países, pues Chile es considerado por el Banco Mundial como un país de muy alto desarrollo humano, con un reducido nivel de pobreza, mientras que Haití está entre los países que constan en los peores lugares de la lista de países con menor desarrollo, con altísimos niveles de pobreza en su población. De tal modo, la asistencia a los desplazados ambientales forzados difiere según la capacidad institucional y económica que tenga el país.

Otra nota específica de 2010 fueron las inundaciones de Colombia, con 3 millones de desplazados, y los fenómenos ambientales producidos en México que provocaron 810.000 desplazados ambientales forzados ${ }^{356}$.

En el período invernal (correspondiente a la estación de lluvias) de 2010, Colombia se vio especialmente afectada por el fenómeno climatológico de La Niña. La Niña influyó aumentando las lluvias y provocando las inundaciones en gran parte del territorio de ese país.

\section{Según DANE ${ }^{357}$ :}

La Niña consiste en el enfriamiento por debajo de lo normal de las aguas del océano Pacífico tropical y provoca un cambio en el patrón de comportamiento de los vientos y por ende en el patrón de comportamiento de las lluvias con un incremento de estas sobre las regiones Caribe y Andina en el territorio colombiano ${ }^{358}$.

Además, es importante destacar que Colombia es considerado un país desarrollado.

El 2010 fue un año muy complicado para México, porque este país se vio afectado por una serie de desastres naturales: un sismo de 7,2 grados de la escala Richter, tres huracanes y las inundaciones ${ }^{359}$.

En el año 2011, los 10 peores desplazamientos ambientales forzados ocurrieron en Asia: en China, Tailandia, Filipinas, India, Japón, Bangladesh y Sri Lanka.

\footnotetext{
${ }^{355}$ IDMC-NRC. Disceplacement due to natural hazard- induced disasters. Global estimates for 2009 and 2010, 2011b, Op.cit., p. 12.

${ }^{356}$ IDMC-NRC. Disceplacement due to natural hazard- induced disasters. Global estimates for 2009 and 2010, 2011b. Op.cit., p. 13.

${ }^{357}$ DANE es el Departamento Nacional de Estadística del Gobierno de Colombia.

358 DEPARTAMENTO NACIONAL DE ESTADISTICA (DANE) del Gobierno de Colombia. Reporte final de áreas afectadas por inundaciones 2010-2011, 30 de agosto de 2011, p. 4. Disponible en: $<$ https://www.dane.gov.co/files/noticias/Reunidos_presentacion_final_areas.pdf $>$ acceso 10 de octubre de 2014 .

${ }^{359}$ CNN MEXICO. La Cruz Roja dice que 2010 es el año más caótico en desastres naturales, 8 de octubre de 2010. Disponible en: <http://mexico.cnn.com/nacional/2010/10/08/la-cruz-roja-dice-que-2010-es-el-ano-mascaotico-en-desastres-naturales $>$ acceso 10 de octubre de 2014.
} 
El Informe de las Estimaciones Globales de 2011 de IDMC observa que el desastre ambiental más devastador de ese año ocurrió en China con las inundaciones de junio a septiembre, con un saldo de 3.514.000 desplazados ambientales forzados. Además, las inundaciones constituyeron la causa de los grandes desplazamientos en Tailandia, Filipinas, India, Bangladesh y Sri Lanka ${ }^{360}$.

Sri Lanka es un país insular que se encuentra en el Océano Índico, sus costas sobre el Golfo de Bengala, localizado al sur de India. Tiene una población de 21.128.773 habitantes (según el censo de 2008). Su superficie es de $65.000 \mathrm{~km}$.

En el año 2011, este país fue afectado por grandes inundaciones que invadieron un área de 300.000 hectáreas, destruyendo todo lo que las aguas encontraban a su paso, comenzando por las casas, y produciendo grandes desplazamientos de personas. El testimonio de un desplazado ambiental forzado que retornó a su hogar es el siguiente:

Perdí todo. Alimentos, utensilios de cocina y ropa. Hay serpientes en mi casa y mi campo de arroz está bajo el agua. Tendré que volver al campamento de asistencia social del gobierno por unos días más, por lo menos. No sé lo que haré. Probablemente voy a tener que trabajar como jornalero temporal con el fin de ganar algo de dinero ${ }^{361}$.

${ }^{360}$ INTERNAL DISPLACEMENT MONITORING CENTER. NORWEGIAN REFUGEE COUNCIL (IDMCNRC). Global estimates 2011. Peaple displaced by natural hazard-induced disasters, junio, 2012b, p. $20-21$. Disponible en: <http://www.internal-displacement.org/assets/publications/2012/2012-global-estimates-2011global-en.pdf>.

361 OXFAM. Las necesidades básicas de la población afectada por las inundaciones en Sri Lanka aún no están cubiertas, Subathra Yogasingham, Batticaloa, 18 de enero de 2011. Disponible en: $<$ http://www.oxfam.org/es/sala-de-prensa/notas-de-prensa/2011-01-18/las-necesidades-basicas-de-la-poblacionafectada-por-las $>$ acceso octubre de 2014. 


\section{Imagen 8- Sri Lanka}

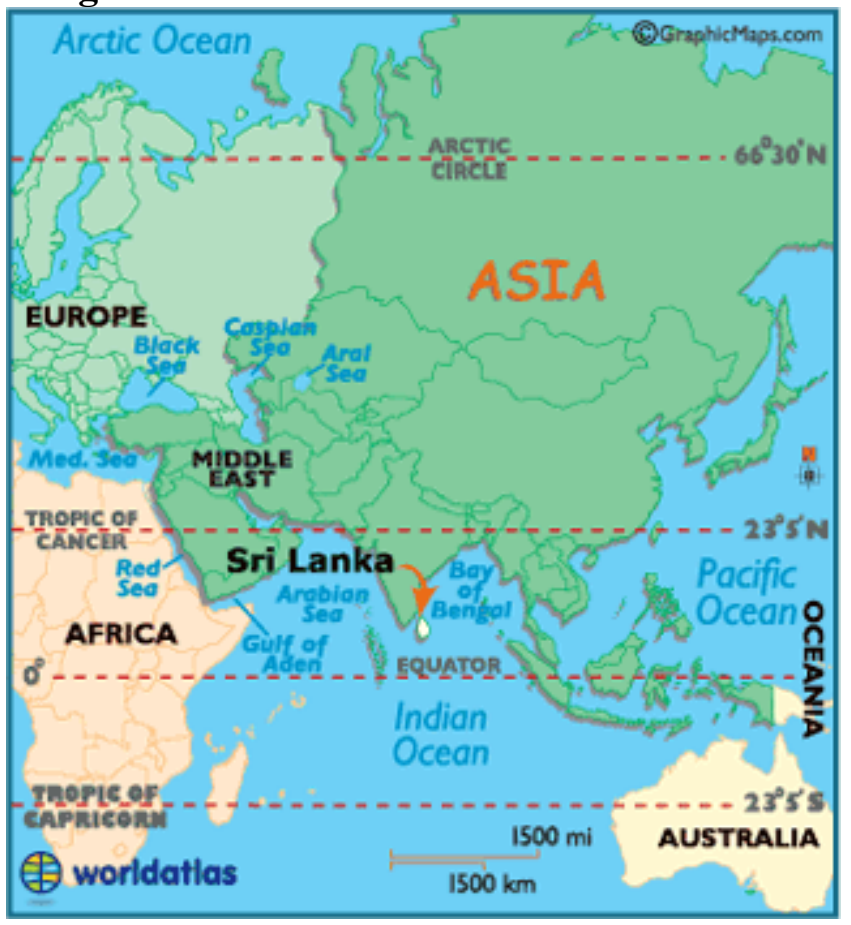

Fuente: $<$ http://www.worldatlas.com/webimage/countrys/asia/lk.htm>.

\section{Imagen 9- Sri Lanka, en detalle}

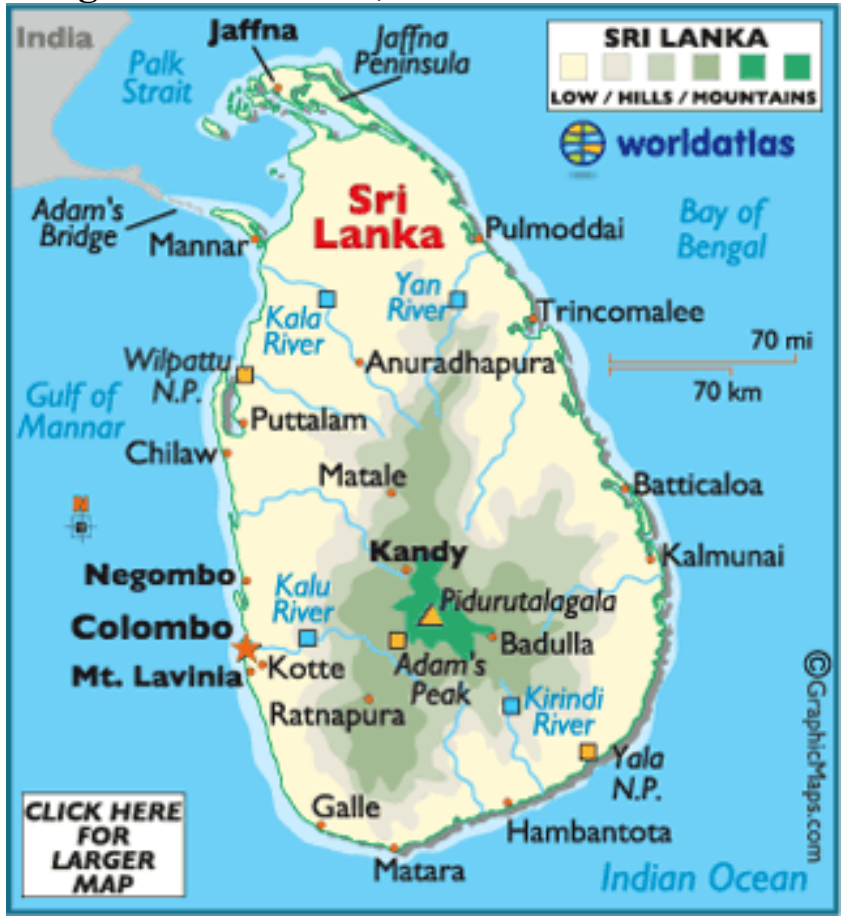

Fuente: $<$ http://www.worldatlas.com/webimage/country $>$. 
Japón sufrió un terremoto de 9 grados en marzo de 2011, y un tsunami. Ese terremoto causó un daño en la Planta Nuclear de Amos Fukushima Daiichi provocando la liberación de material radioactivo. Las personas debieron abandonar sus hogares. El gobierno tuvo que evacuar toda la región. Japón hizo frente a la emergencia sin pedir el auxilio de los organismos internacional $^{362}$.

Los países desarrollados asumen por sí mismos la emergencia ante el desastre, como ha sido constatado en los casos de Japón, Chile y Estados Unidos (Sandy), en tanto que los países menos adelantados o con menor desarrollo no consiguen hacer frente a la emergencia del desastre, repercutiendo esto en el mayor sufrimiento de sus habitantes que se convierten en desplazados ambientales forzados. Estos últimos países precisan de la ayuda de la comunidad internacional. En muchos casos, estas personas se convierten en desplazados ambientales forzados continuos debido a la repetición de los desastres ambientales repentinos, pues no consiguen salir de esta situación, como lo demuestran los testimonios presentados.

En 2011, Asia fue el continente más afectado por los desastres ambientales (89\% del total), América tuvo el 7\% del total de los desplazados ambientales y África tuvo 227.490 desplazados ambientales (en Angola, donde ocurrieron las inundaciones de diciembre). Sri Lanka, con sus 689.924 desplazados ambientales forzados, fue el país con "el mayor porcentaje" en relación con el número total de sus habitantes ${ }^{363}$.

En el año 2012, los países con mayores desplazamientos ambientales forzados fueron: Nigeria (6.088.580), India (5.659.900), China (5.659.900), Filipinas (3.672.370) y Paquistán $(1.856 .570)$.

Se puede observar que todos estos países tienen gran parte de sus poblaciones pobres, como será considerado posteriormente.

En 2012, China padeció de 11 tifones e inundaciones. Por otro lado, tal Informe observa que África fue afectada por las inundaciones que produjeron 7,6 millones de desplazados ambientales forzados en Benín, Camerún, República Centroafricana, Chad, la República Demócrata del Congo, Gabón, Gambia, Mali, Níger, Nigeria, Senegal, Sudán y Sudán del Sur. IDMC observa:

Nigeria, Níger, Chad y Sudán del Sur fueron los más afectados, con los más altos niveles de desplazamientos provocados por las inundaciones y con poblaciones extremadamente vulnerables que enfrentan la inseguridad de múltiples facetas y

\footnotetext{
${ }^{362}$ FERRIS, Elizabeth; PETZ, Daniel. The year that shook the rich: a review of natural disasters in 2011. Londres: The Brookings Institution/London School of Economics. Project on Internal Displacement, 2012, p. 918.

${ }^{363}$ IDMC-NRC. Global estimates 2011. Op.cit., p. 14-15.
} 
desplazamientos por conflictos en curso. Además, estos países tienen algunas de las clasificaciones más bajas del mundo en el Índice de Desarrollo Humano de 2013. De 186 países, Níger ocupa el puesto 186, Chad es 184 y Nigeria es 153. Sudán del Sur no está incluido en el Índice de $2013^{364}$.

En Nigeria, las inundaciones se han producido en la temporada de lluvias (agosto y septiembre de 2012), provocando la destrucción de todo lo que encontraron a su paso (medios de comunicación, edificios, casas) y las personas han sido obligadas a abandonar sus hogares para alojarse a otros sitios ${ }^{365}$.

Este ha sido el segundo peor desastre de 2012, ya que las inundaciones dejaron 6 millones de desplazados, los cuales tuvieron que valérselas por sí mismos. Las autoridades de Nigeria insistían para que los desplazados retornasen a sus casas ${ }^{366}$.

Las inundaciones de 2012 han sido las peores en 40 años. El informe observa que, posteriormente, las personas trataban de retornar a sus casas, pero estas habían desaparecido debajo de las aguas. Además, era difícil llegar a algunos lugares debido a la pérdida de los medios de comunicación. Muchas personas aún están refugiadas en lugares improvisados ${ }^{367}$.

En realidad, esa situación se debe a que el gobierno de ese país no tiene ni estructura institucional ni económica para brindarles ayuda.

\footnotetext{
${ }^{364}$ IDMC-NRC. Global Estimatives 2012. Peaple displaced by disasters. Op.cit., p. 19.

365 INTERNATIONAL FEDERETION OF RED CROSS AND RED CRESCENT SOCIETIES. Emergency Appeal $\mathbf{N}^{\circ}$ MDRNG014. GLIDE $\mathbf{N}^{\circ}$ FL-2012-000138-NGA, mayo, 2013. Disponible en: $<$ http://www.ifrc.org/docs/Appeals/12/MDRNG014rea.pdf > acceso 10 de octubre de 2014.

${ }^{366}$ IDMC-NRC. Global Estimatives 2012. Peaple displaced by disasters. Op.cit., p. 19-20 y 31.

${ }^{367}$ OFFICE FOR THE COORDINATION OF HUMANITARIAN AFFAIRS (OCHA). Nigeria: Floods Situation Report No 2, 15 de noviembre de 2012, p. 2. Disponible en:

$<$ http://reliefweb.int/sites/reliefweb.int/files/resources/Full\%20Report_1141.pdf> acceso 10 de octubre de 2014.
} 


\section{Imagen 10- Nigeria}

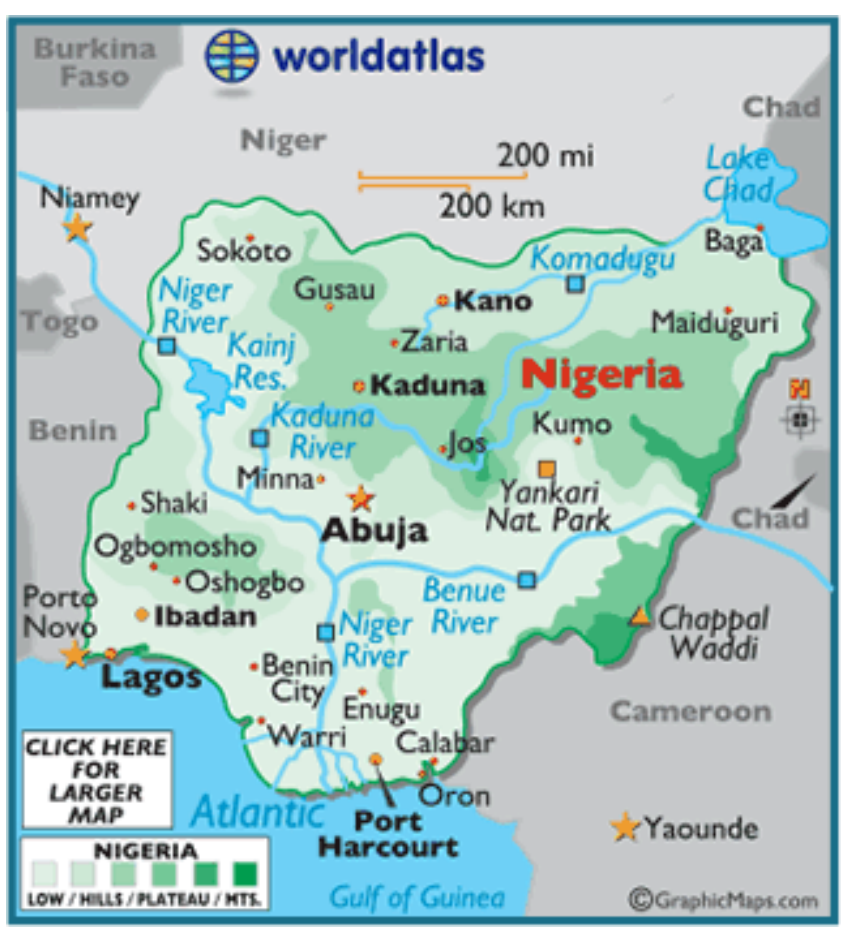

Fuente: $<$ http://www.worldatlas.com $>$.

\section{Imagen 11- Nigeria, en detalle}

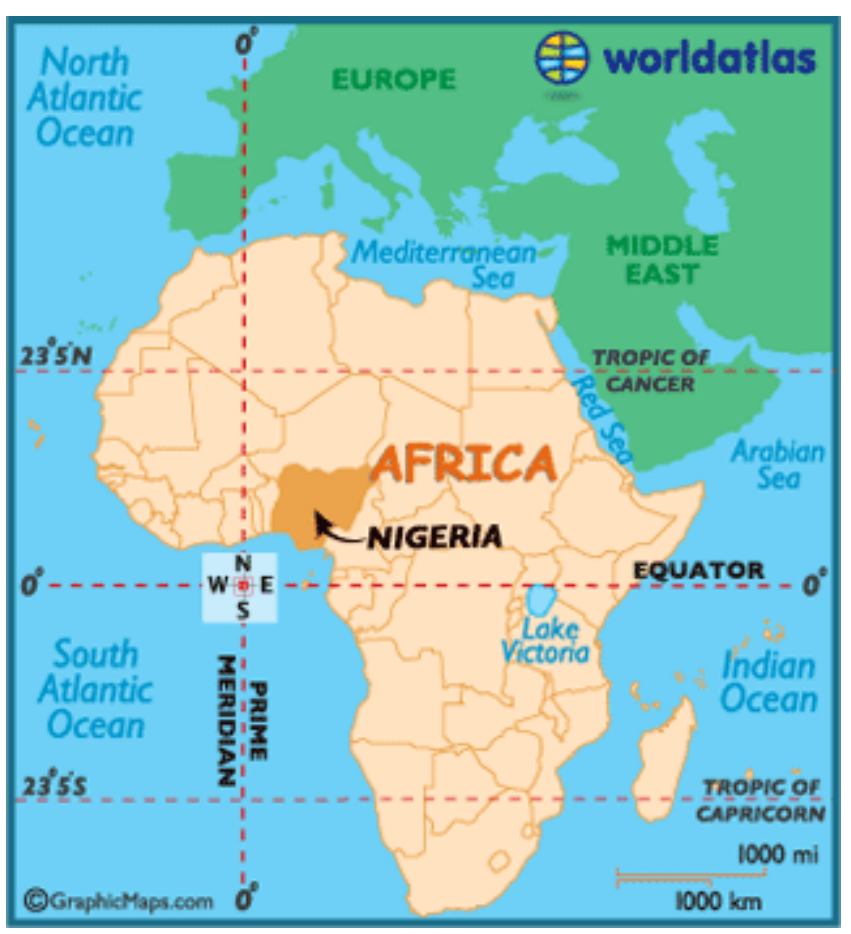

Fuente: $<$ http://www.worldatlas.com $>$. 
En 2012, en Paquistán se produjeron los desastres ambientales en el sur de Punjab, Baluchistán y Sindh, siendo que estas regiones son las que tienen mayores poblaciones. IDMC observa:

\begin{abstract}
Muchos de los distritos afectados, en particular en Baluchistán y Sindh, ya estaban luchando para recuperarse de las inundaciones de 2010 y 2011, algunos siendo inundados por tercer año consecutivo. También, Baluchistán fue golpeado por el terremoto de 2010. Además, las sucesivas inundaciones anuales han profundizado la crisis alimentaria en Sindh, provocando una desnutrición severa. Hacia finales de 2011, el $72 \%$ de la población de la provincia estaba en inseguridad alimentaria, incluyendo el $16,8 \%$ que sufrían de hambre severa ${ }^{368}$.
\end{abstract}

Las lluvias intensivas provocaron las grandes y devastadoras inundaciones que arrasaron Paquistán en 2012. El escenario de estas catástrofes ambientales se repite, áreas agrícolas y ganaderas perdidas, así como todo lo que las aguas encontraron en su paso. Además, los desplazados ambientales forzados sufrieron la falta de asistencia en sus necesidades básicas $^{369}$.

Según el Informe de las Estimaciones Globales de IDMC, Filipinas tuvo 3,9 millones de desplazados forzados de los desastres ambientales en 2012. Estos fueron la consecuencia de tifones múltiples, inundaciones, tormentas y monzones.

Otro problema a ser observado es la repetición de los desastres ambientales en los mismos lugares y en algunos casos durante en el mismo año. Esto hace que haya personas que viven en continuo estado de desplazamiento y, consecuentemente, estos afectados no consiguen reconstruir sus vidas.

Tales circunstancias demuestran la falta de preparación de los países ante la repetición de las catástrofes que ocurren todos los años.

En 2012, algunos países, como es el caso de India, China y Filipinas, sufrieron más de un desastre ambiental. Un ejemplo de esto fue la región del noroeste de Assam y la de Arunachal Pradesh en India, las cuales sufrieron dos megadesastres, totalizando un número de 8.900.000 desplazados ambientales forzados. Uno de los desastres ocurrió en junio y julio, siendo que el segundo fue en agosto y septiembre. Ambos fueron inundaciones provocados por monzones.

\footnotetext{
${ }^{368}$ IDMC-NRC. Global Estimatives 2012. Peaple displaced by disasters. Op.cit., p. 17-18.

369 INTERNAL PLANNING DOCUMENT-HCT PAKISTAN. Monzon 2012. Revised Humanitarian Operations Plan (MHOP). Revised, febrero, 2013, p. 9-10. Disponible en: $<$ http://pakresponse.info/Portals/0/Policy/MHOP_Revision_HCT\%20endorsed_updated\%2006032013.pdf> acceso 10 de octubre de 2014.
} 
Otro caso es el de Haití, que padeció cuatro desastres: dos huracanes (Isaac y Sandy) y dos inundaciones ${ }^{370}$.

En 2011, China, Filipinas, Sri Lanka, India y Japón sufrieron más de un desastre ambiental. Filipinas padeció de 20 desastres durante ese año ${ }^{371}$.

\title{
IV.6.2. Desplazamientos ambientales forzados, vulnerabilidad y pobreza
}

El Informe sobre las Estimaciones Globales del año 2012 de IDMC observa:

\begin{abstract}
La gran mayoría de las personas desplazadas (98\% en 2008-2012) se encontraba en los países en vías de desarrollo, con una renta media y baja. Esto apunta al fuerte vínculo entre la pobreza y la vulnerabilidad, y el número de personas expuestas a peligros y desplazamientos. Proporciones similares se encuentran en los desplazamientos del año $2012^{372}$.
\end{abstract}

La relación entre pobreza, vulnerabilidad y desplazamientos es evidente, pues en aquellos países donde existe una gran parte de la población sumergida en la pobreza, se puede observar que aumenta la vulnerabilidad frente a los riesgos ambientales.

En estas situaciones de pobreza, las personas construyen sus casas donde pueden, donde encuentran un lugar, y por esto terminan viviendo en lugares de alto riesgo y proclives a desplazamientos, al margen de ríos, en regiones costeras bajas.

Además, es necesario observar que algunos de estos países sufren conflictos armados internos.

La vulnerabilidad se refiere a la falta de capacidad de una comunidad para hacer frente a los impactos negativos que repercuten sobre ese sector de la sociedad.

El nivel de la vulnerabilidad de una comunidad depende de los recursos institucionales establecidos por el Estado, así como de los recursos económicos que permitan el aumento de los mecanismos necesarios para combatir los impactos negativos.

Cuando la amenaza está constituida por los impactos negativos del desastre ambiental, existirá mayor vulnerabilidad en las sociedades o comunidades o países más pobres.

Esas comunidades ya sufren el mal de la pobreza, la falta de mecanismos institucionales y de recursos económicos del Estado. Estos últimos se traducen en la falta de asistencia pública a la salud, a las condiciones de sanidad, a la vivienda, a las condiciones de urbanización, es decir, la falta de efectividad de sus derechos humanos.

\footnotetext{
${ }^{370}$ IDMC-NRC. Global Estimatives 2012. Peaple displaced by disasters. Op.cit., p. 12, 15-16 y 35.

${ }^{371}$ IDMC-NRC. Global Estimates 2011. Op.cit., p. 14, 16 y 20.

${ }^{372}$ IDMC-NRC. Global Estimatives 2012. Peaple displaced by disasters. Op.cit., p. 31.
} 
Existen muchas de estas comunidades que viven en condiciones infrahumanas con cloacas abiertas y falta de agua, donde aparecen enfermedades infecciosas o virales que afectan a la población.

La falta de un proceso de formación educativo impide la capacitación de las personas para mejores trabajos. Estas personas tienen trabajos precarios o informales que les rinden bajos recursos económicos. La ausencia de derechos laborales es otra de las características del trabajo informal, lo cual agrava la situación de las comunidades.

Todo este marco propio de la pobreza representa la alta vulnerabilidad de estas poblaciones ante los impactos de los desastres ambientales.

IDMC señala:

\begin{abstract}
[...] Mientras, el número de personas desplazadas en países de Alto Desarrollo Humano es relativamente bajo [...].

Los países más pobres de todo el mundo merecen especial atención en vista de su mayor vulnerabilidad y limitados recursos para proteger a las personas desplazadas, para gestionar los desastres y para recuperarse sin ayuda externa. En 2012, más de 1,8 millones de personas desplazadas fueron de estos Estados categorizados como países menos adelantados (PMA) por el Banco Mundial (11,7 millones de personas en más de cinco años). En África, esto incluye los desplazamientos en el Chad, Madagascar, Mali, Níger y Sudan. En Asia, esto incluye a Afganistán, Bangladesh, Nepal, Myanmar (Birmania) y Yemen ${ }^{373}$.
\end{abstract}

En 2011, Japón, Tailandia y Nueva Zelandia sufrieron graves desastres. Estos países desarrollados no solicitaron la ayuda internacional: se hicieron cargo por sí mismos de las situaciones de desastres. Japón solamente pidió consejos al sistema humanitario internacional para afrontar los impactos del terremoto y del tsunami ${ }^{374}$.

Así, se puede observar la diferencia en la respuesta a los impactos de los desastres ambientales que existe según sea un país desarrollado o uno menos adelantado o menos desarrollado.

Además, los conflictos internos de los países agravan la situación de los desplazados ambientales forzados y, a su vez, la vida de los desplazados de esos conflictos se hace más difícil, por causa de los desastres. Es decir, se provoca un círculo vicioso que lleva a hundir cada vez más la vida de los desplazados ambientales forzados, dejándolos a la vera de la desolación.

\footnotetext{
${ }^{373}$ IDMC-NRC. Global Estimatives 2012. Peaple displaced by disasters. Op.cit., p. 33.

374 OFFICE FOR THE COORDINATION OF HUMANITARIAN AFFAIRS (OCHA), Annual Report 2011. Ginebra: United Nations Department of Public Information. Ginebra, 2011, p. 5.
} 
Cuando se hace referencia a los impactos de los desastres ambientales en tales países es necesario tener en cuenta la gestión del desplazamiento, la cual difícilmente será realizada por los Estados con menor nivel institucional, frágil gobernanza y grandes poblaciones de pobres.

En la mayoría de los casos de los desplazamientos de los desastres ambientales, gran parte de las personas escapan de sus hogares por sí mismas sin ningún tipo de apoyo institucional.

\section{IV.6.3. Observaciones metodológicas}

El siguiente análisis de los datos sobre los desplazamientos ambientales forzados derivados de desastres abruptos considera los datos brindados por Internal Displacement Monitoring Center de Norwegian Refugee Council.

Los desplazamientos ambientales forzados que serán considerados son aquellos que impliquen más de 200.000 personas, durante los años 2012, 2011 y 2010.

\section{IV.6.3.1. Los mayores desplazamientos ambientales forzados en 2012}

En 2012, según el análisis de la situación en Asia-Pacífico, los países localizados en esta región que más han sufrido los desastres ambientales son China, India, Paquistán, Filipinas, Bangladesh, Japón y Corea del Norte.

A continuación, consideraremos los mayores desplazamientos ambientales forzados (de más de 200.000 desplazados ambientales forzados) del año 2012 según los datos brindados por el Internal Displacement Monitoring Center de Norwegian Refugee Council ${ }^{375}$.

India fue afectada por las inundaciones de los monzones de junio y julio, que provocaron 6.900.000 desplazados ambientales forzados. En el mes de agosto y septiembre, también hubo grandes inundaciones de los monzones que causaron 2.000.000 de desplazados ambientales forzados. En octubre, se produjo la Cyclonic Storm Nilam, que ocasionó el desplazamiento de 210.000 personas.

China sufrió cinco desastres ambientales, el primero fueron las inundaciones del Tifoon Haikui (en agosto) que dejó 2.079.000 desplazados ambientales forzados. En junio y julio, las inundaciones de los monzones originaron el desplazamiento de 1.419 .900 personas. En agosto del mismo año, los desastres ambientales fueron los “Twin Typhons Saola y Damrey", los cuales ocasionaron 867.000 desplazados ambientales forzados. En el mismo mes, también

${ }^{375}$ IDMC-NRC. Global Estimatives 2012. Peaple displaced by disasters. Op.cit., p. 43. 
ocurrió el tifón Kai Tak que dejó 530.000 desplazados ambientales forzados. En abril y mayo, China volvió a sufrir con las inundaciones de los monzones, que tuvieron como resultado 443.000 desplazados ambientales forzados.

En Nigeria, las inundaciones ocurridas de septiembre a octubre provocaron 6.088.580 desplazados ambientales forzados.

Filipinas sufrió dos desastres ambientales, el primero fue el tifón Pablo que ocurrió en diciembre y provocó el desplazamiento de 1.931 .970 personas. En junio y agosto, se produjeron las inundaciones y los impactos del tifón, lo que originó 1.553.080 desplazados ambientales forzados. El tercer desastre fue el ciclón Nilan que dejó 187.320 desplazados ambientales forzados.

En Paquistán, las inundaciones de los monzones de agosto y setiembre causaron 1.856.570 desplazados ambientales forzados.

En Estados Unidos, el huracán Sandy de octubre dejó 775.7610 desplazados ambientales forzados.

En Bangladesh, las inundaciones de los monzones originaron 600.000 desplazados ambientales forzados.

En Níger, la estación de las lluvias causó grandes inundaciones que produjeron el desplazamiento de 530.000 personas.

En Chad, las inundaciones de julio y octubre originaron 500.000 desplazados ambientales forzados.

En Cuba, el huracán Sandy de octubre desencadenó el desplazamiento de 343.230 personas.

Sudán del Sur fue aquejado por grandes inundaciones que causaron 340.000 desplazados ambientales forzados.

En Japón, las inundaciones y los deslizamientos ocurridos en julio dejaron 250.000 desplazados ambientales forzados.

Corea del Norte fue perjudicado por las inundaciones de los monzones de junio y julio que desencadenaron 212.000 desplazados ambientales. 
Cuadro - Desplazamientos ambientales forzados, 2012 (Los siguientes datos han sido extraídos del Cuadro: Global Estimatives 2012 -Peaple Displaced by Disasters- IDMC, página 43)

DESPLAZADOS AMBIENTALES FORZADOS DEL AÑO 2012 (Considerando mas de 200.000 desplazados por pais afectado)

\begin{tabular}{|c|c|c|c|c|}
\hline PAIS & FECHA & EVENTO & $\begin{array}{c}\text { NUMERO DE } \\
\text { DESPLAZADOS } \\
\text { AMBIENTALES }\end{array}$ & TOTAL POR PAIS \\
\hline NIGERIA & Setiembre - Octubre & Inundacion & 6.088 .580 & 6.088 .580 \\
\hline IND|A & $\begin{array}{c}\text { Junio - Julio } \\
\text { Agosto- Setiembre } \\
\text { Octubre }\end{array}$ & $\begin{array}{l}\text { Inundacion } \\
\text { Inundacion } \\
\text { Ciclon }\end{array}$ & $\begin{array}{c}6.900 .000 \\
2.000 .000 \\
210.000\end{array}$ & 9.110 .000 \\
\hline CHNA & $\begin{array}{c}\text { Agosto } \\
\text { Junio-Julio } \\
\text { Agosto } \\
\text { Agosto } \\
\text { Abril- Mayo } \\
\text { Setiembre } \\
\text { Octubre }\end{array}$ & $\begin{array}{c}\text { Tifon } \\
\text { Inundacion } \\
\text { Tifon } \\
\text { Tifon } \\
\text { Monzon } \\
\text { Terremoto } \\
\text { Tifon } \\
\end{array}$ & $\begin{array}{l}2.079 .000 \\
1.419 .900 \\
867.000 \\
530.000 \\
443.000 \\
185.000 \\
136.000 \\
\end{array}$ & 5.659 .900 \\
\hline FILIPINAS & $\begin{array}{c}\text { Diciembre } \\
\text { Junio- Agosto } \\
\text { Febrero }\end{array}$ & $\begin{array}{c}\text { Tifon } \\
\text { Inundacion } \\
\text { Terremoto } \\
\end{array}$ & $\begin{array}{c}1.931 .970 \\
1.553 .080 \\
187.320 \\
\end{array}$ & 3.672 .370 \\
\hline PAKISTAN & Agosto - Setiembre & Inundacion & 1.856 .570 & 1.856 .570 \\
\hline ESTADOS UNIDOS & Octubre & Huracan Sandy & 775.761 & 775.761 \\
\hline BANGLADESH & Junio & Inundacion & 600.000 & 600.000 \\
\hline NIGER & Jullio - Agosto & Inundacion & 530.000 & 530.000 \\
\hline CHAD & Julio - Octubre & Inundacion & 500.000 & 500.000 \\
\hline CUBA & Octubre & Huracan Sandy & 343.230 & 343.230 \\
\hline SUDAN DEL SUD & Junio - Julio & Inundacion & 340.000 & 340.000 \\
\hline JAPON & Junio - Julio & $\begin{array}{c}\text { Inundacion / } \\
\text { Deslizmiento de } \\
\text { Tierra } \\
\end{array}$ & 250.000 & 250.000 \\
\hline COREA DEL NORTE & Junio - Jullio & Inundaciones & 212.000 & 212.000 \\
\hline
\end{tabular}

Fuente :Global Estimates 2012 - People Displaced by disasters -IDMC - Pagina 43 
Cuadro - Desplazamientos ambientales forzados, 2012

\begin{tabular}{|l|r|}
\hline \multicolumn{2}{|c|}{$\begin{array}{c}\text { Desplazados Ambientales Forzados del año 2012 } \\
\text { (Considerando más de 200.000 desplazados por país afectado) }\end{array}$} \\
\hline País & Número de desplazados ambientales forzados \\
\hline Nigeria & 6.088 .580 \\
\hline India & 9.110 .000 \\
\hline China & 5.659 .900 \\
\hline Filipinas & 3.672 .370 \\
\hline Pakistan & 1.856 .570 \\
\hline Estados Unidos & 775.761 \\
\hline Bangladesh & 600.000 \\
\hline Níger & 530.000 \\
\hline Chad & 500.000 \\
\hline Cuba & 343.230 \\
\hline Sudan del Sur & 340.000 \\
\hline Japón & 250.000 \\
\hline Corea del Norte & 212.000 \\
\hline
\end{tabular}

Fuente: Estimación Global, 2012.

\section{IV.6.3.2. Los mayores desplazamientos ambientales forzados en 2011}

A continuación, serán considerados los mayores desplazamientos ambientales forzados (de más de 200.000 desplazados ambientales forzados) del año 2011, según los datos brindados por el Internal Displacement Monitoring Center de Norwegian Refugee Council ${ }^{376}$.

En 2011, China sufrió tres desastres ambientales, de junio a septiembre se produjeron grandes inundaciones que provocaron 3.514.000 desplazados ambientales forzados. El segundo desastre fue el tifón Kabajan que dejó 360.000 desplazados ambientales forzados. El tercero fue el tifón Pedring con 300.000 desplazados ambientales. El cuarto desastre fue el terremoto Yunnan de marzo que originó 130.000 desplazados ambientales forzados.

En Tailandia, las inundaciones de agosto a enero causaron 1.500.000 desplazados ambientales forzados.

En Filipinas, las inundaciones de enero y febrero provocaron 672.131 desplazados ambientales forzados. En diciembre, la tormenta tropical Washi motivó el surgimiento de 441.037 desplazados ambientales forzados. En agosto, ocurrió el tifón Mine que causó el

${ }^{376}$ IDMC-NRC. Global estimates 2011. Op.cit., p. 20-21. 
desplazamiento de 227.446 personas. En mayo, se produjo el tifón Chedng que desplazó a 225.694 personas. En el mes de junio hubo 212.655 desplazados ambientales forzados. En septiembre, el tifón Peding desencadenó 168.000 desplazados ambientales forzados. En julio, la tormenta tropical Juaning dejó 150.952 desplazados ambientales forzados. El séptimo desastre en Filipinas fue el tifón Quiel con 143.703 desplazados ambientales forzado.

India fue afectada por cinco desastres ambientales. Las inundaciones de Assam dejaron 570.000 desplazados ambientales forzados. En septiembre y octubre, se produjeron las inundaciones de Odisha que provocaron el desplazamiento de 280.320 personas. El tercer desastre ambiental fue el ciclón Thane con 250.000 desplazados ambientales forzados. En agosto y setiembre, las inundaciones de West Bengal causaron 190.000 desplazados ambientales forzados. En el mismo mes de septiembre, ocurrieron las inundaciones de Odisha, dejando 130.000 desplazados ambientales forzados.

Japón tuvo dos desastres ambientales en 2011. En marzo, ocurrieron los terremotos de Tohoku y el Tsunami, que dejaron 492.000 desplazados ambientales forzados. El segundo desastre ambiental fue el deslizamiento de tierras que provocó 400.000 desplazados ambientales forzados, en el mes de Julio.

En Bangladesh, las inundaciones de julio causaron 400.000 desplazados ambientales forzados.

En Sri Lanka, las inundaciones de febrero ocasionaron el desplazamiento de 325.448 personas. En enero, hubo inundaciones que provocaron 362.646 desplazados ambientales forzados.

Paquistán fue afectado por inundaciones en agosto y noviembre, que provocaron 300.000 desplazados ambientales forzados.

En junio y julio, México sufrió un primer desastre: se produjeron fuertísimas tormentas que causaron 280.000 desplazados ambientales forzados. El segundo desastre fue la tormenta tropical Arlene que dejó 261.000 desplazados ambientales forzados.

En Camboya, las inundaciones de agosto a noviembre desencadenaron 214.000 desplazados ambientales forzados.

Angola tuvo inundaciones en el mes de diciembre que produjeron 204.000 desplazados ambientales forzados.

Vietnam sufrió las grandes inundaciones (de setiembre y octubre) que ocasionaron 200.000 desplazados ambientales forzados. 
En Turquía, se produjo el terremoto de Van en el octubre, este desastre ambiental suscitó el desplazamiento de 252.000 personas.

Cuadro - Desplazamientos ambientales forzados, 2011. (Los siguientes datos han sido extraídos del Cuadro: Global Estimatives 2011 - Peaple Displaced by Natural hazardinduced disasters- IMDC, página 21).

DESPLAZADOS AMBIENTALES FORZADOS DEL AÑO 2011 (Considerando mas de 200.000 desplazados por pais afectado)

\begin{tabular}{|c|c|c|c|c|}
\hline PAIS & FECHA & EVENTO & $\begin{array}{c}\text { NUMERO DE } \\
\text { DESPLAZADOS } \\
\text { AMBIENTALES }\end{array}$ & TOTAL POR PAIS \\
\hline CHINA & $\begin{array}{c}\text { Junio - Setiembre } \\
\text { Agosto } \\
\text { Setiembre - Octubre } \\
\text { Marzo }\end{array}$ & $\begin{array}{c}\text { Inundacion } \\
\text { Tifon } \\
\text { Tifon } \\
\text { Sismo } \\
\end{array}$ & $\begin{array}{c}3.514 .000 \\
360.000 \\
300.000 \\
130.000 \\
\end{array}$ & 4.304 .000 \\
\hline FILIPINAS & $\begin{array}{c}\text { Enero- Febrero } \\
\text { Diciembre } \\
\text { Junio } \\
\text { Julio } \\
\text { Octubre } \\
\text { Setiembre } \\
\text { Mayo } \\
\text { Agosto }\end{array}$ & $\begin{array}{l}\text { Inundacion } \\
\text { Tormenta } \\
\text { Tormenta } \\
\text { Tormenta } \\
\text { Tifon } \\
\text { Tifon } \\
\text { Tifon } \\
\text { Tifon } \\
\end{array}$ & $\begin{array}{l}672.131 \\
441.037 \\
212.655 \\
150.952 \\
143.703 \\
168.000 \\
225.694 \\
227.446 \\
\end{array}$ & 2.241 .618 \\
\hline TAlLANDIA & Agosto-Enero & Inundacion & 1.500 .000 & 1.500 .000 \\
\hline INDIA & $\begin{array}{c}\text { Agosto-Octubre } \\
\text { Diciembre } \\
\text { Setiembre } \\
\text { Agosto - Setiembre } \\
\text { Setiembre - Octubre }\end{array}$ & $\begin{array}{l}\text { Inundacion } \\
\text { Ciclon } \\
\text { Inundacion } \\
\text { Inundacion } \\
\text { Inundacion }\end{array}$ & $\begin{array}{l}570.000 \\
250.000 \\
130.000 \\
190.000 \\
280.320 \\
\end{array}$ & 1.420 .320 \\
\hline JAPON & $\begin{array}{c}\text { Marzo } \\
\text { Julio } \\
\end{array}$ & \begin{tabular}{|c|} 
Terremoto y Sunami \\
Deslizamiento de tierra \\
\end{tabular} & $\begin{array}{l}492.000 \\
400.000 \\
\end{array}$ & 892.000 \\
\hline SRI LANKA & $\begin{array}{c}\text { Enero } \\
\text { Febrero } \\
\end{array}$ & \begin{tabular}{|l|} 
Inundacion \\
Inundacion \\
\end{tabular} & $\begin{array}{l}362.646 \\
325.448 \\
\end{array}$ & 688.094 \\
\hline MEXICO & $\begin{array}{c}\text { Junio - Julio } \\
\text { Octubre }\end{array}$ & $\begin{array}{l}\text { Tormenta } \\
\text { Tormenta } \\
\end{array}$ & $\begin{array}{l}280.000 \\
261.000 \\
\end{array}$ & 541.000 \\
\hline PAKISTAN & Agosto-Noviembre & Inundacion & 300.000 & 300.000 \\
\hline TURKIA & Octubre & Terremoto & 252.000 & 252.000 \\
\hline CAMBOYA & Agosto-Noviembre & Inundacion & 214.000 & 214.000 \\
\hline ANGOLA & Diciembre & Inundacion & 204.000 & 204.000 \\
\hline VIETNAM & Setiembre- Octubre & Inundacion & 200.000 & 200.000 \\
\hline
\end{tabular}

Fuente :Global Estimates 2011 - People Displaced by natural hazard-induced disasters -IDMC - Pagina 21 
Cuadro - Desplazamientos ambientales forzados, 2011

\begin{tabular}{|l|r|}
\hline \multicolumn{2}{|c|}{$\begin{array}{r}\text { Desplazados Ambientales Forzados del año 2011 } \\
\text { (Considerando más de 200.000 desplazados por país afectado) }\end{array}$} \\
\hline País & Número de desplazados ambientales forzados \\
\hline China & 4.304 .000 \\
\hline Filipinas & 2.241 .618 \\
\hline Tailandia & 1.500 .000 \\
\hline India & 1.420 .320 \\
\hline Japón & 892.000 \\
\hline Sri Lanka & 688.094 \\
\hline México & 541.000 \\
\hline Pakistan & 300.000 \\
\hline Turquía & 252.000 \\
\hline Camboya & 214.000 \\
\hline Angola & 204.000 \\
\hline Vietnam & 200.000 \\
\hline
\end{tabular}

Fuente: Estimación Global, 2011.

\section{IV.6.3.3. Los mayores desplazamientos ambientales en 2010}

E1 IDMC observa:

El informe mostró que hubo más de 42 y 17 millones de personas de nuevos desplazados por desastres súbitos de inicio en 2010 y 2009 respectivamente. Se destaca:

- Desastres en gran escala representaron más del 90\% del número total de desplazados a nivel mundial cada año,

- 90\% del desplazamiento fue causado por desastres relacionados con el clima, principalmente inundaciones y tormentas,

- Asia fue de lejos la región más afectada ${ }^{377}$.

En 2010, ACNUR solicitó la ayuda de IDMC para la creación de los grupos de trabajo para la protección ante los desastres ${ }^{378}$.

${ }^{377}$ INTERNAL DISPLACEMENT MONITORING CENTER. NORWEGIAN REFUGEE COUNCIL (IDMCNRC). Quarterly Update, abril-junio, 2011a. Disponible en $<\mathrm{http}: / / \mathrm{www}$.internaldisplacement.org/assets/publications/2011/2011-QU2-corporate-en.pdf $>$ acceso 20 octubre de 2014 .

378 INTERNAL DISPLACEMENT MONITORING CENTER. NORWEGIAN REFUGEE COUNCIL (IDMCNRC). Quarterly Update, octubre-diciembre, 2010. Disponible en: <http://www.internaldisplacement.org/assets/publications/2010/2010-QU4-corporate-en.pdf $>$ acceso 20 de octubre de 2014. 
Seguidamente, serán mencionados los mayores desplazamientos ambientales forzados (de más de 200.000 desplazados ambientales forzados) del año 2010 según los datos brindados por el Internal Displacement Monitoring Center de Norwegian Refugee Council ${ }^{379}$.

China tuvo tres desastres ambientales. En primer lugar, las inundaciones de mayo de 2010, dejaron 15.200.000 desplazados ambientales forzados. El segundo desastre ocurrió en el mes de octubre (inundaciones), originando el desplazamiento de 270.000 personas. En septiembre, las fuertísimas tormentas causaron 186.000 desplazados ambientales forzados.

En Paquistán hubo grandes inundaciones en el mes de julio que desencadenaron 11.000.000 de desplazados ambientales forzados.

El terremoto ocurrido el 27 de febrero de 2010 en Chile provocó 2.000 .000 de desplazados ambientales forzados.

También, Haití sufrió un terremoto en el mes de enero que originó 1.500.000 desplazados ambientales forzados.

Colombia tuvo dos inundaciones: la primera fue en abril, causando el desplazamiento ambiental forzado de 1.500 .000 personas y la segunda fue en julio con 1.500 .000 desplazados ambientales forzados.

Tailandia fue afectada por las inundaciones en octubre que provocaron 1.000 .000 de desplazados ambientales forzados.

En México, las inundaciones de septiembre suscitaron 810.000 desplazados ambientales forzados.

Nigeria sufrió las inundaciones de septiembre que dejaron 560.000 desplazados ambientales forzados.

En Bangladesh, las inundaciones de octubre provocaron 500.000 desplazados ambientales forzados.

En India ocurrieron dos desastres. Las inundaciones de julio que provocaron 523.000 desplazados ambientales forzados. En abril, el segundo desastre fue una terrible tormenta que produjo el desplazamiento ambiental forzado de 455.285 personas.

En India, en julio, las inundaciones produjeron 523.000 y las tormentas ocasionaron 455.285 desplazados ambientales forzados.

Las inundaciones en Filipinas, en el mes de noviembre, produjeron 383.969 desplazados ambientales forzados. Además, hubo tormentas en octubre que causaron 150.240 desplazados

\footnotetext{
${ }^{379}$ IDMC-NRC. Disceplacement due to natural hazard-induced disasters. Global estimates for 2009 and 2010, 2011 b, Op.Cit., p. 26-27.
} 
ambientales forzados y otras tormentas (en julio) provocaron otros 137.445 desplazados ambientales forzados.

En Indonesia, el desastre fue la erupción del volcán que ocasionó 360.557 desplazados ambientales forzados.

El país de Benín fue afectado por inundaciones en el mes de julio, las que dejaron 275.000 desplazados ambientales forzados.

Las tormentas de agosto en Vietnam causaron 241.705 desplazados ambientales forzados.

En Níger, las inundaciones del mes de agosto dejaron 198.740 desplazados ambientales. 
Cuadro - Desplazamientos ambientales forzados, 2010. (Los siguientes datos han sido extraídos del Cuadro: Displacemente due to natural hazard- induced disasters- Global Estimates for 2009 and 2010- IDMC- página 29)

DESPLAZADOS AMBIENTALES FORZADOS DEL AÑO 2010 (Considerando mas de 200.000 desplazados por pais afectado)

\begin{tabular}{|c|c|c|c|c|}
\hline PAIS & FECHA & EVENTO & $\begin{array}{c}\text { NUMERO DE } \\
\text { DESPLAZADOS } \\
\text { AMBIENTALES }\end{array}$ & TOTAL POR PAIS \\
\hline CHINA & $\begin{array}{c}\text { Mayo } \\
\text { Setiembre } \\
\text { Setiembre } \\
\text { Octubre }\end{array}$ & $\begin{array}{c}\text { Inundacion } \\
\text { Tormenta } \\
\text { Tormenta } \\
\text { Inundacion }\end{array}$ & $\begin{array}{c}15.200 .000 \\
128.000 \\
186.000 \\
270.000 \\
\end{array}$ & 15.784 .000 \\
\hline PAKISTAN & Setiembre & Inundacion & 11.000 .000 & 11.000 .000 \\
\hline CHILE & Febrero & Terremoto & 2.000 .000 & 2.000 .000 \\
\hline COLOMBIA & $\begin{array}{l}\text { Mayo } \\
\text { Julio }\end{array}$ & $\begin{array}{l}\text { Inundacion } \\
\text { Inundacion }\end{array}$ & $\begin{array}{l}1.500 .000 \\
1.500 .000 \\
\end{array}$ & 3.000 .000 \\
\hline HAITI & Enero & Terremoto & 1.500 .000 & 1.500 .000 \\
\hline INDIA & $\begin{array}{l}\text { Abril } \\
\text { Julio } \\
\end{array}$ & $\begin{array}{c}\text { Tormenta } \\
\text { Inundacion }\end{array}$ & $\begin{array}{l}500.000 \\
523.000 \\
\end{array}$ & 1.023 .000 \\
\hline TAlLANDIA & Octubre & Inundacion & 1.000 .000 & 1.000 .000 \\
\hline MEXICO & Setiembre & Inundacion & 810.000 & 810.000 \\
\hline FILIPINAS & $\begin{array}{c}\text { Julio } \\
\text { Octubre } \\
\text { Noviembre }\end{array}$ & $\begin{array}{l}\text { Tormenta } \\
\text { Tormenta } \\
\text { Inundacion }\end{array}$ & $\begin{array}{l}137.000 \\
150.240 \\
383.969 \\
\end{array}$ & 671.209 \\
\hline NIGERIA & Setiembre & Inundacion & 560.000 & 560.000 \\
\hline INDONESIA & Octubre & Volcan & 360.557 & 360.557 \\
\hline BENIN & Julio & Inundacion & 275.000 & 275.000 \\
\hline VIETNAM & Agosto & Tormenta & 241.705 & 241.705 \\
\hline
\end{tabular}

Fuente : Displacement due to natural hazard-induced disasters - Global Estimates for 2009 and 2010 - IDMC - Pagina 29 
Cuadro - Desplazamientos ambientales forzados, 2010

\begin{tabular}{|l|r|}
\hline \multicolumn{2}{|c|}{$\begin{array}{c}\text { Desplazados Ambientales Forzados del año 2010 } \\
\text { (Considerando más de } 200.000 \text { desplazados por país afectado) }\end{array}$} \\
\hline País & Número de desplazados ambientales forzados \\
\hline China & 15.784 .000 \\
\hline Pakistan & 11.000 .000 \\
\hline Chile & 2.000 .000 \\
\hline Colombia & 3.000 .000 \\
\hline Haiti & 1.500 .000 \\
\hline India & 1.023 .000 \\
\hline Tailandia & 1.000 .000 \\
\hline México & 810.000 \\
\hline Filipinas & 671.209 \\
\hline Nigeria & 560.000 \\
\hline Indonesia & 360.557 \\
\hline Benín & 275.000 \\
\hline Vietnam & 241.705 \\
\hline
\end{tabular}

Fuente: Estimación Global, 2010.

\section{IV.7. Análisis de la situación de pobreza en los países donde ocurrieron los desplazamientos ambientales forzados en 2010, 2011 y 2012}

\section{IV.7.1. Consideraciones metodológicas}

¿Cómo decir que un país tiene gran parte de su población sumergida en la pobreza? Existen diferentes criterios que podrían ser considerados.

Se ha concluido que un criterio que es más apropiado y representativo es el del Mapa de la pobreza del Banco Mundial.

El Producto Bruto Interno (PIB) de los Estados es un criterio que permite visualizar el nivel de riqueza de la economía que tiene cada país. Aunque decir que un país tenga un alto $\mathrm{PIB}$, no significa que sus nacionales sean ricos, pues pueden existir grandes desigualdades en la distribución interna de la renta del país. Este es el caso de China e India, los cuales tienen altos niveles de Producto Bruto Interno, mientras tienen grandes cantidades de pobres que viven en las condiciones más precarias.

Otro criterio es el establecido por PNUD, el Índice de Desarrollo Humano. Este indicador es el resultado de la combinación de una serie de factores que se traducen en el bienestar de la población. De tal modo, PNUD establece cuatro grupos de países: los de 
desarrollo humano muy alto, aquellos de desarrollo humano alto, los de desarrollo humano medio y los de desarrollo humano bajo.

Los extremos, es decir, de un lado, los países con desarrollo humano muy alto y los de desarrollo humano alto, así como, de otro lado, aquellos que tienen un "desarrollo bajo" quedan claramente definidos. Aunque el problema surge con los países de desarrollo humano medio porque en estos últimos se puede observar que muchos aspectos vitales, en cuanto al nivel del bienestar de la población, están por debajo de lo que se podría considerar un nivel medio de desarrollo.

Según el Banco Mundial, el concepto de los países en desarrollo incluye los de desarrollo humano medio y bajo.

El criterio utilizado por Elizabeth Ferris y Daniel Petz (en The year that shook the rich: a review of natural disasters in 2011) para designar a "los países ricos" fue considerar como tales a los que integran la lista de los países que son miembros de OCDE (Australia, Austria, Bélgica, Canadá, Chile, República Checa, Dinamarca, Estonia, Finlandia, Francia, Alemania, Grecia, Hungría, Islandia, Irlanda, Israel, Italia, Japón, Corea del Sur, Luxemburgo, México, Países Bajos, Nueva Zelandia, Noruega, Polonia, Portugal, Eslovaquia, España, Suecia, Suiza, Turquía, Reino Unido y Estados Unidos) ${ }^{380}$.

El Banco Mundial considera en su Mapa de la pobreza las desigualdades internas de cada país, midiendo el porcentaje de población que vive con hasta 1,90 dólares y 3,10 dólares por día.

En este análisis realizado en octubre de 2016, el criterio que se utiliza es el nivel de pobreza de los países establecido a través del Mapa de la pobreza creado por el Banco Mundial, considerando el porcentaje de la población de cada país que vive en el umbral de hasta 3,10 de dólares por día. Esto se justifica porque en un estudio anterior de esta cuestión realizado en octubre de 2012, el Banco Mundial establecía como niveles de pobreza 2,5 y 4 dólares por día. Por lo tanto, como promedio, considerando los criterios anteriores, se ha llegado a la conclusión de reconocer como nivel de pobreza: los que viven con hasta 3,10 dólares por día.

Los años de referencia usados para definir el nivel de pobreza de cada país fueron los correspondientes al último año de información disponible en el site del Mapa de la pobreza del Banco Mundial $^{381}$.

${ }^{380}$ FERRIS; PETZ, 2012. Op.cit.

381 THE WORLD BANK. IBRO-IDA. Op.cit. Disponible en: http://databank.worldbank.org/data/ Acceso: $10 \mathrm{de}$ octubre de 2016 
A los fines de este trabajo, se define como pobres a las personas que disponen de hasta 3,10 dólares por día (siendo esta una de las definiciones internacionales de pobreza de acuerdo con los criterios del Banco Mundial).

Esta situación puede cotejarse con el cuadro de elaboración propia con base en los datos sobre la pobreza del Banco mundial obtenidos a través de su site ${ }^{382}$.

\section{IV.7.2. La pobreza en los países donde ocurrieron los desplazamientos ambientales forzados en 2012, 2011 y 2010}

Durante el año 2012, los países afectados con más de un millón de desplazados ambientales forzados fueron India, Nigeria, China, Filipinas y Paquistán.

En tanto que los países con más de 200.000 mil desplazados ambientales forzados ${ }^{383}$ fueron Estados Unidos, Bangladesh, Níger, Chad, Sudán del Sur, Japón y Corea del Norte. También, puede ser incluida Madagascar, ya que tuvo 190.000 desplazados ambientales forzados.

Con excepción de Estados Unidos y Japón, cabe observar que la mayoría de estos eventos han ocurrido en países donde existe un alto porcentaje de la población que vive con hasta 1,90 y 3,10 dólares por día, siendo esta una de las definiciones de pobreza de acuerdo al Banco Mundial. Aunque a los efectos de este trabajo será considerada como linea de pobreza 3,10 dólares por día.

India tiene 731,9 millones de personas que viven con hasta 3,10 dólares por día en absoluta precariedad y vulnerabilidad, constituyendo el 58\% de su población total. Además, hay 268 millones de personas que subsisten con hasta 1,90 dólares por día, siendo el 21\% del total de habitantes (datos disponibles del año 2011).

El caso de Nigeria es aún peor en términos relativos, pues 121,9 millones de personas viven en el nivel definido anteriormente de pobreza (hasta 3,10 dólares al día) representando el 77 de la población, mientras hay 85,2 millones que viven con hasta 1,90 dólares por día, constituyendo el 54\% de la población (datos disponibles del año 2009).

Paquistán es un país con una población muy pobre. A los fines de presentar una referencia sobre la pobreza en ese país, han sido utilizados los datos del año 2011 del Banco Mundial. De tal modo, en Paquistán, la población que vive con hasta 3,10 dólares por día

\footnotetext{
382 THE WORLD BANK. IBRO-IDA. Op.cit.

${ }^{383}$ Y menos de 1 millón de desplazados ambientales forzados.
} 
representa el $44 \%$ de la población, lo que se traduce en 77,3 millones de personas, mientras que los que viven con hasta 1,90 dólares por día, son 14,10 millones, correspondiendo al 8\% de la población.

Filipinas tiene 36,1 millones de pobres que subsisten con hasta 3,10 dólares, representando el 38\% de la población en 2012. Por otro lado, hay 12,60 millones que viven con hasta 1,90 dólares por día.

China es un caso impactante de pobreza por sus valores absolutos, revelando 257,3 millones de pobres que viven con hasta 3,10 dólares por día, constituyendo estos el 19\% de la población. Existe 87,3 millones de personas que subsisten con hasta 1,90 dólares por día, representando el 7\% de la población, según datos del año 2012.

De tal modo, se puede decir que estos países con más de 1 millón de desplazados son los que tienen grandes poblaciones de pobres, sea porcentualmente o en términos absolutos.

En relación con el grupo de países con más de 200.000 desplazados ambientales forzados, cabe observar nuevamente una constante: la pobreza que reina en su población, como será observado seguidamente.

Madagascar es un país con un 93\% de su población que sobrevive con hasta 3,10 dólares por día. Ese porcentaje se traduce en 19,6 millones de pobres. Hay 17,2 millones de habitantes que viven con hasta 1,90 dólares por día, siendo el $82 \%$ de la población de ese país (según datos de 2010).

Chad es otro país tiene un alto porcentaje de personas que viven con hasta 3,10 dólares, el cual es de $64 \%$, representando 8 millones de personas. El 38\% de su población sobrevive con hasta 1,90 dólares, constituyendo 4,7 millones de personas, en el año 2011.

Bangladesh tiene 86,1 millones de pobres que viven con hasta 3,10 dólares por día, lo cual significa el 57\% de la población (2010). Hay 28,10 millones de habitantes que viven con hasta 1,90 dólares, siendo el 19\% del total de población (datos disponibles del año 2011).

Níger cuenta con $82 \%$ de su población que vive con hasta 3,10 dólares por día, siendo que constituyen 8 millones de personas. El 50\% de su población viven con hasta 1,9 dólares, correspondiendo a 13,9 millones de personas (año 2011).

Cabe señalar que no constan datos en el Banco Mundial sobre Sudán del Sur y Corea del Norte.

Aun es necesario observar que, en ese grupo, hubo dos países desarrollados que sufrieron los desastres ambientales: Estados Unidos y Japón. También China, dado que es un 
país que tiene alto crecimiento económico, aunque se caracteriza por tener un gran número de pobres en términos absolutos: 257,3 millones de personas sumergidas en la pobreza.

Así, considerando el resto de los países en el año 2012, del total de estos Estados con desplazados ambientales forzados se puede observar que el 57\% tienen poblaciones abajo del nivel de pobreza.

Cabe concluir que, en el año 2012, se verifica la idea sostenida en este trabajo de que los desplazados ambientales forzados viven en países con poblaciones pobres.

En el año 2011, los países con más de 1 millón de desplazados ambientales forzados fueron China, India, Filipinas, Tailandia.

En tanto que, en ese mismo año, los países afectados con más de 200.000 desplazados ambientales forzados ${ }^{384}$ fueron Bangladesh, Paquistán, Vietnam, Camboya, Angola, Sri Lanka, México, Turquía, y Japón.

Angola es un país que tiene gran parte de su población sumergida en la pobreza, siendo que el 55\% de sus habitantes viven con menos de 3,10 dólares por día. Esto significa que 10,8 millones de personas. Ese país tiene 6 millones de personas que viven con hasta 1,90 dólares por día, siendo el 30\% de su población total (datos disponibles del año 2008).

Camboya es un país que tiene el $26 \%$ de la población que viven con hasta 3,10 dólares por día, constituyendo 3,7 millones de personas, siendo que hay 500.000 de habitantes que viven con hasta 1,9 dólares por día. Estos últimos corresponden al 3\% del total de personas (datos del año 2011).

Vietnam tiene el 14\% de su población que vive con menos de 3,10 dólares por día, lo que significa que tiene 12,3 millones de personas pobres. Hay 2,90 millones de personas que viven con hasta 1,90 dólares por día, lo cual representa el 3\% del total de habitantes. (año 2008).

Sri Lanka es un país que tiene el 15\% de las personas que viven con hasta 3,10 dólares por día, lo cual implica 3 millones de pobres. En este país, hay un $2 \%$ que viven con hasta 1,90 dólares por día (400.000 personas, año 2012).

Tailandia cuenta con 800.000 personas que viven con hasta 3,10 dólares, constituyendo el 1\% de su población (datos disponibles del año 2012).

México tiene 12,6 millones de personas que viven con hasta 3,10 dólares por día, lo que se traduce en el 10\% y, además tiene 3,3 millones que viven con hasta 1,90 dólares por día, siendo el 3\% del total de habitantes de ese país. (datos disponibles del año 2012).

${ }^{384}$ Y menos de 1 millón de desplazados ambientales forzados. 
Turquía tiene 3,10 millones de personas pobres, siendo el 4,10\% de su población (datos disponibles del año 2010).

El análisis de estos datos sobre la pobreza de estos países que fueron afectados por los desastres ambientales revela que 7 de ellos tienen grandes niveles de pobreza. Estos países son China, India, Filipinas, Bangladesh, Paquistán, Angola y Sri Lanka.

Japón es un país de muy alto desarrollo, Tailandia, México y Turquía son países de alto desarrollo humano, siendo que estos tres últimos tienen un índice de pobreza de menos del 10\% de su población. Vietnam y Camboya son paises con alto desarrollo humano. Por lo tanto, excluyendo estos del cálculo, y también China (debido a que es un alto crecimiento económico), aunque sea un país con un altísimo número de personas sumergidas en la pobreza en términos absolutos.

De tal modo, en 2011, se puede concluir que, en los países que tuvieron mayor número de desplazados ambientales forzados, hubo un promedio de casi el 53\% de poblaciones inmersas en la pobreza.

Por lo tanto, en el año 2011, el análisis de los datos de pobreza de los países afectados permite comprobar nuevamente que la mayoría de los desplazados ambientales forzados viven en países con poblaciones mayoritariamente pobres.

En 2010, los países con más de 1 millón de desplazados ambientales forzados fueron China, Paquistán, Chile, Haití, Colombia, Tailandia e India.

Mientras que en el mismo año (2010), los países que sufrieron desplazamientos ambientales forzados de menos de 1 millón y más de 200.000 personas fueron: México, Nigeria, Bangladesh, Filipinas, Indonesia, Benín, Vietnam y Níger.

Haití es un país que tiene gran parte de su población sumergida en la pobreza, sumando a esto los desastres ambientales que ocurrieron en enero del 2010, con 1,5 millones de desplazados ambientales estimados, la situación de la población es desesperante, dependiendo absolutamente de la ayuda internacional.

En relación con el nivel de pobreza en Haití, los datos disponibles en el Banco Mundial del año 2012 permiten tener una referencia sobre los niveles de pobreza. En ese país hubo el $72 \%$ de la población con hasta 3,10 dólares por día, es decir 7,3 millones de pobres. Existe un $54 \%$ de personas que viven con hasta 1,90 dólares por día, constituyendo 5,5 millones de personas. 
Los datos disponibles en el Banco Mundial sobre la pobreza en Benín correspondientes al año 2011: 7,4 millones de personas viven con hasta 3,10 dólares por día, constituyendo el $76 \%$ de toda la población del país.

Indonesia es un país con 103,4 millones de habitantes que viven con hasta 3,10 dólares, equivalente al $42 \%$ del total de su población. Por otro lado, este país tiene 29,2 millones de personas que viven con hasta 1,90 dólares, representando el $12 \%$ de la población. (datos de 2012).

Chile es un país con bajo porcentaje de pobreza en su población, siendo 500.000 personas que viven con hasta 3,10 dólares por día, lo que constituye un 3\% (año 2010).

Colombia tiene 7,6 millones de personas que viven con hasta 3,10 dólares, lo que implica el 16\% del total de la población (datos del año 2012).

\section{Cuadro 12. Países Afectados por los Desastres Repentinos y sus poblaciones pobres debajo de la linea de la pobreza (3,10 dólares por día), según datos extraídos del Banco Mundial}

\begin{tabular}{|c|c|c|c|c|c|}
\hline Pais & Año & $\begin{array}{l}\text { Porcentaje de la poblacion } \\
\text { con menos de } 1,90 \text { dolares } \\
\text { (PPP) al dia }\end{array}$ & $\begin{array}{c}\text { Millones de habitantes con } \\
\text { menos de 1,90 dolares (PPP) } \\
\text { al dia }\end{array}$ & $\begin{array}{l}\text { Porcentaje de la poblacion } \\
\text { con menos de } 3,10 \text { dolares } \\
\text { (PPP) al dia }\end{array}$ & $\begin{array}{c}\text { Millones de habitantes con } \\
\text { menos de } 3,10 \text { dolares } \\
\text { (PPP) al dia }\end{array}$ \\
\hline India & 2011 & $21 \%$ & 268,0 & $58 \%$ & 731,9 \\
\hline Vietnam & 2012 & $3 \%$ & 2,9 & $14 \%$ & 12,3 \\
\hline Filipinas & 2012 & $14 \%$ & 12,6 & $38 \%$ & 36,1 \\
\hline Indonesia & 2012 & $12 \%$ & 29,2 & $42 \%$ & 103,4 \\
\hline Nigeria & 2009 & $54 \%$ & 85,2 & $77 \%$ & 121,9 \\
\hline Angola & 2008 & $30 \%$ & 6,0 & $55 \%$ & 10,8 \\
\hline Paquistan & 2011 & $8 \%$ & 14,1 & $44 \%$ & 77,3 \\
\hline Bangladesh & 2011 & $19 \%$ & 28,1 & $57 \%$ & 86,1 \\
\hline Camboya & 2011 & $3 \%$ & 0,5 & $26 \%$ & 3,7 \\
\hline Chad & 2011 & $38 \%$ & 4,7 & $64 \%$ & 8,0 \\
\hline Niger & 2011 & $50 \%$ & 8,5 & $82 \%$ & 13,9 \\
\hline Benim & 2011 & $53 \%$ & 5,2 & $76 \%$ & 7,4 \\
\hline Madagascar & 2010 & $82 \%$ & 17,2 & $93 \%$ & 19,6 \\
\hline China & 2012 & $7 \%$ & 87,3 & $19 \%$ & 257,3 \\
\hline Sri Lanka & 2012 & $2 \%$ & 0,4 & $15 \%$ & 3,0 \\
\hline Colombia & 2012 & $7 \%$ & 3,3 & $16 \%$ & 7,6 \\
\hline Tailandia & 2012 & $0 \%$ & 0,1 & $1 \%$ & 0,8 \\
\hline Mexico & 2012 & $3 \%$ & 3,3 & $10 \%$ & 12,6 \\
\hline Chile & 2011 & $1 \%$ & 0,2 & $3 \%$ & 0,5 \\
\hline Total & & & 582,3 & & $1.521,5$ \\
\hline
\end{tabular}

World Bank, Development Research Group. Data are based on primary household survey data obtained from government statistical agencies and World Bank country departments. Data for high-income economies are from the Luxembourg Income Study database. For more information and methodology, please see PovcalNet (http://iresearch.worldbank.org/PovcalNet/index.htm).

Fuente: Elaboración propia con base en datos del World Bank IBRO-IDA- octubre de 2016 
En el año 2010, excluyendo Chile, Colombia, Tailandia y Mejico, debido a que son países con alto desarrollo humano, y China (debido a que es un alto crecimiento económico), los países con mayores desplazamientos ambientales forzados tienen $54 \%$ de sus poblaciones que están abajo del nivel de la pobreza.

De tal modo, en 2010, una vez más, se ha comprobado la idea sostenida de que la mayoría de los países con desplazados ambientales forzados son Estados con los más altos índices de pobreza.

Además, cabe observar que como consecuencia de todo lo referido anteriormente, el problema de estos países es que precisan de la ayuda internacional para hacer frente a emergencias que surge del desastre ambiental o degradación. En tanto que aquellos países con bajas cantidades de pobres no precisan de esta ayuda, pues estos Estados tienen sus propios mecanismos institucionales para proteger a sus desplazados ambientales. Esto último ya ha quedado demostrado, analizando el caso de Japón, Chile y Estados Unidos.

\section{IV.8. Consideraciones finales}

Tanto los desastres repentinos como los derivados de procesos lentos (la desertificación y el aumento del nivel del mar) causan la violación de los derechos humanos de los desplazados. Ha sido constatado que en cada una de las catástrofes ambientales observadas se repiten las mismas situaciones: las personas pierden sus viviendas, tienen que escapar para salvar sus vidas, no tienen alimentos, ni agua, ni asistencia médica, perdiendo sus medios de subsistencia, pasando a vivir una situación infrahumana. En la mayoría de los casos se observa que la huida es desorganizada, así como los lugares de refugio son precarios.

Existe una diferencia en la respuesta al desastre por parte de los gobiernos de los países ricos y los de menor desarrollo o en desarrollo. Los países ricos consiguen hacer frente por sí mismos sin necesidad de la ayuda de internacional, como ha sido el caso de Japón en 2011, Estados Unidos (huracán Sandy) y Chile (terremoto de 2010). Por otro lado, los países menos adelantados y con menor desarrollo precisan de la ayuda internacional, pues no tienen los medios económicos ni institucionales para brindar la asistencia a la emergencia.

La repetición de los desastres repentinos en los mismos lugares, o el empeoramiento de la situación de las tierras bajas de islas o regiones costeras, demuestra la falta de políticas preventivas y de asistencia en la emergencia por parte de los Estados afectados. El fenómeno 
de la repetición de los mismos tipos de desastres en los mismos lugares permitiría que fueran creadas medidas planificadas de ayuda. Además, se observa la falta de respuesta de la comunidad internacional, que en los países menos desarrollados podría hacer una diferencia.

La teoría de la Justicia Ambiental permite comprender la problemática de los desplazados ambientales forzados, porque estos viven principalmente en los países con altísima cantidad de pobres, como ya fue comprobado.

El núcleo teórico de esta teoría que sustenta que los impactos ambientales negativos son sufridos por las comunidades más desfavorecidas (sean por el color o por los ingresos bajos) o por los países menos adelantados o con menor desarrollo con grandes poblaciones bajo el nivel de la pobreza, concuerda con la situación analizada de los desplazados ambientales forzados.

Los impactos negativos ambientales son las catástrofes ambientales, sean estos desastres de lenta duración (el aumento del nivel del mar o la erosión de las regiones costeras o la desertificación) o desastres repentinos (como tsunamis, intensificación de las tormentas, accidentes nucleares, inundaciones). Según el Panel Intergubernamental de Expertos en Cambios Climáticos, todos estos desastres van a aumentar por causa de los cambios climáticos.

Los países que sufren de mayor número de desplazados ambientales forzados tienen gran cantidad de pobres. Además, es necesario observar que estos países han sido los que menos han contribuido a las emisiones de los gases que producen el efecto estufa invernadero. No existe una respuesta de la comunidad internacional a este problema.

En el período de tiempo que comprende los años 2010, 2011, 2012, se puede verificar que la gran mayoría de los desplazados ambientales forzados viven en países con mayoría de población sumergida en la pobreza.

De este modo, el análisis de la relación entre los datos de los países donde ocurrieron los mayores desplazamientos ambientales forzados y los datos sobre la pobreza de las poblaciones en tales países permite decir que la mayoría de los desplazados ambientales forzados están en países que tienen la mayoría de su población abajo del índice de la pobreza. Consecuentemente, se puede concluir que la falta de interés de la comunidad internacional a través de Naciones Unidas y del concierto de naciones reside en que los más afectados con la problemática de los desplazados ambientales forzados son países con poblaciones muy pobres.

Además, cabe destacar que los países ricos o desarrollados no precisan de la ayuda internacional para proteger a sus nacionales ante desplazamientos ambientales forzados, como fue el caso de Sandy, en Estados Unidos, o el caso de Japón. 
Por lo tanto, comprometerse formalmente con el problema de los desplazados ambientales forzados, la creación de un régimen legal internacional en tal sentido y la designación de un organismo específico para que trate el problema, significaría para los países desarrollados asumir mayores cargas económicas, aumentar las responsabilidades, reconocer la deuda ecológica, reconocer la responsabilidad por las emisiones de gases estufa de efecto invernadero (causantes del calentamiento climáticos y de los cambios climáticos, así como del aumento del nivel del mar) y hasta tener que reconocer obligaciones tales como las de abrir sus barreras migratorias para los afectados.

Por otro lado, es necesario concluir que la teoría del Ecologismo de los Pobres o Justicia Ambiental sirve para explicar la situación de los desplazados ambientales forzados en el mundo. Porque se verifica el eje principal de tal corriente, el cual sustenta que los impactos ambientales negativos son sufridos por las comunidades más desfavorecidas de la sociedad, incluyendo las clases sociales con menores ingresos, así como los países con mayores poblaciones pobres. Esto ha sido comprobado a través del análisis de los datos de la situación de los desplazados ambientales forzados entre 2010 y 2012. 


\section{CAPITULO V}

\section{PROPUESTAS DE INSTRUMENTOS INTERNACIONALES PARA LA PROTECCION DE LOS DESPLAZADOS AMBIENTALES FORZADOS}

\section{V.1. Introducción}

Los desplazados ambientales forzados son personas que sufren la violación de sus derechos humanos o fundamentales y cuya dignidad ha sido menoscabada como consecuencia de los impactos del desastre o de la degradación ambiental.

A pesar de todas estas violaciones sufridas por estos seres humanos, el derecho internacional no les brinda protección. Esas personas han tenido o tienen que abandonar sus hogares debido a un desastre o degradación ambiental, siendo que estos son de tal magnitud que pueden llevar a la pérdida de las vidas o de la sobrevivencia de estas personas que se ven obligadas a escapar de sus hogares y hábitats.

En el final de la Segunda Guerra Mundial, la comunidad internacional de países reconoció las aberraciones a los derechos humanos que habían sufrido aquellas personas, las cuales habían sido obligadas a escapar de sus países. Los refugiados quedaron deambulando por Europa sin destino. En 1951, fue creada la Convención del Estatuto de los Refugiados e instituido el Alto Comisionado de Naciones Unidas para los Refugiados. Este reconocimiento en el derecho internacional se produjo como consecuencia de la situación dramática que padecían estos seres humanos, los refugiados.

Ahora, ante la crisis ambiental que se está viviendo, la cual resulta en el aumento de los desastres y de la degradación ambiental, surgen estas personas que sufren la violación de sus derechos humanos, que son obligadas a abandonar sus hogares y a deambular.

Los refugiados y los desplazados internos son figuras afines de los desplazados ambientales forzados, caracterizados por grandes similitudes. Aunque existe una diferencia, los primeros están protegidos por la Convención del Estatuto de los Refugiados de 1951 y su Protocolo Anexo, los segundos están amparados por los Principios Rectores de los Desplazados Internos. 
Mientras, los desplazados ambientales forzados no tienen ninguna protección en el ámbito internacional, constituyendo esto una laguna jurídica, pues existe el problema en la realidad, aunque no tiene solución en el ámbito jurídico.

Estas tres figuras tienen diversas convergencias: la necesidad forzada de estas personas de escapar de sus residencias; la violación de los derechos humanos que sufren estos grupos; la existencia de un hecho de violencia, sea un acto político, sea un conflicto armado y en el caso de los desplazados ambientales, la violación de los derechos humanos causada por el desastre o la degradación ambiental repentina o gradual. Todos estos hechos interrumpen la vida de estas personas dejándolas desprotegidas, desestructuradas de igual forma que las otras dos figuras mencionadas anteriormente. Aunque no hay una protección del derecho internacional para los desplazados ambientales forzados.

La naturaleza del problema de los desplazados ambientales forzados es internacional, debido a diversas causas. Una de ellas es que la violación de los derechos humanos de estas personas eleva el problema al nivel internacional. Otra cuestión es que la naturaleza del desastre puede abarcar diversos países y, además, provocar desplazamientos transfronterizos forzados, lo cual justifica la necesidad de la protección internacional.

Ante esta laguna legal han surgido diversas propuestas de la doctrina que buscan encontrar una solución al problema.

Carolina de Abreu Batista Claro reconoce que los refugiados ambientales deben tener su propio sistema de instituciones que los protejan. Aunque en este primer momento es necesario que se actúe con las instituciones existentes, dadas las condiciones y limitaciones existentes en el sistema del derecho internacional ${ }^{385}$.

En el ámbito del derecho internacional, los desplazados ambientales forzados que atraviesan las fronteras no tienen ningún tipo de protección, aunque aquellos desplazados ambientales internos tienen la protección de los Principios Rectores de los Desplazados Internos, porque este cuadro normativo incluye dentro de esa categoría a los desplazados de los desastres naturales "internos". Por otro lado, existe IASC, que fue creada como parte de la reforma de Naciones Unidas, cuyo objetivo es brindar la protección a la emergencia humanitaria y a los desastres naturales. Su función es brindar apoyo a aquellos desplazados internos que escapan de los desastres repentinos. En 2006, IASC creó las Directrices Operacionales sobre la protección de las personas en situaciones de desastres naturales, aunque estas son meras recomendaciones y abordan el problema de forma parcial, pues sólo se refieren a los

${ }^{385}$ CLARO. Op.cit., p. 74. 
desplazados de los desastres naturales, dejando de lado todos los otros escenarios que hacen parte del cuadro de los desplazados ambientales forzados.

Una de las contradicciones es que los desplazados internos de los desastres naturales están protegidos, mientras que los transfronterizos no lo están.

Por otro lado, en el ámbito interno de los países, hay algunos que tienen sus propias legislaciones, como es el caso de Suecia, Finlandia, Argentina, Estados Unidos y la Comunidad Europea.

Estas iniciativas nacionales son loables, aunque no solucionan el problema porque es de naturaleza internacional, consecuentemente, la solución precisa ser de naturaleza internacional.

Después de todo lo discutido en los capítulos anteriores, ha quedado en evidencia la necesidad de un ordenamiento jurídico que proteja a los desplazados ambientales forzados. Esto ha sido reconocido por algunos autores como BIERMANN y BOAS, DOCHERTY y GIANNINI, HODKINSGTON, MAYER, CRIDEAU ${ }^{386}$ y por los gobiernos de Maldivas y Pequeños Estados Insulares en Desarrollo, entre los autores con mayor reconocimiento.

Cada uno de estos tiene una visión propia de la cuestión, pero todos coinciden en la gravedad y en la importancia de que sea presentada una solución a este problema.

El aporte de estos autores ayuda tanto en la construcción del consenso en la comunidad internacional sobre la necesidad de la respuesta, como en el proceso de formación de un derecho internacional que atienda a esta problemática.

El objetivo de este capítulo es presentar un análisis detallado de las principales propuestas de protección de los desplazados ambientales forzados elaboradas por los autores.

En primer lugar, serán consideradas las principales propuestas existentes en la doctrina internacional.

En segundo lugar, serán establecidas algunas observaciones finales sobre las cuestiones comunes y las divergencias existentes entre las propuestas.

\section{V.2. Creación del Protocolo en el marco de la Convención de Naciones Unidas sobre el Clima: Biermann y Boas}

BIERMANN y BOAS proponen la creación de un Protocolo que proteja a los desplazados ambientales forzados que esté inserido en el UNFCCC, el cual se denominaría

\footnotetext{
${ }^{386}$ CRIDEAU es el Centro de Investigación Interdisciplinaria en Derecho del Medio Ambiente, del Desarrollo y Urbanístico (CENTRE DE RECHERCHE INTERDISCIPLINAIRE EN DROIT DE L 'ENVIRONNEMENT, DE L'AMÉNAGEMENT ET DE L'URBANISME).
} 
"Protocolo para el Reconocimiento, Protección y Restablecimiento de los Refugiados del Clima" 387.

En la Reunión de Cancún de 2010, hubo un grupo de Estados formado por los Pequeños Estados Insulares en Desarrollo que apoyaba la inserción de un Protocolo en el UNFCCC ${ }^{388}$.

DOCHERTY y GIANNINI critican la idea de inserir ese Protocolo en UNFCCC porque en este último marco legal no hay referencias ni a los derechos humanos, ni a la asistencia humanitaria para los refugiados climáticos. Por otro lado, en UNFCCC se han establecido obligaciones entre los Estados, pero no así obligaciones de los Estados con las personas. Además, el objetivo del UNFCCC es obtener la reducción de la emisión de los gases de efecto invernadero, siendo que ni siquiera se ha alcanzado consenso en relación con este objetivo. Mucho más difícil sería la tentativa de inserir el Protocolo ${ }^{389}$.

HODGKINSON critica la idea de inserir ese Protocolo en UNFCCC, pues sostiene que no es el ámbito adecuado para la protección de los desplazados ambientales forzados. En tal sentido, el autor afirma:

UNFCCC tiene limitaciones como marco cuadro para negociar el desplazamiento de los cambios climáticos. El desplazamiento no es el foco; sus preocupaciones son otras. Su estructura y sus instituciones no son designadas para direccionar al desplazamiento y cuestiones asociadas con este. Más aun, "tal no discute las obligaciones que los Estados tienen con los individuos o con las comunidades, así como tampoco lo referente a los derechos humanos o la ley de refugiados" 390 .

MAYER observa que, en Cancún, en la Conferencia de las Partes de UNFCCC, fue solicitada la inclusión de un Protocolo para los migrantes forzados del cambio climático. Eso se fundó en el artículo 3 de la Convención Marco, “en el cual prevé que los países desarrollados (partes) deberían tomar el liderazgo en el combate a los cambios climáticos y sus efectos adversos". Aunque esta tentativa no tuvo ningún éxito ${ }^{391}$.

Katrina Miriam WYMAN critica la propuesta de inserir un Protocolo en el UNFCCC porque piensa que es inviable la realización de las negociaciones entre los países para la creación de tal instrumento internacional. Esto queda en evidencia después del análisis de las

\footnotetext{
${ }^{387}$ BIERMANN; BOAS. Op.cit., p. 26.

${ }^{388}$ MAYER, 2011. Op.cit.

${ }^{389}$ DOCHERTY; GIANNINI. Op.cit., p. 394-395.

${ }^{390}$ HODGKINSON, David et al. 'The Hour When the Ship Comes In': A Convention for Persons Displaced by Climate Change, 36 MONASH UNIV. L. REV. 69, 2010, p. 13. Disponible en: $<$ http://www.ccdpconvention.com/documents/CCDP_Convention_Summary.pdf $>$ acceso 25 de mayo de 2014.

${ }^{391}$ MAYER, 2011. Op. cit., p. 406.
} 
dificultades presentadas en las negociaciones en el ámbito del Protocolo de Kioto y de la Convención Marco de Naciones Unidas sobre los Cambios Climáticos ${ }^{392}$.

Carolina de Abreu Batista CLARO rechaza esta propuesta porque considera que en el seno de UNFCCC ya existe una puja muy grande por los intereses de los Estados en relación con la reducción de las emisiones de gases de efecto invernadero, lo cual ha llevado a grandes dificultades en tales negociaciones.

En este sentido, la autora explica:

Las últimas COPs, por ejemplo, no apenas produjeron declaraciones vagas e imprecisas, así como fallaron en tratar asuntos polémicos como mecanismos de comando y control sobre reducción de las emisiones de gases de efecto invernadero o mismo sobre el destino de millares de migrantes inducidos por los cambios climáticos $^{393}$.

BIERMANN y BOAS definen los refugiados climáticos como:

Personas que han tenido o tendrán que salir de sus hábitats, inmediatamente o en un futuro próximo, debido a alteraciones repentinas o graduales en su ambiente natural relativas al menos a uno de los tres impactos del cambio climático: aumento del nivel del mar, los fenómenos meteorológicos extremos y la sequía y la escasez de agua ${ }^{394}$.

La definición de estos autores no establece diferencias entre los refugiados climáticos internos y transfronterizos ${ }^{395}$.

El concepto de refugiados climáticos solamente abarca aquellos que fueron obligados a escapar debido a los impactos de los cambios climáticos. Estos últimos serían únicamente: el aumento del nivel del mar, los fenómenos meteorológicos extremos y la sequía y escasez del agua. De tal forma, la definición de estos autores es muy restricta.

BIERMANN y BOAS consideran tres aspectos principales en relación con el régimen de protección de los desplazados ambientales forzados:

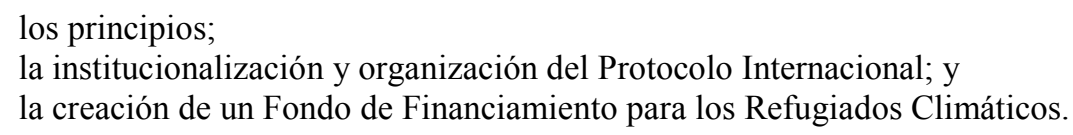

Este régimen de protección de los desplazados ambientales forzados establece cinco principios básicos: “el Principio de Recolocación y de Restablecimiento Planificados, el

\footnotetext{
392 WYMAN, Katrina Miriam. Responses to Climate Migration. In Harvard Environmental Law Review, Vol. 37, 2013, p. 201. Disponible en: <http://harvardelr.com/wp-content/uploads/2013/05/Wyman.pdf> acceso 28 de mayo de 2014.

${ }^{393}$ CLARO. Op.cit., p. 60.

${ }^{394}$ BIERMANN; BOAS. Op.cit., p. 8.

${ }^{395}$ DOCHERTY; GIANNINI. Op.cit., p. 368.
} 
Principio de Restablecimiento en vez del asilo temporario, el Principio de los Derechos Colectivos para las poblaciones locales, el Principio de Asistencia Internacional para las Medidas Domésticas y el Principio de Compartir las Cargas o las Responsabilidades". En cada una de las etapas que atraviesan los desplazados ambientales forzados sufren la violación de sus derechos humanos, ya sea cuando dejan sus tierras (en el momento en que escapan), trasladándose para otros lugares provisorios, o después del desastre, cuando ellos precisan restablecerse definitivamente. Estos autores observan la importancia de que todas esas actividades sean planificadas, tratando de prevenir las violaciones a los derechos humanos y evitando mayores perjuicios ${ }^{396}$. En tal sentido, sostienen el Principio de Recolocación y de Restablecimiento Planificados.

El concepto de los desplazados ambientales forzados de estos autores tiene la particularidad de considerar solamente tres situaciones de desastre o degradación ambiental caracterizadas como procesos de lenta duración (la de aquellos localizados en las regiones costeras o de islas que van a quedar sumergidas, así como las situaciones de la degradación ambiental debida a las sequías y a la escasez de agua).

El análisis de estos procesos de desastres de larga duración hace posible que sean localizadas las regiones que van a sufrir los impactos. También, permite verificar el tipo y la magnitud de los efectos del desastre ambiental, previamente. Así, es posible la aplicación del principio de la planificación.

La recolocación hace referencia al momento en el que esas personas afectadas escapan del desastre. El restablecimiento es la etapa final en la que es necesario encontrar un lugar para que vivan definitivamente. En ambos momentos, es necesaria la utilización del Principio de la Planificación.

En el caso de los desastres repentinos también es necesaria la planificación, pues una de las características de estos tipos de desastres es la repetición, lo que haría posible la aplicación del Principio de Recolocación Planificada. Aunque estos autores consideran únicamente los desastres producidos por los cambios climáticos, la planificación es imprescindible en las otras situaciones de degradación ambiental que provocan el surgimiento de los desplazados ambientales forzados.

La existencia de un marco normativo específico y de una estructura orgánica preparada para actuar en la emergencia aumentaría la posibilidad de una respuesta más eficaz, previsible y planificada.

${ }^{396}$ BIERMANN; BOAS. Op.cit., p. 25. 
El segundo Principio se refiere al derecho de "establecimiento permanente, en vez del asilo temporario". El concepto de desplazados ambientales forzados de estos autores abarca la situación de las personas que no podrán volver a sus lugares de origen nunca más, principalmente debido a que esos territorios van a desaparecer, generando la imposibilidad del regreso. De tal modo, el asilo temporario no serviría para estas personas, por eso los autores lo sustituyen por el derecho a establecerse de modo definitivo ${ }^{397}$.

La diferencia entre el desplazamiento forzado temporario y el permanente reside en que este último es el más grave, haciendo necesaria la reubicación permanente. Este es uno de los retos más importantes y más difíciles que deben ser solucionados por el derecho internacional.

En los últimos años, ACNUR ha desarrollado diversos trabajos sobre esta cuestión ${ }^{398}$.

Otro de los Principios enunciados por BIERMANN y BOAS es el de "los derechos colectivos de las poblaciones locales". Este se refiere a los casos en los que los afectados son los grupos sociales de etnias o las comunidades tradicionales ${ }^{399}$.

Los derechos colectivos son aquellos que protegen los intereses comunes de un grupo social. Las comunidades tradicionales tienen una cosmovisión diferente de la occidental. En tal sentido, esta perspectiva del derecho no es individual, sino colectiva, como ocurre con el derecho colectivo de la propiedad en la visión de las comunidades indígenas.

El Principio de la "Asistencia Internacional para el Establecimiento de Medidas a Nivel Doméstico" sirve para brindar ayuda a aquellos países en desarrollo que tienen pocos recursos económicos y humanos para asumir la responsabilidad por los desplazados ambientales forzados $^{400}$.

En realidad, la mayoría de los países más afectados por los desastres ambientales son países en vías de desarrollo, que necesitan del apoyo internacional porque no tienen medios propios.

Además, el problema de los desplazados ambientales forzados es una situación de naturaleza global, lo cual justifica la ayuda y la asistencia de la sociedad internacional.

\footnotetext{
${ }^{397}$ BIERMANN; BOAS. Op.cit., p. 25.

398 GEORGETOWN UNIVERSITY'S INSTITUTE FOR THE STUDY OF INTERNATIONAL MIGRATION (ISIM); UNITED NATIONS HIGH COMMISSIONER FOR REFUGEES (UNHCR); THE BROOKINGS-LSE PROJECT ON INTERNAL DISPLACEMENT (BROOKINGS INSTITUTION). Planned relocation, disasters and climate change: consolidating good practices and preparing for the future report. San Remo, 12-14 de marzo de 2014. Disponible en: < http://www.brookings.edu/ /media/research/files/papers/2014/03/14-plannedrelocations-climate-change/planned-relocations-disaste $>$ acceso 17 de diciembre de 2015.

${ }^{399}$ BIERMANN; BOAS. Op.cit., p. 25.

${ }^{400}$ BIERMANN; BOAS. Op.cit., p. 26.
} 
Algunos autores como DOCHERTY y GIANNINI consideran que los desplazados ambientales forzados internos deben ser excluidos del problema porque la intervención de la comunidad internacional podría ser interpretada como un acto contrario al principio de la soberanía $^{401}$.

Aunque esto es infundado, porque la asistencia internacional para los países que tienen desplazados internos de desastres solo podrá ocurrir cuando sea expresado el pedido de ayuda internacional del gobierno nacional y cuando sea manifestado el consentimiento del Estado nacional. De modo que no habría posibilidad de intervención internacional sin previo consentimiento expresado por el país ${ }^{402}$. Así también esto constituye una exigencia del Sistema de Naciones Unidas para la Emergencia-IASC.

Finalmente, BIERMANN y BOAS sostienen el principio de la "carga compartida", el cual implica "la responsabilidad común pero diferenciada según las capacidades" ante la situación de los desplazados ambientales forzados.

Los países industrializados han contribuido al aumento de las emisiones de gases de efecto invernadero, siendo que esto ha sido la causa del aumento del nivel del mar por el derretimiento de las capas polares y del calentamiento de la atmósfera, de los cambios climáticos, origen de desastres y degradación ambiental. Por lo tanto, estos países precisan asumir las consecuencias de tales acciones a través de la responsabilidad.

Por otro lado, los autores se refieren a la estructura orgánica para viabilizar el régimen de los desplazados ambientales forzados.

El Protocolo propuesto por los autores considera la creación de un Comité Ejecutivo que responda a la Conferencia de países partes de UNFCCC. La función del Comité Ejecutivo es llevar a cabo la protección de los desplazados ambientales forzados. La formación de ese Comité estará integrada tanto por los países afectados con desplazados ambientales forzados como por los que contribuyen económicamente.

De tal modo, la naturaleza de este Comité es intergubernamental, pues está integrado solamente por los representantes de los países.

BIERMANN y BOAS sostienen que las decisiones del Comité serian realizadas por el mecanismo de la mayoría ${ }^{403}$.

En general, en el derecho de las organizaciones internacionales existen tres mecanismos de decisión: unanimidad, consentimiento o mayoría. El mecanismo de unanimidad es aquel en

\footnotetext{
${ }^{401}$ DOCHERTY; GIANNINI. Op.cit., p. 374.

${ }^{402}$ NACIONES UNIDAS. Principios Rectores... Op.cit.

${ }^{403}$ BIERMANN; BOAS. Op.cit., p. 26-27.
} 
el que todos los integrantes tienen que expresar su conformidad, siendo que constituye un mecanismo que lleva a grandes dificultades en el momento de tomar las decisiones, porque puede transformar los procesos de decisión en procesos indeterminados en el tiempo, provocando la parálisis de la organización internacional. Este es el caso de lo que ocurrió en la Sociedad de Naciones. El mecanismo del consentimiento consiste en que no puede haber ningún integrante que exprese su contrariedad a la decisión. Finalmente, el mecanismo de la mayoría es aquel en el que las decisiones son formadas por la voluntad de la mitad más uno de los integrantes del organismo. Esta forma de decisión es un tipo más ágil para la formación de decisiones. De tal modo, la decisión del organismo refleja la voluntad de la mayoría de los integrantes del órgano.

Además, se crearía una Secretaría para cuidar del Protocolo, la cual podría formar parte de la Secretaría del UNFCCC. El Protocolo de BIERMANN y BOAS completa la estructura orgánica con la creación de un Fondo para Financiar el Protocolo, siendo que el Comité Ejecutivo decidiría el envío de los financiamientos ${ }^{404}$.

\section{V.3. Convención Independiente sobre los Desplazados Ambientales: propuesta de Docherty y Giannini}

DOCHERTY y GIANNINI proponen la creación de un instrumento independiente que proteja a los refugiados de los cambios climáticos ${ }^{405}$. Este instrumento constaría de tres aspectos: la protección a los derechos humanos y asistencia humanitaria, las cargas compartidas entre los países y la estructura institucional, siendo que esta última está formada por un Fondo para financiar la protección de los refugiados de los cambios, "una Agencia Coordinadora y un Consejo de Científicos, Expertos y Técnicos”406.

La visión de la temática de estos autores resalta la importancia de los derechos humanos y la asistencia internacional, pues estas personas viven en una situación muy precaria.

Además, estos autores le dan gran envergadura al rol del Consejo de Científicos, Expertos y Técnicos. Del mismo modo, en la Conferencia NANSEN, realizada en junio de 2011, fue resaltada la actuación de la ciencia en relación con tan compleja temática, y uno de los ejes analizados en esa ocasión fue: cuál sería el aporte de la ciencia ${ }^{407}$.

\footnotetext{
${ }^{404}$ BIERMANN; BOAS. Op.cit., p. 29.

${ }^{405}$ Esta es la denominación adoptada por estos autores.

${ }^{406}$ DOCHERTY; GIANNINI. Op.cit., p. 373.

${ }^{407}$ NORWEGIAN REFUGEE COUNCIL. Nansen Conference, Climate Change and Displacemente in the 21

st Century. Oslo: Nansen Published-Norwegian Refugee Council, 2011, p. 6. Disponible en: $<$ http://www.unhcr.org/4ea969729.pdf> acceso 10 de enero de 2014.
} 
La definición de DOCHERTY y GIANNINI de los desplazados ambientales forzados solamente se preocupa por los transfronterizos, dejando de lado a los internos. Este recorte se fundamenta en que la ayuda internacional a los desplazados ambientales forzados internos podría ser interpretada como un ataque al principio de la soberanía de los países (lo cual ya fue refutado anteriormente, pues para que sea enviada la asistencia internacional, el país afectado precisa hacer la solicitud y expresar su consentimiento, según los Principios Orientadores de los Desplazados Internos y la guía de IASC). DOCHERTY y GIANNINI consideran que la definición de los refugiados de los cambios climáticos está integrada por los siguientes elementos:

- La migración forzada;

- reubicación temporal o permanente;

- movimiento a través de las fronteras nacionales;

- disrupción consistente con el cambio climático;

- perturbación repentina o gradual del medio ambiente; y

- un estándar "muy probable de contribución humana a la disrupción" 408.

Uno de los elementos es la reubicación temporal o permanente, en el primer caso existiría la posibilidad de regresar al lugar de origen después de que la situación del desastre haya desaparecido y no exista más riesgo contra la vida y la sobrevivencia. En otros casos de refugiados de los cambios climáticos, estos ya no podrán regresar a sus hogares pues las consecuencias del desastre se han convertido en permanentes, como por ejemplo cuando ha desaparecido el territorio, como sería en el caso de una isla o de una región costera de tierras bajas.

El reconocimiento de los refugiados, establecido en la Convención sobre el Estatuto de los Refugiados de 1951, y su Protocolo Anexo, es un mecanismo individual ${ }^{409}$.

DOCHERTY y GIANNINI defienden el reconocimiento colectivo de los refugiados climáticos debido al tipo de impacto producido por el desastre, el cual abarca regiones enteras sin hacer diferenciaciones individuales, sino que los efectos se expanden de forma global ${ }^{410}$.

Los países desarrollados se opondrían a ese reconocimiento colectivo porque podría significar la obligación de abrir la puerta para flujos masivos de refugiados de los cambios climáticos.

Por otro lado, surge la dificultad para definir los criterios para la determinación de a quiénes les correspondería ese reconocimiento colectivo.

\footnotetext{
${ }^{408}$ DOCHERTY; GIANNINI. Op.cit., p. 372.

${ }^{409}$ UNHCR. La Convención del Estatuto de los Refugiados, Op.Cit.

${ }^{410}$ DOCHERTY; GIANNINI. Op.cit., p. 375.
} 
Según DOCHERTY y GIANNINI es el Consejo Científico quien tiene la competencia para determinar la gravedad del desastre, y las implicancias directas en el desplazamiento de las personas ${ }^{411}$.

Estos autores encuentran la respuesta al problema introduciendo la participación de los científicos. Así, este arreglo surge cubierto de la neutralidad que parece caracterizar a la ciencia.

Esta solución presentada es muy acertada, pues permite que un grupo especializado con autoridad científica sobre los avances de la ciencia sea quien establezca si la situación de emergencia del desastre o degradación ambiental es lo suficientemente grave para que las personas sean forzadas a desplazarse. De tal modo, no quedarían dudas sobre el otorgamiento colectivo de la condición de refugiados de los cambios climáticos.

El Grupo de Científicos ejercería un rol fundamental dado que su autoridad sería reconocida por la comunidad científica, debido a sus conocimientos de los aspectos técnicos y científicos. Todo esto les permitiría el análisis y la evaluación del grado de desastre o degradación ambiental.

Sin embargo, sería interesante que se mantuviesen las dos formas de otorgamiento de la condición: individual y colectivo, aplicables según el caso.

El reconocimiento de la condición de los refugiados de los cambios climáticos permite que estos puedan ser sujetos de derechos de forma especial debido a la situación excepcional por la que atraviesan, en la cual se encuentra violada su dignidad de persona y sus derechos humanos. Así se les brindaría una protección especial por el derecho internacional. Aunque lo que se esperaría es que la situación calamitosa del refugiado de los cambios climáticos sea transitoria, porque es una situación de crisis. Se supone que con el soporte de la comunidad internacional y de los países, los refugiados de los cambios climáticos conseguirían superarla en algún momento. La cesación del estatus de refugiado de los cambios climáticos se produciría cuando la crisis terminase, siendo que estas personas podrían retornar a su hábitat originario debido a que ya no habría amenazas a la vida o se habrían restablecido las condiciones de sobrevivencia.

La cesación de la condición de refugiado de los cambios climáticos se produciría cuando estas personas accediesen a la nacionalidad del país receptor o cuando obtuviesen la residencia permanente ${ }^{412}$.

\footnotetext{
${ }^{411}$ DOCHERTY; GIANNINI. Op.cit., p. 375.

${ }^{412}$ DOCHERTY; GIANNINI. Op.cit., p. 375.
} 
Estas condiciones de cesación del estatus de los refugiados de los cambios climáticos son similares a las establecidas en el Estatuto del Refugiado, tales como cuando el refugiado adquiere la ciudadanía o la residencia permanente del país donde vive, o de otro Estado, dejando de estar desprotegido. Otra de las hipótesis de cesación del Estatuto de Refugiados es cuando cesa el peligro o el riesgo a la vida, pudiendo retornar a su país.

Por otro lado, DOCHERTY y GIANNINI consideran que, en relación con la protección de los refugiados de los cambios climáticos, existen dos cuestiones de importante relevancia: los derechos humanos y la asistencia humanitaria.

El principio de no discriminación está reconocido en el Estatuto de los Refugiados, donde se observa que "los Estados Contratantes aplicarán las disposiciones de esta Convención a los refugiados sin discriminación en cuanto a la raza, la religión o país de origen" ${ }^{413}$.

Los autores señalan que el principio de la no discriminación es fundamental para proteger los derechos de los desplazados ambientales forzados. Este principio es reconocido en el Estatuto de los Refugiados ${ }^{414}$.

Además, los autores observan que debe ser reconocido un tratamiento especial por la edad y el género.

Este tratamiento especial consiste en acciones afirmativas sobre el principio de igualdad, porque esos dos aspectos aumentan la vulnerabilidad de las personas. La edad es una determinante de dos grupos específicos de personas que son más susceptibles de ser afectados: los ancianos y los niños. En muchos desplazamientos, estos grupos llegan a quedar abandonados o distanciados de sus familias, haciendo más difícil la situación de estas personas. Por esto, es necesario que el instrumento contenga medidas afirmativas, brindando mayor protección para estos grupos. El género es otra de las determinantes que aumenta la vulnerabilidad de los refugiados de los cambios climáticos.

La relevancia del principio de no discriminación para los refugiados de los cambios climáticos tiene que ver con uno de los fundamentos de los derechos humanos: la igualdad.

Los derechos humanos están fundados en los principios de igualdad y de libertad. La discriminación es una negación directa a la igualdad entre las personas, pues esa acción consiste en establecer preferencias entre las personas según criterios arbitrarios creados por los que tienen el poder. De tal modo, la discriminación genera una situación de injusticia entre las

\footnotetext{
${ }^{413}$ UNHCR. La Convención del Estatuto de los Refugiados. Op.cit.

${ }^{414}$ DOCHERTY; GIANNINI. Op.cit., p. 376.
} 
personas desplazadas ambientales, siendo que todas son igualmente víctimas del desastre o degradación ambiental.

Los autores reconocen la necesidad de que a los refugiados de los cambios climáticos les sean asegurados "los derechos civiles, políticos, económicos, sociales y culturales" $" 415$.

Estos derechos fundamentales están contenidos en las Declaraciones de los Derechos Humanos. Los derechos humanos son indivisibles, lo cual significa que todos constituyen un núcleo único que permite la realización de la dignidad de la persona humana.

Norberto BOBBIO observa que los derechos humanos son una conquista de la humanidad que han sido alcanzados después de muchos siglos de luchas ${ }^{416}$.

El derecho a naturalizarse sería una acción afirmativa en beneficio de los refugiados de los cambios climáticos fundada en la situación específica de menoscabo sufrida por estas personas.

Los autores advierten la relevancia de la asistencia humanitaria para los refugiados de los cambios climáticos, reconociendo el Principio de la Asistencia a la Víctima. Este principio fue primeramente establecido en la Convención sobre Municiones en Racimo ${ }^{417}$ de 2008, siendo que su contenido en este instrumento se refiere a: "tratamiento psicológico, médico e inclusión social y económica". El contenido de este principio aplicado a "los refugiados de los cambios climáticos" debería asegurar: agua, alimentación, ropas, abrigo y salud (tanto la asistencia médica como medicamentos $)^{418}$.

La Convención sobre Municiones en Racimo establece específicamente: "Resueltos a hacer todo lo posible para proporcionar asistencia a las víctimas de municiones en racismo, incluida atención médica, rehabilitación y apoyo psicológico, así como para proveer los medios para lograr su inclusión social y económica [...]" ${ }^{419}$.

La tercera cuestión tratada es la responsabilidad compartida por todos los países, siendo que esto está fundado en la responsabilidad común y diferenciada. La responsabilidad común significa que todos los países precisan contribuir con sus acciones a la preservación del medio ambiente. Mientras que la responsabilidad diferenciada está relacionada con la capacidad específica de los países en contribuir económicamente con el problema de los refugiados de los cambios climáticos. Por otro lado, esto está relacionado con la necesidad de que los países que

\footnotetext{
${ }^{415}$ DOCHERTY; GIANNINI. Op.cit., p. 376.

416 BOBBIO. Op.cit.

${ }^{417}$ Es la también denominada Convención "Cluster Munition”.

418 DOCHERTY; GIANNINI. Op.cit., p. 378.

419 CONFERENCIA DIPLOMÁTICA PARA LA ADOPCIÓN DE UNA CONVENCIÓN SOBRE MUNICIONES EN RACIMO. Convención sobre Municiones en Racimo. Dublín, 19-30 de mayo de 2008 , p. 1. Disponible en: <https://www.icrc.org/spa/assets/files/other/icrc_003_0961.pdf> acceso 23 de diciembre de 2015.
} 
realicen actividades de polución sean los que paguen por los daños causados, según el principio de derecho ambiental de que "el que hace actividades de polución, tiene que pagar" 420 .

El financiamiento de ACNUR no se basa en el principio de las cargas compartidas, sino en las contribuciones voluntarias ${ }^{421}$.

DOCHERTY y GIANNINI afirman que el Consejo de Científicos, Técnicos y Expertos sería quien establecería los pareceres en relación con las responsabilidades de los países frente a los refugiados de los cambios climáticos. Este instrumento introduce la creación de una Agencia de Coordinación, que tendría como objetivo la protección de los refugiados de los cambios climáticos. Además, esta propuesta establece la creación de un Fondo Financiero ${ }^{422}$.

El Consejo de Científicos, Técnicos y Expertos es un órgano importante, porque la naturaleza del problema de los cambios climáticos es una cuestión que precisa del estudio de la ciencia. La crisis ambiental que actualmente existe hace que la ciencia tenga un papel relevante. A pesar de que los cambios climáticos y la degradación ambiental han hecho que la ciencia pierda gran parte de su poder de previsión.

La importancia del grupo de científicos, técnicos y expertos reside en que la problemática de los refugiados de los cambios climáticos abarca una serie de cuestiones que precisan de los avances de la ciencia para determinar futuros escenarios. Esta situación que se genera es dinámica, y cada vez va agravándose más. Por lo tanto, es muy importante el aporte de la ciencia para poder hacer frente a estos tipos de emergencia, tanto con nuevas formas de innovación tecnológicas que sirvan para medir y prever el aumento del deterioro ambiental, o que permitan nuevas acciones de mitigación y adaptación a los cambios climáticos, como por ejemplo, para contener el avance del nivel del mar sobre las regiones costeras. También, se pueden determinar actividades que permitan disminuir el aumento de las regiones de desertificación, nuevas formas para prever los tsunamis y tormentas extremas y otros tipos de mitigación para evitar el aumento de los cultivos intensivos que erosionan el suelo.

WYMAN observa que esta propuesta hace hincapié principalmente en la protección de los derechos de los desplazados climáticos, en tanto que la de Biemann y Boas se refiere más al soporte que debe ser dado a los Estados afectados ${ }^{423}$.

\footnotetext{
${ }^{420}$ DOCHERTY; GIANNINI. Op.cit., p. 379-382.

${ }^{421}$ MAYER, 2011. Op.cit.

${ }^{422}$ DOCHERTY; GIANNINI. Op.cit., p. 388, 389, 390 y 385.

${ }^{423}$ WYMAN, 2013. Op.cit., p. 186.
} 
HODGKINSON critica ambas propuestas enunciadas porque estas no establecen en detalle la forma de funcionamiento de los organismos para efectivizar la protección de los desplazados ambientales forzados. En tal sentido, observa:

Estas propuestas describen restrictamente las agencias de coordinación o las agencias
para administrar la convención, ninguna propuesta intenta establecer de manera
detallada el funcionamiento de una organización de cambio climático de
desplazamiento, sus órganos, y cómo esos organismos trabajan juntos e interactúan ${ }^{424}$.

\section{V.4. Propuesta de Hodgkinson}

HODGKINSON et al. observan la necesidad que existe de dar una respuesta en el derecho internacional al problema de los desplazados climáticos, considerando que las respuestas aisladas no llevan a soluciones. Es necesario crear un tratado independiente que establezca un régimen jurídico de protección a estas personas y la creación de una organización que cuide del problema. Estos autores no concuerdan con la propuesta de que sea en el ámbito del UNFCCC, porque este está dirigido a los Estados. Además, porque no hace referencia ni al problema de los desplazados climáticos, ni a los derechos humanos ${ }^{425}$.

Por otro lado, consideran que tal protección debe abarcar la situación de los desplazados de los cambios climáticos transfronterizos y de los internos. La protección de los desplazados climáticos internos tendría la barrera del principio de la soberanía. Aunque esto ya ha sido solucionado porque en los Principios Rectores de los Desplazados Internos se exige que el Estado afectado realice el pedido de ayuda a Naciones Unidas, como fue observado anteriormente $^{426}$.

Esa propuesta de Convención considera la reubicación de los desplazados temporales y de los permanentes.

Por otro lado, trata de forma específica el problema de aquellos desplazados de los cambios climáticos de las islas que puedan llegar a desaparecer por el aumento del $\operatorname{mar}^{427}$.

Tales autores sostienen que el modelo de protección de derechos establecido en la Convención del Estatuto de los Refugiados debe ser seguido en este caso.

\footnotetext{
${ }^{424}$ HODGKInSON, David; BURTON, Tess. Towards a Convention for Persons Displaced by Climate Change. Seminar presentation at the Grantham Research Institute on Climate Change, the London School of Economics, 6 de marzo de 2009, p. 18. Disponible en:

$<$ http://www.ccdpconvention.com/documents/DH\%20TB\%20LSE\%20presentation.pdf> acceso 15 de mayo de 2014.

${ }^{425}$ HODGKINSON et al., 2010. Op.cit., p. 15.

${ }^{426}$ HODGKINSON; YOUNG, 2009. Op.cit., p. 7.

${ }^{427}$ HODGKINSON et al., 2009. Op.cit., p. 14.
} 
Los autores agregan que la propuesta de Convención debe respetar "los derechos civiles, políticos, económicos, sociales y culturales”. Esta propuesta establece un tratamiento estándar mínimo que asegure los derechos más importantes para la persona del desplazado climático. Además, son reconocidos el Principio de No Devolución para los desplazados climáticos, "el derecho a retorno a su país", "el derecho de no retornar" si el peligro no ha pasado, "el derecho de adquirir la nueva nacionalidad”. Los Estados Receptores y la Comunidad Internacional tienen la obligación de hacer efectivos estos derechos ${ }^{428}$.

Además, HODGKINSON et al. observan que su propuesta de Convención instituye la creación de una organización internacional que se ocuparía de este problema, llamada Organización del Desplazamiento Climático. La principal función de esta organización sería la protección de los desplazados de los cambios climáticos. En tal sentido, señalan:

\section{Nuestra propuesta intenta subsanar este vacío mediante la presentación de una estructura de la organización para los desplazamientos de los cambios climáticos; dentro de esa estructura, se definen las funciones y obligaciones de los participantes de la convención $[\ldots]$}

HODGKINSON et al. proponen que esa organización sea formada por una Asamblea, por un Consejo, un Comité de Apelación, un Fondo para el desplazamiento de los Cambios Climáticos, un Organismo de Ciencia en Desplazamientos de Cambios Climáticos y Grupos de Implementación de los Cambios Climáticos. La Asamblea estaría integrada por los Estados miembros de la organización que se reunirían cada dos años. Este órgano sería el que decidiría las cuestiones de financiamiento. El Comité de Apelación resolvería los pedidos de financiamiento rechazados. El Consejo estaría integrado por representantes de los países, de la sociedad civil, de los organismos internacionales y de las ONG. Sus funciones serían: reconocer la condición de refugiados climáticos y verificar la evolución de las actividades desarrolladas. Los Grupos de Implementación estarían formados por miembros de los países de origen, de recepción, representantes de Naciones Unidas, de la Organización de Desplazados por Cambios Climáticos. Estos grupos serían los que realizarían la reubicación de los desplazados climáticos en los nuevos lugares. El Organismo de Ciencia en Desplazamientos de Cambio Climático se ocuparía de realizar los aportes científicos relacionados a las cuestiones ${ }^{429}$.

Katrina WYMAN sostiene que no hay voluntad en los países para entablar negociaciones ni referentes al régimen jurídico de los desplazados climáticos, ni mucho menos sobre la creación de una organización internacional como la propuesta por Hodgkinson, porque

\footnotetext{
${ }^{428}$ HODGKINSON; YOUNG, 2009. Op.cit., p. 17, 38-39.

${ }^{429}$ HODGKINSON et al. Op.cit., p. 21, 23-27.
} 
esta temática envuelve dos cuestiones muy delicadas que generan tensiones entre los países: la migración y los cambios climáticos ${ }^{430}$.

\section{V.5. Propuesta de Mayer sobre la creación de una Resolución de la Asamblea General de Naciones Unidas}

MAYER sostiene que la forma de introducir el marco legal para los desplazados climáticos es a través de una Resolución de la Asamblea General de Naciones Unidas. Esta Resolución instituiría la creación de una Agencia Especial y un Programa Específico dentro del Marco de Naciones Unidas, cuyo objetivo sería trabajar para establecer soluciones al problema de los desplazados climáticos y fomentar las negociaciones entre los Estados y las organizaciones internacionales.

El autor compara esta situación con lo que ocurrió con la ampliación de las competencias de ACNUR para socorrer a los desplazados internos. En este caso, la extensión del mandato se realizó a través de una Resolución de la Asamblea de Naciones Unidas.

El autor analiza si esta Resolución debería ser del Consejo de Seguridad o de la Asamblea General de Naciones Unidas, concluyendo que el ámbito correcto es la Asamblea, porque esta cuestión no hace parte de la temática del Consejo de Seguridad. Además, una Resolución de la Asamblea General de Naciones Unidas tendría mayor legitimidad y representatividad. Estos dos últimos aspectos derivan de que en la Asamblea hay un proceso de votación de mayoría de los Estados que forman parte de este organismo. Este proceso de votación sería arduo y difícil, aunque las dificultades no serían ni comparables a las que serían enfrentadas para la realización de un tratado independiente ${ }^{431}$.

Por otro lado, MAYER observa que las Resoluciones de la Asamblea General hacen parte del Derecho "Soft", el cual no genera obligaciones para los Estados. Aunque, por otro lado, no es necesario atravesar por las dificultades y resistencias del proceso de creación de un tratado internacional o "Hard Law", así como por las ratificaciones.

La definición de MAYER es restringida pues solamente considera aquellos desplazados de los cambios climáticos y no incluye los de otros tipos de catástrofes ambientales. Porque considera que si estos últimos fueran introducidos no se podría hablar de la responsabilidad diferenciada de los países industrializados por las actividades que causan polución. Otra de las

\footnotetext{
${ }^{430}$ WYMAN, 2013. Op.cit.

${ }^{431}$ MAYER, 2011. Op.cit., p. 408-409.
} 
características es que se trate de desplazamientos permanentes. Además, el concepto de los refugiados climáticos no abarca a los desplazados climáticos internos, se remite a los transfronterizos ${ }^{432}$.

MAYER observa sobre los “migrantes climáticos":

Personas desplazadas como consecuencia de los cambios climáticos antropogénicos mundiales, mientras que la categoría de "migrantes ambientales" es más amplia, porque también incluye a las personas desplazadas por otros cambios en las condiciones ambientales, por ejemplo, después de un tsunami, un terremoto o una epidemia $^{433}$

Mayer afirma un conjunto de principios que tiene por finalidad proteger a los desplazados climáticos transfronterizos:

- Respuesta rápida y sustentable;

- respuesta global al problema de los desplazados ambientales;

- reconocimiento de los derechos colectivos e individuales;

- cargas compartidas entre los países;

- $\quad$ subsidiaridad.

La afirmación del principio de la protección de los derechos colectivos y de los derechos individuales es muy importante porque significa el reconocimiento de la indivisibilidad de los derechos humanos. La eficacia de los derechos humanos también depende del reconocimiento de los derechos colectivos ${ }^{434}$.

La naturaleza de la catástrofe hace que sean afectados pueblos enteros. En muchos casos, estos pueblos no pueden retornar, lo cual lleva a la perdida de su cultura. Uno de los derechos colectivos es el derecho al ser cultural de un pueblo.

La eficacia de los derechos humanos significa la efectividad de la dignidad humana, es decir, la protección de la integridad del hombre. El derecho a la identidad de la persona con su pueblo es un derecho fundamental, porque se refiere a la integridad psicológica. El derecho al ser cultural de un pueblo abarca el conjunto de tradiciones, idioma, músicas, formas de sobrevivencia propias, relación con la naturaleza, su historia.

Los desplazados ambientales forzados son obligados a abandonar sus hogares y pueblos, dejando atrás su identidad cultural. Esto constituye una violación a los derechos humanos.

\footnotetext{
432 MAYER, 2011. Op.cit., p. 368-369.

${ }^{433}$ MAYER, Benoit. The International Legal Protection of Climate (or Environmental) Migrants at the Crossroads: Fraternity, Responsibility and Sustainability, 1 de abril de 2011. En MORIN, Michel et al. Responsibility, Fraternity and Sustainability in Law: In Memory of the Honourable Charles Doherty Gonthier. Markham: LexisNexis Canada, 2012, p. 724. Disponible en: $<$ http://papers.ssrn.com/sol3/papers.cfm?abstract_id=1806760> acceso el 10 de mayo de 2014.

${ }^{434}$ MAYER, 2011. Op.cit., p. 391.
} 
BIERMANN y BOAS también reconocen el principio de los derechos colectivos para las poblaciones locales, como fue observado anteriormente ${ }^{435}$.

En el mismo sentido, DOCHERTY y GIANNINI reconocen la relevancia de todos los derechos humanos de los "desplazados climáticos".

El principio de la respuesta temprana y sustentable significa que no se puede esperar a que ocurran las catástrofes. La posibilidad de previsibilidad de los impactos de los cambios climáticos permite que la asistencia y la protección puedan ser rápidas ${ }^{436}$.

Este principio está relacionado con la necesidad de planificación. En el supuesto de los procesos lentos de desastres o degradación ambiental es posible la planificación. En los casos de desastres o degradación ambiental repentina, la planificación puede realizarse con mayor éxito cuando estas circunstancias son repetidas. La gran mayoría de los desastres repentinos se caracterizan por la reiteración.

MAYER establece que el principio del abordaje global de la migración del cambio del clima implica que la ayuda debe ser internacional. Esto está fundado en la naturaleza internacional de los desastres climáticos que provocan los desplazamientos.

Este autor sostiene que la subsidiariedad es un principio que permite realizar la división de las competencias. Estas son repartidas entre los niveles nacionales e internacional. El principio de subsidiariedad significa que los organismos internacionales actuarán en caso de ausencia de respuesta de los Estados.

MAYER reconoce el principio de responsabilidad común y diferenciada. El fundamento del principio de la responsabilidad común está contenido en "la Declaración de Río sobre el Desarrollo y Medio Ambiente y en el UNFCCC ${ }^{\text {437 }}$. El principio de responsabilidad común y diferenciada tiene varios sentidos. En relación con lo primero (responsabilidad común), significa que todos los Estados son responsables por el medio ambiente. Por otro lado, lo segundo (responsabilidad diferenciada), puede tener dos formas de apreciación: la primera, considera las actividades de polución que han realizado los Estados, contribuyendo al aumento de los desastres y de la degradación ambiental. La propuesta de CRIDEAU establece que los fundamentos de la responsabilidad común están en la protección de generaciones futuras y en la igualdad ${ }^{438}$.

\footnotetext{
${ }^{435}$ BIERMANN; BOAS. Op.cit., p. 25.

${ }^{436}$ MAYER, 2011. Op.cit., p. 389.

${ }^{437}$ MAYER, 2011. Op.cit., p. 393, 398 y 394.

${ }^{438}$ CRIDEAU (CENTRE DE RECHERCHE INTERDISCIPLINAIRE EN DROIT DE L 'ENVIRONNEMENT, DE L 'AMÉNAGEMENT ET DE L'URBANISME) E PELO CRDP (CENTRE DE RECHERCHE SUR LES DROITS DE LA PERSONNE). Draft Convention on the International Status of Environmentally Displaced
} 
De tal modo, los Estados precisan cooperar y contribuir con la asistencia de los desplazados climáticos como consecuencia de sus propias actividades de polución. Estos países desarrollados se han beneficiado económicamente, en detrimento del medio ambiente. Uno de los fundamentos de la responsabilidad diferenciada es el principio de que "el Estado que realiza actividades de polución, es el que paga", lo cual se traduce en la contribución por los perjuicios causados al medio ambiente.

La segunda interpretación de la responsabilidad diferenciada se basaría en que existen diferentes exigencias según "la capacidad financiera de contribuir del Estado". Por lo tanto, la contribución económica de los países estaría fundada en un sentido moral. Los países desarrollados no reconocen el primer sentido de la responsabilidad diferenciada ${ }^{439}$.

La Resolución establecería la responsabilidad de los Estados y de la comunidad internacional para proteger los derechos de las personas. Los primeros a responder ante las violaciones a los derechos son los países de origen y, en segundo lugar, emerge la obligación de la comunidad internacional. El autor observa:

\begin{abstract}
Algunos derechos humanos individuales y colectivos deberían ser subrayados explícitamente, como el derecho a la vida, el derecho de no sufrir tratos inhumanos y degradantes, el derecho a la salud y el derecho a una vida familiar, como también los derechos culturales, el derecho a una identidad colectiva, el derecho a la autodeterminación y los derechos de las minorías. Las aplicaciones particulares de los derechos humanos universales deben ser identificadas, tales como el derecho a la no devolución y el derecho a un lugar para vivir con seguridad y dignidad ${ }^{440}$.
\end{abstract}

El derecho a la no devolución está reconocido en la Convención sobre el Estatuto de los Refugiados de $1951^{441}$.

Finalmente, esa propuesta de Resolución establece la estructura orgánica para implementar el Fórum de Negociaciones regionales y entre los países para ayudar a proteger a los desplazados climáticos transfronterizos. En este sentido, es necesario incentivar la realización de acuerdos regionales, porque estos son más fáciles de ser alcanzados que los que implican la participación de diferentes regiones del planeta, como los de carácter universalista. La Agencia tendría por función el fomento de negociaciones regionales y bilaterales entre los países y el aumento de la cooperación con otros organismos de Naciones Unidas para conjuntamente realizar las actividades para la implementación de la guía, tales organismos

Persons. Mayo de 2010. Disponible en: <http://intergenlaw.com/wp-content/uploads/2015/02/Draft-Conventionon-the-International-Status-on-environmentally-displaced-persons-third-version.pdf $>$ acceso 5 de abril de 2014 .

${ }^{439}$ MAYER, 2011. Op.cit., p. 394.

${ }^{440}$ MAYER, 2011. Op. cit., p. 412.

${ }^{441}$ UNHCR. La Convención del Estatuto de los Refugiados. Op.cit. 
serían UNHCR, UNFCCC, UNEP, UNDP, GEF. El Fondo estaría conformado por contribuciones voluntarias de los países. Finalmente, es necesario observar que la resolución serviría de fórum para realizar negociaciones regionales o bilaterales sobre la problemática entre los países ${ }^{442}$.

\section{V.6. Propuesta de CRIDEAU - Centre de Recherches Interdisciplinares en Droit de I 'Environment, de I 'Aménagement et de l'Urbanisme - y por el CRDP (Centre De Recherche Sur les Droits de la Personne).}

En mayo de 2010, el CRIDEAU (Centre de Recherches Interdisciplinares en Droit de l'Environment, de l'Aménagement et de 1'Urbanisme) y el CRDP (Centre De Recherche Sur les Droits de la Personne) presentaron una propuesta de Convención sobre los Desplazados Ambientales. Esta propuesta contiene dos aspectos muy importantes: establece los principios y los derechos de los afectados; y propone la creación de la Agencia Mundial para Personas Desplazadas Ambientales (World Agency for Environmentally-Displaced Persons-WAEP) con su estructura orgánica.

En primer lugar, la propuesta de Convención establece sus objetivos y las definiciones de las figuras. En segundo lugar, queda determinado el ámbito de aplicación, y los principios que darán norte a esta propuesta, entre los cuales son considerados: el de solidaridad, de responsabilidad común y diferenciada, de protección efectiva, de no discriminación y el de no expulsión.

En tercer lugar, establece los derechos específicos de las personas que están en peligro de desplazamientos, los cuales son el derecho a acceso a la información sobre la situación de posible desastre, el derecho a la participación en la elaboración de políticas y el derecho de estas personas a desplazarse.

En cuarto lugar, son enunciados los derechos de los desplazados ambientales forzados: el derecho a asistencia, derecho al agua y a los alimentos, a la salud, al reconocimiento de la personalidad jurídica, derechos civiles y políticos, a la vivienda, a la familia, al trabajo, a la educación y formación, a su cultura específica, derecho a los bienes y posesiones personales, el derecho de regresar, la prohibición de regreso forzado y derecho a la nacionalidad.

En tal sentido, corresponde observar que la propuesta de Tratado está compuesta por 35 artículos, dividida en ocho capítulos: el Capítulo 1 establece los conceptos básicos de la Convención en los artículos 1 al 3; el Capítulo 2 (art. 4 al 7) considera los Principios; el Capítulo

${ }^{442}$ MAYER, 2011. Op.cit., p. 414, 416. 
3 (artículo 8 al 10) establece los derechos de las personas durante el desplazamiento; el Capítulo 4 observa los derechos de los desplazados; el Capítulo 5 considera las reglas referentes al reconocimiento del estatus de desplazados ambiental, y comprende del artículo 11 al 12; el Capítulo 6 instituye la estructura orgánica (formado por los artículos 20 al 24); el Capítulo 7 establece las formas de implementar la Convención en los artículos 25 y 26; el último Capítulo (artículos 28 a 33) considera las disposiciones finales ${ }^{443}$.

El artículo 1 afirma el objetivo de la Propuesta de Convención es:

\begin{abstract}
Establecer un marco jurídico que garantice los derechos de las personas desplazadas ambientales y de organizar su recepción, así como su eventual retorno, en aplicación del principio de solidaridad.

Con este fin, cada Parte Contratante se compromete a proteger los desplazados del medio ambiente de conformidad con los derechos humanos garantizados por el derecho internacional y a garantizar el pleno ejercicio de esos derechos específicamente previstos por el presente texto.
\end{abstract}

El artículo 2 define a las personas desplazadas ambientales como "los individuos, las familias y las poblaciones que enfrentan una catástrofe ambiental súbita o gradual que inexorablemente afecta a sus condiciones de vida, dando lugar a su desplazamiento forzado, desde su residencia habitual".

Hay un concepto definido por el artículo 2.3 que establece la figura del desplazado forzado, considerándolo como "cualquier desplazamiento temporario o permanente inevitable, de personas, familias o poblaciones, causado por el desastre ambiental, ya sea dentro de un Estado o del Estado de residencia para otro o más Estados de recepción”.

Ese mismo artículo define:

\footnotetext{
2.1 “desastre ambiental súbito" es una degradación que ocurre rápidamente de origen natural y/o humano.

2.2 "desastre ambiental gradual" es una degradación lenta, progresiva o planificada de origen natural y / o humana.
}

La Convención tiene aplicabilidad tanto para los desplazados internos como para los que atraviesan las fronteras. Según el artículo 3, "el presente Convenio se aplica también igualmente a los desplazamientos ambientales causados por conflictos armados o actos de terrorismo".

La propuesta de Tratado establece principios que son directrices que van a regir ese ordenamiento normativo de los desplazados ambientales: la solidaridad, la responsabilidad común y diferenciada, la protección efectiva y el de no discriminación.

${ }^{443}$ CRIDEAU, 2010. Op.cit. 
El principio de la solidaridad establece que todos los Estados deben prestar su ayuda ante el problema sufrido por los desplazados ambientales.

El principio de la responsabilidad común y diferenciada fue tratado anteriormente.

Sobre el principio de la protección efectiva, el artículo 6 observa:

\begin{abstract}
A fin de hacer concretos y efectivos los derechos conferidos por el presente Convenio, la Agencia Mundial para las Personas Desplazadas-Ambientalmente (WAEP) y los Estados Partes tienen obligaciones positivas para desarrollar e implementar políticas que permitan a las personas desplazadas ambientales el ejercicio de los derechos garantizados por la presente Convención.
\end{abstract}

Esto implica que no importan tanto las construcciones teóricas sino lo que ocurre en el plano de la realidad.

El artículo 7 establece el Principio de la No Discriminación:

Se garantizará el disfrute de los derechos reconocidos en la presente Convención sin distinción alguna por motivos, entre otros, de sexo, orientación sexual, raza, color, idioma, religión, opiniones políticas o de otra índole, origen nacional o social, la etnia, la riqueza, el nacimiento, discapacidad o edad.

Los derechos de los desplazados ambientales forzados son: el derecho al agua, a los alimentos, a la asistencia de la salud, a una casa. Además, reconoce los derechos civiles y políticos, el derecho a la personalidad jurídica y a la documentación. La propuesta reafirma el derecho a la unidad de la familia, lo cual significa que el núcleo familiar precisa ser mantenido junto. Por otro lado, en el caso de que la familia se encuentre separada, existe el derecho a la reunión familiar. Los desplazados ambientales tienen derecho al trabajo, derecho a la educación, derecho al ser cultural de su pueblo, derecho de mantener la nacionalidad y derecho de poder solicitar la nacionalidad del país receptor ${ }^{444}$.

El capítulo 6 de la estructura orgánica, en su artículo 21 instituye la creación de la World Agency for Environmentally-Displaced Persons (WAEP):

\footnotetext{
Artículo 21 - Agencia Mundial para las Personas Desplazadas Ambientales (WAEP) 1.Debido al previsible crecimiento y a los permanentes desplazamientos ambientales, la Agencia Mundial para las Personas Desplazadas-Ambientales (WAEP) supervisará la aplicación del presente Convenio.

2. WAEP es una Agencia Especializada de las Naciones Unidas.

3. WAEP incluye un consejo de directores, un consejo científico y una Secretaría.

4. WAEP tiene como funciones:

- conducir estudios prospectivos sobre la evolución de los desplazamientos ambientales;

- evaluar las políticas susceptibles de creación de los desplazamientos ambientales;

- movilizar los medios que puedan reducir las vulnerabilidades, las cuales están en el origen de los desplazamientos ambientales;
} 
- contribuir a la organización general de la asistencia destinada a la prevención, limitando los desplazamientos y promoviendo el regreso lo antes posible de las personas desplazadas ambientales;

- evaluar los programas para prevenir los desplazamientos ambientales y para ayudar a los desplazados;

- brindar soporte activamente a la organización de la recepción y retorno, cuando posible, de los desplazados medioambientales.

Algunos autores como FALSTROM y BURSON sostienen que es muy difícil de que sea celebrada una conferencia internacional para la creación de una Convención Internacional independiente ${ }^{445}$.

Finalmente, esta Propuesta de Convención establece la estructura orgánica que va a permitir la realización del Tratado, la cual está integrada por la Conferencia de Estados partes, por el Alto Comisionado, por el Fondo Mundial para los desplazados ambientales y por WAEP.

La Conferencia de Estados Partes se reunirá cada dos años, realizando los encuentros en los que participaran los Estados Partes. Una de las competencias de la Conferencia es la elección de los integrantes del Alto Comisionado, del Consejo Ejecutivo de la Agencia Mundial para las Personas Desplazadas Ambientales y los del Fondo Mundial.

El Alto Comisionado estará integrado por 21 representantes de cada una de las regiones del mundo. El mandato tiene una duración de seis años.

Según el artículo 22.2:

La Alta Autoridad tiene la facultad de:

- Definir los criterios y los procedimientos para la adquisición de la condición de persona desplazada ambiental;

- escuchar la apelación de las decisiones de conceder o denegar la condición de desplazado ambiental;

- $\quad$ para decidir el estado de las solicitudes de los nacionales de Estados que no son Parte en la Convención o en caso de incumplimiento por un Estado Parte, como último recurso;

- decidir sobre cuestiones relativas a la interpretación y aplicación de la Convención a petición de las comisiones nacionales o de cualquier persona física o moral interesada;

- evaluar el cumplimiento de las disposiciones nacionales con el Convenio, a petición de cualquier persona física o moral interesada y preparar una síntesis de los informes de ejecución. Esta síntesis indicará las deficiencias, así como buenas prácticas;

- $\quad$ proponer recomendaciones a la Conferencia de las Partes;

- proponer enmiendas a la presente Convención.

El artículo 23 establece que el Fondo Mundial Para los Desplazados Ambientales (World Fund for the Environmentally-Displaced- WFED) tiene por principal función brindar el

${ }^{445}$ MAYER, 2011. Op.cit., p. 407. 
apoyo financiero a los desplazados ambientales, siendo que las contribuciones son voluntarias y obligatorias (estas últimas se basan en las acciones de polución realizadas por los Estados) ${ }^{446}$.

\title{
V.7. La Reforma de la Convención sobre el Estatuto de los Refugiados: Propuesta del gobierno de Maldivas
}

El gobierno de Maldivas así como el Grupo de Pequeños Estados Insulares en Desarrollo (Small Island Developing States-SIDS) sostienen que la única solución para el problema de los desplazados ambientales forzados es que la figura del "refugiado ambiental" sea introducida en la Convención sobre el Estatuto de los Refugiados de 1951.

La modificación en la definición del refugiado consistiría en agregar:

\begin{abstract}
Miedo de poner en peligro la vida, daño o pérdida de la vida debido a un impacto ambiental severo o debido a los materiales dejados, existentes o a ser liberados en el lugar del desplazamiento por el Estado, o por las entidades comerciales, o ambos ${ }^{447}$.
\end{abstract}

Los países que hacen esta propuesta son los que más están sufriendo la problemática porque el aumento del nivel del mar puede llevar a la desaparición de sus territorios.

De tal modo, estos Estados son los que están luchando de forma más directa a nivel internacional y se han convertido en las voces de los desplazados ambientales forzados en el orden internacional.

La desaparición de un Estado no solamente significa un problema a nivel político, sino que es mucho más grave a nivel de sus ciudadanos. Este segundo aspecto trae terribles pérdidas para la persona, porque significa la ausencia de la protección jurídica del ciudadano. Además, incide sobre los derechos humanos y la dignidad de la persona, pues lo que es aún más grave es la pérdida de la identidad individual y colectiva de la persona.

Algunos autores consideran que la modificación de la Convención del Estatuto de los Refugiados de 1951 podría causar la pérdida de algunas garantías de los refugiados estatutarios. La Convención del Estatuto de los Refugiados no reconoce el principio de la responsabilidad común y diferenciada, el cual es esencial en el tratamiento de los refugiados climáticos ${ }^{448}$.

Según Mayer, otro de los problemas es que la Convención del Estatuto de los Refugiados establece la protección de los derechos individuales, siendo que por la naturaleza de la figura de los desplazados forzados se exige el reconocimiento de los derechos colectivos.

\footnotetext{
${ }^{446}$ CRIDEAU, 2010. Op.cit.

${ }^{447}$ BOANO et al. Op.cit., p. 25.

448 DOCHERTY; GIANNINI. Op.cit., p. 394.
} 
Por otro lado, en el caso de los desplazados ambientales forzados existe el problema de que la propia naturaleza exige muchas veces el restablecimiento permanente, mientras que, en la Convención de 1951, el objetivo principal es lograr el retorno de los refugiados estatutarios.

La Convención del Estatuto de los Refugiados solamente protege a los que han salido del país. En tanto que esto no tiene relación con los desplazados ambientales, pues en muchas situaciones ellos no han ultrapasado las fronteras, sino que son internos ${ }^{449}$.

Otra cuestión es que la naturaleza del hecho catastrófico que genera esta figura hace que sea necesario un reconocimiento colectivo, pues se trata de grupos de personas, mientras que la Convención sobre el Estatuto de los Refugiados de 1951 y su Protocolo Anexo solamente establecen el reconocimiento individual.

\title{
V.8. Otras Propuestas
}

Alexander BETTS sostiene que, en vez de establecer únicamente la protección para los desplazados ambientales forzados, es preciso que la protección sea para los inmigrantes vulnerables, incluyendo dentro de este concepto a los desplazados ambientales forzados. El concepto de migrantes vulnerables contiene a todas aquellas personas que se desplazan, pero no tienen la protección de la Convención del Estatuto de los Refugiados de Ginebra.

El concepto de inmigrantes vulnerables de Alexander BETTS abarca las siguientes categorías:

\begin{abstract}
A) Las personas que no pueden ser consideradas en ningún grupo, quienes huyen desesperados de la penuria económica y social, por ejemplo, como resultado del colapso del Estado, quienes están en necesidad de algún tipo de protección subsidiaria, pero que no son considerados como refugiados de la Convención de 1951.

B) Las personas que huyen de desastres naturales, como tsunamis, terremotos e inundaciones, para los cuales el ACNUR está proporcionando cada vez más protección, pero que no tienen ningún estatuto jurídico claro y para quienes las respuestas operativas son ad hoc.

C) Las personas que han sido desplazadas por causas relacionadas con la degradación del medio ambiente o de las consecuencias del cambio climático ${ }^{450}$.
\end{abstract}

Se puede observar que lo diferente de este concepto de "migrantes vulnerables" es la inclusión de aquellas personas que escapan de "situaciones de estrés económico o social".

Este último grupo de personas precisa ser protegido por el derecho internacional, aunque no pueden ser objeto de la misma protección que los desplazados ambientales forzados por

\footnotetext{
${ }^{449}$ MAYER, 2011. Op.cit., p. 382, 390, 405-406.

${ }^{450}$ BETTS, Alexander. Forwards a "Soft Law" Framework foro te Protección of Vulnerable Irregular Migrants. 22 INT'L J. REFUGEE L., 2010, p. 211. Disponible en:
}

$<$ http://ijrl.oxfordjournals.org/content/22/2/209.full.pdf $>$ acceso 20 de abril de 2014. 
diversas razones. Una de las causas es que los desplazados ambientales forzados tienen sus particularidades específicas: se trata de comunidades o partes de pueblos o pueblos enteros. Esta última característica está asociada a la naturaleza del fenómeno que provoca el desplazamiento, el cual constituye un desastre o degradación ambiental, siendo que la forma en que se produce y su magnitud hace que afecte a áreas enteras de forma uniforme, sin diferenciar en clases sociales, como observa Beck, en relación con el efecto democrático de los riesgos globales.

Otra diferencia entre esos dos grupos de personas es que la protección internacional de los desplazados ambientales forzados está basada en parte en el principio de la responsabilidad común y diferenciada, siendo que la primera se funda en que todos los Estados tienen obligación de proteger el medio ambiente y la segunda se basa en las actividades de polución realizadas por los países, lo cual también está relacionado con el principio de derecho ambiental: "el que hace actividades de polución, tiene que pagar".

Este concepto de responsabilidad de los países es específico para la protección de los desplazados ambientales forzados.

El mayor problema que surge del concepto de los "inmigrantes vulnerables" es la posible asociación de los desplazados ambientales forzados con la figura de los "inmigrantes", y específicamente con los económicos, porque la conceptualización de estos últimos puede llevar a incluir a aquellos que no son forzados.

Además, Alexander BETTS sostiene que es necesario establecer un régimen de protección jurídica internacional para los "migrantes vulnerables", a través de una Resolución de Naciones Unidas. Esta resolución debería contener los derechos que precisan ser protegidos así como los “mecanismos de colaboración inter-agencias para asegurar la implementación de estas normas y principios"

Christine GIBB y James FORD sostienen que la protección a los desplazados ambientales forzados debe inserirse en el United Nations Framework Convention on Climate Change, pues en el Cancún Adaptation Framework de 2010 (cláusula 14) establece la necesidad de los países de apoyar la cuestión de los desplazados ambientales y la de los impactos de los cambios climáticos.

Estos autores observan que la protección de los desplazados ambientales debe ser proporcionada por un organismo internacional especializado en la cuestión, así sería alcanzada una protección más eficaz de los derechos, siendo este uno de los argumentos que sirven de

${ }^{451}$ BETTS, 2010. Op.cit., p. 210-211, 223-227. 
apoyo para que sea considerado UNFCCC como el ámbito más adecuado para cuidar de los desplazados ambientales forzados ${ }^{452}$.

\section{V.9. Consideraciones finales}

Las propuestas son las presentadas por los autores más reconocidos en el tema; todos coinciden en la necesidad de regulación en el derecho internacional sobre esta problemática. A su vez, cada uno presenta un abordaje con aspectos coincidentes y con otros diferentes. De todos modos, todas brindan un aporte para el avance en el proceso de formación de un derecho internacional que proteja a los desplazados ambientales forzados.

Cabe ahora analizar las diferentes propuestas realizadas en relación con la viabilidad del instrumento que introduciría la protección de los desplazados ambientales forzados en el derecho internacional.

En relación con la primera categoría, se observa la posición de BIERMANN y BOAS: proponen la creación de un Protocolo que se insiera en el UNFCCC, así como la de otros que sugieren la creación de un tratado independiente (DOCHERTY y GIANNINI), o la de HODGKINSON, que avanza más en ese sentido y plantea la creación de un tratado independiente y de una organización internacional.

El segundo tipo de mecanismo es el sostenido por el gobierno de Maldivas y otros Pequeños Estados Insulares, quienes proponen la modificación de la definición de refugiados establecida en la Convención sobre el Estatuto de los Refugiados.

Finalmente, otros autores sostienen que el régimen de protección debe ser introducido por una Resolución de la Asamblea General de Naciones Unidas (MAYER y BETTS).

Todas estas ideas son loables, aunque la gran mayoría es difícil de que lleguen a ser aplicadas.

En relación con la idea de un Protocolo inserido en el UNFCCC, es necesario observar que el principal objetivo de las negociaciones en el UNFCCC es avanzar sobre la disminución de la emisión de gases de efecto invernadero, siendo que la temática sobre la protección de los desplazados ambientales forzados es parcialmente relacionada porque solamente abarcaría a aquellos que han sido afectados por los impactos de los cambios climáticos. En 2010, en Cancún, un grupo de ONG hizo esa propuesta, pero fue negada. Además, la creación de un

${ }^{452}$ GIBB, Christine; FORD, James. Should the United Nations Framework Convention on Climate Change Recognize Climate Migrants? 7 ENVTL. RES. LETT. 1, 4, 2012. Disponible en: $<$ http://iopscience.iop.org/article/10.1088/1748-9326/7/4/045601/pdf $>$. 
protocolo es tan difícil como la de un tratado, pues ambas dependen de la formación de una conferencia internacional.

En segundo lugar, sobre la creación de un tratado, es una propuesta muy lejos de la realidad, porque requiere que exista el consenso de los países para la realización de una conferencia internacional, y es evidente que no existe ese consenso. Porque hay temas relacionados con la cuestión que los Estados no están muy animados a tratar, tales como la responsabilidad por estas personas, la recepción de los desplazados ambientales forzados, el financiamiento de estas actividades.

En tercer lugar, ACNUR se niega a llamarlos "refugiados ambientales", pues este organismo considera que esto podría crear confusión con los refugiados estatutarios. Además, este organismo internacional es contrario a la idea de la modificación de la Convención sobre el Estatuto de los Refugiados, pues teme que este tipo modificaciones puedan alterar negativamente los derechos de los refugiados estatutarios.

De esta forma, el horizonte actual de las relaciones internacionales no se muestra propicio a la realización de una conferencia con el objetivo de establecer la regulación de los desplazados ambientales forzados.

Otros se refieren a la posibilidad de que fuese introducido un régimen de protección para estos afectados a través de una Resolución; es la propuesta de MAYER y BETTS. En el caso de MAYER, se propone que ese instrumento sea una Resolución de la Asamblea de Naciones Unidas. Además, ese autor hace referencia a que sea creado un Fórum de Negociaciones Regionales.

Por otro lado, BETTS también considera la posibilidad de la creación de una Resolución como medio de instituir el régimen de protección, aunque este autor no se refiere específicamente a los desplazados ambientales forzados o refugiados ambientales o climáticos, sino que la figura que considera es la de los migrantes vulnerables. Este último aspecto es muy criticable porque no hace otra cosa que traer confusión al escenario específico de los desplazados ambientales forzados, dado que la figura propuesta por BETTS incluye también dentro de la misma categoría a los inmigrantes económicos, lo cual no tiene ningún tipo de fundamentación teórica, como ya ha sido señalado.

Todas las propuestas coinciden en reconocer la necesidad de que sean protegidos los derechos humanos de los desplazados ambientales forzados. Algunos también hacen referencia a los derechos colectivos. 
Una novedad es la propuesta de DOCHERTY y GIANNINI sobre la realización de un reconocimiento colectivo de la condición de refugiados de los cambios climáticos, porque los desastres tienen grandes magnitudes y arrastran con todo lo que encuentran, implicando a pueblos enteros.

Además, esos autores observan que sea considerado el Principio de Asistencia a la Víctima, el cual fue consagrado por primera vez en 2008, en la Convención de Cluster Munition. Este principio debería ser adaptado al caso de los desplazados ambientales forzados, siendo que incluiría asegurar el derecho a los alimentos, al agua potable y servicios sanitarios, a la ropa, al refugio y a la salud.

Además, es señalado el Principio de No Discriminación, el cual implica que no sean establecidos privilegios en relación con algunos de los desplazados ambientales forzados, sino que todos deben ser tratados con el mismo grado de igualdad.

La mayoría de los autores señalan que el principio de la responsabilidad común y diferenciada precisa ser reconocido. Este se traduce en que todos los países tienen una responsabilidad común ante el medio ambiente. Aunque también existe una responsabilidad diferenciada porque cada país debe contribuir económicamente en la medida de su capacidad económica y según las actividades de polución que llevaron al aumento de la emisión de los gases de efecto invernadero. Porque existe un principio en el derecho internacional ambiental que establece que "el que realiza actividades de polución, debe pagar".

Por otro lado, gran parte de los autores se refieren al rol de la ciencia en esta cuestión, considerando en este sentido la necesidad de la creación de un grupo de científicos para tratar estas problemáticas. Esto se debe a que los hechos que originan la figura de los desplazados ambientales forzados son los desastres o la degradación ambiental, tanto repentina como ocasionada por procesos de larga duración. Estos hechos precisan del aporte constante de la ciencia.

BIERMANN y BOAS consideran el principio de la reubicación planificada, para que sean atenuados o evitados los posibles perjuicios de los desastres y la degradación ambiental. Muchos precisan de un lugar permanente para vivir.

El principio de la solidaridad de la comunidad internacional, el cual se traduce en el apoyo a los afectados. 


\section{CAPITULO VI}

\section{LOS REFUGIADOS AMBIENTALES Y ACNUR}

\section{VI.1. Introducción}

Las víctimas fatales de los desastres ambientales ya no pueden hablar, sus seres queridos quedaron como testimonios de la terrible tragedia, ellos ya nunca volverán a ser los mismos, pues se ha producido un cisma en el interior de esas personas, que les ha marcado la vida para siempre, su futuro, su porvenir. Esto se refleja en la expresión de las caras de los sobrevivientes de los desastres ambientales.

Las muertes producidas por la catástrofe constituyen el escenario de la tragedia de los desastres ambientales, y el que queda siente que está cayendo en un pozo sin fin. Después de esa caída al vacío, la persona queda en un abismo y tiene que recomenzar la difícil y lenta subida, pero esa subida no es linealmente evolutiva, sino que está llena de nuevas recaídas.

Los sobrevivientes del desastre ambiental son los que además de la pérdida de sus seres queridos tendrán que enfrentar la nueva realidad: el día después del desastre ambiental. Esto significa la continuación de la tragedia del desastre ambiental, que es el día en que estas personas se hacen conscientes de la pérdida de su familia, de su historia, de su lugar, de su hogar. Tal vez ellos sean los muertos vivos que deambulan entre lo que ha quedado del ciclón, del terremoto, de la inundación, de la avalancha. Ellos son los desplazados ambientales forzados.

Hay muchas discusiones sobre ellos, unos los niegan, otros los ignoran, muchos dicen que las reglamentaciones internacionales existentes ya son suficientes para protegerlos. Hay acalorados debates sobre las denominaciones.

En 2012, hubo 72 millones de víctimas de desastres ambientales, ¿será que ese número de víctimas es suficiente para que la atención de los Estados y de las organizaciones internacionales sobre los desplazados ambientales forzados sea mayor?

La naturaleza de este problema no es nacional, sino internacional porque se produce la violación de los derechos humanos de los desplazados ambientales forzados, lo cual lleva la cuestión al ámbito internacional. Por otro lado, en muchos casos, la magnitud de estas catástrofes provoca desplazamientos hacia otros países. Además, el empeoramiento de los 
desastres naturales, así como el aumento de su frecuencia, se debe a las actividades de polución realizadas por los países desarrollados, generando una responsabilidad internacional.

La peor consecuencia del desastre natural es el aspecto humano, generando muertes y personas desamparadas que comienzan a desplazarse.

En este trabajo se sustenta que $\mathrm{ACNUR}^{453}$ es el líder natural para enfrentar los problemas de los desplazados ambientales forzados. Esta afirmación está justificada en la historia del organismo de Naciones Unidas, que demuestra vasta experiencia en atender a los refugiados, en la similitud entre los desplazados ambientales forzados y los desplazados internos de desastres (estos últimos ya forman parte del mandato de ACNUR).

Por otro lado, ACNUR ha demostrado su interés en asumir la misión de proteger a los desplazados ambientales forzados, aunque no ha sido autorizada para llevar a cabo ese papel.

La Organización de Naciones Unidas ha desarrollado un marco de asistencia humanitaria para dar una respuesta a las situaciones de emergencia generadas por los impactos de los desastres naturales, aunque solamente protege a los desplazados internos de los desastres. Este cuadro institucional está formado por IASC ${ }^{454}$.

Además, ACNUR forma parte del sistema de IASC, brindando asistencia y protección solamente a los desplazados "internos" de los desastres naturales.

Aunque desde 2007 ACNUR ya no se conforma con ese papel, sino que reclama para sí el rol de líder en la protección de todos los desplazados de los desastres naturales. Esta posición está fundada en la vocación del mandato para el cual fue creada, en su experiencia demostrada para solucionar estos problemas, en que no existe diferencia entre desplazados internos de desastres naturales y desplazados ambientales forzados de desastres naturales, y en su desempeño exitoso en las diferentes situaciones de desplazados forzados ambientales en las que intervino.

Este recurrente pedido de ACNUR se enfrenta con diversas resistencias.

En primer lugar, serán considerados los principales aspectos del Sistema de Asistencia Humanitaria de Naciones Unidas para hacer frente a la emergencia generada por el desastre natural, integrado por la Oficina de Coordinación de Asuntos Humanitarios (OCHA) e InterAgencies Standing Committee (Comité Permanente entre Organismos) (IASC). Serán

\footnotetext{
${ }^{453}$ ACNUR es el Alto Comisionado de Naciones Unidas para los Refugiados.

${ }^{454}$ IASC es un sistema de coordinación de los organismos humanitarios (entre los cuales está ACNUR) de Naciones Unidas, cuyo objetivo es hacer frente a la crisis de las emergencias. Posteriormente, será analizada de forma particular.
} 
analizados su génesis, las resoluciones que le dieron origen, así como su funcionamiento y finalidad.

En segundo lugar, será considerada la posición adoptada en el seno de ACNUR en relación con los desplazados ambientales forzados (la cual coincide con nuestra sustentación en el sentido de que ese es el organismo internacional más apto para asumir esa protección).

En tercer lugar, será analizada la forma jurídica que posibilite el aumento de las competencias de ACNUR para que pueda asumir el mandato para proteger a los desplazados ambientales forzados externos o transfronterizos.

En cuarto lugar, serán realizadas las consideraciones finales sobre el asunto.

\section{VI.2. Estructura de Naciones Unidas ante desastres ambientales: ERC, IASC y OCHA}

\section{VI.2.1. Emergencias y desastres ambientales en la órbita de Naciones Unidas}

Una de las peores consecuencias de las emergencias y de los desastres ambientales es la situación de calamidad en la que quedan los lugares afectados, la destrucción de la vida de las personas afectadas, muchos de ellos muertos, otros sobrevivientes. Estos últimos viviendo en circunstancias precarias de alimentación, sanidad, vivienda, y con la violación de sus derechos humanos fundamentales, derivando en los desplazamientos forzados de personas. Toda esta situación quedaba librada a la falta de una respuesta organizada por parte de Naciones Unidas, ya que no contaba con un órgano específico que pudiese hacer frente a ese drama.

La Resolucion 46/ 182 de la Asamblea General de Naciones Unidas de diciembre de 1991 establece la respuesta que debe ser dada por el Sistema de Naciones Unidas al desastre y a la emergencia.

Esta respuesta consiste en:

- la creación de un Fondo para hacer frente al Desastre y a la Emergencia;

- los Llamamientos Unificados;

- la creación del cargo del Coordinador del Socorro en la Emergencia (ERC).

- la institucionalización del Comité Permanente Inter-agencias (Inter-Agencies Standing Committee o IASC). 
El Fondo para financiar las actividades para hacer frente a la Emergencia y al Desastre fue creado por el Secretario General de Naciones Unidas. Este Fondo fue formado por contribuciones voluntarias, e inicialmente fue de 50 millones de dólares, según lo establecido en los paragrafos 22, 23, 24, 25 y 26 de la Resolucion 46/ 182.

La Resolución 46/182, en el parágrafo 31 instituyó los Llamamientos unificados_de los organismos de Naciones, los cuales consisten en que, una vez realizado el pedido de ayuda internacional por parte del Estado afectado, será organizada la respuesta al desastre y a la emergencia que incluya a todos los organismos de Naciones Unidas. Este llamamiento debe ser realizado en la primera semana, y cuando se trate de las emergencias prolongadas, los llamamientos a los organismos de Naciones Unidas podrán ser realizados en cuatro semanas.

El Coordinador de Ayuda en la Emergencia será nombrado por el Secretario General y responderá por el cumplimiento de sus funciones al Secretario General.

Será creada una Secretaria para ayudar al Coordinador de Ayuda en la Emergencia, la cual estará “basado en una United Nations Disaster Relief Organization"455”(parágrafo 36 de la Resolución 46/ 182).

La Resolución 46/ 182, en su parágrafo 38 crea el Comité Permanente entre Organismos (IASC), el cual consiste en una entidad que reúne a organismos de Naciones Unidas, OIM, al Comité Internacional de la Cruz Roja, a la Liga de la Cruz Roja y a la Sociedad de la Media Luna Roja, con el intuito de hacer frente al desastre y a la Emergencia. Además, establece que el Comité Permanente entre Organismos (IASC) recibirá el apoyo del United Nations Disaster Relief Coordinador.

El parágrafo 39 de la Resolución 46/ 182 establece:

el Coordinador Residente normalmente coordinaría la asistencia humanitaria del sistema de las Naciones Unidas en el nivel de los países. El / ella debería facilitar la preparación del Sistema de Naciones Unidas y asistir para lograr una rápida transición del socorro a la rehabilitación y al desarrollo. El / ella debería promover el uso de todas las capacidades local o regionales disponibles para el socorro. El coordinador residente debe presidir las operaciones de emergencia de los grupos de cada campo representados y de los expertos del sistema ${ }^{456}$.

En 1992, se creó el Departamento de Asuntos Humanitarios, siendo que este Departamento quedó a cargo del Coordinador del Socorro de Emergencias (ERC). El objetivo

\footnotetext{
${ }^{455}$ Oficina de Naciones Unidas de Socorro para Desastres

${ }^{456}$ UNITED NATIONS. GENERAL ASSEMBLY. A/RES/46/182. Op.cit., parágrafo 39.
} 
de la creación de todo este marco institucional fue para hacerle frente al problema de las emergencias y de los desastres naturales ${ }^{457}$.

En 1998, el Departamento de Asuntos Humanitarios (DHA) fue transformado en la Oficina para la Coordinación de Asuntos Humanitarios (OCHA), la cual quedó a cargo del Coordinador del socorro en la Emergencia ${ }^{458}$.

En ese último sentido, se observa sobre el Coordinador del Socorro en la Emergencia:

Su mandato se amplió para incluir la coordinación de la respuesta humanitaria, el desarrollo y promoción de políticas humanitarias. OCHA lleva a cabo su función de coordinación, principalmente a través del (IASC) Inter-agencias Standing (Comité Permanente entre Organismos), que está presidido por el Coordinador de Socorro de Emergencias (ERC) $)^{459}$.

Por lo tanto, el Coordinador del Socorro de Emergencias tiene a su cargo la dirección de IASC y OCHA.

La Resolución 46/ 182, en el parágrafo 33, establece el liderazgo del Secretario General frente a las emergencias y desastres, el cual estará basado en el Comité Permanente, y en el Fondo para la Emergencia.

El Secretario General de Naciones Unidas tiene que asegurar los acuerdos entre los organismos de Naciones Unidas, así como con otras organizaciones internacionales en relación a la respuesta al Desastre y a la situación de Emergencia (parágrafo 37, de la Resolución 46/ 182) ${ }^{460}$.

\section{IV.2.2. Modificación de IASC}

A inicios de 2005, el Coordinador del Socorro de Emergencia (ERC) hizo una evaluación de la situación ocurrida en Darfur y decidió realizar las modificaciones en IASC para mejorar las respuestas a los desastres naturales y emergencias.

En setiembre de 2005, IASC fue organizado a través de un sistema de nueve "clusters"461 o grupos divididos por sectores para la Asistencia Humanitaria. Cada grupo de

\footnotetext{
${ }^{457} \mathrm{Ver}<\mathrm{http}: / /$ www.unocha.org/about-us/who-we-are/history $>$ acceso 10 de octubre de 2014.

${ }^{458} \mathrm{Ver}<$ http://www.unocha.org/about-us/who-we-are/history $>$ acceso 10 de octubre de 2014.

${ }^{459} \mathrm{Ver}<\mathrm{http}$ ://www.unocha.org/about-us/who-we-are/history $>$ acceso 10 de octubre de 2014.

460 UNITED NATIONS. GENERAL ASSEMBLY. A/RES/46/182, parágrafo 33, 19 de diciembre de 1991. Disponible en: <http://www.un.org/documents/ga/res/46/a46r182.htm> acceso 10 de octubre de 2014.

${ }^{461}$ La Guidance Note On Using The Cluster Approach To Strengthen Humanitarian Response considera que "Clusters leads" puede ser llamado de "sectores, grupos sectoriales, y líderes de sectores (grupos temáticos, grupos de fuerza, grupos de trabajo).” INTER-AGENCY STANDING COMMITTEE (IASC). Guidance Note On Using
} 
sector tiene un líder, el cual es ejercido por un organismo internacional. Además, existen dos niveles: el internacional y el nacional ${ }^{462}$.

A su vez, los grupos de sector de IASC se dividen en tres tipos: por actividades, por áreas transversales y por áreas de servicios comunes. Estas últimas son aquellas que se refieren a servicios que son necesarios ante cualquier tipo de emergencia: logística y telecomunicaciones. Los grupos correspondientes a las áreas transversales son aquellos que atraviesan todas las emergencias: refugio, campamentos y recuperación temprana. Los de las actividades específicas se refieren a alimentos, salud y agua ${ }^{463}$.

De tal modo, la situación resultante del desastre natural o de una emergencia compleja es abordada por IASC mediante el sistema que lidera la acción coordinada de nueve organismos de Naciones Unidas, considerando cada uno de los aspectos de la emergencia. Aunque solamente protege a los desplazados "internos", como ya fue observado.

IASC está organizado a través de una lógica que sigue la siguiente dinámica: ante un aspecto específico del problema de la emergencia humanitaria, habrá un grupo de sector (cluster) que actuará en tal área de la situación. Además, hay un organismo que es líder de cada grupo de sector, el cual dirigirá la acción para sea alcanzada la solución de las necesidades que se presenten en ese aspecto (ejemplo: refugio).

Con la reforma, se trató de que el sistema de IASC fuese más flexible, incorporando las necesidades de cada país y dando un rol principal al líder nacional, a través del Coordinador Residente o el Coordinador Humanitario. A pesar de toda esta reforma, en 2010, ACNUR evaluó los resultados de estas modificaciones, considerándolos disfuncionales ${ }^{464}$.

\footnotetext{
The Cluster Approach To Strengthen Humanitarian Response, 24 de noviembre de 2006a, p 5. Disponible en: $<$ http://www.refworld.org/pdfid/460a8ccc2.pdf $>$ acceso 20 de diciembre de 2013.

462 OFFICE FOR THE COORDINATION OF HUMANITARIAN AFFAIRS (OCHA). Questions and answers on the cluster approach and cluster implementation issues. 200.. Disponible en: $<$ http://www.internal.displacement.org/8025708F004CFA06/(httpKeyDocumentsByCategory)/6151B855F525> acceso 20 de diciembre de 2013.

${ }^{463}$ INTER-AGENCY STANDING COMMITTEE (IASC), 2006a. Op.cit., p. 3.

${ }^{464}$ UNITED NATIONS. HIGH COMMISSIONER FOR REFUGEES (UNHCR). Earth, wind and fire A review of UNHCR's role in recent natural disasters. Policy development and evaluation service (PDES), Ginebra, 2010, p. 8. Disponible en: <http://www.refworld.org/docid/4c21ae7f2.html> acceso 10 de enero de 2014.
} 


\section{Cuadro de la estructura de IASC}

(Extraído de IASC, Guidance Note On Using The Cluster Approach To Strengthen Humanitarian Response del 24 de Noviembre de 2006, p. 3) ${ }^{465}$

\section{Líder de los Grupos de Sectores (Global "cluster leads")}

(Según lo acordado por los representantes del IASC en diciembre de 2005)

Sector o Área de Actividad

Áreas técnicas específicas

1. Nutrición

2. Salud

3. Agua/ Servicios Sanitarios

Áreas transversales

4. Refugio

5. Coordinación de

Campos

6. Protección

$$
\begin{aligned}
& \text { IDPs }^{466} \text { (de conflictos) } \\
& \text { Situaciones de Desastre } \\
& \text { IDPs (de conflictos) } \\
& \text { Situaciones de Desastres } \\
& \text { IDPs (de conflictos) } \\
& \text { Desastres / civiles } \\
& \text { afectados por } \\
& \text { conflicto (que sean } \\
& \text { desplazados internos) }
\end{aligned}
$$

Líder del Grupo de Sector

(Global Cluster Leader)

UNICEF

WHO

UNICEF

UNHCR

IFRC

UNHCR

IOM

UNHCR

UNHCR/OHCHR/UNICEF

\section{Áreas de Servicios Comunes}

7. Recuperación Temprana

UNDP

Áreas de Actividades Comunes

8. Logística

WFP

9. Emergencias em telecomunicaciones:

OCHA/UNICEF/WFP

${ }^{465}$ INTER-AGENCY STANDING COMMITTEE (IASC). Guidance Note On Using The Cluster Approach To Strengthen Humanitarian Response, 24 de noviembre de 2006a, p 5. Disponible en: $<$ http://www.refworld.org/pdfid/460a8ccc2.pdf $>$ acceso 20 de diciembre de 2013

${ }^{466}$ Personas Desplazadas Internas. 


\section{VI.3. ACNUR y los desplazados ambientales forzados}

En esta parte del Capítulo será analizada la voluntad de ACNUR de asumir bajo su mandato a los desplazados ambientales forzados. Esta voluntad del organismo es el resultado de un proceso que se inició en 2007. Este proceso será analizado a través de tres aspectos. El primero considerará el examen de los hechos de ACNUR en relación con la cuestión, incluyendo entre estos tanto las declaraciones del Alto Comisionado, como las intervenciones y las publicaciones en tal sentido.

El segundo aspecto será el examen de las Resoluciones de la Asamblea General de Naciones Unidas aprobando los debates de las Reuniones Anuales del Comité Ejecutivo desde 2006 a 2012.

El tercer aspecto a ser considerado será el análisis de las Resoluciones de la Asamblea General de Naciones Unidas aprobando el Informe del Alto Comisionado de Refugiados de Naciones Unidas desde 2006 a 2012.

\section{VI.4. ACNUR y los desplazamientos ambientales forzados desde 2007 a 2010}

Hasta 2007, se puede observar que ACNUR no marcó una posición en relación con los desplazados ambientales forzados, aunque a partir de ese año es posible analizar un cambio en el interés demostrado por este problema, lo cual se podrá verificar a través del análisis de los actos realizados por el Alto Comisionado de Naciones Unidas para los Refugiados.

En tal sentido, Nina Hall observa que desde 2007 ACNUR fue modificando su actitud en relación con los desplazamientos ambientales forzados, siendo que hasta ese año ACNUR no había demostrado ningún tipo de interés en esa cuestión.

Esa autora enuncia los hechos más importantes realizados por ACNUR del año 2007 a 2009. En primer lugar, en 2007, el Alto Comisionado comenzó a hacer diversas manifestaciones de su preocupación sobre la incidencia de las cinco mega-tendencias sobre los desplazamientos, siendo que una de estas consistía en los cambios climáticos. En segundo lugar, en 2008, todas las Agencias de Naciones Unidas fueron instadas a trabajar sobre la relación de los cambios climáticos y los desplazamientos, a pedido del Secretario General de Naciones Unidas. En tal sentido, ACNUR creó un grupo de trabajo para analizar la cuestión. Por otro lado, en ese mismo año, IASC instó al Alto Comisionado a participar de un grupo de Agencias para desarrollar ese trabajo. Además, durante 2008, ACNUR presentó su publicación “Climate Change, Natural 
Disasters and Human Displacement: a UNHCR Perspective”. En 2009, este organismo participó en la CMNUCC ${ }^{467}$.

Así, se verifica que en ese período que se inicia en 2007 se produce un cambio que significa una ruptura con la posición de ACNUR observada anteriormente en relación con la cuestión. Este cambio fue impulsado por el Alto Comisionado Guterres, quien a través de sus declaraciones demostró la importancia y la urgencia en el tratamiento de la cuestión de los desplazamientos de los cambios climáticos. Seguidamente, serán considerados de forma específica algunos de los principales eventos en este sentido.

En el año 2007, el Alto Comisionado llamó la atención sobre las mega-tendencias que influirían en el aumento de los desplazamientos forzados. El Alto Comisionado Guterres observó que existían cinco mega-tendencias que influirán sobre el desplazamiento forzado de personas. Tales eran: “el aumento de población, la urbanización, la inseguridad alimentaria y energética, la escasez de agua y el cambio climático".

Hay una observación muy interesante de Guterres que considera:

[...] que el desplazamiento causado por los efectos de evolución lenta del cambio climático es en gran parte interno. Pero a través de la aceleración de la sequía, la desertificación, la salinización de las aguas subterráneas y el suelo, y el aumento del nivel del mar, el cambio climático, también, se puede contribuir al desplazamiento de personas a través de fronteras internacionales ${ }^{468}$.

De tal forma, se puede observar que específicamente en el caso de los desastres producidos por procesos de lenta evolución, los desplazamientos se producen en primer lugar dentro del país, pero cuando se agravan, la trayectoria del viaje de los desplazados aumenta, llegando a ser transfronteriza. Otra peculiaridad de este tipo de desastres es que, en los primeros tiempos, los desplazamientos son voluntarios y en la medida en que se agrava la situación del desastre, las personas se ven obligadas a escapar hacia otros lugares, donde puedan sobrevivir. Uno de los ejemplos de este tipo de desastre es la sumersión de una isla, de una región costera o de un lugar habitado (como fue el caso de los Inuits, cuyo hábitat desapareció por causa del derretimiento de las capas de hielo del Polo Norte).

La producción del desastre en estos casos es gradual, al igual que el proceso del desplazamiento de personas.

\footnotetext{
${ }^{467}$ HALL, Nina. Moving beyond Its Mandate? UNHCR and Climate Change Displacement. 4 J. of Int'1 Orgs Studies, 2013. Disponible en:

$<$ http://journal-iostudies.org/sites/journal-iostudies.org/files/JIOSfinal_7_3.pdf > acceso 5 de enero de 2014.

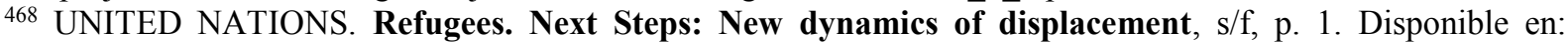
$<$ http://www.un.org/en/globalissues/briefingpapers/refugees/nextsteps.html > acceso 15 de enero de 2014.
} 
En abril de 2008, Craig L. Johnstone (UN Deputy High Commissioner for Refugees) observó que el problema de los desplazamientos por los cambios climáticos no era una cuestión del futuro, sino del presente, y que tal exigía una respuesta a nivel internacional. Por otro lado, consideró el problema de los costos, que deberían ser asumidos por los países industrializados ya que estos fueron los que contribuyeron al problema de los cambios climáticos; por lo tanto, esos Estados eran los responsables por las actividades de polución.

Además, él opinó:

El ACNUR es llamado con frecuencia para ayudar en emergencias internacionales causadas por los desastres naturales, tales como terremotos, inundaciones y tormentas violentas, no porque la gente afectada por estos acontecimientos caiga bajo el mandato del ACNUR, sino porque ACNUR tiene la experiencia y la capacidad para ayudar y, además, tiene una obligación humanitaria en estas situaciones $[\ldots]^{469}$.

En octubre de 2008, el Alto Comisionado volvió a insistir en que los cambios climáticos motivarán grandes desplazamientos forzados. Por lo tanto, es necesario que sean tomadas medidas para reducir las actividades de polución que influyen en el aumento de la crisis ambiental. Los lugares donde más incidirá el cambio climático son las regiones del sudeste asiático, las islas de tierras bajas, así como las regiones costeras bajas. Este desafío precisa de un consenso de la comunidad internacional. En tal sentido, observa que "un pacto mundial para hacer frente a los desplazamientos en masa debe respetar los principios de solidaridad internacional y responsabilidad compartida" ${ }^{\prime 470}$.

En ese mismo año, ACNUR realizó una publicación llamada “Climate Change, Natural Disasters and Human Displacement: a UNHCR Perpective", donde manifiesta su preocupación por la magnitud del problema de los desplazamientos ambientales forzados y considera la actuación de ese organismo en cada uno de los escenarios de desastre o degradación presentados por Kälin.

KÄLIN y SCHREPFER consideraron específicamente los escenarios de los desplazamientos ambientales forzados:

1. Desastres repentinos, tales como inundaciones, tormentas de vientos (huracanes/tifones/ciclones) o deslizamientos de tierras causados por fuertes lluvias pueden provocar grandes desplazamientos: las personas son evacuadas o dejan sus hogares antes de los desastres, o tienen que dejar sus hogares debido a la destrucción de sus casas, infraestructura y servicios. [...]

469 JOHNSTONE, Craig L. The future is now. En FMR, No 31, abril 2008. Disponible en: $<$ http://www.fmreview.org/FMRpdfs/FMR31/FMR31.pdf $>$ acceso 15 de enero de 2014.

470 GUTERRES, António. Millions Uprooted, Saving Refugees and the displaced. En Foreign Affairs, septiembre-octubre 2008. Disponible en: <http://www.cfr.org/humanitarian-intervention/millionsuprooted/p17038> acceso 15 de enero de 2014. 
2. Procesos de lenta degradación ambiental causados por aumento del nivel del mar, aumento de la salinización de los suelos, efectos de larga duración derivados de recurrentes inundaciones, deshielo del permafrost, así como las sequías y la desertificación y otras formas de reducción de los recursos hídricos, son previstos como impactos negativos a largo plazo del cambio climático. [...]

3. Los Pequeños Estados Insulares bajos representan un caso especial de los desastres de evolución lenta. Como consecuencia del aumento del nivel del mar y su topología de baja altitud, estas áreas pueden convertirse cada vez en más inhabitables, lo cual provoca la emigración a otros países, la gente pierde la fe que hay un futuro para ellos en su tierra natal. La degradación ambiental será un proceso muy lento [...]

4. Como consecuencia del cambio climático, los gobiernos designan áreas prohibidas de ser habitadas por personas. [...]

5. Por último, los serios disturbios del orden público, la violencia o incluso conflictos armados que perturban gravemente, pueden ser provocados, al menos parcialmente, por la disminución de los recursos esenciales debido al cambio climático (como el agua, las tierras de cultivo o pastos) $[\ldots]^{471}$.

En estas situaciones citadas, se pueden verificar dos casos: los desplazados internos y los que ultrapasan las fronteras. En el primer caso, es evidente que quien tiene la principal responsabilidad de proteger a esas personas es el Estado nacional. En la segunda situación, se observa:

\begin{abstract}
Cuando las personas afectadas por este tipo de desastres cruzan una frontera internacional, por ejemplo, porque son las únicas vías de escape. Ellos normalmente no calificarían como los refugiados que tienen derecho a la protección dentro del marco internacional existente de los refugiados, ni necesariamente se los podría clasificarse como migrantes. [...]

Determinar si los movimientos transfronterizos son forzados o voluntarios, no es posible en la inmensa mayoría de los casos, pero esto no es el elemento más relevante en virtud del derecho internacional. El quid de la cuestión es si las personas tienen una necesidad de protección internacional; $y$, en caso afirmativo, en qué se basa el grado de esta necesidad $[\ldots]^{472}$.
\end{abstract}

Aunque en este último sentido, lo que ocurre es que existe una identidad entre la situación (de los que sufren el desastre o la degradación ambiental) en la que se precisa de la protección del derecho internacional y el desplazamiento forzado, pues el denominador común es la violación de los derechos humanos de los desplazados ambientales forzados y las otras figuras citadas. Además, porque tanto la violación de sus derechos humanos como la naturaleza internacional del desastre y de la degradación ambiental elevan la situación de estas personas a la instancia internacional.

Por otro lado, cuando el Estado nacional solicite la ayuda de Naciones Unidas, IASC deberá dar la respuesta a la situación a través del sistema de clusters. ACNUR ya tiene la facultad de actuar con los desplazados internos.

\footnotetext{
${ }^{471}$ KÄLIN; SCHREPFER. Op.cit., p. 13-16.

${ }^{472}$ UNHCR, 2008. Climate change, natural disasters and human displacement. Op.cit., p. 4-5.
} 
Aquí se observa una contradicción en el sentido de que Naciones Unidas le ha otorgado el liderazgo a ACNUR para proteger a los desplazados "internos" de desastres naturales, pero no en el caso de aquellos que "ultrapasen las fronteras". La situación de los desplazados internos de los desastres naturales es más delicada debido a la cuestión de la soberanía, mismo así se le ha otorgado ese mandato a ACNUR. Por otro lado, la naturaleza del problema de los desplazados ambientales forzados que atraviesan las fronteras es del ámbito internacional. De tal modo, existe una necesidad internacional que se identifica con el mandato de ACNUR, y aun así no se les ha otorgado la protección de ACNUR.

Hay otra contradicción que consiste en que en vez de que ACNUR sea el líder para este grupo, se coloquen organismos que no tienen nada que ver con el refugio, como es el caso de UNESCO.

En relación con el primer escenario enunciado por KÄLIN, es necesario observar que el desastre es abrupto, y de una magnitud suficiente que obliga a las personas a abandonar sus hogares, dejándolas en una situación de emergencia absoluta, con la única esperanza de sobrevivir.

La segunda y tercera situación enunciada por KÄLIN consiste en procesos lentos de degradación o desastre, donde pueden verificarse dos momentos, siendo que solamente interesa la segunda etapa, pues es cuando son forzados porque (como fue observado anteriormente) es cuando el desastre o la degradación se vuelven incontrolables y las personas son obligadas a escapar, verificándose tanto la falta de voluntad en la elección del lugar para establecer su hogar (violación de la libertad de elegir donde residir) como la violación de sus derechos humanos (derechos a vida, salud, alimentos, refugio o vivienda, ropas, agua).

El cuarto escenario de los desplazados ambientales forzados podría ser apreciado a la luz del derecho de los apátridas, pues el aumento del nivel del mar producirá la pérdida del territorio de esos países insulares. El quinto escenario es aquel que se configura por los conflictos derivados de la lucha por la falta de recursos desencadenada por los cambios climáticos. Los desplazados ambientales forzados surgidos en este caso podrían ser considerados como refugiados según las leyes complementarias ${ }^{473}$ de $\mathrm{ACNUR}^{474}$.

En noviembre de 2009, GUTERRES reiteró su preocupación de que los cambios climáticos producirían el aumento en el número de desastres naturales, teniendo como consecuencia los desplazamientos masivos que podrían ser internos o a través de las fronteras.

\footnotetext{
${ }^{473}$ Las leyes complementarias de ACNUR son las Resoluciones de la Asamblea General de Naciones Unidas. ${ }^{474}$ UNHCR, 2008. Op.cit. p. 5.
} 
En el caso de los internos, la responsabilidad principal es del Estado nacional, que tiene la obligación de brindar protección a sus habitantes, como ya se observó. En la segunda situación de los que marchan al extranjero, no existe ninguna protección internacional ${ }^{475}$.

En 2010, ACNUR realizó otra publicación: Earth, wind and fire. A review of UNHCR's role in recent natural disasters, donde sostuvo que era necesario que fuese establecida su participación en los casos de los migrantes forzados del cambio climático. Es importante observar la crítica a IASC:

\begin{abstract}
En general, se reconoce que los arreglos existentes establecidos para la designación del organismo Coordinador-Líder del Grupo de Protección a nivel de país para responder a los desastres naturales tal como fue previsto en 2006 por el Comité Permanente entre Organismos (IASC) a través la Nota de orientación sobre el uso del Enfoque del Cluster para el Fortalecimiento de la Respuesta Humanitaria han demostrado ser disfuncionales ${ }^{476}$.
\end{abstract}

IASC es el Comité Permanente de Inter-Agencias de Naciones Unidas que hace frente a las Emergencias de los Desastres Naturales y Emergencias Complejas, aunque solamente se ocupa de los desplazados internos de los desastres naturales, dejando de lado a los desplazados de los desastres naturales transfronterizos, a los cuales nadie les brinda protección.

IASC organizó un grupo de trabajos sobre los cambios climáticos y desplazamientos, del cual participaron ACNUR y OIM que comenzó en el año 2008. El resultado de ese trabajo sería presentado en las negociaciones de la Convención Marco de Naciones Unidas sobre Cambio Climático (CMNUCC) realizadas en Cancún en 2010. En relación con esto, Mc Adam observa:

\begin{abstract}
ACNUR y la OIM fueron fundamentales en la defensa de los desplazamientos transfronterizos que se abordarán en este contexto. [...] En diciembre de 2010, la Conferencia sobre Cambio Climático de la ONU (COP16) adoptó el Marco de Adaptación de Cancún, que fue el resultado de tres años de negociaciones sobre la adaptación por los Estados Partes en la CMNUCC ${ }^{477}$.
\end{abstract}

De ese modo, en diciembre de 2010, en la Conferencia de Cambio Climático fue reconocido el aspecto humano de los impactos de los Cambios Climáticos. Esto consta en el parágrafo 14 (f) del Acuerdo:

\footnotetext{
${ }^{475}$ GUTERRES, António. Five 'mega-trends' -including population growth, urbanization, climate changemake contemporary displacement increasingly complex, third committee told. Third Committee, General Assembly GA/SHC/3964. Nueva York: United Nations, 3 de noviembre de 2009. Disponible en: $<$ http://www.un.org/press/en/2009/gashc3964.doc.htm> acceso 2 de enero de 2014.

${ }^{476}$ UNHCR, 2010. Earth, wind and fire, Op.cit., p. 1.

477 MC ADAM, Jane. Creating New Norms on Climate Change, Natural Disasters and Displacement: International Developments 2010-2013, 2013b. Disponible en: < http://www.unhcr.org/542e9a509.pdf $>$ acceso 15 de enero de 2016.
} 
14. Invita a todas las Partes para mejorar las medidas de adaptación bajo el Marco de Adaptación de Cancún, teniendo en cuenta sus responsabilidades comunes pero diferenciadas y respectivas capacidades, y prioridades de desarrollo nacionales y regionales, los objetivos y las circunstancias, emprendidas, entre otras cosas, lo siguiente: $[\ldots]$

(f) Medidas para mejorar la comprensión, la coordinación y la cooperación con respecto al desplazamiento inducido por el cambio climático, la migración y la reubicación planificada, donde proceda, en los planos nacional, regional e internacional $^{478}$.

Este parágrafo es muy importante porque constituye el primer reconocimiento a nivel internacional de la problemática de los desplazados ambientales forzados, si bien solamente se refiere a aquellos que resultan de los cambios climáticos. En segundo lugar, este dispositivo haría que fuese posible la utilización del Fondo de Financiamiento Verde para el Clima, pues considera a estos tipos de desplazamientos como medidas de adaptación. Por otro lado, cabe destacar que esa normativa llevó a que esta problemática sea colocada en la agenda internacional $^{479}$.

\section{VI.5. La situación de ACNUR en el año 2011}

\section{VI.5.1. Reunión de Bellagio}

El año 2011 fue muy especial y lleno de expectativas para el Alto Comisionado debido a que se conmemoraba el 60 aniversario de la Convención sobre el Estatuto de los Refugiados, y se esperaba que se asigne a ACNUR como el organismo que se haría cargo de la protección de los desplazados ambientales forzados transfronterizos.

Todos esos años anteriores desde 2007, el Alto Comisionado de Naciones Unidas para los Refugiados venía alertando sobre los desplazamientos y los cambios climáticos, sobre la falta de una regulación que garantizase los derechos específicos de estos afectados, y que estableciese las acciones necesarias que deberían ser realizadas en cada una de las etapas de la emergencia del desastre o la degradación. Por otro lado, también resaltaba la falta de institucionalización de un organismo internacional para sumir el problema de los desplazados ambientales forzados que atravesaran las fronteras.

ACNUR era el organismo con mayor experiencia en relación con los desplazamientos forzados, tanto por su trabajo desarrollado desde 1951 con los refugiados definidos en la Convención sobre el Estatuto de los Refugiados de 1951, como en la ayuda brindada a aquellos

\footnotetext{
${ }^{478}$ COP. The Cancun Agreements. Op.cit.

${ }^{479}$ KALIN, Walter. From the Nansen Principles to the Nansen Initiative. IN FMR 41, p. 48. Disponible en: http://www.fmreview.org/preventing/kalin Consultado el 15 de Enero de 2014.
} 
refugiados que no constaban en tal definición, y en la protección de los desplazados internos. En estos últimos casos, las resoluciones de la Asamblea General de Naciones Unidas habían ampliado las competencias para que ACNUR pudiese brindar protección y ayuda a estas personas afectadas.

De tal forma, en febrero de 2011, ACNUR organizó una Reunión de Expertos que se llevó a cabo en Bellagio, donde el principal objetivo era constatar la falta de reglamentación para el problema de los desplazados ambientales forzados transfronterizos, así como alcanzar el apoyo para que fuese designado ACNUR como organismo internacional capaz de brindarles protección y asistencia. Este encuentro fue muy rico en el aporte de nuevas perspectivas y consideraciones para la situación ${ }^{480}$.

Una de las recomendaciones más importantes que surgieron de la Reunión de Bellagio fue la siguiente:

\footnotetext{
- Existe una necesidad de desarrollar un marco de referencia global o un instrumento para aplicar a situaciones de desplazamiento externo distinto de los contemplados en la Convención de 1951, especialmente el desplazamiento resultante de los desastres repentinos. Los Estados, junto con el ACNUR y otras organizaciones internacionales, son animados a explorar más a fondo. Consideraciones deberían ser hechas tomando en cuenta si tal marco o instrumento también debería abarcar otras formas contemporáneas de desplazamiento externo ${ }^{481}$.
}

Además, se resaltó la importancia del rol de la ciencia en estos procesos de desplazamientos forzados ambientales, dada la complejidad que emerge de los cambios climáticos, los cuales son una de las causas que motivan los desastres y los procesos de degradación. Otra de las cuestiones que surgieron fue que las respuestas a estas situaciones debían estar fundadas en los principios de "humanidad, dignidad, derechos humanos, cooperación internacional, consentimiento, participación y preocupación por los grupos vulnerables" $" 482$.

En realidad, los principios de humanidad, dignidad y derechos humanos están interrelacionados, pues los "derechos humanos" son aquellos derechos mínimos que deben ser asegurados a todos los hombres para que puedan tener una vida "digna". La dignidad es la finalidad de la búsqueda de la eficacia universal de los derechos humanos.

El consentimiento debe ser prestado por el Estado afectado en el caso de los desplazamientos ambientales forzados.

\footnotetext{
${ }^{480}$ UNHCR. Summary of Deliberations on Climate Change and Displacement. Op.cit. 
La participación asegura que sea escuchada la voz de aquellos que sufren el proceso de degradación o del desastre, que constituyen los principales actores, pues son quienes sufren las violaciones a sus derechos humanos y su dignidad. Esto implica que el proceso de la formación de las directivas que rijan la situación de la catástrofe surja de abajo hacia arriba. De este modo, serán contempladas las principales necesidades de los afectados.

La relevancia de considerar una especial protección a los grupos vulnerables, se debe a que en el proceso de la degradación o del desastre ocurrido en países en desarrollo, se verifica un denominador común que es la vulnerabilidad. A esta situación se suma la mayor vulnerabilidad de aquellas personas que están en una situación de inferioridad frente al resto de los afectados, como es el caso de los niños, los ancianos, las mujeres y las comunidades tradicionales.

\section{VI.6. Conferencia NANSEN}

En la ciudad de Oslo, entre los días 3 y 7 de junio de 2011, fue realizada la Conferencia NANSEN, donde concurrieron 230 académicos y representantes de los países.

La realización de la Conferencia NANSEN fue propulsada por Noruega y por el Consejo para los Refugiados de Noruega. "Aunque el ACNUR no fue formalmente uno de los patrocinadores del evento, fue un jugador clave en su diseño. Fue uno de los nueve miembros del Consejo Asesor de la conferencia". Por otro lado, Conferencia NANSEN "reunió a actores de alto nivel de la ONU y otras organizaciones internacionales, los gobiernos, las ONG y la comunidad científica y académica, entre una amplia gama de disciplinas" ${ }^{483}$.

El antecedente de la Conferencia NANSEN fue la Reunión de Bellagio, realizada por ACNUR en febrero de 2011, pues el objetivo de esta última era tratar la relación entre los cambios climáticos y los desplazamientos, sirviendo las conclusiones elaboradas como base para la discusión de la Conferencia NANSEN.

De este modo, se puede observar que la Conferencia NANSEN surgió en el clima de búsqueda de soluciones sobre los cambios climáticos y sus desplazamientos, creado por la activa participación de ACNUR.

ACNUR buscaba crear consensos en la comunidad internacional para abordar la problemática de los desplazamientos provocados por los cambios climáticos y especialmente

${ }^{483}$ MC ADAM, 2013b. Op.cit. 
en relación con la falta de protección internacional de estas personas afectadas que escapaban hacia otros países.

La Conferencia NANSEN fue un paso inicial para la construcción del consenso en relación con la problemática tratada, porque fue la génesis de la Iniciativa NANSEN, la cual será tratada posteriormente. También, reunió gran parte de actores de la comunidad internacional, demostrando los puntos focales más importantes para la búsqueda de soluciones, y aportó los Principios NANSEN, los cuales abordan los principales problemas enfrentados en estos tipos de desplazamientos.

Cabe observar:

\begin{abstract}
La reunión se centró en el intercambio de experiencias sobre la vulnerabilidad, la resiliencia y la capacidad de adaptación de las comunidades en zonas propensas a desastres debidos al cambio climático, así como sobre la protección de las personas desplazadas; y la promoción de acciones para ayudar a prevenir o controlar el desplazamiento ${ }^{484}$.
\end{abstract}

De tal forma, se puede constatar que existen puntos focales sobre los cuales giraría la discusión, como el problema de la vulnerabilidad de las comunidades que viven en regiones afectadas por los desastres, la falta de protección de los desplazamientos de personas por los desastres y la posibilidad de establecer acciones para prevenir los desplazamientos.

Sobre este último aspecto, se puede considerar que en relación con la producción de los desastres repentinos y de procesos prolongados existe la posibilidad de la utilización del principio de prevención y planificación, porque gran parte de estos acontecimientos ocurren en lugares que presentan ciertas características que hacen que puedan ser predeterminados.

Las zonas propensas a los desastres naturales pueden ser delimitadas, pues abarcan las regiones costeras bajas y las islas de tierras bajas, así como las regiones localizadas en los trópicos.

La utilización de los principios de prevención y de planificación requiere el aporte de la ciencia. Esto posibilitaría que sean efectivizados tales principios, lo cual permitiría una mejoría en la respuesta a los desastres. El soporte de la ciencia posibilitaría la disminución de la incertidumbre que reina en materia de desastres ambientales.

El análisis de los datos aportados por el IDMC permite que pueda ser establecido un padrón de países más afectados. De tal forma, los países con mayores desplazamientos por los

\footnotetext{
${ }^{484}$ INTERNATIONAL INSTITUTE FOR SUSTAINABLE DEVELOPMENT (IISD). Nansen Conference on Climate Change and Displacement Bulletin. A Summary Report of the Nansen Conference on Climate Change and Displacement in the 21st Century. International Institute for Sustainable Development. Reporting Service. Vol., 189, No 1, 10 de mayo de 2011, p. 1. Disponible en:

$<$ http://www.iisd.ca/download/pdf/sd/ymbvol189num1e.pdf $>$ acceso 10 de enero de 2014 .
} 
desastres durante 2010 y 2012 fueron: China, India, Paquistán, Bangladesh, Tailandia, Filipinas y Nigeria. Por otro lado, los países insulares que pueden quedar sumergidos por el aumento del nivel del mar son: Tuvalu, Islas Maldivas, Kiribati e Islas Marshall.

En relación con la primera cuestión planteada sobre la vulnerabilidad de estas comunidades y la posibilidad de adaptación, es necesario observar que gran parte de estos países afectados tienen grandes poblaciones pobres. Por esto, el problema de los desastres ambientales se agrava dado que estos Estados no tienen los recursos financieros ni institucionales para hacer frente a la emergencia que surge del desastre o de la degradación ambiental, necesitando de la ayuda internacional para poder llegar a superar esa situación. Mientras que cuando los países afectados por los desastres son ricos, estos consiguen hacer frente a la emergencia por sí mismos y sin la ayuda internacional.

Hubo tres cuestionamientos que dirigieron la reunión:

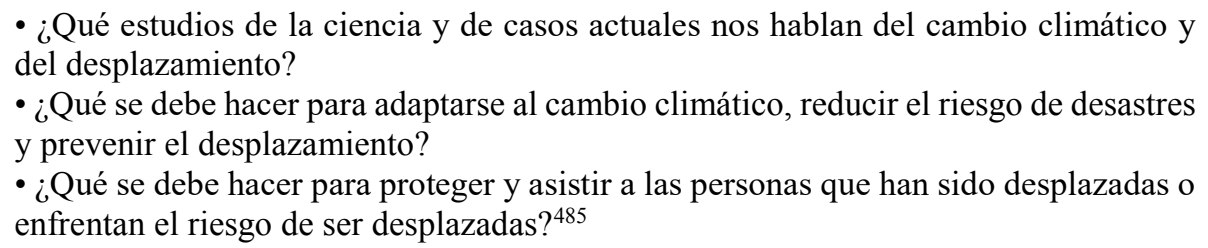

La naturaleza de los cambios climáticos que originan algunos de los desplazamientos ambientales forzados es una temática que merece ser estudiada, pues el avance científico podría introducir las medidas que permitan una mejor adaptación o preparación ante los desastres. La discusión desarrollada en la Conferencia NANSEN tuvo uno de sus ejes en el apoyo al desarrollo de la ciencia en la relación entre cambios climáticos y desplazamientos.

Las principales propuestas (DOCHERTI y GIANNINI, BIERMANN y BOAS, HODKINGSON y otros) de regulación de los desplazamientos ambientales forzados consideran la relevancia de la creación de un organismo de ciencia, como fue analizado en el capítulo anterior.

En tal sentido, se han realizados estudios sobre el aumento de la temperatura por causa de los cambios climáticos y sobre las consecuencias que pueden traer. Existe una certeza en relación con que los países precisan disminuir sus emisiones de gases de efecto invernadero.

- Existe la posibilidad del $50 \%$ del aumento de la temperatura global para $3-4^{\circ} \mathrm{C}$, incluso si los países se adhieren a las reducciones de emisiones comprometidas en las negociaciones climáticas de la ONU en Cancún en 2010. A pesar de la meta de la media limitante del aumento de la temperatura global a $2{ }^{\circ} \mathrm{C}$, los resultados más graves son mucho más propensos que los más benignos.

${ }^{485}$ NORWEGIAN REFUGEE COUNCIL. Nansen Conference... Op.cit., p. 6. 
- La gestión de riesgos implica que la incertidumbre no puede ser una barrera para la acción. Decisiones de políticas públicas en otras áreas son adoptadas en virtud de mayores niveles de incertidumbre que existe sobre la ciencia del cambio climático, impactos o decisiones políticas.

- En el caso de un aumento de más de $4^{\circ} \mathrm{C}$ de calentamiento, no sólo es probable que los movimientos de población inducidos por el clima serán más considerables, pero también sus patrones podrían ser significativamente diferente ya que la gente puede reaccionar de manera diferente a los cambios de la temperatura que representarían una amenaza para su supervivencia. La migración se convertirá menos en una elección ${ }^{486}$.

Esta Conferencia tuvo como resultado los diez Principios NANSEN.

KALIN observa:

Los Principios NANSEN no son un instrumento vinculante, sino que esbozan a grandes rasgos un marco de política para hacer frente a desplazamientos inducidos por desastres mediante la identificación de los actores claves y las áreas de actividad pertinentes. Como tales, constituyen un paso importante en el proceso de poner tal desplazamiento en la agenda internacional ${ }^{487}$.

Los principios no constituyen ni siquiera derecho internacional light (aquel derecho que no es obligatorio). La naturaleza de estos principios es de declaración o de meras recomendaciones.

Los diez Principios NANSEN apuntan a los aspectos que más necesitan de apreciación. Los dos primeros aluden a la importancia del aporte de la ciencia, a la aplicación de los principios de los derechos humanos, a la protección especial de los grupos vulnerables, y a la responsabilidad primordial del Estado nacional frente a los desplazamientos. El principio III señala el desarrollo de las capacidades locales, nacionales y regionales.

Los principios VII, VIII y IX también son muy importantes pues se refieren a la cuestión normativa internacional sobre la materia.

El Principio I establece que las soluciones a los problemas de los desplazamientos ambientales deben estar apoyadas en el sólido aporte de la ciencia, dada la naturaleza de los cambios climáticos, como fue observado anteriormente.

En tal sentido, afirma: “1. Las respuestas al desplazamiento ambiental y climático necesitan ser informadas por el conocimiento adecuado y guiadas por los principios fundamentales de humanidad, dignidad humana, derechos humanos y cooperación internacional."

${ }^{486}$ NORWEGIAN REFUGEE COUNCIL. Nansen Conference... Op.cit, p. 6.

${ }^{487}$ KÄLIN, Walter. From the Nansen Principles to the Nansen Initiative. En Migration Forced. s/f, p. 48. Disponible en: < http://www.fmreview.org/en/preventing/kalin.pdf>. 
Este principio fue sostenido por primera vez en la Conferencia de Bellagio de febrero de 2011, organizada por ACNUR.

Por otro lado, señala los principios fundamentales que deben regir el tratamiento de la problemática. En el Capítulo III fue establecida la relación entre el principio de la dignidad y los derechos humanos, siendo que la vigencia del primero constituye la finalidad de la efectividad de los segundos. Además, es preciso destacar que estos dos aspectos son inseparables. Estas cuestiones fueron analizadas en detalle en el Capítulo III.

La doctrina, considerada en el capítulo anterior, reconoce la relevancia del principio de respeto a los derechos humanos. En tal sentido, Docherty y Giannini, Mayer, Hodkingson y otros, reconocen la necesidad de que sea aplicado el principio de los derechos humanos; la propuesta de CRIDEAU establece el principio de la efectividad de los derechos humanos, además de garantizarlos e individualizarlos.

En segundo lugar, se trataron las medidas de adaptación al cambio climático y desplazamientos ambientales.

El principio II establece que la principal responsabilidad de protección de los desplazados ambientales es del Estado nacional. Además, afirma la necesidad de que haya una especial protección para las necesidades particulares de los grupos más vulnerables (mujeres, niños, ancianos, discapacitados y grupos de comunidades tradicionales).

Docherty y Giannini se refieren a que es preciso que exista una protección especial a los grupos vulnerables según edad y sexo.

También, debe ser observada cada etapa ("el desplazamiento, las comunidades de recepción y los que están en riesgo de desplazamiento”) derivada de la situación del desastre.

Por otro lado, el principio III considera que los Estados nacionales, así como los liderazgos locales precisan participar de las acciones de protección porque estos tienen la posibilidad de establecer las particulares necesidades de cada caso.

En tal sentido, observa:

\footnotetext{
III. El liderazgo y compromiso de los gobiernos locales y comunidades, sociedad civil y el sector privado, son necesarios para abordar con eficacia los desafíos planteados por el cambio climático, incluyendo aquellos vinculados a movilidad humana.
}

Esto se relaciona con el principio de los derechos humanos de la participación, lo cual implica que las comunidades afectadas deben ser invitadas para contribuir en la creación de las soluciones, pues son los que tienen intereses más directos en la referida cuestión. 
El principio IV es muy importante pues se alude a la ayuda internacional de los países en desarrollo.

Específicamente, este principio observa que, si los gobiernos locales no pueden brindar la ayuda por falta de recursos, es necesario el soporte de la comunidad internacional. Esta brindará la asistencia humanitaria y ayudará en el desarrollo de las capacidades nacionales.

Tal principio establece:

IV. Cuando la capacidad nacional es limitada, los marcos regionales y la cooperación internacional deben apoyar la acción a nivel nacional y contribuir a la construcción de la capacidad nacional, apuntar al desarrollo de planes, previniendo desplazamiento, asistiendo y protegiendo a las personas y las comunidades afectadas por dicho desplazamiento y encontrando soluciones durables.

Los países en vías de desarrollo son los que más necesitan de la ayuda internacional, porque no tienen los recursos necesarios para hacerle frente al desplazamiento ambiental, ni al desastre o degradación ambiental. Por todo esto, es necesaria la creación de un marco jurídico que regule la situación de los deslazados ambientales forzados. En otras palabras, es necesaria la actuación conjunta de los actores a nivel nacional e internacional para poder brindar una solución adecuada a la situación. De tal modo, se hace referencia a la cooperación internacional, en concordancia con el principio I.

El principio V sostiene:

La prevención y la capacidad de recuperación precisan fortalecerse en todos los niveles, especialmente a través de recursos adecuados.

Los actores internacionales, regionales y locales tienen una responsabilidad compartida para implementar los principios consagrados en el Marco de Acción de Hyogo para 2005.

El principio VI observa:

La construcción de la capacidad local y nacional para la preparación y respuesta a desastres es fundamental. Al mismo tiempo, el sistema internacional de respuesta a desastres necesita ser reforzado. El desarrollo de los sistemas de alerta temprana para múltiples peligros que vinculan los niveles locales y globales es crítico.

En primer lugar, queda establecida la relevancia de la necesidad de un marco que permita la vigencia de un "sistema de alerta temprana" como respuesta al desastre, siendo que es necesario que tal sea tanto a nivel nacional como internacional. Esto implica la necesidad del desarrollo de la ciencia y de las voluntades políticas. Además, incluye el principio de la previsibilidad y de la prevención ante los desastres.

En la doctrina, en tal sentido, MAYER establece "el principio de la respuesta rápida y sustentable", esto ya ha sido considerado en el Capítulo V. 
En la Conferencia NANSEN fue afirmado que era necesario que fuese creado un marco normativo para proteger a los desplazados ambientales forzados transfronterizos, debido a la falta de protección que estos sufren.

Los principios VII, VIII y IX presentan el problema de la ausencia de protección en el derecho internacional referente a los desplazados ambientales transfronterizos.

El principio VII es fundamental, pues reconoce la existencia de la laguna en el derecho internacional, el cual observa: "VII. Las normas existentes del derecho internacional deben ser utilizadas en su totalidad, y establecidas y abordadas las lagunas normativas".

De esta forma resulta evidente la laguna normativa existente en relación con estas personas que están desprotegidas por el derecho internacional, así como la necesidad de que sea abordada.

El principio VIII declara:

Los Principios Rectores de los Desplazamientos Internos proporcionan un marco jurídico sólido para abordar los problemas de protección que surgen de los desplazamientos internos relacionados con el medio ambiente o clima. Los Estados son animados a garantizar la adecuada implementación y puesta en funcionamiento adecuado de estos principios a través de la legislación nacional, las políticas y las instituciones.

El Principio IX completa esta situación, pues dispone la necesidad de que sea creado un marco que reglamente la situación de los desplazados de los desastres, a nivel internacional. En tal sentido, establece:

IX. El más coherente y consistente enfoque a nivel internacional es necesario para satisfacer la protección de las necesidades de las personas desplazadas externas por causa de desastres repentinos. Los Estados, que trabajando en conjunto con ACNUR y otros actores relevantes, podrían desarrollar una guía marco o instrumento a este respecto.

El principio X sustenta:

Las políticas nacionales e internacionales, incluyendo la reubicación planificada, deben ser implementadas sobre la base de la no discriminación, el consentimiento, el empoderamiento, la participación y las alianzas con los afectados, con la debida sensibilidad a aspectos de edad, género y diversidad. Las voces de los desplazados o de los amenazados con el desplazamiento, que sufren con la pérdida del hogar o medios de vida, deben ser escuchadas y tomadas en cuenta, sin dejar de lado a los que pueden optar por permanecer.

KALIN observa:

La Conferencia NANSEN de junio 2011 era el siguiente paso que debería haber conducido a los Estados para asumir el compromiso de abordar la cuestión en la Reunión Ministerial del ACNUR de diciembre de 2011 de conmemoración de los 
aniversarios 60a y 50a de las Convenciones de la ONU de refugiados y la de apátrida, respectivamente. Sin embargo, el comunicado ministerial aprobado en esta ocasión no contiene ninguna referencia directa a los movimientos transfronterizos provocados por el clima y otros desastres naturales. Esto no fue un accidente, sino más bien la expresión de una falta de voluntad de la mayoría de los gobiernos, ya sea por razones de soberanía, las prioridades de competencias o el papel de liderazgo de ACNUR en el proceso $^{488}$.

Todos los estudios presentados en tal Conferencia servirían de apoyo para que en la Reunión Ministerial de 2011 se aprobase el liderazgo de ACNUR para la protección de los desplazados ambientales forzados, aunque esto no ocurrió.

Porque las conclusiones a las que se arribaron en la Conferencia NANSEN serían el soporte teórico a la posición del Alto Comisionado que sería presentada en diciembre en la Conferencia de Delegados, donde ACNUR pediría el apoyo a los representantes de los países miembros para hacerse cargo de la protección de esta problemática según la propuesta del plan piloto de IASC, del que hablaremos posteriormente ${ }^{489}$.

\section{VI.7. El Plan Piloto de IASC para que ACNUR fuese el líder en la protección de los desplazados ambientales forzados (2011)}

Después de las reiteradas manifestaciones de ACNUR en relación con su capacidad de asumir la protección de estos afectados, y a las diversas respuestas lideradas por este organismo ante los desplazamientos de los desastres, el Alto Comisionado guardaba la esperanza de que finalmente asumiera la responsabilidad ante estos afectados.

Según la reforma de 2005 del Sistema de Ayuda Humanitaria de Naciones Unidas para hacer frente a los desastres naturales y a las emergencias complejas, había tres agencias internacionales que podían ser líderes en la respuesta a la protección en la emergencia de los desastres naturales. El proceso de elección del líder del grupo hacía que la respuesta fuese demorada, causando grandes perjuicios en la población afectada. De tal modo, a comienzos de 2011, IASC planteó un plan piloto, en el cual ACNUR se haría cargo del liderazgo del grupo de protección de los desplazados de los desastres naturales ${ }^{490}$.

Esa propuesta era muy apropiada, pues ACNUR es el organismo más especializado en la protección de desplazados ambientales forzados, y con mayor experiencia en tal sentido, ya que desde 1951, venía desarrollando estas actividades para proteger y asistir a los refugiados, y

\footnotetext{
${ }^{488}$ KÄLIN. From the Nansen Principles to the Nansen Initiative. Op.cit., p. 49.

${ }^{489}$ MC ADAM, 2013b. Op.cit.

${ }^{490}$ UNITED NATIONS. HIGH COMMISSIONER FOR REFUGEES (UNHCR). Executive Committee of the High Commissioner's Programme Standing Committee. 51st meeting. EC/62/SC/CRP.19, 6 de junio de 2011, parágrafos $1-4$.
} 
en los últimos tiempos para proteger a los desplazados internos (incluyendo aquellos que escapan de los desastres naturales), como fue observado anteriormente.

Además, ACNUR ya había actuado como líder del grupo de protección de los desplazados de los desastres naturales, basándose en el mecanismo de "los buenos oficios"491.

Específicamente, los desastres naturales más importantes en los que ACNUR intervino fueron: el tsunami de 2004, "Paquistán (2010 inundaciones), Filipinas (2009 inundaciones), Myanmar (2008 ciclón Nargis) y Sri Lanka (2004 tsunami)”492.

El concepto establecido en la reforma de 2005 de IASC de "Líder de Grupo de Protección" hacía referencia a "las responsabilidades para coordinación, gestión de la información, la planificación estratégica [...] actuando en el contexto interinstitucional como la agencia de "proveedor de último recurso""493.

Los problemas concretos que sufren los desplazados forzados ambientales son muy similares a los de los desplazados internos derivados de conflictos armados y a los de los refugiados estatutarios.

Tales situaciones son: peligro de vida, “documentación perdida, vivienda, la tierra y la propiedad, el acceso a la información y a los servicios básicos", así como la necesidad de protección especial a los grupos vulnerables como "los niños que han sido separados de sus familias, las mujeres y los niños expuestos a la violencia sexual y de género, personas con discapacidad y los ancianos"

Estas cuestiones están previstas en el Estatuto de los Refugiado, en los Principios Rectores de los Desplazados Internos, aunque estos regímenes jurídicos solamente amparan a los refugiados estatutarios y a los desplazados internos (incluyendo los de los desastres naturales), dejando desprotegidos a los desplazados ambientales forzados que atraviesan las fronteras.

Tales problemas constituyen violaciones a los derechos humanos de todos esos grupos de personas, como ya ha sido tratado en el capítulo de los derechos humanos de los desplazados ambientales forzados.

Todo esto constituye las violaciones a los derechos humanos de todos esos grupos de los desplazados ambientales forzados.

\footnotetext{
491 UNITED NATIONS. HIGH COMMISSIONER FOR REFUGEES (UNHCR). Questions and answers on UNHCR's Protection Cluster coordination role in natural disasters, 2011, parágrafo 4.

${ }^{492}$ UNHCR. Executive Committee of the High Commissioner's Programme Standing Committee. 51st meeting. EC/62/SC/CRP.19. Op.cit., parágrafo 9.

${ }^{493}$ UNHCR. Questions and answers on UNHCR's Protection Cluster... Op.cit., parágrafo 10.

${ }^{494}$ UNHCR. Questions and answers on UNHCR's Protection Cluster... Op.cit., parágrafo 11.
} 
La propuesta de IASC para que ACNUR se hiciera cargo del liderazgo del grupo de protección de los desplazados de los desastres naturales fue realizada en la reunión de los delegados de los países miembros de ACNUR, celebrada en junio de 2011. La mayoría de los delegados de los países participaron del debate y en un principio expresaron su apoyo, aunque hubo muchas objeciones. Finalmente, ellos concluyeron rechazar la propuesta. Las principales objeciones fueron: la cuestión de la soberanía, los recursos económicos destinados para atender estas nuevas actividades, las repercusiones que tendría esto sobre su mandato central, el problema de la salida del país afectado, la necesidad de mayores informaciones sobre la cuestión y la necesidad de una resolución de la Asamblea General de Naciones Unidas ${ }^{495}$.

El rechazo de la propuesta constituyó un golpe muy fuerte e inesperado para ACNUR, que pensaba que obtendría el apoyo de las delegaciones.

ACNUR (a partir de sus experiencias en las emergencias) estableció una serie de principios para actuar frente a esas circunstancias. Las objeciones hechas por los delegados en esa reunión de junio de 2011 tienen sus repuestas en cada uno de los principios creados por ACNUR.

En relación con el temor de los Estados de que la soberanía fuese afectada por la intervención de ACNUR es superado a través de la aplicación del principio II: "El consentimiento del Estado". Este sostiene que la participación de ACNUR en el desastre natural está sujeta a la necesidad de que el Estado afectado solicite la ayuda a Naciones Unidas y a que exprese su consentimiento sobre tal intervención.

Además, el principio I, "La responsabilidad del Estado", establece que la responsabilidad primaria es del Estado nacional de cuidar de sus nacionales, siendo que ACNUR solamente actúa brindando apoyo al Estado nacional para que este haga frente al desastre. Asimismo, ACNUR trata de ayudar para que los órganos nacionales desarrollen sus capacidades (principio III: "La asistencia humanitaria y desarrollo de las capacidades").

En relación con la objeción sobre la necesidad de aumentar los recursos económicos que serían necesarios para que ACNUR desarrolle estas actividades, fue superada por lo establecido en el principio VII, "Fuente de financiación": el cual dispone que el financiamiento deriva del Fondo de Respuesta a Emergencias (CERF).

495 EXECUTIVE COMMITTEE OF THE HIGH COMMISSIONER'S PROGRAMME STANDING COMMITTEE. 52nd meeting. Draft report of the 51st meeting of the Standing Committee (21-23 June 2011). EC/62/SC/CRP.25, 16 de septiembre de 2011, paragrafos 30, 32 y 33. 
Sobre la dificultad de ACNUR para salir del país, después de la emergencia, el principio "Estrategia de salida": considera que ACNUR crearía previamente un Plan de salida ${ }^{496}$.

Sobre la cuestión sustentada por algunos delegados sobre la necesidad de que ACNUR se centrase en su mandato principal, corriendo el riesgo de que perdiera su foco, el Comité Ejecutivo respondió que ACNUR ya había realizado actividades de protección de los desplazados de los desastres, con lo cual quedó demostrado que esto no interfirió en nada en el mandato básico de este organismo ${ }^{497}$.

Los otros principios que ACNUR elaboró para dirigir sus actividades de protección de las personas afectadas por los desastres naturales son:

- "Protección vinculada a la catástrofe": las actividades de ACNUR están únicamente limitadas a dar una respuesta al desastre, y no puede intervenir en problemas anteriores.

- "Respuesta de emergencia": ACNUR desarrollará sus actividades únicamente en la fase de la emergencia, incluyendo en esta etapa el retorno.

- "La coordinación entre organismos y la asociación": ACNUR tendrá un rol de liderazgo del grupo de los organismos internacionales que participan del sistema IASC y de los nacionales ${ }^{498}$.

\section{VI.8. Iniciativa NANSEN y ACNUR en 2012}

La Iniciativa NANSEN surgió para tratar la problemática de los desplazados ambientales forzados transfronterizos.

Fue creada en octubre de 2012 por el esfuerzo conjunto del gobierno de Noruega y Suiza.

La Iniciativa NANSEN tiene como objetivo "construir consenso sobre una agenda de protección frente a las necesidades de las personas desplazadas a través de las fronteras internacionales en el contexto de desastres naturales, incluidos los efectos adversos del cambio climático" ${ }^{499}$.

\footnotetext{
${ }^{496}$ UNHCR. Executive Committee of the High Commissioner's Programme Standing Committee. 51st meeting. EC/62/SC/CRP.19. Op.cit., parágrafo 19.

${ }^{497}$ UNHCR. Questions and answers on UNHCR's Protection Cluster... Op.cit., parágrafo 2.

${ }^{498}$ UNHCR. Executive Committee of the High Commissioner's Programme Standing Committee. 51st meeting. EC/62/SC/CRP.19, Op.cit.

${ }^{499}$ Ver <http://www.nanseninitiative.org/objectives>.
} 
Su ámbito de interés se limita a los desplazados ambientales transfronterizos, no haciendo diferencia en relación con la causa que les originó ${ }^{500}$.

Es necesario observar que la Iniciativa NANSEN también se preocupa de cuestiones relacionadas con la problemática de los desplazados ambientales forzados transfronterizos o externos, como: "la reducción del riesgo de desastres, el desplazamiento interno, o la gestión de la migración como una medida de adaptación”. Además, la agenda de la Iniciativa NANSEN considera tres momentos del desplazamiento, previendo las acciones para cada uno de estos. En este sentido, "la preparación antes de que ocurra el desplazamiento; la protección y asistencia durante el desplazamiento; y de la transición para las soluciones de las consecuencias del desastre" 501 .

La estructura organizativa de la Iniciativa NANSEN está formada por el Grupo Directivo, una Secretaría y un Comité Consultivo.

El Grupo Directivo “es copresidido por el gobierno de Noruega y Suiza”. Los miembros de este Grupo son Australia, Bangladesh, Costa Rica, Alemania, Kenia, Noruega, México, Filipinas y Suiza. Además, ACNUR e IOM participan como invitados. "Los miembros del Comité Consultivo trabajan en las áreas de (i) el desplazamiento y la migración; (ii) los asuntos humanitarios; (iii) la reducción del riesgo de desastres y la gestión del riesgo de desastres; (iv) el cambio climático; y (v) el desarrollo". La secretaría tiene su sede en Ginebra, Suiza ${ }^{502}$.

Su financiamiento es realizado por Noruega, Suiza, Alemania, la Comisión Europea y la Fundación Mac Arthur ${ }^{503}$.

La forma de trabajar de la Iniciativa NANSEN fue estructurada para recopilar datos de diferentes regiones más afectadas por los desastres, dividiéndose el trabajo por áreas. Estas fueron: "Pacífico (Islas Cook y Fiji), América Central (Costa Rica y Guatemala), el Cuerno de África (Kenia), Asia Sudoriental (Filipinas y Tailandia)"504.

En esas áreas fueron realizadas consultas con la sociedad civil, los afectados, los gobiernos y otros actores interesados en la problemática que aqueja a los desplazados transfronterizos. Por ello, se denomina a este proceso de "abajo hacia arriba" o bottom to up. Esto implica la efectiva realización del principio de los derechos humanos de "participación",

\footnotetext{
${ }^{500}$ NANSEN INITIATIVE. Disaster-Induced Cross-Border Displacement. Information Note, Ginebra, 25 de abril de 2013.

${ }^{501}$ NANSEN INICIATIVE. The Nansen Iniciative leaflet. Towards a protection agenda for people displaced across borders in the context of disasters and the effects of climate change, 23 de octubre de 2014. Disponible en: <http://www.unhcr.org/5448c7939.html>.

502 Ver $<$ http://www.nanseninitiative.org/organizational-structure $>$.

${ }^{503} \mathrm{Ver}<$ https://www.nanseninitiative.org/secretariat/>.

${ }^{504}$ NANSEN INICIATIVE. The Nansen Iniciative leaflet. Op.cit.
} 
el cual es muy importante pues permite la intervención de los principales interesados, los afectados.

La publicación de 2015 de ACNUR revela:

\begin{abstract}
Las consultas regionales de la Iniciativa NANSEN en el Pacífico, América, África y Asia han puesto de relieve que el desplazamiento por el desastre tiene un impacto devastador en las personas y sus comunidades, plantea múltiples problemas de protección y socava el desarrollo de muchos Estados. El cierre formal del proceso de "Consulta Global" de Estados tuvo lugar el 12 y 13 octubre de 2015 en Ginebra ${ }^{505}$.
\end{abstract}

La participación de ACNUR en la Iniciativa NANSEN ha sido muy importante ${ }^{506}$.

\title{
VI.9. Observaciones sobre ACNUR y los desplazados ambientales forzados, 2013-2015
}

En Ginebra, el 23 de febrero de 2013, fue celebrado "el Seminario sobre los Impactos adversos y el goce de los derechos Humanos", donde se hicieron observaciones sobre los desplazados ambientales transfronterizos. De un lado, fueron observados los aspectos positivos de la participación del Consejo de Derechos Humanos de Naciones Unidas y el reconocimiento en la Conferencia de las Naciones Unidas de la Convención Marco sobre el Cambio Climático (CMNUCC), de Cancún en 2010. Por otro lado, se consideró la falta de actuación en relación con el problema de la ausencia de protección de los desplazados ambientales transfronterizos. También, se hicieron unas observaciones sobre la reubicación de estas personas ${ }^{507}$.

En febrero de 2014, ACNUR presentó las Directrices sobre las Medidas de Protección Temporal (Temporary Protection or Stay Arrangement-TPSA). Esta guía constituye un soporte para el desarrollo de las medidas que precisan ser desarrolladas por cada país, para hacer frente a los desplazados forzados de la emergencia de la crisis humanitaria, "particularmente en situaciones donde las respuestas existentes no son adecuadas". Los Principios Orientadores establecen los aspectos esenciales que deben ser contemplados. La guía de TPSA considera el momento del ingreso al país, la estadía y la solución final de la situación. En relación con el primer estadio, reconoce los derechos a la entrada al país, al acceso a la documentación, y que

\footnotetext{
${ }^{505}$ UNITED NATIONS. HIGH COMMISSIONER FOR REFUGEES (UNHCR). UNHCR, The Environment \& Climate Change, 2015. Op.cit., p. 10. ${ }^{506}$ UNITED NATIONS. HIGH COMMISSIONER FOR REFUGEES (UNHCR). UNHCR, The Environment \& Climate Change, 2015. Op.cit., p. 10.

507 UNITED NATIONS. HIGH COMMISSIONER FOR REFUGEES (UNHCR). Seminar to Address the Adverse Impacts of Climate Change on the Full Enjoyment of Human Rights Session 2: International Cooperation and Respect for Human Rights, Remarks of Mr. José Riera Senior Adviser Division of International Protection, Palais des Nations, Ginebra, Salle XII, 23 de febrero de 2013. Disponible en: $<$ http://www.unhcr.org/543e77a19.html > acceso 14 de octubre de 2015.
} 
sean satisfechas las situaciones derivadas de la emergencia, como la falta de alimentos, agua, salud, vivienda y unidad familiar. En esa etapa inicial es fundamental que sea realizada la inscripción de las personas afectadas para mejorar el reconocimiento. El registro de estos desplazados forzados podría considerar los aspectos particulares de la situación que aflige a estos grupos o individuos. Esto permitiría que fuese brindado un mejor tratamiento para estos damnificados. Además, son considerados los derechos mínimos asegurados para estas personas, los cuales consisten en que les sea garantizada una vida digna. Esto implica los derechos a vivienda adecuada (asegurándoles el acceso al agua potable), salud, alimentos, educación, trabajo, el derecho a la documentación necesaria, el derecho a la libertad de circulación, el derecho a la seguridad, unidad familiar, que les sean brindados los medios para localizar a los parientes desaparecidos y protección para los niños y los discapacitados ${ }^{508}$.

En marzo de 2014, ACNUR convocó a una reunión en San Remo, con la participación de dos instituciones, Brookings Institution y Georgetown University's Institute for the Study of International Migration (ISIM), donde se inició la discusión sobre "adaptación, desarrollo, los desplazamientos inducidos y reasentamiento, gestión del riesgo de desastres, protección civil, medio ambiente y cambio climático, asistencia humanitaria y de derechos humanos" ${ } 509$.

El 5 de junio de 2014, en Bonn, la Universidad de Naciones Unidas y la Iniciativa NANSEN presentaron un trabajo en el cual fueron considerados los impactos negativos de los cambios climáticos y los desplazamientos forzados. En este estudio, se reconoce que los países precisan incorporar los desplazamientos forzados de los cambios climáticos y la reubicación planificada. El informe observa el caso de Kiribati, este país insular realizó la incorporación a su Plan de Adaptación Nacional, dando educación a sus nacionales para que tuvieran las condiciones para afrontar el mercado internacional. Hannah Entwisle Chapuisat, de la Iniciativa NANSEN, observó que "es crucial que los países desarrollen las medidas centradas en la prevención del desplazamiento cuando sea posible, proporcionando oportunidades positivas para la adaptación como la migración voluntaria o reubicación planificada" ${ }^{\text {510 }}$.

En junio de 2014, Koko Warner, de UNU-EHS, alerta:

Para muchas personas en todo el mundo, como los que luchan contra el aumento del nivel del mar en los Estados Insulares del Pacífico y los que luchan contra las sequías

\footnotetext{
508 UNITED NATIONS. HIGH COMMISSIONER FOR REFUGEES (UNHCR). DIVISION OF INTERNATIONAL PROTECTION. Guidelines on Temporary Protection or Stay Arrangements, febrero, 2014, p. 4-5. Disponible en: <http://www.unhcr.org/542e99fd9.html > acceso 14 de octubre de 2015. ${ }^{509}$ UNITED NATIONS. HIGH COMMISSIONER FOR REFUGEES (UNHCR). UNHCR, The Environment \& Climate Change, 2015. Op.cit., p. 11. 510 INICIATIVA NANSEN, 2014a. Op.cit.,
} 
persistentes y cada vez más intensas en el Cuerno de África, están obligados a moverse y ya no es distante, sino es una realidad ${ }^{511}$.

Se consideran algunos hechos relacionados con la actuación de ACNUR sobre los desplazamientos forzados ambientales:

\begin{abstract}
Una reunión de expertos se celebró en Washington el 13 de febrero de 2015 para centrarse específicamente en las definiciones de la terminología. La Institución Brookings, en colaboración con el ACNUR y el Instituto de la Universidad de Georgetown para el Estudio de la Migración Internacional (ISIM), convocaron a una pequeña consulta de expertos en Bellagio, Italia, en el mes de junio de 2015, para desarrollar nuevas orientaciones para los gobiernos en la realización de traslados previstos en el contexto del cambio climático y los desastres. La guía se publicó el 7 de octubre de $2015^{512}$.
\end{abstract}

De tal modo, fue presentada una guía con definiciones. Por otro lado, en Bellagio, en mayo de 2015, se comenzó a tratar la Reubicación Planificada o Reasentamiento ${ }^{513}$.

En octubre de 2015, ACNUR presentó su más actual publicación, "UNHCR, The Environment \& Climate Change", la cual revela que hay 59,5 millones de personas que viven en las regiones más vulnerables a los desastres. Además, observa:

\begin{abstract}
ACNUR desempeñó un papel importante en la protección de las poblaciones afectadas por, entre otras, las sequías en Somalia en 2011 y 2012, las inundaciones en Paquistán entre 2010 y 2012, las tormentas y las inundaciones en Myanmar en 2013 y los tifones en Filipinas (Washi/Sendong en 2011/2012 y Haiyan/Yolanda en 2013) las víctimas del ciclón y las inundaciones. [...]

Más recientemente, en 2015, el ACNUR prestó asistencia en Myanmar, en los Estados de Rakhine y Kachin, las víctimas del devastador terremoto asistidas en Nepal y la reubicación de 50.000 refugiados afectados por las inundaciones en Etiopía. [...]

A modo de ejemplo, el ACNUR alcanzó casi medio millón de sobrevivientes del tifón Haiyan (Filipinas, 2013) con suministros vitales. ACNUR sigue prestando asistencia a los sobrevivientes más vulnerables del tifón, en particular, los pueblos indígenas como los Badjao ${ }^{514}$.
\end{abstract}

De tal forma, es necesario reconocer que ACNUR ha actuado brindando ayuda a los desplazados ambientales forzados en los años 2010, 2011, 2012, 2013 y 2015.

\footnotetext{
${ }^{511}$ INICIATIVA NANSEN, 2014a. Op.cit.,

${ }^{512}$ UNHCR. UNHCR, The Environment \& Climate Change, 2015. Op.cit., p. 11.

${ }^{513}$ UNHCR. UNHCR, The Environment \& Climate Change, 2015. Op.cit., p. 10-11.

${ }^{514}$ UNHCR. UNHCR, The Environment \& Climate Change, 2015. Op.cit., p. 9.
} 


\section{VI.10. Análisis del derecho de las organizaciones internacionales derivado: la Asamblea General de Naciones Unidas y ACNUR desde 2005 a 2012}

En primer lugar, es necesario hacer algunas consideraciones relacionando los hechos sobre los desplazados ambientales forzados que han ocurrido en ACNUR y las Resoluciones que serán analizadas a continuación.

Se podrá observar que desde 2010, se produce un cambio en el contenido de estas Resoluciones, pues tales comienzan a tratar la temática.

Esto es el reflejo del cambio que se produjo en el seno de ACNUR desde 2007, cuando el Alto Comisionado comenzó a expresar su preocupación por los desplazados ambientales forzados. Además, en el año 2010, ACNUR publicó un documento en el cual criticaba la actuación de IASC, y expresaba la voluntad de asumir dentro de su mandato a este tipo de desplazados forzados. El año 2011 fue muy importante en ese sentido, porque IASC propuso el plan piloto para que ACNUR asumiese el liderazgo de la protección de los desplazados ambientales forzados, aunque esta tentativa fracasó.

Todas estas situaciones han tenido reflejos positivos en el sentido de que la Asamblea General de Naciones Unidas comenzó a incorporar esta relación entre ACNUR y los desplazados ambientales forzados.

\section{VI.10.1. Las Resoluciones de la Asamblea General sobre ACNUR de 2005 a 2012}

La Asamblea General de Naciones Unidas tiene la potestad de aumentar las competencias de ACNUR sobre los desplazados ambientales forzados por medio de sus Resoluciones, como ya lo hizo en diversos casos, uno de estos fue en relación con los desplazados internos.

En esto reside la relevancia de analizar sus Resoluciones relacionadas a ACNUR. Además, este examen sirve como un termómetro para evaluar su visión sobre la inclusión en el mandato de ACNUR de los desplazamientos forzados de los desastres naturales y de la degradación ambiental.

Por otro lado, es necesario observar que las Resoluciones de la Asamblea General de Naciones Unidas que aprobaron el Informe del Alto Comisionado para los Refugiados de 
Naciones Unidas de $2005^{515}, 2006^{516}$ y $2007^{517}$ no incluyen nada en relación con la emergencia, los desplazamientos emergentes de los desastres naturales y la degradación ambiental, ni sobre la relación de ACNUR y OCHA.

En la Resolución de 2008 de la Asamblea General de Naciones Unidas que aprobó el Informe del Alto Comisionado de Naciones Unidas solamente establece que este organismo debe continuar actuando en las emergencias ${ }^{518}$.

La Resolución de la Asamblea General de 2009 insta a aumentar la colaboración en OCHA y además observa:

31. Expresa profunda preocupación por los retos que el cambio climático y la degradación ambiental suponen para las actividades de protección de la Oficina del Alto Comisionado y la asistencia que proporciona a las poblaciones vulnerables de su competencia en todo el mundo, en particular en los países menos adelantados, e insta a la Oficina a que siga respondiendo a esos retos en su labor, en el marco de su mandato, y en consulta con las autoridades nacionales y en cooperación con los organismos competentes en sus operaciones ${ }^{519}$.

Del mismo modo, en 2010, la Asamblea General de Naciones Unidas en su Resolución observa:

Habiendo examinado el informe del Alto Comisionado de las Naciones [...]

12. Alienta a la Oficina del Alto Comisionado a que trabaje en asociación y en plena cooperación con las autoridades nacionales competentes, las oficinas y organismos de las Naciones Unidas, las organizaciones internacionales e intergubernamentales, las organizaciones regionales y las organizaciones no gubernamentales para contribuir al continuo desarrollo de la capacidad de respuesta humanitaria a todos los niveles, y recuerda la función de la Oficina como líder de grupo en materia de protección, coordinación y gestión de los campamentos, y refugio de emergencia en situaciones complejas; $[\ldots]$

13. Alienta $[\ldots]$ a que siga trabajando con la Oficina de Coordinación de Asuntos Humanitarios de la Secretaría para aumentar la coordinación, la eficacia y la eficiencia de la asistencia humanitaria y a que contribuya, en consulta con los Estados, según proceda, a seguir avanzando hacia la preparación de evaluaciones conjuntas de las necesidades humanitarias $[\ldots]^{520}$.

515 NACIONES UNIDAS. ASAMBLEA GENERAL. A/RES/60/129 Resolución de Aprobación del Informe del Alto Comisionado de Naciones Unidas, 16 de diciembre de 2005.

${ }^{516}$ NACIONES UNIDAS. ASAMBLEA GENERAL. A/RES/61/137 Resolución de aprobación del informe del Alto Comisionado de Naciones Unidas, 19 de diciembre de 2006.

${ }^{517}$ NACIONES UNIDAS. ASAMBLEA GENERAL. A/RES/62/124 Resolución de Aprobación del Informe del Alto Comisionado de Naciones Unidas, 18 de diciembre de 2007.

518 NACIONES UNIDAS. ASAMBLEA GENERAL. A/RES/63/148 Resolución de Aprobación del Informe del Alto Comisionado de Naciones Unidas, 18 de diciembre de 2008.

519 NACIONES UNIDAS. ASAMBLEA GENERAL. A/RES/64/127 Resolución de Aprobación del Informe del Alto Comisionado de Naciones Unidas, 27 de enero de 2010, p. 5-6.

${ }^{520}$ NACIONES UNIDAS. ASAMBLEA GENERAL. A/RES/65/194. Resolución, 21 de diciembre de 2010, p. 3. 
Además, la Asamblea General de Naciones Unidas observa la importancia de que ACNUR actúe frente a la emergencia, fortaleciendo la cooperación con la Oficina de Coordinación de Asuntos Humanitarios de la Secretaría. Por otro lado, también observa:

\begin{abstract}
32. Expresa profunda preocupación por los retos que el cambio climático y la degradación ambiental suponen para las actividades de protección de la Oficina del Alto Comisionado y la asistencia que proporciona a las poblaciones vulnerables de su competencia en todo el mundo, en particular en los países menos adelantados, e insta a la Oficina a que siga respondiendo a esos retos en su labor, en el marco de su mandato, y en consulta con las autoridades nacionales y en cooperación con los organismos competentes en sus operaciones ${ }^{521}$.
\end{abstract}

La Resolución de la Asamblea de Naciones Unidas referente a $2011^{522}$ y la de $2012^{523}$ observaron lo mismo que la anterior.

Las resoluciones de la Asamblea General de Naciones Unidas aprobando los Informes del Alto Comité Ejecutivo de ACNUR de los años 2009, 2010, 2011 ${ }^{524}$ y 2012 525 , fueron reiterando dos cuestiones.

En primer lugar, la Asamblea General insta al aumento de la relación entre ACNUR y OCHA (Oficina de Coordinación de Asuntos Humanitarios).

En segundo lugar, se observa que la Asamblea incorpora en sus observaciones la preocupación por la actuación de ACNUR en los desplazamientos de los desastres naturales y

${ }^{521}$ NACIONES UNIDAS. ASAMBLEA GENERAL. A/RES/65/194. Resolución, 21 de diciembre de 2010, p. 5. 522 NACIONES UNIDAS. ASAMBLEA GENERAL. A/RES/66/133, 19 de diciembre de 2011, p. 3 y 6 . En tal sentido, esta Resolución sostiene:

"12. Alienta también a la Oficina del Alto Comisionado, [...] a que siga trabajando con la Oficina de Coordinación de Asuntos Humanitarios de la Secretaría para mejorar la coordinación, la eficacia y la eficiencia de la asistencia humanitaria, y a que contribuya en consulta con los Estados, según proceda, a seguir avanzando en la preparación de evaluaciones conjuntas de las necesidades humanitarias, como se indicó, entre otras cuestiones de importancia, en la Resolución 65/133 de la Asamblea General, del 15 de diciembre de 2010, relativa al fortalecimiento de la coordinación de la asistencia humanitaria de emergencia que prestan las Naciones Unidas. [...]

30. Expresa preocupación por los desafíos que los retos relacionados con el cambio climático y la degradación ambiental plantean para las actividades de protección de la Oficina del Alto Comisionado y la asistencia que proporciona a las poblaciones vulnerables de su competencia en todo el mundo, en particular en los países menos adelantados, e insta a la Oficina a que siga respondiendo a esos retos en su labor, en el marco de su mandato, y en consulta con las autoridades nacionales y en cooperación con los organismos competentes en sus operaciones".

${ }^{523}$ NACIONES UNIDAS. ASAMBLEA GENERAL. A/RES/67/149, 20 de diciembre de 2012, p. 3 y 6 . En tal sentido, esta Resolución sostiene:

"12. Alienta también a la Oficina del Alto Comisionado, entre otras organizaciones competentes de las Naciones Unidas y otras organizaciones intergubernamentales e instancias pertinentes en las esferas humanitaria y del desarrollo, a que siga trabajando con la Oficina de Coordinación de Asuntos Humanitarios de la Secretaría para mejorar la coordinación, la eficacia y la eficiencia de la respuesta humanitaria [...].

33. Expresa preocupación por los desafíos que el cambio climático y la degradación ambiental plantean para las operaciones de la Oficina del Alto Comisionado y la asistencia que proporciona a las poblaciones vulnerables de su competencia en todo el mundo, en particular en los países menos adelantados, e insta a la Oficina a que siga respondiendo a esos desafíos en su labor, en el marco de su mandato, en consulta con las autoridades nacionales y en cooperación con los organismos competentes en sus operaciones".

${ }^{524}$ NACIONES UNIDAS. ASAMBLEA GENERAL. A/RES/66/133, 19 de diciembre de 2011.

${ }^{525}$ NACIONES UNIDAS. ASAMBLEA GENERAL. A/RES/67/149, 20 de diciembre de 2012. 
de la degradación ambiental, así como las poblaciones vulnerables de los países menos adelantados.

Por otro lado, hay un avance muy importante, que no pasa desapercibido, el cual expresa la preocupación con el cambio climático y la degradación ambiental, y solicita que ACNUR continúe prestando la asistencia a las personas afectadas por estos.

Muchos autores y organismos internacionales diferencian entre los desplazamientos emergentes de desastres y aquellos que se deben a la degradación ambiental (como ha sido observado en el Capítulo II y III), aunque las citadas Resoluciones de la Asamblea General de Naciones Unidas se refieren a ambos, sin distinguirlos, considerando principalmente el problema humano derivado de estas catástrofes ambientales.

\section{VI.10.2. Análisis de los Informes de las Reuniones Anuales del Comité Ejecutivo de ACNUR desde el año 2006}

Este análisis de las Resoluciones de la Asamblea de Naciones Unidas aprobando los informes de las Reuniones Anuales del Comité Ejecutivo de ACNUR permite verificar como cada año ha sido introducida más abiertamente la discusión de la cuestión de los desplazamientos forzados de los desastres ambientales en el seno de sus Reuniones Anuales.

En los años 2008, 2009, 2010, 2011 y 2012 ha ido aumentado el debate sobre la problemática asociada con los cambios climáticos, como se podrá observar a continuación de la observación de cada uno de los debates de las reuniones anuales del Comité Ejecutivo.

En octubre de 2006, la Oficina de Coordinación de Asuntos Humanitarios (OCHA) participó en el debate de la reunión del Comité Ejecutivo de ACNUR.

El Alto Comisionado observó "la participación del ACNUR como asociado en el nuevo enfoque conjunto del sistema de las Naciones Unidas y de la comunidad internacional en general para ayudar a las personas internamente desplazadas de todo el mundo”. Además, también hizo referencia a la participación de ACNUR con los desplazados internos en Darfur, y se observó la urgente necesidad de brindarles ayuda ${ }^{526}$.

Por otro lado, es relevante contemplar que el Alto Comisionado "reconoció que el ACNUR debía convertirse en una organización más flexible, eficaz y orientada a los resultados. Por consiguiente, ACNUR ha iniciado un proceso exhaustivo de examen y reforma de sus

\footnotetext{
526 NACIONES UNIDAS. ASAMBLEA GENERAL. A/AC.96/1035 Aprobación del Informe del Comité Ejecutivo de ACNUR sobre su 57 Período de Sesiones, 2-6 de octubre de 2006.
} 
procedimientos y estructura" ${ }^{\text {"27 }}$. No fue hecha ninguna observación en relación con los desplazamientos de los desastres naturales y degradación ambiental ${ }^{528}$.

En octubre de 2007, en la Reunión del Comité Ejecutivo de ACNUR participó el Secretario General Adjunto de Asuntos Humanitarios y Coordinador del Socorro de Emergencia, Sir John Holmes. En este debate, las delegaciones observaron que ACNUR "se enfrentaba a retos nuevos y difíciles, especialmente ante el cambio climático, la degradación del medio ambiente y las corrientes de migración mixtas que añadían una dimensión aún más compleja a los problemas de desplazamiento forzado"529.

En la Reunión del Comité Ejecutivo de ACNUR de octubre de 2008, el Alto Comisionado pidió que se hiciera un análisis sobre:

\begin{abstract}
Algunas cuestiones fundamentales relativas a la forma en que la comunidad internacional debería responder a la creciente magnitud y complejidad del desplazamiento forzado, incluidos sus efectos en el cambio climático; la idoneidad del actual marco jurídico y normativo de la Oficina; la pertinencia de los principios tradicionales de la acción humanitaria y su relación con nuevos conceptos como la "seguridad humana" y la "responsabilidad de proteger"; y la idoneidad de la actual arquitectura humanitaria ${ }^{530}$.
\end{abstract}

Estas palabras del Alto Comisionado son muy relevantes porque introducen la cuestión de los desplazamientos como resultado del cambio climático, observando la necesidad de respuesta, el problema de la laguna jurídica y la capacidad de la estructura de la asistencia humanitaria.

En el debate de la Reunión del Comité Ejecutivo de ACNUR de octubre de 2009, las delegaciones solicitaron:

\begin{abstract}
Nuevas formas de cooperación para hacer frente a retos mundiales tales como el cambio climático, la crisis financiera y económica y la inseguridad alimentaria, del agua y de la energía. Varios oradores alentaron al Alto Comisionado a que contribuyera a la acción para hacer frente a los efectos del cambio climático ${ }^{531}$.
\end{abstract}

En el debate de la Reunión del Comité Ejecutivo de ACNUR de octubre de 2011, el Alto Comisionado enfatizó que la reforma interna del organismo que se estaba realizando permitiría mejorar en las respuestas a las emergencias.

\footnotetext{
${ }^{527}$ NACIONES UNIDAS. ASAMBLEA GENERAL. A/AC.96/1035. Op.cit., p. 20.

${ }^{528}$ NACIONES UNIDAS. ASAMBLEA GENERAL. A/AC.96/1035. Op.cit.

529 NACIONES UNIDAS. ASAMBLEA GENERAL. A/AC.96/1048 Aprobación del Informe del Comité Ejecutivo de ACNUR sobre su $\mathbf{5 8}^{\circ}$ período de sesiones, 10 de octubre de 2007, p. 20.

${ }_{530}$ NACIONES UNIDAS. ASAMBLEA GENERAL. A/AC.96/1063 Aprobación del Informe del Comité Ejecutivo de ACNUR sobre su $5^{\circ}$ período de sesiones, 22 de octubre de 2008, p. 17.

531 NACIONES UNIDAS. ASAMBLEA GENERAL. A/AC.96/1078 Aprobación del Informe del Comité Ejecutivo de ACNUR sobre su $\mathbf{6 0}^{\circ}$ período de sesiones, 9 de octubre de 2009, p. 10.
} 
Las delegaciones observaron:

ACNUR trabajaba en un entorno cada vez más complejo. Tendencias como el cambio climático, los desastres naturales, la inseguridad alimentaria e hídrica, así como las crecientes vulnerabilidades y los conflictos armados, aumentaban las exigencias que pesaban sobre el sistema humanitario.

Por otro lado, fueron enfatizados los esfuerzos que realiza ACNUR para dar una respuesta a la emergencia, así como la preocupación del organismo con los problemas de la falta de regulación ${ }^{532}$.

En el debate de la Asamblea General de 9 de marzo de 2012, el Sr Lang (de Alemania) realizó algunas consideraciones:

El daño causado por los desastres naturales se ha cuadruplicado en los últimos 30 años y considera que es necesario analizar con más detalle las nuevas tendencias en materia de desplazamientos relacionados con el cambio climático y elaborar estrategias para solucionarlos, en particular mejorando la preparación para los casos de desastre.

Se puede recurrir a mejorar "el análisis exhaustivo de las amenazas o la intensificación de la cooperación y el intercambio de información entre los asociados humanitarios" ${ }^{233}$.

Por otro lado, la Sra. Ingres (de Francia):

\begin{abstract}
Considera interesante la propuesta formulada por el Alto Comisionado Auxiliar para la Protección [...] de desarrollar un marco orientativo mundial sobre los desplazamientos relacionados con el cambio climático [...]. En ese sentido, cabe preguntarse si los textos que protegen a los desplazados internos y refugiados son suficientes para contemplar esos nuevos tipos de desplazamientos. Por consiguiente, Francia reitera su propuesta de que se lleve a cabo una reflexión sobre los desafíos mundiales en materia de protección, reflexión que parece tanto más importante cuanto que el ACNUR desea participar en mayor medida en la protección en casos de desastres naturales.
\end{abstract}

Además, agrega que es necesario considerar: “¿en qué condición se debe conceder y qué protección se puede ofrecer a las personas desplazadas como consecuencia de cambios climáticos? Y ¿cuál sería la responsabilidad de los Estados?”534.

El Sr Hanniffy (de Irlanda):

Acoge con satisfacción el compromiso del ACNUR de fortalecer su capacidad y la protección de sus efectivos sobre el terreno. La protección también se podría reforzar mediante una mejor coordinación de las iniciativas internacionales en el marco de un

\footnotetext{
532 NACIONES UNIDAS. ASAMBLEA GENERAL. A/AC.96/1107 Aprobación del Informe del Comité Ejecutivo de ACNUR sobre su $62^{\circ}$ período de sesiones, 11 de octubre de 2011, p. 10.

${ }^{533}$ NACIONES UNIDAS. A/AC.96/SR.654. Comité Ejecutivo del Programa del Alto Comisionado de las Naciones Unidas para los Refugiados. $\mathbf{6 2}^{\circ}$ período de sesiones. Acta resumida de la $\mathbf{6 5 4}^{\circ}$ sesión, 9 de marzo de 2012, p. 2-3.

${ }^{534}$ NACIONES UNIDAS. A/AC.96/SR.654. Op.cit., p. 3.
} 
módulo de protección eficaz que permitiera aprovechar mejor la experiencia y las competencias del ACNUR, en particular en situaciones de desastres naturales ${ }^{535}$.

En el debate de la Reunión del Comité Ejecutivo del ACNUR de octubre de 2012 se expresó la necesidad de que ACNUR aumentara su colaboración con OCHA y con el Comité Permanente para poder hacer frente a la emergencia humanitaria ${ }^{536}$.

En la reunión del Comité Ejecutivo de octubre de 2013, principalmente, se hizo énfasis en la cooperación con $\mathrm{OCHA}^{537}$.

\section{VI.11. Las competencias de ACNUR y los desplazados ambientales forzados}

ACNUR es un organismo de Naciones Unidas, y fue constituido por la Resolución 319 A (IV), de 3 de diciembre de 1950.

Este organismo no fue creado por la firma de un Tratado Constitutivo (Derecho Originario de las Organizaciones Internacionales), lo cual sería necesario para la creación de una organización internacional.

La Resolución 428 (V) de la Asamblea General de Naciones Unidas crea el Estatuto del Alto Comisionado.

Esa Resolución hace parte del derecho derivado de Naciones Unidas, y en tal se establecen las competencias de dicho organismo, así como todas las reglas para su funcionamiento.

En el Estatuto están contenidos su finalidad, objetivos, reglas del funcionamiento, así como las competencias de ACNUR.

A lo largo de su historia, ACNUR trató de ajustar su actuación a los cambios de la realidad, manteniéndose dentro de su mandato. De tal modo, en los casos que se presentaban que no coincidían con la definición estricta del refugiado estatutario, aunque se tratase esencialmente de refugiados no estatutarios, ACNUR utilizó el principio de los Buenos Oficios.

\footnotetext{
${ }^{535}$ NACIONES UNIDAS. A/AC.96/SR.654. Op.cit., p. 3.

${ }^{536}$ NACIONES UNIDAS. A/AC.96/119 Informe del Comité Ejecutivo del Programa del Alto Comisionado de las Naciones Unidas para los Refugiados sobre su $\mathbf{6 3}^{\mathbf{0}}$ período de sesiones, 9 de octubre de 2012 , p. 11.

${ }^{537}$ NACIONES UNIDAS. A/AC.96/1132 Aprobación del Informe del Comité Ejecutivo sobre su $\mathbf{6 4}^{\circ}$ período de sesiones, 9 de octubre de 2013, p. 13.
} 


\title{
VI.11.1. ACNUR y su actuación con los desplazados internos
}

Según el mandato de ACNUR, solamente podría ocuparse de los refugiados estatutarios ${ }^{538}$, pero ¿cómo fue ampliado este mandato en relación con los desplazados internos? El mandato de ACNUR fue extendido a los desplazados internos a través de las Resoluciones de la Asamblea General de Naciones Unidas, las cuales aumentaron sus competencias.

El análisis del proceso de incorporación de los desplazados internos al mandato de ACNUR a través de las Resoluciones de la Asamblea General de Naciones Unidas permite verificar que lo mismo podría ser realizado en relación con los desplazados ambientales forzados.

La ampliación de las potestades de ACNUR en relación con los desplazados internos no estaba establecida en forma expresa en su Estatuto. Esa facultad derivó de las competencias residuales de los apartados 3 y 9 del Estatuto.

En tal sentido, el Comité Ejecutivo observa:

\begin{abstract}
ACNUR no tiene un mandato general o exclusivo para los desplazados internos. La participación de la organización en relación con los desplazados internos, incluidos los afectados por desastres naturales, ha evolucionado a partir de las competencias residuales que le confieren los apartados 3 y 9 de su Estatuto [...]. Las resoluciones subsiguientes de la Asamblea General han endosado actividades y funciones adicionales, sobre todo la primera Resolución "Ómnibus" reconociendo las actividades del ACNUR en favor de los desplazados internos de $1992^{539}$.
\end{abstract}

Las competencias de ACNUR fueron definidas en su Estatuto. Esos poderes son explícitos, pero también hay competencias residuales, las cuales derivan de los apartados 3 y 9 del Estatuto.

El apartado 3 del Estatuto de ACNUR dice que "El Alto Comisionado seguirá las directrices establecidas por la Asamblea General o el Consejo Económico y Social”.

El apartado 9 del Estatuto de ACNUR establece: "El Alto Comisionado emprenderá cualquier actividad adicional que determine la Asamblea General, incluida la repatriación y el reasentamiento de los refugiados dentro de los límites de los recursos a su disposición”.

En el año 1972, ACNUR comenzó a proteger a los desplazados internos, porque esta tarea le fue encomendada a través de diversas Resoluciones de ECOSOC y de la Asamblea General de Naciones Unidas. Estas Resoluciones fueron las siguientes: la Resolución 1655 (LII)

\footnotetext{
538 "Los refugiados estatutarios" son los que figuran en la definición de la Convención sobre el Estatuto de los Refugiados de 1951 y en el Protocolo Anexo de 1967.

539 UNHCR. Executive Committee of the High Commissioner's Programme Standing Committee. 51st meeting. EC/62/SC/CRP.19. Op.cit.
} 
del Consejo Económico y Social del 1 de junio de 1972, la Resolución 1705 (LIII) del Consejo Económico y Social (ECOSOC), del 27 de julio de 1972 y la Resolución 2958 (XXVII) de la Asamblea General de las Naciones Unidas del 12 de diciembre de 1972. Además, en 1992, el Secretario General de Naciones Unidas dio instrucciones para que ACNUR actuase con los desplazados internos de Sri Lanka ${ }^{540}$.

Según el análisis del Comité Ejecutivo, las competencias de ACNUR en relación con la protección de los desplazados internos remiten a las AG res. 47/105, AG res. 48/116, AG res. $49 / 169^{541}$, las cuales serán analizadas seguidamente.

En abril de 1993, en el Cuadragésimo Séptimo período de sesiones de la Asamblea de Naciones Unidas, tema 96, se estableció que ACNUR debería ocuparse de los desplazados internos. En tal sentido, se aprobó la Resolución (A/Res/47/105) que estableció en su primera parte:

Observando con preocupación que ha seguido aumentando el número de refugiados y de personas desplazadas de que se ocupa el Alto Comisionado, así como de otras personas a las que se pide que preste asistencia y protección su Oficina.

El apartado 3 de dicha Resolución observa:

Destaca la necesidad de mantener ininterrumpidamente en el programa político internacional las cuestiones relacionados con los refugiados, las personas desplazadas $[\ldots]$.

En el apartado 14, se establece:

\begin{abstract}
Encomienda, en ese contexto, los esfuerzos del Alto Comisionado, en cumplimiento de solicitudes expresas del Secretario General o de los principales órganos competentes de Naciones Unidas y con el consentimiento del Estado interesado, por realizar actividades en favor de las personas desplazadas dentro de sus países, teniendo en cuenta la complementariedad de los mandatos y conocimientos especializados de otras organizaciones pertinentes ${ }^{542}$.
\end{abstract}

Posteriormente, en marzo de 1994, en el Cuadragésimo Octavo Período de Sesiones, tema 113, de la Asamblea General de Naciones Unidas, este organismo vuelve a preocuparse por los desplazados internos estableciendo en su Resolución (A/Res. n. 48/116):

Reafirma su apoyo a las actividades del Alto Comisionado, en cumplimiento de solicitudes expresas del Secretario General o de los principales órganos competentes de las Naciones Unidas y con el consentimiento del Estado interesado, y teniendo en

\footnotetext{
${ }^{540}$ UNITED NATIONS. HIGH COMMISSIONER FOR REFUGEES (UNHCR). Reunión consultiva oficiosa. La Protección de los Desplazados Internos y el Papel del ACNUR, 27 de febrero de 2007, p. 1-2. Disponible en: <http://www.acnur.es/PDF/7694_20120417112142.pdf> acceso 2 de enero de 2014.

${ }^{541}$ UNHCR. Executive Committee of the High Commissioner's Programme Standing Committee. 51st meeting. EC/62/SC/CRP.19. Op.cit.

${ }^{542}$ UNITED NATIONS. GENERAL ASSEMBLY. A/Res. n. 47/105, 26 de abril de 1993, p. 2, apartado 3.
} 
cuenta la complementariedad de los mandatos y la especialización de otras organizaciones pertinentes, para proporcionar asistencia y protección humanitaria a las personas desplazadas dentro de sus países en situaciones concretas para las que se requiere la experiencia particular de la Oficina, sobre todo en los casos en que esas actividades puedan contribuir a prevenir o a solucionar problemas de refugiados ${ }^{543}$.

En esta resolución es considerado que ACNUR podrá brindar sus actividades en relación con los desplazados internos con la previa condición de que el Estado interesado le otorgue su consentimiento. Esta condición es necesaria para evitar los conflictos entre la actuación de ACNUR y el Estado afectado, siendo respetada la soberanía del Estado nacional.

En el año 1995, la Asamblea a través de su Resolución (A/Res. n. 49/169. 24 de febrero de 1995), vuelve a referirse a la importancia de la función del Alto Comisionado en relación con los desplazados internos, observando:

\begin{abstract}
Tomando nota de que el desplazamiento involuntario de personas dentro de su propio país sigue siendo un problema de gran preocupación humanitaria, y que las numerosas y diversas causas subyacentes de los desplazamientos internos involuntarios y de los movimientos de refugiados son similares en numerosos casos,

Reconociendo que las acciones de la comunidad internacional, en consulta y coordinación con el Estado de que se trate, en nombre de los desplazados internos podrían contribuir a la disminución de las tensiones y la resolución de los problemas producidos por el desplazamiento [...]

Tomando nota de que, en varios casos, los desplazados internos se presentan junto con los refugiados, los repatriados o la población local vulnerable, en situaciones en las que no es razonable, ni factible tratar las categorías de manera diferente en la respuesta a sus necesidades de asistencia y protección.

$[\ldots]$

11. Exhorta a la comunidad internacional a que proporcione oportuna y pronta asistencia humanitaria y el apoyo a los países afectados por los desplazamientos internos para que puedan cumplir sus obligaciones con los desplazados;

12. Exhorta, asimismo, a los Estados y a todas las partes en conflicto, a tomar todas las medidas necesarias para garantizar la imparcialidad, seguro y oportuno acceso humanitario a las personas necesitadas de protección y asistencia;

13. Reconoce la continuidad de la estrecha cooperación entre el Alto Comisionado y el representante del Secretario General sobre los desplazados internos en el ejercicio de su mandato, y reconoce la importancia de la estrecha cooperación y de la cooperación con el Comité Internacional de la Cruz Roja, en lo que respecta a la prevención, protección, asistencia humanitaria y soluciones ${ }^{544}$.
\end{abstract}

Es importante considerar que, en esta resolución, la Asamblea General observa que ante la situación problemática es necesaria la actuación para proteger y brindar asistencia a los afectados, no haciendo diferencias entre desplazados internos, refugiados o repatriados. Esto muestra como la Asamblea dio prioridad a los denominadores comunes de estos grupos, los cuales hacen referencia a las necesidades y derechos afectados.

\footnotetext{
${ }^{543}$ UNITED NATIONS. GENERAL ASSEMBLY. A/Res. n. 48/116, 24 de marzo de 1994, apartado 12. ${ }^{544}$ UNITED NATIONS. GENERAL ASSEMBLY. A/Res. n. 49/169, 24 de febrero de 1995, p. 4-5.
} 
En todas estas disposiciones se observa que la Asamblea instruye a ACNUR para que se haga cargo de los desplazados internos, siendo que este proceso de ampliación del mandato es anterior a creación del sistema de IASC.

En relación con los desplazados internos existen dos cuestiones de derecho internacional que son diferentes, una es el proceso de formación de los Principios Rectores de los Desplazados Internos, donde son reconocidos los derechos de estas personas, los cuales están contenidos en la Resolución de la Asamblea de Naciones Unidas de 1998.

La segunda cuestión es el proceso de incorporación de los desplazados internos, al mandato de ACNUR, lo cual se produjo a través de un conjunto de Resoluciones de la Asamblea de Naciones Unidas.

En relación con el primer proceso, la creación de los Principios, se puede observar que el inicio del tratamiento de la problemática de los desplazados internos en las Naciones Unidas se produjo en 1990. Esto comenzó cuando ECOSOC solicitó un Informe sobre los desplazados internos al Secretario General, y concluyó en 1998 cuando fueron creados los Principios Rectores de los Desplazados Internos.

De tal modo, es necesario diferenciar dos procesos diferentes: por un lado, la designación de la función de ACNUR para proteger y dar asistencia a los desplazados internos, lo cual ya brinda un precedente; por otro lado, el proceso de creación de los Principios Rectores de los Desplazados Internos.

Estos fueron procesos que se desarrollaron paralelamente, los cuales demuestran cómo estas cuestiones pudieron ser solucionadas a través de Resoluciones de la Asamblea General de Naciones Unidas sin que fuese necesaria la realización de tratados, siendo que lo más importante es la voluntad política de los principales órganos de Naciones Unidas, especialmente del Secretario General, de la Asamblea General y del Consejo de Seguridad.

Estas resoluciones forman parte del derecho de las organizaciones internacionales derivado, y permiten demostrar la eficacia de este tipo de derecho internacional (a pesar de que muchos autores lo llaman de light).

\section{VI.11.2. ¿Las competencias de ACNUR permiten que se haga cargo de los desplazados ambientales forzados?}

Como ya fue observado, la competencia de ACNUR en relación con los desplazados internos fue ampliada a partir de las Resoluciones de la Asamblea de Naciones Unidas y de los apartados 3 y 9 del Estatuto del Alto Comisionado. 
De tal modo, la protección de los desplazados internos quedó resuelta a través del derecho derivado de Naciones Unidas, tanto en relación con la asignación de un organismo que se ocupe de ellos, como en relación con el reconocimiento de los Principios Rectores de los Desplazados Internos a través de las Resoluciones de la Asamblea General de Naciones Unidas.

Así quedó demostrado que la constitución de una protección internacional eficaz para los desplazados internos pudo establecerse a través de las Resoluciones, sin necesidad de la creación de un tratado internacional.

De forma semejante, ACNUR podría proteger a los desplazados ambientales forzados sin que fuese necesaria la creación de un tratado internacional en el que se establecieran tales competencias. Porque el mandato de ACNUR puede ser ampliado a través de los apartados 3 y 9 del Estatuto de los Refugiados, ya que el apartado 9 hace referencia a las competencias residuales y el apartado 3 establece que el Alto Comisionado debe seguir lo establecido por la Asamblea General o por ECOSOC.

Por lo tanto, bastaría una resolución de la Asamblea General para que ACNUR pudiese actuar en relación con los desplazados ambientales forzados, sin necesidad de la creación de otro tratado.

ACNUR ya ha actuado en diversos episodios de desastres naturales, ayudando a los desplazados ambientales forzados, aun antes de la existencia del Sistema de Naciones Unidas para asistir las emergencias. En tales situaciones, ACNUR realizó sus actividades a través de su mecanismo de Buenos Oficios" ${ }^{545}$.

\section{VI.12. Consideraciones finales}

La tercera hipótesis de esta tesis sostiene que ACNUR es el organismo internacional que debería hacerse cargo de los desplazados ambientales forzados.

Después del estudio precedente ha quedado demostrado que ACNUR ha expresado su voluntad en tal sentido desde el año 2007. Por su parte, el Sistema Humanitario de Naciones Unidas para hacer frente a las Emergencias de los Desastres Naturales (IASC) así lo ha expresado también. En febrero de 2011, IASC propuso un Plan Piloto para que ACNUR asumiese esa función.

Esta hipótesis se fundamenta en que ACNUR es el organismo que tiene una vocación especial para asumir la protección de los desplazados ambientales forzados, debido a que su

${ }^{545}$ UNHCR. Questions and answers on UNHCR's Protection Cluster... Op.cit., parágrafo 1. 
mandato consiste en proteger a los refugiados. Las similitudes entre estos y los desplazados ambientales forzados sirven para demostrar que este organismo tendría la plena capacidad y experiencia para realizar tales actividades. Además, ACNUR ya se hace cargo de los desplazados internos de los desastres naturales.

IASC es el Sistema de Asistencia a la Emergencia Humanitaria de Naciones Unidas formado por nueve organismos internacionales. De todos los organismos que forman parte de IASC, y especialmente del grupo de protección, ACNUR es el que reúne las mejores cualidades para esa tarea.

En primer lugar, es necesario considerar la posibilidad de ampliación del mandato de ACNUR. Este organismo de Naciones Unidas fue creado para proteger a los refugiados definidos en su Estatuto, aunque ha prestado asistencia a otros refugiados que no encuadraban en esa definición restricta, a través del principio de los buenos oficios contenido en una de las Resoluciones de la Asamblea General de Naciones Unidas. Esto lo ha realizado para adecuarse a la realidad y a los nuevos problemas. Además, la Asamblea General de Naciones Unidas, por medio de sus Resoluciones, le ha ampliado el mandato para proteger a los desplazados internos (incluyendo los de los desastres naturales). Por lo tanto, es una contradicción que ACNUR haya asumido la asistencia de este tipo de desplazados internos de los desastres naturales, pero no puede encargarse de los desplazados ambientales que atraviesan las fronteras.

Lo más contradictorio de esto último es que existirían más resistencias derivadas de la protección de los desplazados internos de desastres naturales por causa de posibles problemas en relación con la soberanía, que el caso de los que atraviesan las fronteras. Sin embargo, los primeros han sido colocados bajo el mandato de ACNUR, y no estos últimos.

Además, la similitud tanto en las figuras como en las necesidades de los refugiados estatutarios, los desplazados internos, los desplazados internos de los desastres naturales (de los que cuida ACNUR) y de los desplazados ambientales forzados demuestran que la protección de estos últimos no implicaría nada nuevo para este organismo de Naciones Unidas.

En segundo lugar, es preciso observar que ACNUR tiene la voluntad de asumir la protección de estos desplazados, y lo ha manifestado desde el año 2007, a través de las declaraciones del Alto Comisionado, así como de las diversas iniciativas en tal sentido, como el apoyo brindado para la creación de la Iniciativa NANSEN en el año 2012 (dedicada exclusivamente a los desplazados ambientales forzados que atraviesan las fronteras).

Además, esa voluntad del organismo de Naciones Unidas surge del análisis del contenido de las Resoluciones sobre los Informes Anuales del Comité Ejecutivo de ACNUR y 
de las Resoluciones de aprobación de los Informes de las Reuniones Anuales de Delegados, en el período 2006-2012.

En tercer lugar, es importante resaltar la experiencia de ACNUR en la problemática de refugio acumulada desde el año 1951.

Este organismo se ha ocupado de los refugiados de desastres naturales, aun antes de que fuese reformado el sistema de IASC, como lo sustenta:

\begin{abstract}
Incluso antes del régimen instaurado por la reforma humanitaria, el ACNUR tenía experiencia en la actuación en apoyo de los Estados afectados por desastres naturales, en particular cuando la magnitud del desastre minó la capacidad del Estado para responder, por ejemplo, en respuesta al tsunami de 2004. Durante los últimos siete años, la Oficina ha apoyado respuestas de protección en once desastres naturales, [...] con las respuestas más importantes en Paquistán (inundaciones de 2010), Filipinas (inundaciones de 2009), Myanmar (ciclón Nargis en 2008) y Sri Lanka (tsunami en $2004)^{546}$
\end{abstract}

Es evidente que, si se comparan los tres organismos internacionales indicados por IASC, será ACNUR el que tenga la mayor capacidad, pues es su mandato: ocuparse de los desplazados ambientales.

El liderazgo del grupo de protección de IASC tendría que ser concedido a ACNUR, considerando la acción efectiva ya realizada en el sector, la historia del organismo y el liderazgo natural del organismo en el sector. Por esto, se justifica el liderazgo efectivo de ACNUR con los desplazados, sean estos de conflictos o de desastres ambientales.

Una de las objeciones sustentada por los Delegados de los países miembros es que sería necesario aumentar el financiamiento, lo cual es falso, pues para la protección de los desplazados ambientales forzados existe una línea de financiamiento especial (CERF).

El modo más simple y más rápido de ampliar el mandato de ACNUR en relación con los desplazados ambientales forzados es a través de las competencias residuales establecidas en el apartado 3 y 9 del Estatuto sobre los Refugiados. Estos dispositivos legales establecen que ECOSOC y la Asamblea General de Naciones Unidas pueden adicionar más actividades a ACNUR, por medio de sus Resoluciones. Esto ya ha ocurrido cuando fue ampliado el mandato de ACNUR en relación con los desplazados internos. Este procedimiento se realizó a través de las Resoluciones de la Asamblea General de Naciones Unidas. De ese mismo modo, podría ser realizado en este caso.

\footnotetext{
546 UNHCR. Executive Committee of the High Commissioner's Programme Standing Committee. 51st meeting. EC/62/SC/CRP.19. Op.cit., parágrafo 9.
} 


\section{CAPÍTULO VII}

\section{LA PROPUESTA DE UN RÉGIMEN PARA LOS DESPLAZADOS AMBIENTALES FORZADOS}

\section{VII.1. Consideraciones previas}

Como ha sido observado en el transcurso de este trabajo, el concepto de desplazados ambientales forzados abarca tanto a los internos como a los transfronterizos, especialmente considerando que los segundos son los que no tienen protección en el derecho internacional. Aunque, en este trabajo se insiste en que sean tratados ambos dentro del mismo régimen, porque el hecho de que esas personas atraviesen una frontera no incide en la formación del concepto de los desplazados ambientales forzados, como ya ha sido observado en el Capítulo II. La única diferencia es que unos tienen los recursos económicos para atravesar una frontera y los otros son los más pobres, que no tienen forma de iniciar un viaje más largo. La distancia de la trayectoria depende de la cantidad de recursos económicos con los que estos cuenten.

Además, existen algunas particularidades propias que los diferencian de los desplazados internos en general ${ }^{547}$.

En esta propuesta, en primer lugar, es considerada nuestra definición postulada de los desplazados ambientales forzados, la cual permite delimitar el ámbito humano que precisa de protección, así como el ámbito espacial que requiere también de protección.

En segundo lugar, son establecidas las necesidades básicas y fundamentales que sufren los desplazados ambientales forzados, las cuales les impiden tener una vida digna, y en virtud de estas, son considerados los derechos humanos de estas personas que precisan ser protegidos.

En tercer lugar, son reconocidos los principios que deben ser seguidos por los Estados, las organizaciones internacionales y la comunidad internacional con el objetivo de que la problemática sea tratada de forma adecuada, incidiendo esto en la efectividad de los derechos humanos de los que son titulares estas personas.

En cuarto lugar, es considerado el organismo internacional que se responsabilice por los desplazados ambientales forzados. Nuestra propuesta es que sea ACNUR.

\footnotetext{
${ }^{547}$ Tales como responsabilidad diferenciada y planificación.
} 
En quinto lugar, se establece el mecanismo a través del cual puede ser consagrado el Régimen de los Desplazados Ambientales Forzados, así como el organismo que cuide de la cuestión.

Estos aspectos han sido nutridos tanto de las consideraciones de la doctrina tratada en el Capítulo V, así como por las Directrices para la Protección de los Desplazados (internos) de los Desastres Naturales de IASC, por los Principios de la Iniciativa NANSEN y los Principios de ACNUR, siendo que estos dos últimos constan en el Capítulo VI.

\section{VII.2. Observaciones conceptuales}

Nuestra propuesta de definición para los desplazados ambientales forzados es la siguiente.

El desplazado forzado ambiental es toda persona, pueblo o parte de un pueblo que es obligado a dejar su hábitat, debido a un desastre ambiental o degradación ambiental, porque estos colocan su vida en peligro, o porque no permiten asegurar su sobrevivencia, que sufre la violación de los derechos humanos y que por esa situación es obligado a trasladarse a otro lugar dentro o fuera de su país, y que no puede ser obligado a retornar a sus hábitats mientras dure esa situación de inseguridad para su vida y sus derechos, a quien necesariamente se le debe aplicar el Principio de Asistencia a la Víctima.

De este concepto se desprende que la protección propuesta se restringe a los desplazados ambientales que son forzados, pues no pueden ejercer el derecho a la libertad de elegir entre quedarse o irse de sus hogares. También, la violencia del desastre o de la degradación ha arrasado con los derechos humanos de estos afectados.

Además de estos dos criterios que sirven para la determinación de este tipo de desplazados ambientales, existen otros dos parámetros que deben ser analizados: la necesidad de aplicación del Principio de No Devolución y de Asistencia a la Víctima ${ }^{548}$.

El ámbito de aplicación es el internacional, porque la naturaleza de la catástrofe ambiental no respeta fronteras, sino que puede extenderse sobre varios países en la mayoría de los casos. Por otro lado, la violación de los derechos humanos de estas personas obliga a elevar esta cuestión a la instancia internacional. Por lo tanto, se desprende que la solución a esta problemática debe ser a nivel internacional.

\footnotetext{
${ }^{548}$ Todos estos aspectos de la definición han sido analizados de forma particular en el Capítulo II. El criterio del Principio de la No Devolución aplicado a los desplazados ambientales forzados fue introducido por Kälin, mientras que la aplicación del Principio de la Víctima fue introducido por Docherty y Giannini.
} 


\section{VII.3. Reconocimiento colectivo e individual}

Estas personas deben tener derecho a ingresar en el país receptor y a que sea realizado el reconocimiento de la condición de desplazados ambientales forzados. Esto se debe a la naturaleza del desastre, así como a su magnitud que abarca regiones y consecuentemente afecta a pueblos enteros o partes de pueblos en su gran mayoría. En estos casos, es preciso que sea establecido un reconocimiento colectivo. Docherty y Giannini son los que introducen el reconocimiento colectivo, que según estos autores debería ser realizado por el Consejo de Científicos, Expertos o Técnicos. Esta última consideración es muy acertada, pues nadie más con las mejores condiciones para hacer estas tareas, ya que pueden considerar la magnitud, tipo e implicancias del desastre ambiental y las condiciones específicas de los afectados.

Aunque, también debe ser asegurado el reconocimiento individual, porque hay otras situaciones en las que esto es necesario, como consta en la Convención sobre el Estatuto de los Refugiados.

\section{VII.4. Derechos de los desplazados ambientales forzados en cada etapa del desplazamiento}

El régimen de los desplazados ambientales forzados debe asegurar todos los derechos humanos (incluyendo los derechos civiles, políticos, económicos, sociales y culturales, así como los de tercera y cuarta generación) de estas personas en todas las etapas del desplazamiento.

Existe una etapa previa al desastre o degradación ambiental. Hay lugares que ya están determinados o son determinables como proclives a los desastres o a la degradación ambiental, tales como islas de baja altitud y regiones costeras de tierras bajas. Estas primeras son propicias a los desastres o degradación de lenta duración, aunque también pueden ser afectadas por los desastres meteorológicos extremos. En estos casos, existe la posibilidad de predeterminar la producción del desastre, derivando de esto la obligación de alertar a la población sobre la posible realización del desastre o degradación ambiental grave. Otras regiones son propensas a los desastres meteorológicos repentinos. En este caso, es más difícil la previsión del desastre, aunque este tipo de catástrofe ambiental tiene una característica que es que se repiten todos los años y en las mismas épocas de cada año. Por lo tanto, en estos casos, cuando sea posible la previsión es una obligación la realización de la alerta. Esta obligación es de los Estados nacionales, aunque también de los organismos internacionales. Además, es necesario establecer 
que esa obligación se extiende durante todos los momentos del desastre, porque este puede producirse en diversos episodios.

En el momento en que se produce el desastre ambiental, es preciso que sean retiradas las personas afectadas de la región de emergencia. El segundo momento es cuando se efectúa el traslado y es necesario que se realice la reubicación temporaria. La tercera etapa es cuando ha pasado la emergencia y han desaparecido los peligros para la vida de las personas. En ese momento, algunos afectados podrán regresar a sus lugares de origen, aunque otros no podrán hacerlo porque esos lugares han desaparecido, como en el caso de islas de tierras bajas o regiones costeras bajas (sumergidas por las aguas del océano). Otros desplazados podrán optar por quedarse en los lugares donde viven o ir hacia otros lugares ${ }^{549}$.

Cuando se produce el desastre ambiental, las personas son obligadas a escapar para salvar sus vidas y su sobrevivencia. Este momento se caracteriza por la violencia del desastre o degradación ambientales graves ejercida sobre estas personas, que los obliga a abandonar sus hogares para salvar sus vidas y sobrevivir.

En esta etapa, debe producirse la asistencia para facilitar la evacuación de estas personas, buscando principalmente la protección del derecho a la vida.

Luego, los desplazados son llevados a campamentos donde recibirán los primeros auxilios a través de la asistencia médica, se les brindarán alimentos y agua potable, refugio, ropas y seguridad. Los lugares del refugio deben ser adecuados y seguros para las personas y sus familias, facilitando una vida digna. Esta es una etapa transitoria y provisoria que debe tener la mínima duración temporal.

Tanto en el primero como en el segundo momento de la tragedia, los afectados quedan en una situación infrahumana, porque los desplazados ambientales forzados sufren la violación de sus derechos humanos. Por lo tanto, será necesario aplicar el Principio de Asistencia a la Víctima, el cual asegura los derechos mínimos como el derecho a la vida, a los alimentos, al agua, a la salud, a la vivienda y a la seguridad. Aunque este Principio debe ser aplicado a los desplazados ambientales forzados mientras estos tengan las necesidades vitales no satisfechas.

En la segunda etapa de la vida de los desplazados ambientales forzados, se produce una situación extraordinaria porque estas personas se encuentran viviendo fuera de sus lugares de origen, donde hubieran podido llevar una vida en normalidad, trabajando, teniendo acceso a los

\footnotetext{
${ }^{549}$ Estos aspectos son observados en las Directrices de IASC sobre los Desplazados Internos de los Desastres Naturales, así como también en la Propuesta de Convención de CRIDEAU, considerada en el Capítulo V.
} 
alimentos, a la educación de sus hijos, a la salud, al agua potable, al ejercicio de sus religiones, a su vida cultural natural y las relaciones con su pueblo.

Esta etapa es cuando las personas son trasladadas a los campos de refugiados, constituyendo una situación de excepcionalidad, donde es fundamental que sean satisfechas las necesidades básicas y especialmente que sea garantizada la seguridad. Todas estas situaciones extraordinarias hacen que las personas se encuentren en una situación de inferioridad respecto del resto de la sociedad. Por esto, la ayuda de los Estados receptores y de la comunidad internacional debe acentuar las acciones afirmativas que permitan colocar a estas personas en una relación de igualdad ante la nueva sociedad.

En esta segunda etapa, es necesario que tanto los Estados receptores y los organismos internacionales les brinden la protección en relación con la unidad familiar, la documentación necesaria para ejercer la personalidad jurídica, así como las informaciones acerca de los

parientes desaparecidos. Además, deben ser garantizados todos los derechos humanos, y específicamente el derecho al ejercicio de la religión, derechos a su cultura, derecho a la educación según su cultura.

Es preciso destacar que el derecho a la documentación permite que estas personas puedan desarrollar sus vidas y viajar. También, posibilita el reconocimiento de la personalidad jurídica, lo cual implica que puedan ser sujetos de derechos y obligaciones. El derecho a que las familias permanezcan juntas y todos estos últimos derechos enunciados permiten que sea asegurada la integridad de la persona.

En la última etapa, precisa ser facilitada la asimilación a la nueva sociedad o el derecho a regresar al país de origen. La integración a la sociedad solamente se producirá si son asegurados sus derechos humanos enunciados en la Declaración Universal de Derechos del Hombre y en los Pactos sobre Derechos Humanos y, de forma especial, acentuando en el derecho a la documentación, a un trabajo digno y a la educación, así como a una vivienda digna.

\section{VII.5. Los derechos de los desplazados ambientales según la protección a la vida o sobrevivencia, a la libertad o a la igualdad}

En esta parte serán tratados los derechos humanos que precisan ser garantizados a los desplazados ambientales forzados. Por lo tanto, hace referencia a las obligaciones de los Estados y de la comunidad internacional en relación con estas personas.

El reconocimiento de los derechos humanos de los desplazados ambientales forzados hace que sea necesario el restablecimiento de la integridad física y psíquica, estando estas dos 
íntimamente relacionadas porque la pérdida de la primera afecta directamente a la segunda. De la integridad psíquica derivan la identidad individual y colectiva. Es imprescindible el respeto a estos aspectos porque los desplazados ambientales forzados fueron afectados por el desastre, el cual ha quebrado la normalidad de sus vidas transformándolos en parias que viven en situaciones de excepción, porque además de la pobreza, andan deambulando de un lado para otro.

Ha quedado establecido en el Capítulo III que los derechos humanos son interdependientes y que la realización de unos permite la efectividad de los otros, por lo tanto, no es posible establecer un orden o un nivel de jerarquía. Estas afirmaciones permiten dejar en claro que la enunciación de unos antes que los otros no significa un nivel de importancia.

Por otro lado, en primer lugar, serán enunciados los derechos que aseguran la protección del derecho a la vida, esto es, a la integridad física.

En segundo lugar, serán afirmados los derechos que aseguran la integridad física y psíquica, así como la identidad individual y colectiva de la persona humana.

\section{VII.5.1. Derechos a la vida y la sobrevivencia}

En todos los momentos por los que atraviesa el desplazado ambiental forzado es necesario que sean asegurados los derechos que hacen a la sobrevivencia de la persona, los cuales son derecho a la vida, a la alimentación, al agua, a la salud, al refugio y a la vestimenta.

La garantía del derecho a la vida implica que no sean realizados actos que atenten contra esta, con lo cual es necesario que sean brindadas las medidas de seguridad. Por otro lado, requiere que sean aseguradas las condiciones mínimas para que la persona tenga una vida digna, a pesar de las circunstancias. Este segundo aspecto requiere la vigencia de los otros derechos enunciados anteriormente. Los derechos humanos son indivisibles, y esta característica queda en evidencia cuando se consideran las relaciones necesarias entre tales, como ya fue analizado en el Capítulo III.

El derecho a los alimentos implica que les sea asegurada la posibilidad de accesibilidad, adecuación y disponibilidad. Este derecho es transversal, pues la falta de estos atenta directamente contra la vida y la salud.

El derecho a la salud incluye que haya atención médica, así como medicamentos y tratamiento psicológico. La violación de este derecho ataca también el derecho a la vida. El 
tratamiento médico psicológico de las víctimas es muy importante porque ellas pasan por una situación de ruptura que seguramente afectará su psiquis.

El derecho al agua precisa ser garantizado pues, así como la persona no puede sobrevivir sin alimentos, tampoco lo puede hacer sin agua. Este derecho incluye la manutención de un sistema de agua potable.

El derecho al refugio o a una vivienda digna y segura es fundamental para que la persona pueda sobrevivir, donde tenga el acceso al agua potable y a los servicios sanitarios.

Todos estos derechos constituyen las condiciones mínimas necesarias para la sobrevivencia digna de la persona que está pasando por la situación de emergencia derivada del desastre o de la degradación ambiental aguda. Docherty y Giannini se refieren al Principio de Asistencia a la Víctima, cuyo contenido traducido para los desplazados ambientales forzados se identifica con los que aquí se denominan derechos de sobrevivencia. Esto ha sido examinado en el Capítulo V.

Los derechos a la vida, a los alimentos, al agua, a la salud y a la vivienda o refugio garantizan la integridad física de las personas. Aunque es necesario reconocer que esta última incide sobre la integridad psíquica, porque una persona desprovista de condiciones mínimas que aseguren una vida digna, tiene afectada tanto su integridad psíquica como su identidad de persona.

A continuación, serán considerados los derechos a la unidad familiar, a la entrada al país, a la documentación y al reconocimiento de la personalidad jurídica, todos ellos permiten alcanzar las necesidades básicas del ser humano que vive continuamente en sociedad, ya sea la propia u otra.

El derecho a la unidad familiar debe ser garantizado en todas las etapas del desplazamiento ambiental forzado. Porque ¿qué puede ser peor y más traumático que la separación o pérdida de la familia? Las operaciones de socorro deben respetar este derecho, impidiendo la separación de la familia. Además, cuando haya familiares desaparecidos deben ser informados sobre los avances de las búsquedas ${ }^{550}$, porque ¿qué puede afectar más la integridad psíquica de la persona que no poder enterrar a sus muertos? Este derecho tiene relación directa con la integridad psíquica y la identidad individual de la persona.

Además, las personas tienen derecho a ingresar a otros países porque están escapando para salvar sus vidas. El derecho a la entrada a otros países consiste en un derecho de sobrevivencia dado que el afectado por el desastre es obligado a escapar a otros lugares para

${ }^{550}$ Esto consta en la Guía de Directivas de IASC para los desplazados internos de los desastres naturales. 
salvar su vida. De tal modo, no puede ser considerada la entrada ilegal al país y, en estos casos, el Estado receptor debe darles un tiempo para que puedan legalizar su situación. Además, el Estado precisa brindarles el asesoramiento para que estas personas puedan normalizar su situación dentro del país.

Es necesario que sea realizado el registro de las personas con la individualización de las condiciones de vida y que sean otorgados los documentos necesarios para la persona.

Una consecuencia del desastre es que las personas pierden sus documentos, y los Estados tienen que brindárselos, para que puedan movilizarse dentro del Estado o fuera de él. Por lo tanto, debe ser asegurado el derecho a la documentación. Además, este derecho es fundamental para que los afectados puedan realizar los actos civiles necesarios.

La falta de la documentación implica la violación de la integridad psicológica, porque el documento no sólo significa un papel otorgado por el Estado, sino que hace a la identidad psicológica de la persona humana. Por estas circunstancias es preciso que sea dado un tratamiento psicológico.

Otro derecho fundamental es el reconocimiento de la personalidad jurídica, pues así las personas podrán ser titulares de derechos, y permitiendo que realice los actos propios de la vida civil. Esto está establecido en la Convención sobre el Estatuto de los Refugiados de 1951.

Estos dos últimos derechos, a la documentación y al reconocimiento de la personalidad jurídica, tienen relación directa con la integridad psicológica y con la identidad de la persona, pues hacen que los afectados se incorporen a la vida civil de la que están excluidos por su situación de desplazados ambientales forzados.

\section{VII.5.2. Derechos derivados de la libertad}

El derecho a la libertad de circulación y a la libertad de elección de la residencia necesita ser asegurado. Estos derechos están consagrados en el Estatuto de los Refugiados, así como en los Principios Orientadores de los Desplazados Internos y en las Directrices para Proteger a los Desplazados internos en los Desastres Naturales de IASC. Otros derechos que deben ser efectivizados son el de la libertad de pensamiento, de expresión y de opinión, la libertad de reunión y de asociación, el derecho al ejercicio de sus tradiciones y culturas y a la libertad de religión. Este último implica la posibilidad de poder realizar actos religiosos, así como brindar educación religiosa a los hijos.

Es necesario que sean efectivizados todos estos derechos porque hacen a la integridad de la persona. 
El ser humano precisa que sea garantizada su integridad tanto física como psíquica, pues constituye una unidad. La integridad psíquica de los desplazados ambientales forzados está profundamente afectada por la situación vivida, y estas personas se encuentran en una situación infrahumana, la cual implica no solamente la violación de la integridad física, sino psíquica. Porque las vivencias del desastre dejan secuelas graves en la psiquis de las personas, siendo que en muchos casos no es posible superarlas a lo largo de la vida, marcándoles la existencia para siempre.

Este conjunto de derechos se refiere a la libertad de la persona humana, como ya fue considerado en el Capítulo III, constituye uno de los pilares de los derechos humanos. El derecho a la libertad es tan importante para las personas como el aire que respiran porque significa el libre ejercicio de la autonomía de la voluntad.

El otro principio rector de los derechos humanos es la igualdad. La vigencia de los derechos humanos requiere la existencia de un equilibrio entre la libertad y la igualdad, porque cuando solamente rige la libertad, es en desmedro de la igualdad (como ocurrió posteriormente a la Revolución Francesa, cuando sólo había una igualdad formal). Del mismo modo, la absolutización de la igualdad lleva a perjudicar los derechos derivados de la libertad. Esto puede ser verificado tanto en el análisis histórico como en el análisis de los sistemas políticos extremos. Fue lo que ocurrió con la Declaración Universal de los Derechos del Ciudadano en 1789, cuando regia la libertad de forma más absoluta y sólo existía una igualdad formal. La igualdad precisa ser real, la cual significa que todos tengan garantizada la posibilidad de ejercer los derechos, asegurando a través de la actuación del Estado las acciones necesarias para la efectividad de los derechos derivados de la igualdad.

\section{VII.5.3. Derechos derivados de la igualdad: derechos sociales, económicos y culturales}

En este sentido, los derechos sociales, económicos y culturales derivan del principio de la igualdad, así como el conjunto de derechos que hace a la sobrevivencia. Dadas las circunstancias vividas por los desplazados ambientales forzados es necesario que sean realizadas acciones afirmativas para que estos derechos puedan ser ejercidos y sean efectivos.

Además, deben ser asegurados los derechos a la educación y el derecho de trabajar.

La garantía del derecho al trabajo es la forma más importante de integración de la persona desplazada ambiental forzada, pues significa que ya puede sobrevivir por sus propios medios y no precisa de la aplicación del Principio de Asistencia a la Víctima. Implica la plena realización de la persona, pues le permite acceder a los bienes y servicios esenciales sin 
necesidad de recurrir a la ayuda internacional o del país receptor. Este derecho debe permitir que la persona pueda tener una vida digna.

El derecho a la educación para los hijos de los afectados es primordial para que estos se inserten en la nueva sociedad y en el futuro puedan hacer frente a los desafíos de la vida.

Es necesario que los grupos vulnerables sean protegidos especialmente, estos son los niños, ancianos, mujeres, discapacitados y comunidades tradicionales ${ }^{551}$. Este tratamiento diferencial se justifica en que estas personas están en una situación de inferioridad del resto, sea por causa de la edad, del género o de las condiciones de salud. Todas estas circunstancias reflejan una situación de incapacidad e inferioridad en relación con el resto y, por lo tanto, pueden ser objeto de actos discriminatorios. Docherty y Giannini reconocen la relevancia de este aspecto.

La naturaleza del desastre o de la degradación ambiental implica que haya áreas afectadas, lo cual implica que los desplazados ambientales forzados puedan constituir pueblos enteros o partes de pueblos, en la mayoría de los casos. Esto hace que sea necesario considerar situaciones especiales como la necesidad de asegurar los derechos a la cultura del pueblo.

El derecho a la cultura implica que sea necesario asegurar que el pueblo pueda realizar todas las actividades culturales, que sean garantizados los derechos a las costumbres, que sea preservada la historia del pueblo, su idioma, su religión, sus formas de sobrevivencia, de uso de su vestimenta.

Estos derechos están íntimamente relacionados con la identidad colectiva que precisa ser preservada porque su violación incide sobre la identidad individual y sobre la integridad psicológica de las personas.

Es necesario que sea brindada una especial atención y protección a las comunidades tradicionales, pues estas son las más vulnerables, dado que su sobrevivencia está íntimamente ligada al medio ambiente.

La reubicación planificada de estas comunidades requiere que sea respetado el principio de la proximidad, para que sean aseguradas condiciones ambientales que hacen a los medios de sobrevivencia de las comunidades tradicionales y que sea posible la recreación del ambiente donde han vivido, impidiendo de esta forma que las personas sientan violados sus derechos al

\footnotetext{
${ }^{551}$ El Principio II de la Conferencia NANSEN hace referencia al tratamiento especial para los grupos vulnerables, incluyendo entre estos a las comunidades tradicionales, que viven en gran parte de los Pequeños Estados Insulares en Desarrollo, cuyas características son diferenciales del resto de la población, pues sus medios de vida son de subsistencia y estas están en relación directamente con los recursos que el medio ambiente les proporciona. De tal modo, su sobrevivencia está en relación directa con el medio ambiente.
} 
ser cultural del pueblo y su identidad colectiva, y que se produzca la desintegración de los pueblos.

Estas comunidades tradicionales tienen una visión diferente de la que impera en el mundo occidental, porque esta última es individualista, mientras que la que impera en las primeras es colectiva. Por esto, la importancia que sean reconocidos los derechos colectivos. Por ejemplo, el derecho de propiedad no es un derecho individual sino colectivo, según estos pueblos. De tal forma, precisan ser asegurados los derechos colectivos, aquellos que corresponden a los grupos y pueblos, tales como el derecho a la cultura de los pueblos, a sus tradiciones, a su idioma, a su historia, a su religión.

BIERMANN, BOAS y MAYER se refieren a este último tipo de derechos, los colectivos, como ha sido considerado en el Capítulo V.

En la etapa final, es decir cuando ha pasado la situación de emergencia del desastre o degradación ambiental, es preciso que sea asegurado el derecho al retorno voluntario de estas personas.

En el caso de que no exista posibilidad de volver porque las consecuencias del desastre o degradación ambiental son definitivas, es necesario asegurar la reubicación planificada y definitiva. BIERMANN y BOAS se refieren al Principio de Recolocación Planificada, tratado en el Capítulo V.

También, debe ser reconocido el derecho al no retorno, es decir, cuando las personas no quieren volver a sus países de origen no pueden ser obligadas. Esto es en virtud del Principio de No Devolución.

Además, debe ser asegurado el derecho a naturalizarse para que el desplazado forzado ambiental pueda vivir en condiciones de igualdad con los nacionales. También, deben ser considerados los derechos al medio ambiente sano y al desarrollo.

\section{VII.6. Principios. Consideraciones previas}

Los Principios deben dirigir la actuación de los actores locales (Estados), regionales e internacionales, según las particularidades de las catástrofes ambientales y los desplazamientos ambientales forzados.

Después de todo lo considerado en este trabajo, se puede concluir que la problemática de los desplazados ambientales forzados es dinámica.

Es posible observar que existe cierto grado de certeza sobre las regiones propensas a los desastres ambientales. Además, se pueden establecer las regiones proclives a los procesos de 
degradación lenta. Por otro lado, existe un grado de incertidumbre sobre la producción de los desastres repentinos, aunque se ha observado, en tal sentido, una característica que es la repetición. Esto último permite visualizar un cierto grado de certeza sobre los países que pueden ser más afectados por estas catástrofes reiteradas.

Por otro lado, es necesario considerar que algunos de los desastres y degradación ambiental causados por los cambios climáticos requieren del aporte de la ciencia, debido a la naturaleza y a la complejidad de estos fenómenos. Todo esto refuerza la relevancia del aporte de la ciencia en relación con esta problemática.

Otro aspecto importante es que la dimensión de estas catástrofes ambientales puede abarcar uno o varios países, de lo que deriva la necesidad de la actuación a nivel internacional.

Todas las etapas del desplazamiento ambiental forzados precisan ser regidas por los Principios de los Derechos Humanos, de la Asistencia a la Víctima y de la Dignidad Humana.

La primera etapa, cuando ocurre la catástrofe ambiental, debe estar apoyada en los Principios de Alerta Temprana, brindar informaciones, protección de los afectados, esto último significa que la participación debe ser inmediata de los organismos internacionales para proteger a las personas, buscando garantizar el derecho a la vida; otro principio es el de la garantía de los Derechos Humanos, la No Discriminación.

En la segunda etapa, también debe ser asegurado el Principio de Protección a la Víctima, los Derechos Humanos, la dignidad de la persona humana.

En la tercera etapa, debe regir el Principio de la Integración de las víctimas a la sociedad actual, o en los lugares de origen.

\section{VII.6.1. EI Principio de No Discriminación}

El Principio de No Discriminación precisa ser asegurado a los desplazados ambientales forzados. Este principio ha sido establecido en la Convención sobre el Estatuto de los Refugiados, en los Principios Orientadores de los Desplazados Internos, en la Convención contra la Tortura y Otros Tratos o Penas Crueles, Inhumanas o Degradantes y es considerado en la mayoría de las propuestas de regímenes establecidos por la doctrina ${ }^{552}$. Ello implica la eficacia del tratamiento igualitario de las personas, lo cual significa que en los casos de los grupos vulnerables precisan ser establecidas acciones afirmativas. De esta forma, significa que

${ }^{552}$ La posición de estos últimos autores es tratada en el Capítulo V. 
donde existe una desigualdad natural puede ser restablecida la igualdad en el tratamiento de las personas.

\section{VII.6.2. El Principio de No Devolución}

La situación del desastre o degradación ambiental aguda implica la posibilidad de pérdida de la vida o daños a la persona, por lo tanto, mientras duren estas circunstancias, las personas no pueden ser ni obligadas, ni incitadas a volver. Esto implica la aplicación del Principio de No Devolución, el cual fue consagrado en la Convención sobre el Estatuto de los Refugiados, en la Convención contra la Tortura y Otros Tratos o Penas Crueles, Inhumanas o Degradantes y en los Principios Rectores de los Desplazados Internos. Este Principio ha sido enunciado por la doctrina, como ha quedado demostrado en el Capítulo V.

\section{VII.6.3. EI Principio de la Efectividad de los Derechos Humanos}

La efectividad de los derechos humanos ${ }^{553}$ debe regir todo el proceso, desde el momento que la persona es afectada por el desastre hasta cuando ha pasado el peligro y ella pretenda retornar voluntariamente o permanecer en la sociedad que le acogió o reintegrarse a otra sociedad.

El reconocimiento de estos derechos no basta, sino que precisan ser efectivizados. Muchos pueden considerar esto como un deseo, pero es posible a través de la creación de un régimen internacional que establezca cada una de las acciones necesarias para garantizar los derechos, conjuntamente con la aplicación de los principios de respuesta rápida, previsibilidad, planificación y la activa participación de la ciencia.

Obviamente, no se puede negar que, en algunos de los casos de desastres repentinos, donde rige la incertidumbre absoluta, la protección efectiva de los derechos humanos es más difícil, aunque con la aplicación de tales principios se minimizaría la violación de los derechos humanos.

${ }^{553}$ Este Principio fue presentado por la Propuesta de Convención de CRIDEAU. Sostenía la obligación de los países de elaborar políticas que ayudasen a hacer efectivos y reales los derechos humanos de los desplazados ambientales forzados. 


\section{VII.6.4. EI Principio de la Activa Participación de la Ciencia}

Consecuentemente, es necesaria que sea implementada la regla de la activa participación de la ciencia. Esto es fundamental por todo lo anteriormente comentado y porque las situaciones de los desastres ambientales se caracterizan por ser muy dinámicos y avanzar mucho más rápido que la actividad del hombre.

Especialmente, considerando la complejidad de los desastres producidos por los cambios climáticos, las posibilidades de que el grupo de científicos establezca las regiones propensas a los desastres, los procesos de lenta degradación, la gravedad de los desastres y las repercusiones en los desplazamientos forzados. También, es preciso observar que la condición colectiva o individual de refugiados ambientales podrá ser tarea del grupo de científicos. Además, puede establecer la reubicación planificada para aquellos casos en los que no puedan retornar porque sus territorios hayan desaparecidos o hayan quedado con un deterioro ambiental permanente.

\section{VII.6.5. Principio de Previsibilidad}

En estas situaciones de emergencia es necesaria la aplicación del Principio de Previsibilidad.

En este sentido, hay casos de desastres o degradación ambiental que son previsibles, tales como aquellos que se producen lentamente, como algunos desastres repentinos caracterizados por la repetición en las mismas épocas y lugares, como ha sido observado en el Capítulo IV. De tal modo, sería posible determinar las áreas propensas a los desastres ambientales, pues del análisis de los desastres se verifica que hay países más afectados. Por otro lado, otro parámetro que permite esta verificación son las características físicas de los países que hacen que sean más vulnerables, tales como islas de tierras bajas, regiones costeras bajas, Pequeños Estados Insulares en Desarrollo.

En los casos de los desastres o degradación ambiental de procesos de lenta duración, la previsibilidad aumenta porque la situación insostenible no se produce de una hora para la otra, como es en los Pequeños Estados Insulares, o en las regiones costeras bajas o en los lugares donde se produce desertificación. 


\section{VII.6.6. El Principio de Planificación}

El Principio de Planificación debe regir todos los momentos por los que atraviesan los desplazados ambientales forzados, porque permite asegurar que puedan ser evadidas las situaciones en las que se produce la violación de los derechos humanos de los afectados.

Es posible la implementación gracias al aporte científico, pues este es el que garantiza que sea posible un nivel de previsibilidad de las situaciones caóticas que se producen con el desastre y la degradación ambiental, así como la planificación de las soluciones.

De todos modos, es necesario destacar que en los casos de los desastres o degradación repentinos rige en gran medida la incertidumbre. Ante lo cual, la ciencia encuentra sus límites, pues el paradigma de la sociedad de la modernidad y de su ciencia, donde todo podía ser controlado, queda ultrapasado por el desconcierto, el acaso y los riesgos.

\section{VII.6.7. El Principio de la Respuesta Rápida}

Es necesaria una respuesta rápida y organizada tanto del Estado nacional como de los organismos internacionales ${ }^{554}$. Los países afectados por los desastres o la degradación ambiental, así como los Estados receptores de los contingentes de afectados precisan pedir ayuda internacional, y expresar su consentimiento para la entrada de los organismos internacionales. De este modo, no se podrá argumentar que la soberanía de estos Estados es afectada.

El Principio de la Respuesta Rápida debe estar articulado con la previsibilidad y la planificación.

\section{VII.6.8. EI Principio de Participación de las comunidades afectadas}

El Principio de la Participación de las comunidades afectadas en la toma de decisiones es muy relevante porque permite que en las decisiones participen quienes tienen mayores intereses en la búsqueda de soluciones, los afectados. Además, el proceso de decisión surge de abajo hacia arriba, y esto hace que sea más efectivo. Este Principio tiene su génesis en la Reunión de Bellagio realizada por ACNUR en febrero de 2011.

\footnotetext{
${ }^{554}$ En tal sentido, la Iniciativa NANSEN establece el Principio que señala: "La construcción de la capacidad local y nacional para la preparación y respuesta a desastres es fundamental. Al mismo tiempo, el sistema internacional de respuesta a desastres necesita ser reforzado. El desarrollo de los sistemas de alerta temprana para múltiples peligros que vinculan los niveles locales y globales es crítico".
} 


\section{VII.6.9. EI Principio de las Cargas Compartidas}

El Principio de las Cargas Compartidas implica la responsabilidad común y diferenciada. La primera significa que todos los países son responsables por el medio ambiente, mientras que la segunda se refiere a que cada país debe contribuir financieramente según su propia capacidad económica y según la contribución con las emisiones de gases de efecto invernadero. Además, los Estados deben tratar de recibir el mayor número de desplazados ambientales forzados. Este principio ha sido considerado por la mayoría de las propuestas presentadas por la doctrina.

\section{VII.7. El caso de los desplazamientos ambientales forzados: Comunidades/ pueblos o partes de pueblos y la Reubicación Permanente}

Es necesario prestar atención especial a dos aspectos: cuando los desplazamientos ambientales sean de comunidades/ pueblos o partes de pueblos y sean permanentes, porque estos son los que se encuentran en la peor situación ya que no podrán retornar a sus lugares de origen debido al grado de deterioro de estos lugares o a que algunos de esos terrictorios han desaparecidos.

En esta situación, estas personas precisan ser reubicadas de forma permanente, y los lugares elegidos deben ser semejantes a los lugares de origen para que sean preservados sus derechos al ser cultural del pueblo, a su idioma, a su historia, sus modos de sobrevivencia.

Además, en estos casos debe aplicarse el principio de la planificación de la reubicación permanente, pues esta permitirá que los lugares del re-establecimiento final sean los adecuados.

También es necesario que sean reconocidos todos derechos de los pueblos indígenas y tribales tales como están establecidos em la Declaración de 2007, anteriormente citada.

\section{VII.8. Refugiados de los Cambios Climáticos}

Es necesario observar que es preciso considerar a los Refugiados de los Cambios Climáticos, con sus propias características y necesidades, pues son una subcategoria de los desplazados ambientales forzados o refugiados ambientales. Esas necesidades serán 
satisfechas según los derechos y los principios observados anteriormente, como el de la Responsablidad Diferenciada.

\section{VIII.9. Creación de un Fondo}

La realización de todas las actividades de protección y asistencia a los desplazados ambientales forzados exige que sea necesario que haya recursos económicos suficientes para hacer frente a la emergencia, al desastre y a la degradación.

Por eso, es necesario que sea creado un Fondo que permita el financiamiento de estas actividades.

\section{VII.10. ACNUR debe ser el organismo encargado por la protección de los desplazados ambientales forzados}

ACNUR es el organismo que tiene la vocación humanitaria para hacerse cargo de los desplazados ambientales forzados, además tiene una experiencia acumulada desde 1951 con los refugiados, y se ocupa de los desplazados internos desde 1992, competencia asignada por una Resolución de la Asamblea General de Naciones Unidas.

Por otro lado, se ha hecho cargo de algunos desplazamientos ambientales forzados, tales como el caso del tsunami de 2004, Haití en 2010, Paquistán, Filipinas, Myanmar y Sri Lanka. Esto ha sido posible gracias al mecanismo de los buenos oficios, establecido en sus reglas de funcionamiento.

\section{VII.11. Mecanismo para la introducción del régimen especial para los desplazados ambientales forzados y responsabilidad de ACNUR, creado a través de la Resolución de Naciones Unidas}

Nuestra propuesta es que sea establecido un régimen de protección de los desplazados ambientales forzados a través de una Resolución de la Asamblea General de Naciones Unidas, como fue lo que ocurrió con los Principios Orientadores de los Desplazados Internos creados por una Resolución de ese tipo en el año 1998.

En segundo lugar, se considera que sea designado ACNUR para hacerse cargo de la situación de los desplazados ambientales forzados a través de una Resolución de la Asamblea General de Naciones Unidas. Este segundo aspecto está fundamentado en la experiencia de ACNUR para hacer frente a esas situaciones y a otras similares. 
ACNUR ha venido desarrollando la protección y la asistencia de los refugiados estatutarios, así como de los de hecho desde 1951. También, desde su creación ha demostrado una voluntad y una flexibilidad para hacer frente a las situaciones a pesar de que las reglas de su Estatuto y de la Convención sobre el Estatuto de los Refugiados eran muy estrictas. También, ha hecho frente "ad hoc" a diversos casos de desplazados ambientales forzados de los desastres, como fue señalado en el capítulo precedente. Por otro lado, ACNUR es el encargado de los desplazados internos, siendo que ese concepto incluye a los desplazados internos de los desastres.

Todos estos avances han sido logrados gracias a las competencias residuales de los apartados 3 y 9 del Estatuto del ACNUR, los cuales permiten que puedan ser ampliadas sus competencias por medio de una Resolución de la Asamblea General de Naciones Unidas, como ha sido mencionado en el capítulo anterior.

Por otro lado, es necesario destacar que, si ACNUR ha sido creado por una Resolución de la Asamblea General de Naciones Unidas, del mismo modo pueden ser modificadas sus competencias por otra Resolución de la misma naturaleza. 


\section{CONCLUSIONES}

Hasta finales de los años noventa y los primeros años de la década pasada, había discusiones en la doctrina en relación con la existencia de los desplazados ambientales forzados. Aunque recientemente se ha llegado a la evidencia de la existencia de los desplazamientos ambientales. Esto, en parte, debido a los numerosos estudios que fueron realizados sobre este objeto de estudio y, también, por causa del aumento de los desastres y la degradación ambiental que producen los desplazamientos ambientales forzados.

En esta tesis, se ha analizado la problemática de la falta de regulación internacional para la protección de los desplazados ambientales forzados transfronterizos y la necesidad de que sea creada esa protección. Esta cuestión tiene una naturaleza internacional indiscutible, debido a que estas personas tienen que escapar de sus países de origen y no tienen la protección de ningún país. Además, existe la necesidad de una amplia protección internacional que abarque tanto a aquellos que escapan dentro del país como a los que parten hacia otros países, como ha quedado demostrado, pues ambos casos tienen las mismas necesidades específicas. La violación de sus derechos humanos de estos desplazados ambientales forzados ha quedado demostrada. Este último aspecto justifica que esta temática esté inserida en la instancia del derecho internacional.

La naturaleza internacional de la necesidad de la creación de un Marco Internacional de Protección a los desplazados ambientales forzados se justifica en que existe una responsabilidad común de los Estados y de la comunidad internacional por proteger los derechos humanos en los casos de violación, en la responsabilidad común de todos por preservar el medio ambiente, en los principios de cooperación internacional y la solidaridad internacional y en la responsabilidad diferenciada de los países para hacer frente a la emergencia humanitaria derivada de los desplazamientos ambientales forzados.

La primera hipótesis sostenida en esta tesis es si sería posible conceptualizar la figura de los refugiados ambientales o desplazados ambientales forzados constituyendo una única figura, con independencia de:

- si fueron desplazamientos internos o externos,

- si el desastre obedeció a las causas de los cambios climáticos u otros cambios ambientales,

- si el desastre fue producido por la actuación del hombre, de la naturaleza o de ambos. 
Se ha podido observar en el transcurso de este estudio, que la comunidad internacional, a través de los Organismos de Naciones Unidas, ha intentado dividir el tratamiento de la cuestión de los desplazados ambientales forzados, en vez de establecer una figura única. Por un lado, en 2008, el Secretario General de Naciones Unidas ha designado al Alto Comisionado de Naciones Unidas para los Derechos Humanos y al Consejo de Derechos Humanos de Naciones Unidas para que asuman la competencia sobre la relación entre los cambios climáticos, los desplazamientos derivados de tales impactos y los derechos humanos.

Esto ha derivado en exámenes parciales, porque estos organismos solamente se ocupan de los desplazamientos ambientales forzados causados por los impactos de los cambios climáticos.

Por otro lado, a través de la Resolución 46/182 de la Asamblea de Naciones Unidas fue designado: el Comité Permanente entre Agencias (IASC) para hacer frente a los desastres naturales y emergencias complejas, el Coordinador del Socorro en la Emergencia, quien preside IASC. De este entramado, surgen otras dos divisiones en el tratamiento de los desplazados ambientales forzados: en primer lugar, solamente serán protegidos por IASC y OCHA los desplazamientos ambientales forzados de los desastres naturales, dejando de lado todos aquellos que derivan de la acción humana o de ambos; en segundo lugar, IASC solamente se ocupa de proteger a los desplazados de los desastres naturales internos.

Esta última línea de separación sobre esta cuestión es injustificada, como ya ha sido observado, porque la trayectoria del desplazamiento ambiental forzado en la mayoría de los casos no depende de la voluntad de los afectados, sino de los recursos económicos con que estos cuentan. Por lo tanto, la única diferencia entre los internos y los externos es que atraviesan la frontera internacional de un país.

El marco de protección internacional de los internos está constituido por la Resolución de la Asamblea General de Naciones Unidas que instituye los Principios Rectores de los Desplazados Internos y por la Resolución de ese mismo organismo que establece que la responsabilidad ante los desplazados internos es de ACNUR. La definición de los desplazados internos contenida en ese marco jurídico de tal Resolución incluye a los que resultan de desastres naturales. Además, se revela una contradicción de todo esto. En primer lugar, existe un Principio que sostiene que la responsabilidad primordial ante los desplazados internos es del Estado nacional. Este Principio ha sido consagrado en diversas instancias, como en Principios Rectores de los Desplazados Internos, en los Principios NANSEN, en los Principios de ACNUR, entre otros. En segundo lugar, y derivado directamente de ese primer Principio, surge 
otro que es que el Estado nacional afectado tendrá que solicitar la ayuda internacional y declarar su expreso consentimiento para poder recibir esa ayuda. Por lo tanto, esta problemática es primeramente de naturaleza doméstica de los Estados. Mientras que la situación de los desplazados ambientales forzados que atraviesan las fronteras constituye un problema de verdadera naturaleza internacional, pues no tienen ningún tipo de protección nacional.

De todo este análisis concerniente al tratamiento parcializado de la cuestión de los desplazados ambientales forzados, cabría establecer algunos cuestionamientos, como cuáles serían los intereses que están por detrás del tratamiento fraccionado.

Por otro lado, es necesario destacar que la Corte Europea de Derechos Humanos ha desarrollado un cuerpo de jurisprudencia, donde no han sido consideradas ninguna de esas diferencias, sino que la problemática ha sido relacionada con los desplazamientos forzados de la degradación ambiental. Otras instancias internacionales que tampoco han considerado esas diferenciaciones, han sido la Corte Interamericana de Derechos Humanos y la Comisión Interamericana de Derechos Humanos, como ha sido observado en el Capítulo III.

En efecto, es necesario afirmar que en esta tesis se ha trabajado con la idea de una figura única de los desplazados ambientales forzados, sin diferenciar si fueron causados por los actos del hombre o de la naturaleza o de ambos. Tampoco se ha considerado si estos afectados son internos o externos. Porque en la construcción de la conceptualización de los desplazados ambientales forzados han sido considerados los aspectos esenciales que componen esta figura.

En consecuencia, nuestra propuesta de definición es: los desplazados ambientales forzados son aquellas personas, pueblos o parte de estos que han sido obligados a dejar sus hábitats originales por causa de los impactos del desastre o de la degradación ambiental, que han colocado en peligro su vida o la sobrevivencia, violando sus derechos humanos, y consecuentemente obligándolos a desplazarse a otros lugares, dentro o fuera del país de origen, y que no pueden ser obligados a retornar a sus lugares de origen mientras duren las amenazas a sus derechos humanos y a quienes necesariamente se les debe aplicar el Principio de Asistencia a la Víctima.

De este concepto surgen los aspectos más significativos que hacen referencia a la violación de la libertad de la persona de irse o quedarse, siendo que en lugar de esta surge la obligación de escapar sin la voluntad de hacerlo o contra su propia voluntad, transformándolos de este modo en desplazados forzados.

Otro aspecto que se observa es el acontecimiento que desencadena esta situación de la catástrofe ambiental, con independencia de si fue causada por el hombre, por la naturaleza o 
por ambos. En lugar de estas referencias a las causas consideradas por la doctrina y algunos organismos internacionales, se consideran los escenarios que producen los desplazamientos.

La violencia de la catástrofe deja en peligro la vida o la sobrevivencia de estas personas, provocando la violación de los derechos humanos y convirtiendo a la escapatoria en la única salida, implicando con esto un desplazamiento forzado.

La inexorable aplicación del Principio de No Devolución es otro de los parámetros que permiten determinar si se trata de un desplazamiento forzado de estas personas afectadas, pues su retorno implicaría un peligro a la vida o sobrevivencia de estas personas.

Otro criterio que permite diferenciar a la figura de los desplazados ambientales forzados es la obligatoriedad de la aplicación del Principio de Asistencia a la Víctima, cuyo contenido se traduce en la protección de las vidas y en brindar alimentos, agua potable, refugios, ropas, asistencia médica y sanitaria.

La segunda hipótesis sostenida en esta tesis es que los desplazados ambientales forzados sufren la violación de sus derechos humanos, lo cual eleva la cuestión a la instancia internacional, demostrando la necesidad de que sea establecido un régimen de protección específico en el derecho internacional.

La violación de los derechos humanos de los desplazados ambientales forzados ha sido reconocida a nivel internacional por diversos organismos de Naciones Unidas, aunque no se puede dejar de observar que algunos de estos reconocimientos hacen referencia a las violaciones de los desplazados de los cambios climáticos, otros a los de los desastres naturales, otros solamente a los desplazados ambientales forzados internos. En tanto que la Corte Europea de Derechos Humanos reconoce estas violaciones a los derechos humanos en relación con los desplazados ambientales forzados. De tal forma, hay otros organismos internacionales que se refieren a la protección de forma integral.

Por otro lado, en 2005, IASC creó las Directrices Operacionales sobre la Protección de las Personas en situaciones de Desastres Naturales, donde son reconocidos cada uno de los derechos humanos de los desplazados de los desastres naturales internos.

Además, el reconocimiento de esta situación de violación de los derechos humanos de estas personas llevó al Secretario General de Naciones Unidas a designar Alto Comisionado de Naciones Unidas para los Derechos Humanos y al Consejo de Derechos Humanos para el tratamiento de los derechos humanos de estas personas, aunque estos organismos únicamente consideran a los derechos humanos de los desplazados ambientales forzados de los cambios 
climáticos. Esto se ha verificado a través del análisis de las Resoluciones emitidas por estos dos organismos internacionales desde 2008, las cuales han sido tratadas en el Capítulo III.

Este conjunto de Resoluciones reconoce la violación de los derechos humanos de estas personas causados por los desastres provocados por los cambios climáticos $\mathrm{y}$, en tal sentido, cabe destacar la Resolución A/HRC/10/61 que realiza un estudio detallado de la violación a estos derechos humanos, considerando el derecho a la vida, a la alimentación, al agua potable, a la vivienda, a los servicios médicos y a la autodeterminación de los pueblos. Además, observa la necesidad de que sean tratados con especial cuidado los grupos vulnerables. Otra Resolución que merece destacarse es la $\mathrm{A} / \mathrm{HRC} / 19 / 10$ de mayo de 2012 , que instituye un relator independiente para tratar esta cuestión específica.

Asimismo, es necesario destacar las recomendaciones sobre la violación sufrida por estas personas desplazadas ambientales forzadas en el Comité de Derechos Económicos, Sociales y Culturales de ECOSOC. En tal sentido, la Observación $\mathrm{N}^{0} 15$ sobre el derecho al agua, establece la obligación de los Estados Partes de asegurar este derecho a las personas que están en una emergencia o desastres naturales. La observación 12 de ese Comité asegura el derecho a los alimentos a estos afectados de forma particular.

También, se observa que la Corte Europea de Derechos Humanos, a través de sus decisiones, ha reconocido estas violaciones, aunque de forma más integral, considerando la relación entre los derechos humanos y la degradación ambiental. Una de las decisiones más significativas ha sido el juzgamiento de Oneryildez contra Turquía, donde fueron reconocidas las violaciones al derecho a la vida causadas por la degradación ambiental.

Igualmente, la Comisión Interamericana de Derechos Humanos, a través de sus decisiones, también ha afirmado estas violaciones. Uno de los casos más significativos ha sido el de los Yanomami versus Brasil, donde fueron reconocidas las violaciones a los derechos humanos de este pueblo indígena.

Además, estas violaciones han sido reconocidas por ACNUR y por los Principios NANSEN.

Las propuestas de la doctrina tratadas en el Capítulo $\mathrm{V}$ hacen referencia a la protección de los derechos humanos de los desplazados ambientales forzados.

De tal forma, cabe concluir que ha sido reconocida a nivel internacional la violación de los derechos humanos de los desplazados ambientales forzados, producida por la violencia provocada por el desastre o la degradación ambiental. Consecuentemente, queda justificada la necesidad de protección en el derecho internacional de los desplazados ambientales forzados. 
Por otro lado, es necesario observar la violación de los derechos humanos de los desplazados ambientales forzados que puede ocurrir durante todo el proceso del desplazamiento. Aunque esto podría ser evitado si existieran los mecanismos adecuados tanto de los Estados como de los organismos internacionales y si hubiera un régimen internacional específico de protección y un organismo internacional previamente designado para asumir la responsabilidad ante estas personas.

Durante el desastre o la degradación ambiental, lo más importante es que los organismos internacionales protejan la vida de esas personas, ante todo. Esto, también, debe ser considerado cuando se realiza la evacuación de las personas en medio del desastre o degradación ambiental grave. Además, se debe brindar atención médica para aquellas personas que han sufrido daños corporales a consecuencia del desastre, o que sufren enfermedades. También, precisa aplicarse el Principio de Asistencia a la Víctima, garantizando alimentos, agua potable, ropas, refugio y salud.

Después de la evacuación, se produce el traslado a un lugar provisorio, el cual podría ser un campo de refugiados. Aquí, también debe ser asegurado el Principio de Asistencia a la Víctima, la No Discriminación, brindando principal protección a los grupos vulnerables como niños y ancianos separados de las familias, mujeres, personas con discapacidades, comunidades tradicionales.

Posteriormente, los organismos internacionales precisan brindar soluciones permanentes como facilitarles una vivienda digna donde puedan desarrollar su vida familiar, sus relaciones personales y su intimidad. La vivienda debe ser adecuada a las condiciones de la familia, y además precisa contar con agua potable y servicios sanitarios. De tal modo, que se posibilite que la familia consiga alcanzar un nivel de seguridad. Además, precisa ser asegurada la unidad de familia como ha sido observado en el Capítulo III.

Los organismos internacionales y, especialmente, los Estados deben posibilitar que las familias o personas encuentren los medios de sobrevivencia, como trabajos para que puedan salir de la etapa de auxilio social. Aunque hasta que esto no ocurra, regirá el Principio de Asistencia a la Víctima (alimentos, agua potable, salud, refugio, vestimenta).

Los Estados receptores, así como los Estados de origen (en el caso de los desplazados forzados que permanecen en sus países) necesitan brindar las documentaciones necesarias para estas personas que han perdido todo en medio del desastre.

Estas personas precisan poder acceder a los servicios médicos de salud gratuitos. Especialmente, es necesario que se les brinde asistencia psicológica, pues el desastre deja a las 
personas en estado de shock, y la posterior etapa de pérdida total hasta de sus familiares hace que estas personas queden quebradas psicológicamente.

Es importante que sea resguardado el derecho a la seguridad física y psíquica de las personas. Por otro lado, también es preciso garantizar los derechos al ejercicio de su religión, a la educación, a sus costumbres y a su cultura.

Todas las etapas deben estar regidas por los Principios de vida, igualdad y libertad, de los cuales son fundamentos de los derechos humanos.

En la etapa final, es necesario asegurar al desplazado ambiental forzado la integración a la sociedad nueva en la que vive, o a otra donde él pretenda establecerse o el retorno a su país, asegurándoles todos los derechos humanos enunciados anteriormente. Es imprescindible que se asegure a estas personas los derechos a sus posesiones y propiedades tanto de sus bienes muebles como inmuebles.

En la medida en que el proceso se desarrolle de este modo, los desplazados ambientales forzados conseguirán alcanzar la integridad física y especialmente psíquica, su identidad, y de ese modo será asegurada la dignidad humana.

La tercera hipótesis consiste en afirmar que la causa de la falta de interés de la comunidad internacional en relación con establecer un régimen que asegure la protección de los derechos de los desplazados ambientales forzados reside en que los que más van a precisarlo son aquellos que viven en los países con mayores poblaciones pobres o los que viven en países menos adelantados o en desarrollado. Además, cabe señalarse que la voluntad de los países desarrollados que es contraria a brindar la protección a los desplazados ambientales forzados transfronterizos, como queda en evidencia.

La demostración de esta hipótesis ha sido muy difícil, porque ha surgido el problema de definir el criterio de pobreza de los países.

Por otro lado, ha sido necesario utilizar conceptos de la Economía, significando esto un esfuerzo interdisciplinario. En tal sentido, algunos de estos conceptos son: Crecimiento Económico de un país, Producto Bruto Interno, Desarrollo Humano y diferentes Índices de Desarrollo de un país.

Además, otra de las dificultades que fue enfrentada es la relacionada con que algunos de esos Índices demuestran una situación del país que no representa ni la pobreza vivida por su población, ni el nivel de fragilidad institucional de los Estados. Este es el caso de China e India: estos países tienen altos Índices de Crecimiento Económico, los cuales no se traducen en el nivel de riqueza de sus poblaciones, ni en un grado de institucionalización del país para hacer 
frente a los impactos negativos de los desastres o degradación ambiental sufridos por sus poblaciones, como ya ha sido observado en el Capítulo IV.

En primer lugar, cabe observar que cuando los desastres o degradación ambiental se producen en países desarrollados, el auxilio es brindado por el propio Estado nacional, como ha sido observado en el Capítulo IV. Como ejemplos se pueden citar el caso del tsunami y terremoto de Japón en 2011, el terremoto en Chile y el Sandy en Estados Unidos. Todos estos Estados están en la categoría de los países muy desarrollados, y no precisan de la ayuda internacional para hacer frente a la emergencia humanitaria de los desastres ambientales.

Los países menos desarrollados o menos adelantados o con problemas de gobernabilidad o con mayores poblaciones pobres no tienen ni las estructuras institucionales, ni recursos económicos, ni humanos que posibiliten que por sí mismos puedan hacerse cargo de la situación de catástrofe ambiental, precisando indudablemente de la ayuda internacional.

El aporte de la teoría del Ecologismo de los Pobres o Justicia Ambiental ha servido para dar la sustentación conceptual a esta problemática, pues esta teoría introduce la dimensión global de países "no desarrollados", en las palabras de Martínez Allier, sustentando que el crecimiento económico de los países desarrollados produce impactos ambientales negativos que son sufridos por los países más pobres.

Además, esta teoría tuvo que realizar un esfuerzo teórico para identificar la coincidencia de la pobreza de las comunidades afectadas y los lugares donde se producían los impactos ambientales negativos en Estados Unidos. Esto se refería a que los depósitos de residuos tóxicos, la instalación de fábricas con actividades de polución y los basurales eran colocados en los barrios donde vivían comunidades de origen africano, de minorías étnicas, o de menores recursos económicos.

De tal modo, esta teoría tuvo que recurrir al mapeamiento de las regiones o barrios, donde se producían las externalidades del crecimiento económico, llegando a la conclusión de que existiría una coincidencia entre los lugares donde vivían esas comunidades más pobres y los locales donde se producían los impactos ambientales negativos del crecimiento económico. Todo esto se pudo verificar a través de los tres estudios ya citados en el Capítulo IV, los cuales influyeron en que el gobierno de Estados Unidos tuviese que incluir la cuestión en la agenda de la EPA, en 1994. Del análisis de estos tres estudios sobre los mapeamientos surgió la idea de la posibilidad de analizar la relación entre los desplazamientos ambientales forzados, la localización de estos desplazamientos y el nivel de pobreza de las poblaciones de los países que sufrían los desastres o degradación ambiental. 
Es necesario observar que, sobre la relación entre la pobreza y los países afectados por los desplazamientos ambientales forzados, se han considerados los países con grandes poblaciones sumergidas en la pobreza. La herramienta utilizada para la demostración de esta hipótesis es el mapa de la pobreza del Banco Mundial, donde es medido el nivel de pobreza de las poblaciones de los países, considerando aquellas poblaciones que viven con hasta 3,10 dólares por día.

Además, otra variable que es preciso contemplar es que, en algunos casos, la medición del nivel de pobreza de las poblaciones que viven con hasta de 3,10 dólares por día de estos Estados afectados no corresponden al mismo año, dependiendo esto último del año en el que se han sido recibidos los datos, aunque se ha tratado de considerar los datos referentes a los años 2010, 2011 y 2012, debido a que este es el período estudiado. De todos modos, esta herramienta utilizada sirve para brindar una idea al respecto.

Por otro lado, es importante tener en cuenta que hay países que no figuran en el Mapa de la pobreza, especialmente los Pequeños Estados Insulares en Desarrollo.

En este análisis de los desplazamientos ambientales forzados no se diferencia entre los desplazamientos internos y los externos, pues como ha sido justificado anteriormente, lo que prevalece es un concepto unificado de los desplazados ambientales forzados.

Se puede verificar que hay dos tipos de catástrofes ambientales: los desastres repentinos y los procesos graduales de degradación.

En primer lugar, se han examinado los países que sufren desplazamientos ambientales forzados de más de 200.000 personas, siendo que no se trata de Pequeños Estados Insulares en Desarrollo. En relación con estos últimos, se han considerado los años 2010, 2011 y 2012.

Es preciso establecer la determinación de la coincidencia entre los lugares donde se producen los desplazamientos ambientales forzados y la pobreza. En este último sentido, son considerados los países con grandes poblaciones de pobres. Se ha utilizado el Mapa de la pobreza del Banco Mundial para la especificación del nivel de la pobreza de las poblaciones de estos países. También, ha sido definida como línea de la pobreza, aquellas personas que viven con hasta 3,10 por día, como ya ha sido mencionado.

Específicamente, se puede observar que algunos de estos países aparecen desplazados por los desastres, recurrentemente en el transcurso de los años analizados. Los Estados más afectados son Paquistán, Filipinas, Bangladesh, Myanmar, Haití, Indonesia, Sri Lanka, Nigeria, Chad, Níger, Sudán del Sur, China e India. 
Como se ha analizado, existe la contradicción en relación con India y China, que son países que tienen altos crecimientos económicos, aunque, por otro lado, tienen grandes partes de sus poblaciones sumergidas en la pobreza.

En el Capítulo IV, fueron establecidos los niveles de pobreza de las poblaciones de los países afectados. Aquí cabe mencionarlos.

En el año 2010, estos países con más de 200.000 desplazados ambientales forzados fueron: China, Paquistán, Chile, Haití, Colombia, Tailandia, India, México, Nigeria, Bangladesh, Filipinas, Indonesia, Benín, Vietnam y Níger.

En el año 2011, los países afectados con más de 200.000 desplazados ambientales forzados fueron: China, India, Filipinas, Tailandia, Bangladesh, Paquistán, Vietnam, Camboya, Angola, Sri Lanka, México, Turquía y Japón.

En el año 2012, los países que sufrieron más de 200.000 desplazados ambientales forzados fueron: India, Nigeria, China, Filipinas, Paquistán, Estados Unidos, Bangladesh, Níger, Chad, Sudán del Sur, Japón y Corea del Norte. También, puede ser incluida Madagascar, ya que tuvo 190.000 desplazados ambientales forzados.

China es uno de los países con mayor cantidad de pobres, lo cual equivale a 257 millones de pobres que viven con hasta 3,10 dólares. La situación de India es más grave, pues tiene 731 millones de personas pobres que viven 3,10 dólares, representando el 58\% de los habitantes.

Paquistán tiene $44 \%$ bajo el nivel de la pobreza (2011), lo cual se traduce en 77,3 millones de pobres.

Nigeria tiene $77 \%$ de su población que vive con menos de 3,10 dólares por día, que se traduce en 121,9 millones de personas pobres. Bangladesh tiene 57\% de su población bajo la línea de pobreza (2011), esto es 86,1 millones de pobres. Indonesia tiene el $42 \%$ de sus habitantes viviendo con menos de 3,1 dólares por día (103,4 millones de pobres). Níger tiene $82 \%$ de personas bajo el nivel de la pobreza según datos de 2011 (13,9 millones de personas).

Filipinas tiene $38 \%$ de población pobre, lo que significa 36,1 millones de personas (2012), Vietnam tiene $14 \%$ de su población bajo la línea de la pobreza (3,10 dólares por día), lo que significa 12,3 millones de personas. También en el caso de Benín los datos son del año 2011, según los cuales el 76\% de su población vive bajo la línea de pobreza (7,4 millones de pobres).

Camboya tiene el $26 \%$ de sus habitantes que viven con hasta 3,10 dólares por día según los datos de 2011 (3,7 millones de pobres). 
Angola tiene el 77\% de su población bajo la línea de la pobreza (año 2010), lo que se traduce en 14,6 millones de personas.

Sri Lanka tiene el 38\% de pobres que viven con menos de 2,5 dólares por día, significando 7,9 millones de habitantes. Aunque, en este caso, si se amplía la línea de la pobreza para 4 dólares por día, el porcentaje de pobres equivale al 70\% de su población (año 2010).

En el caso de Chad, según los datos disponibles de 2011, el 64\% de su población vive con hasta 3,10 dólares por día, traduciéndose en 8 millones de pobres.

El 93\% de la población de Madagascar vive con hasta 3,10 dólares por día, representando 19,6 millones de pobres.

En relación con Sudán del Sur y Corea del Norte no hay datos disponibles en el Mapa de la pobreza del Banco Mundial.

Por otro lado, se puede concluir que existe una repetición de los desplazados ambientales forzados en los países. La reiteración de estas catástrofes se produce tanto durante el año, como en el transcurso de los años analizados.

De todo esto, se puede examinar que los países con mayores poblaciones que viven con hasta 3,10 dólares por día y afectados con desplazamientos ambientales forzados mayores de 200.000 personas son: China, Paquistán, Chile, Haití, India, Nigeria, Bangladesh, Filipinas, Indonesia, Benín, Vietnam, Níger, Camboya, Angola, Sri Lanka, Chad, Sudán del Sur y Corea del Norte.

La gran mayoría de estos países no han conseguido enfrentar los desplazamientos ambientales forzados, precisando de la ayuda internacional, como se deprende de lo examinado en el Capítulo IV.

Por otro lado, el caso de Turquía es diferente de los anteriores, pues según los datos del Banco Mundial de 2010, este país tiene solamente $8 \%$ de la población que viven con hasta 3,10 dólares.

Además, según estos datos se puede observar que los países afectados por los desplazamientos ambientales forzados y con menores poblaciones que viven con hasta 3,10 dólares por día, son: Tailandia, México, Colombia, Chile, Turquía, Japón y Estados Unidos.

En este sentido, los países con más bajo nivel de pobreza en sus poblaciones son Tailandia y México, siendo que Tailandia tiene 1\% de su población (2012), lo que implica 800.000 de pobres. México tiene un 10\% de su población que vive con menos de 3,10 dólares, lo que significa 12,6 millones de personas. Colombia tiene 16\% de población pobre (2012), lo cual se traduce en 7,6 millones de pobres. En igual sentido, Chile es un país considerado de 
muy alto desarrollo y tiene solamente 3\% de personas bajo el nivel de la pobreza (2011), constituyendo 500.000 personas. Además, es necesario observar que China es uno de los países con mayor crecimiento económico, a pesar de que tiene un gran número de personas sumergidas en los niveles de la pobreza.

La mayoría de estos países han podido hacer frente por sí mismos, con sus recursos institucionales, económicos y humanos, sin precisar de la ayuda internacional, como ha sido analizado en el Capítulo IV.

De tal modo, ha quedado en evidencia la relación positiva entre la imposibilidad de hacer frente a los desastres y los desplazamientos ambientales forzados consecutivos, la vulnerabilidad y pobreza. En sentido contrario, ha sido demostrada la relación positiva entre los países desarrollados, la producción de tales acontecimientos, la mayor adaptación y la respuesta positiva del Estado a tales catástrofes ambientales.

En segundo lugar, ha sido considerada la situación de los Pequeños Estados Insulares en Desarrollo, los cuales padecen un gradual aumento del mar con sus consecuencias y, además, son afectadas por los desastres meteorológicos extremos debido a su ubicación geográfica. Algunos de estos países van a perder sus territorios total o parcialmente, siendo que en los peores casos son las Islas Maldivas, Islas Marshall, Tuvalu y Kiribati. Algunos de estos están clasificados como países en desarrollo. Aunque, en el análisis del Índice del Producto Bruto Interno de estos Estados se deduce que ocupan las peores ubicaciones. En tal sentido, de un total de 192 países analizados, Maldivas ocupa el lugar 165, las Islas Marshall está en la posición 190, Kiribati en la 191 y Tuvalu se encuentra en el peor puesto de la escala, 192. Los impactos ambientales negativos graduales son muy severos como ya ha sido considerado en el Capítulo IV, pues afectan la vida y la subsistencia de los habitantes de estos países.

Todo este escenario repercute en la vida de las personas, las cuales en la gran mayoría están formadas por comunidades tradicionales. Estos afectados tienen sus medios de sobrevivencia dependientes de la naturaleza, y la pérdida de esta incide en la vida de estas comunidades. Además, lo que agrava la situación de estos pueblos es que sus economías son pequeñas y dependientes del exterior, también se trata de economías de sobrevivencia en los casos de las comunidades tradicionales. Otra característica que empeora la cuestión es que sus recursos naturales y territorios son limitados. Además, tienen poblaciones pequeñas.

Estos países se han unido en la Alianza de Pequeños Estados Insulares en Desarrollo como mecanismo para hacer oír sus voces en el entorno de la comunidad internacional para 
hacer frente a los desastres y situaciones de emergencia, aunque muy poco se ha logrado en este sentido.

Los Estados Miembros de la Alianza de los Pequeños Estados Insulares en Desarrollo son: Antigua y Barbuda, Bahamas, Barbados, Belice, Cape Verde, Comoros, Cook Islands, Cuba, Dominica, República Dominicana, Fiji, Federated States of Micronesia, Grenada, Guinea-Bissau, Guyana, Haití, Jamaica, Kiribati, Maldivas, Islas Marshall, Mauritius, Nauru, Niue, Palau, Papua New Guinea, Samoa, Singapur, Seychelles, Santo Tomé y Principe, Solomon Islands, St. Kitts and Nevis, St. Lucia, St. Vincent and the Grenadines, Suriname, Timor Oriental, Tonga, Trinidad y Tobago, Tuvalu y Vanuatu.

Según el Índice de los países Menos Adelantados son: Comoros, Guinea Bissau, Haití, Kiribati, Santo Tomé y Príncipe, Salomon Islands, Timor Oriental, Tuvalú y Vanuatu.

Los países con Déficit Alimentario son Comoros, Cuba, Guinea Bissau, Haití, Kiribati, Maldivas, Papua Nueva Guinea, Samoa, Saint Tomé y Príncipe, Islas Solomon, Tuvalu y Vanualu.

Todos estos países insulares en desarrollo ocupan las posiciones más bajas en el Índice de PBI, lo que demuestra que son Estados con menor repercusión en el concierto de los países.

De tal forma, queda demostrada la tercera hipótesis sobre la coincidencia entre la localización de los desplazamientos ambientales forzados y los países con mayores poblaciones pobres, tanto de los Pequeños Estados Insulares como en los otros países considerados.

De ese modo, la ausencia de respuesta de los organismos internacionales a este problema concuerda con que los países con grandes poblaciones pobres o países menos desarrollados o menos adelantados o con problemas de instituciones frágiles han sido los más afectados por los desplazamientos ambientales forzados, y son los que más precisan de la ayuda internacional.

Consecuentemente, se desprende la coincidencia entre la localización de los mayores desplazamientos ambientales forzados, los países con mayores poblaciones de pobres, y la ausencia de regulación internacional para proteger a los desplazados ambientales forzados, quedando demostrada la hipótesis establecida sobre la causa de la falta de regulación internacional señalada anteriormente.

Además, diversas instancias internacionales han reconocido que los más afectados son los países en desarrollo, o menos desarrollados o menos adelantados o con instituciones más frágiles o con mayores poblaciones pobres.

El Informe del Panel Intergubernamental de Expertos, Técnicos y Científicos para los Cambios Climáticos de UNFCCC ha resaltado este problema, reconociendo que los países en 
desarrollo o menos desarrollados o menos adelantados serían los que tendrían que hacer frente a los desastres naturales. Por otro lado, el Consejo de Derechos Humanos de Naciones Unidas y el Alto Comisionado de Naciones Unidas para los Derechos Humanos se han expresado en el mismo sentido, llamando la atención acerca de que los que más sufrirán con los impactos ambientales negativos son los países en desarrollo. Por otro lado, gran parte de la doctrina apoya estas afirmaciones.

La cuarta hipótesis presentada en esta tesis es que ACNUR es el organismo más apto para asumir la protección de los desplazados ambientales forzados externos.

Se puede observar que ACNUR es el organismo cuyo mandato es el más específico y más a fin a la protección de los desplazados ambientales forzados que el de otros organismos internacionales, porque desde 1951, ha venido cuidando de los refugiados estatutarios y de los de hecho. De tal modo, ha demostrado tener una amplia e indiscutible experiencia en esa área, a lo largo de los años.

Además, se puede verificar que desde el año 2007, ACNUR ha manifestado su interés en hacerse cargo de los desplazados ambientales forzados, como se desprende del análisis de las declaraciones del Alto Comisionado, así como de las diversas actuaciones en este sentido tales como la actuación de ACNUR en el grupo de trabajo creado por IASC en 2008, donde junto con OIM trataron la problemática de los desplazamientos forzados y los cambios climáticos con vistas a la presentación en la Conferencia de UNFCCC de Cancún en 2010.

En el mismo sentido, las reuniones preparadas en 2011 por el Alto Comisionado de Naciones Unidas para los Refugiados, tuvieron la finalidad de incorporar a los desplazados ambientales forzados a su mandato. Por otro lado, la propuesta de IASC de Plan Piloto con duración de un año para que ACNUR asumiese el liderazgo de protección de los desplazados de los desastres.

El apoyo brindado por ACNUR para la realización de la Conferencia NANSEN en finales de 2011, así como el apoyo para la creación de la Iniciativa NANSEN en 2012 demuestran la voluntad de este organismo internacional en relación a la situación de los desplazados ambientales forzados.

Asimismo, la actuación efectiva de ACNUR para proteger y asistir a los desplazados ambientales forzados de los desastres del tsunami de 2004, de Myanmar, de Paquistán, de Sri Lanka, Haití y Filipinas, donde ACNUR actuó “ad hoc” a través del mecanismo de los buenos oficios. 
Además, es necesario considerar en apoyo de esta tesis los establecido en el Principio IX de la Conferencia NANSEN, donde se sostiene que "[...] los Estados, que trabajando en conjunto con ACNUR y otros actores relevantes, podrían desarrollar una guía marco o instrumento a este respecto".

De este modo, lo analizado en esta tesis, especialmente discutido en el Capítulo I y en el Capítulo VI, demuestra que ACNUR es el organismo internacional con mayor capacidad para asumir la responsabilidad sobre los desplazados ambientales forzados.

La siguiente hipótesis sustentada en esta tesis consiste en que la forma de establecer el régimen de protección específico a nivel internacional, así como la designación de ACNUR como organismo responsable por estos afectados, debe ser a través del mecanismo de una Resolución de la Asamblea General de Naciones Unidas.

En primer lugar, es necesario considerar el proceso que dio origen a ACNUR, del cual se desprende la forma en que ACNUR consiguió realizar la adaptación a los nuevos desafíos que se le fueron presentando, examinando solamente el período de tiempo desde su creación hasta el año 1960, como fue analizado en el Capítulo I. Porque el estudio de su Estatuto permite verificar que nació como un organismo transitorio, dependiente y limitado en su actuación y en los recursos financieros asignados. Todo esto hacía que inicialmente y según sus Estatuto, ACNUR tuviese una acción muy restringida.

El análisis del origen y la creación de ACNUR realizado en el Capítulo I, permite verificar las resistencias que tuvo que enfrentar este organismo para su creación y para el diseño de su Estatuto. Estas se refieren principalmente a que algunos países pretendían un organismo absolutamente dependiente de Naciones Unidas, que no tuviera la competencia de solicitar fondos financieros, así como las restricciones a que las competencias de este organismo, las cuales se reducían a que pudiese realizar únicamente acciones de protección y no de asistencia material. En este sentido, las competencias de protección consistían en la tramitación para la admisión de los refugiados en los países. Este último aspecto derivaba tanto de lo establecido en su Estatuto como del escaso financiamiento con el que contaba inicialmente.

La génesis de ACNUR fue un proceso de tensas negociaciones entre los dos polos de poder: de un lado, Estados Unidos y sus países aliados; y del otro, la Unión Soviética y los países socialistas, el cual se desarrolló en el medio de la etapa más tensa de la Guerra Fría. La Unión Soviética era absolutamente contraria a la creación de este organismo, pues consideraba que esta sería una forma de ayudar a los que querían escapar de los países socialistas, mientras 
que Estados Unidos tenía recelos en relación a un organismo internacional que estuviera fuera de su comando.

En este marco histórico surge la creación de ACNUR, con un Estatuto que limitaba su actuación solamente a la protección de los refugiados, temporal porque su duración era de tres años y la continuidad sería decidida por la Asamblea General de Naciones Unidas, y dependiente en su actuación de ECOSOC y de la Asamblea General de Naciones Unidas. Sobre su duración de tres años, según el Estatuto, demostraba la voluntad de los países de que fuese un organismo transitorio. Aunque esta barrera fue vencida gracias a que la Asamblea General de Naciones Unidas ha permitido la continuidad de su existencia hasta nuestros días.

En relación con la cuestión del financiamiento de ACNUR, el cual era inicialmente muy limitado, impidió la realización de actividades que eran propias de su objeto. En 1951, la Fundación Ford realizó un aporte de 3.100 .000 dólares. Por otro lado, en 1954, se creó el Fondo para los Refugiados de Naciones Unidas.

En el período inmediatamente posterior a la creación de ACNUR surgieron determinados grupos de refugiados que tenían que ver con la vocación para la cual había sido creado este organismo, aunque formalmente estaban fuera de su alcance debido a las restricciones establecidas en la definición de los refugiados de la Convención sobre el Estatuto de los Refugiados de 1951. Porque el concepto de refugiados establecía dos limitaciones, una temporal y otra espacial; la primera que remitía solamente a los refugiados de los acontecimientos ocurridos hasta enero de 1951. En relación con la restricción espacial, se refería a los refugiados de Europa, aunque esta última estaba flexibilidad, ya que constaban las dos opciones: originarios de Europa o de otros países, siendo que cada país al firmar el tratado elegía la opción que le fuera más conveniente.

Por otro lado, la naturaleza consultiva de ACNUR reconocida en su Estatuto limitaba la actuación, pues solamente consideraba que podría dedicarse a la protección de los refugiados, consistiendo esto en la realización de trámites de admisión en los países sin poder brindarles asistencia material.

Los desafíos que se presentaron a ACNUR fueron los refugiados de Hungría que escapaban en 1954 y 1955, los refugiados chinos que huían del régimen comunista en 1953 y 1954, y los refugiados argelinos de 1960, entre otros. Todas estas situaciones correspondían a eventos posteriores a enero de 1951. 
El apartado 3 del Estatuto de ACNUR establecido en la Resolución 428 (v) de la Asamblea de Naciones Unidas del 14 de diciembre de 1950 observa que este organismo adoptará las decisiones de la Asamblea General de Naciones Unidas y de ECOSOC.

Por otro lado, el apartado 9 del mismo Estatuto considera que ACNUR emprenderá cualquier actividad adicional establecida por la Asamblea General de Naciones Unidas. Estas dos disposiciones permitieron que ACNUR pudiera hacer frente a estos desafíos que estaban fuera de su mandato. Porque para cada una de los problemas enunciados anteriormente, la Asamblea General de Naciones Unidas dictó una Resolución autorizando la actuación de ACNUR en cada una de estas situaciones concretas. En un primer momento, las Resoluciones se refirieron a estas nuevas situaciones concretas, aunque posteriormente, se puede observar del contenido de estas Resoluciones que tratan de forma general esta problemática, estableciendo el mecanismo de los buenos oficios, el cual autorizaba la protección de aquellos refugiados que estuvieran fuera del mandato de ACNUR.

Además, fue modificada la naturaleza consultiva de este organismo, pues esta impedía que realizase actos de asistencia material. Finalmente, en 1959, la Resolución 1388 de la Asamblea de Naciones Unidas estableció que ACNUR contaría con el mecanismo de los buenos oficios y podría proveer asistencia a los refugiados que están fuera de su mandato.

De este modo, el análisis de la creación, así como del período inmediatamente posterior hasta 1960, demuestra que ACNUR ha sido un organismo que enfrentó muchas limitaciones en su actuación inicial, pero a pesar de esto consiguió hacer frente a los nuevos desafíos que se le fueron presentando, demostrando una vocación de servicio flexible y atenta a los problemas de los refugiados.

Por otro lado, y ya más cerca de nuestros días, el mecanismo establecido en los apartados 3 y 9 del Estatuto de ACNUR posibilitaron la ampliación de sus competencias. Así, estos mecanismos han sido utilizados para permitir que este organismo se haga cargo de los desplazados internos, siendo que ese concepto incluye a los desplazados internos de los desastres, como ya fue observado en el Capítulo VI.

El examen del entramado de las soluciones parciales presentadas por los organismos internacionales para la protección de los desplazados internos de los desastres tanto de los Principios Rectores de los desplazados Internos como la de IASC, detallado anteriormente, deja una evidencia que las vías utilizadas para la creación de todo ese marco jurídico de derecho internacional han sido las Resoluciones de la Asamblea General de Naciones Unidas. 
ACNUR nació como un organismo internacional que únicamente podría proteger a los refugiados definidos en la Convención, y con naturaleza consultiva. Los desafíos que fueron presentándose a ACNUR, hicieron que tuviese que adaptase a esa nueva realidad, para lo cual tuvo que recurrir al mecanismo del apartado 3 y 9 de su Estatuto, donde se establece que las competencias de ACNUR pueden ser ampliadas por resoluciones de la Asamblea General de Naciones Unidas.

Finalmente, todo este estudio permite verificar la hipótesis que afirma que la forma más apropiada para que este organismo pueda asumir ese encargo es a través de los mecanismos previstos en los apartados 3 y 9 de su Estatuto, es decir, por medio de una Resolución de la Asamblea General de Naciones Unidas.

Además, ACNUR es un organismo de Naciones Unidas que fue creado por una Resolución de la Asamblea General de Naciones Unidas, y su Estatuto también fue creado por otra Resolución de la misma naturaleza. Por lo tanto, si fue creado por una Resolución de la Asamblea General de Naciones Unidas, también podrían ser modificadas o ampliadas sus competencias por otra de la misma especie.

Así, se puede concluir que la forma más apropiada para establecer el Régimen Internacional para la protección de los desplazados ambientales es a través de una Resolución de la Asamblea General de Naciones Unidas. De la misma forma, se puede deducir que el mecanismo apropiado para designar a ACNUR como organismo encargado de los desplazados ambientales forzados es una Resolución de la Asamblea General de Naciones Unidas. 


\section{REFERENCIAS BIBLIOGRÁFICAS}

ABRAMOVICH, Victor et al. Protección internacional de refugiados en el sur de Sudamérica. $1^{\circ}$ Ed. Buenos Aires: Remedios de Escalada, UNLa-Universidad Nacional de Lanús, 2012.

ACNUR. Manual de procedimientos y criterios para determinar la condición de refugiado en virtud de la Convención de 1951 y el Protocolo de 1967 sobre el Estatuto de los Refugiados. HCR/IP/4/Rev.1, 1979. Primera publicación en español en 1988, 1992. Disponible en: <http://www.refworld.org/docid/4f5897892.html> acceso 18 de mayo de 2016.

ACNUR. Manual de Procedimientos y Criterios para Determinar La Condición de Refugiado en virtud de la Convención de 1951 y el Protocolo de 1967 sobre el Estatuto de los Refugiados. HCR/IP/4/Spa/Rev.1 diciembre 1992.

ACNUR. La situación de los refugiados en el mundo: Cincuenta años de acción humanitaria. Barcelona: ICARIA Editorial, 2000. Disponible en: $<$ http://www.acnur.org/t3/fileadmin/scripts/doc.php?file=biblioteca/pdf/2004> acceso 3 de septiembre de 2012.

ACNUR. Manual de Reasentamiento del ACNUR. Ginebra: Edición ACNUR, 2004. Disponible $\quad$ en: $\quad<\mathrm{http}: / / \mathrm{www}$.acnur.org/t3/que-hace/solucionesduraderas/reasentamiento/manual-de-reasentamiento-del-acnur/>.

ACNUR. CENTRO DE PROTEÇÃO INTERNACIONAL DE DIREITOS HUMANOS; INSTITUTO MIGRAÇÕES E DIREITOS HUMANOS. Manual de Procedimentos e Critérios para Determinar a Condição de Refugiado: de acordo com a Convenção de 1951 e o Protocolo de 1967 relativos ao Estatuto dos Refugiados. [S.1.] Brasil: ACNUR, 2004. Disponible

en: $<$ http://www.asylumlawdatabase.eu/sites/asylumlawdatabase.eu/files/aldfiles/UNHCR $\% 20 \mathrm{Ha}$ ndbook\%20ES.pdf $>$ acceso 11 de agosto de 2012.

ACNUR, Resumen, la situación de los refugiados en el mundo. Ginebra: Acnur, 2012. 
ACNUR, COMITÉ EJECUTIVO. Conclusiones del Comité Ejecutivo del Programa del ACNUR, 1975-2000. Colección de Instrumentos Jurídicos Internacionales Relativos a Refugiados, Derechos Humanos y Temas Conexos. Tomo IV. México DF: Alto Comisionado de las Naciones Unidas para los Refugiados (ACNUR), Comisión Nacional de los Derechos Humanos (CNDH) y Universidad Iberoamericana, 2002. Disponible en: $<$ http://www.acnur.es/PDF/3065_20120402174630.pdf>.

ACNUR, COMITÉ EJECUTIVO. Conclusiones del Comité Ejecutivo del Programa del ACNUR, 1975-2000. Conclusión No 22 (XXXII) de 1981, Protección de las personas que buscan asilo en situaciones de afluencia en gran escala. En Colección de Instrumentos Jurídicos Internacionales Relativos a Refugiados, Derechos Humanos y Temas Conexos. Tomo IV. México DF: Alto Comisionado de las Naciones Unidas para los Refugiados (ACNUR), Comisión Nacional de los Derechos Humanos (CNDH) y Universidad Iberoamericana, 2002. Disponible en: <http://www.acnur.es/PDF/3065_20120402174630.pdf $>$ acceso 16 de mayo de 2016.

ACNUR, COMITÉ EJECUTIVO. Conclusiones del Comité Ejecutivo del Programa del ACNUR, 1975-2000. Conclusión $N^{\circ} 15$ (XXX) de 1981, Refugiados sin País de Asilo (30 período de sesiones del Comité Ejecutivo), 1979. En Colección de Instrumentos Jurídicos Internacionales Relativos a Refugiados, Derechos Humanos y Temas Conexos. Tomo IV. México DF: Alto Comisionado de las Naciones Unidas para los Refugiados (ACNUR), Comisión Nacional de los Derechos Humanos (CNDH) y Universidad Iberoamericana, 2002. Disponible en: < http://www.acnur.es/PDF/3065_20120402174630.pdf > acceso 16 de mayo de 2016.

ACNUR, COMITE EJECUTIVO. Conclusiones del Comité Ejecutivo del Programa del ACNUR, 1975-2000, Conclusión No 39 (ILIX) de 1981, Las Mujeres Refugiadas y la Protección Internacional. En Colección de Instrumentos Jurídicos Internacionales Relativos a Refugiados, Derechos Humanos y Temas Conexos. Tomo IV. México DF: Alto Comisionado de las Naciones Unidas para los Refugiados (ACNUR), Comisión Nacional de los Derechos Humanos (CNDH) y Universidad Iberoamericana, 2002. Disponible en: $<$ http://www.acnur.es/PDF/3065_20120402174630.pdf > acceso 14 de mayo 2016.

ACNUR, COMITÉ EJECUTIVO. Conclusiones del Comité Ejecutivo del Programa del ACNUR, 1975-2000. Conclusión N 73 (XLIV) Protección de los Refugiados y Violencia Sexual, de 1981. En Colección de Instrumentos Jurídicos Internacionales Relativos a Refugiados, Derechos Humanos y Temas Conexos. Tomo IV. México DF: Alto Comisionado de las Naciones Unidas para los Refugiados (ACNUR), Comisión Nacional de los Derechos Humanos $(\mathrm{CNDH})$ y Universidad Iberoamericana, 2002. Disponible en: $<$ http://www.acnur.es/PDF/3065_20120402174630.pdf> acceso 14 de mayo de 2016. 
ACSELRAD, Henri. Justiça ambiental e construção social do risco. Trabajo presentado en el XIII Encontro da Associação Brasileira de Estudos Populares, Ouro Preto, noviembre, 2002.

ALLIANCE OF SMALL ISLAND STATES. About AOSIS. Disponible en: $<$ http://aosis.org/about/> acceso 10 de agosto de 2014.

ALLIANCE OF SMALL ISLAND STATES. Leaders Declaration, 2014.

AMARAL JUNIOR, Alberto; PERRONE-MOISES, Cláudia (Org.). O cinquentenário da Declaração Universal dos Direitos do Homem. São Paulo: Editora da Universidade de São Paulo, 1999.

AMMER, Margit; BOLTZMANN, Ludwig. Climate change and Human Rights: The Status of Climate Refugees in Europe. Swiss Initiative to Commemorate the 60th Anniversary of the UDHR. Protecting Dignity: An Agenda for Human Rights. Research Project on Climate Change, Austria, junio, 2009. Disponible en: $<$ http://www.udhr60.ch/report/ClimateChangepaper0609.pdf> acceso 16 de julio de 2014.

ANDRADE, José Enrique Fischel. A Política de Proteção dos Refugiados da Organização de Nações Unidas. Sua Gênese no Período Pós-Guerra (1946-1952). Tesis de Doctorado, Universidade de Brasília. Instituto de Relações Internacionais, Brasília, 2006.

AN INDEPENDENT REPORT COMMISSIONED BY THE UNITED NATIONS EMERGENCY RELIEF COORDINATOR \& UNDER-SECRETARY-GENERAL FOR HUMANITARIAN AFFAIRS, OFFICE FOR THE COORDINATION OF HUMANITARIAN AFFAIRS (OCHA). Humanitarian Response Review. Nueva York: Naciones Unidas, agosto, $2005 . \quad$ Disponible en: $<$ https://interagencystandingcommittee.org/system/files/legacy_files/HRR.pdf $>$ 
ANISIMOV, O.A.; VAUGHAN, D.G.; CALLAGHAN, T.V.; FURGAL, C.; MARCHANT, H.; PROWSE, T.D.; VILHJÁLMSSON, H.; WALSH, J.E. Polar regions (Arctic and Antarctic). Climate Change 2007: Impacts, Adaptation and Vulnerability. Contribution of Working Group II to the Fourth Assessment Report of the Intergovernmental Panel on Climate Change. PARRY, M.L.; CANZIANI, O.F.; PALUTIKOF, J.P.; LINDEN, P.J. van der; HANSON, C.E. (Eds.). Cambridge: Cambridge University Press, 2007, p. 653-685.

ARRIAGA LEGARDA, Alicia; PARDO BUENDÍA, Mercedes. Justicia Ambiental. El estado de la cuestión. Revista Internacional de Sociología (RIS), Vol. 69, setiembre-diciembre, 2011, p. 627-648.

ATKINSON, Ian. Assumption of Risk inUnited States Refugee Law. The Virginia Journal of International Law Association, Vol. 49, $\mathrm{N}^{\mathrm{o}}$ 1, 2008, p. 273. Disponible en: $<$ http://www.vjil.org/assets/pdfs/vol49/issue1/49_273-306.pdf $>$ acceso 15 de mayo de 2016.

ALEINIKOFF, Alexander. Protected characteristics and social perceptions: an analysis of the meaning of "membership of a particular social group". Cambridge: Cambridge University Press, junio, 2003. Disponible $<$ http://www.refworld.org/docid/470a33b30.html> acceso 15 de mayo de 2016.

AZORBO, M.; DESCHAMP, B.; LOHSE, S. Earth Wind and Fire. A review of UNHCR's role in recent natural disasters. Ginebra: United Nations High Commissioner For Refugees. Policy Development And Evaluation Service (Pdes), junio, 2010.

BALERA, Wagner (Coord.). Comentários à Declaração Universal dos Direitos do Homem. Brasilia: Fortium Editora, 2008.

BECK, Ulrich. La sociedad del riesgo: hacia una nueva modernidad. Barcelona: Litografia Roses S/A, 2006.

BECK, Ulrich. Liberdade ou capitalismo/Ulrich Beck conversa com Johannes Willms. São Paulo: Editora UNESP, 2003. 
BETTS, Alexander. Forwards a "Soft Law" Framework for the Protección of Vulnerable Irregular Migrants. In 22 Int'l J. Refugee Law. Oxford: Published by Oxford University Press, 2010, p. 209 a 236. Disponible en: <http://ijrl.oxfordjournals.org/content/22/2/209.full.pdf> acceso 20 de abril de 2014.

BIERMANN Frank; BOAS, Ingrid. Preparing for a Warmer World: Towards a Global Governance System to Protect Climate Refugees. In Global Environmental Politics, $N^{\circ} 10$, Amnsterdam, 2007. Disponible en: $<\mathrm{http}: / / \mathrm{www}$.environmentalmigration.iom.int/preparingwarmer-world-towards-global-governance-system-protect-climate-refugees $>$ acceso 15 de febrero de 2014.

BITTAR, Eduardo. Curso de ética jurídica: ética geral e profissional. São Paulo: Saraiva, 2010.

BLACK, Richard. Environmental Refugees: Myth or Reality? New Issues in Refugee Research Working Paper 34. Ginebra: United Nations High Commissioner for Refugees, 2001. Disponible en: <http://www.unhcr.org/3ae6a0d00.pdf> acceso 20 de febrero de 2014.

BOANO, Camillo; ZETTER, Roger; MORRIS, Tim. Environmentally displaced people. Understanding the linkages between environmental change, livelihoods and forced migration. Forced Migration Policy Briefing 1, Refugee Studies Centre, Oxford: University of Oxford, noviembre, 2008.2 Disponible en $<$ http://www.unicef.org/socialpolicy/files/Environmentally_displaces_people.pdf $>$ acceso 10 de abril de 2014.

BOBBIO, Norberto. A era dos direitos. Rio de Janeiro: Editora Campus, 2004.

BORRAS PENTINAT, Susana. Refugiados ambientales: el nuevo desafío del derecho internacional del medio ambiente. In Rev. derecho (Valdivia) [online]. 2006, Vol.19, No 2, p. 85-108. Disponible en: <http://dx.doi.org/10.4067/S0718-09502006000200004> acceso 10 de junio de 2014. 
BYRAVAN, Sujatha; RAJAN, Sudhir Chella. Providing New Homes for Climate Change Exiles. Climate Policy, Vol. 6, p. 247-252, 2006. Disponible en: $<$ http://ssrn.com/abstract=950329>. Acceso el 19 de junio de 2014.

CABRÉ, Àlex Peñalver. Aproximación al marco jurídico del derecho humano al agua: una perspectiva desde el derecho interno. Disponible en: $<$ http://eva.universidad.edu.uy/pluginfile.php/212347/mod_resource/content/0/Unidad_3/Pagi nas_de_AguaPotableySaneamiento.pdf> acceso 20 de julio de 2014.

CANÇADO TRINDADE, Antonio A. Derecho Internacional de los Refugiados y Derecho Internacional de los Derechos Humanos: aproximaciones y convergencias. Disponible en: $<$ http://www.revistaei.uchile.cl/index.php/REI/article/viewFile/15126/29127>. Acceso en 30 de agosto de 2014

CASTLES, Stephen. Environmental change and forced migration: making sense of the debate. New issues in refugee research. Working Paper $N^{0} 70$. Refugees Studies Centre. Oxford: University of Oxford, 2002. Disponible en: <www.unhcr.ch $>$ acceso 14 de marzo de 2014.

CLARKE, Meghan Elisabeth. Climate Change and Human Rights: A Case Study of the Canadian Inuit and Global Warming in the Canadian Arctic. Tesis de Master of Laws (LLM). Graduate Department of the Faculty of Law, University of Toronto, Toronto, 2010. Disponible

en: $\mathrm{j}<\mathrm{https}$ ://tspace.library.utoronto.ca/bitstream/1807/25457/1/Clarke_Meghan_E_201011_LLM _thesis.pdf $>$ acceso 10 de julio de 2014 .

CLARO, Carolina de Abreu Batista. Refugiados Ambientais: mudanças climáticas, migrações internacionais e governança global. Tesis de Maestría, Centro de Desenvolvimento Sustentável, Universidade de Brasília, Brasília, 2012.

CNN MEXICO. La Cruz Roja dice que 2010 es el año más caótico en desastres naturales, 8 de octubre de 2010. Disponible en: <http://mexico.cnn.com/nacional/2010/10/08/la-cruzroja-dice-que-2010-es-el-ano-mas-caotico-en-desastres-naturales $>$ acceso 10 de octubre de 2014. 
CNUMAD, Conferencia de las Naciones Unidas sobre el Medio Ambiente y el Desarrollo. Disponible en: $<$ http://www.un.org/spanish/conferences/wssd/unced.html $>$ acceso 6 de abril de 2016.

COHEN, Roberta. Lessons Learned from the Development of the Guiding Principles on Internal Displacement. Georgetown University. Institute of Estudy for International Migration. Working Paper, octubre, 2013.

COHEN, Roberta; MEGAN, Bradley. Disasters and Displacement: Gaps in Protection. In Journal of International Legal Studies, Vol. 1, 2010.

COMPARATO, Fabio Konder. Afirmação histórica dos Direitos Humanos. São Paulo: Editora Saraiva, 2011.

CONFERENCIA DE PEQUEÑOS ESTADOS INSULARES EN DESARRROLLO. Male' Declaration on the Human Dimension of Global Climate Change. Male', Maldivas, 14 de noviembre de 2007.20 Disponible $<$ http://www.ciel.org/Publications/Male_Declaration_Nov07.pdf $>$ acceso 7 de julio de 2014.

CONFERENCIA DIPLOMÁTICA PARA LA ADOPCIÓN DE UNA CONVENCIÓN SOBRE MUNICIONES EN RACIMO. Convención sobre Municiones en Racimo. Dublín, 19-30 de mayo de 2008. Disponible en: $<$ https://www.icrc.org/spa/assets/files/other/icrc_003_0961.pdf $>$ acceso 23 de diciembre de 2015.

COP (CANCUN). The Cancun Agreements: Outcome of the work of the Ad Hoc Working Group on Long-Term Cooperative Action under the Convention, Decision 1/CP.16. Report of the Conference of the Parties on its sixteenth session, Addendum, Part Two: Action taken by the Conference of the Parties, FCCC/CP/2010/7/Add.1, 15 de marzo de 2011, parágrafo 14 (f). Disponible en: <http://unfccc.int/resource/docs/2010/cop16/eng/07a01.pdf $>$ acceso 7 de febrero de 2014. 
CORTE EUROPEA DE DERECHOS HUMANOS. Case of Öneryildiz v. Turkey. Judgement, 41 EHRR, 30 de noviembre de 2004. Disponible en: $<$ http://swarb.co.uk/oneryildiz-v-turkey-echr-30-nov-2004/> Acceso: 12 de junio de 2014.

CORTE EUROPEA DE DERECHOS HUMANOS. Budayeva And Others v Russia (App no 15339/02) \& Ors (20 March 2008). 37 Centre for Minority Rights Development on behalf of Endorois Community v. Kenya, Comm. 276/2003, mayo, 2009.

CRIDEAU (CENTRE DE RECHERCHE INTERDISCIPLINAIRE EN DROIT DE L'ENVIRONNEMENT, DE L'AMÉNAGEMENT ET DE L'URBANISME) E PELO CRDP (CENTRE DE RECHERCHE SUR LES DROITS DE LA PERSONNE). Draft Convention on the International Status of Environmentally Displaced Persons. Mayo de 2010. Disponible en: <http://intergenlaw.com/wp-content/uploads/2015/02/Draft-Convention-onthe-International-Status-on-environmentally-displaced-persons-third-version.pdf $>$ acceso 5 de abril de 2014.

CUADRA, Héctor. Protección Internacional de los Derechos Humanos. Instituto de Investigaciones Jurídicas de la UNAM, México DF, 1970.

CUADRADO QUESADA, Gabriela. El reconocimiento del derecho a un medio ambiente sano en el derecho internacional y en Costa Rica. In Revista Cejil Debates sobre Derechos Humanos y el Sistema Interamericano, Año IV, $N^{0}$ 5, diciembre, 2009, p. 104-113. Disponible en: $<$ http://www.corteidh.or.cr/tablas/r24270.pdf $>$ acceso 6 de abril de 2016.

CUNHA FERRAZ, Anna; BITTAR, Eduardo C.B. (Orgs.). Direitos Humanos Fundamentais, Positivação e Concretização. Osasco: Edifieo, 2006.

DALLARI, Dalmo de Abreu. Elementos de teoria geral do Estado. São Paulo: Saraiva, 2003. 
DEPARTAMENTO NACIONAL DE ESTADISTICA (DANE) del Gobierno de Colombia. Reporte final de áreas afectadas por inundaciones 2010-2011, 30 de agosto de 2011, p. 4. Disponible

$<$ https://www.dane.gov.co/files/noticias/Reunidos_presentacion_final_areas.pdf $>$ acceso $10 \mathrm{de}$ octubre de 2014.

DUM, Olivia; GEMENME, François. Defining "Environmental Migration". In Forced Migration Revieu, $\mathrm{N}^{\mathrm{o}} 31,2008, \quad$ p. 10. Disponible en: $<$ https://www.fmreview.org/en/FMRpdfs/FMR31/10-11.pdf > Acceso: 20 de marzo de 2014.

DOCHERTY, Bonnie; GIANNINI, Tyler. Confronting a Rising Tide: A Proposal for a Convention on Climate Change Refugees. In Harvard Environmental Law Review. Harvard School, julio, 2009, p. 349. Disponible en:

$<$ http://www.law.harvard.edu/students/orgs/elr/vol33_2/Docherty\%20Giannini.pdf $>$ acceso 15 de marzo de 2014.

DUONG, Tiffany T.V. When Islands Drown: The Plight of "Climate Change Refugees" and Recourse to International Human Rights Law. In University of Pennsylvania Journal of International Law, Vol. 31, $\mathrm{N}^{\mathrm{o}}$ 4, Summer, 2010, 2014. Disponible en: $<$ https://www.law.upenn.edu/journals/jil/articles/volume31/issue4/Duong31U.Pa.J.Int\%271L. $1239 \% 282010 \% 29$.pdf $>$ acceso 20 de marzo de 2015.

EL-HINNAWI, Essam. Environmental Refugees. Nairobi: United Nations Environment Programme, 1985.

ELIE, Jérôme B. (Coord.). The UNHCR and the Cold War: a Documented Reflection on the UN Refugee Agency's Activities in the Bipolar Context. A working-paper of "The UNHCR and the Global Cold War, 1971-1984". A joint UNHCR/GIIS/GCSP project with funding from the GIAN. Junio, 2007. Disponible en: $<$ http://hei.unige.ch/sections/hp/UNHCRProject.htm> acceso 5 de agosto de 2015. 
ENTWISLE, Hannah. The world turned upside down. A review of protection risks and UNHCR's role in natural disasters. United Nations High Commissioner For Refugees. Policy Development And Evaluation Service (PDES) y Division Of International Protection (DIP), marzo, 2013.

EXECUTIVE COMMITTEE OF THE HIGH COMMISSIONER'S PROGRAMME STANDING COMMITTEE. 52nd meeting. Draft report of the 51st meeting of the Standing Committee (21-23 June 2011). EC/62/SC/CRP.25, 16 de septiembre de 2011.

FAO. Índice de Déficit Alimentario. Disponible en: $<$ http://www.fao.org/docrep/meeting/008/j2993s/j2993s01.pdf> acceso 8 de abril de 2014.

FERREIRA FILHO, Manoel Gonçalves. Princípios do direito constitucional: o estado da questão no início do século XXI, em face do direito comparado e, particularmente, do direito brasileiro. São Paulo: Saravia, 2015.

FERRIS, Elizabeth. Protecting Civilians in Disasters and Conflicts, Brookings-Bern Project on Internal Displacement, Policy Brief, marzo de 2011.

FERRIS, Elizabeth; PAUL, Diane. Protection in Natural disasters. Paper submitted to Protecting people in conflict and crisis: Responding to the challenges of a changing world, The Refugee Studies Centre at the University of Oxford (RSC), en colaboración con Humanitarian Policy Group at the Overseas Development Institute (HPG), Harris Manchester College \& Queen Elizabeth House, University of Oxford, septiembre de 2009. Disponible en: $<$ http://www.brookings.edu/research/papers/2009/09/22-natural-disasters-ferris $>$ acceso $10 \mathrm{de}$ marzo de 2014.

FERRIS, Elizabeth; PETZ, Daniel. The year that shook the rich: a review of natural disasters in 2011. Londres: The Brookings Institution/London School of Economics. Project on Internal Displacement, 2012. 
FRANCO, Leonardo; NORIEGA, Jorge Santistevan de. La contribución del Proceso de Cartagena al desarrollo del Derecho Internacional de Refugiados en América Latina. In ACNUR. La Protección de los refugiados en América. Quito: Mantis Comunicación, diciembre, 2011, p. $141 . \quad$ Disponible en: $<$ http://www.acnur.es/PDF/8340_20120402180124.pdf> acceso 12 de agosto de 2012.

GALINDO VÉLEZ, Francisco. Consideraciones sobre la determinación de la condición de refugiado. In NAMIHAS, Sandra. (Coord.). Derecho Internacional de los Refugiados. Pontificia Universidad Católica del Perú. Instituto de Estudios Internacionales, 2001, p. 59.

GEORGETOWN UNIVERSITY'S INSTITUTE FOR THE STUDY OF INTERNATIONAL MIGRATION (ISIM); UNITED NATIONS HIGH COMMISSIONER FOR REFUGEES (UNHCR); THE BROOKINGS-LSE PROJECT ON INTERNAL DISPLACEMENT (BROOKINGS INSTITUTION). Planned relocation, disasters and climate change: consolidating good practices and preparing for the future report. San Remo, 12-14 de marzo de 2014. Disponible

en:

$<$ http://www.brookings.edu/ /media/research/files/papers/2014/03/14-planned-relocationsclimate-change/planned-relocations-disaste $>$ acceso 17 de diciembre de 2015.

GIBB, Christine; FORD, James. Should the United Nations Framework Convention on Climate Change Recognize Climate Migrants? 7 ENVTL. RES. LETT. 1, 4, 2012. Disponible en: < http://iopscience.iop.org/article/10.1088/1748-9326/7/4/045601/pdf>.

GUTERRES, António. Five 'mega-trends' -including population growth, urbanization, climate change- make contemporary displacement increasingly complex, third committee told. Third Committee, General Assembly GA/SHC/3964. Nueva York: United Nations, 3 de noviembre de 2009. Disponible en: <http://www.un.org/press/en/2009/gashc3964.doc.htm> acceso 2 de enero de 2014.

GUTERRES, António. Millions Uprooted, Saving Refugees and the displaced. In Foreign Affairs, septiembre-octubre 2008. Disponible en: <http://www.cfr.org/humanitarianintervention/millions-uprooted/p17038> acceso 15 de enero de 2014. 
HODGKINSON, David et al. 'The Hour When the Ship Comes In': A Convention for Persons Displaced by Climate Change, 36 MONASH UNIV. L. REV. 69, 2010. Disponible en: <http://www.ccdpconvention.com/documents/CCDP_Convention_Summary.pdf $>$ acceso 25 de mayo de 2014.

HODGKINSON, David; BURTON, Tess. Towards a Convention for Persons Displaced by Climate Change. Seminar presentation at the Grantham Research Institute on Climate Change, the London School of Economics, 6 de marzo de 2009. Disponible en: $<$ http://www.ccdpconvention.com/documents/DH\%20TB\%20LSE\%20presentation.pdf $>$ acceso 15 de mayo de 2014.

HODGKINSON, David; YOUNG, Lucy. "In the face of looming catastrophe": a Convention for Climate Change Displaced Persons, 2009, p. 7. Disponible en: $<$ http://www.ccdpconvention.com/documents/A\%20Convention $\% 20$ for $\% 20$ Climate $\% 20$ Chan ge\%20Displaced\%20Persons\%20\%28January\%202012\%29.pdf> acceso 20 de febrero de 2014.

HALL, Nina. Climate change and institutional change in UNHCR. Conference Paper for UNU-EHS Summer Academy on Protecting Environmental Migration: Creating New Policy and Institutional Frameworks. Department of International Relations. University of Oxford, 2531 de julio de 2010.

HALL, Nina. Moving beyond Its Mandate? UNHCR and Climate Change Displacement. 4 J. of Int'l Orgs Studies, 2013. Disponible en: <http://journal-iostudies.org/sites/journaliostudies.org/files/JIOSfinal_7_3.pdf> acceso 5 de enero de 2014.

HULME, M. 'Commentary: Climate Refugees: Cause for a New Agreement?' In Environment, noviembre-diciembre, 2008.2 Disponible $<$ http://www.environmentmagazine.org/Archives/Back\%20Issues/NovemberDecember\%202008/hulme-full.html> 
HUMAN RIGHTS COMMITTEE. General Comment 6, Article 6 (Sixteenth session, 1982). Compilation of General Comments and General Recommendations Adopted by Human Rights Treaty Bodies, U.N. Doc. HRI/GEN/1/Rev.1 at 6 (1994), In UN Doc./A/37/40, 30 de abril de 1982. Disponible en: $<$ www.unhchr.ch/tbs/doc.nsf/(Symbol)/84ab9690ccd81fc7c12563ed0046fae3?Opendocument $>$ acceso 10 de julio de 2014 .

HUMAN RIGHTS COUNCIL. Resolution 7/23 on Human Rights and Climate Change, Res. 7/23, UN Doc. A/HRC/7/78, 28 de marzo de 2008.

HUMAN RIGHTS COUNCIL. Resolution 10/4 on Human Rights and Climate Change, Res. 10/4, UN Doc. A/HRC/10/L.11; A/HRC/7/11, 31 de marzo de 2009.

HUMAN RIGHTS COUNCIL. Resolution 19/10, Human Rights and the Environment, UN Doc. A/HRC/19/10, 22 de marzo de 2012.

HUMAN RIGTH WATCH. Briefing to the 60th Session of the UN Commission on Human Rights, 29 de enero de 2004. Disponible en: $<$ http://www.hrw.org/news/2004/01/28/tortureand-non-refoulement $>$ acceso 15 de febrero de 2014.

HUGO, Graeme. Climate Change and migration some lessons from existing knowledge of migration in southeast Asia. Cap. 4. En LORRAINE, Elliott. Climate Change, Migration and Human Security in Southeast Asia. S. Rajaratnam School of International Studies. Booksmith: $\quad$ Singapur, 2012. Disponible en: $<$ http://reliefweb.int/sites/reliefweb.int/files/resources/Monograph24.pdf $>$ acceso 15 de febrero de 2014.

INICIATIVA NANSEN. Human mobility and climate change adaptation: UN University and Nansen Initiative present new policy brief, 5 de junio de 2014a. Disponible en: $<$ https://www.nanseninitiative.org/human-mobility-and-climate-change-adaptation-ununiversity-and-nansen-initiative-present-new-policy-brief/> acceso 14 de octubre de 2015. 
INICIATIVA NANSEN. Linking human mobility, disasters and disaster risk reduction, octubre, 2014b. Disponible en: <http://www.unhcr.org/5448c8269.html>.

INTER-AGENCY STANDING COMMITTEE (IASC). Frequently Asked Questions on International Humanitarian, Human Rights and Refugee Law in the Context of Armed Conflict, marzo, 2004. Disponible $<$ http://www.refworld.org/docid/4a54bc03d.html> acceso 13 de diciembre de 2013.

INTER-AGENCY STANDING COMMITTEE (IASC). Guidance Note On Using The Cluster Approach To Strengthen Humanitarian Response, 24 de noviembre de 2006a. Disponible en: <http://www.refworld.org/pdfid/460a8ccc2.pdf $>$ acceso 20 de diciembre de 2013.

INTER-AGENCY STANDING COMMITTEE (IASC). Operational Guidelines on Human Rights and Natural Disasters. Protecting persons affected by natural disasters. Washington: Brookings-Bern Project on Internal Displacement, 2006b.

INTER-AGENCY STANDING COMMITTEE (IASC). Climate Change, Migration and Displacement: Who Will Be Affected? 31 de octubre de 2008. Disponible en:

$<$ http://unfccc.int/resource/docs/2008/smsn/igo/022.pdf > acceso 4 de marzo de 2014.

INTER-AGENCY STANDING COMMITTEE (IASC). Directrices operacionales del IASC sobre la protección de las personas en situaciones de desastres naturales. Proyecto de Brookings-Bern sobre Desplazamiento Interno, mayo de 2011a. Disponible en: $<$ http://www.hewsweb.org/floods/flood.asp?FID=198379> acceso 20 de julio de 2014.

INTER-AGENCY STANDING COMMITTEE (IASC). 80th IASC Working Group meeting. Working Group Operationalizingthe IASC Principals Transformative Agenda. Nueva York, 16-18 de noviembre de 2011b. Disponible en: $<$ http://www.humanitarianinfo.org/iasc/downloaddoc.aspx\%3FdocID\%3D6073\%26type\%3D pdf>. 
INTER-AGENCY STANDING COMMITTEE (IASC). IASC transformative agenda 2012. 2012.

INTER-AMERICAN COMMISSION ON HUMAN RIGHTS. Case of Yanomami Indians, Judgement, 1985. Case 7615 (Brazil), Inter-Am. C.H.R., OEA/Ser.L/V/II.66 doc. 10 rev. 1985. Disponible en: <www.cidh.org/annualrep/84.85eng/Brazil7615.htm> acceso 15 de julio de 2014.

INTERNAL DISPLACEMENT MONITORING CENTER. NORWEGIAN REFUGEE COUNCIL (IDMC-NRC). Quarterly Update, octubre-diciembre, 2010. Disponible en: $<$ http://www.internal-displacement.org/assets/publications/2010/2010-QU4-corporate-en.pdf $>$ acceso 20 de octubre de 2014.

INTERNAL DISPLACEMENT MONITORING CENTER. NORWEGIAN REFUGEE COUNCIL (IDMC-NRC). Quarterly Update, abril-junio, 2011a. Disponible en $<$ http://www.internal-displacement.org/assets/publications/2011/2011-QU2-corporate-en.pdf $>$ acceso 20 octubre de 2014.

INTERNAL DISPLACEMENT MONITORING CENTER. NORWEGIAN REFUGEE COUNCIL (IDMC-NRC). Disceplacement due to natural hazard-induced disasters. Global estimates for 2009 and 2010, junio, 2011b. Disponible en: <http://www.internaldisplacement.org/assets/publications/2011/2011-global-estimates-2009-2010-global-en.pdf> acceso 10 de octubre de 2014.

INTERNAL DISPLACEMENT MONITORING CENTER. NORWEGIAN REFUGEE COUNCIL (IDMC-NRC). Quarterly Update, enero-marzo, 2012a.

INTERNAL DISPLACEMENT MONITORING CENTER. NORWEGIAN REFUGEE COUNCIL (IDMC-NRC). Global estimates 2011. Peaple displaced by natural hazardinduced disasters, junio, 2012b, p. 20-21. Disponible en: <http://www.internaldisplacement.org/assets/publications/2012/2012-global-estimates-2011-global-en.pdf $>$ acceso 15 de octubre de 2014. 
INTERNAL DISPLACEMENT MONITORING CENTER. NORWEGIAN REFUGEE COUNCIL (IDMC-NRC). Global estimatives 2012. Peaple displaced by disasters, mayo 2013. Disponible en: <http://www.internal-displacement.org/assets/publications/2013/2012global-estimates-corporate-en.pdf $>$ acceso 10 de octubre de 2014.

INTERNAL DISPLACEMENT MONITORING CENTER. NORWEGIAN REFUGEE COUNCIL (IDMC-NRC). Disaster-induce internacional displacement in Philippines. The case of Tropical Storm Washi/Sendong, 2013. Disponible en: <http://www.internaldisplacement.org/assets/publications/2013/2013-ap-philippines-DRR-country-en.pdf $>$ acceso 14 de julio de 2014.

INTERNAL DISPLACEMENT MONITORING CENTER. NORWEGIAN REFUGEE COUNCIL (IDMC-NRC). Global estimates 2012. People displaced by disasters, mayo, 2013. Disponible en: <http://www.internal-displacement.org/assets/publications/2013/2012global-estimates-corporate-en.pdf $>$ acceso 8 de diciembre de 2015.

INTERNAL DISPLACEMENT MONITORING CENTER. NORWEGIAN REFUGEE COUNCIL (IDMC-NRC). Neglected displacement. Human mobility in Pacific disaster risk management and climate change adaptation mechanisms, septiembre, 2014a.

INTERNAL DISPLACEMENT MONITORING CENTER. NORWEGIAN REFUGEE COUNCIL (IDMC-NRC). Global Estimatives 2014. Peaple displaced by disasters, 2014b.

INTERNAL DISPLACEMENT MONITORING CENTER. NORWEGIAN REFUGEE COUNCIL (IDMC-NRC). Global Estimatives 2015. Peaple displaced by disasters, 2015.

INTERNATIONAL INSTITUTE FOR SUSTAINABLE DEVELOPMENT (IISD). Nansen Conference on Climate Change and Displacement Bulletin. A Summary Report of the Nansen Conference on Climate Change and Displacement in the 21st Century. International Institute for Sustainable Development. Reporting Service. Vol, 189, Nº 1, 10 de mayo de 2011, p. 1. Disponible en: <http://www.iisd.ca/download/pdf/sd/ymbvol189num1e.pdf $>$ acceso $10 \mathrm{de}$ enero de 2014. 
INTERNAL PLANNING DOCUMENT- HCT PAKISTAN. Monzon 2012. Revised Humanitarian Operations Plan (MHOP). Revised, febrero, 2013, p. 9-10. Disponible en: $<$ http://pakresponse.info/Portals/0/Policy/MHOP_Revision_HCT\%20endorsed_updated $\% 200$ 6032013.pdf $>$ acceso 10 de octubre de 2014.

INTERNATIONAL FEDERETION OF RED CROSS AND RED CRESCENT SOCIETIES. Emergency Appeal $\mathbf{N}^{\circ}$ MDRNG014. GLIDE $\mathbf{N}^{\circ}$ FL-2012-000138-NGA, mayo, 2013. Disponible en: <http://www.ifrc.org/docs/Appeals/12/MDRNG014rea.pdf> acceso $10 \mathrm{de}$ octubre de 2014.

INTERNATIONAL ORGANISATION FOR MIGRATION (IOM). Discussion Note: Migration and the Environment. MC/INF/288, 1 de noviembre de 2007, Ninety Fourth Session. Ginebra: International Organization for Migration, 14 de febrero de 2008.

JOHNSTONE, Craig L. The future is now. In FMR, $\mathrm{N}^{\mathrm{o}}$ 31, abril 2008. Disponible en: $<$ http://www.fmreview.org/FMRpdfs/FMR31/FMR31.pdf $>$ acceso 15 de enero de 2014.

JORGE BATISTA, Fanny Mery. "El caso de Tuvalu. Redefinición de las nociones de refugiado, desplazado, asilado y apátrida". Disertación de Maestría, Pontificia Universidad Javeriana, Bogotá, 2009, p. 45-46.

KÄLIN, Walter. From the Nansen Principles to the Nansen Initiative. In Migrition Forced. s/f. Disponible en: <http://www.fmreview.org/en/preventing/kalin.pdf>.

KÄLIN, Walter; KÄLIN, Schrepfer. Protecting People Crossing Borders in the Context of Climate Change Normative Gaps and Possible Approaches. University of Bern, UNHCR, 2012. Disponible en: <http://www.unhcr.org/4f33f1729.pdf> acceso 17 de febrero de 2014. 
KOIVUROVA, Timo; DUYCK, Sébastien; HEINÄMÄKI, Leena. Climate Change and Human Rights. En HOLLO, Erkki J.; KULOVESI, Kati; MEHLING, Michael. (eds.). Climate Change and the Law. Ius Gentium: Comparative Perspectives on Law and Justice, Vol. 21, 7 de octubre de 2013, Dordrecht: Springer, p. 287-325. Disponible en: $<$ http://ssrn.com/abstract $=2336876>$ acceso 15 de julio de 2014 .

KOLMANNSKOG, Vikram Odedra. Future floods of refugees: a comment on climate change, conflict and forced migration. Oslo: Norwegian Refugee Council, 2008. Disponible en: <http://www.nrc.no/arch/_img/9268480.pdf> acceso 16 de febrero de 2014.

LAFER, Celso. A reconstrução dos Direitos Humanos. Um diálogo com o pensamento de Hannah Arendt. São Paulo: Companhia das Letras, 1988.

LEFF, Enrique. Saber Ambiental: sustentabilidade, racionalidade, complejidade, poder. Petrópolis, RJ: Vozes, 2001.

LÓPEZ, Iván. Justicia ambiental. Eunomía. Revista en Cultura de la Legalidad, № 6 , Universidad Carlos III de Madrid, marzo-agosto, 2014, p. 262.

MAYER, Benoit. The International Legal Challenges of Climate-Induced Migration: Proposal for an International Legal Framework, 22 COLO. J. INT'L ENVTL. L. \& POL'Y 357, 366, 2011. Disponible en: $<$ http://www.colorado.edu/law/sites/default/files/Mayer\%20\%28Corrected\%29-S.pdf $>$ acceso 15 de marzo de 2014.

MAYER, Benoit. The International Legal Protection of Climate (or Environmental) Migrants at the Crossroads: Fraternity, Responsibility and Sustainability, 1 de abril de 2011. In MORIN, Michel et al. Responsibility, Fraternity and Sustainability in Law: In Memory of the Honourable Charles Doherty Gonthier. Markham: LexisNexis Canada, 2012. Disponible en: $<$ http://papers.ssrn.com/sol3/papers.cfm?abstract_id=1806760 $>$ acceso el 10 de mayo de 2014 .

MARCONI, Marina de Andrade. Antropologia: uma introdução. São Paulo: Atlas, 2011. 
MARTÍNEZ ALLIER, Joan. O Ecologismo dos pobres: conflitos ambientais e linguagens de valoração. São Paulo: Contexto, 2007.

MASON, Moya K. Tuvalu: Flooding, Global Warming, and Media Coverage, s/f.

Disponible en: <http://www.moyak.com/papers/tuvalu-climate-change.html > acceso 4 de abril de 2015.

MC ADAM, Jane. Climate Change Displacement and International Law: Complementary Protection Standards. Division of International Protection. United Nations High Commissioner For Refugees (UNHCR), 2011.

MC ADAM, Jane. Soluciones jurídicas: si un tratado no es la respuesta, entonces ¿qué es? Conferencia ClimMig de Derechos Humanos, Cambio Ambiental, Migración y desplazamiento, Viena, 20-21 de septiembre de 2012.

MC ADAM, Jane, Creating new norms? The Nansen Initiative on Disaster-induced CrossBorder Displacement, Asia Pacific Migration and Environment Network (APMEN), 1 de enero de 2013a. Disponible en: < http://apmen.iom.int/en/m/editorials/item/104-creating-newnorms-the-nansen-initiative-on-disaster-induced-cross-border-displacement>.

MC ADAM, Jane. Creating New Norms on Climate Change, Natural Disasters and Displacement: International Developments 2010-2013, 2013b. Disponible en: $<$ http://www.unhcr.org/542e9a509.pdf > acceso 15 de enero de 2016.

MC DERMOTT, Anthony Goebel. Ecologismo de los pobres y marginalidad social: vehículos de complementariedad y puentes dialógicos. In Reflexiones, Vol. 89, № 1, 2010. 
MIMURA, N.; NURSE, L.; MCLEAN, R.F.; Agard, J.; BRIGUGLIO, L.; LEFALE, P.; PAYET, R.; SEM, G. 2007: Small islands. Climate Change 2007: Impacts, Adaptation and Vulnerability. Contribution of Working Group II to the Fourth Assessment Report of the Intergovernmental Panel on Climate Change. M.L. Parry, O.F. Canziani, J.P. Palutikof, P.J. van der Linden y C.E. Hanson (eds.). Cambridge: Cambridge University Press, 2007, p. 690.

MORAES, Alexandre de. Direitos humanos fundamentais: teoria geral, comentários aos artigos 1 ao 5 da Constituição da República Federativa de Brasil, doutrina e jurisprudência. São Paulo: Atlas, 2005.

MOREIRA, Julia Bertino. A questão dos refugiados no contexto internacional (de 1943 aos dias atuais). Disertación de Maestría. Universidade Estadual de Campinas. Instituto de Filosofia y Ciencias Humanas, 2006, p. 56. Disponible en: $<$ http://pt.scribd.com/doc/6735041/Refugiados $>$ acceso 7 de septiembre de 2012.

MORROW, Karen. Climate change and human rights: the defining dilemma of our times? In Journal of Human Rights and the Environment, Vol. 1, No 2, 1 de septiembre de 2010, p. 131-134.

MUNDIAL BANK. Gross domestic product, 2014. Disponible en: $<$ http://databank.worldbank.org/data/download/GDP.pdf > acceso 8 de abril de 2016.

NACIONES UNIDAS. Declaración Universal de los Derechos del Hombre. Disponible en: $<$ http://www.un.org/es/documents/udhr/index_print.shtml> acceso 24 de agosto de 2012.

NACIONES UNIDAS. Estatuto del Alto Comisionado de las Naciones Unidas para los Refugiados. Aprobado el 14 de diciembre de 1950. Disponible en: $<$ http://www.cidadevirtual.pt/acnur/acn_lisboa/a-estat.html $>$ acceso 5 de agosto de 2012. 
NACIONES UNIDAS. ASAMBLEA GENERAL. XI Resolución 428 (V), 14 de diciembre de 1950. Establecimiento de la Oficina del Alto Comisionado de las Naciones Unidas para los Refugiados. Disponible en: $<$ http://www.acnur.org/t3/recursos/bdl/bdl/\%3FeID\%3Ddam_frontend_push\%26docID\%3D5 615> acceso 5 de agosto de 2012.

NACIONES UNIDAS. ASAMBLEA GENERAL. Resolución 1006, 9 de noviembre de 1956, $571^{\circ}$ Sesión Plenaria.

NACIONES UNIDAS. ASAMBLEA GENERAL. Resolución 1167 (XII) Chinese refugees in Hong Kong, 26 de noviembre de 1957, 723 Sesión Plenaria.

NACIONES UNIDAS. ASAMBLEA GENERAL. Resolución 1285 (XIII) World Refugees Year, 5 de diciembre de 1958, $782^{\circ}$ Sesión Plenaria.

NACIONES UNIDAS. ASAMBLEA GENERAL. Resolución 1388 (XIV) Report of United Nations High Comissioner for Refugees, 20 de noviembre de 1959, 841 ${ }^{\circ}$ Sesión Plenaria.

NACIONES UNIDAS. ASAMBLEA GENERAL. Resolución 1500 (XV) Refugees form Argelia in Morocco and Tunisia, 5 de diciembre de 1960, 935 Sesión Plenaria.

NACIONES UNIDAS. ASAMBLEA GENERAL. Resolución 1673 (XVI) Report of United Nations High Comissioner for Refugees, 18 de diciembre de 1961, 1081º Sesión Plenaria.

NACIONES UNIDAS. Pacto Internacional de los Derechos Civiles y Políticos, 1966. Disponible en: <http://www.ohchr.org/SP/ProfessionalInterest/Pages/CCPR.aspx $>$ acceso 24 de agosto de 2012. 
NACIONES UNIDAS. Convención Internacional sobre la Eliminación de todas las Formas de Discriminación Racial. Adoptada y abierta a la firma y ratificación por la Asamblea General en su resolución 2106 A (XX), 21 de diciembre de 1965. Entrada en vigor 4 de enero de 1969. Disponible en: <http://www.ohchr.org/SP/ProfessionalInterest/Pages/CERD.aspx> acceso 24 de agosto de 2012.

NACIONES UNIDAS. Convención sobre Todas las Formas de Discriminación contra la Mujer, $1979 . \quad$ Disponible en: $<$ http://www.msssi.gob.es/ssi/igualdadOportunidades/internacional/onu/Documentos/conv_eli m_todas_formas_discrim_c_mujer.pdf> acceso 20 de mayo de 2016.

NACIONES UNIDAS. Declaración sobre la eliminación de todas las formas de intolerancia y discriminación fundadas en la religión o las convicciones, Proclamada por la Asamblea General de las Naciones Unidas, 25 de noviembre de 1981 [resolución 36/55]. Disponible en: <http://www.ohchr.org/SP/ProfessionalInterest/Pages/ReligionOrBelief.aspx > acceso 24 de agosto de 2012.

NACIONES UNIDAS. Principios Rectores de los Desplazados Internos, Oficina de Coordinación de Asuntos Humanitarios, 1998. Disponible en: $<$ http://www.law.georgetown.edu/idp/spanish/GPSpanish.pdf $>$ acceso diciembre de 2014.

NACIONES UNDAS, COMITÉ DE DERECHOS ECONÓMICOS, SOCIALES Y CULTURALES. Observación General $N^{\circ} 4$, El derecho a una vivienda adecuada (párrafo 1 del artículo 11 del Pacto) E/1992/23, 13 de diciembre de 1991.

NACIONES UNIDAS. CONSEJO ECONÓMICO Y SOCIAL, COMITÉ DE DERECHOS ECONÓMICOS, SOCIALES Y CULTURALES. Observación $\mathbf{N}^{\circ}$ 12: El derecho a una alimentación adecuada (art. 11), 1999.

NACIONES UNIDAS. Committee on Economic, Social, and Cultural Rights, General Comment No 15, The Right to Water, U.N. Doc. E/C.12/2002/11, 26 de noviembre de 2002. Reprinted in Compilation of General Comments and General Recommendations Adopted by Human Rights Treaty Bodies, U.N. Doc. HRI/GEN/1/Rev.6 at 105, 2003. 
NACIONES UNIDAS. ASAMBLEA GENERAL. A/RES/60/129 Resolución de Aprobación del Informe del Alto Comisionado de Naciones Unidas, 16 de diciembre de 2005.

NACIONES UNIDAS. ASAMBLEA GENERAL. A/AC.96/1035 Aprobación del Informe del Comité Ejecutivo de ACNUR sobre su 57² Período de Sesiones, 2-6 de octubre de 2006.

NACIONES UNIDAS. ASAMBLEA GENERAL. A/RES/61/137 Resolución de aprobación del informe del Alto Comisionado de Naciones Unidas, 19 de diciembre de 2006.

NACIONES UNIDAS. ASAMBLEA GENERAL. A/AC.96/1048 Aprobación del Informe del Comité Ejecutivo de ACNUR sobre su 58 período de sesiones, 10 de octubre de 2007.

NACIONES UNIDAS. ASAMBLEA GENERAL. A/RES/62/124 Resolución de Aprobación del Informe del Alto Comisionado de Naciones Unidas, 18 de diciembre de 2007.

NACIONES UNIDAS. ASAMBLEA GENERAL. A/AC.96/1063 Aprobación del Informe del Comité Ejecutivo de ACNUR sobre su 59º período de sesiones, 22 de octubre de 2008.

NACIONES UNIDAS. ASAMBLEA GENERAL. A/RES/63/148 Resolución de Aprobación del Informe del Alto Comisionado de Naciones Unidas, 18 de diciembre de 2008.

NACIONES UNIDAS. ASAMBLEA GENERAL. A/64/255. Sexagésimo cuarto período de sesiones. Tema 71 b) del programa provisional. Promoción y protección de los derechos humanos: cuestiones de derechos humanos, incluidos otros medios de mejorar el goce efectivo de los derechos humanos y las libertades fundamentales, 6 de agosto de 2009.

NACIONES UNIDAS. ASAMBLEA GENERAL. A/AC.96/1078 Aprobación del Informe del Comité Ejecutivo de ACNUR sobre su $\mathbf{6 0}^{\circ}$ período de sesiones, 9 de octubre de 2009. 
NACIONES UNIDAS. ASAMBLEA GENERAL. A/RES/64/127 Resolución de Aprobación del Informe del Alto Comisionado de Naciones Unidas, 27 de enero de 2010, p. 5-6.

NACIONES UNIDAS. ASAMBLEA GENERAL. A/65/261, 9 de agosto de 2010.

NACIONES UNIDAS. Report of the 2010 Social Forum, UN Doc. A/HRC/16/62 at paras. 12, 43 and 60a, Ginebra, 4-6 de octubre de 2010.

NACIONES UNIDAS. ASAMBLEA GENERAL. A/RES/65/194. Resolución, 21 de diciembre de 2010.

NACIONES UNIDAS. ASAMBLEA GENERAL. A/HRC/18/L.26/Rev.1 Consejo de Derechos Humanos. $1^{\circ}$ período de sesiones. Tema 3 de la agenda. Promoción y protección de todos los derechos humanos, civiles, políticos, económicos, sociales y culturales, incluido el derecho al desarrollo, 28 de septiembre de 2011.

NACIONES UNIDAS. ASAMBLEA GENERAL. A/AC.96/1107 Aprobación del Informe del Comité Ejecutivo de ACNUR sobre su $6^{\circ}{ }^{\circ}$ período de sesiones, 11 de octubre de 2011.

NACIONES UNIDAS. ASAMBLEA GENERAL. A/RES/66/133, 19 de diciembre de 2011.

NACIONES UNIDAS. A/AC.96/SR.654. Comité Ejecutivo del Programa del Alto Comisionado de las Naciones Unidas para los Refugiados. $62^{\circ}$ período de sesiones. Acta resumida de la $654^{\circ}$ sesión, 9 de marzo de 2012. 
NACIONES UNIDAS. ASAMBLEA GENERAL. Distr. General. Sexagésimo período de sesiones. Promoción y protección de los derechos humanos: los derechos humanos, preguntas, incluidos distintos criterios para mejorar el goce efectivo de los derechos humanos y las libertades fundamentales. Los derechos humanos de los migrantes. Nota del Secretario General. Informe preparado por el Relator Especial sobre los Derechos Humanos de los Migrantes, François Crépeau, de conformidad con la resolución 66/172 de la Asamblea General. A/67/299, 13 de agosto 2012.

NACIONES UNIDAS. A/AC.96/119 Informe del Comité Ejecutivo del Programa del Alto Comisionado de las Naciones Unidas para los Refugiados sobre su $63^{\circ}$ período de sesiones, 9 de octubre de 2012.

NACIONES UNIDAS. ASAMBLEA GENERAL. A/RES/67/149, 20 de diciembre de 2012.

NACIONES UNIDAS. A/AC.96/1132 Aprobación del Informe del Comité Ejecutivo sobre su $64^{\circ}$ período de sesiones, 9 de octubre de 2013.

NACIONES UNIDAS. List of Least Developed Countries, 16 de febrero de 2016. Disponible en: <http://www.un.org/en/development/desa/policy/cdp/ldc/ldc_list.pdf $>$ acceso 8 de abril de 2016.

NANSEN INITIATIVE. Disaster-Induced Cross-Border Displacement. Information Note, Ginebra, 25 de abril de 2013.

NANSEN INITIATIVE. Towards a Protection Agenda for Disaster-Induced Cross-Border Displacement. Information Note. Ginebra, 20 de octubre de 2013. Disponible en $<$ https://www.nanseninitiative.org $>$ acceso 20 de febrero de 2014. 
NANSEN INICIATIVE. The Nansen Iniciative leaflet. Towards a protection agenda for people displaced across borders in the context of disasters and the effects of climate change, 23 de octubre de 2014. Disponible en: <http://www.unhcr.org/5448c 7939.html > acceso 15 de enero de 2015.

NAMIHAS, Sandra. (Coord.). Derecho Internacional de los Refugiados. Pontificia Universidad Católica del Perú. Instituto de Estudios Internacionales, 2001.

NELSON. David. El monzón en Pakistán: "un desastre de primera magnitud”. En El País, Madrid, 3 de agosto de 2010.2 Disponible en: $<$ http://internacional.elpais.com/internacional/2010/08/03/actualidad/1280786401_850215.ht $\mathrm{ml}>$ acceso 14 de octubre de 2014

NASER, Mostafa Mahmud. Climate Change- Induced Displacement: definitional issues and concerns, 2011-2012. Disponible en: $<$ http://studentorgs.kentlaw.iit.edu/ckjeel/?attachment_id=24> acceso 10 de marzo de 2014.

NEW ZEALAND'S IMMIGRATION. How do I qualify for residence under the Pacific access category? $\mathrm{s} / \mathrm{f}$. Disponible $<$ http://www.immigration.govt.nz/migrant/stream/live/pacificaccess/residence/> acceso abril de 2015.

NORWEGIAN REFUGEE COUNCIL. Nansen Conference, Climate Change and Displacemente in the 21 st Century. Oslo: Nansen Published-Norwegian Refugee Council, 2011, p. 6. Disponible en: <http://www.unhcr.org/4ea969729.pdf > acceso 10 de êneo de 2014.

NUEVA ZELANDIA, MINISTERIO DE RELACIONES EXTERIORES. New Zealand's immigration relationship with Tuvalu, s/d. 
NÚCLEO DE ESTUDOS DE POLÍTICAS PÚBLICAS EM DIREITOS HUMANOS (Universidade Federal de Rio de Janeiro- UFRJ). Introdução, Estatuto do alto comissariado das Nações Unidas para os refugiados, 1949. Disponible en: <http://www.neppdh.ufrj.br/onu15-9.html> acceso 5 de agosto de 2012.

OEA. Maya indigenous community of the Toledo District v. Belize, Case 12.053, Report $\mathrm{N}^{\mathbf{o}}$ 40/04, Inter-Am. C.H.R., OEA/Ser.L/V/II.122 Doc. 5 rev. 1 at 727, 2004a.

OEA.San Mateo de Hanchor v. Peru, Case 12.471, InterAm. C.H.R., Report No 69/04, admissibility decisión, 15 de octubre de 2004, OEA/Ser.L/V/II.122, doc. 5 rev. 1, 487, 2004b.

OFFICE OF THE UNITED NATIONS HIGH COMMISSIONER FOR REFUGEES (in cooperation with the Norwegian Refugee Council, The Representative Of The SecretaryGeneral On The Human Rights Of Internally Displaced Persons And The United Nations University). Forced Displacement in the context of climate change: Challenges for States under international law. 6th session of the Ad Hoc Working Group on Long Term Cooperative Action under the Convention (AWG-LCA 6), Bonn, 19 de mayo de 2009. Disponible en: $<$ http://unfccc.int/resource/docs/2009/smsn/igo/049.pdf $>$ acceso 10 de febrero de 2014.

OFFICE FOR THE COORDINATION OF HUMANITARIAN AFFAIRS (OCHA). Questions and answers on the cluster approach and cluster implementation issues. 200.. Disponible en:

http://www.internal.displacement.org/8025708F004CFA06/(httpKeyDocumentsByCategory)/ 6151B855F525 Acceso 12 diciembre de 2013.

OFFICE FOR THE COORDINATION OF HUMANITARIAN AFFAIRS (OCHA)- IDMC. Monitoring disaster displacement in the context of climate change. Findings of a study by the United Nations Office for the Coordination of Humanitarian Affairs and the Internal Displacement Monitoring Centre, septiembre, 2009, p. 15. Disponible en: $<$ http://www.internal-displacement.org/assets/publications/2009/200909-monitoring-disasterdisplacement-thematic-en.pdf $>$ acceso 15 de marzo de 2014. 
OFFICE FOR THE COORDINATION OF HUMANITARIAN AFFAIRS (OCHA)- IDMC. Natural disasters and forced displacement in the context of climate change. Policy brief based on the findings of the forthcoming. OCHA-IDMC study, 8 de junio de 2009 . Disponible en: <http://www.preventionweb.net/english/professional/news/v.php?id=9835> acceso 12 de febrero de 2014.

OFFICE FOR THE COORDINATION OF HUMANITARIAN AFFAIRS (OCHA), Annual Report 2011. Ginebra: United Nations Department of Public Information. Ginebra, 2011, p. 5.

OFFICE FOR THE COORDINATION OF HUMANITARIAN AFFAIRS (OCHA). Nigeria: Floods Situation Report $\mathbf{N}^{\mathbf{0}}$ 2, 15 de noviembre de 2012, p. 2. Disponible en: $<$ http://reliefweb.int/sites/reliefweb.int/files/resources/Full\%20Report_1141.pdf $>$ acceso $10 \mathrm{de}$ octubre de 2014.

OHCHR. Study on the relationship between climate change and human rights: Openended consultation meeting, Summary of Discussions, Palais des Nations, Ginebra, Room XII, 22 de octubre de 2008. Disponible en: $<$ http://www.ohchr.org/EN/Issues/HRAndClimateChange/Pages/Consultation.aspx $>$ acceso 12 de julio 2014.

OHCHR. Report of the Office of the United Nations High Commissioner for Human Rights on the Relationship between Climate Change and Human Rights, UN Doc. A/HRC/10/61, 15 de enero de 2009a. Disponible en: $<$ http://www.ohchr.org/Documents/Press/AnalyticalStudy.pdf $>$ acceso 12 de julio 2014.

OHCHR. Summary of Discussion of Human Rights Council Panel Discussion on the Relationship between Climate Change and Human Rights, 15 de junio de 2009b, parágrafo 104. Palais des Nations, Ginebra. Disponible en: $<$ http://www.ohchr.org/EN/Issues/HRAndClimateChange/Pages/HRClimateChangeIndex.asp $\mathrm{x}>$ acceso 30 de julio de 2014. 
OIM. Glossary on Inmigration. Genova: Editado por International Organization for Migration, ISSN 1813-2278, 2004, p. 87. Disponible en: <http://www.iomvienna.at/sites/default/files/IML_1_EN.pdf >, acceso: 17 de octubre de 2016.

OIM. International Migration Law N ${ }^{\circ} 5$ - Glossary on Migration. Richard Perruchoud and Jillyanne Redpath-Cross, eds. Volume: 25, ISSN: 1813-227825, Ginebra: 2011, p. 32. Disponible en: < http://www.epim.info/wp-content/uploads/2011/01/iom.pdf $>$ acceso: 17 de octubre de 2016.

OXFAM. Las necesidades básicas de la población afectada por las inundaciones en Sri Lanka aún no están cubiertas, Subathra Yogasingham, Batticaloa, 18 de enero de 2011. Disponible en: <http://www.oxfam.org/es/sala-de-prensa/notas-de-prensa/2011-01-18/lasnecesidades-basicas-de-la-poblacion-afectada-por-las $>$ acceso octubre de 2014.

PATIL, Yuvraj D. Disaster affected Environmental Refugees \& Human Rights, 2012. Disponible en: $<$ http://ssrn.com/abstract=2002497> acceso 20 de junio de 2014 .

PEDROSO, Antonio Carlos. A dimensão antropológica dos Direitos Humanos. En CUNHA FERRAZ, Anna; BITTAR, Eduardo C.B. (orgs.). Direitos Humanos Fundamentais, Positivação e Concretização. Osasco: Edifieo, 2006.

PEREIRA, Luciana Diniz Durães. O direito internacional dos refugiados: análise crítica do conceito de "refugiado ambiental", Belo Horizonte, 2009.

PÉREZ BARAHONA, Sergio. El Estatuto de "Refugiado" en la Convención de Ginebra de 1951. In REDUR, No 1, 2003, p. 247.

PIGUET, Etiene. Climate change and forced migration. UNCHR, Policy Development and Evaluation Service. New Issues In Refugee Research. Research Paper No 153, 2008. 
PIOVESAN, Flávia. Direitos Humanos e Direito Constitucional internacional. São Paulo: Saraiva, 2011.

PIOVESAN, Flávia. Direitos Humanos: desafios da ordem internacional contemporânea. In PIOVESAN, Flavia (org.). Direitos Humanos, V. I. Curitiba: Jurúa, 2007 (2006), p. 22.

POGGE, Thomas. La importancia internacional de los Derechos humanos. En Revista Argentina de Teoría Jurídica, Vol. 2, $\mathrm{N}^{\mathrm{o}}$ 1, noviembre de 2000. Disponible en: $<$ https://es.scribd.com/document/239006007/Thomas-Pogge-La-Importancia-Internacionalde-Los-Derechos-Humanos> Acceso 20 de agosto de 2014.

RAIOL, Ivanilson Paulo Corrêa. Ultrapassando Fronteiras: a proteção jurídica dos refugiados ambientais. Porto Alegre: Nuria Fabris, 2010.

RAMOS, André de Carvalho; RODRIGUES, Gilberto; ALMEIDA, Guilherme de Assis. (Orgs.). 60 anos de ACNUR: perspectivas de futuro. São Paulo: Editora CL-A Cultural, 2011.

RAMOS, André de Carvalho. Teoria Geral dos Direitos Humanos. São Paulo: Saraiva, 2015.

RAMOS, André de Carvalho. Curso de Direitos Humanos. São Paulo: Saraiva, 2016.

REALE, Miguel. Introducción al Derecho. Madrid: Ediciones Pirámide, 1988.

RENAUD, Fabrice; BOGARDI, Janos J.; DUN, Olivia; WARNER, Koko. Environmental Degradation and Migration, 2008. Disponible en: $<$ http://www.berlin-institut.org/en/onlinehandbookdemography/environment/environmental-migration.html $>$ acceso 8 de febrero de 2014. 
RENAUD, Fabrice; BOGARDI, Janos J.; DUN, Olivia; WARNER, Koko. Control, Adapt or Flee, How to Face Environmental Migration? UNU Institute for Environment and Human Security (UNU-EHS). Bonn: Paffenholz: Bornheim, 2007, p. 13. Disponible en $<$ http://collections.unu.edu/eserv/UNU:1859/pdf3973.pdf> acceso 20 de marzo de 2014.

REIS DE FREITAS, Luisa. The Maldives Islands' Case: Climate Change and Climate Refugees. ICE Case Studies 283, mayo, 2013. Disponible en: $<\mathrm{http}: / /$ www1.american.edu/ted/ICE/maldives.html> acceso 4 de abril de 2015.

REPUBLICA DE KIRIBATI, OFFICE OF THE PRESIDENT. Governance Roadmap on Water Reserves first workshop, complete, 2014. Disponible en: $<$ http://www.climate.gov.ki/2014/10/31/governance-roadmap-on-water-reserves-firstworkshop-complete/> acceso 23 de agosto de 2014.

REPUBLIC OF MALDIVES. National Adaptation Program of Action. Ministry of Environment, Energy and Water, 2006, p. 23-25.

SAGÜÉS, Néstor P. Elementos de Derecho Constitucional, Tomo I. Buenos Aires: Astrea, 1997.

SANCHEZ LEGIDO, Ángel. El Estatuto de los Refugiados cincuenta años después. Facultad de Derecho de Albacete (UCLM), s/f. Disponible en: $<$ www.uclm.es/profesorado/asanchez/webdih/03Materiales/refugiados.txt.doc $>$.

SANTILLI, Julia. Os "novos" direitos socioambientais. En FREITAS, Vladimir Passos de. (Coord.). Direito Ambiental em Evolução. Curitiba: Jurúa, 2007, p. 227. 
SCHUTER, Olivier de. Relator Especial sobre el Derecho a la Alimentación, por el Consejo de Derechos Humanos de Naciones Unidas. Nota Explicativa 6, del Relator Especial sobre el Derecho a la Alimentación: "Una revolución de derechos: La aplicación del Derecho a la Alimentación a nivel nacional en América Latina y el Caribe", 27 de setiembre de 2011. Disponible en: <http://www.srfood.org/es/notas-explicativas $>$ acceso 18 de julio de 2014.

SCHUTER, Olivier de. Relator Especial sobre el Derecho a la Alimentación, por el Consejo de Derechos Humanos de Naciones Unidas. Briefing Note 5, by the Special Rapporteur on the right to food: "From Charity to Entitlement: Implementing the right to food in Southern and Eastern Africa", 20 de junio de 2012. Disponible en: <http://www.srfood.org/es/notasexplicativas> acceso 18 de julio de 2014 .

SIQUEIRA JUNIOR, Paulo Hamilton; OLIVEIRA, Miguel Augusto Machado de. Direitos Humanos e cidadania. São Paulo: Editora Revista dos Tribunais, 2009, p. 41.

STAVROPOUlOU, Maria. Drowned in definitions? En Forced Migration Review, $\mathrm{N}^{\mathrm{o}}$ 31, Climate Change and Displacement, octubre, 2008. Disponible en: $<$ http://reliefweb.int/report/world/forced-migration-review-no-31-climate-change-anddisplacement $>$ acceso 8 de marzo de 2014.

STEINER, Achim. Help small island states win their battle against climate change, $\mathrm{s} / \mathrm{f}$. Disponible en: <www.theguardian.com> acceso 29 de agosto 2014.

STOJANOV, R. Environmental Refugees. Introduction. En Acta Universitatis Palackianae Olomucensis, Geographica, Vol. 38, $\mathrm{N}^{\mathrm{o}}$ 1, 2004, p. 77-84. Disponible en: $<$ http://www.stojanov.org/cs/publikace.html > acceso 10 de marzo de 2014.

SUHRKE A. Pressure Points: Environmental Degradation, Migration and Conflict. Cambridge, MA: American Academy of Arts and Sciences, 1993. 
TERMINIELLO, Juan Pablo. Los desastres naturales, el cambio climático y la protección de los derechos humanos. Realidades y desafíos frente al desplazamiento forzado. En ABRAMOVICH, Víctor et al. Protección internacional de refugiados en el sur de Sudamérica. Remedios de Escalada: UNLa-Universidad Nacional de Lanús, 2012. Disponible en:

$<$ http://www.unla.edu.ar/documentos/centros/derechos_humanos/Proteccion\%20Internacional $\% 20 \mathrm{de} \% 20$ refugiados $\% 20 \mathrm{en} \% 20 \mathrm{el} \% 20 \mathrm{sur} \% 20 \mathrm{de} \% 20$ sudamerica.pdf $>$ acceso 14 de febrero de 2014.

TINANT, Eduardo. El principio de dignidad humana. En Revista del Consejo Académico de Ética en Medicina, Nº 931. Buenos Aires: Academia Nacional de Medicina, 2012.

TINANT, Eduardo. El Holocausto y su influencia en el nacimiento de la Bioética. Del Código de Núremberg a la Declaración de Helsinki. En Revista de Derecho de Familia y de las Personas, La Ley, 2013.

THE WORLD BANK. IBRO-IDA. Poverty \& Equity, s/f. Disponible en: $<$ http://povertydata.worldbank.org/poverty/country/COL> acceso 4 de abril de 2015.

TRINDADE, António Augusto Cançado. O Legado da Declaração Universal e o Futuro da proteção internacional dos Direitos Humanos. En AMARAL JUNIOR, Alberto; PERRONEMOISÉS, Cláudia. (Org.). O cinquentenário da Declaração Universal dos Direitos do Homem. São Paulo: Editora da Universidade de São Paulo, 1999.

UNITED NATIONS. GENERAL ASSEMBLY. A/RES/46/182, 19 de diciembre de 1991. Disponible en: <http://www.un.org/documents/ga/res/46/a46r182.htm> acceso 10 de octubre de 2014.

UNITED NATIONS. GENERAL ASSEMBLY. A/Res. n. 47/105, 26 de abril de 1993. 
UNITED NATIONS. GENERAL ASSEMBLY. A/Res. n. 48/116, 24 de marzo de 1994.

UNITED NATIONS. GENERAL ASSEMBLY. A/Res. n. 49/169, 24 de febrero de 1995.

UNITED NATIONS. GENERAL ASSEMBLY. A/Res. n. 53/125, 12 de febrero de 1999.

UN Doc. UNITED NATIONS. GENERAL ASSEMBLY. A/HRC/10/61,15 de enero de 2009.

UNOHRLLS. Peid Miembros y No Miembros de Naciones Unidas, s/f. Disponible en: $<$ http://unohrlls.org/about-sids/country-profiles/> Acceso 10 de octubre de 2016.

UNITED NATIONS. Refugees. Next Steps: New dynamics of displacement, s/f. Disponible en: <http://www.un.org/en/globalissues/briefingpapers/refugees/nextsteps.html > acceso $15 \mathrm{de}$ enero de 2014.

UNITED NATIONS. HIGH COMMISSIONER FOR REFUGEES (UNHCR). La Convención del Estatuto de los Refugiados, 1951; Protocolo Anexo, 1961, art. 1.

UNITED NATIONS. HIGH COMMISSIONER FOR REFUGEES (UNHCR). Convención contra la Tortura y Otros Tratos o Penas Crueles, Inhumanos o Degradantes. Adoptada y abierta a la firma, ratificación y adhesión por la Asamblea General en su resolución 39/46, 10 de diciembre

de 1984. Entrada en vigor: 26 de junio de 1987, de conformidad con el artículo 27 (1). Disponible en: $<$ http://www2.ohchr.org/spanish/law/cat.htm> acceso 28 de marzo de 2014. 
UNITED NATIONS. HIGH COMMISSIONER FOR REFUGEES (UNHCR). Office of the United Nations High Commissioner for Refugees, G.A. res. 48/116, 48 U.N. GAOR Supp. (No 49) at 231, U.N. Doc. A/48/49, 1993.

UNITED NATIONS. HIGH COMMISSIONER FOR REFUGEES (UNHCR), UNHCR's Operational Experience With Internally Displaced Persons, septiembre, 1994. Disponible en: <http://www.refworld.org/docid/3ae6b3400.html > acceso 3 de febrero de 2014.

UNITED NATIONS. HIGH COMMISSIONER FOR REFUGEES (UNHCR). Reunión consultiva oficiosa. La Protección de los Desplazados Internos y el Papel del ACNUR, 27 de febrero de 2007. Disponible en: <http://www.acnur.es/PDF/7694_20120417112142.pdf> acceso 2 de enero de 2014.

UNITED NATIONS. HIGH COMMISSIONER FOR REFUGEES (UNHCR). Climate Change, Natural Disasters and Human Displacement: A UNHCR Perspective, 23 de octubre de 2008. Disponible en: <http://www.refworld.org/docid/492bb6b92.html > acceso 10 de marzo de 2014.

UNITED NATIONS. HIGH COMMISSIONER FOR REFUGEES (UNHCR). Earth, wind and fire A review of UNHCR's role in recent natural disasters. Policy development and evaluation service (PDES), Ginebra, 2010. Disponible en: $<$ http://www.refworld.org/docid/4c21ae7f2.html> acceso 10 de enero de 2014.

UNITED NATIONS. HIGH COMMISSIONER FOR REFUGEES (UNHCR). Climate Change And Displacement: Identifying Gaps And Responses. Expert Roundtable. Concept Note. Bellagio Conference Centre With the support of the Rockefeller Foundation, Bellagio, 22-26 de febrero de 2011. Disponible en: <http://www.unhcr.org/4d1c92bb9.html > acceso 15 de febrero de 2014.

UNITED NATIONS. HIGH COMMISSIONER FOR REFUGEES (UNHCR). Summary of Deliberations on Climate Change and Displacement, 22-25 de febrero de 2011. Disponible en: <http://www.unhcr.org/4da2b5e19.pdf> acceso 15 de marzo de 2014. 
UNITED NATIONS. HIGH COMMISSIONER FOR REFUGEES (UNHCR). Questions and answers on UNHCR's Protection Cluster coordination role in natural disasters, 2011.

UNITED NATIONS. HIGH COMMISSIONER FOR REFUGEES (UNHCR). Executive Committee of the High Commissioner's Programme Standing Committee. 51st meeting. EC/62/SC/CRP.19, 6 de junio de 2011.

UNITED NATIONS. HIGH COMMISSIONER FOR REFUGEES (UNHCR). Ministerial Meeting to Commemorate the 60th Anniversary of the 1951 Convention relating to the Status of Refugees and the 50th anniversary of the 1961 Convention on the Reduction of Statelessness, Palais des Nations, Ginebra, 7-8 de diciembre de 2011.

UNITED NATIONS. HIGH COMMISSIONER FOR REFUGEES (UNHCR). The State of the World's Refugees: In Search of Solidarity, 2012. Disponible en: <http://www.refworld.org/docid/5100fec32.html> acceso 12 de diciembre de 2013.

UNITED NATIONS. HIGH COMMISSIONER FOR REFUGEES (UNHCR). Meeting Features Launch of Nansen Initiative to Protect People Displaced by Natural Disasters, Ginebra, octubre, 2012. Disponible en: $<$ http://climate-1.iisd.org/news/unhcr-meeting-featureslaunch-of-nansen-initiative-to-protect-people-displaced-by-natural-disasters/>.

UNITED NATIONS. HIGH COMMISSIONER FOR REFUGEES (UNHCR). Seminar to Address the Adverse Impacts of Climate Change on the Full Enjoyment of Human Rights Session 2: International Cooperation and Respect for Human Rights, Remarks of Mr. José Riera Senior Adviser Division of International Protection, Palais des Nations, Ginebra, Salle XII, 23 de febrero de 2013. Disponible en: <http://www.unhcr.org/543e77a19.html $>$ acceso 14 de octubre de 2015.

UNITED NATIONS. HIGH COMMISSIONER FOR REFUGEES (UNHCR). DIVISION OF INTERNATIONAL PROTECTION. Guidelines on Temporary Protection or Stay Arrangements, febrero, 2014. Disponible en: $<\mathrm{http}: / / \mathrm{www}$.unhcr.org/542e99fd9.html $>$ acceso 14 de octubre de 2015. 
UNITED NATIONS. HIGH COMMISSIONER FOR REFUGEES (UNHCR). UNHCR, The Environment \& Climate Change, octubre, 2015. Disponible en: $<$ http://www.unhcr.org/540854f49.pdf>.

UNITED NATIONS. HIGH COMMISSIONER FOR REFUGEES (UNHCR). PLEDGES 2011. Ministerial Intergovernmental Event on Refugees and Stateless Persons. UNHCR ministerial meeting to commemorate the 60th anniversary of the 1951 Convention relating to the Status of Refugees and the 50th anniversary of the 1961 Convention on the Reduction of Statelessness. Ginebra: UNHCR/Division of International Protection, 2012.

UNITED NATIONS. HIGH COMMISSIONER FOR REFUGEES (UNHCR). Meeting Features Launch of Nansen Initiative to Protect People Displaced by Natural Disasters. Dsiponible en: <http://climate-1.iisd.org/news/unhcr-meeting-features-launch-of-nanseninitiative-to-protect-people-displaced-by-natural-disasters/>.

UNITED NATIONS. GENERAL ASSEMBLY. A/RES/67/149. Oficina del Alto Comisionado de las Naciones Unidas para los Refugiados, 20 de diciembre de 2012.

UNITED NATIONS. GENERAL ASSEMBLY. Sixty-eighth session. Economic and Social Council. Substantive session of 2013. A/68/x-E/2013/y /Strengthening of the coordination of humanitarian and disaster relief assistance of the United Nations, including special economic assistance: strengthening of the coordination of emergency humanitarian assistance of the United Nations, Ginebra, 1-25 de julio de 2013.

UNITED NATIONS. FRAMEWORK CONVENTION ON CLIMATE CHANGE- UNFCCC. Climate Change: Impacts, Vulnerabilities And Adaptation In Developing Countries.

UNITED NATIONS. DEPARTMENT OF ECONOMIC AND SOCIAL AFFAIRS. DIVISION FOR SUSTAINABLE DEVELOPMENT. Trends in sustainable development. Small island developing states (SIDS). Nueva York, 2010. 
UNIVERSIDAD DE MINNESOTA. HUMAN RIGHTS LIBRARY. Training Manual on Human Rights Monitoring. Chapter X: Monitoring and Protecting the Human Rights of Refugees and/or Internally Displaced Persons Living in Camps, s/f. Disponible en: $<$ http://www1.umn.edu/humanrts/monitoring/monitoring-training.html $>$ acceso 20 de julio de 2014.

UNSTATS. Environment Statistics Country Snapshot. Maldivas, s/f. Disponible en: $<$ https://unstats.un.org/unsd/ENVIRONMENT/envpdf/Country_Snapshots_Aug\%202013/Ma ldives.pdf $>$ acceso 4 de abril de 2015.

VERGUEIRO, C.M.A. Refugiados africanos no Brasil. Alguns aspectos políticos, culturais, históricos e sociais. Faculdade de Ciências e Letras de Araraquara, Universidade Estadual Paulista. Disponible en: <www.forumafrica.com.br/textoforumafrica12006.pdf>.

VIEIRA, Ligia Ribeiro. Refugiados Ambientais [dissertação]: desafios à sua aceitação pelo Direito Internacional. Florianópolis, 2012, p. 203.

WARNER, Koko. Environmental Change and Migration: Issues for European governance and migration management. En Network Migration in Europe. Disponible en: $<$ www.migrationeducation.org $>$ acceso 20 de marzo de 2014.

WATT-CLOUTIER, Sheila. Petition to the Inter-American Commission on Human Rights Seeking Relief from Violations Resulting from Global Warming Caused by Acts and Omissions of the United States,7 de diciembre de 2005. Disponible en: $<$ http://www.ciel.org/Publications/ICC_Petition_7Dec05.pdf $>$ acceso 18 de julio de 2014.

WEWERINKE, Margaretha. Climate Change, Human Rights and the International Legal Or der: The Role of the UN Human Rights Council. 4CMR Working Paper Series. Cambridge Centre for Climate Change Mitigation Research (4 CMR). Disponible en: $<$ http://be.4cmr.group.cam.ac.uk/working-papers/pdf/4CMR_WP_04.pdf $>$ acceso 5 de junio de 2014. 
WORLD BANK. Gross domestic product, 2014. Disponible en: $<$ http://databank.worldbank.org/data/download/GDP.pdf $>$ acceso 8 de abril de 2016.

WYMAN, Katrina Miriam. Responses to Climate Migration. En Harvard Environmental Law Review, Vol. 37, 2013, p. 165-217. Disponible en: <http://harvardelr.com/wpcontent/uploads/2013/05/Wyman.pdf $>$ acceso 28 de mayo de 2014 .

ZETTER, R. Protecting Environmentally Displaced People: Developing the Capacity of Legal and Normative Frameworks. Refugee Studies Centre Research Report, febrero, 2011. Disponible en: <http://www.unhcr.org/4da2b6189.pdf > acceso 15 de febrero de 2014.

Sites de investigación

$<$ http://www.ohchr.org/EN/HRBodies/HRC/RegularSessions/>

$<\mathrm{http}: / / \mathrm{www} \cdot$ liser.eu/>

$<\mathrm{http}: / /$ www.forcedmigration.org/about/whatisfm> 